\title{
SCANNING ELECTRON MICROSCOPIC AIDS FOR IDENTIFICATION OF LARVAL AND POST-LARVAL BIVALVES
}

\author{
RICHARD A. LUTZ, ${ }^{\text {* }}$ JACOB D. GOODWIN, ${ }^{1}$ BRAD S. BALDWIN, ${ }^{2}$ GAVIN BURNELL, ${ }^{3}$ \\ MICHAEL CASTAGNA, ${ }^{4}$ SAMUEL CHAPMAN, ${ }^{5}$ AL CHESTNUT, ${ }^{6}$ PATRICK DABINETT, ${ }^{7}$ \\ CHRIS DAVIS, ${ }^{5}$ ARNOLD G. EVERSOLE,${ }^{8}$ S. CYNTHIA FULLER, ${ }^{1}$ SCOTT M. GALLAGER, ${ }^{9}$ \\ RONALD GOLDBERG, ${ }^{10}$ JOY GOODSELL, ${ }^{1}$ JUDITH GRASSLE, ${ }^{1}$ RICHARD G. GUSTAFSON, ${ }^{11}$ \\ HERBERT HIDU, ${ }^{5}$ YA-PING HU, ${ }^{1}$ DAVID JABLONSKI, ${ }^{12}$ SHANNON JOHNSON, ${ }^{13}$ \\ VICTOR S. KENNEDY,${ }^{14}$ MARCEL LE PENNEC, ${ }^{15}$ ROGER MANN, ${ }^{16}$ CARTER NEWELL, \\ ALAN S. POOLEY, ${ }^{1}$ ANTONIETO S. TAN, ${ }^{1}$ ROBERT C. VRIJENHOEK ${ }^{13}$ \\ AND A. PARTRIDGE ${ }^{17}$ \\ ${ }^{1}$ Department of Marine and Coastal Sciences, Rutgers University, 71 Dudley Road, New Brunswick, NJ \\ 08901; ${ }^{2}$ Department of Biology, 23 Romoda Drive, St. Lawrence University, Canton, $N$ Y 13617; ${ }^{3}$ School \\ of Biological, Earth and Environmental Sciences, University College Cork, North Mall Campus, Distillery \\ Fields, Cork, Ireland T23 N73K; ${ }^{4}$ Virginia Institute of Marine Science, College of William and Mary, \\ 40 Atlantic Avenue, Wachapreague, VA 23480; ${ }^{5}$ Ira C. Darling Center, University of Maine, 193 Clarks \\ Cove Road, Walpole, ME 04573; ${ }^{6}$ Department of Biology, Belhaven College, 1701 N. State Street, \\ Jackson, MS 39202; ${ }^{7}$ Marine Sciences Research Laboratory, Memorial University of Newfoundland, \\ 230 Elizaabeth Avenue, St. John's, NF A1C 5S7, Canada; ${ }^{8}$ Department of Aquaculture, Fisheries and \\ Wildlife, 261 Lehotsky Hall, Clemson University, Clemson, SC 29634; ${ }^{9}$ Woods Hole Oceanographic \\ Institution, 266 Woods Hole Road, Woods Hole, MA 02543; ${ }^{10}$ Northeast Fisheries Center, National \\ Marine Fisheries Service, Milford Laboratory, 212 Rogers Avenue, Milford, CT 06460; ${ }^{11}$ Northwest \\ Fisheries Science Center, National Marine Fisheries Service, National Oceanic and Atmospheric \\ Administration, 2725 Montlake Blvd. E., Seattle, WA 98112; ${ }^{12}$ Department of Geophysical Sciences, \\ University of Chicago, 5734 S. Ellis Ave., Chicago, IL 60637; ${ }^{13}$ Monterey Bay Aquarium Research \\ Institute, 7700 Sandholdt Road, Moss Landing, CA 95039; ${ }^{14}$ Chesapeake Biological Laboratory, \\ University of Maryland Center for Environmental Science, 146 Williams Street, Solomons, MD 20688; \\ ${ }^{15}$ Laboratoire des Sciences de l'Environnement Marin (LEMAR), Institut Universitaire Européen de la \\ Mer, Place Nicolas Copernic, Plouzané 29280, France; ${ }^{16}$ Virginia Institute of Marine Science, College of \\ William and Mary, 1375 Greate Road, Gloucester Point, VA 23062; ${ }^{17}$ in a pear tree
}

\begin{abstract}
The identification of bivalve larvae and early postlarvae in plankton and benthic samples has long been a challenge, hampering both basic and applied research efforts in marine, estuarine, and freshwater environments. The usefulness of published optical micrographs of the early life-history stages of bivalves is limited because of the great morphological similarity of the imaged articulated shells, particularly at the early (straight-hinge) developmental stages. While a number of techniques have been refined in recent years and show promise for use in routine identifications of larval and post-larval bivalves (e.g., single-step nested multiplex polymerase chain reaction; in situ hybridization protocols through color coding with taxon-specific, dye-labeled DNA probes; coupled fluorescence in situ hybridization and cell sorting; and image analysis techniques using species-specific shell birefringence patterns under polarized light), no adequate comprehensive reference source exists that accurately depicts the morphology and morphometry of the shells of larval and post-larval stages of target bivalve species in a consistent format to assist in identification of such stages. To this end, scanning electron micrograph (SEM) sequences are presented of the disarticulated shell valves of laboratory-reared larval and post-larval stages of 56 species of bivalve molluscs from a wide spectrum of marine, estuarine, and freshwater habitats. Emphasis is placed on the usefulness of the morphology and morphometrics of consistentlyoriented, disarticulated shell valves and associated hinge structures in discriminating the early life-history stages of these various bivalve species. Although the scanning electron micrograph sequences presented accurately depict the gross morphologies/ morphometrics and hinge structures of the disarticulated shell valves of the larvae and/or postlarvae of the 56 species of bivalves, it is important to emphasize that a scanning electron microscope is not necessary to observe even fine hinge structures associated with the early ontogenetic stages of these species. Such structures are readily visible using a wide range of optical compound microscopes equipped with high-intensity reflected light sources, although the disarticulated shell valves must be viewed in several planes of focus to discern the often subtle details seen clearly in the scanning electron micrographs. These morphological characters provide researchers with invaluable aids for the routine identification of the early life-history stages of these species isolated from plankton and benthic samples.
\end{abstract}

KEY WORDS: bivalve, larvae, postlarvae, identification, scanning electron microscopy

*Corresponding author. E-mail: rlutz@marine.rutgers.edu DOI: $10.2983 / 035.037 .0202$ 


\section{INTRODUCTION}

The identification of bivalve larvae and early postlarvae has been important for many ecological research efforts in marine, estuarine, and freshwater environments for over a century (Stafford 1912, Odhner 1914, Lebour 1938, Werner 1939, Jørgensen 1946, Sullivan 1948, Rees 1950, Miyazaki 1962, Loosanoff \& Davis 1963, Newell \& Newell 1963, Loosanoff et al. 1966, Le Pennec \& Lucas 1970, Chanley \& Andrews 1971, de Schweinitz \& Lutz 1976, Lutz \& Jablonski 1978a, 1978b, 1979, 1981, Jablonski \& Lutz 1980, Le Pennec 1980, Lutz et al. 1982a, 1982b, Lutz 1988, 2012, Fuller \& Lutz 1989, Kennedy et al. 1989, 1991, Goodsell et al. 1992, Hu et al. 1992, 1993, Lutz \& Kennish 1992, Baldwin et al. 1994, Hare et al. 2000, Garland \& Zimmer 2002, Tiwari \& Gallager 2003a, 2003b, Hendriks et al. 2005, Larsen et al. 2005, 2007, Wang et al. 2006, North et al. 2008, Henzler et al. 2010, Thompson et al. 2012a, 2012b, Malchus \& Sartori 2013, Goodwin et al. 2014, 2016a, 2016b). As Hendriks et al. (2005) emphasized, "Despite the importance of the planktonic larval stage in intertidal bivalves, our understanding of this stage is still insufficient. A major obstacle in the quantification of planktonic larval distributions is the identification of sampled larvae."

In early efforts to assist with the identification of larval bivalves isolated from plankton samples, Chanley and Andrews (1971) published a key to the larval stages of a number of bivalve species along the east coast of North America based on optical micrographic sequences of articulated shells of laboratorycultured larval specimens; however, the usefulness of this key is limited because of the great morphological similarity of the imaged articulated shells, particularly at the early (straighthinge) developmental stages. Although a number of techniques have been refined in recent years and show promise for use in routine identifications of larval and post-larval bivalves (e.g., single-step nested multiplex polymerase chain reaction; in situ hybridization protocols through color coding with taxonspecific, dye-labeled DNA probes; coupled fluorescence in situ hybridization and cell sorting; and image analysis techniques using species-specific shell birefringence patterns under polarized light; Larsen et al. 2005, 2007, Henzler et al. 2010, Thompson et al. 2012a, 2012b, Goodwin et al. 2014, 2016a, 2016b, 2018), no adequate comprehensive reference source exists that accurately depicts the morphology and morphometry of the shells of larval and post-larval stages of target bivalve species in a consistent format to assist in identification of such stages.

With the aforementioned as background, in this monograph scanning electron micrograph (SEM) sequences of the disarticulated shell valves of laboratory-reared larval and post-larval stages of 56 species of bivalve molluscs from a wide spectrum of aquatic habitats are presented (Table 1). Emphasis is placed on the usefulness of the morphology and morphometrics of consistently-oriented, disarticulated shell valves and associated hinge structures in discriminating the early life-history stages of these species. Most of these species are from environments along the east coast of North America and include most of the commercially important species in this region.

Taxonomic nomenclature was assigned according to the latest "accepted name" (or acceptable "alternate representation") and associated classification hierarchy in the World Register of Marine Species (www.marinespecies.org).
Over the years, various workers have used both optical and scanning electron microscopy to describe in detail the larval and/or post-larval hinge structures of a number of bivalves and have suggested that such structures may be diagnostic at the generic, or even specific, level (Chanley 1965, 1969, Turner \& Johnson 1970, Pascual 1971, 1972, Scheltema 1971, Le Pennec 1973, 1978, 1980, LaBarbera 1975, Boyle \& Turner 1976, Culliney \& Turner 1976, Dinamani 1976, Le Pennec \& Masson 1976, Booth 1977, 1979a, 1979b, Siddall 1977, 1978, Lutz \& Jablonski 1978a, 1978b, 1981, Carriker \& Palmer 1979, Lutz \& Hidu 1979, Chanley \& Dinamani 1980, Jablonski \& Lutz 1980, Lutz et al. 1982a, 1982b, Redfearn 1982, 1987, Jablonski \& Lutz 1983, Ramorino \& Campos 1983, Redfearn et al. 1986, Tremblay et al. 1987, Fuller \& Lutz 1989, Fuller et al. 1989a, Kennedy et al. 1989, 1991, Hu et al. 1993, Paugam et al. 2006, Wassnig \& Southgate 2012). Despite these efforts, much of the morphologic and morphometric data obtained over the years has not been presented in an adequate or sufficiently consistent format to permit unambiguous identification of early lifehistory stages of bivalves at various taxonomic levels. In recognition of this shortcoming, the SEM sequences of the larval and post-larval stages of a number of the species depicted in this monograph that have been previously published in various journals are presented here in a consistent format, together with other pertinent details related to procurement, preparation, and descriptions of the specimens comprising these sequences (Lutz et al. 1982b, Fuller \& Lutz 1989, Fuller et al. 1989b, Kennedy et al. 1989, 1991, Goodsell et al. 1992, Gustafson \& Lutz 1992, Hu et al. 1993, Tan et al. 1993). These sequences and pertinent details are included herein, together with a large number of unpublished sequences and associated pertinent details of most of the species in Table 1. The goal is to present a coherent compilation of all 56 species in one single publication to assist in the discrimination of larval and postlarval stages of these species isolated from a variety of aquatic environments.

\section{MATERIALS AND METHODS}

Sexually mature adults of 56 species of bivalves were obtained from the sources indicated in Table 1 . These adults were induced to spawn (or larvae/juveniles were obtained from spontaneous spawning/release events in the case of certain species with nonplanktotrophic modes of development) using a variety of protocols described by various workers (Loosanoff \& Davis 1963, Morse et al. 1977, Lutz et al. 1982a, 1982b, Gibbons \& Castagna 1984, Fuller \& Lutz 1989, Fuller et al. 1989a, Kennedy et al. 1991, Gustafson \& Lutz 1992). The larvae and postlarvae of most of these species were reared using standard hatchery techniques (e.g., techniques described by Loosanoff \& Davis 1963, Turner \& Johnson 1970, Chanley \& Andrews 1971, Castagna 1975, Castagna \& Kraeuter 1977). Further specific details concerning the culture of the larvae and postlarvae of a number of these species may be found in Lutz et al. (1982b), Fuller and Lutz (1989), Fuller et al. (1989a), Kennedy et al. (1989), (1991), Goodsell et al. (1992), Gustafson and Lutz (1992), Hu et al. (1993), and Tan et al. (1993).

Cultured larval and post-larval specimens were sampled at frequent intervals (frequency dependent on the growth of organisms since the previous sampling period) and placed in distilled water for $30 \mathrm{~min}$ (Calloway \& Turner 1979). Immediately 
following this treatment, specimens were preserved in $95 \%$ ethanol. After various lengths of time (up to 2 months), specimens were removed from the ethanol, rinsed in distilled water, and immersed in a $5 \%$ solution of sodium hypochlorite (Rees 1950) for approximately 10 min to facilitate separation of shell valves and removal of soft tissue. After rinsing in distilled water, disarticulated valves were mounted on copper or silver tape (or double-sided sticky tape), coated (under vacuum) with approximately $400 \AA$ of gold-palladium or a combination of gold and carbon, and examined under an ETEC Autoscan scanning electron microscope [or, in the case of Ostrea stentina (=Ostrea equestris), Solemya velum and Mercenaria campechiensis specimens, under Hitachi S-540 and JEOL 848 scanning electron microscopes].

Procedures used for accurate documentation of shapes and dimensions of the larval and post-larval shells using scanning electron microscopy were those of Fuller et al. (1989b) and are outlined below.

Before imaging individual larval or post-larval specimens under the scanning electron microscope, great care was taken to adjust the microscope so that $x$ and $y$ dimensions were equal on a calibration sphere that was approximately the same size as the specimen being photographed. In turn, these adjustments were made at a magnification close to that at which the specimen was to be photographed. The calibration spheres were sand-blasting beads that were selected for roundness by comparing measurements of the diameter on electron micrographs taken at rotations of 0 , 45, and 90 degrees (see Fuller et al. 1989b for further details).

The method used for consistent orientation of the disarticulated shell valves, in which each larval or post-larval valve is positioned with points of the hinge and shell margin aligned in a plane normal to the axis of the electron optical system, is described by Fuller et al. (1989b, p. 59) as follows. "Specifically, a disarticulated valve with the interior shell surface visible on the microscope screen is rotated until the anterior and posterior margins are at equal working distances. A digital voltmeter (monitoring the reference voltage of the lens control) is used to measure carefully the differences in working distance when opposite margins of the shell are successively focused at $30,000 \times$. A difference of $1 \mathrm{mV}$ on the meter is equal to a change in working distance of about $0.34 \mu \mathrm{m}$. Subsequently, the specimen is tilted perpendicularly to the first axis until the dorsal and ventral margins of the valve also are at the same working distances. A photomicrograph of the shell in this position documents its characteristic shape."

It should be noted that it was necessary to modify the aforementioned procedure to obtain consistent orientations for later post-larval stages of a number of species because of the irregular contours of the shell margins of these stages. In the case of post-larval Teredo navalis, for example, orienting the specimens in a manner similar to that described previously was impossible because points along the post-larval shell margin do not lie in a single plane. As articulated by Fuller et al. (1989a, p. 25) concerning $T$. navalis: Throughout the post-larval developmental period, however, points along the dorsoventral margin of the anterior slope (except those at the extreme ventral region) comprise a plane. Thus, consistent orientation of postlarval shells was achieved by positioning specimens such that this plane was perpendicular (Fuller et al.1989a mistakenly indicated "parallel") to the electron optical axis. Additional adjustments were made so that dorsal and ventral condyles were at an equal working distance. Similar adjustments were also used to obtain consistent orientations of post-larval specimens of Bankia gouldi (Tan et al. 1993).

The dimensions of the larval and post-larval shells were determined by positioning a flat 400-mesh copper transmission electron microscope grid (on the same specimen mount, near the shell valve) normal to the electron optical axis and photographing this grid at the identical magnification at which the shell valve was photographed. Measurements of the shell dimensions are based on the $63.5-\mu \mathrm{m}$ grid spacings of the 400 -mesh grid, rather than on magnification or scale bar displays on the microscope screen (for further details, see Fuller et al. 1989b).

The numbers depicted above each of the micrographs in Figures 1-195 indicate the maximum linear distance in micrometers measured along any axis of the shell, with a few exceptions. In most cases, this maximum distance represents "shell length" as defined by numerous authors (Fuller \& Lutz 1989, Kennedy et al. 1989, 1991, Goodsell et al. 1992, Gustafson \& Lutz 1992, $\mathrm{Hu}$ et al. 1993), although in the case of the larval stages of certain pholads and teredinids [e.g., Bankia gouldi (Tan et al. 1993) (Figs. 69 and 70) and Teredo navalis (Fuller et al. 1989a) (Figs. 73 and 74)], this maximum distance represents "shell height." Shell nomenclature of the teredinids is taken from Turner (1966, 1971). The numbers depicted above the larval stages of Crassostrea gigas, Crassostrea virginica, Ostrea edulis, and Ostrea stentina (= Ostrea equestris) (Figs. 105-123) represent the maximum anteroposterior dimension ("shell length", which in some larval stages of these species is less than or equal to "shell height"; see Hu et al. 1993).

We use the term "provinculum" in the sense of Bernard (1898) and Rees (1950). Provinculum length represents the linear distance between the lateral extremes of the hinge apparatus in larval and early post-larval shells (see Bayne 1976, p. 87, for a diagrammatic illustration of this dimension).

\section{RESULTS AND DISCUSSION}

An inability to identify bivalve larvae and postlarvae within planktonic and benthic samples has long hampered both applied and basic research efforts in marine, estuarine, and freshwater environments (Hu et al. 1992). For example, assessing the impact of natural or anthropogenic disturbances (e.g., chemical pollutants, thermal discharges, oil spills, dredge spoil dumping, ocean acidification, discharges of ships' ballast water containing entrained meroplanktonic organisms) on marine ecosystems; predicting recruitment for fisheries management; optimizing the timing of substrate placement for aquaculture; assessing the impact of fluctuations in climatic conditions; and conducting basic environmental surveys all depend on identifying the temporal and spatial abundance of meroplanktonic and/or early post-larval stages of various species. Along these lines, the discovery of planktonic stages of a myriad of invertebrate organisms within the ballast waters of ships traveling between countries has led to concerns regarding potentially severe and irreversible biological conservation impacts of the introduction of invasive aquatic species via the discharge of such ballast waters in areas where the entrained species are not indigenous (Cohen \& Carlton 1998, Carlton 1999, Ruiz et al. 2000, Gollasch 2002, Murphy et al. 2002). As Hayes and Hewitt (1998) point out: "The assessment of risk associated with ballast 
water discharge depends on reliable knowledge of the identity, viability and quantity of its inhabitants." Hence, while this monograph consists predominantly of species from environments along the east coast of North America, a number of bivalve species (e.g., Arca noae, Pecten maximus, and Ruditapes philippinarum) that various individuals collected from waters in the eastern Atlantic and cultured under controlled laboratory conditions have been included in this treatise.

For over a century, workers have attempted to define larval and post-larval morphological characters diagnostic at various systematic levels (for discussions, see Stafford 1912, Odhner 1914, Werner 1939, Rees 1950, Loosanoff \& Davis 1963, Chanley \& Andrews 1971, Lutz \& Hidu 1979, Fuller \& Lutz 1989, Hu et al. 1993, Hendriks et al. 2005, Larsen et al. 2007, Goodwin et al. 2014, 2016a, 2016b, 2018). Historically, the larval and early post-larval characteristics generally used in routine plankton and benthic identifications have been shell length, height, and depth, as well as the length of the "straighthinge line"; differences in larval shell shape, color, and texture; provinculum length; number and configuration of hinge teeth; and presence or absence of a byssal notch, eyespot, or apical cilia ("apical flagellum") (Loosanoff et al. 1966, Chanley \& Andrews 1971, Turner \& Boyle 1975, Chanley \& Chanley 1980, Lutz et al. 1982b, Fuller \& Lutz 1989, Hu et al. 1993, Tan et al. 1993, Larsen et al. 2007). More recently, a spectrum of image analysis, cell sorting, and genetic techniques has proven useful for the identification of a myriad of larval and postlarval bivalves (Tiwari \& Gallager 2003a, 2003b, Hendriks et al. 2005, Larsen et al. 2005, 2007, Henzler et al. 2010, Thompson et al. 2012a, 2012b, Goodwin et al. 2014, 2016a, 2016b, 2018).

The present monograph is designed to provide additional tools for the identification of larval and post-larval bivalve species isolated from planktonic and benthic samples from aquatic environments. To this end, Figures 1-195 depict scanning electron micrographic sequences of the gross shell morphologies, morphometrics, and details of the hinge regions of disarticulated shell valves of a spectrum of larval and postlarval bivalves at various stages of development. These sequences are presented in a manner (i.e., a consistent orientation of imaged specimens) that will facilitate comparison of the shell morphologies and morphometrics of the early life-history stages of these species. The micrographic sequences depict larval and post-larval shell features of species in 47 genera from 25 bivalve families. The morphologies of the larval hinges range from distinctly taxodont dentition in the case of the Arcoidea, Mytiloidea, and Pectinoidea to a lack of prominent denticular structures in the Arcticoidea, Hiatelloidea, Myoidea, and Veneroidea (with the exception of the venerid Ruditapes philippinarum that has fairly well-defined hinge teeth along the larval shell provinculum). The morphological features of various ontogenetic stages of the disarticulated larval and postlarval shell valves of many of the species are quite distinct, permitting discrimination at the specific level. Although differences in morphological features among many other taxa are subtle, it is believed that they can be defined, permitting discrimination of bivalve larvae and postlarvae at the levels of subfamily and genus, respectively.

The following sections summarize the utility (as articulated by various authors) of comparing scanning electron micrographs of early ontogenetic stages of species from a spectrum of select families for discrimination of larval and post-larval bivalves at various taxonomic levels.

\section{Veneridae and Arcticidae}

From detailed examination and analyses of the SEM sequences of the early life-history stages of five venerids (Chione cancellata -Figs. 168-170; Mercenaria mercenaria-Figs. 173175; Mercenaria campechiensis-Figs. 176-178; Mercenaria campechiensis texana -Figs. 179-181; and Pitar morrhuanusFigs. 186-189), Goodsell et al. (1992) concluded that "documentation and comparison of scanning electron photomicrographs of larval and post-larval venerids would appear to be a successful aid for identification at the levels of subfamily and genus, respectively." As articulated by Lutz et al. (1982b), the sequence of ontogenetic changes in the morphology of the larval hinge apparatus of Arctica islandica (Figs. 149 and 150) is remarkably similar to that described and illustrated by Le Pennec (1978, 1980) for various species of venerids. Throughout larval development, the provinculum of $A$. islandica is slightly wedge shaped with the narrower portion toward the posterior region of the shell (Fig. 150). "Denticles," analogous to those described by Le Pennec (1980) along the provinculum of certain venerids, are absent. During the early straight-hinge stage, an elongated ridge ("fold"; Le Pennec, 1980) develops in the left valve along almost the entire length of the anterior half of the provinculum (Figs. 149 and 150). At the anterior extremity of the provinculum of the left valve, there is a slight depression in shells of specimens greater than approximately $170 \mu \mathrm{m}$ in length. In the right valve, a relatively short projection develops during the early straight-hinge stage along the central region of the provinculum (Fig. 150). This latter projection subsequently develops into the first cardinal tooth (according to the nomenclature of Le Pennec, 1978, 1980), which is readily apparent in the post-larval stages (Figs. 151 and 152) (Lutz et al. 1982b).

No "primary" (after Trueman 1950; "primitive" of Le Pennec 1980) ligament pits ("fossettes ligamentaire" of Bernard 1896a) were observed in Arctica islandica specimens with shell lengths $<200 \mu \mathrm{m}$ (Fig. 150) or in numerous specimens ranging in length from 200 to $230 \mu \mathrm{m}$. Ligament pits, although often very much reduced in size, appeared to be present in all specimens examined with shell lengths $>230 \mu \mathrm{m}$. Since the classic studies of Bernard in the late nineteenth century (Bernard 1895, 1896a, $1896 \mathrm{~b}, 1897,1898)$, numerous workers have commented on the presence of ligaments or ligament pits in "larval" specimens (Rees 1950, Ansell 1962, Loosanoff et al. 1966, Chanley \& Andrews 1971, Bayne 1976; for further discussion concerning the significance of the presence or absence of ligament pits in the shells of early ontogenetic stages of bivalves, see Lutz et al. 1982b). Lutz and Hidu (1979) suggested that "primary" (after Trueman 1950) ligament pits do not form until metamorphosis has been initiated (see also Lutz 1979). It has been further suggested that changes associated with metamorphosis proceed in an orderly fashion (Bayne 1965, 1971, Turner 1976b) and that "any interruption ... in the normal sequence of events affects the ability of the larvae to progress to the next step whether that be the loss of a larval organ or the acquisition of a post-larval one" (Turner 1976a).

In specimens of Arctica islandica examined during the course of preparation of the present monograph, ligament pits were observed in shells of a number of specimens with larval lengths 
ranging between 200 and $230 \mu \mathrm{m}$. If, as suggested by Lutz and Hidu (1979, pp. 117-118), development of the primary ligament pit is "one of the first morphological changes that occurs during metamorphosis," it is reasonable to conclude that larvae within this size range are at least capable of metamorphosis (Lutz et al. 1979). Ligament pits were not observed in any A. islandica specimens with shell lengths $<200 \mu \mathrm{m}$ (Figure 150) (Lutz et al. 1982b). This observation, when coupled with the fact that no pediveliger larva with a length below $200 \mu \mathrm{m}$ was found in any of the cultures, strongly suggests that the larvae of this species are not capable of metamorphosing at shell lengths below this size and has implications for determining the size at which most of the species in this monograph are capable of metamorphosing.

After metamorphosis, relatively dramatic changes take place in the morphology of the hinge apparatus of Arctica islandica. The sequence of ontogenetic changes photographically illustrated in Figures 151 and 152 is similar to that diagrammatically illustrated by Le Pennec $(1978,1980)$ in his detailed summary of the development of the heterodont hinge. A close similarity exists between the early post-larval hinge apparatus of Venus verrucosa figured by Le Pennec (1980, p. 617) and that of $A$. islandica. At a shell length of approximately 1-2 mm (Figs. 151, 152 ), the $A$. islandica hinge has acquired many adult characteristics, although it does not attain its definitive form until specimens have reached a shell length of approximately $4 \mathrm{~mm}$ (Fig. 12 in Lutz et al. 1982b, p. 761).

\section{Mytilidae}

Fuller and Lutz (1989) published scanning electron micrograph sequences of the larvae and postlarvae of six mytilids from the northwestern Atlantic: Arcuatula papyria (= Amygdalum papyrium) (Figs. 77-80); Brachidontes exustus (Figs. 81-84); Geukensia demissa (Figs. 85-88); Ischadium recurvum (Figs. 8992); Modiolus modiolus (Figs. 97-100); and Mytilus edulis (Figs. 101-104). All six species have a long provinculum with taxodont dentition, with provinculum length and number of teeth increasing steadily during the larval period. The bold, comparatively few provincular teeth of $A$. papyria (Fig. 78) and the small, numerous provincular teeth of $M$. edulis (Fig. 102) clearly differentiate these two species. Most of these mytilid species have a low umbo, round posterior margin, and more pointed anterior margin, although $A$. papyria is distinguished by a high, prominent umbo. The larval shells of $G$. demissa and I. recurvum are difficult to differentiate because of the similarity in their shapes and hinge dentition; however, as articulated by Fuller and Lutz (1989), "discriminant analysis using larval shell length, shell height, provinculum length, and number of teeth aided in classification of these and other sympatric species."

By contrast, post-larval stages of these six mytilid species are plainly distinguished by the presence and type of lateral teeth seen in the SEM sequences published by Fuller and Lutz (1989). Brachidontes exustus has all three types of mytilid lateral teeth, including (1) primary lateral teeth, which form immediately posterior to provincular teeth; (2) secondary lateral teeth, which are posterior to the primary lateral teeth and are part of the dissoconch; and (3) dysodont teeth, which form on the anterior margin of the dissoconch (Figs. 83 and 84). Modiolus modiolus has primary lateral teeth (Figs. 99 and 100), Ischadium recurvum has dysodont teeth (Figs. 91 and 92), Mytilus edulis has secondary lateral and dysodont teeth (Figs. 103 and 104), and there are no lateral teeth in Geukensia demissa (Figs. 87 and 88) or Arcuatula papyria (Figs. 79 and 80) during early post-larval development. The provinculum increases in size and complexity during post-larval development in A. papyria, B. exustus, $G$. demissa, I. recurvum, and $M$. modiolus, but not in $M$. edulis (Fuller \& Lutz 1989).

\section{Ostreidae}

$\mathrm{Hu}$ et al. (1993) published scanning electron micrograph sequences to elucidate species-specific shell features in larval and post-larval stages of four Ostreidae species: Crassostrea gigas, Crassostrea virginica, Ostrea edulis, and Ostrea stentina (= Ostrea equestris) (Figs. 105-123). Useful features for distinguishing larvae of the Ostreidae from those within other families of bivalves include asymmetry of left and right valves associated with a pronounced umbo of the left valve; one or two provincular teeth on each side of the provinculum; and a fasciole with a corresponding notch on the left valve. Qualitative characters, such as hinge dentition and shell shape of the larvae and postlarvae of the four ostreids, distinguish noncongeneric species, whereas species in the same genus generally are differentiated by quantitative features such as the dimensions of the provinculum and shell.

The results of the study by $\mathrm{Hu}$ et al. (1993), when combined with those of previous studies on Crassostrea angulata (Pascual 1971), Crassostrea ariakensis (Tanaka 1980), Crassostrea glomerata (Dinamani 1973), Crassostrea iredalei (Ver 1986), Ostrea denselamellosa (Tanaka 1980), Ostrea lurida (Loosanoff et al. 1966), Ostrea permollis (Forbes 1967), Ostrea puelchana (Castro \& Le Pennec 1988), Ostrea stentina (Pascual 1972), and Ostrea spp. (Chanley \& Dinamani 1980), illustrate that the morphological differences between early ontogenetic stages of species within the genus Crassostrea and those within the genus Ostrea are quite striking. The diagnostic characters for larval and postlarval shells of species within these two genera are summarized as follows.

Morphological larval features of species within the genus Crassostrea include (1) a knobby or beak-shaped umbo directed posteriorly; (2) shell height that is generally greater than shell length; (3) provinculum length that ranges from 68 to $88 \mu \mathrm{m}$; (4) the presence of two rectangular teeth on each side of the provinculum; (5) a well-defined central apparatus; and (6) posterior obscured teeth. By contrast, morphological features of species within the genus Ostrea include (1) a round shell with a large, moderately prominent umbo directed dorsally; (2) shell length that is greater than shell height; (3) provinculum length that ranges from 70 to $100 \mu \mathrm{m}$; (4) the presence of one anterior and one posterior tooth on the left valve and two anterior and two posterior teeth on the right valve, with teeth that are square or triangular; (5) a partially developed central apparatus; and (6) anterior obscured teeth.

Post-larval features of species within the genus Crassostrea include (1) a left valve umbo that is beak shaped and skews backward; (2) two posterior hinge teeth in shells up to $500 \mu \mathrm{m}$ in length; and (3) a ligament that is $40 \mu \mathrm{m}$ from the anterior end of the provinculum. By contrast, post-larval features of species within the genus Ostrea include (1) an umbo that is round and prominent dorsally; (2) one or two anterior hinge teeth in shells 
up to $500 \mu \mathrm{m}$ in length; and (3) a ligament that is close to the anterior end of the provinculum (Hu et al. 1993).

The shell morphological features that are most useful for discriminating larval and post-larval specimens of the four ostreids that are included in this monograph are articulated by $\mathrm{Hu}$ et al. (1993) and may be summarized as follows:

(1) The species-specific characteristics of the provinculum remain relatively constant throughout the developmental stages. These diagnostic characters include the dimensions of the provinculum, the shape of the hinge teeth, and the modification pattern of the hinge teeth during the late larval stages. For example, the provinculum of larval and post-larval (up to a shell length of $550 \mu \mathrm{m}$ ) specimens of Crassostrea virginica is shorter but wider $(50 \mu \mathrm{m}$ long and $14 \mu \mathrm{m}$ wide) than that of Crassostrea gigas (56 $\mu \mathrm{m}$ long and $10 \mu \mathrm{m}$ wide). The transverse ridges are less defined and fewer in $C$. gigas than in $C$. virginica. The posterior hinge teeth of $C$. virginica are well defined even in latestage larvae. These observations agree with the pattern of larval hinge modification in the genus Crassostrea postulated by Dinamani (1976). The range of provincular lengths of Ostrea stentina is $70-79 \mu \mathrm{m}$, which is much shorter than the $80-95 \mu \mathrm{m}$ provincular length range of Ostrea edulis (Hu et al. 1993).

(2) The four species have different shell shapes, including prominence of umbos, shapes of anterior and posterior ends, rotation of the longitudinal axis, and shell lengthheight ratio. The shell shape of larval specimens of Crassostrea virginica is relatively compressed dorsoventrally, with a narrow and pointed anterior end, whereas that of Crassostrea gigas larvae is more extended in dorsoventral directions and its anterior end appears broad and blunt. A knobby umbo with an elongated anterior end is present in late-stage larval specimens of Ostrea stentina, whereas the umbo of Ostrea edulis is always flat and the anterior and posterior are nearly equally developed. Shell shape is also useful for identification of post-larval specimens. For example, two shoulders (anterior and posterior dorsal margins) extend at an angle of approximately $90 \mathrm{deg}$ in $C$. gigas and at an angle of $140 \mathrm{deg}$ in $C$. virginica, and were well defined in O. stentina but irregular in O. edulis (Hu et al. 1993).

In summary, generic and species diagnostic shell characters have been identified for early life-history stages of two species within the genus Crassostrea (C. gigas and $C$. virginica) and two species within the genus Ostrea (O. edulis and O. stentina). A key has been presented by $\mathrm{Hu}$ et al. (1993) summarizing these morphological characteristics that should provide a practical tool for the identification of larval and post-larval specimens of these ostreids isolated from planktonic and benthic samples.

\section{Teredinidae}

Scanning electron micrograph sequences published by Fuller et al. (1989a) and Tan et al. (1993) of disarticulated shell valves of Teredo navalis and Bankia gouldi, respectively, revealed qualitative and quantitative differences in larval and post-larval morphological features (Figs. 69-76). These sequences provide useful aids for the identification of larval and post-larval specimens of these two species isolated from plankton and benthic samples. In particular, the following features are important in distinguishing the larvae of B. gouldi from those of T. navalis: slope of the shoulders [the dorsal shell margin on the anterior and posterior ends of the hinge (Chanley \& Dinamani 1980)]; length of the provinculum/ hinge-line; and length of the posterior tooth of the left valve provinculum.

Tan et al. (1993) point out that, in larval shells of similar size, the shoulders of Teredo navalis (Fig. 73) are considerably steeper (less rounded) than those of Bankia gouldi (Fig. 69). This difference in shell shape is useful in distinguishing the two species. The initial size of the planktonic stage of a B. gouldi larva is much smaller than that of the larviparous $T$. navalis because of the difference in their development. Despite the difference in initial larval shell size, both species metamorphose at a shell height of about $230 \mu \mathrm{m}$, as indicated by the appearance of the ligament pit.

The larvae of Bankia gouldi and Teredo navalis can be distinguished on the basis of the length of the provinculum of the left valve. The average length of the provinculum/hinge-line measured by Tan et al. (1993) from micrographs of the left valves of $B$. gouldi $(38.1 \pm 1.8 \mu \mathrm{m}, n=9)$ (Fig. 70) is significantly smaller than that of $T$. navalis $(46.7 \pm 1.3 \mu \mathrm{m}, n=9)$ (Fig. 74). The provincular length measurements of the left valve are more useful than those of the right valve because the latter varies significantly with growth.

Larvae of Bankia gouldi can also be distinguished from those of Teredo navalis by the length of the posterior provincular tooth of the left valve $(6.4 \pm 0.6 \mu \mathrm{m}, n=7)$ (Fig. 70) which is significantly shorter than that of $T$. navalis $(8.2 \pm 0.3 \mu \mathrm{m})$ (Fig. 74) (Tan et al. 1993).

\section{Practical Use of this Monograph}

Although the SEM sequences presented in Figures 1-195 accurately depict the gross morphologies/morphometrics and hinge structures of the disarticulated shell valves of the larvae and/or postlarvae of 56 species of bivalves, it is important to emphasize that a scanning electron microscope is not necessary to observe even fine hinge structures associated with the ontogenetic stages of these species. Such structures are readily visible using a wide range of optical compound microscopes equipped with high-intensity reflected light sources, although the disarticulated shell valves must be viewed in several planes of focus to discern the often subtle details seen clearly in the scanning electron micrographs.

The comparisons of the larval and early post-larval stages of two mytilids (Mytilus edulis and Modiolus modiolus) published by Lutz and Hidu (1979) and depicted in Figures 97-104 dramatically illustrate this point. In their studies, measurements of larval dimensions (shell length, height, and provinculum length) and dentition counts were made under a standard petrographic microscope equipped with a highintensity reflected light source. Using this procedure, Lutz and Hidu (1979) were able to obtain quantitative measurements and counts on approximately 20 specimens per hour. Numerous specimens were also examined and measured under a scanning electron microscope to confirm the accuracy of these optical microscopic measurements and counts. 
Their results indicated that, for a given number of provincular teeth, there was no overlap between the range extremes in either provinculum length or total shell length of the two species. There were no quantitative differences between left and right valve of individual specimens other than occasional minor discrepancies in dentition counts due to the interlocking nature of the hinge teeth. Lutz and Hidu (1979, p. 115) concluded that "careful examination of the hinge morphology of prodissoconchs and early dissoconchs using routine optical microscopic techniques should facilitate unambiguous differentiation of all early life-history stages of these two species."

In conclusion, scanning electron microscopy provides a powerful tool for photographically depicting the accurate gross shell morphology/morphometry and details of the hinge structure of the disarticulated shell valves of the larvae and early postlarvae of known species of bivalves cultured under controlled laboratory conditions. These morphological characters, in turn, provide researchers with invaluable aids for identifying (using routine optical microscopic techniques) the early life-history stages of these species isolated from plankton and benthic samples.

\section{ACKNOWLEDGMENTS}

The authors thank William Arnold, Robert Bisker, Thomas Bright, Bernardita Campos, Judy McDowell Capuzzo, Melbourne Carriker, Paul Chanley, Alison Craig, Greg Debrosse, William Foster, Mary Gibbons, John Grazul, Victor Greenhut, Harold Haskin, Kathleen Huntington, John Kraeuter, Dale Leavitt, Robert Loveland, William Mook, James Moore, Steven Murawski, Elizabeth W. North, Hugh Porter, Robert Prezant, Robert Robertson, John Ropes, William Sacco, Neil Savage, Rudolf Scheltema, Ruth Turner, Rosa Van Dessel, Eric Wagner, Randy Walker, Thomas Waller, Jean Watkinson, and John Whitcomb for their advice, assistance, and helpful comments. This research was supported by the New Jersey and South Carolina Agricultural Experiment Stations; the School of Environmental and Biological Sciences of Rutgers University; the South Carolina Sea Grant Consortium; Steinetz Awards from the Department of Biological Sciences, Rutgers University; a Grant-in-Aid of Research from the Society of Sigma Xi (SCF); the Maryland Power Plant Research Program; the Center for Environmental and Estuarine Studies, University of Maryland; NSF Grants EAR 81-21212 and EAR-84-17011 (RAL); and various NOAA Sea Grants (RAL).

\section{LITERATURE CITED}

Ansell, A. D. 1962. The functional morphology of the larva, and the post-larval development of Venus striatula (da Costa). J. Mar. Biol. Assoc. U.K. 42:419-443.

Baldwin, B. S., A. S. Pooley, Y.-P. Hu, D. B. Conn, V. S. Kennedy \& R. A. Lutz. 1994. Identification of larval and post-larval zebra mussels and co-occurring bivalves in freshwater and estuarine habitats using shell morphology. In: Proceedings of the Fourth International Zebra Mussel Conference. Madison, WI: Wisconsin Sea Grant Institute. pp. 479-488.

Bayne, B. L. 1965. Growth and the delay of metamorphosis of the larvae of Mytilus edulis (L.). Ophelia 2:1-47.

Bayne, B. L. 1971. Some morphological changes that occur at the metamorphosis of the larvae of Mytilus edulis. In: Crisp, D. J., editor. Proceedings of the Fourth European Marine Biology Symposium, Bangor, 1969. New York, NY: Cambridge University Press. pp. 259-280.

Bayne, B. L. 1976. The biology of mussel larvae. In: Bayne, B. L., editor. Marine mussels: their ecology and physiology. New York, NY: Cambridge University Press. pp. 81-120.

Bernard, F. 1895. Première note sur le développement et la morphologie de la coquille chez les lamellibranches. Bull. Soc. Géol. Fr. Ser. 3 23:104-154.

Bernard, F. 1896a. Deuxième note sur le développement et la morphologie de la coquille chez les lamellibranches (Taxodontes). Bull. Soc. Géol. Fr. Ser. 3 24:54-82.

Bernard, F. 1896b. Troisième note sur le développement et la morphologie de la coquille chez les lamellibranches (Anisomyaires). Bull. Soc. Géol. Fr. Ser. 3 24:412-449.

Bernard, F. 1897. Quatrième et dernière note sur le développement et la morphologie de la coquille chez les lamellibranches. Bull. Soc. Géol. Fr. Ser. $325: 559-566$.

Bernard, F. 1898. Recherches ontogéniques et morphologiques sur la coquille des lamellibranches. Premiere partie: taxodontes et anisomyaires. Ann. Sci. Nat. Zool. 8:1-208.

Booth, J. D. 1977. Common bivalve larvae from New Zealand: Mytilacea. N. Z. J. Mar. Freshw. Res. 11:407-440.

Booth, J. D. 1979a. Common bivalve larvae from New Zealand: Pteriacea, Anomiacea, Ostreacea. N. Z. J. Mar. Freshw. Res. 13:131-139.
Booth, J. D. 1979b. Common bivalve larvae from New Zealand: Leptonacea. N. Z. J. Mar. Freshw. Res. 13:241-254.

Boyle, P. J. \& R. D. Turner. 1976. The larval development of the wood boring piddock Martesia striata (L.) (Mollusca: Bivalvia: Pholadidae). J. Exp. Mar. Biol. Ecol. 22:55-68.

Calloway, C. B. \& R. D. Turner. 1979. New techniques for preparing shells of bivalve larvae for examination with the scanning electron microscope. Ann. Rep. Am. Malacol. Union. Inc. 1978: $17-24$.

Carlton, J. T. 1999. Molluscan invasions in marine and estuarine communities. Malacologia 41:439-454.

Carriker, M. R. \& R. E. Palmer. 1979. Ultrastructural morphogenesis of prodissoconch and early dissoconch valves of the oyster Crassostrea virginica. Proc. Natl. Shellfish. Assoc. 69:103-128.

Castagna, M. 1975. Culture of the bay scallop, Argopecten irradians, in Virginia. Mar. Fish. Rev. 37:19-24.

Castagna, M. \& J. Kraeuter. 1977. Mercenaria culture using stone aggregate for predator protection. Proc. Natl. Shellfish. Assoc. 67: $1-6$.

Castro, N. F. \& M. Le Pennec. 1988. Modalities of brooding and morphogenesis of larvae in Ostrea puelchana (D'Orbigny) under experimental rearing. J. Mar. Biol. Assoc. U.K. 68:399-407.

Chanley, P. E. 1965. Larval development of a boring clam, Barnea truncata. Chesap. Sci. 6:162-166.

Chanley, P. E. 1969. Larval development of the coquina clam, Donax variabilis Say, with a discussion of the structure of the larval hinge in the Tellinacea. Bull. Mar. Sci. 19:214-224.

Chanley, P. E. \& J. D. Andrews. 1971. Aids for identification of bivalve larvae of Virginia. Malacologia 11:45-119.

Chanley, P. E. \& M. Chanley. 1980. Reproductive biology of Arthritica crassiformis and $A$. bifurca, two commensal bivalve molluscs (Leptonacea). N. Z. J. Mar. Freshw. Res. 14:31-43.

Chanley, P. E. \& P. Dinamani. 1980. Comparative descriptions of some oyster larvae from New Zealand and Chile, and a description of a new genus of oyster, Tiostrea. N. Z. J. Mar. Freshw. Res. 14:103120.

Cohen, A. N. \& J. T. Carlton. 1998. Accelerating invasion rate in a highly invaded estuary. Science 279:555-558. 
Culliney, J. L. \& R. D. Turner. 1976. Larval development of the deepwater wood boring bivalve, Xylophaga atlantica Richards (Mollusca, Bivalvia, Pholadidae). Ophelia 15:149-161.

de Schweinitz, E. H. \& R. A. Lutz. 1976. Larval development of the northern horse mussel, Modiolus modiolus (L.), including a comparison with the larvae of Mytilus edulis L. as an aid in planktonic identification. Biol. Bull. 150:348-360.

Dinamani, P. 1973. Embryonic and larval development in the New Zealand rock oyster, Crassostrea glomerata (Gould). Veliger 15:295-299.

Dinamani, P. 1976. The morphology of the larval shell in the genus Crassostrea Sacco, 1897 (Ostreidae). J. Moll. Stud. 42:95-107.

Forbes, M. L. 1967. Generic differences in prodissoconchs of Gulf of Mexico oysters. Bull. Mar. Sci. 17:338-347.

Fuller, S. C., Y.-P. Hu, R. A. Lutz \& M. Castagna. 1989a. Shell and pallet morphology in early developmental stages of Teredo navalis $\mathrm{L}$. (Bivalvia: Teredinidae). Nautilus 103:24-35.

Fuller, S. C. \& R. A. Lutz. 1989. Shell morphology of larval and postlarval mytilids from the northwestern Atlantic. J. Mar. Biol. Assoc. U.K. 69:181-218.

Fuller, S. C., R. A. Lutz \& A. Pooley. 1989b. Procedures for accurate documentation of shapes and dimensions of larval bivalve shells with scanning electron microscopy. Trans. Am. Microsc. Soc. 108:58-63.

Garland, E. D. \& C. A. Zimmer. 2002. Techniques for the identification of bivalve larvae. Mar. Ecol. Prog. Ser. 225:299-310.

Gibbons, M. C. \& M. Castagna. 1984. Serotonin as an inducer of spawning in six bivalve species. Aquaculture 40:189-191.

Gollasch, S. 2002. The importance of ship hull fouling as a vector of species introductions into the North Sea. Biofouling 18:105-121.

Goodsell, J. G., S. C. Fuller, A. G. Eversole \& R. A. Lutz. 1992. Larval and early postlarval shell morphology of several venerid clams. $J$. Mar. Biol. Assoc. U.K. 72:231-255.

Goodwin, J. D., R. A. Lutz, S. Gallager, S. Johnson \& V. S. Kennedy. 2018. Optical imaging and molecular sequencing of a preserved collection of bivalve larvae. J. Shellfish. Res. 37:449-466.

Goodwin, J. D., E. W. North \& V. S. Kennedy. 2016b. Identification of Crassostrea virginica using polarized light microscopy in a mesohaline region of Chesapeake Bay. J. Shellfish Res. 35 $157-168$.

Goodwin, J. D., E. W. North, I. D. Mitchell, C. M. Thompson \& H. R. McFadden. 2016a. Improving a semi-automated classification technique for bivalve larvae: automated image acquisitions and measures of quality control. Limnol. Oceanogr. Methods 14 683-697.

Goodwin, J. D., E. W. North \& C. M. Thompson. 2014. Evaluating and improving a semi-automated image analysis technique for identifying bivalve larvae. Limnol. Oceanogr. Methods 12:548-562.

Gustafson, R. G. \& R. A. Lutz. 1992. Larval and early post-larval development of the protobranch bivalve Solemya velum (Mollusca: Bivalvia). J. Mar. Biol. Assoc. U.K. 72:383-402.

Hare, M. P., S. R. Palumbi \& C. A. Butman. 2000. Single-step species identification of bivalve larvae using multiplex polymerase chain reaction. Mar. Biol. 137:953-961.

Hayes, K. R. \& C. L. Hewitt. 1998. A risk assessment framework for ballast water introductions. CRIMP technical report \#14. Hobart, Australia: CSIRO Division of Marine Research. 68 pp.

Hendriks, I. E., L. A. van Duren \& P. M. J. Herman. 2005. Image analysis techniques: a tool for the identification of bivalve larvae? J. Sea Res. 54:151-162.

Henzler, C. M., E. A. Hoaglund \& S. D. Gaines. 2010. FISH-CSa rapid method for counting and sorting species of marine zooplankton. Mar. Ecol. Prog. Ser. 410:1-11.

Hu, Y.-P., S. C. Fuller, M. Castagna, R. C. Vrijenhoek \& R. A. Lutz. 1993. Shell morphology and identification of early life history stages of congeneric species of Crassostrea and Ostrea. J. Mar. Biol. Assoc. U.K. 73:471-496.
Hu, Y.-P., R. A. Lutz \& R. C. Vrijenhoek. 1992. Electrophoretic identification and genetic analysis of bivalve larvae. Mar. Biol. 113:227-230.

Jablonski, D. \& R. A. Lutz. 1980. Molluscan larval shell morphology: ecological and paleontological applications. In: Rhoads, D. C. \& R. A. Lutz, editors. Skeletal growth of aquatic organisms. New York, NY: Plenum Press. pp. 323-377.

Jablonski, D. \& R. A. Lutz. 1983. Larval ecology of marine benthic invertebrates: paleobiological implications. Biol. Rev. Camb. Philos. Soc. 58:21-89.

Jørgensen, C. B. 1946. Lamellibranchia. Medd. Dan. Fisk. Havunders. 4:277-311.

Kennedy, V. S., S. C. Fuller \& R. A. Lutz. 1991. Shell and hinge development of young Corbicula fluminea (Muller) (Bivalvia: Corbiculoidea). Am. Malacol. Bull. 8:107-111.

Kennedy, V. S., R. A. Lutz \& C. A. Fuller. 1989. Larval and early postlarval development of Macoma mitchelli Dall (Bivalvia: Tellinidae). Veliger 32:29-38.

LaBarbera, M. 1975. Larval and post-larval development of the giant clams Tridacna maxima and Tridacna squamosa (Bivalvia, Tridacnidae). Malacologia 15:69-79.

Larsen, J. B., M. E. Frischer, K. W. Ockelmann, L. J. Rasmussen \& B. W. Hansen. 2007. Temporal occurrence of planktotrophic bivalve larvae identified morphologically and by single step nested multiplex PCR. J. Plankton Res. 29:423-436.

Larsen, J. B., M. E. Frischer, L. J. Rasmussen \& B. W. Hansen. 2005. Single-step nested multiplex PCR to differentiate between various bivalve larvae. Mar. Biol. 146:1119-1129.

Lebour, M. V. 1938. Notes on the breeding of some lamellibranchs from Plymouth and their larvae. J. Mar. Biol. Assoc. U.K. 23:119:144.

Le Pennec, M. 1973. Morphogenèse de la charnière chez cinq espèces de Veneridae. Malacologia 12:225-245.

Le Pennec, M. 1978. Génèse de la coquille larvaire et postlarvaire chez divers bivalves marins. Thèse de Doctorat d'Etat, Université de Bretagne Occidentale, Brest, France. 219 pp.

Le Pennec, M. 1980. The larval and post-larval hinge of some families of bivalve molluscs. J. Mar. Biol. Assoc. U.K. 60:601-617.

Le Pennec, M. \& A. Lucas. 1970. Comparative growth and morphology of some venerid larvae (Bivalvia, Veneridae). Malacol. Rev. 3:175-183.

Le Pennec, M. \& M. Masson. 1976. Morphogenese de la coquille de Mytilus galloprovincialis (Lmk.) eleve au laboratoire. Cah. Biol. Mar. 17:113-118.

Loosanoff, V. L. \& H. C. Davis. 1963. Rearing of bivalve mollusks. $A d v$. Mar. Biol. 1:1-136.

Loosanoff, V. L., H. C. Davis \& P. E. Chanley. 1966. Dimensions and shapes of larvae of some marine bivalve mollusks. Malacologia 4:351-435.

Lutz, R. A. 1979. The bivalve "larval ligament pit" as an exclusively post-larval feature. Proc. Natl. Shellfish. Assoc. 69:197 (Abstract).

Lutz, R. A. 1988. Dispersal of organisms at deep-sea hydrothermal vents: a review. Oceanol. Acta 8:23-29.

Lutz, R. A. 2012. Deep-sea hydrothermal vents. In: Bell, E. M., editor. Life at extremes: environments, organisms and strategies for survival. Oxfordshire, UK: CABI. pp. 242-270.

Lutz, R. A., J. Goodsell, M. Castagna, S. Chapman, C. Newell, H. Hidu, R. Mann, D. Jablonski, V. Kennedy, S. Siddall, R. Goldberg, H. Beattie, C. Falmagnem, A. Chestnut \& A. Partridge. 1982a. Preliminary observations on the usefulness of hinge structures for identification of bivalve larvae. J. Shellfish Res. 2:65-70.

Lutz, R. A. \& H. Hidu. 1979. Hinge morphogenesis in the shells of larval and early post-larval mussels (Mytilus edulis L. and Modiolus modiolus (L.). J. Mar. Biol. Assoc. U.K. 59:111-121.

Lutz, R. A. \& D. Jablonski. 1978a. Cretaceous bivalve larvae. Science 199:439-440.

Lutz, R. A. \& D. Jablonski. 1978b. Classification of bivalve larvae and early post-larvae using scanning electron microscopy. Am. Zool. 18:647 (Abstract). 
Lutz, R. A. \& D. Jablonski. 1979. Micro- and ultramorphology of larval bivalve shells: ecological, paleoecological, and paleoclimatic applications. Proc. Natl. Shellfish. Assoc. 69:197-198 (Abstract).

Lutz, R. A. \& D. Jablonski. 1981. Identification of living and fossil bivalve larvae. Science 212:1419.

Lutz, R. A. \& M. J. Kennish. 1992. Ecology and morphology of larval and early postlarval mussels. In: Gosling, E. A., editor. The Mussel Mytilus. Amsterdam, The Netherlands: Elsevier. pp. 53-85.

Lutz, R. A., R. Mann, J. G. Goodsell \& M. Castagna. 1982b. Larval and early post-larval development of the ocean quahog, Arctica islandica. J. Mar. Biol. Assoc. U.K. 62:745-769.

Malchus, N. \& A. F. Sartori. 2013. The early shell: ontogeny, features and evolution. Treatise on invertebrate paleontology, part N, Bivalvia revised, volume 1, chapter 4. Treatise Online 61:1-114.

Miyazaki, I. 1962. On the identification of lamellibranch larvae. Nippon Suisan Gakkaishi 28:955-966.

Morse, D. E., H. Duncan, N. Hooker \& A. Morse. 1977. Hydrogen peroxide induces spawning in mollusks, with activation of prostaglandin endoperoxide synthetase. Science 196:298-300.

Murphy, K. R., D. Ritz \& C. L. Hewitt. 2002. Heterogeneous zooplankton distribution in a ship's ballast tanks. J. Plankton Res. 24:729-734.

Newell, G. E. \& R. C. Newell. 1963. Marine plankton: a practical guide. London, UK: Hutchinson Educational Limited. 207 pp.

North, E. W., Z. Schlag, R. R. Hood, M. Li, L. Zhong, T. Gross \& V. S. Kennedy. 2008. Vertical swimming behavior influences the dispersal of simulated oyster larvae in a coupled particle-tracking and hydrodynamic model of Chesapeake Bay. Mar. Ecol. Prog. Ser. 359:99-115.

Odhner, N. H. 1914. Notizen über die Fauna der Adria bei Rovingo. Berträge zur Kenntnis der marinen Molluskenfauna von Rovigno in Istrien. Zool. Anz. 44:156-170.

Pascual, E. 1971. Morfologiá de la Charnela larvaria de Crassostrea angulata (Lmk) en differentes fases de su desarrollo. Investig. Pesq. 35:549-563.

Pascual, E. 1972. Estudio de las conchas larvarias de Ostrea stentina Payr. y Ostrea edulis L. Investig. Pesq. 36:297-310.

Paugam, A., C. D’Ollone, J.-C. Cochard, P. Garen \& M. Le Pennec. 2006. The limits of morphometric features for the identification of black-lip pearl oyster (Pinctada margaritifera) larvae. J. Shellfish Res. 25:959-967.

Ramorino, L. \& B. Campos. 1983. Larvas y postlarvas de Mytilidae de Chile (Mollusca: Bivalvia). Rev. Biol. Mar. Valparaíso 19:143-192.

Redfearn, P. 1982. Larval shell development of the toheroa, Paphies ventricosa (Gray, 1843) (Mactracea: Mesodesmatidae). N. Z. J. Mar. Freshw. Res. 16:241-252.

Redfearn, P. 1987. Larval shell development of the northern tuatua, Paphies subtriangulata (Bivalvia, Mesodesmatidae). N. Z. J. Mar. Freshw. Res. 21:65-70.

Redfearn, P., P. Chanley \& M. Chanley. 1986. Larval shell development of four species of New Zealand mussels: (Bivalvia, Mytilacea). N. Z.J. Mar. Freshw. Res. 20:157-172.

Rees, C. B. 1950. The identification and classification of lamellibranch larvae. Hull Bull. Mar. Ecol. 3:73-104.

Ruiz, G. M., P. W. Fofonoff, J. T. Carlton, M. J. Wonham \& A. H. Hines. 2000. Invasion of coastal marine communities in North America: apparent patterns, processes, and biases. Annu. Rev. Ecol. Syst. 31:481-531.

Scheltema, R. S. 1971. Dispersal of phytoplanktotropic shipworm larvae (Bivalvia: Teredinidae) over long distances by ocean currents. Mar. Biol. 11:5-11.

Siddall, S. E. 1977. Temperature and salinity effects on mussels. UNFAO Aquacult. Bull. 8:12.

Siddall, S. E. 1978. The development of the hinge line in tropical mussel larvae of the genus Perna. Proc. Natl. Shellfish. Assoc. 68:86 (Abstract).
Stafford, J. 1912. On the recognition of bivalve larvae in plankton collections. Contrib. Can. Biol. 1906-1910:221-242.

Sullivan, C. M. 1948. Bivalve larvae of Malpeque Bay, P.E.I. Bull. Fish. Res. Board Can. 77:1-36.

Tan, A., Y.-P. Hu, M. Castagna, R. A. Lutz, M. J. Kennish \& A. S. Pooley. 1993. Shell and pallet morphology of early developmental stages of Bankia gouldi (Bartsch, 1908) (Bivalva: Teredinidae). Nautilus 107:63-75.

Tanaka, Y. 1980. Identification of bivalve larvae. Aquabiology 2:289291, 369-371.

Thompson, C. M., M. P. Hare \& S. M. Gallager. 2012a. Semiautomated image analysis for the identification of bivalve larvae from a Cape Cod estuary. Limnol. Oceanogr. Methods 10:538-554.

Thompson, C. M., R. H. York \& S. M. Gallager. 2012b. Species-specific abundance of bivalve larvae in relation to biological and physical conditions in a Cape Cod estuary. Mar. Ecol. Prog. Ser. 469:53-69.

Tiwari, S. \& S. M. Gallager. 2003a. Optimizing multiscale invariants for the identification of bivalve larvae. In: Proceedings of the 2003 IEEE International Conference on Image Processing, Barcelona, Spain, September 14-17, 2003.

Tiwari, S. \& S. M. Gallager. 2003b. Machine learning and multiscale methods in the identification of bivalve larvae. In: Proceedings of the 9th IEEE International Conference on Computer Vision, Nice, France, October 14-17, 2003.

Tremblay, M. J., L. D. Meade \& G. V. Hurley. 1987. Identification of planktonic sea scallop larvae (Placopecten magellanicus) (Gmelin). Can. J. Fish. Aquat. Sci. 44:1361-1366.

Trueman, E. R. 1950. Observations on the ligament of Mytilus edulis. Q. J. Microsc. Sci. 91:225-236.

Turner, R. D. 1966. A survey and illustrated catalogue of the Teredinidae (Mollusca: Bivalvia). Cambridge, MA: The Museum of Comparative Zoology, Harvard University. 265 pp.

Turner, R. D. 1971. Identification of marine wood-boring molluscs. In: Jones, E. B. G. \& S. K. Eltringham, editors. Marine borers, fungi and fouling organisms of wood. Paris, France: Organization for Economic Co-operation and Development. pp. 17-64.

Turner, R. D. 1976a. Some factors involved in the settlement and metamorphosis of marine bivalve larvae. In: Sharply, J. M. \& A. M. Kaplan, editors. Proceedings of the 3rd International Biodegradation Symposium, Kingston, RI. London, UK: Applied Science Publishers. pp. 409-416.

Turner, R. D. 1976b. Search for a 'weak link'. In: Bultman, J. D., editor In: Proceedings of a Workshop on the Biodeterioration of Tropical Woods: chemical basis for natural resistance. Washington, DC: Naval Research Laboratory. pp. 31-40.

Turner, R. D. \& P. J. Boyle. 1975. Studies of bivalve larvae using the scanning electron microscope and critical point drying. Bull. Am. Malacol. Union Inc. 40:59-65.

Turner, R. D. \& A. C. Johnson. 1970. Some problems and techniques in rearing bivalve larvae. Ann. Rep. Am. Malacol. Union. Inc. 1969: 9-13.

Ver, L. M. M. 1986. Early development of Crassostrea iredalei (Faustino, 1932) (Bivalvia: Ostreidae), with notes on the structure of the larval hinge. Veliger 29:78-85.

Wang, S., Z. Bao, L. Zhang, N. Li, A. Zhan, W. Guo, X. Wang \& J. Hu. 2006. A new strategy for species identification of planktonic larvae: PCR-RFLP analysis of the internal transcribed spacer region of ribosomal DNA detected by agarose gel electrophoresis or DHPLC. J. Plankton Res. 28:375-384.

Wassnig, M. \& P. C. Southgate. 2012. Embryonic and larval development of Pteria penguin (Röding, 1798) (Bivalvia: Pteriidae). J. Moll. Stud. 78:134-141.

Werner, B. 1939. Über die Entwicklung Artunterscheidung von Muschellarven des Nordseeplanktons, unter besonderer Berücksichtigung der Schalenentwicklung. Zool. Jahrb. Abt. Anat. Ontog. 66: $1-54$. 
TABLE 1.

The 56 species of bivalves for which larval and/or post-larval SEM sequences are depicted in Figures 1-195.

\begin{tabular}{|c|c|c|c|c|c|c|}
\hline $\begin{array}{c}\text { Figure } \\
\text { numbers }\end{array}$ & Order & Family & Genus & Species & Authority & Source of sexually mature adult bivalves \\
\hline $1-4$ & Adapedonta & Hiatellidae & Hiatella & arctica & (Linnaeus, 1767) & Pemaquid, ME \\
\hline $5-8$ & Adapedonta & Pharidae & Ensis & leei & M. Huber, 2015 & Damariscotta River, ME \\
\hline $9-12$ & Arcida & Arcidae & Arca & noae & Linnaeus, 1758 & Istrian Peninsula Coast, Rovinj, Croatia \\
\hline $13-16$ & Arcida & Arcidae & Lunarca & ovalis & (Bruguière, 1789) & Wachapreague, VA \\
\hline $17-19$ & Arcida & Noetiidae & Noetia & ponderosa & (Say, 1822) & Wachapreague, VA \\
\hline $20-23$ & Cardiida & Cardiidae & Dinocardium & robustum & (Lightfoot, 1786) & Indian River near Grant, FL \\
\hline $24-27$ & Cardiida & Cardiidae & Laevicardium & mortoni & (Conrad, 1831) & Coastal bay near Wachapreague, VA \\
\hline $28-31$ & Cardiida & Solecurtidae & Tagelus & plebeius & (Lightfoot, 1786) & Delaware Bay, NJ \\
\hline $32-35$ & Cardiida & Tellinidae & Ameritella & agilis & (Stimpson, 1857) & Wachapreague Inlet, Wachapreague, VA \\
\hline $36-39$ & Cardiida & Tellinidae & Ameritella & mitchelli & (Dall, 1895) & Choptank River, MD \\
\hline $40-43$ & Cardiida & Tellinidae & Limecola & balthica & (Linnaeus, 1758) & Lowe's Cove, Walpole, ME \\
\hline 44 & Carditida & Carditidae & Cyclocardia & borealis & (Conrad, 1832) & Continental Shelf off NJ \\
\hline 45 & Carditida & Astartidae & Astarte & castanea & (Say, 1822) & Continental Shelf off NJ \\
\hline $46-49$ & Myida & Dreissenidae & Dreissena & bugensis & (Andrusov, 1897) & Lake Ontario near Rochester, NY \\
\hline $50-53$ & Myida & Dreissenidae & Dreissena & polymorpha & (Pallas, 1771) & St. Lawrence River near Cape Vincent, NY \\
\hline $54-57$ & Myida & Dreissenidae & Mytilopsis & leucophaeata & (Conrad, 1831) & Hudson River near Piermont, NY \\
\hline $58-61$ & Myida & Myidae & Mya & arenaria & Linnaeus, 1758 & Damariscotta River, Walpole, ME \\
\hline $62-64$ & Myida & Myidae & Mya & truncata & Linnaeus, 1758 & Gulf of Maine off Boothbay Harbor, ME \\
\hline 65,66 & Myida & Pholadidae & Cyrtopleura & costata & (Linnaeus, 1758) & Indian River, FL \\
\hline 67,68 & Myida & Pholadidae & Diplothyra & curta & (G. B. Sowerby I, 1834) & Mississippi Sound, MS \\
\hline $69-72$ & Myida & Teredinidae & Bankia & gouldi & (Bartsch, 1908) & York River, Gloucester Point, VA \\
\hline $73-76$ & Myida & Teredinidae & Teredo & navalis & Linnaeus, 1 & Coastal bay near Wachapreague Inlet, VA \\
\hline $77-80$ & Mytilida & Mytilidae & Arcuatula & papyria & (Conrad, 1 & Indian River, FL \\
\hline $81-84$ & Mytilida & Mytilidae & Brachidontes & exustus & (Linnaeus, & Cabbage Island and Will \\
\hline $85-88$ & Mytilida & Mytilidae & Geukensia & demissa & (Dillwyn, 1817) & Maurice River, NJ \\
\hline $89-92$ & Mytilida & Mytilidae & Ischadium & recurvum & (Rafinesque, 1820) & James River, VA \\
\hline 93,94 & Mytilida & Mytilidae & Leiosolenus & bisulcatus & (d'Orbigny, 1853) & Jamaica, West Indies \\
\hline 95,96 & Mytilida & Mytilidae & Modiolus & americanus & (Leach, 1815) & West coast of Florida \\
\hline $97-100$ & Mytilida & Mytilidae & Modiolus & modiolus & (Linnaeus, 1758) & Cape Newagen, ME \\
\hline $101-104$ & Mytilida & Mytilidae & Mytilus & edulis & Linnaeus, 1758 & Continental Shelf off NJ \\
\hline $105-109$ & Ostreida & Ostreidae & Crassostrea & gigas & (Thunberg, 1793) & Coast Oyster Company, Quilcene, WA \\
\hline $110-114$ & Ostreida & Ostreidae & Crassostrea & virginica & (Gmelin, 1791) & Delaware Bay, NJ \\
\hline $115-118$ & Ostreida & Ostreidae & Ostrea & edulis & Linnaeus, 1758 & Walpole, ME \\
\hline $119-123$ & Ostreida & Ostreidae & Ostrea & stentina & Payraudeau, 1826 & Newport River Estuary, NC \\
\hline $124-127$ & Pectinida & Anomiidae & Anomia & simplex & d'Orbigny, 1853 & Wachapreague Inlet, Wachapreague, VA \\
\hline $128-130$ & Pectinida & Pectinidae & Argopecten & irradians & (Lamarck, 1819) & Cape Cod Bay, MA \\
\hline $131-134$ & Pectinida & Pectinidae & Argopecten & $\begin{array}{l}\text { irradians } \\
\quad \text { concentricus }\end{array}$ & (Say, 1822) & $\begin{array}{l}\text { Coast of North Carolina near Morehead } \\
\text { City }\end{array}$ \\
\hline $135-138$ & Pectinida & Pectinidae & Pecten & maximus & (Linnaeus, 1758) & Coast of Brest, France \\
\hline $139-143$ & Pectinida & Pectinidae & Placopecten & magellanicus & Gmelin, 1791 & $\begin{array}{l}\text { St. John's, Newfoundland (larvae); } \\
\text { Damariscotta River, ME (postlarvae) }\end{array}$ \\
\hline 144,145 & Pholadomyida & Lyonsiidae & Lyonsia & hyalina & (Conrad, 1831) & Mason's Beach, VA \\
\hline 146 & Pholadomyida & Periplomatidae & Periploma & leanum & (Conrad, 1831) & Continental Shelf off New Jersey \\
\hline 147,148 & Solemyida & Solemyidae & Solemya & velum & Say, 1822 & $\begin{array}{l}\text { Upper Buttermilk Bay, MA and Shark } \\
\text { River, NJ }\end{array}$ \\
\hline $149-152$ & Venerida & Arcticidae & Arctica & islandica & (Linnaeus, 1767) & $\begin{array}{l}\text { Continental Shelf, off New Jersey and } \\
\text { Rhode Island }\end{array}$ \\
\hline $153-156$ & Venerida & Mactridae & Mulinia & Lateralis & (Say, 1822) & Wachapreague, VA \\
\hline $157-159$ & Venerida & Mactridae & Rangia & cuneata & $\begin{array}{l}\text { (G. B. Sowerby I, } \\
\text { 1832) }\end{array}$ & Cohansey River near Bridgeton, NJ \\
\hline $160-163$ & Venerida & Mactridae & Spisula & solidissima & (Dillwyn, 1817) & Continental Shelf off Rhode Island \\
\hline $164-167$ & Venerida & Mesodesmatidae & Mesodesma & arctatum & (Conrad, 1831) & $\begin{array}{l}\text { Sable Island Bank (depth } 42 \mathrm{~m} \text { ) off Nova } \\
\text { Scotia, Canada }\end{array}$ \\
\hline $168-170$ & Venerida & Vene & Chione & cancellata & $(\mathrm{Li}$ & Indian River, FL \\
\hline 171,172 & Venerida & Veneridae & Gemma & gemma & (Totten, 1834) & Delaware Bay, NJ \\
\hline $173-175$ & Venerida & Veneridae & Mercenaria & mercenaria & (Linnaeus, 1758) & Milford, CT \\
\hline $176-178$ & Venerida & Veneridae & Mercenaria & campechiensis & (Gmelin, 1791) & Gulf of Mexico near Apalachicola, FL \\
\hline
\end{tabular}


TABLE 1.

continued

\begin{tabular}{|c|c|c|c|c|c|c|}
\hline $\begin{array}{c}\text { Figure } \\
\text { numbers }\end{array}$ & Order & Family & Genus & Species & Authority & Source of sexually mature adult bivalves \\
\hline $179-181$ & Venerida & Veneridae & Mercenaria & $\begin{array}{l}\text { campechiensis } \\
\text { texana }\end{array}$ & (Dall, 1902) & Gulf of Mexico near Galveston, TX \\
\hline $182-185$ & Venerida & Veneridae & Petricolaria & pholadiformis & (Lamarck, 1818) & Continental Shelf off southern New Jersey \\
\hline $186-189$ & Venerida & Veneridae & Pitar & morrhuanus & (Dall, 1902) & Continental Shelf off Wachapreague, VA \\
\hline $190-193$ & Venerida & Veneridae & Ruditapes & philippinarum & $\begin{array}{l}\text { (Adams \& Reeve, } \\
\text { 1850) }\end{array}$ & $\begin{array}{l}\text { Obtained from the Carna Research } \\
\text { Station, Galway, Ireland }\end{array}$ \\
\hline 194,195 & Venerida & Cyrenidae & Corbicula & fluminea & (O. F. Müller, 1774) & Nassawango Creek, MD \\
\hline
\end{tabular}

Taxonomic nomenclature was assigned according to the latest "accepted name" (or acceptable "alternate representation") and associated classification hierarchy in the World Register of Marine Species (www.marinespecies.org). Sexually mature adult bivalves were obtained from the indicated sources and used as broodstock to obtain the larvae and postlarvae depicted in this monograph. 


\section{HIATELLA ARCTICA}

\section{LEFT VALVE}
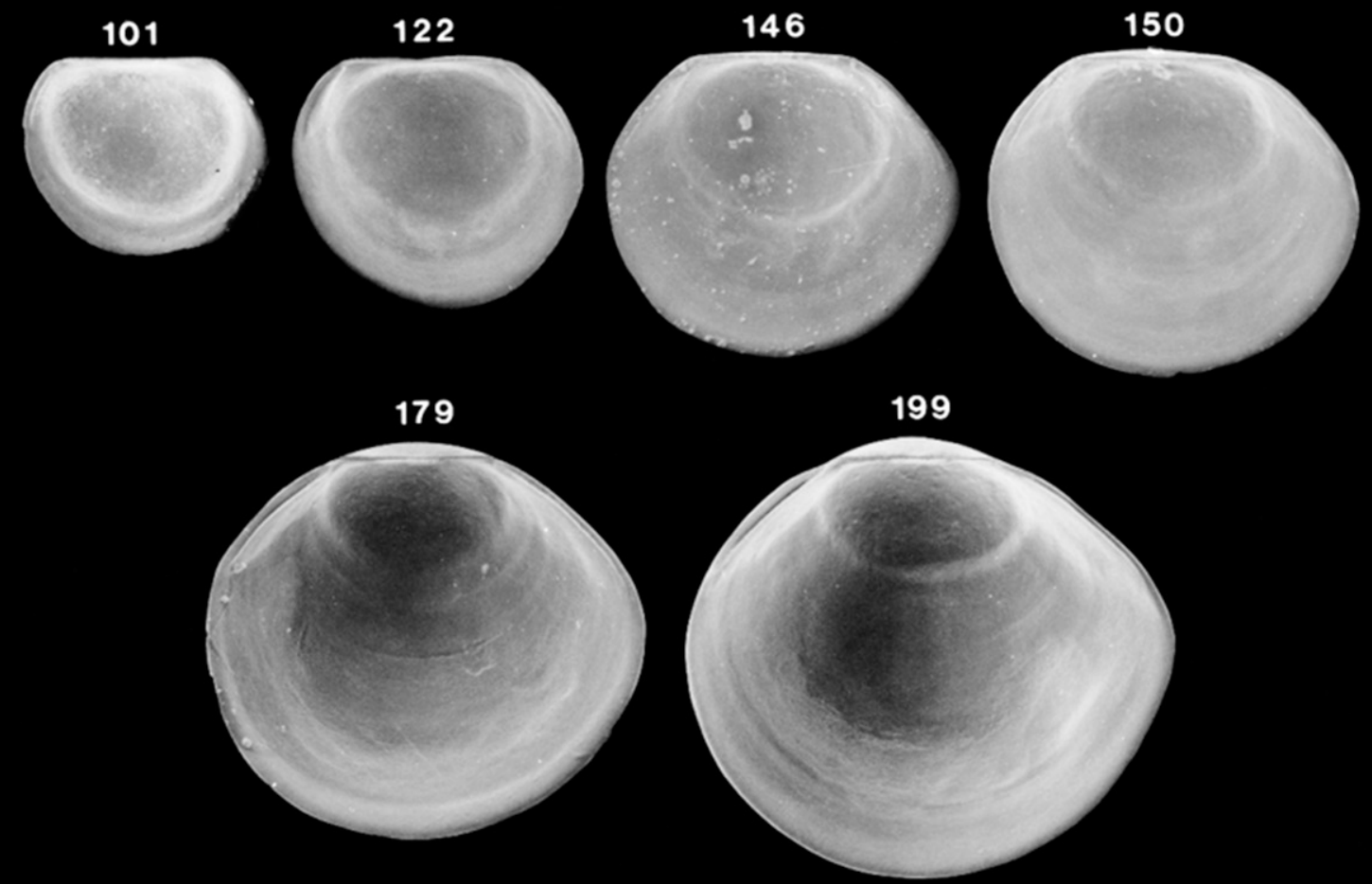

\section{RIGHT VALVE}

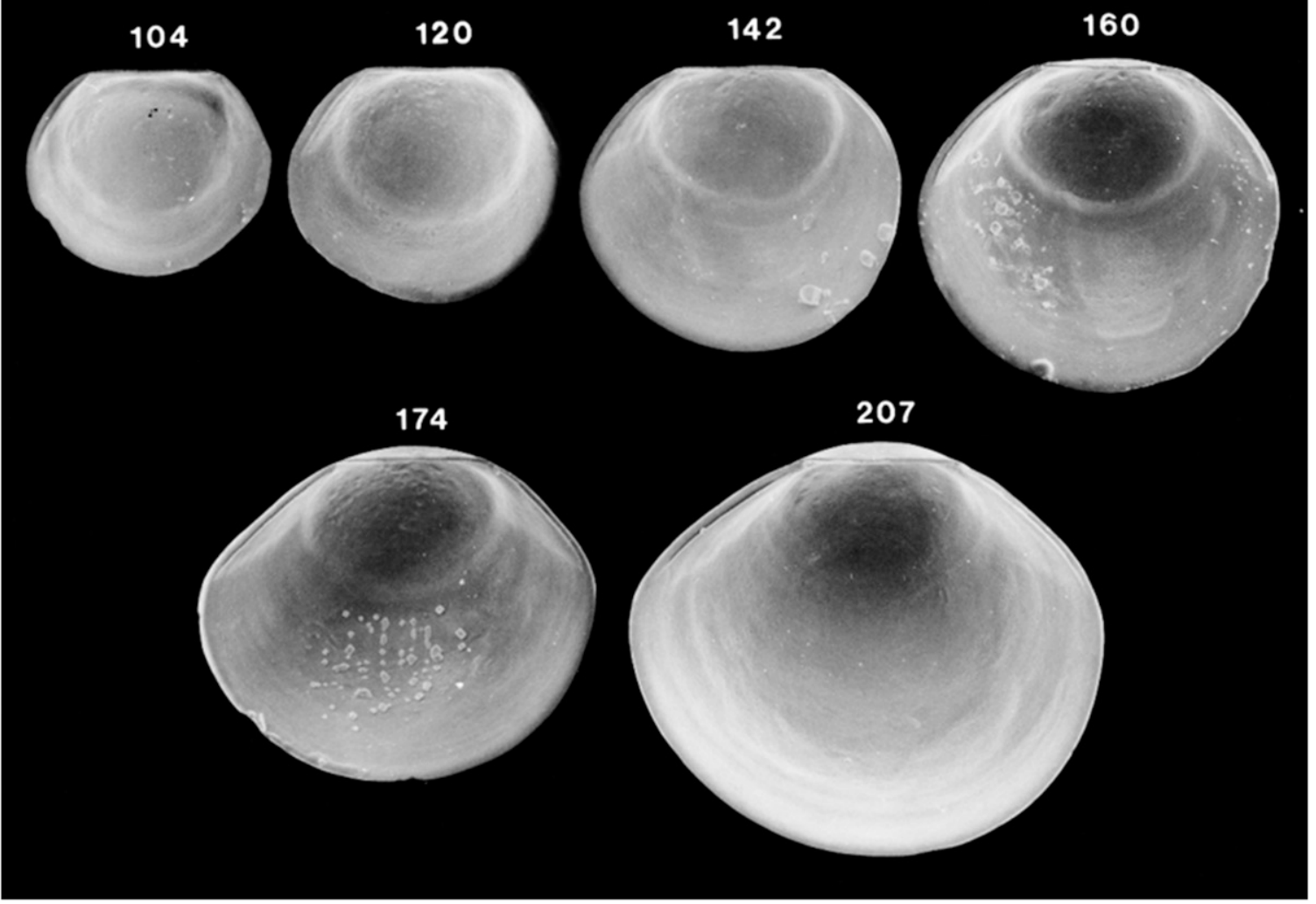

Figure 1. Scanning electron micrographs of disarticulated shell valves of Hiatella arctica larvae. Numbers indicate the maximum linear shell dimension in micrometers. 


\section{HIATELLA ARCTICA}

\section{LEFT VALVE}

\section{1}

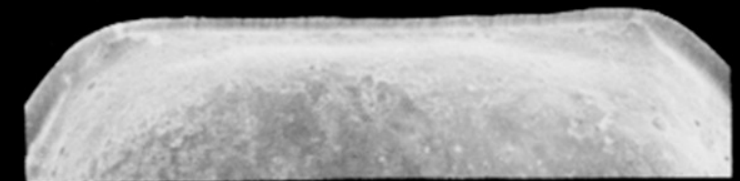

122

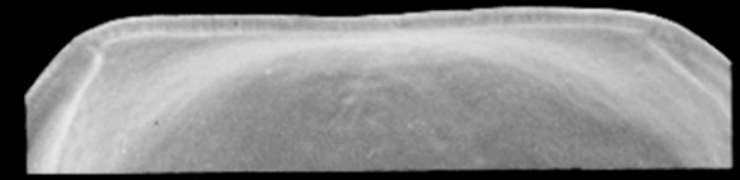

146

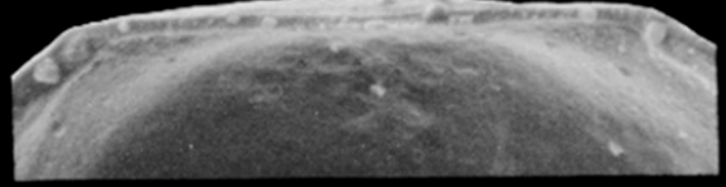

150

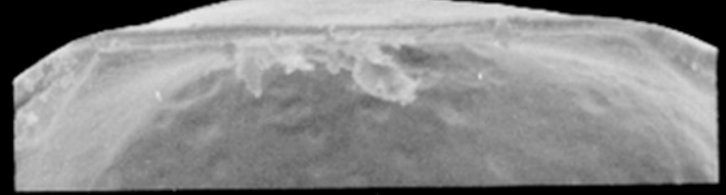

\section{9}

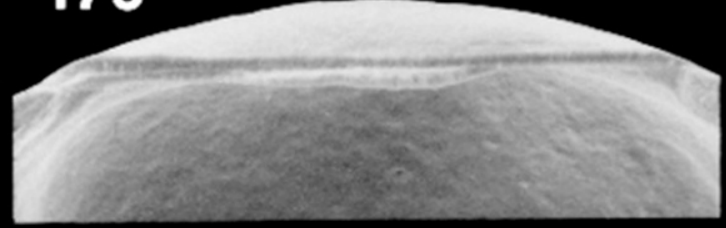

\section{9}

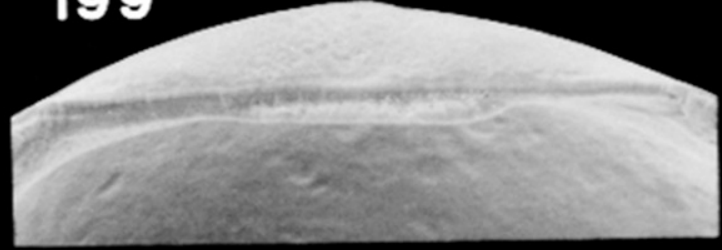

\section{RIGHT VALVE}

\section{4}

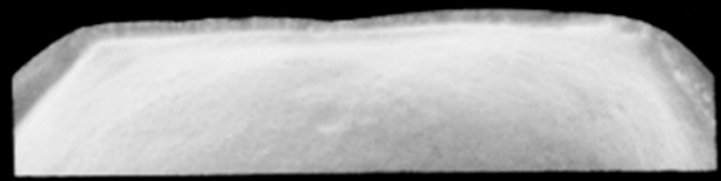

\section{0}

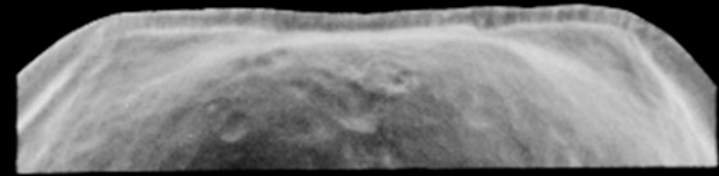

\section{2}

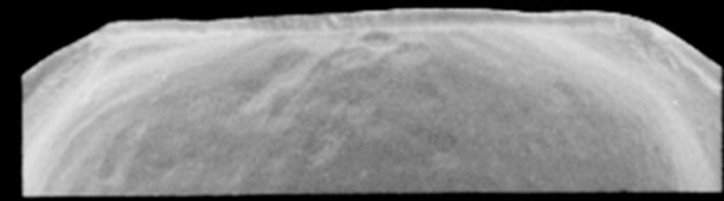

\section{0}

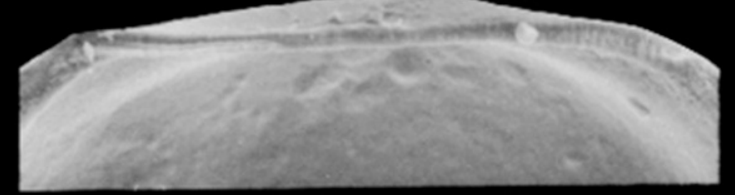

\section{4}

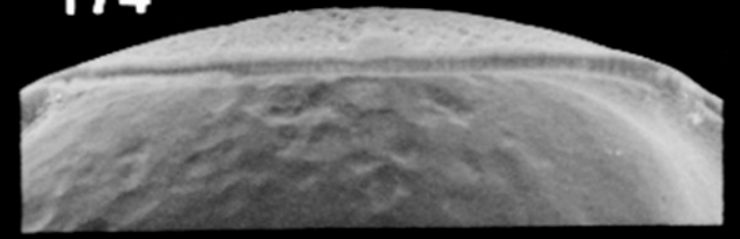

\section{7}

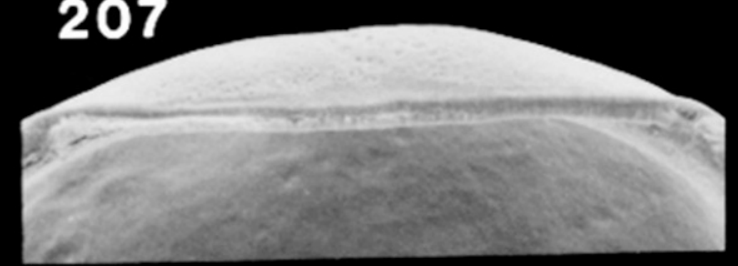

Figure 2. Scanning electron micrographs of the hinge of disarticulated shell valves of Hiatella arctica larvae seen in Figure 1. Numbers indicate the maximum linear shell dimension in micrometers. 


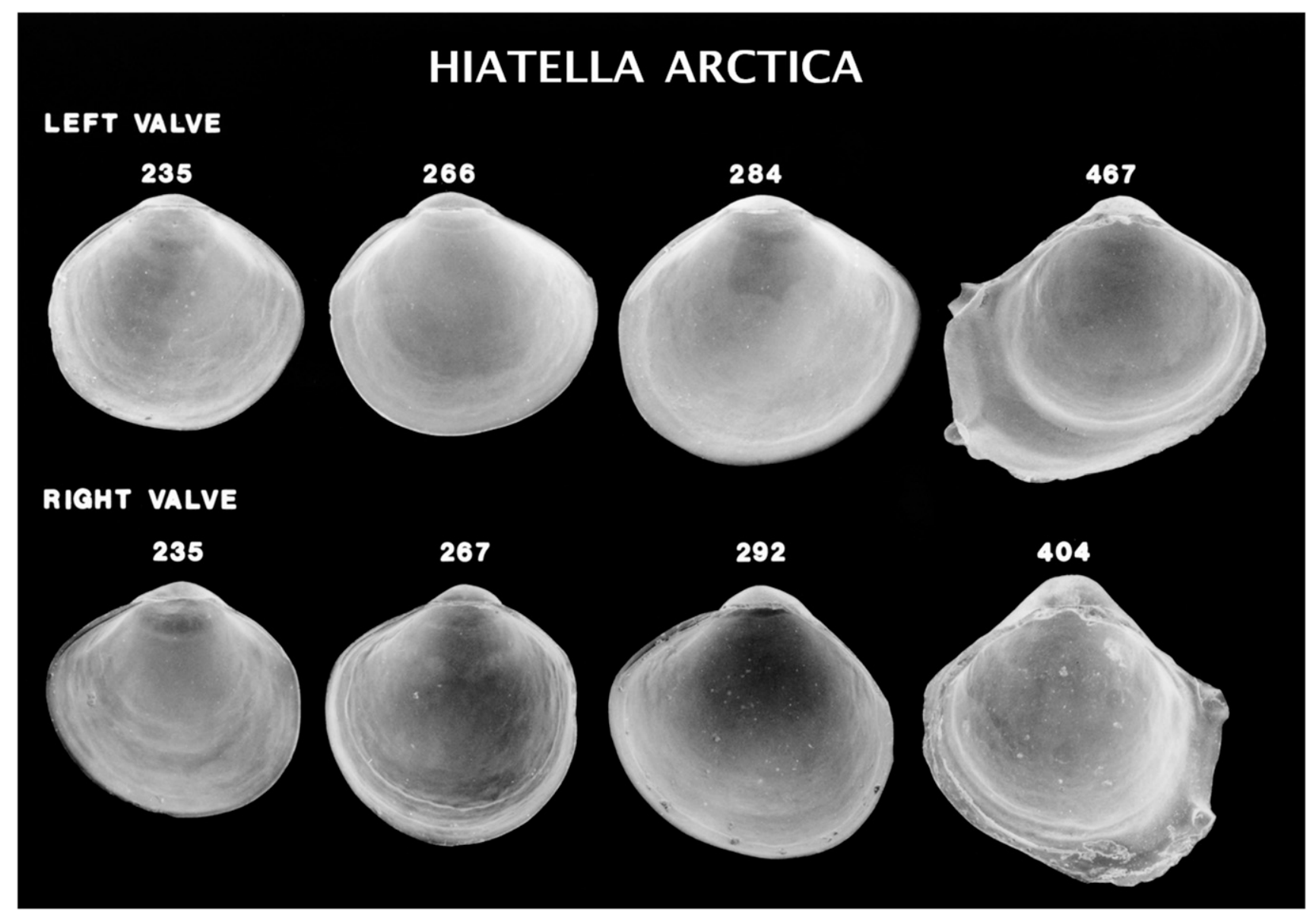

Figure 3. Scanning electron micrographs of disarticulated shell valves of Hiatella arctica postlarvae. Numbers indicate the maximum linear shell dimension in micrometers. 


\section{HIATELLA ARCTICA}

\section{LEFT VALVE}
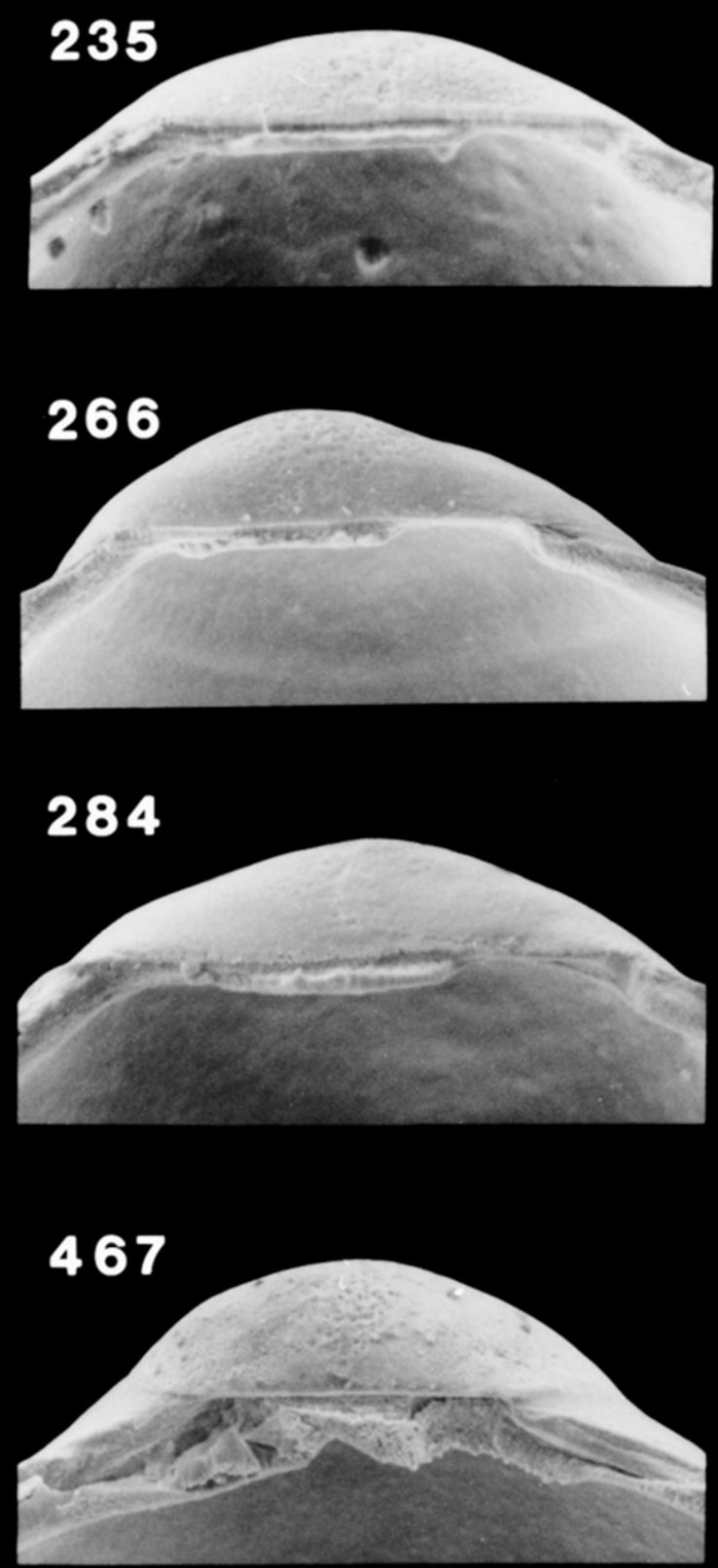

\section{RIGHT VALVE}
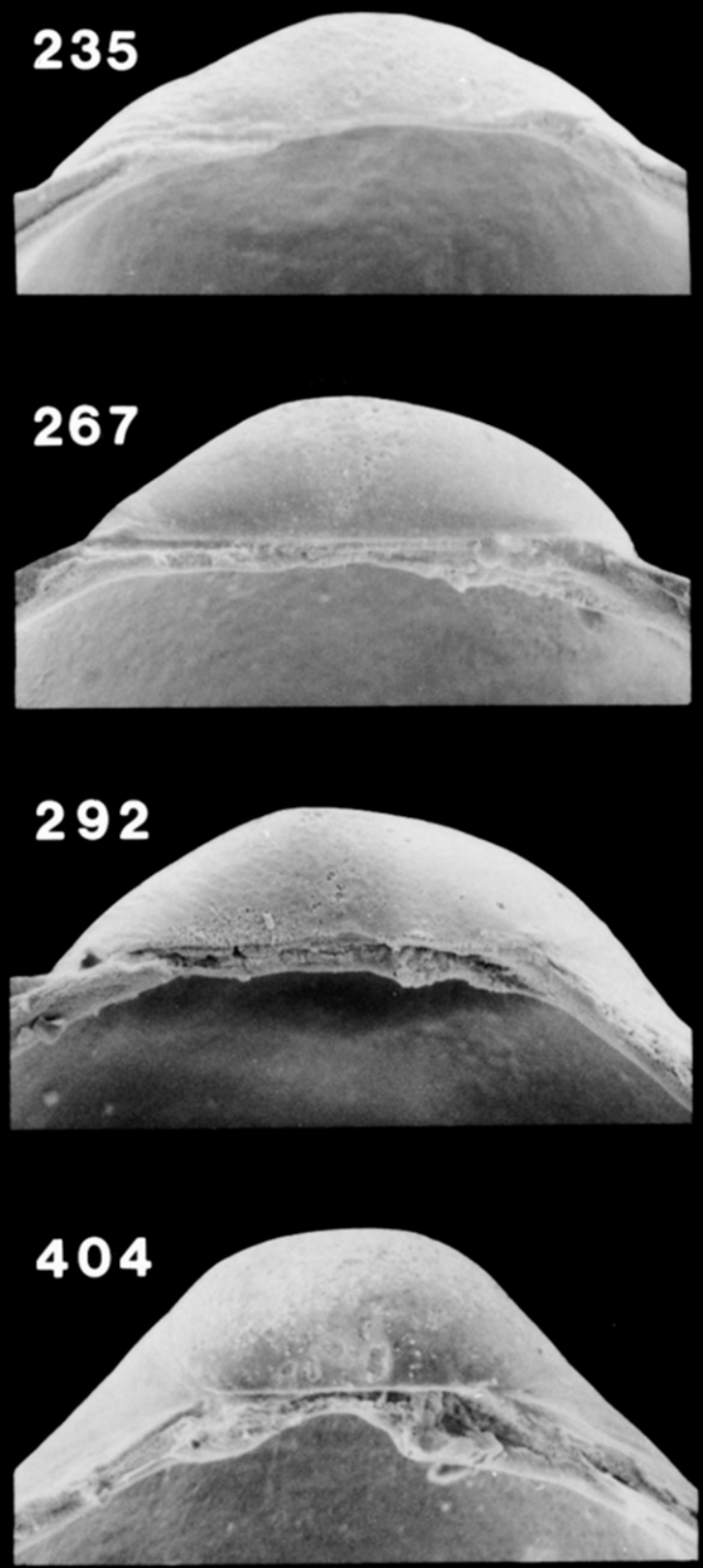

Figure 4. Scanning electron micrographs of the hinge of disarticulated shell valves of Hiatella arctica postlarvae seen in Figure 3. Numbers indicate the maximum linear shell dimension in micrometers. 


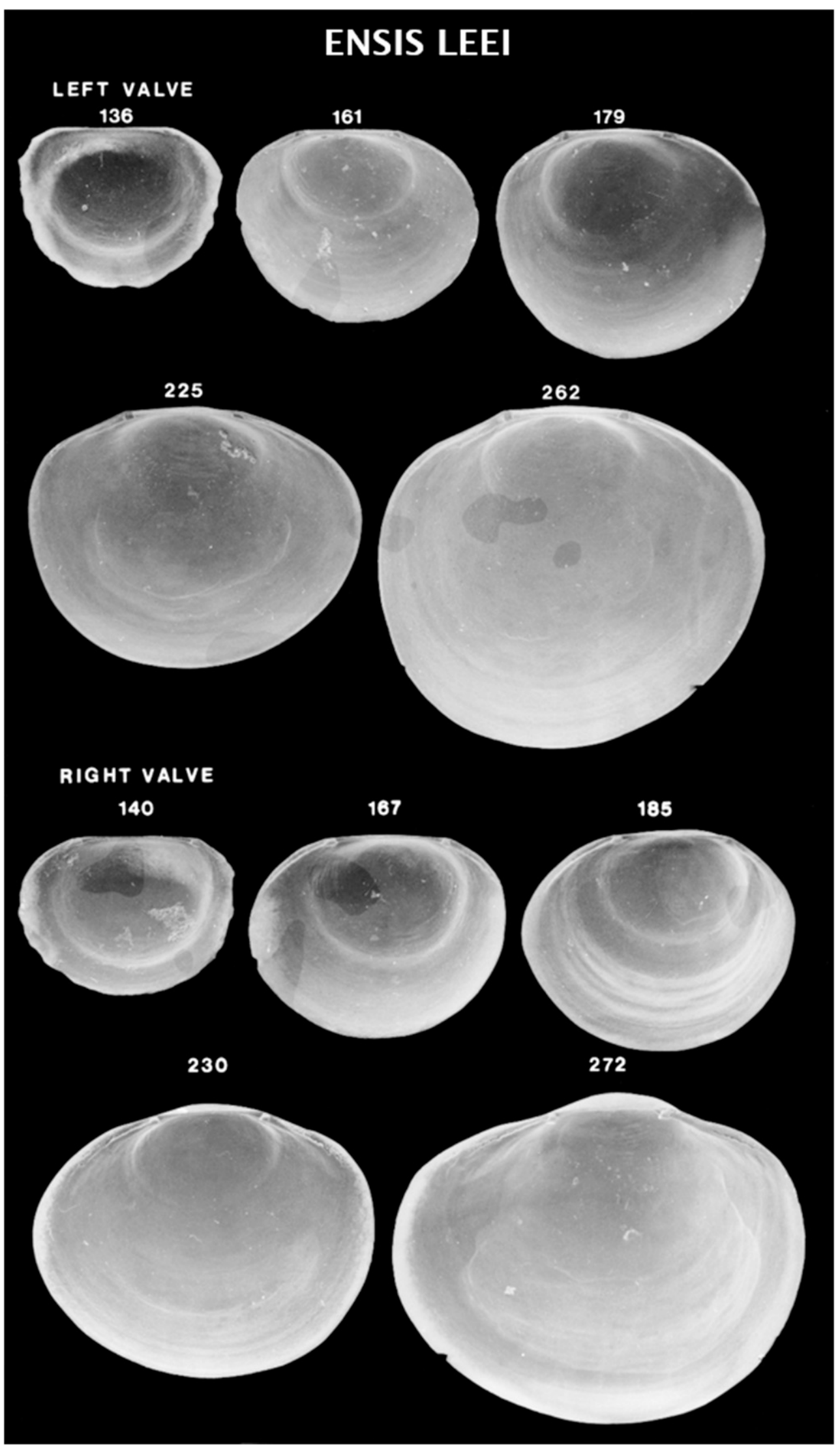

Figure 5. Scanning electron micrographs of disarticulated shell valves of Ensis leei larvae. Numbers indicate the maximum linear shell dimension in micrometers. 


\section{ENSIS LEEI}

\section{LEFT VALVE}

\section{6}

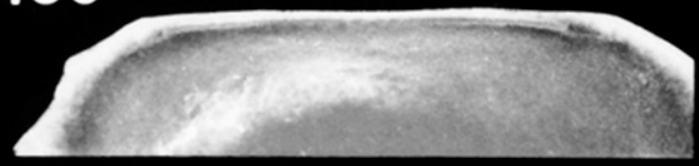

\section{1}

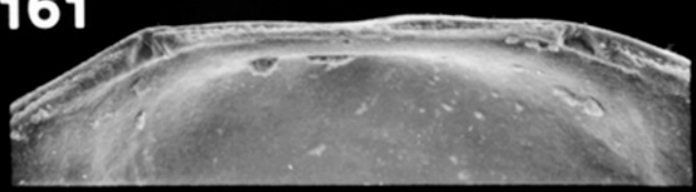

\section{9}

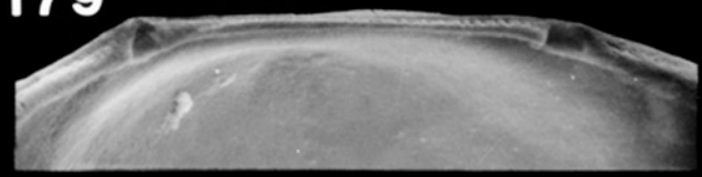

\section{5}

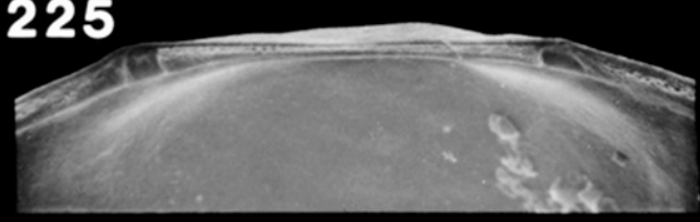

\section{2}

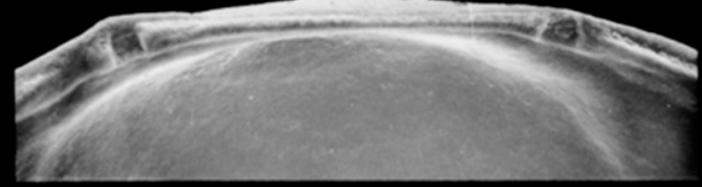

\section{RIGHT VALVE}

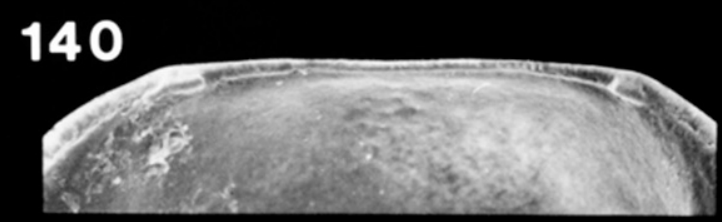

\section{7}

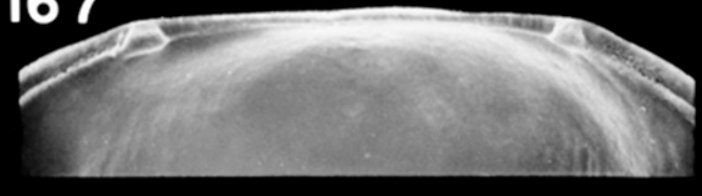

\section{5}

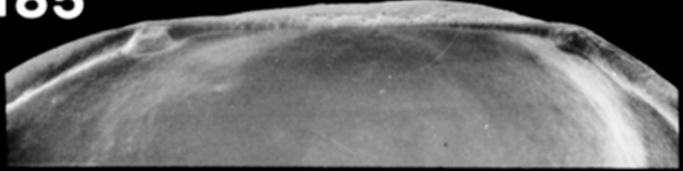

\section{0}

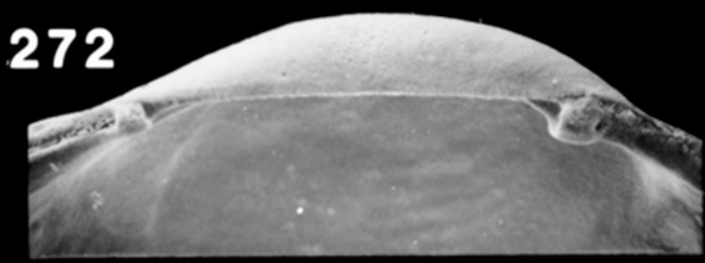

Figure 6. Scanning electron micrographs of the hinge of disarticulated shell valves of Ensis leei larvae seen in Figure 5. Numbers indicate the maximum linear shell dimension in micrometers. 


\section{ENSIS LEEI}

\section{LEFT VALVE}

330

490

592

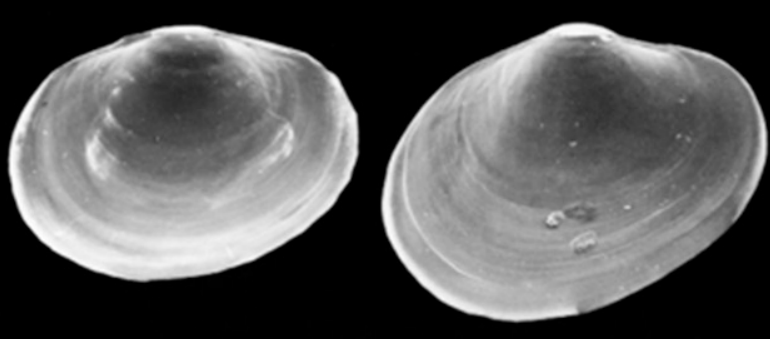

1178

1833

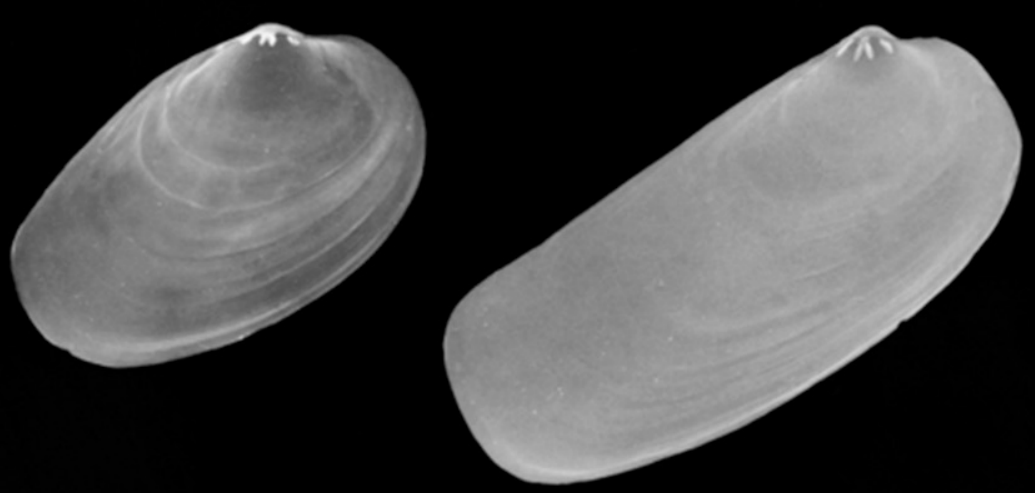

RIGHT VALVE

296

541

617
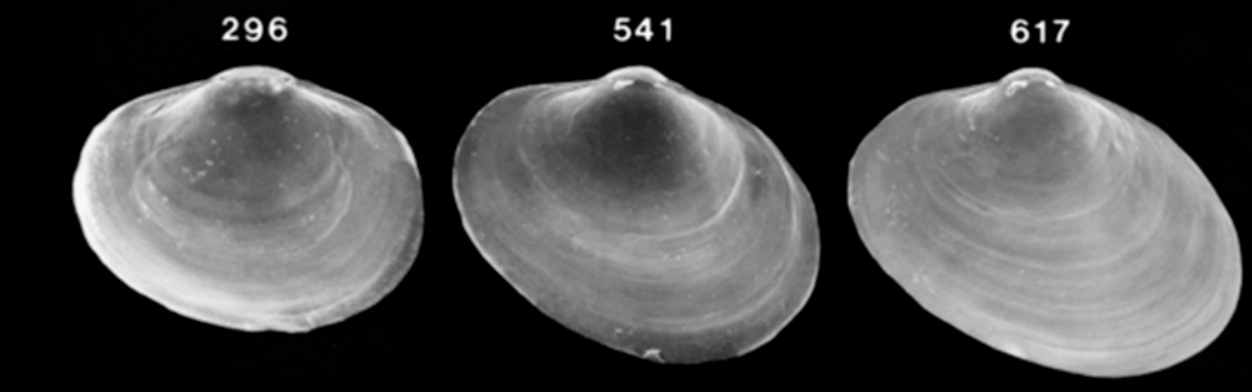

1041

1849
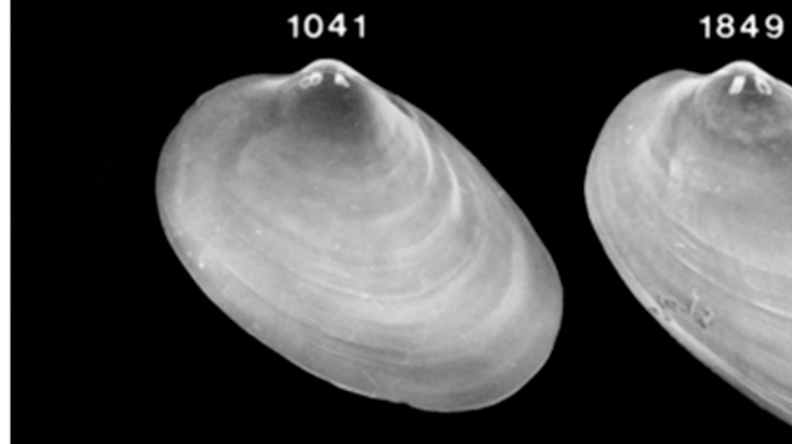


\section{ENSIS LEEI}

\section{LEFT VALVE}

\section{0}

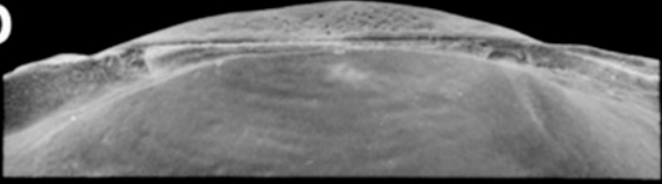

490

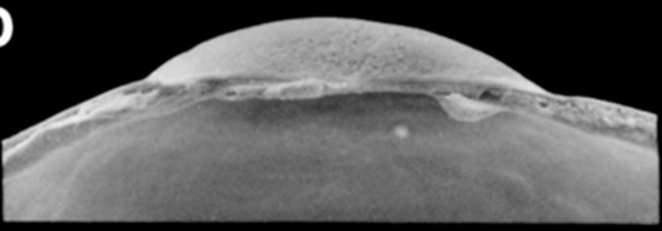

592

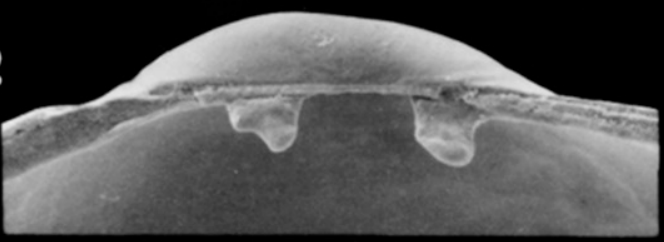

1178

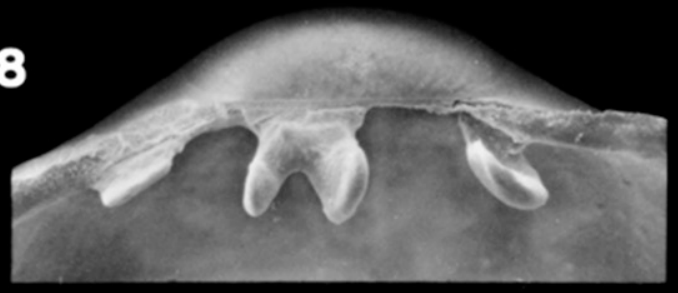

\section{3}

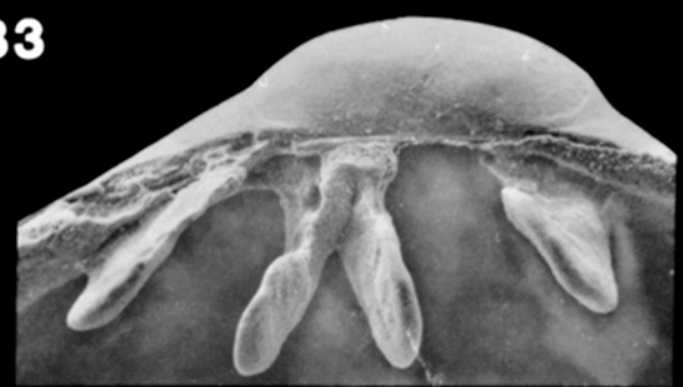

\section{RIGHT VALVE}

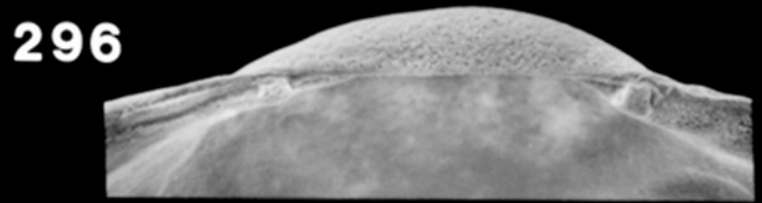

\section{1}

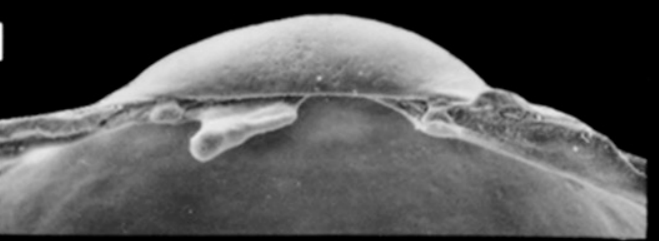

\section{7}
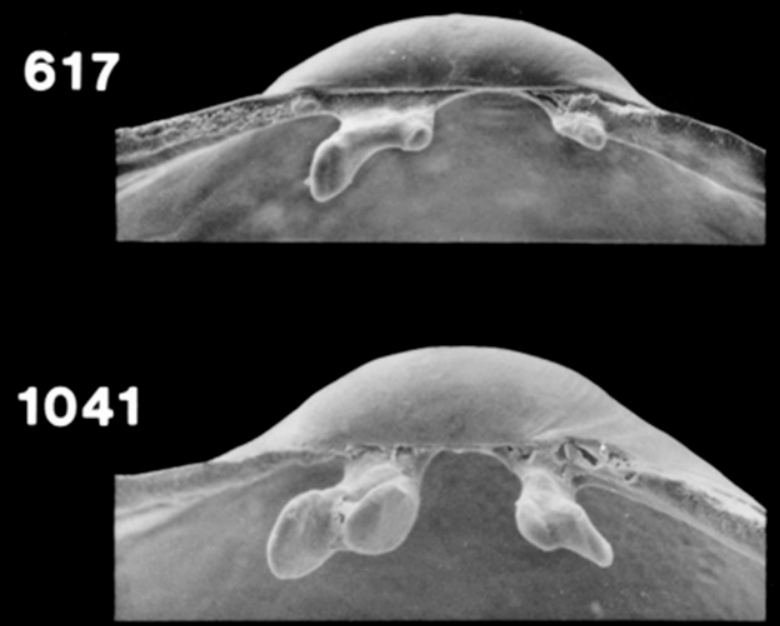

1849

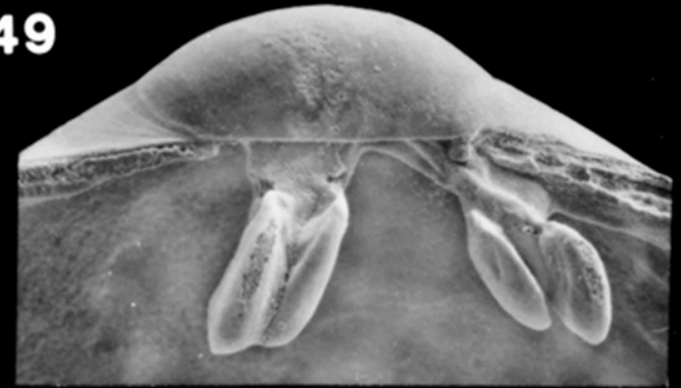

Figure 8. Scanning electron micrographs of the hinge of disarticulated shell valves of Ensis leei postlarvae seen in Figure 7. Numbers indicate the maximum linear shell dimension in micrometers. 


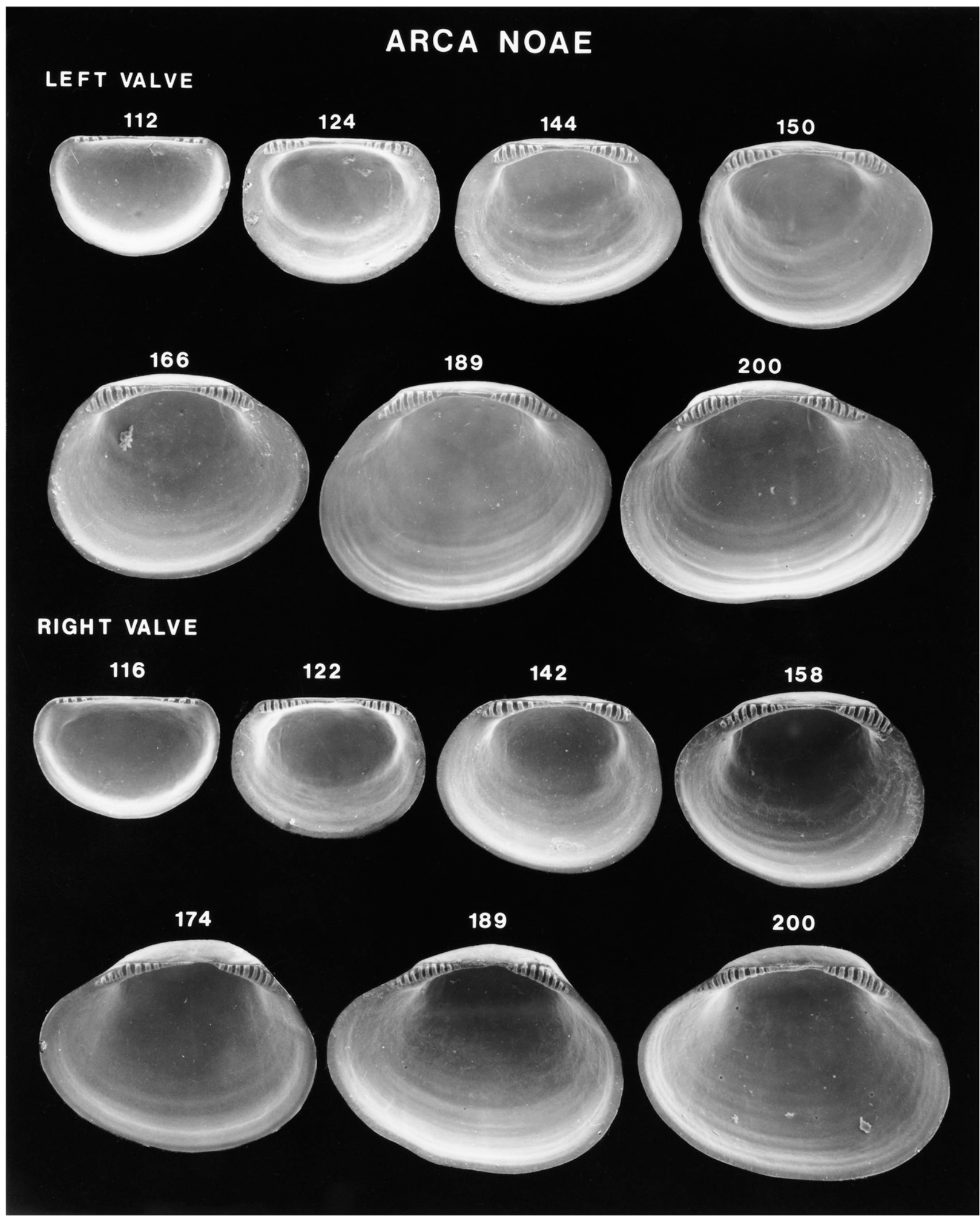

Figure 9. Scanning electron micrographs of disarticulated shell valves of Arca noae larvae. Numbers indicate the maximum linear shell dimension in micrometers. 


\section{ARCA NOAE}

\section{LEFT VALVE}

\section{2}

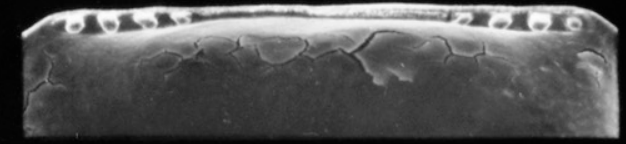

\section{4}

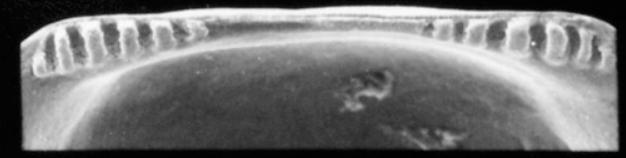

144

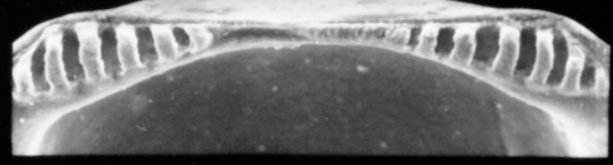

150

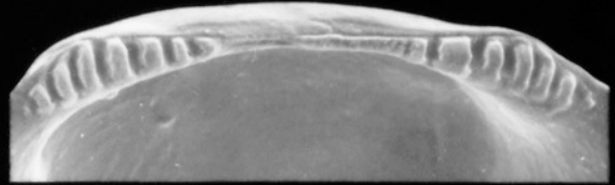

166

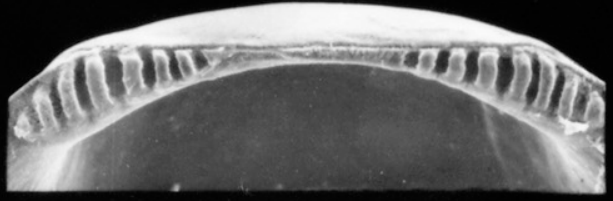

189

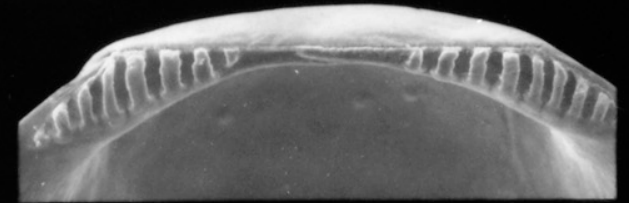

200

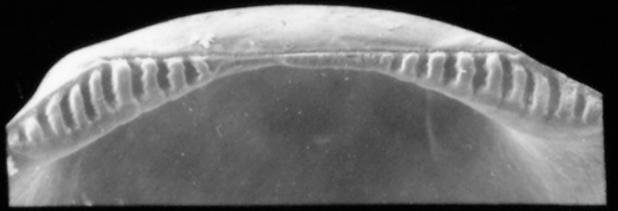

\section{RIGHT VALVE}

\section{6}

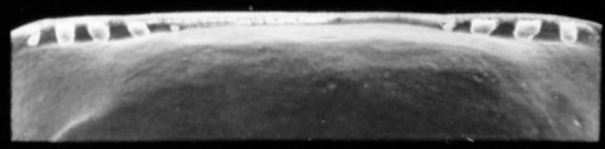

122

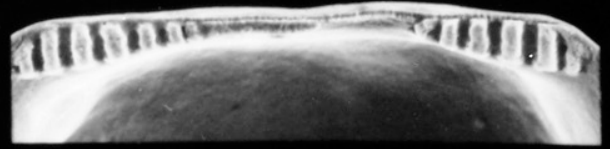

142

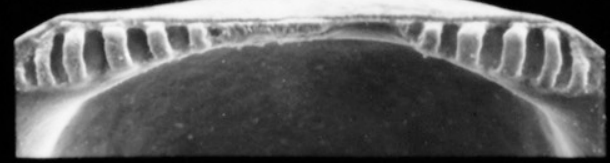

158

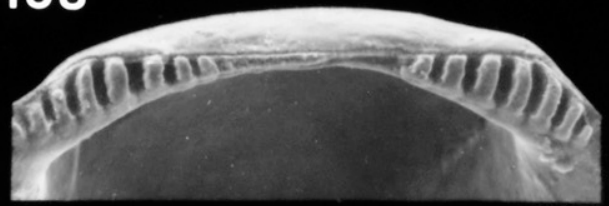

174

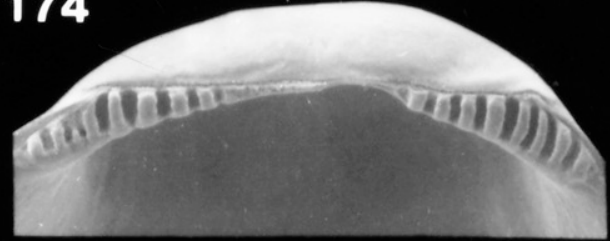

189

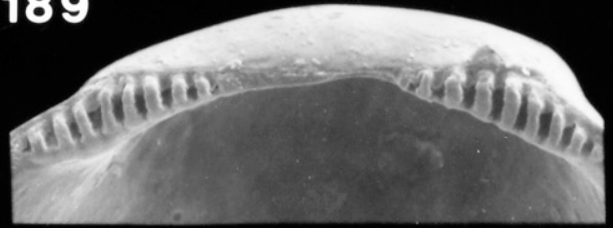

200

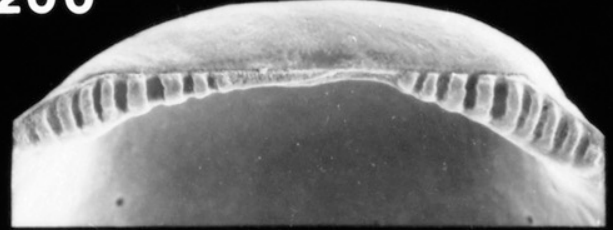

Figure 10. Scanning electron micrographs of the hinge of disarticulated shell valves of Arca noae larvae seen in Figure 9. Numbers indicate the maximum linear shell dimension in micrometers. 


\section{ARCA NOAE}

\section{LEFT VALVE}
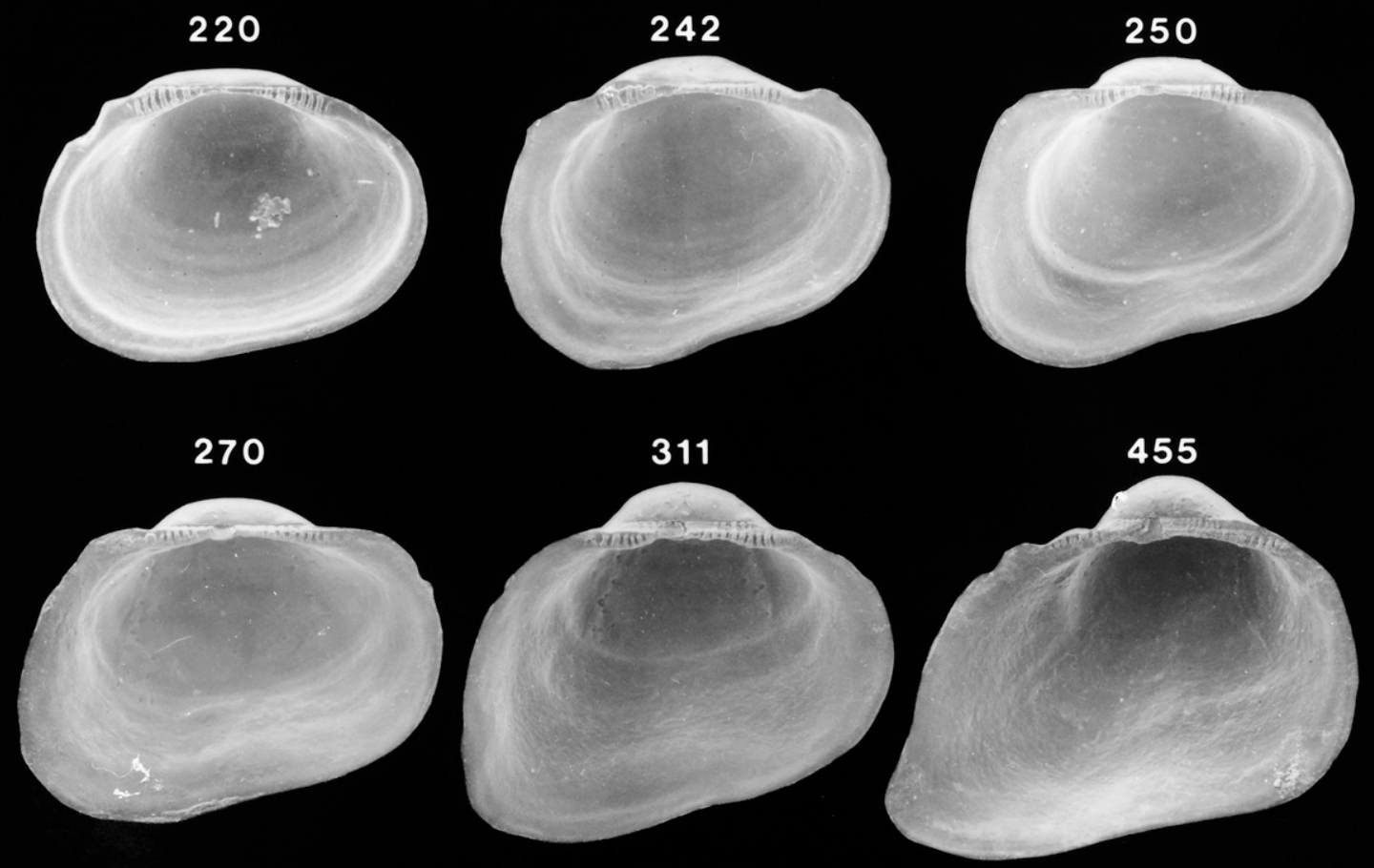

\section{RIGHT VALVE}

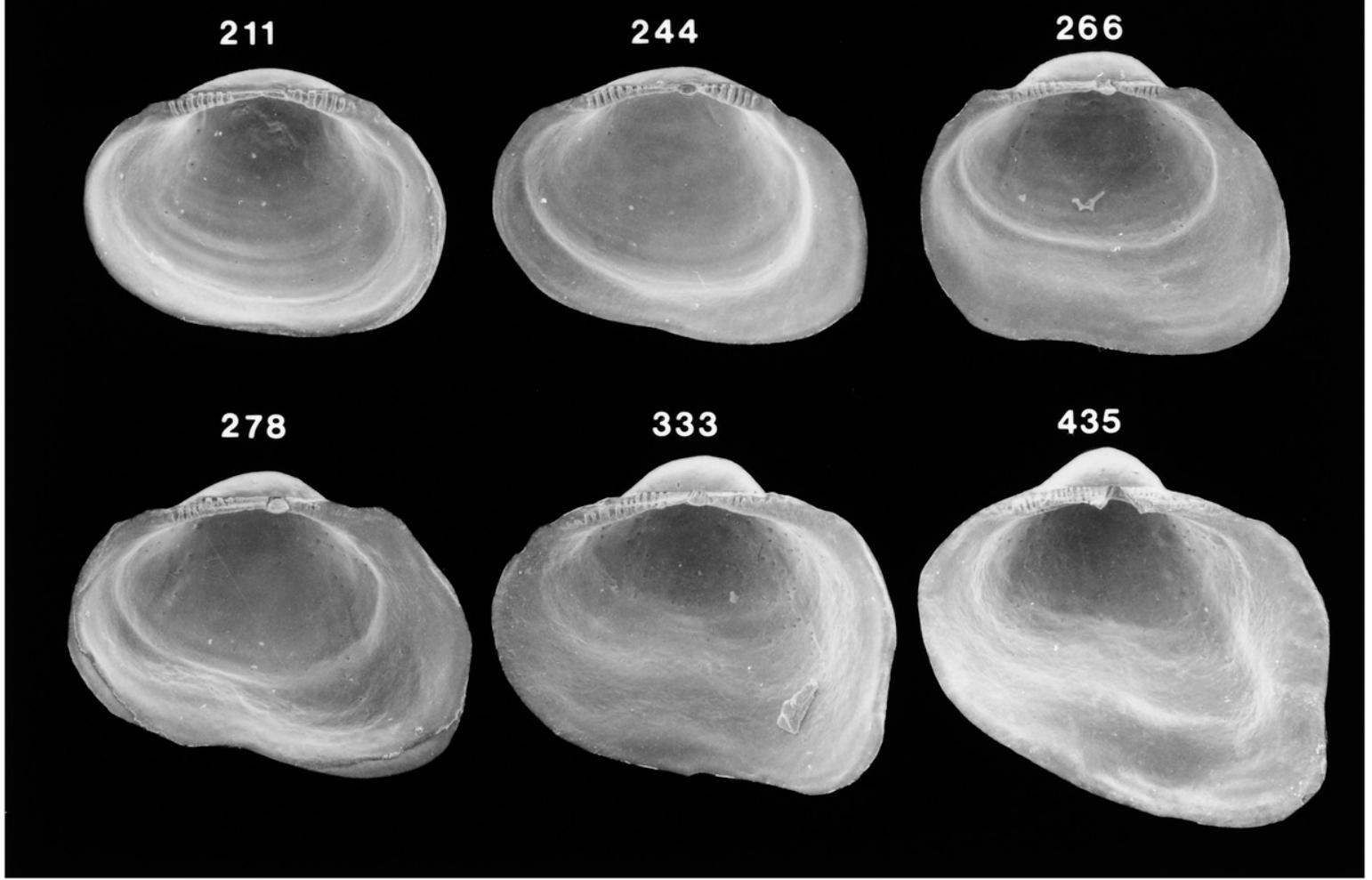

Figure 11. Scanning electron micrographs of disarticulated shell valves of Arca noae postlarvae. Numbers indicate the maximum linear shell dimension in micrometers. 


\section{ARCA NOAE}

\section{LEFT VALVE}
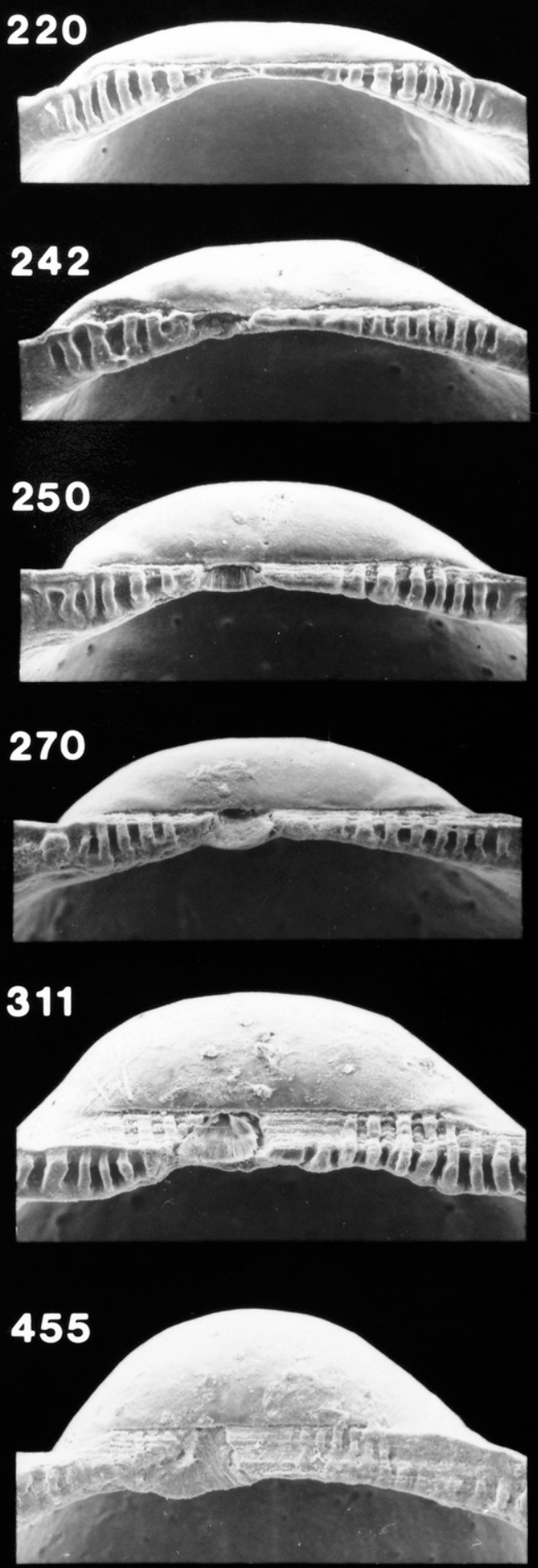

\section{RIGHT VALVE}
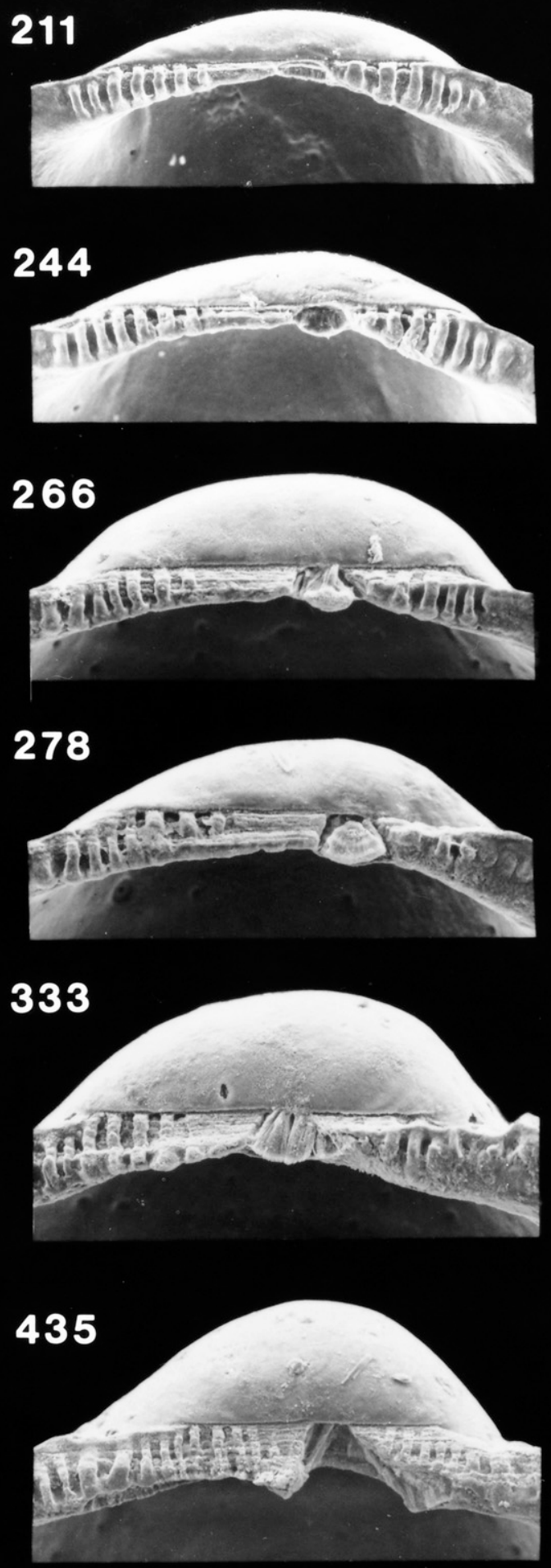


\section{LUNARCA OVALIS}

\section{LEFT VALVE}

85

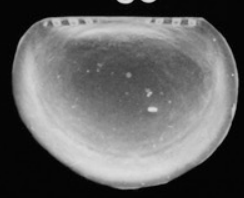

100

110
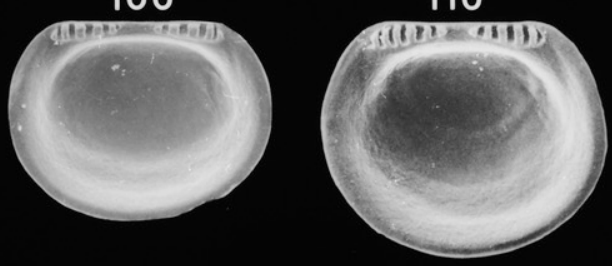

118
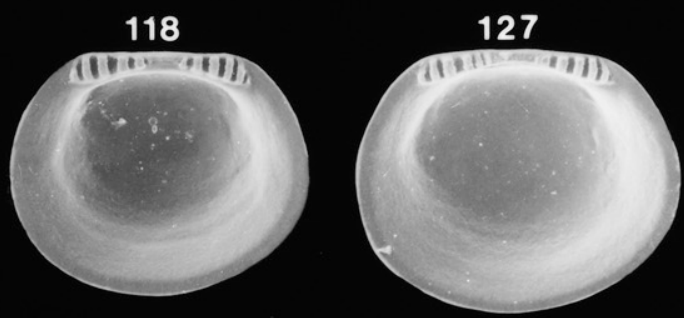

144

178
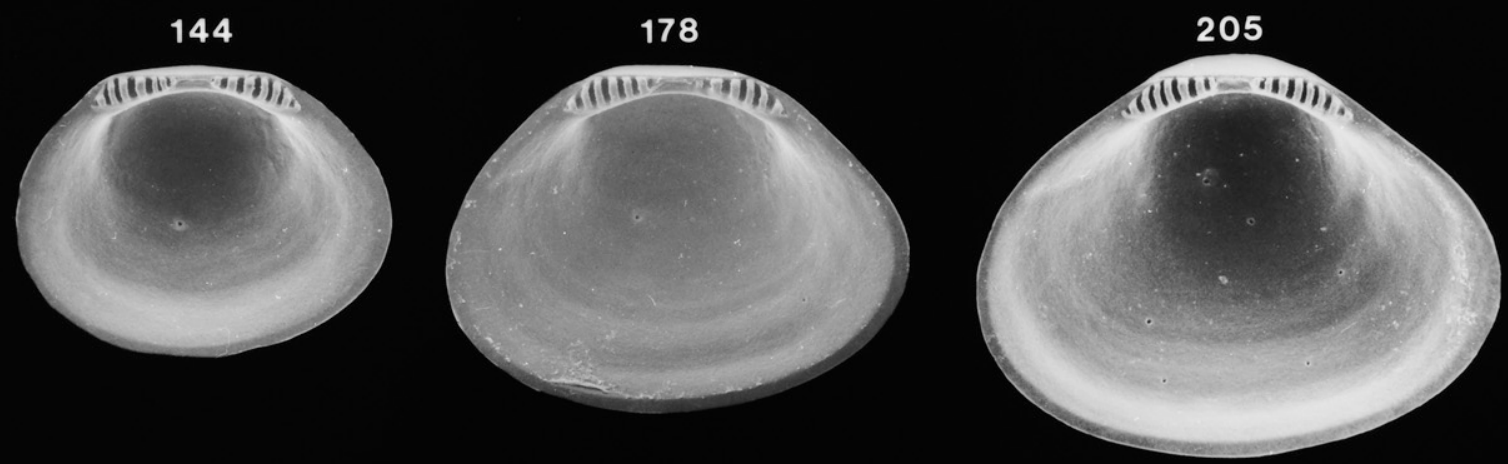

\section{RIGHT VALVE}

87

100

110

124

135
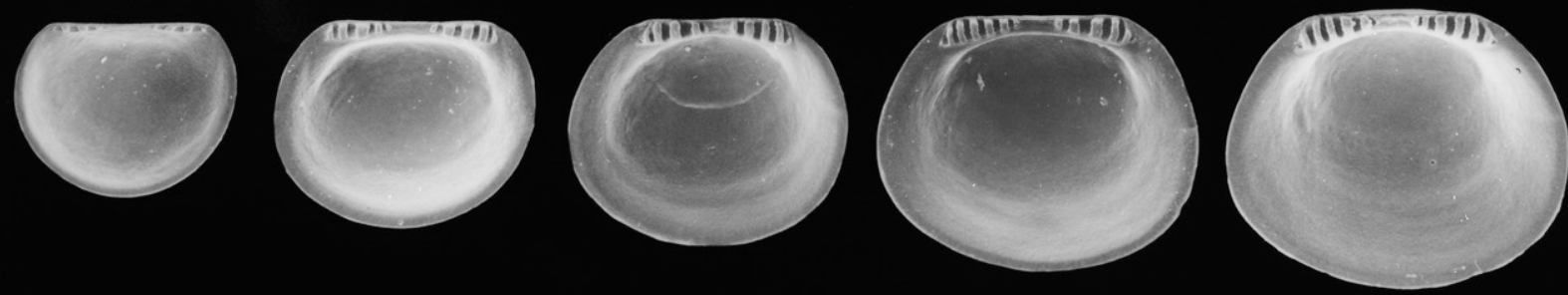

161

183

216

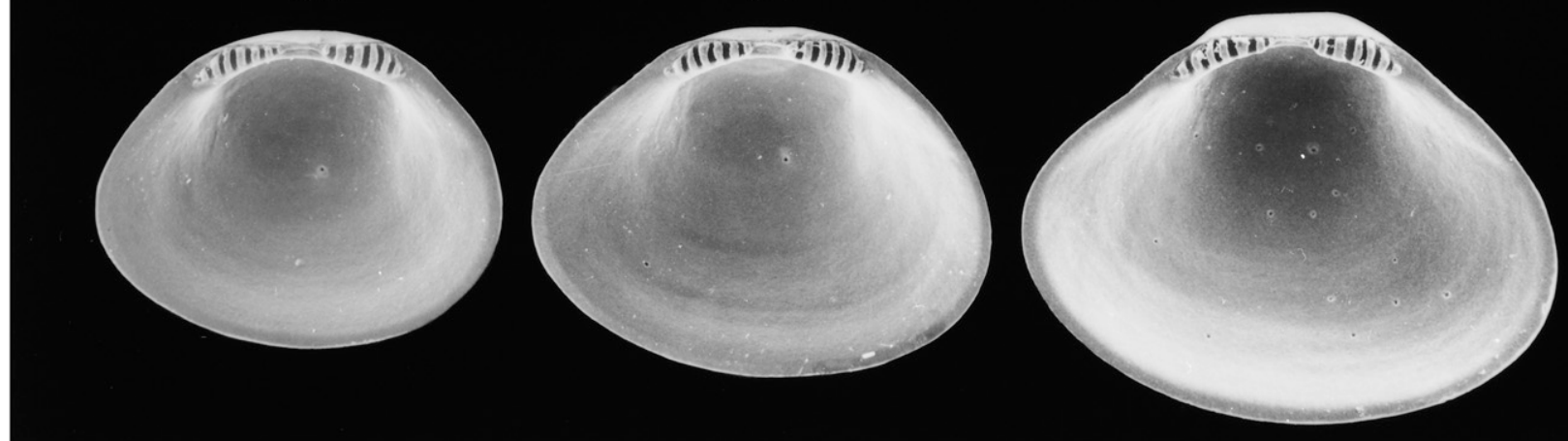

Figure 13. Scanning electron micrographs of disarticulated shell valves of Lunarca ovalis larvae. Numbers indicate the maximum linear shell dimension in micrometers. 


\section{LUNARCA OVALIS}

\section{LEFT VALVE}

85

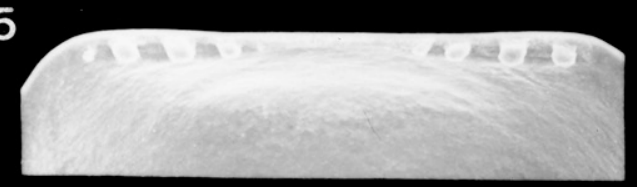

100

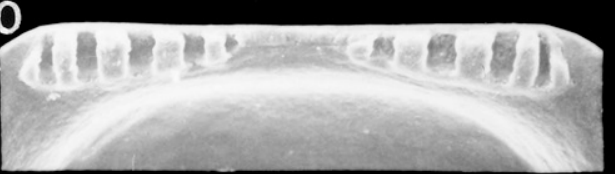

110

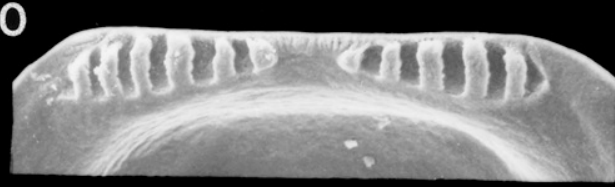

118

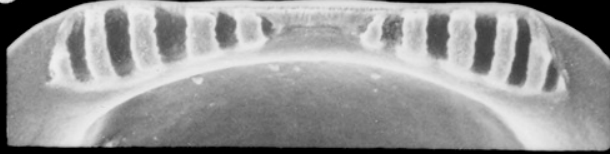

127

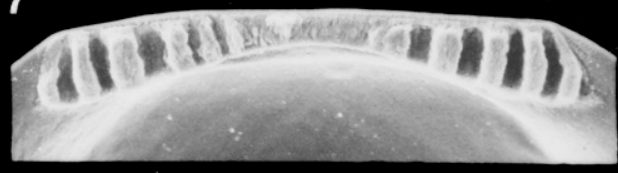

144

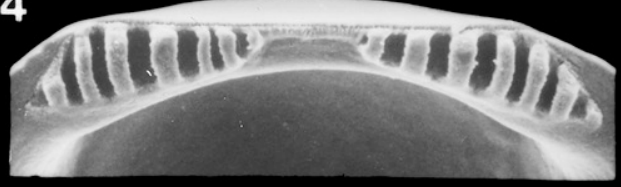

178

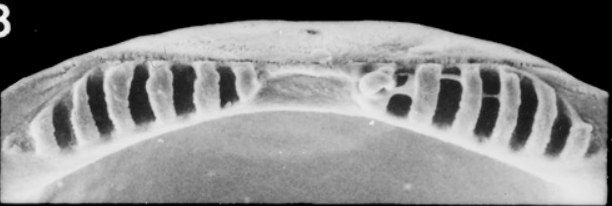

205

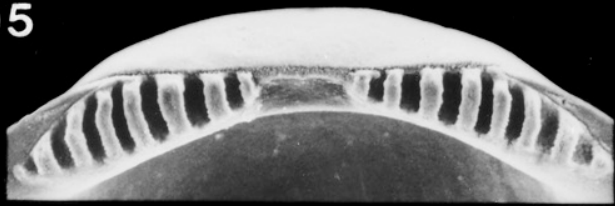

RIGHT VALVE

87

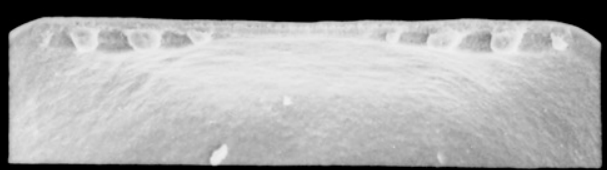

100

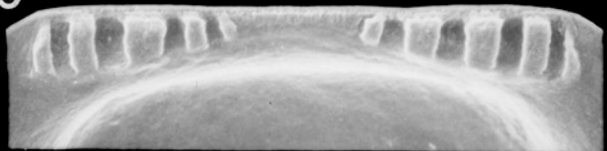

110

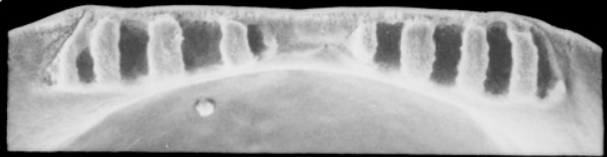

124

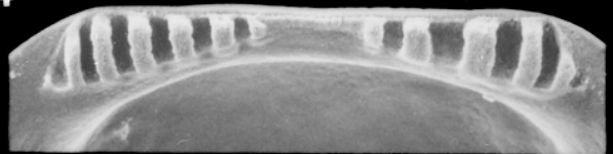

135

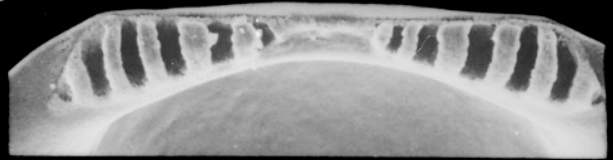

161

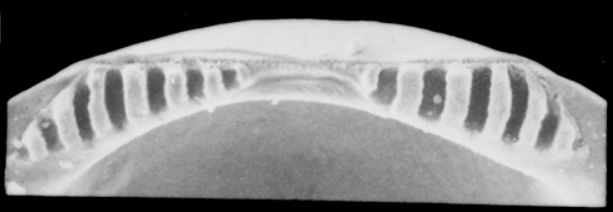

183

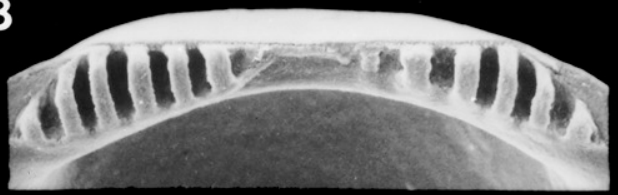

216

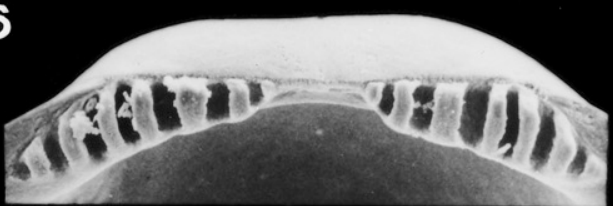

Figure 14. Scanning electron micrographs of the hinge of disarticulated shell valves of Lunarca ovalis larvae seen in Figure 13. Numbers indicate the maximum linear shell dimension in micrometers. 


\section{LUNARCA OVALIS}

\section{LEFT VALVE}
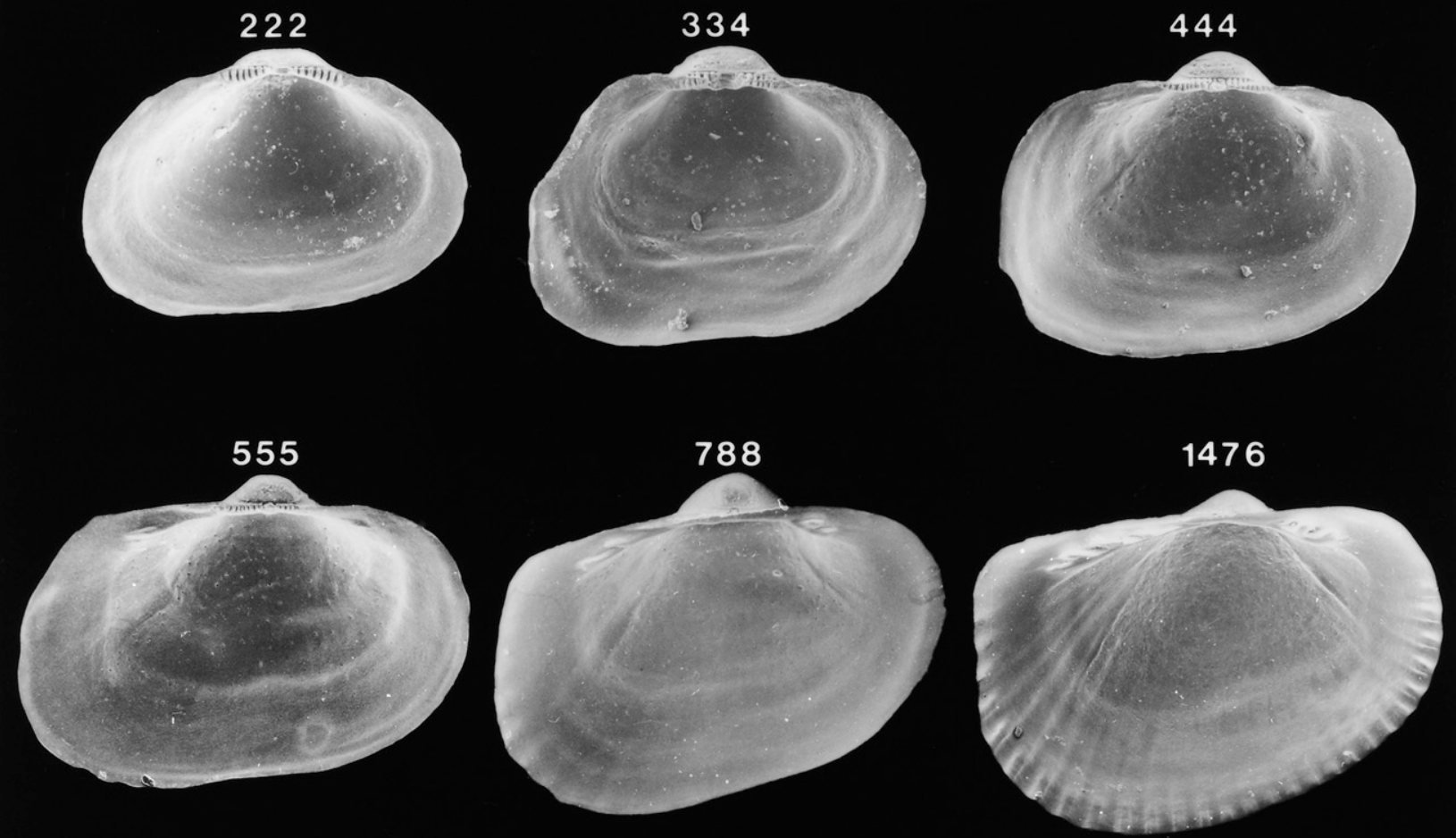

\section{RIGHT VALVE}
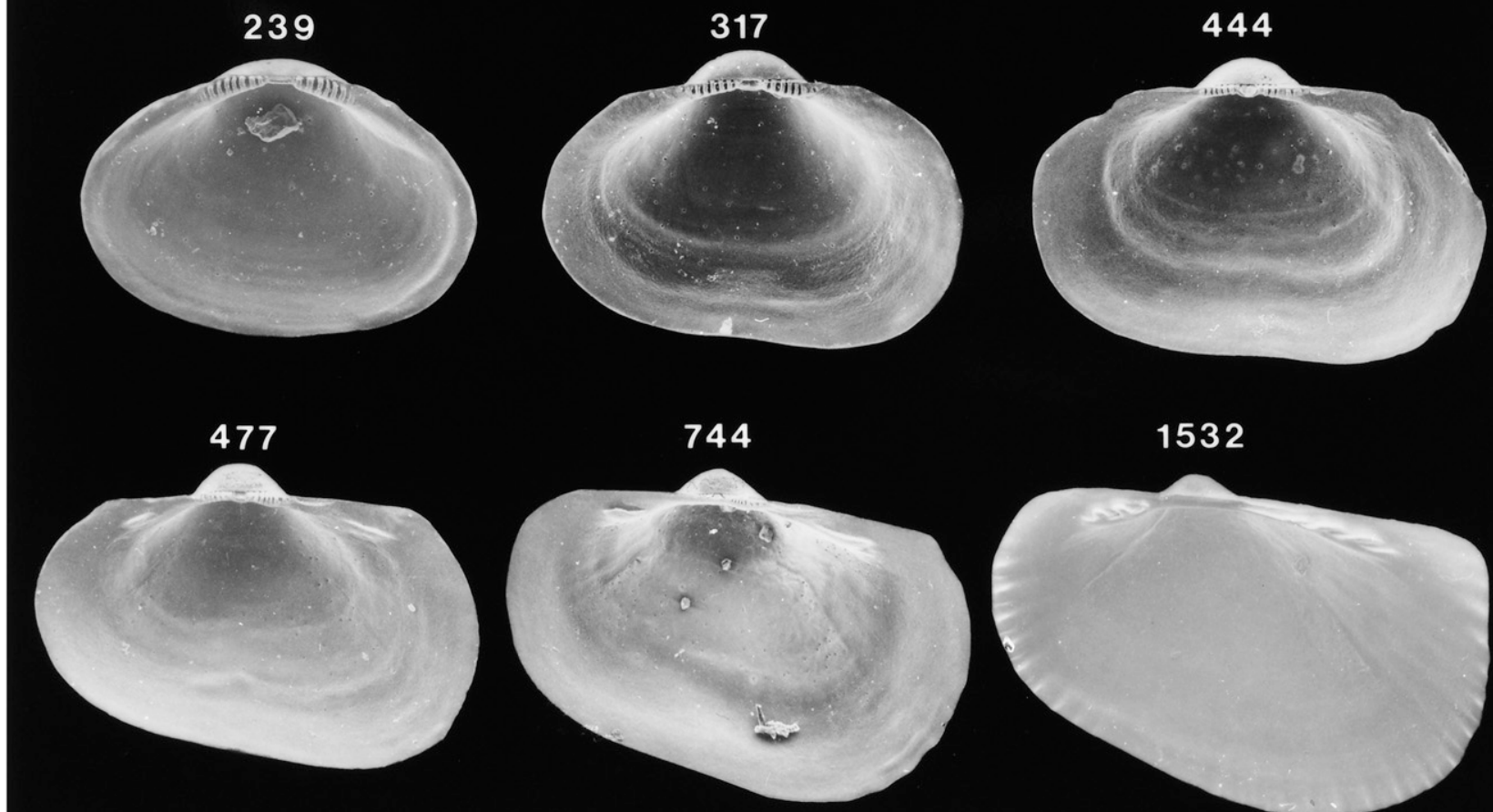

1532

Figure 15. Scanning electron micrographs of disarticulated shell valves of Lunarca ovalis postlarvae. Numbers indicate the maximum linear shell dimension in micrometers. 


\section{LUNARCA OVALIS}

\section{LEFT VALVE}
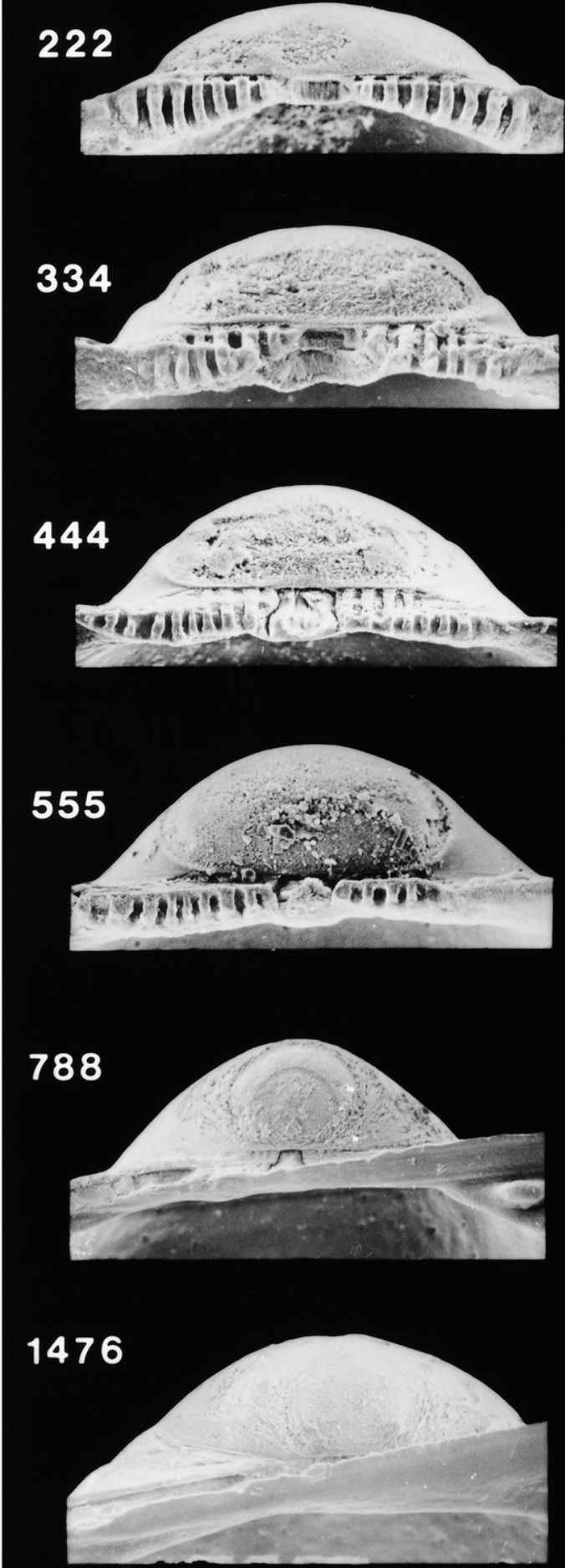

\section{RIGHT VALVE}

\section{9}
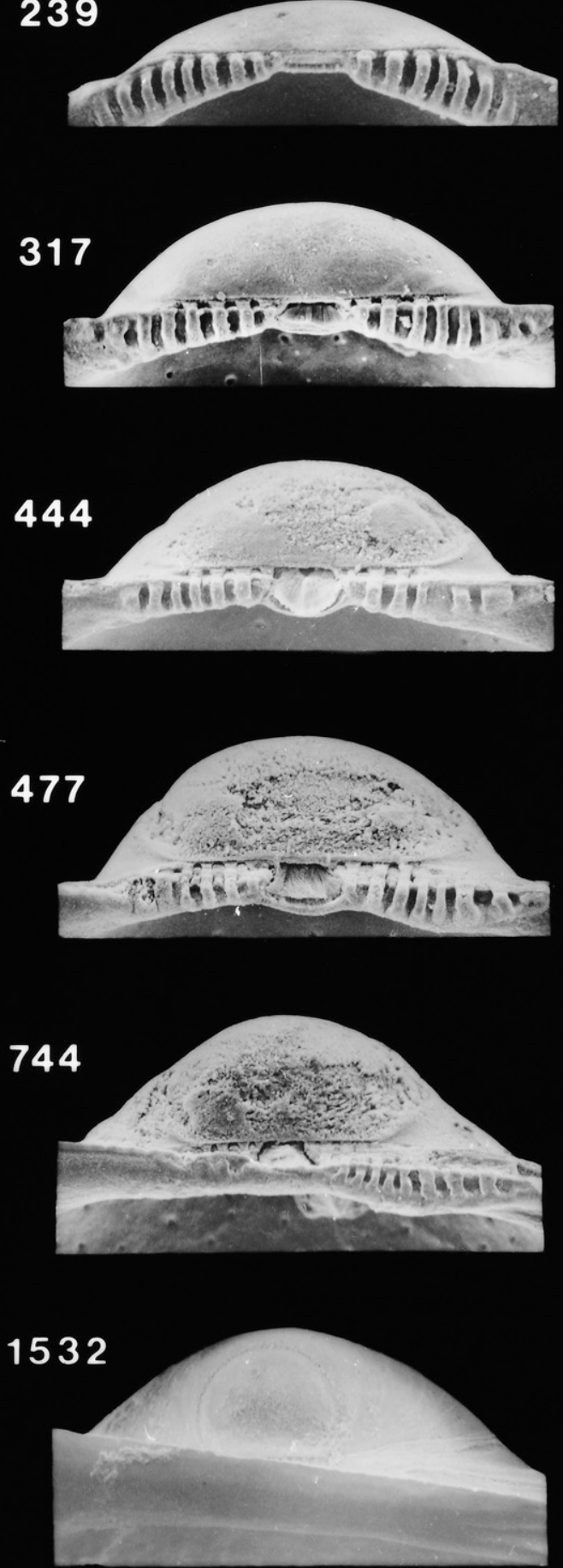


\section{NOETIA PONDEROSA}

\section{LEFT VALVE}

101

121

164
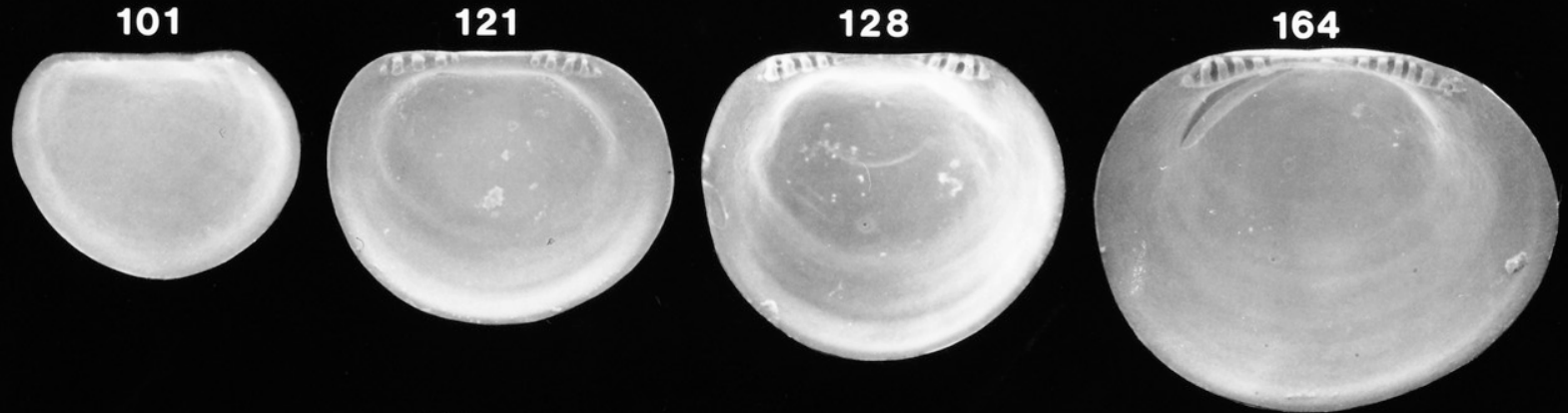

177

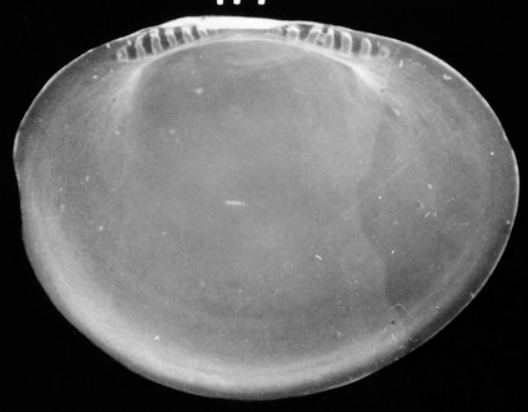

189

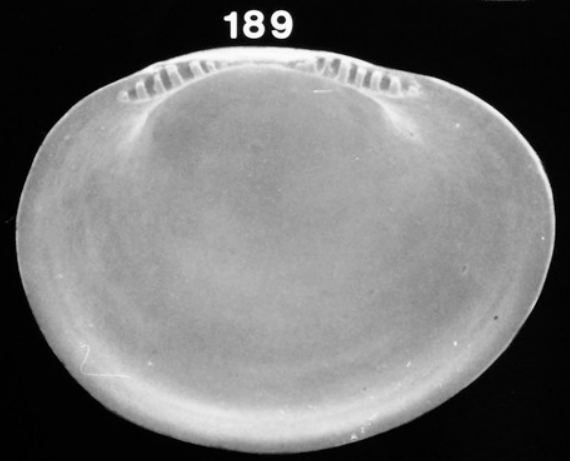

\section{RIGHT VALVE}

97

118

127

152

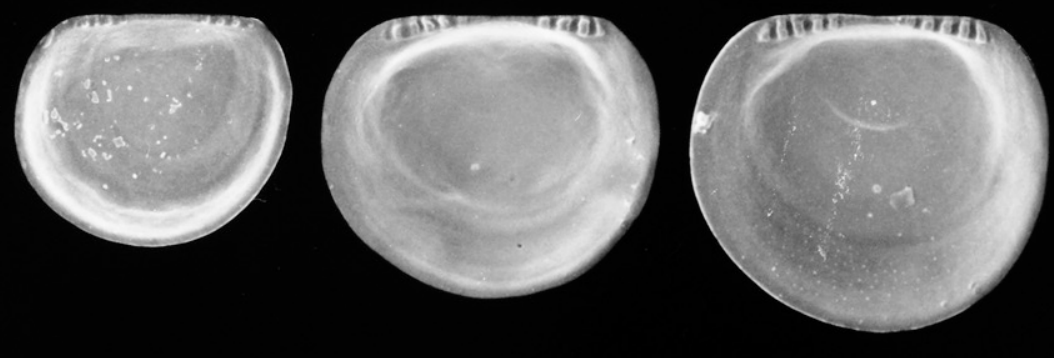

175
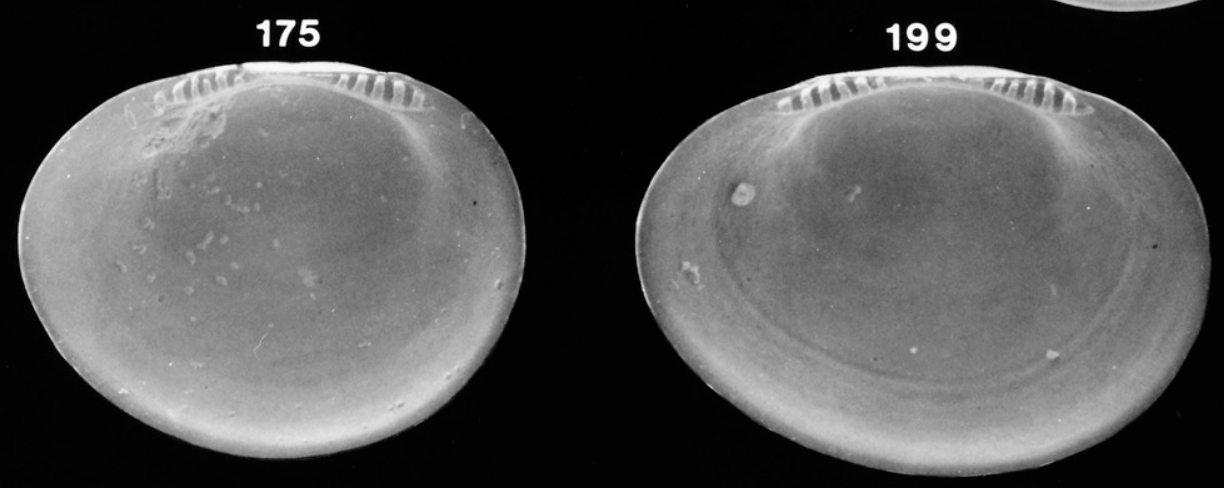

Figure 17. Scanning electron micrographs of disarticulated shell valves of Noetia ponderosa larvae. Numbers indicate the maximum linear shell dimension in micrometers. 


\section{NOETIA PONDEROSA}

\section{LEFT VALVE}

\section{1}

121

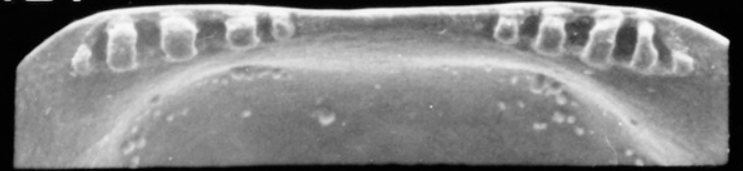

128

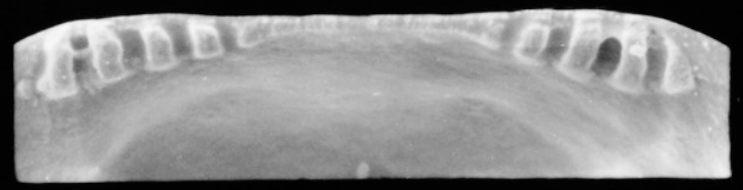

164

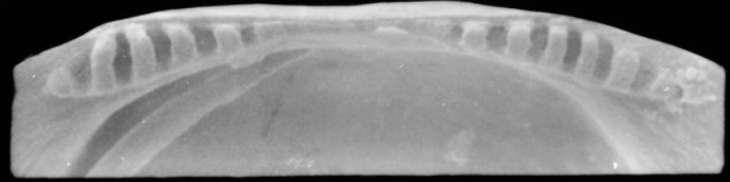

177

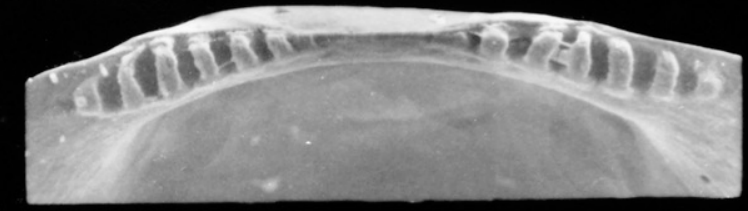

189

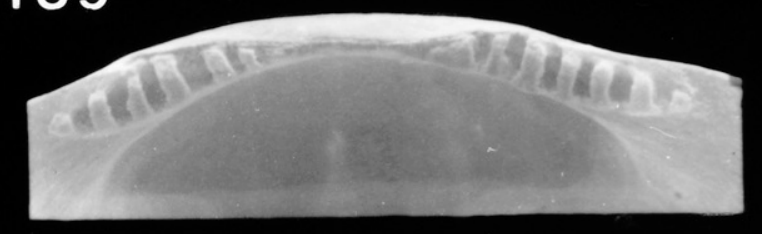

\section{RIGHT VALVE}

97

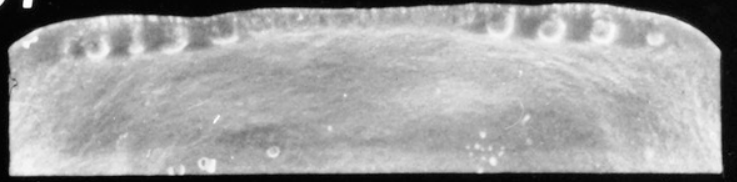

118

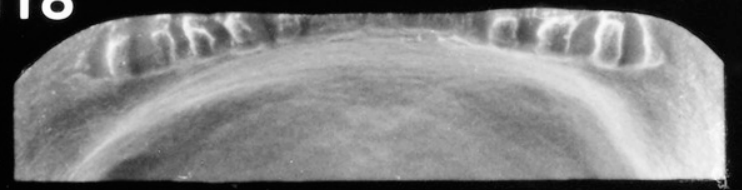

127

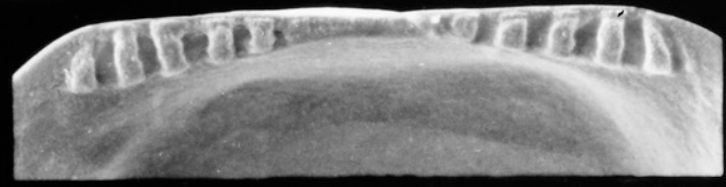

\section{2}

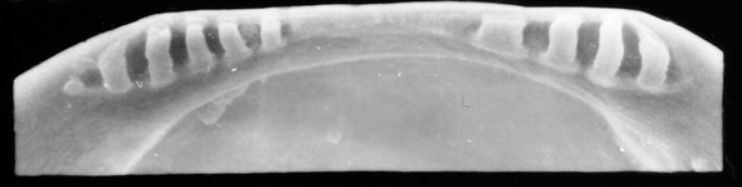

175

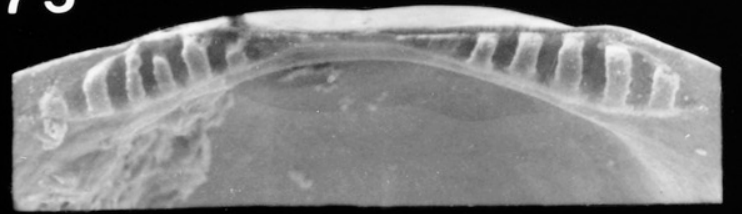

199

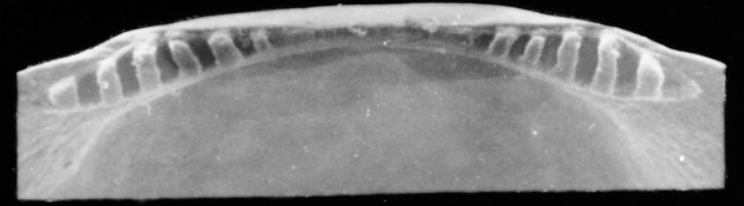

Figure 18. Scanning electron micrographs of the hinge of disarticulated shell valves of Noetia ponderosa larvae seen in Figure 17. Numbers indicate the maximum linear shell dimension in micrometers. 


\section{NOETIA PONDEROSA}

\section{LEFT VALVE}
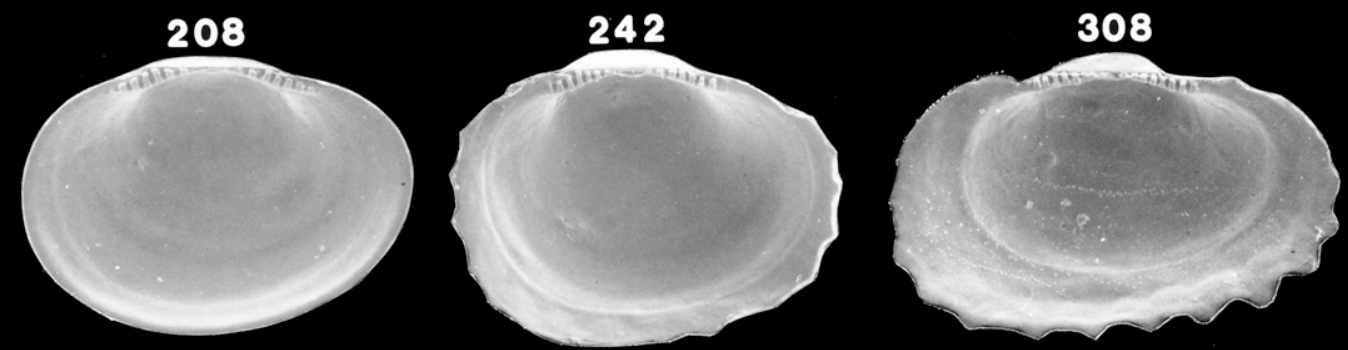

\section{RIGHT VALVE}
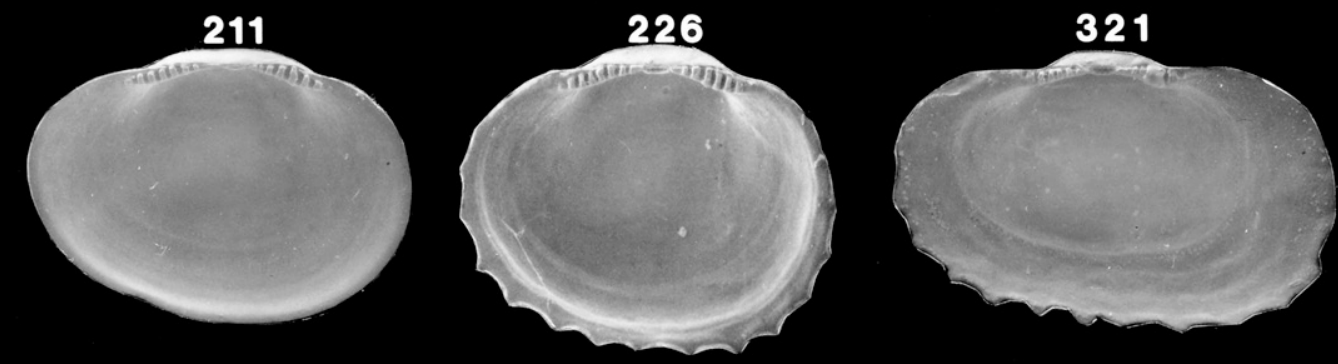

\section{NOETIA PONDEROSA}

\section{LEFT VALVE}
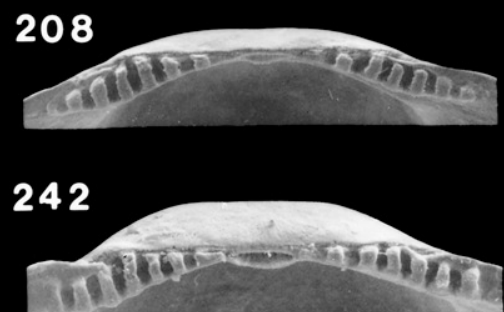

\section{8}

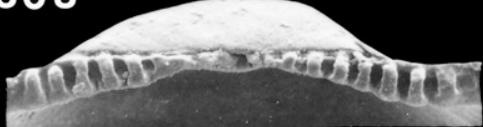

RIGHT VALVE

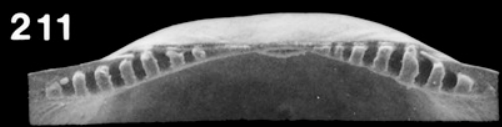

226

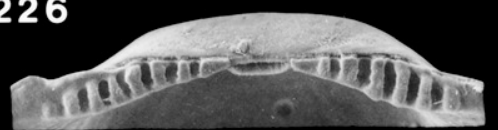

321

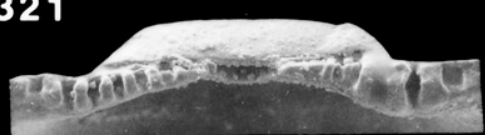

Figure 19. Scanning electron micrographs of disarticulated shell valves of Noetia ponderosa postlarvae (top) and higher magnification scanning electron micrographs of the hinge of these shell valves (bottom). Numbers indicate the maximum linear shell dimension in micrometers. 


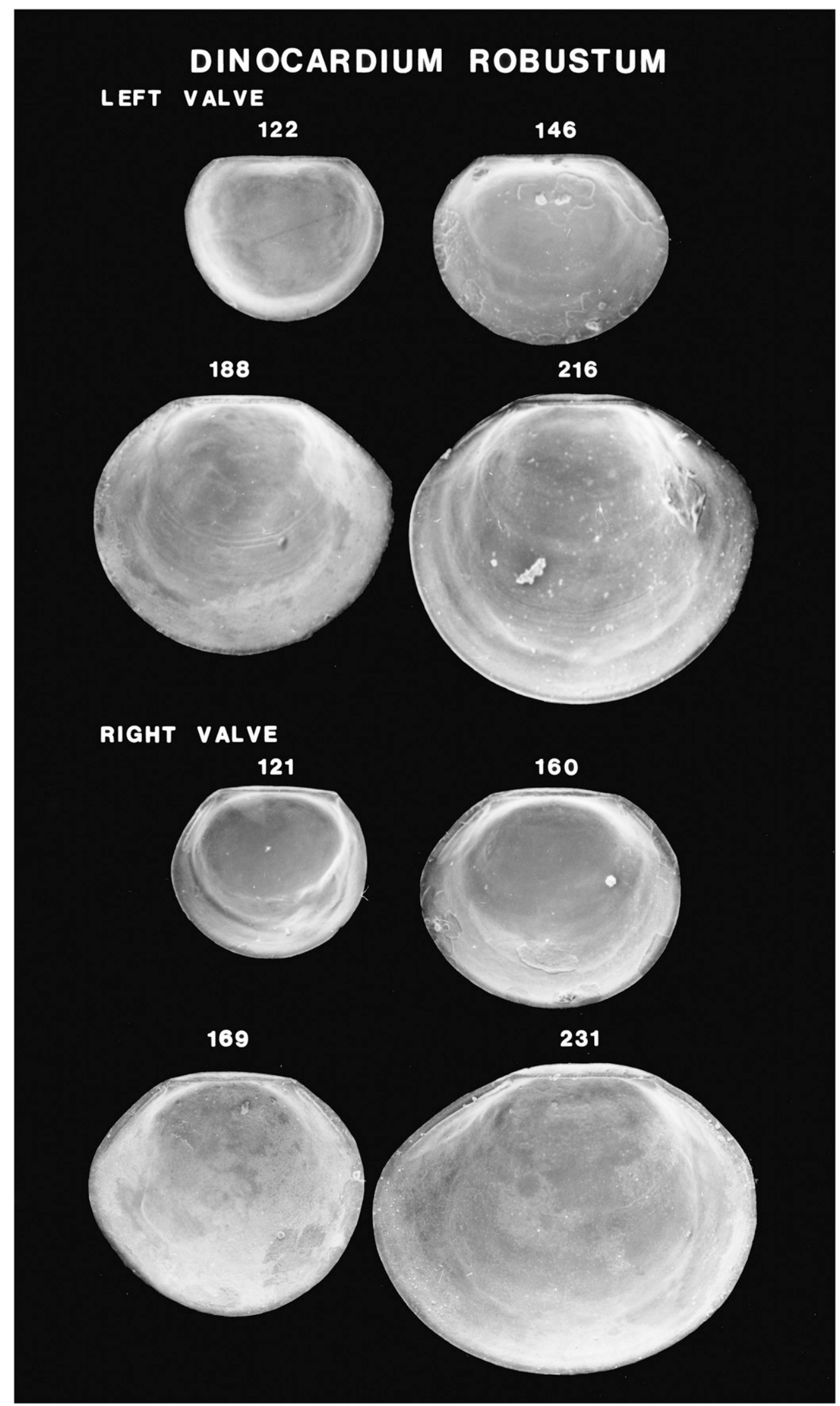

Figure 20. Scanning electron micrographs of disarticulated shell valves of Dinocardium robustum larvae. Numbers indicate the maximum linear shell dimension in micrometers. 


\section{DINOCARDIUM ROBUSTUM}

\section{LEFT VALVE}

\section{2}

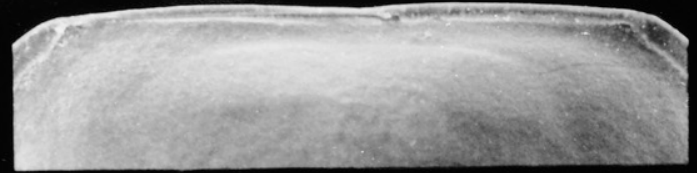

146

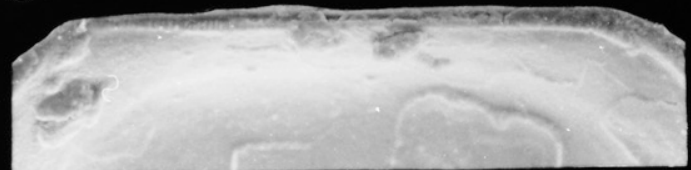

188

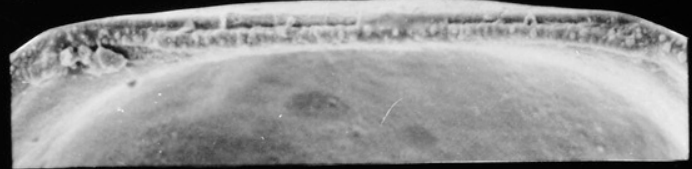

\section{6}

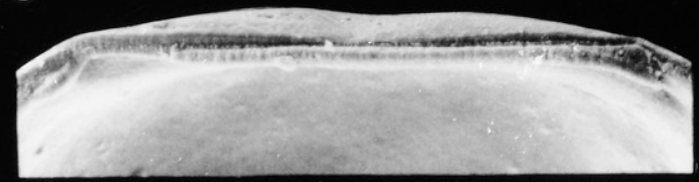

\section{RIGHT VALVE}

121

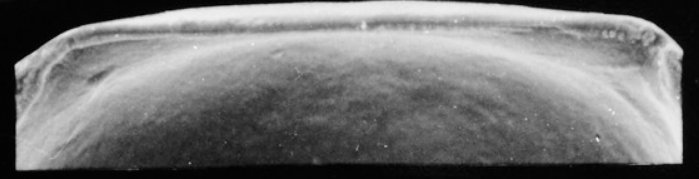

160

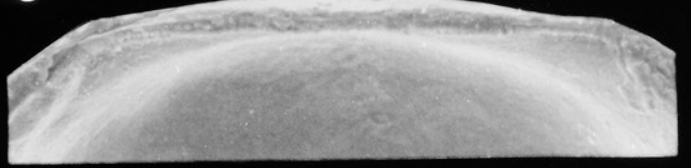

169

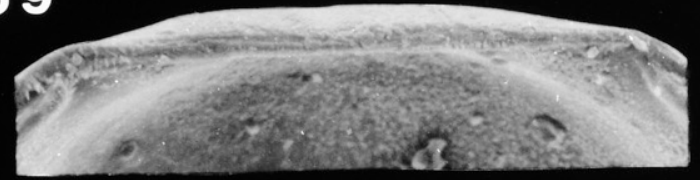

231

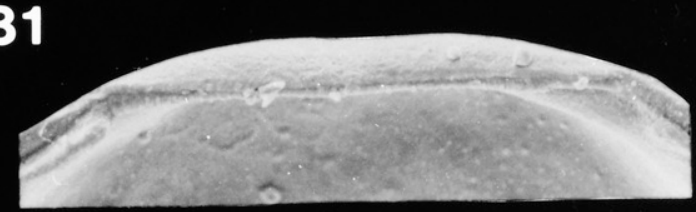

Figure 21. Scanning electron micrographs of the hinge of disarticulated shell valves of Dinocardium robustum larvae seen in Figure 20. Numbers indicate the maximum linear shell dimension in micrometers. 


\section{DINOCARDIUM ROBUSTUM}

\section{LEFT VALVE}
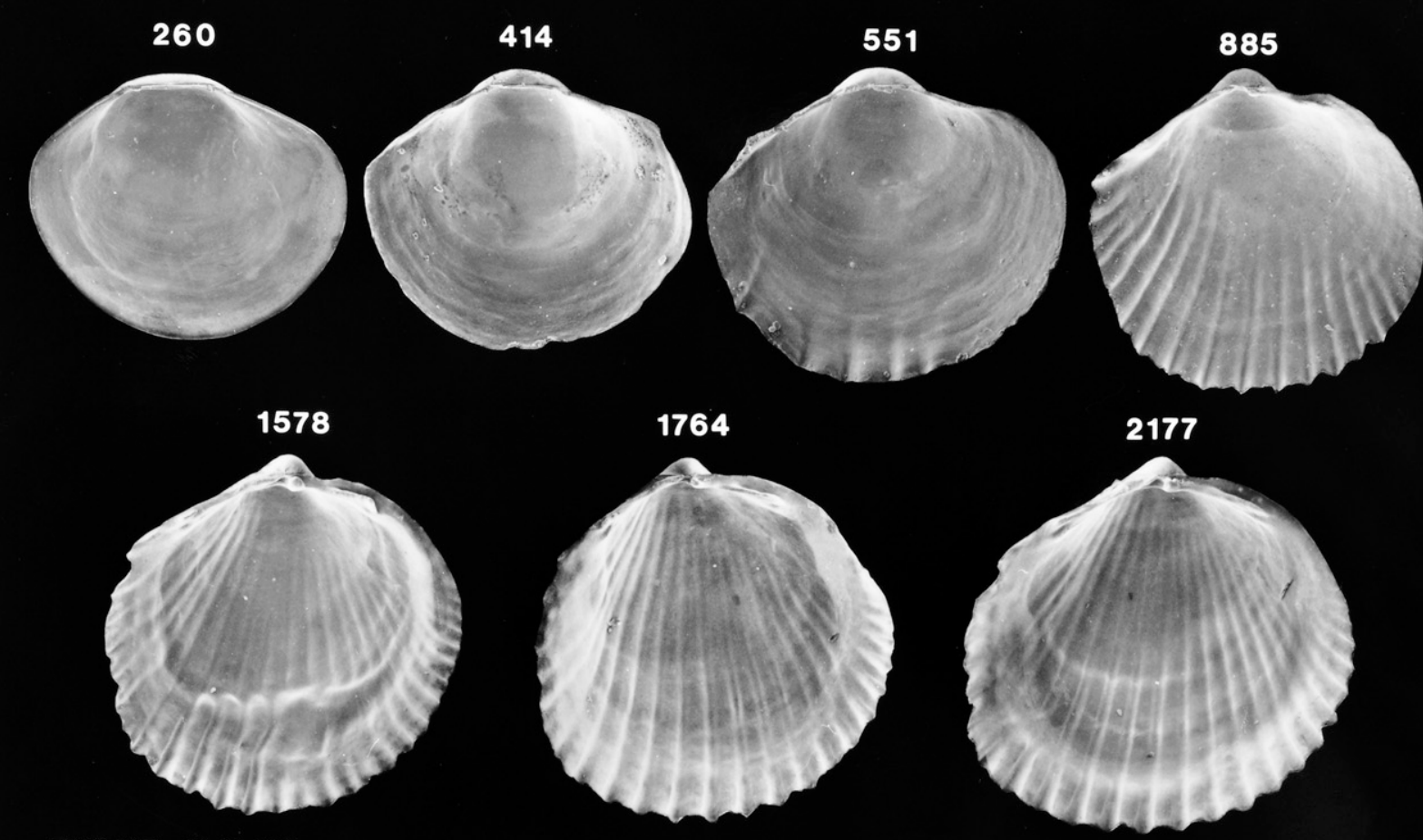

\section{RIGHT VALVE}

262

375

576

833
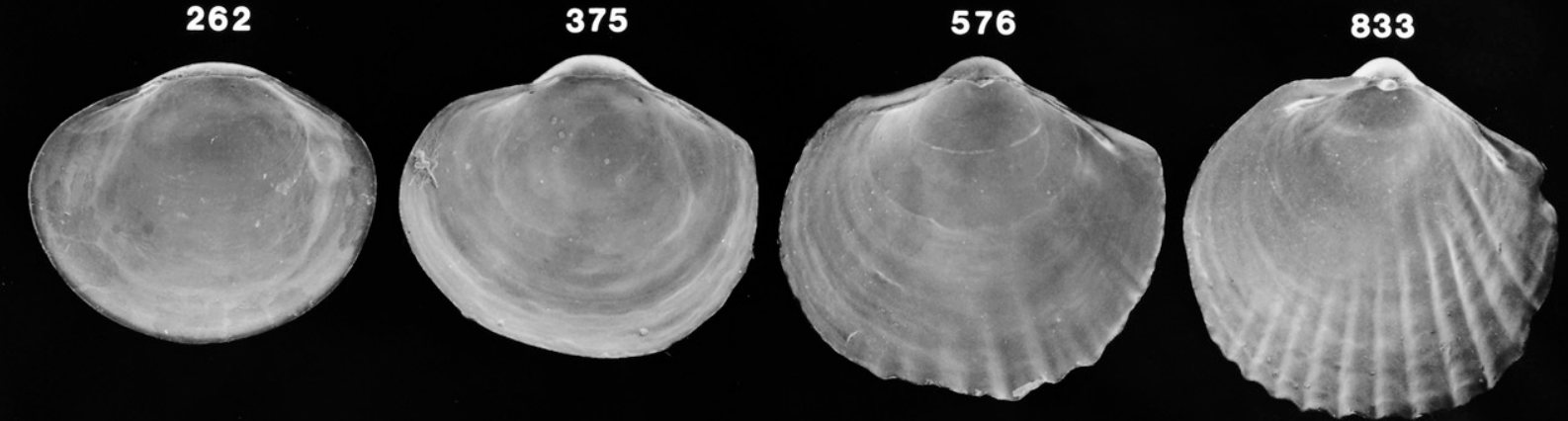

1513

1796

2083
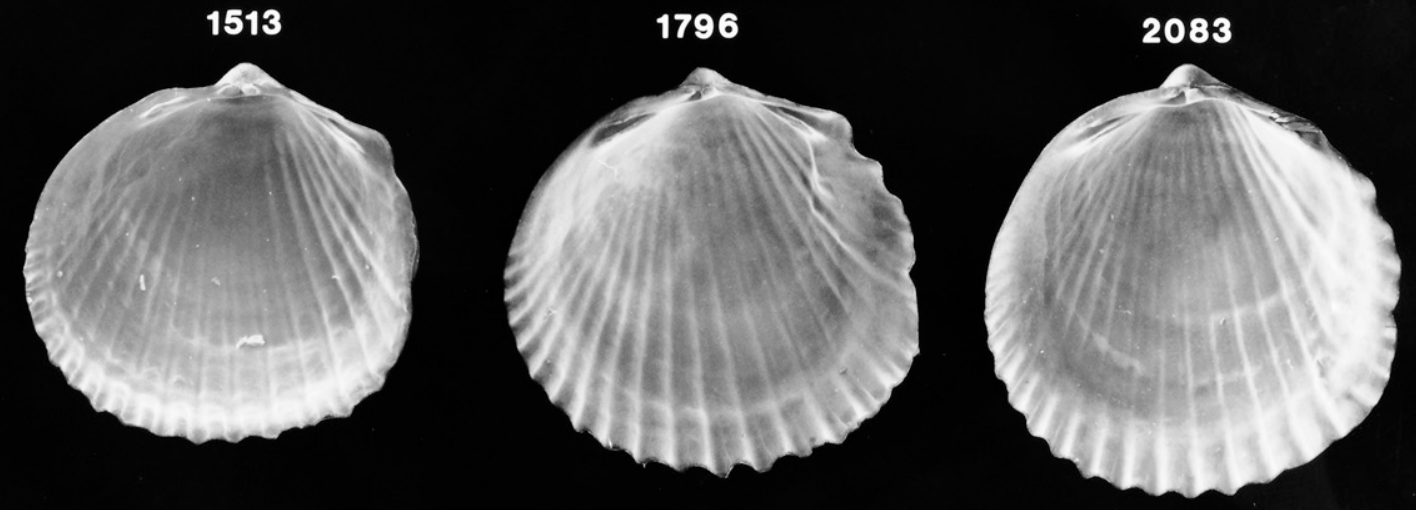


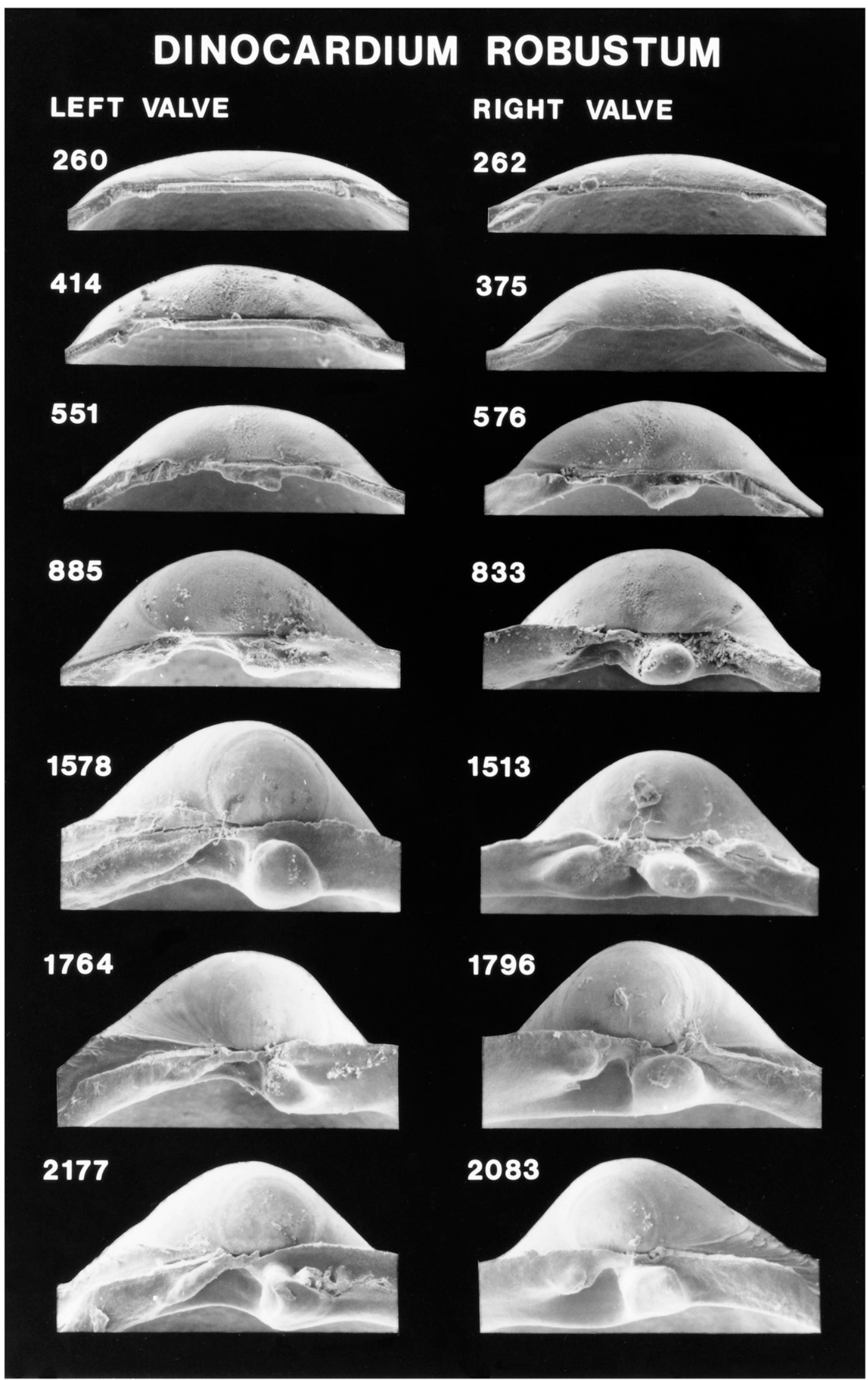

Figure 23. Scanning electron micrographs of the hinge of disarticulated shell valves of Dinocardium robustum postlarvae seen in Figure 22. Numbers indicate the maximum linear shell dimension in micrometers. 


\section{LAEVICARDIUM MORTONI}

\section{LEFT VALVE}

88

95

112

133
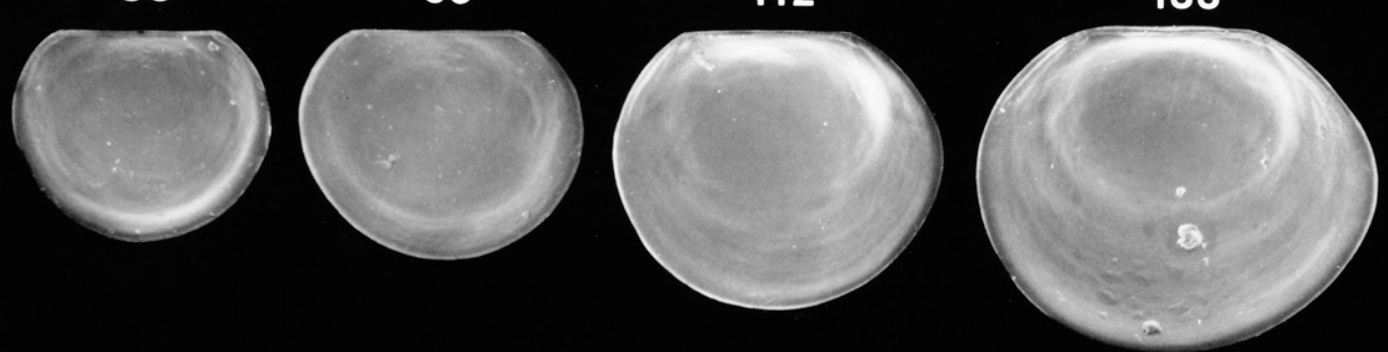

142

150

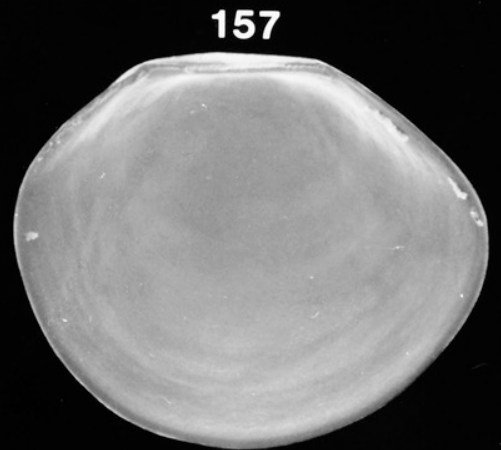

\section{RIGHT VALVE}
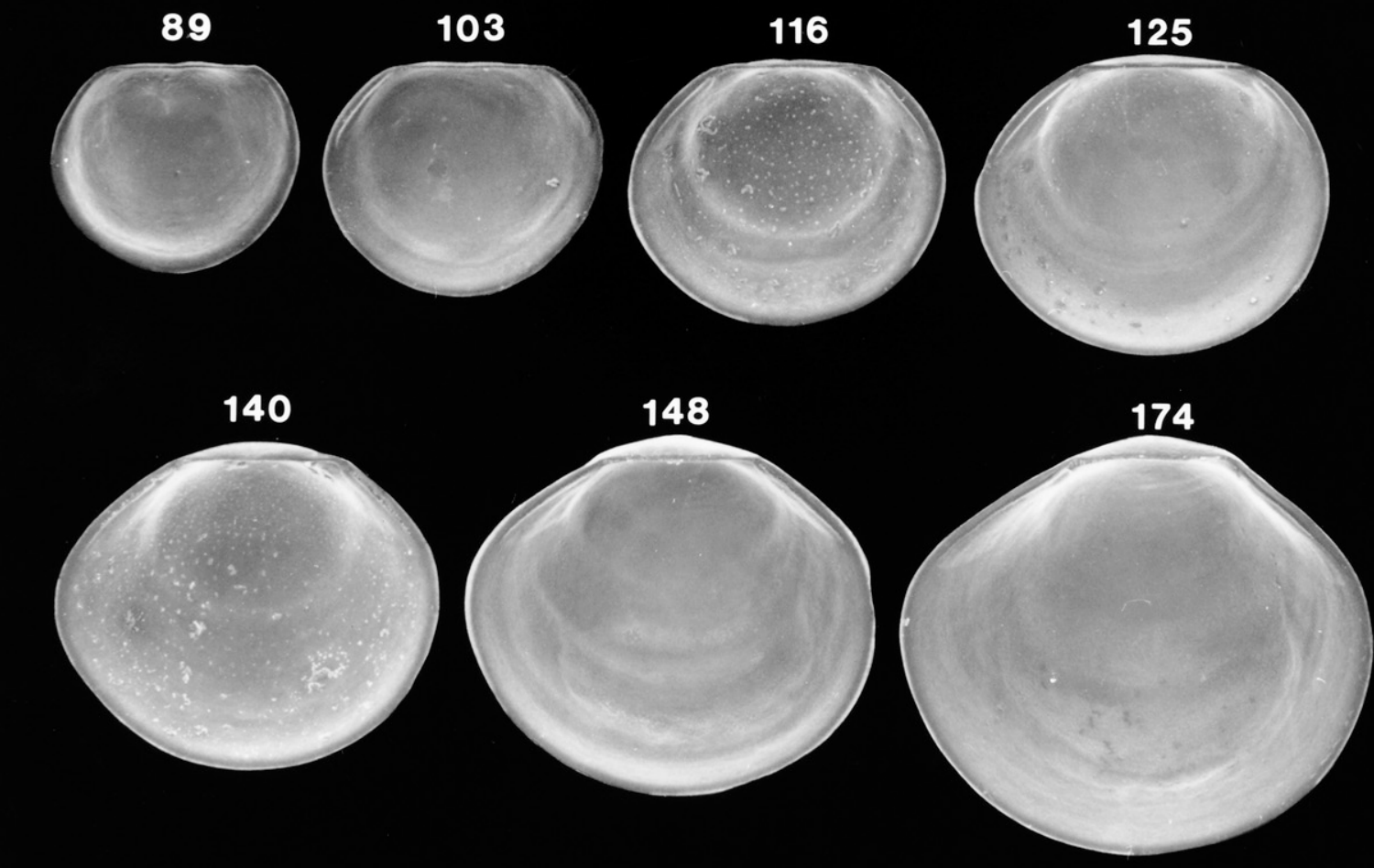

Figure 24. Scanning electron micrographs of disarticulated shell valves of Laevicardium mortoni larvae. Numbers indicate the maximum linear shell dimension in micrometers. 


\section{LAEVICARDIUM MORTONI}

\section{LEFT VALVE}

\section{8}

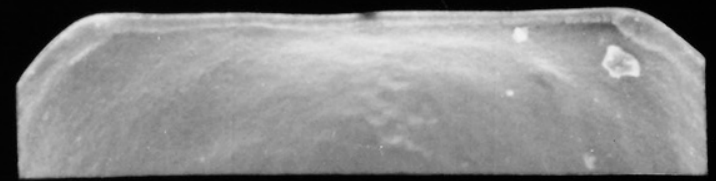

\section{5}

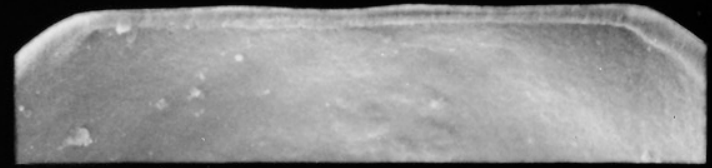

112

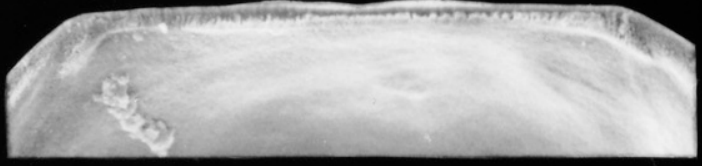

\section{3}

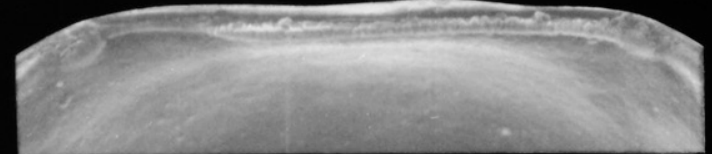

\section{2}

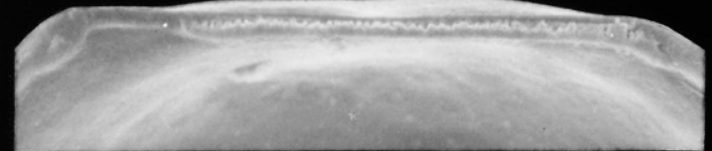

\section{0}

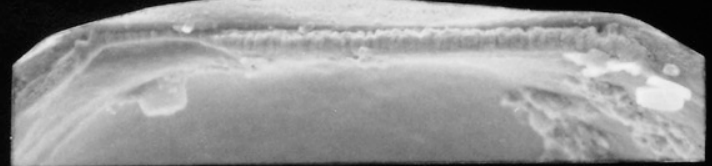

\section{7}

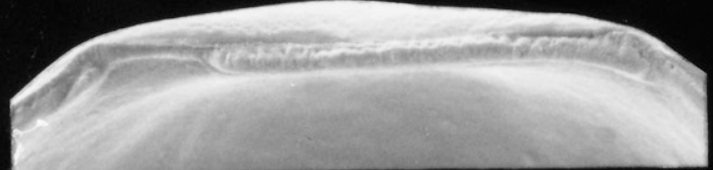

\section{RIGHT VALVE}

89

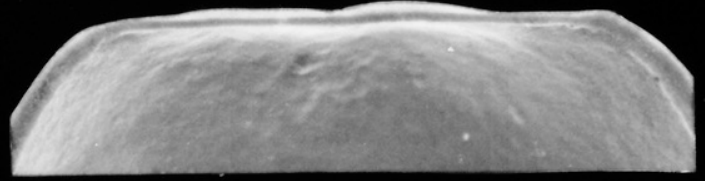

\section{3}

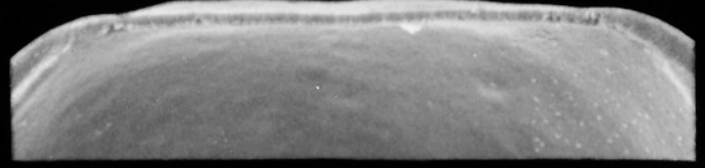

116

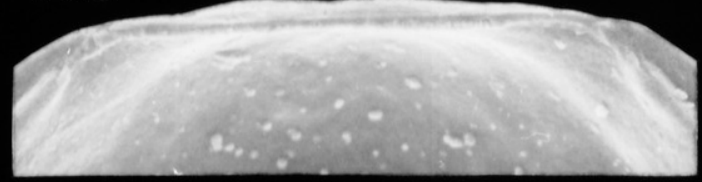

125
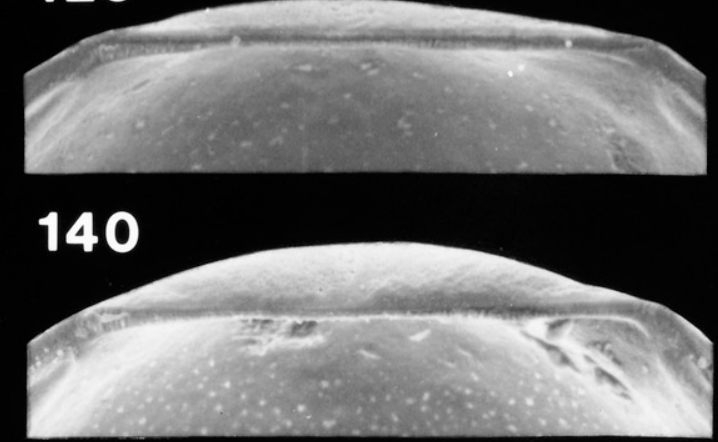

148

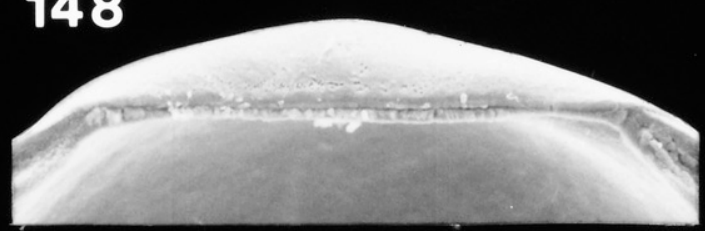

174

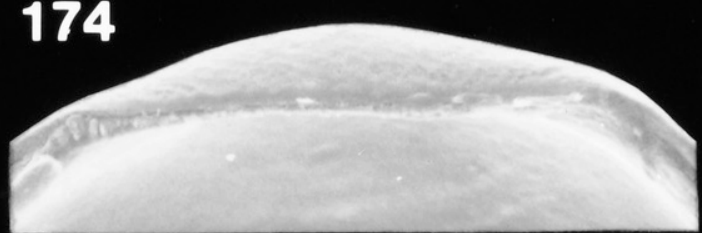




\section{LAEVICARDIUM MORTONI}

\section{LEFT VALVE}

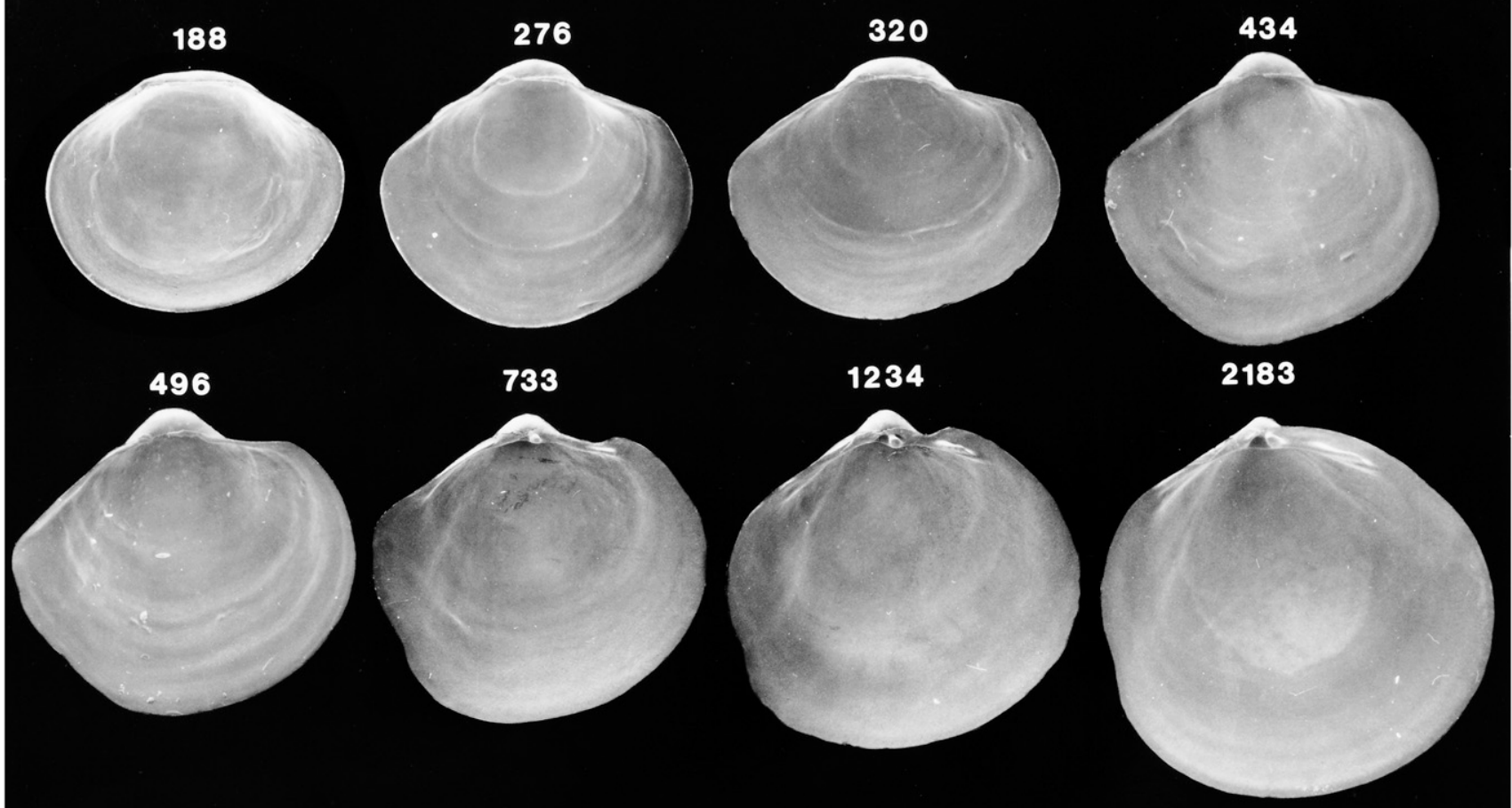

\section{RIGHT VALVE}
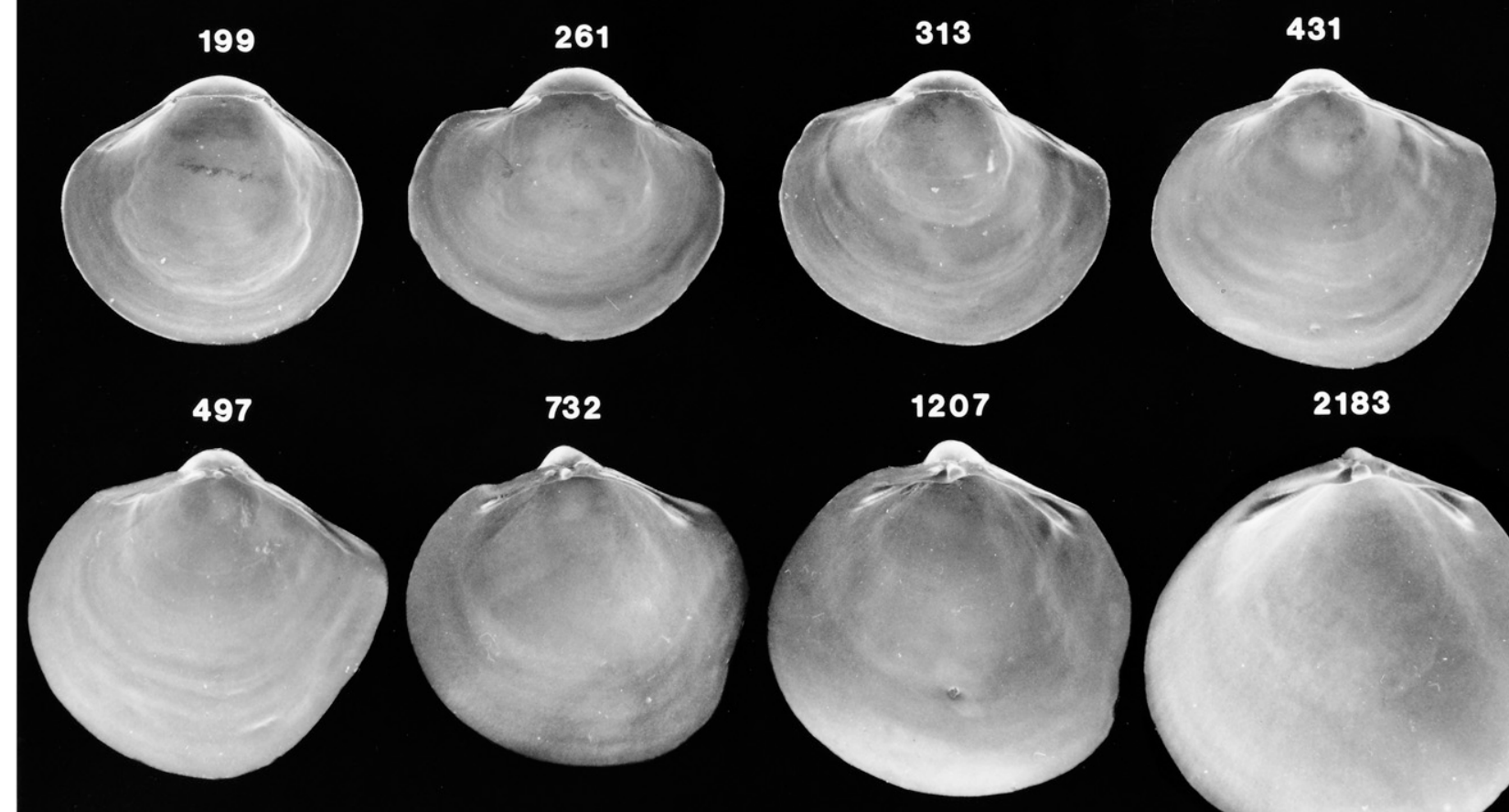

2183 


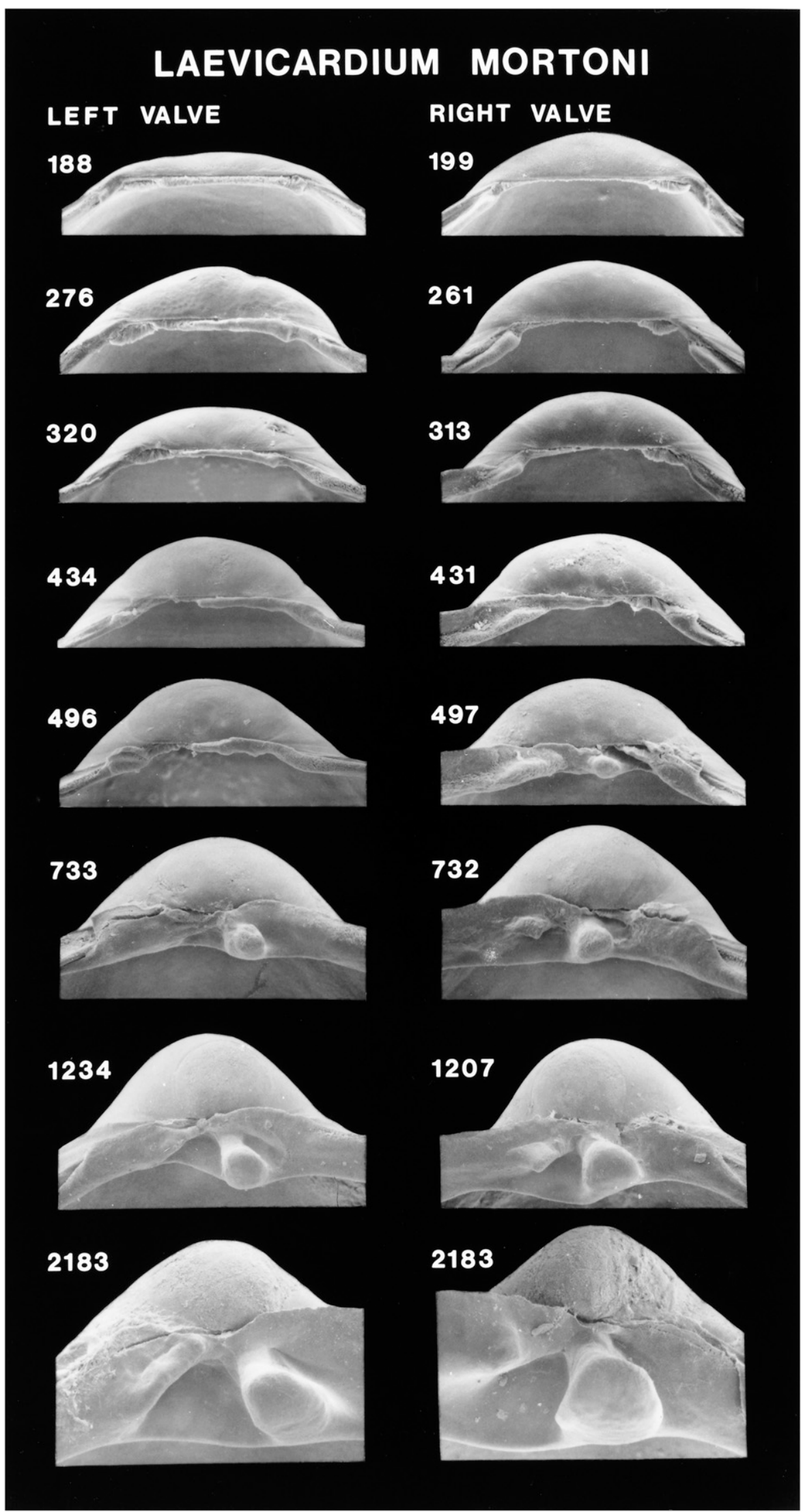

Figure 27. Scanning electron micrographs of the hinge of disarticulated shell valves of Laevicardium mortoni postlarvae seen in Figure 26. Numbers indicate the maximum linear shell dimension in micrometers. 


\section{tAGEluS PLeBeius}

\section{LEFT VALVE}
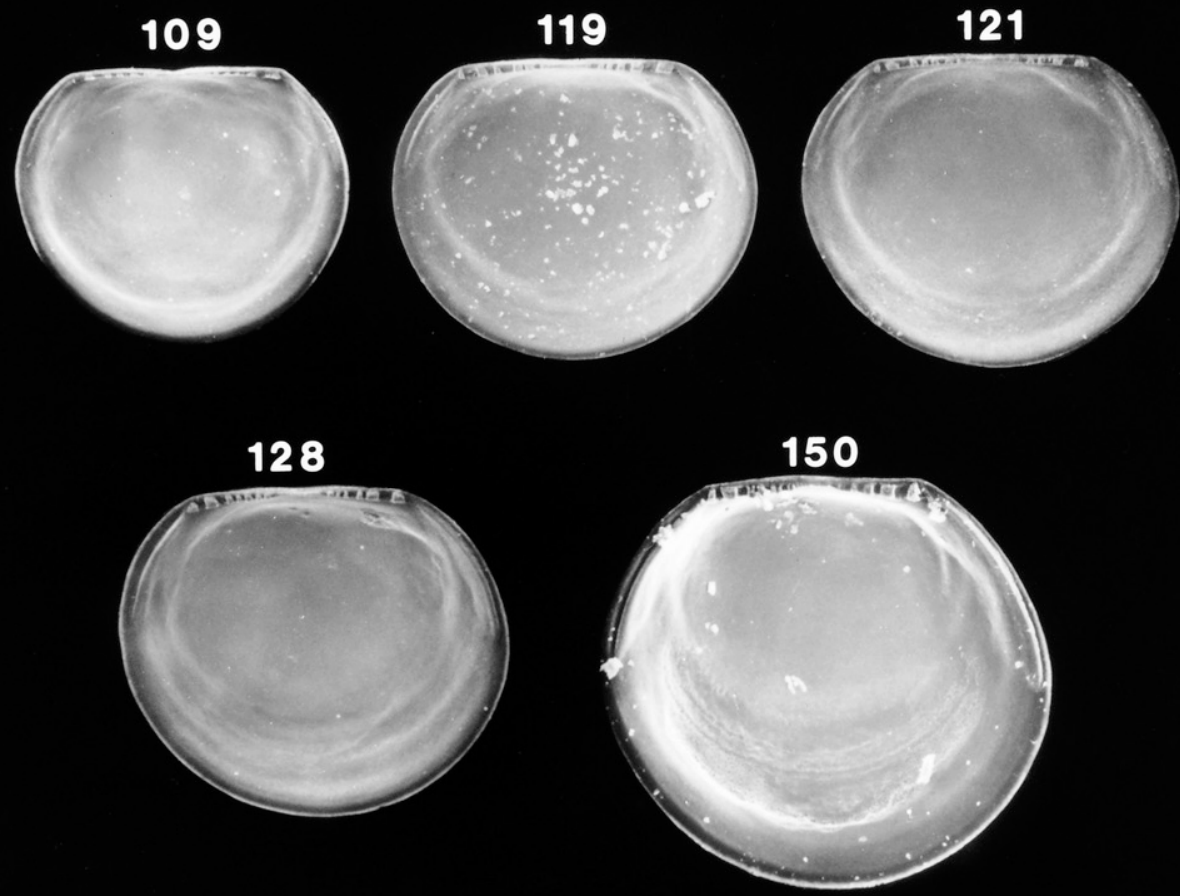

RIGHT VALVE

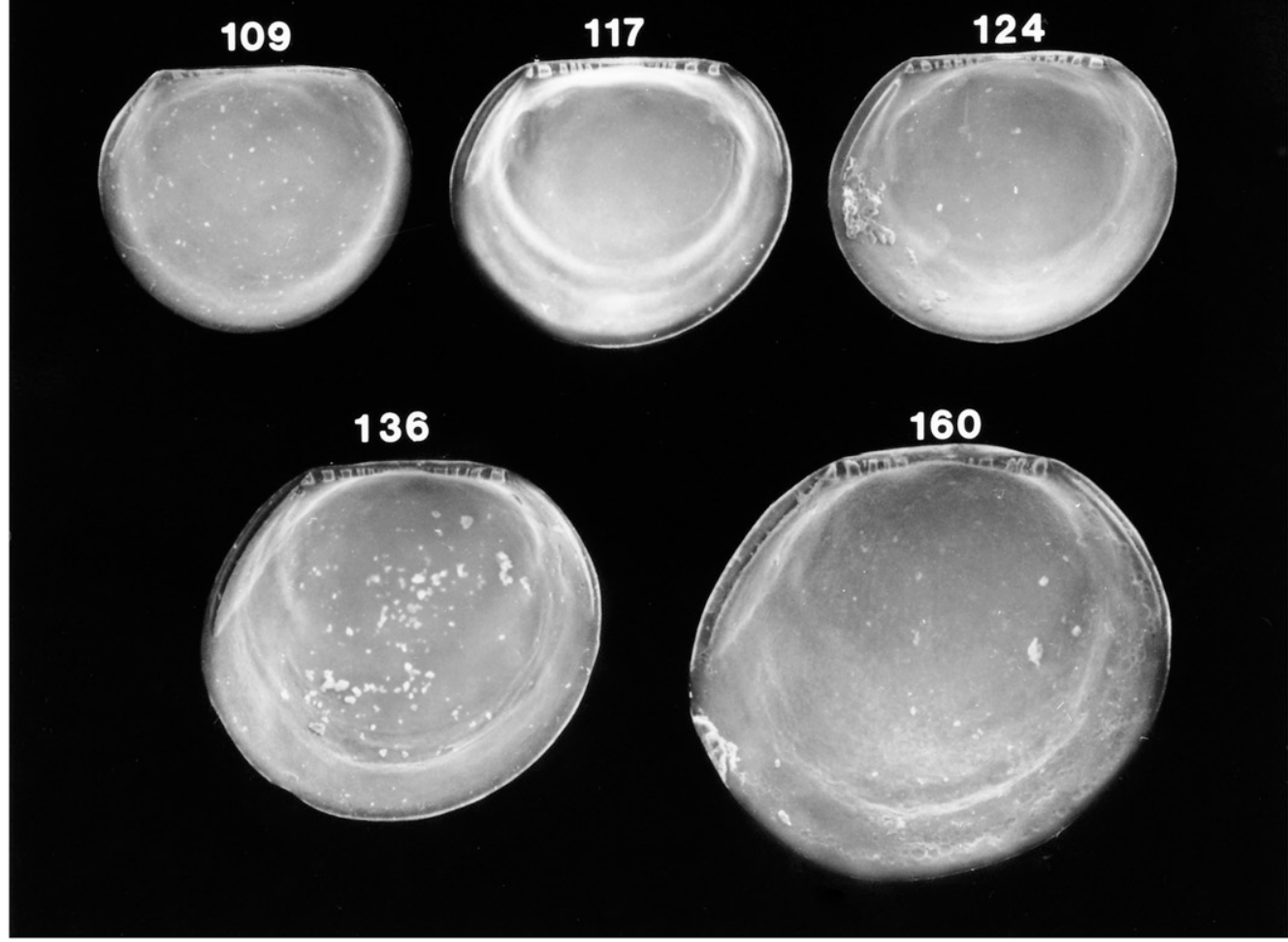

Figure 28. Scanning electron micrographs of disarticulated shell valves of Tagelus plebeius larvae. Numbers indicate the maximum linear shell dimension in micrometers. 


\section{tagelus Plebeius}

\section{LEFT VALVE}

\section{9}

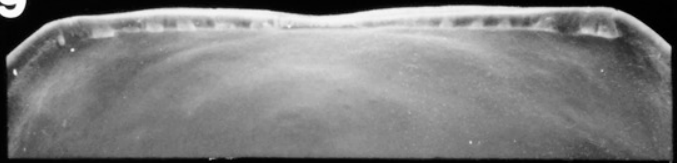

119

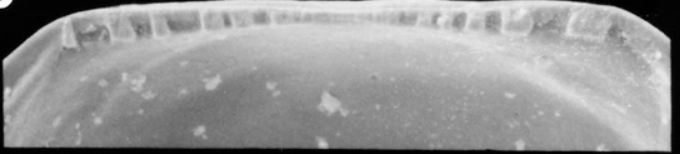

121

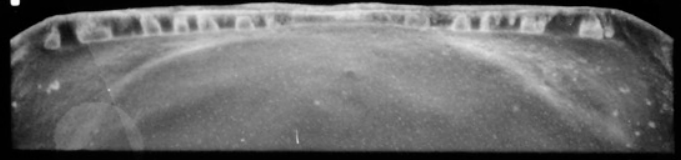

128

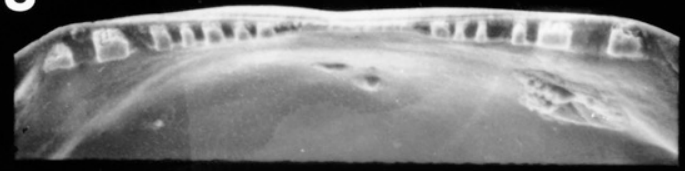

150

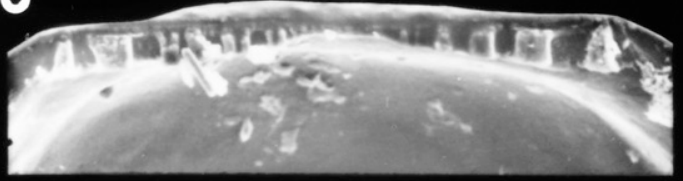

\section{RIGHT VALVE}

\section{9}

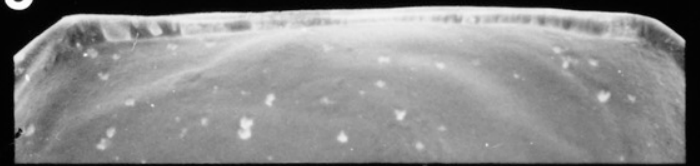

117

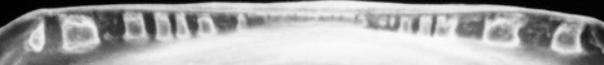

124

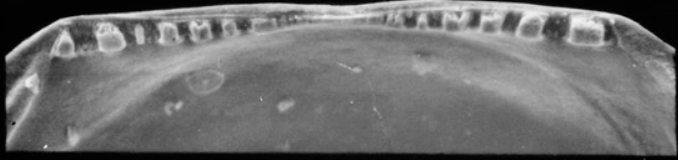

136

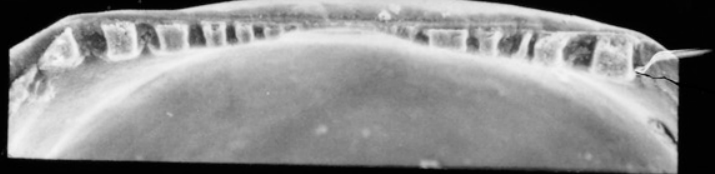

160

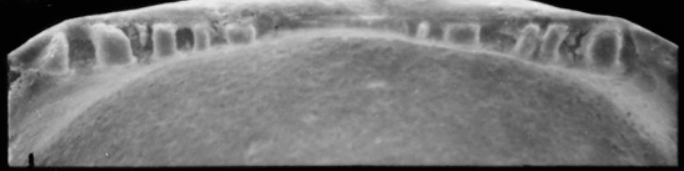

Figure 29. Scanning electron micrographs of the hinge of disarticulated shell valves of Tagelus plebeius larvae seen in Figure 28. Numbers indicate the maximum linear shell dimension in micrometers. 


\section{TAGELUS PLEBEIUS}

\section{LEFT VALVE}
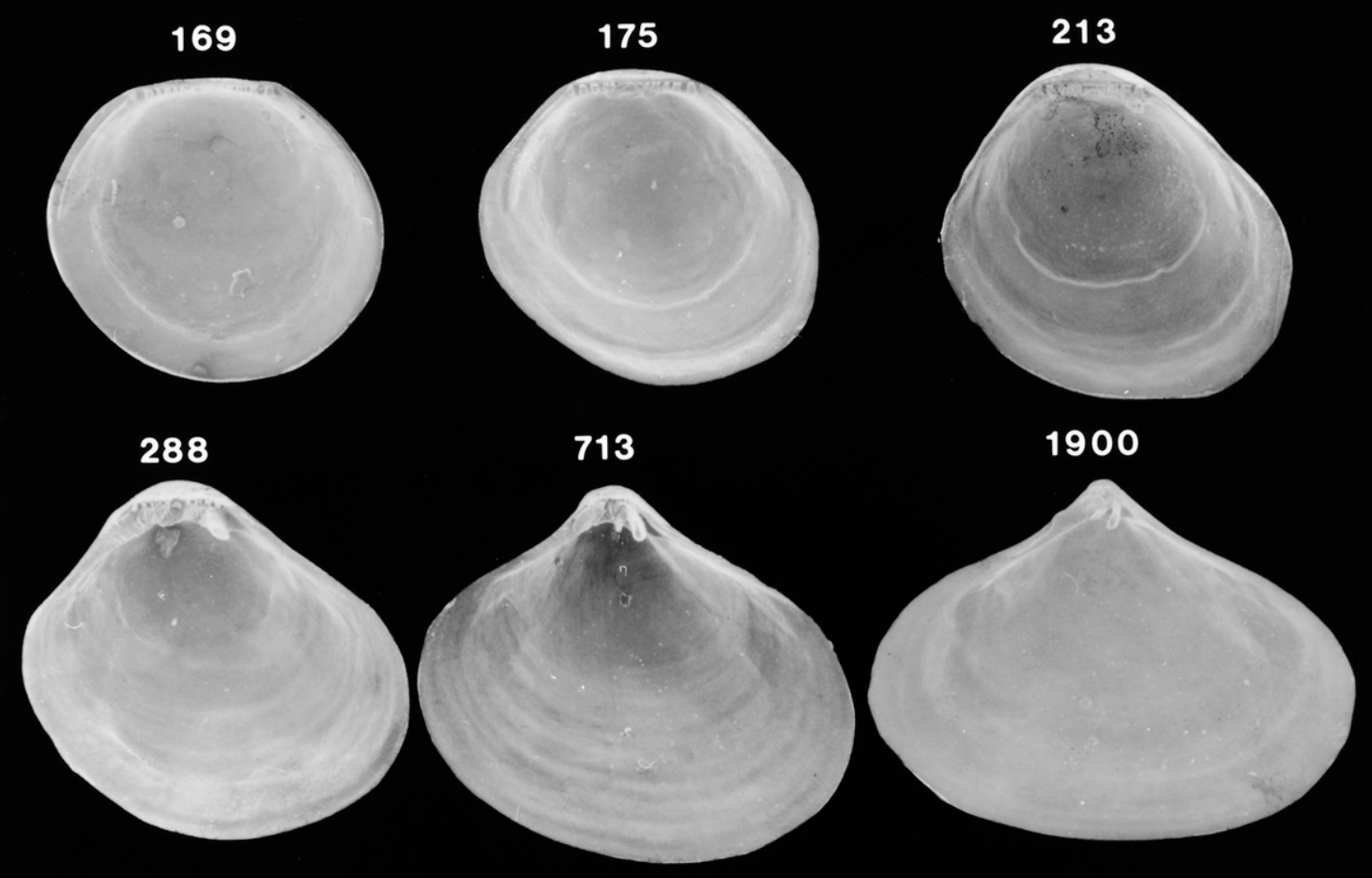

\section{RIGHT VALVE}

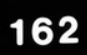

177
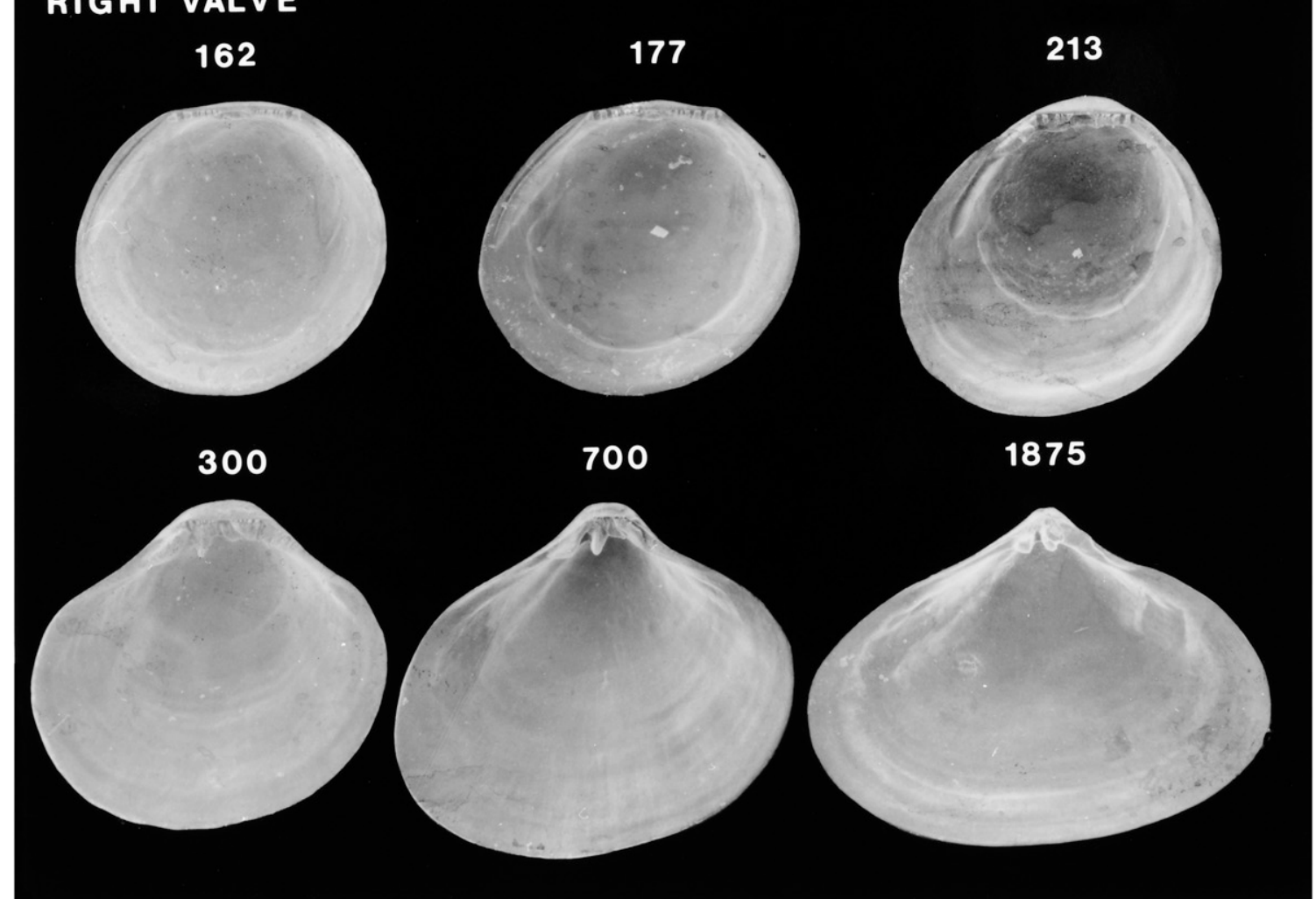

Figure 30. Scanning electron micrographs of disarticulated shell valves of Tagelus plebeius postlarvae. Numbers indicate the maximum linear shell dimension in micrometers. 


\section{TAGELUS PLEBEIUS}

\section{LEFT VALVE}

\section{9}

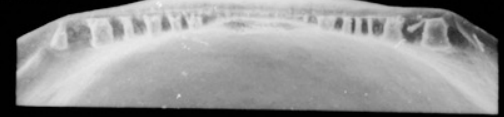

175
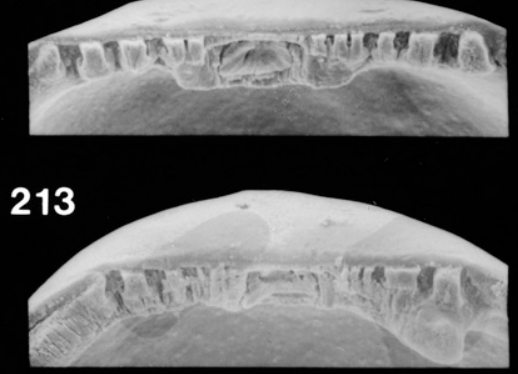

288

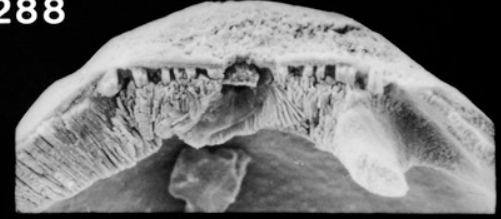

713

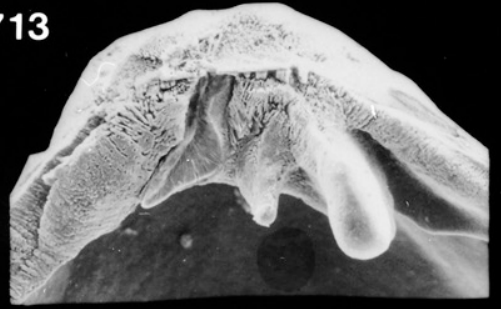

1900

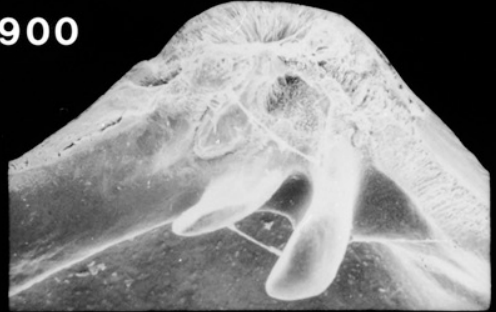

2842

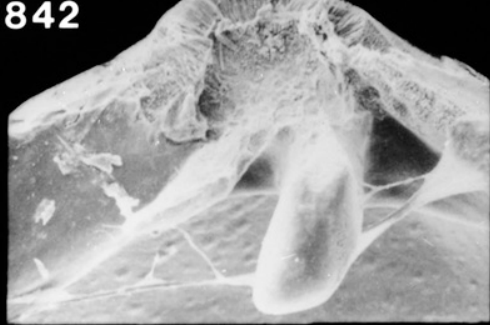

\section{RIGHT VALVE}

162

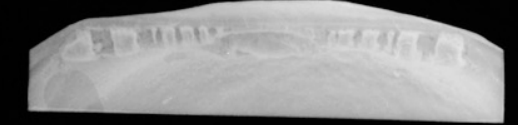

177
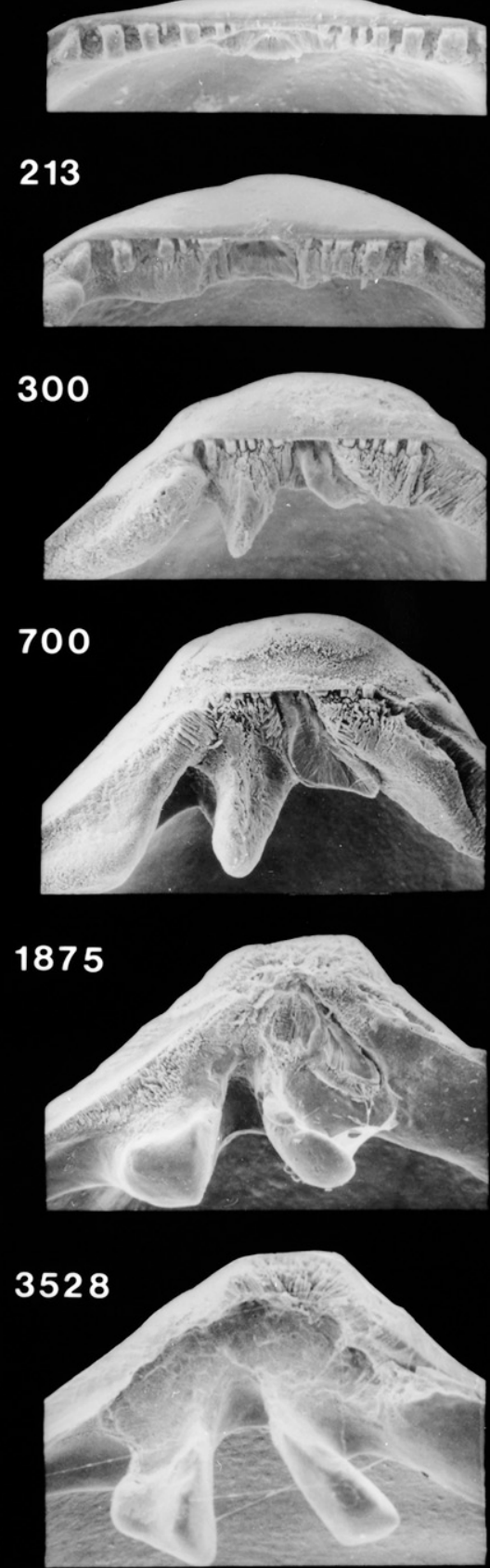


\section{AMERITELLA AGILIS}

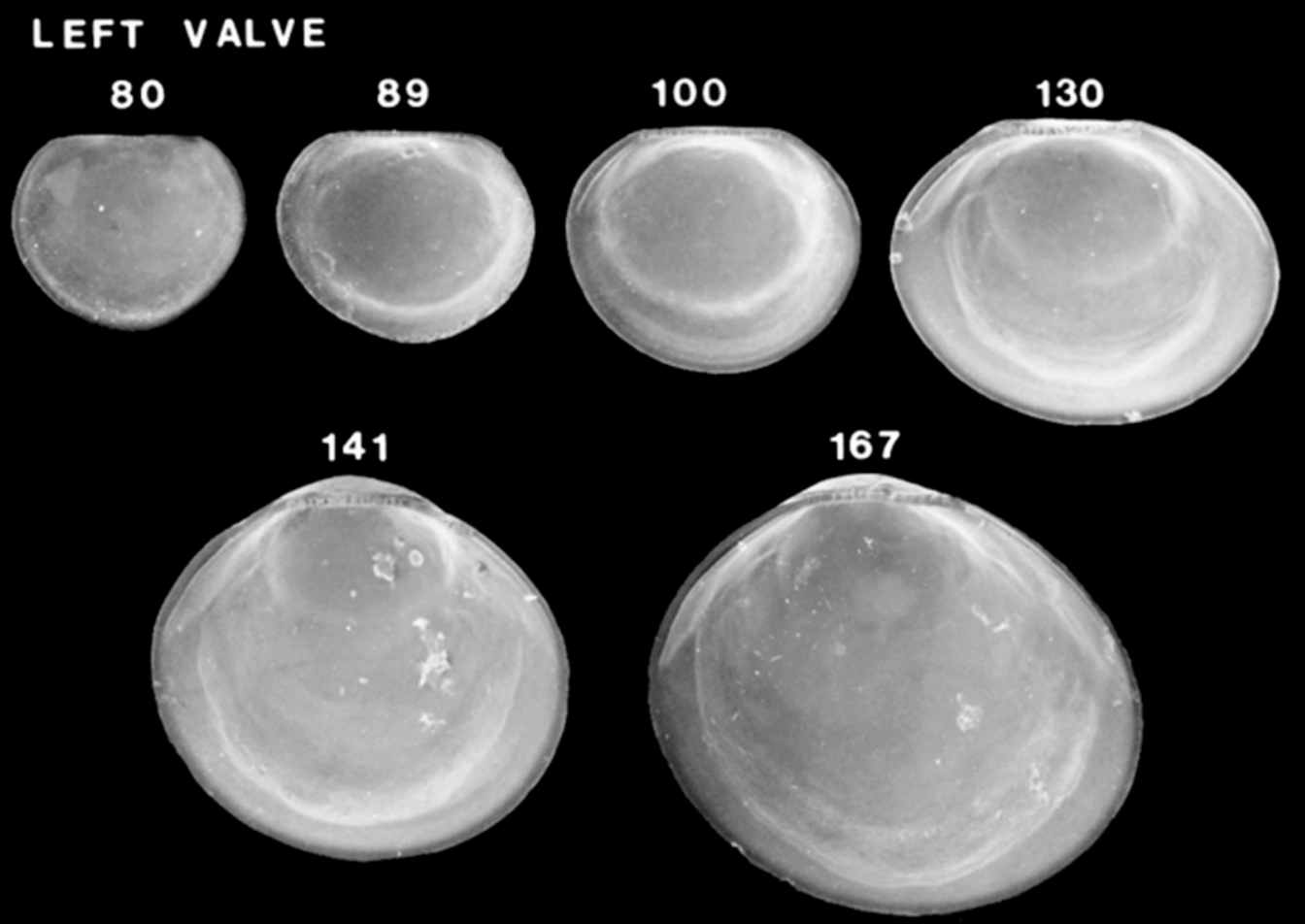

RIGHT VALVE

77

89

100

124
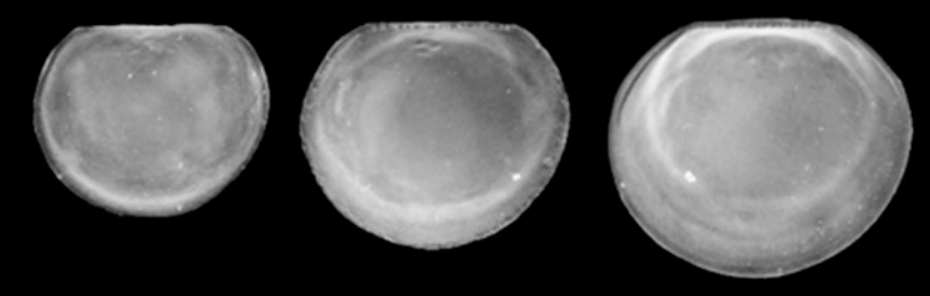

145

167
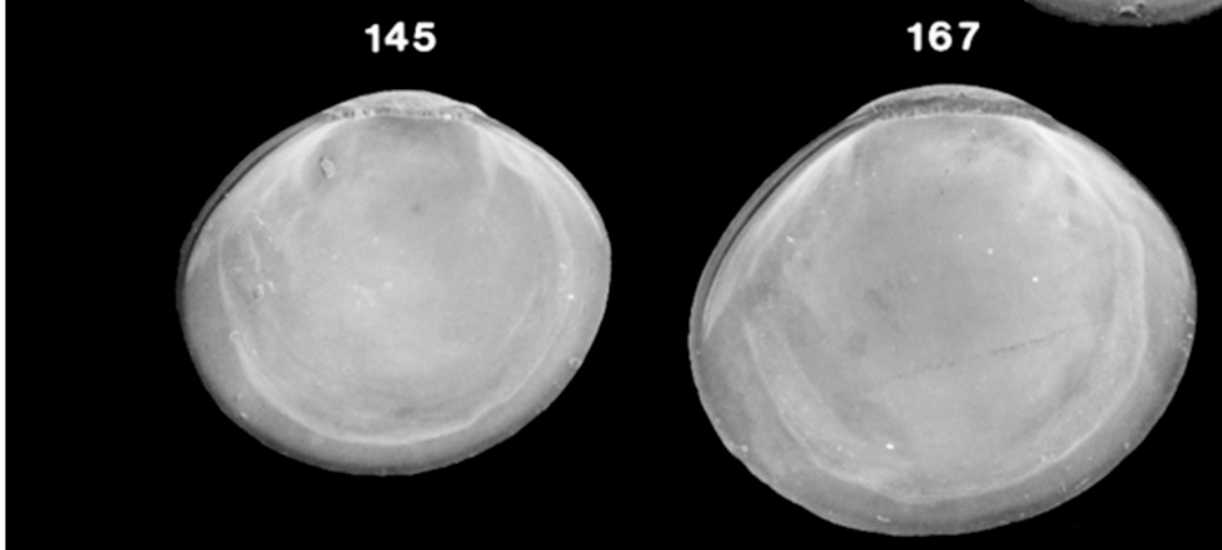

Figure 32. Scanning electron micrographs of disarticulated shell valves of Ameritella agilis larvae. Numbers indicate the maximum linear shell dimension in micrometers. 


\section{AMERITELLA AGILIS}

\section{LEFT VALVE}

\section{0}

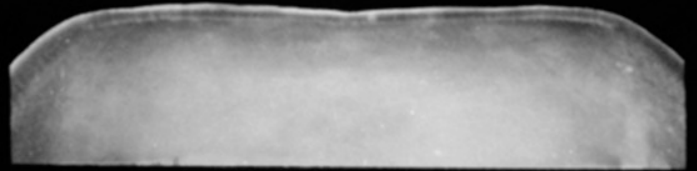

89

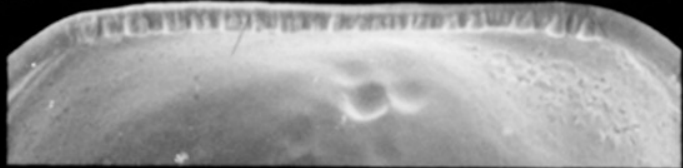

100

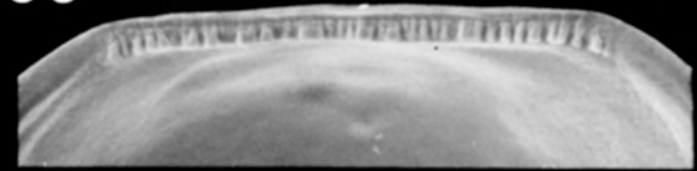

130

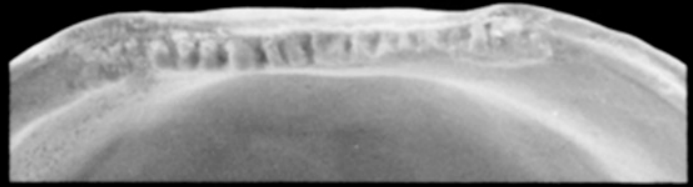

141

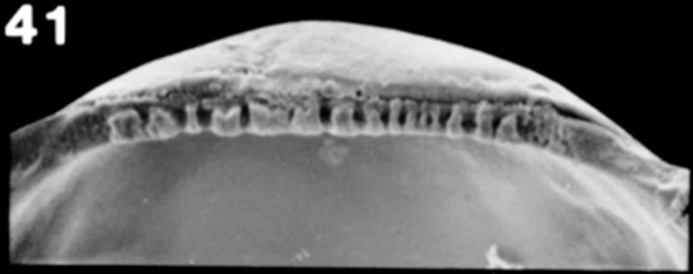

167

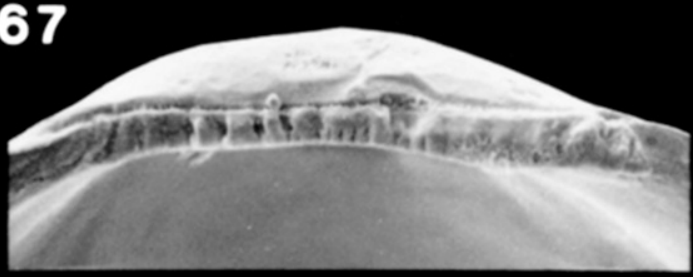

\section{RIGHT VALVE}

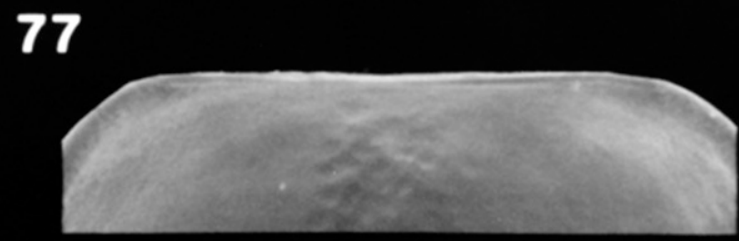

89

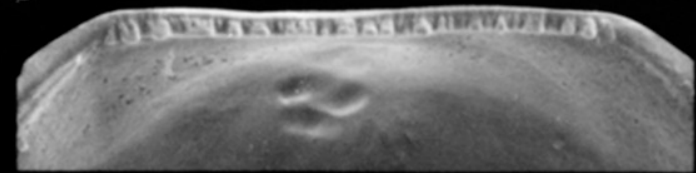

\section{0}

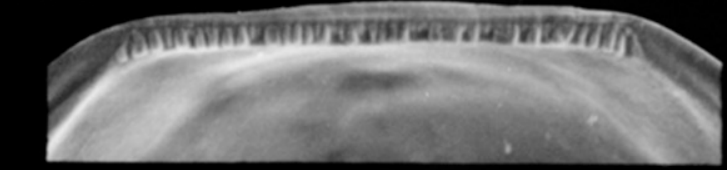

124
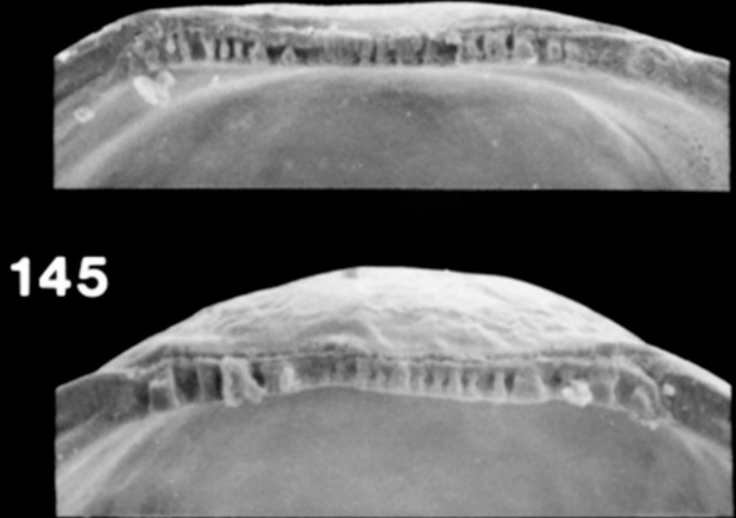

167

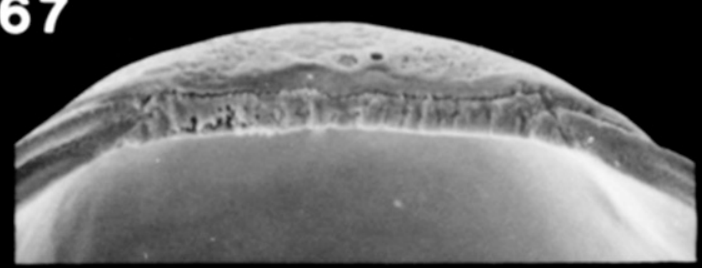

Figure 33. Scanning electron micrographs of the hinge of disarticulated shell valves of Ameritella agilis larvae seen in Figure 32. Numbers indicate the maximum linear shell dimension in micrometers. 


\section{AMERITELLA AGILIS}

\section{LEFT VALVE}
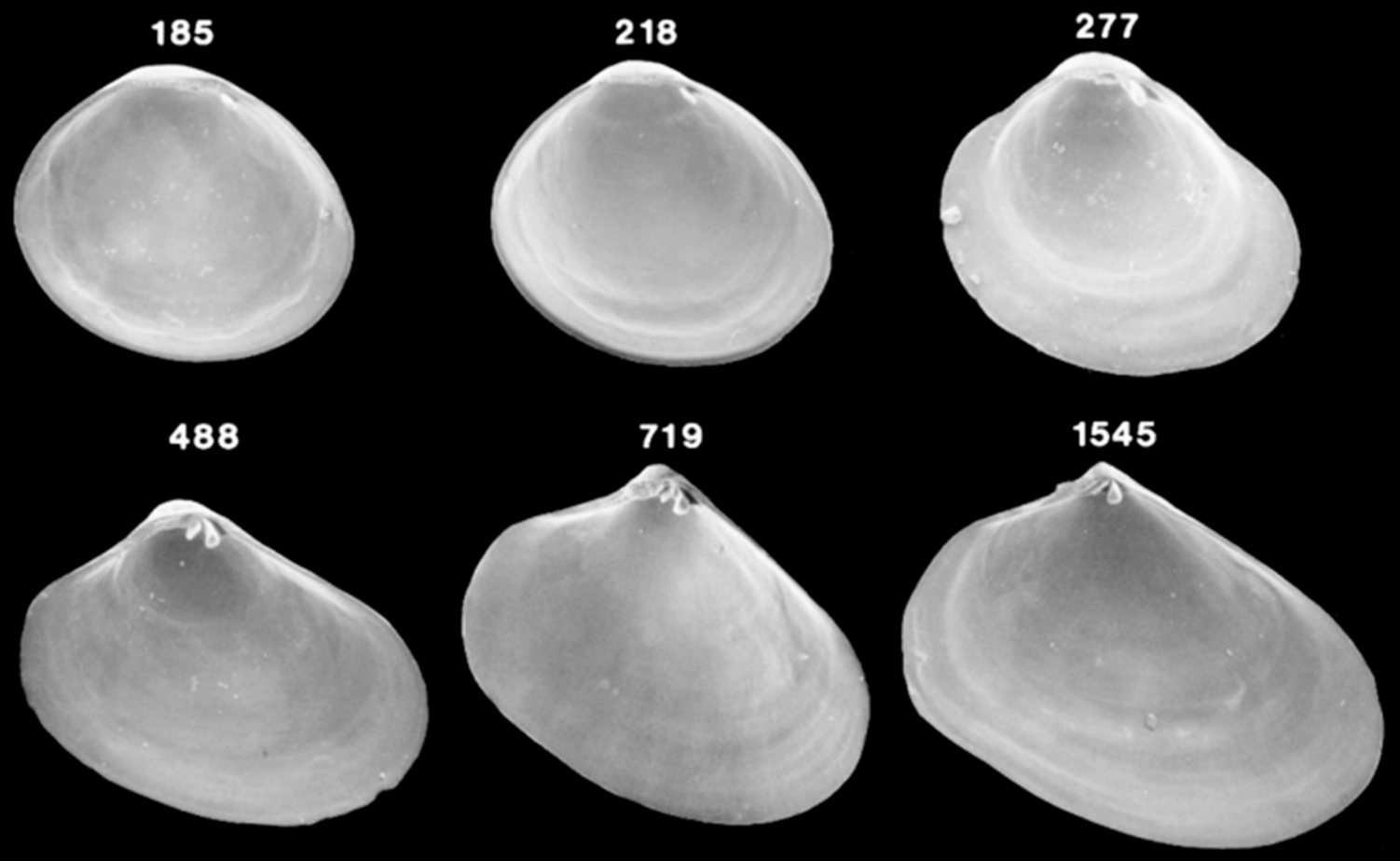

\section{RIGHT VALVE}
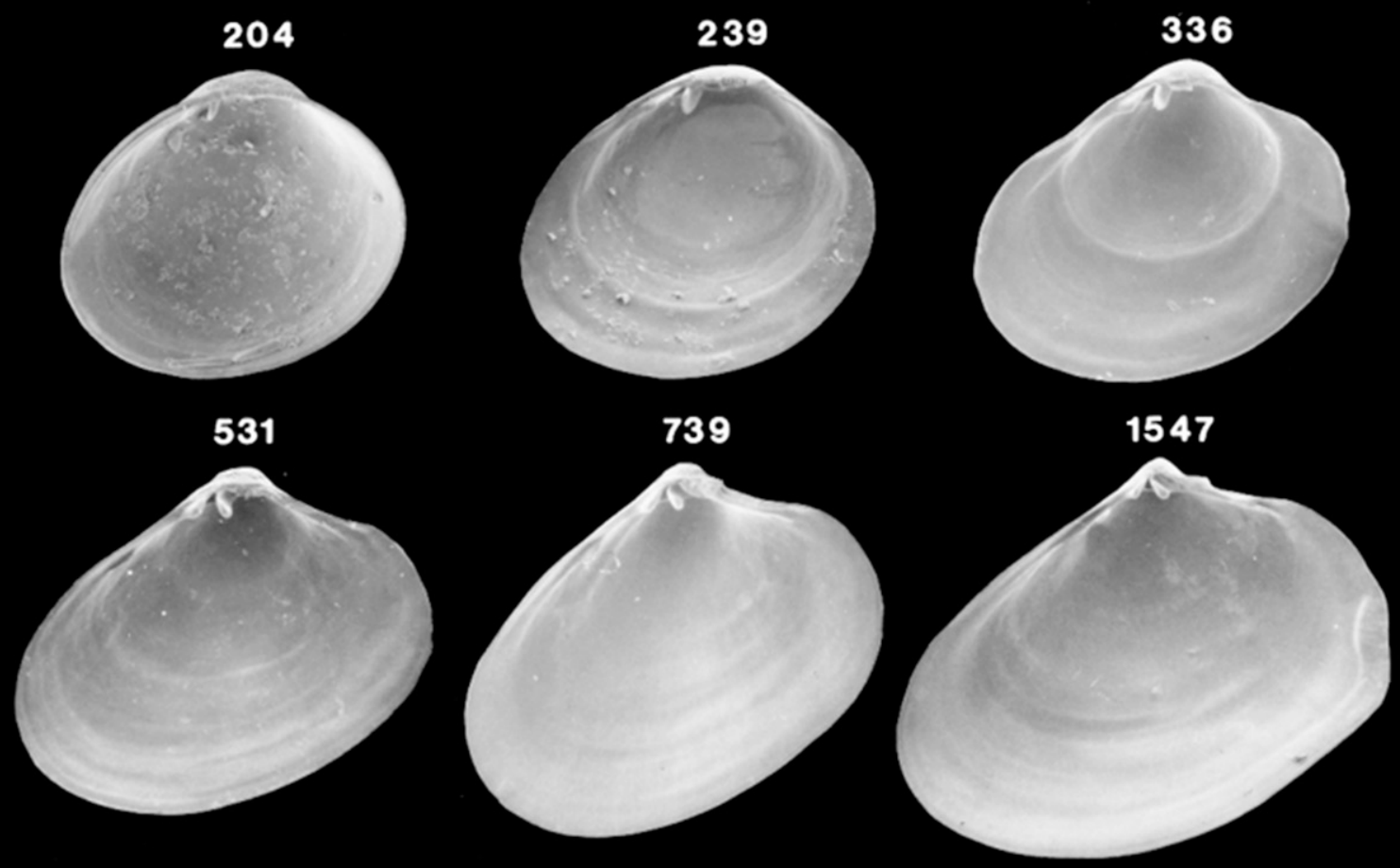

Figure 34. Scanning electron micrographs of disarticulated shell valves of Ameritella agilis postlarvae. Numbers indicate the maximum linear shell dimension in micrometers. 


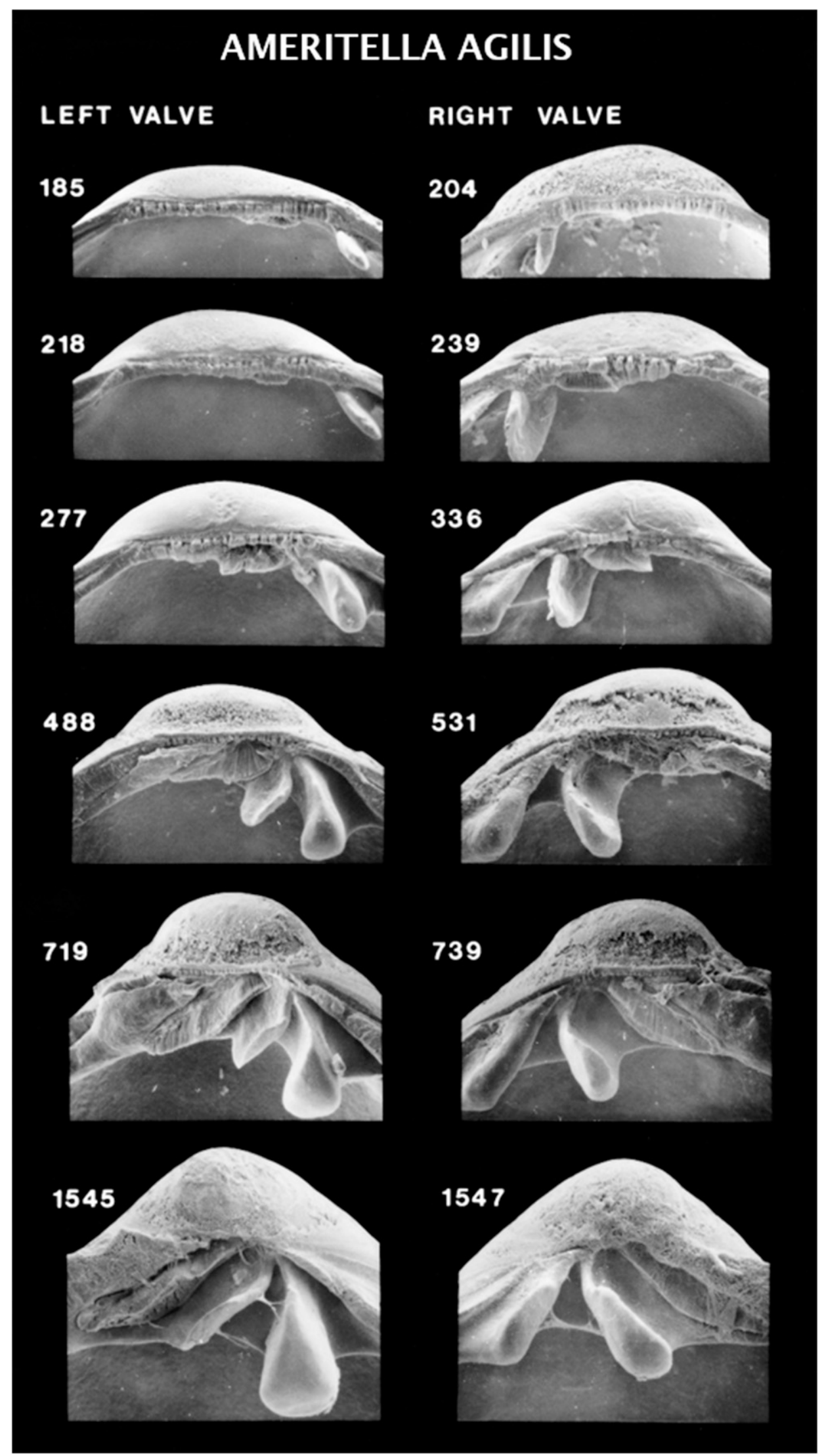

Figure 35. Scanning electron micrographs of the hinge of disarticulated shell valves of Ameritella agilis postlarvae seen in Figure 34. Numbers indicate the maximum linear shell dimension in micrometers. 


\section{AMERITELLA MITCHELLI}

\section{LEFT VALVE}
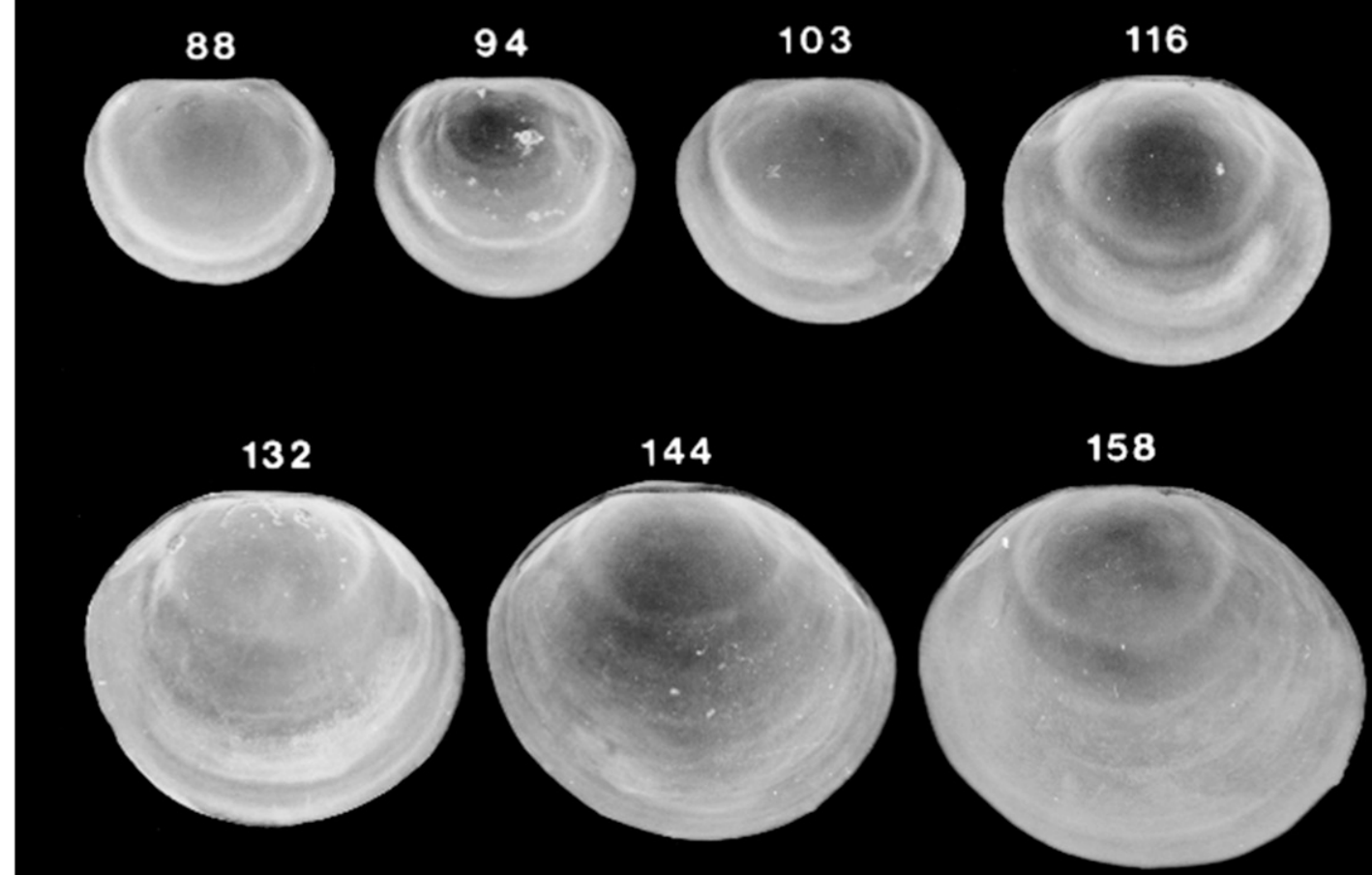

\section{RIGHT VALVE}

\section{1}

96

102

117
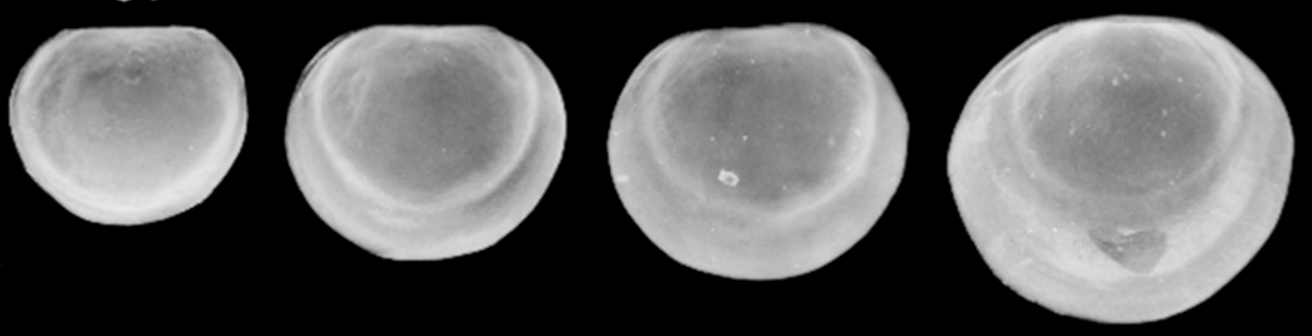

128

142

151

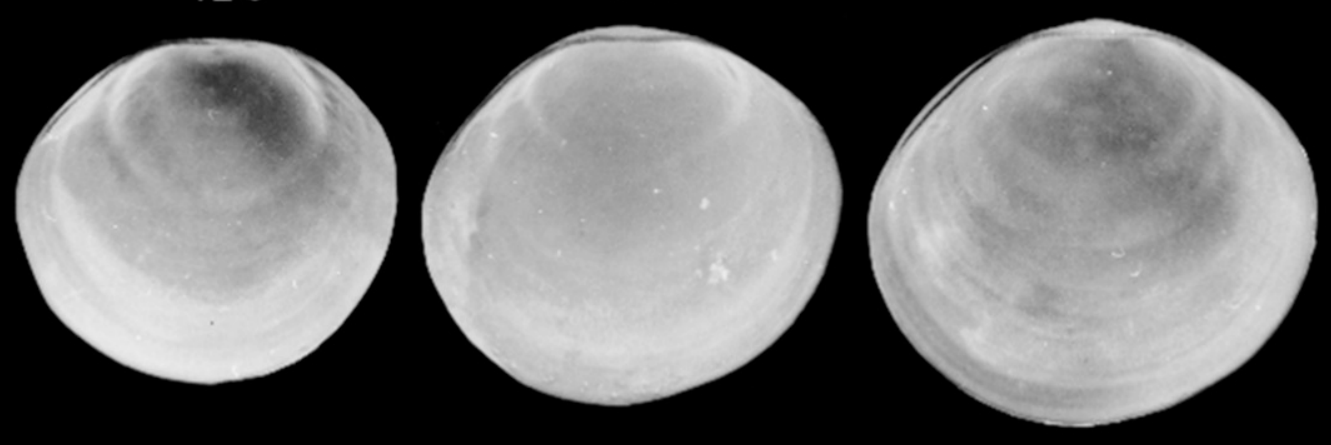

Figure 36. Scanning electron micrographs of disarticulated shell valves of Ameritella mitchelli larvae. Numbers indicate the maximum linear shell dimension in micrometers. Modified from Kennedy et al. (1989). 


\section{AMERITELLA MITCHELLI}

\section{LEFT VALVE}

\section{8}

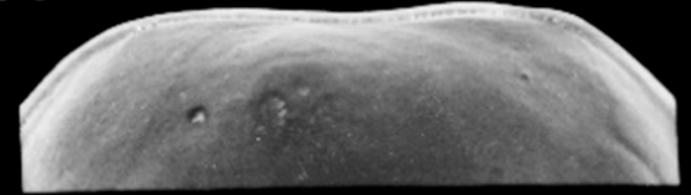

94

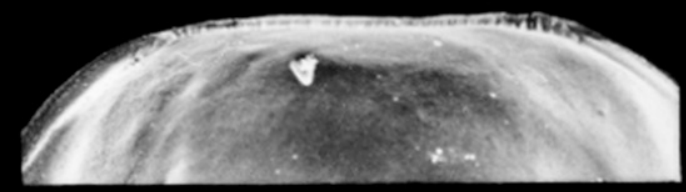

\section{3}

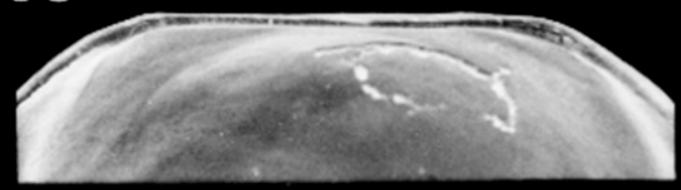

\section{6}

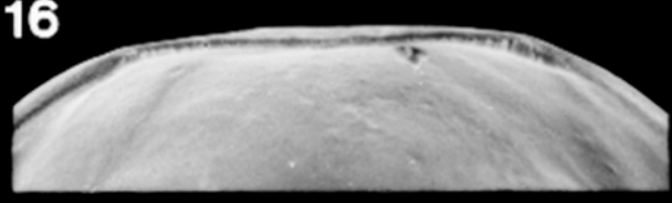

132

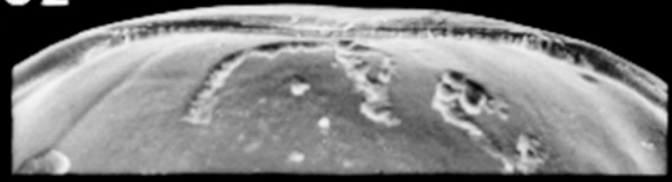

144

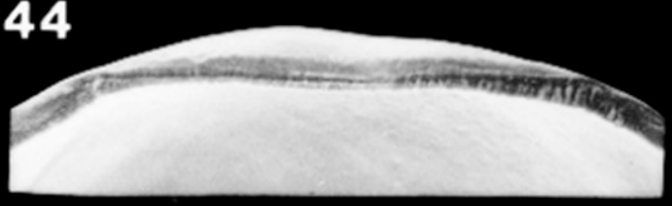

\section{8}

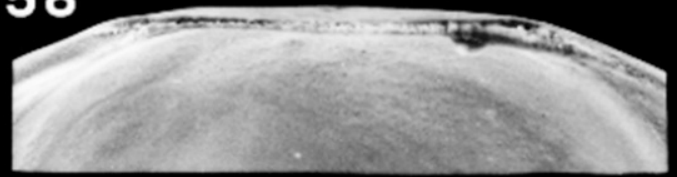

\section{RIGHT VALVE}

81

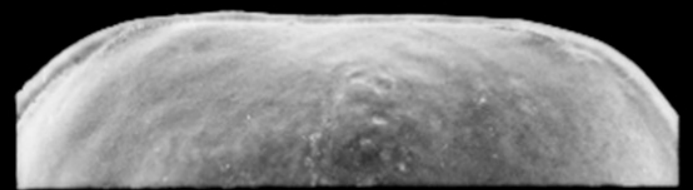

96

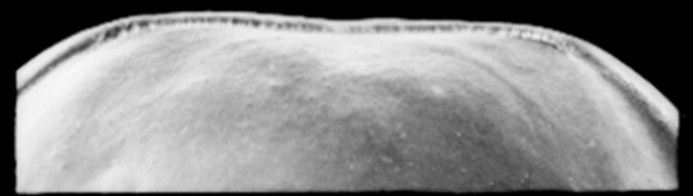

\section{2}

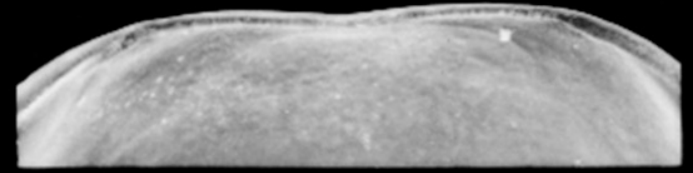

\section{7}

128

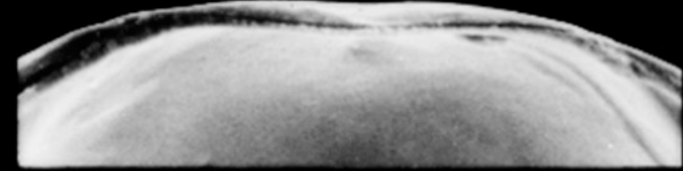

142

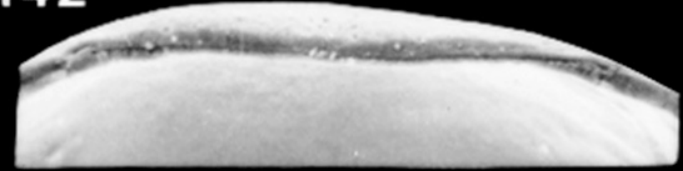

151

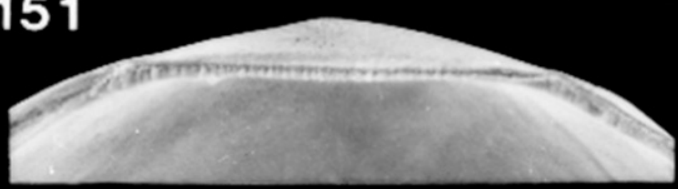




\section{AMERITELLA MITCHELLI}

\section{LEFT VALVE}
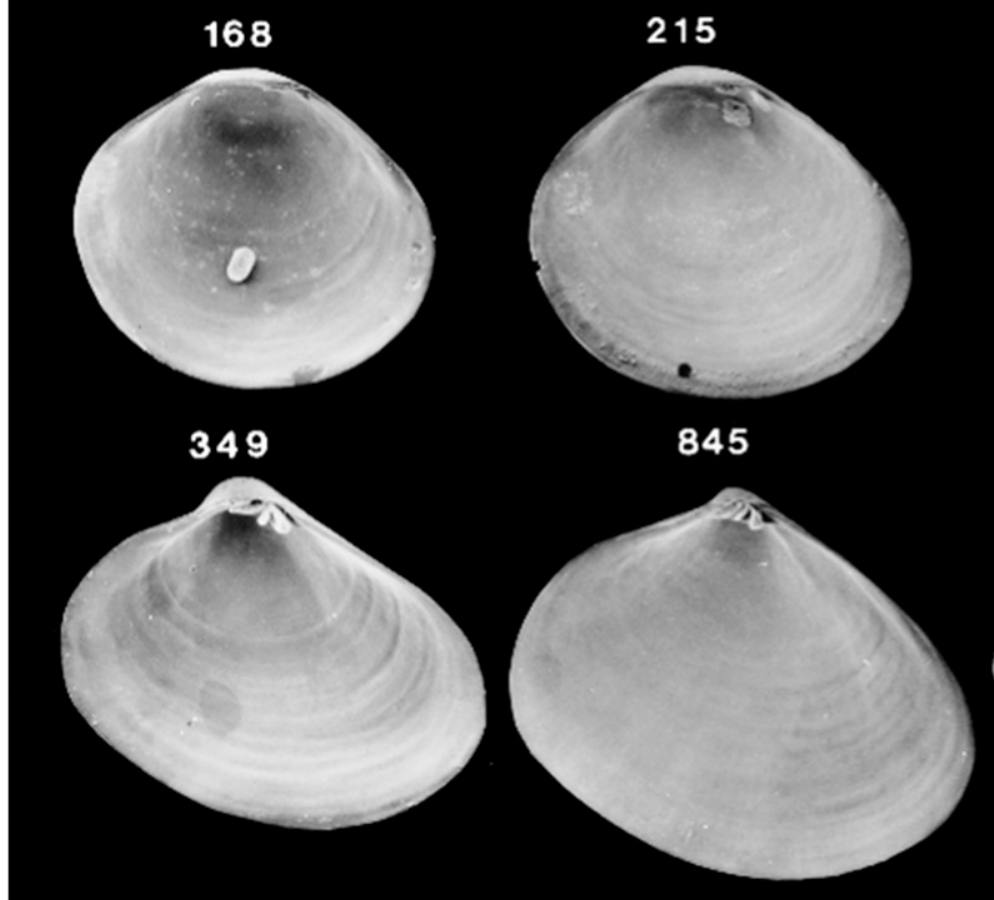

845
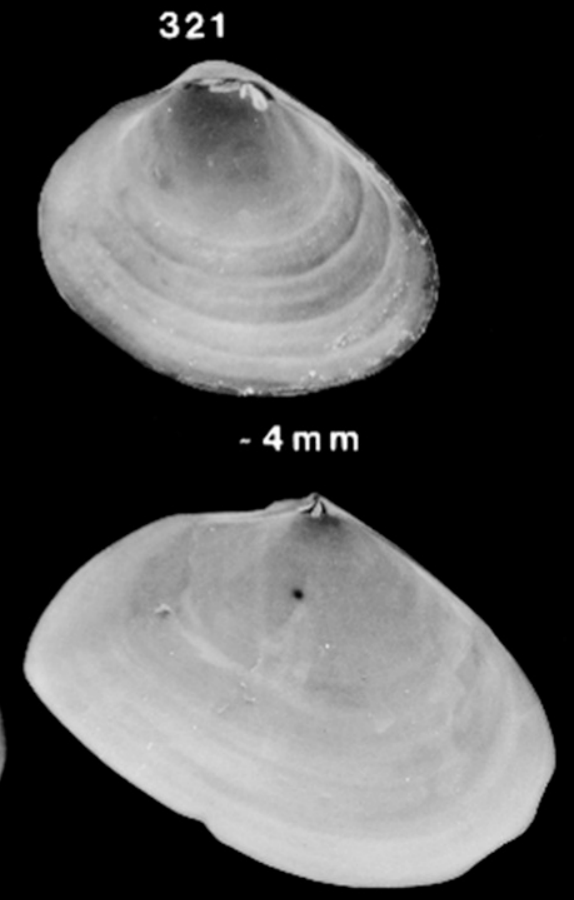

\section{RIGHT VALVE}
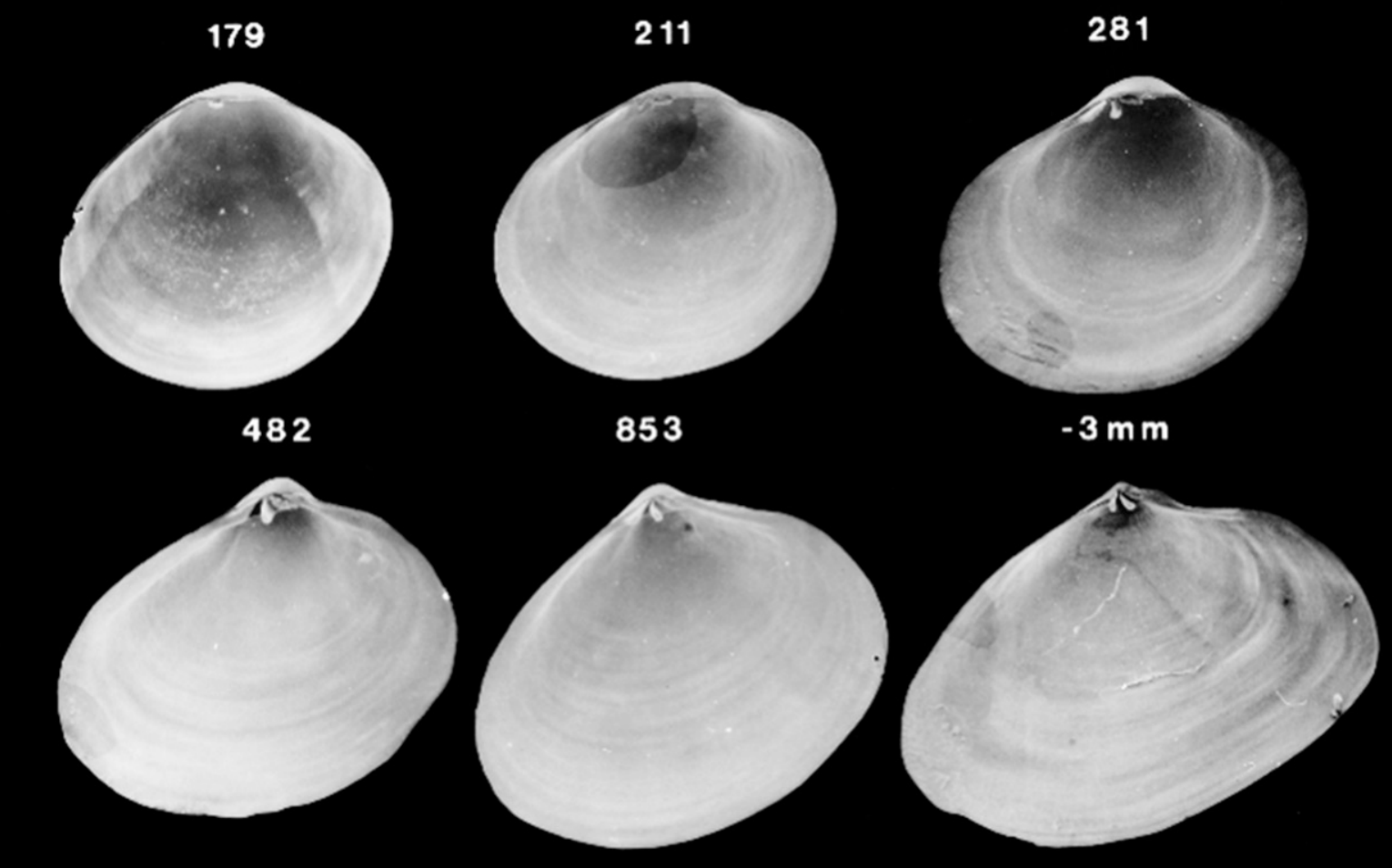

Figure 38. Scanning electron micrographs of disarticulated shell valves of Ameritella mitchelli postlarvae. Numbers indicate the maximum linear shell dimension in micrometers. Modified from Kennedy et al. (1989). 


\section{AMERITELLA MITCHELLI}

\section{LEFT VALVE}
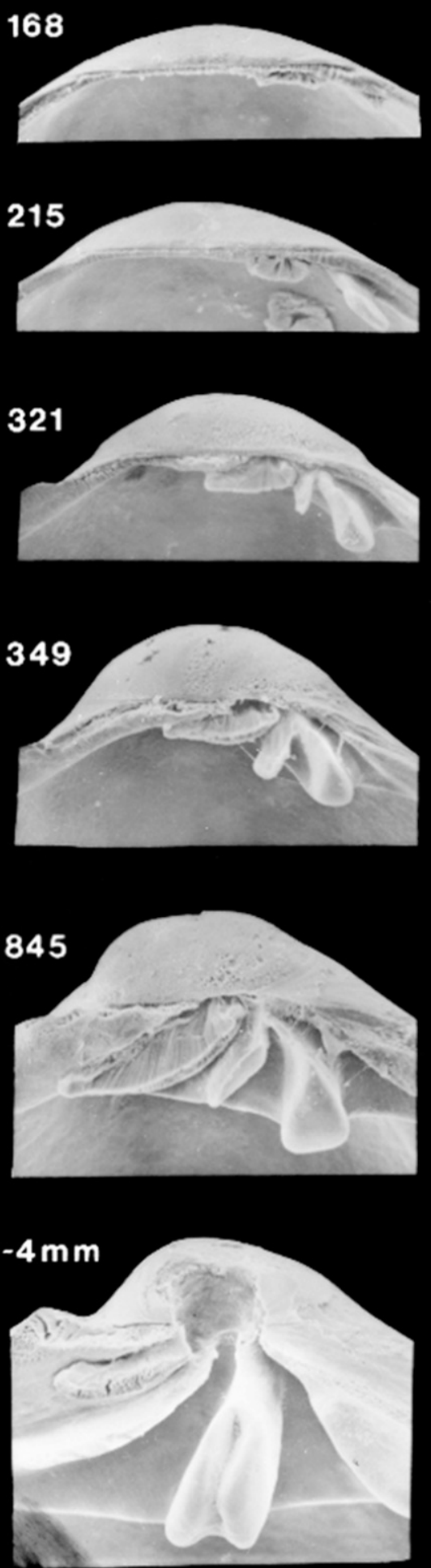

\section{RIGHT VALVE}
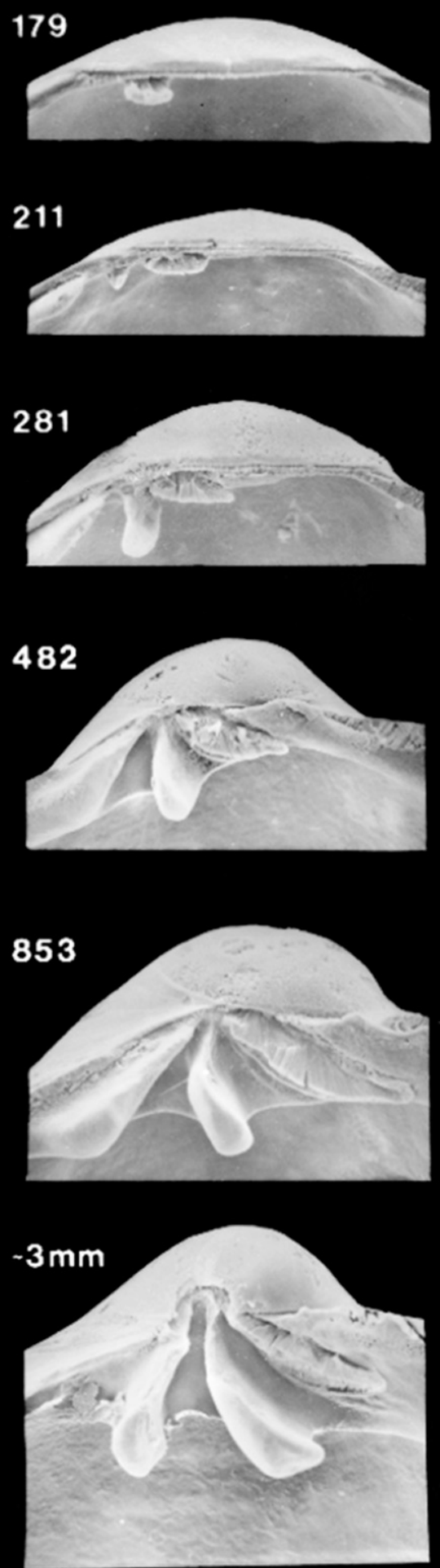

Figure 39. Scanning electron micrographs of the hinge of disarticulated shell valves of Ameritella mitchelli postlarvae seen in Figure 38 . Numbers indicate the maximum linear shell dimension in micrometers. Modified from Kennedy et al. (1989). 


\section{LIMECOLA BALTHICA}

\section{LEFT VAL VE}

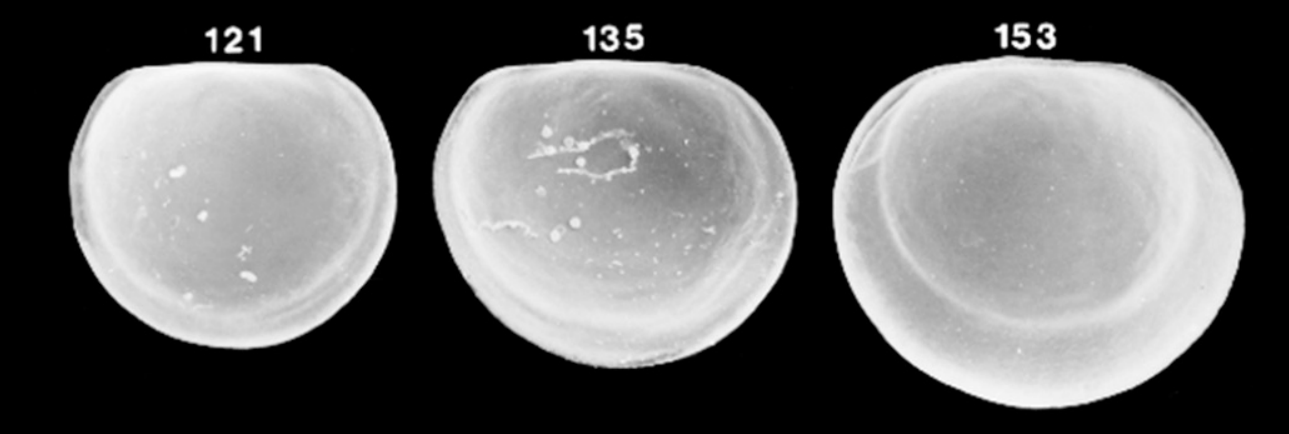

161
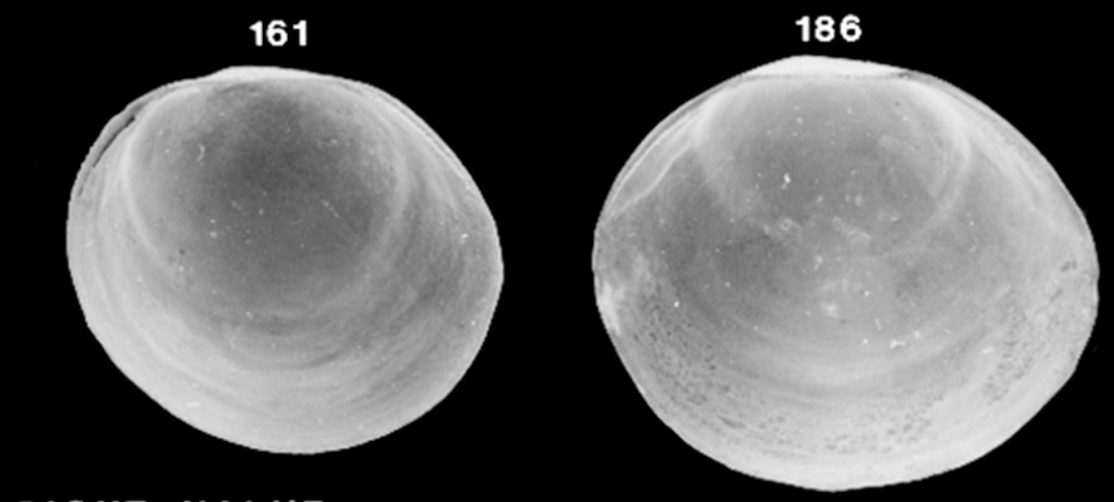

\section{RIGHT VALVE}

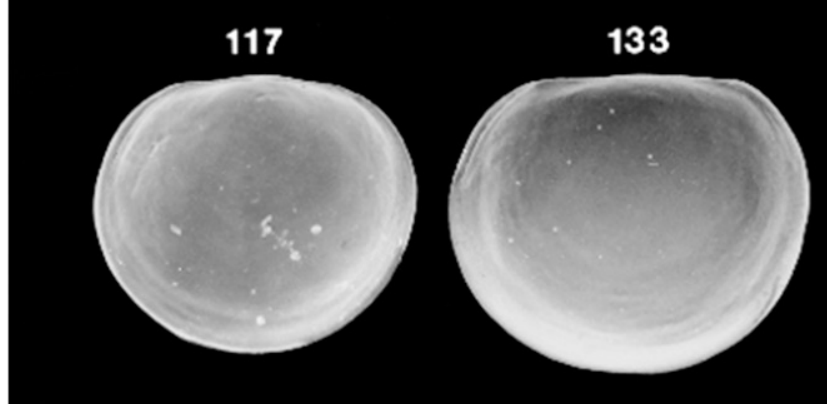

167

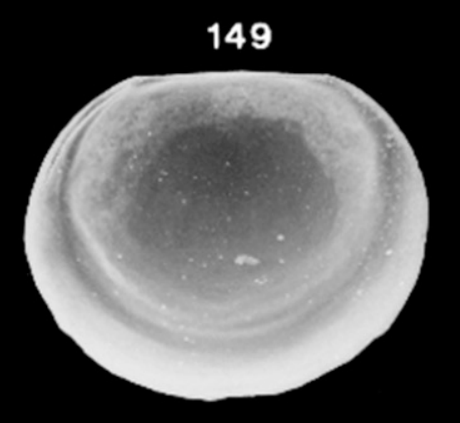

186

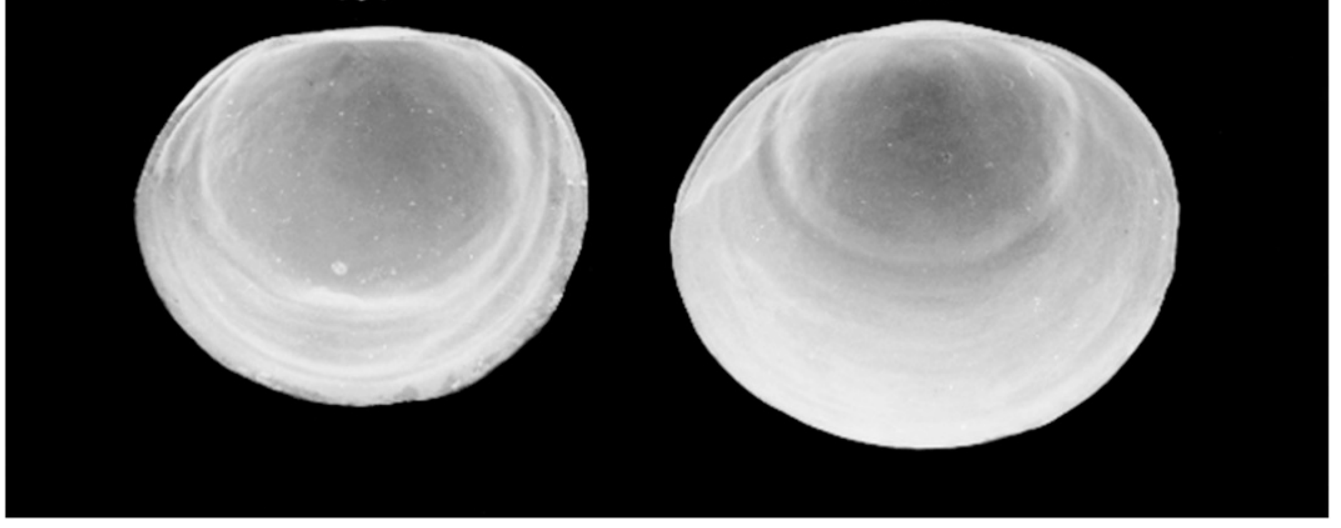

Figure 40. Scanning electron micrographs of disarticulated shell valves of Limecola balthica larvae. Numbers indicate the maximum linear shell dimension in micrometers. 


\section{LIMECOLA BALTHICA}

\section{LEFT VAL VE}

\section{1}

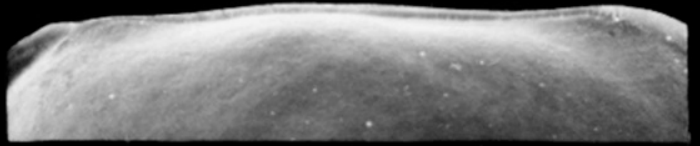

135

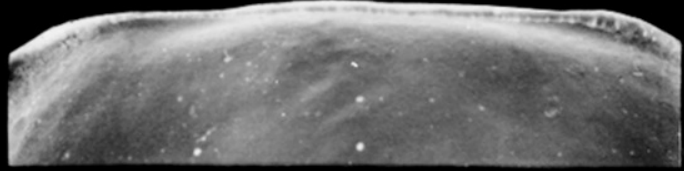

153

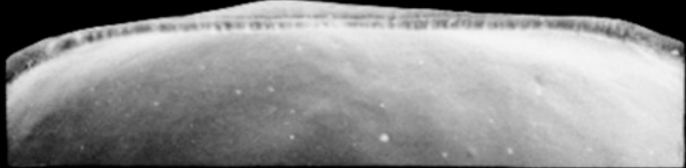

161

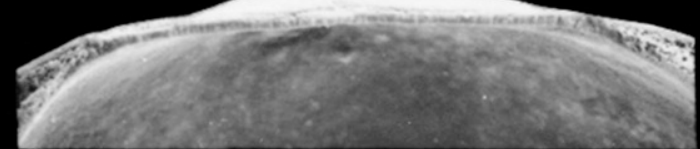

186

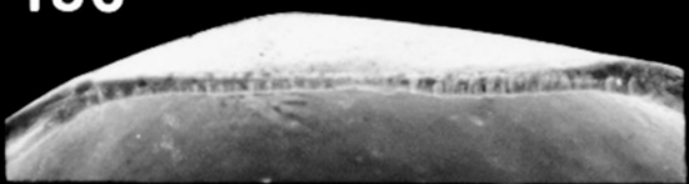

\section{RIGHT VALVE}

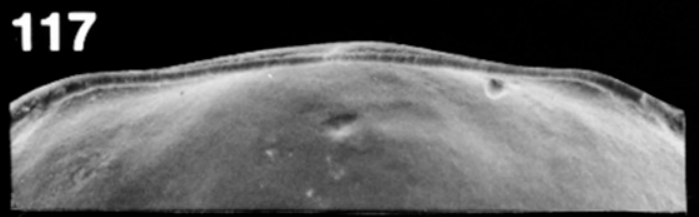

\section{3}

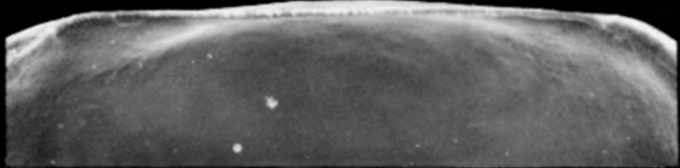

\section{9}

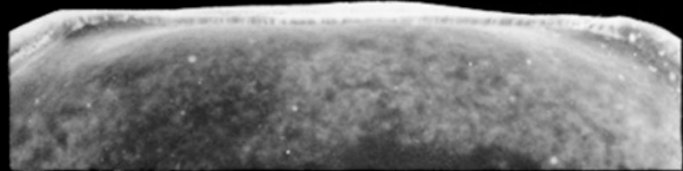

167

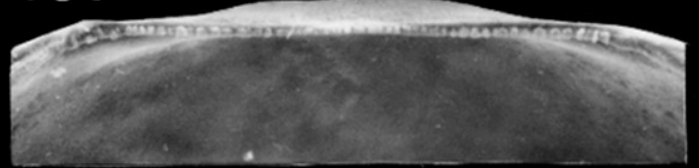

186

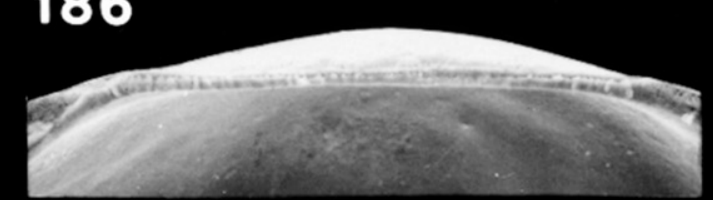

Figure 41. Scanning electron micrographs of the hinge of disarticulated shell valves of Limecola balthica larvae seen in Figure 40. Numbers indicate the maximum linear shell dimension in micrometers. 


\section{LIMECOLA BALTHICA}

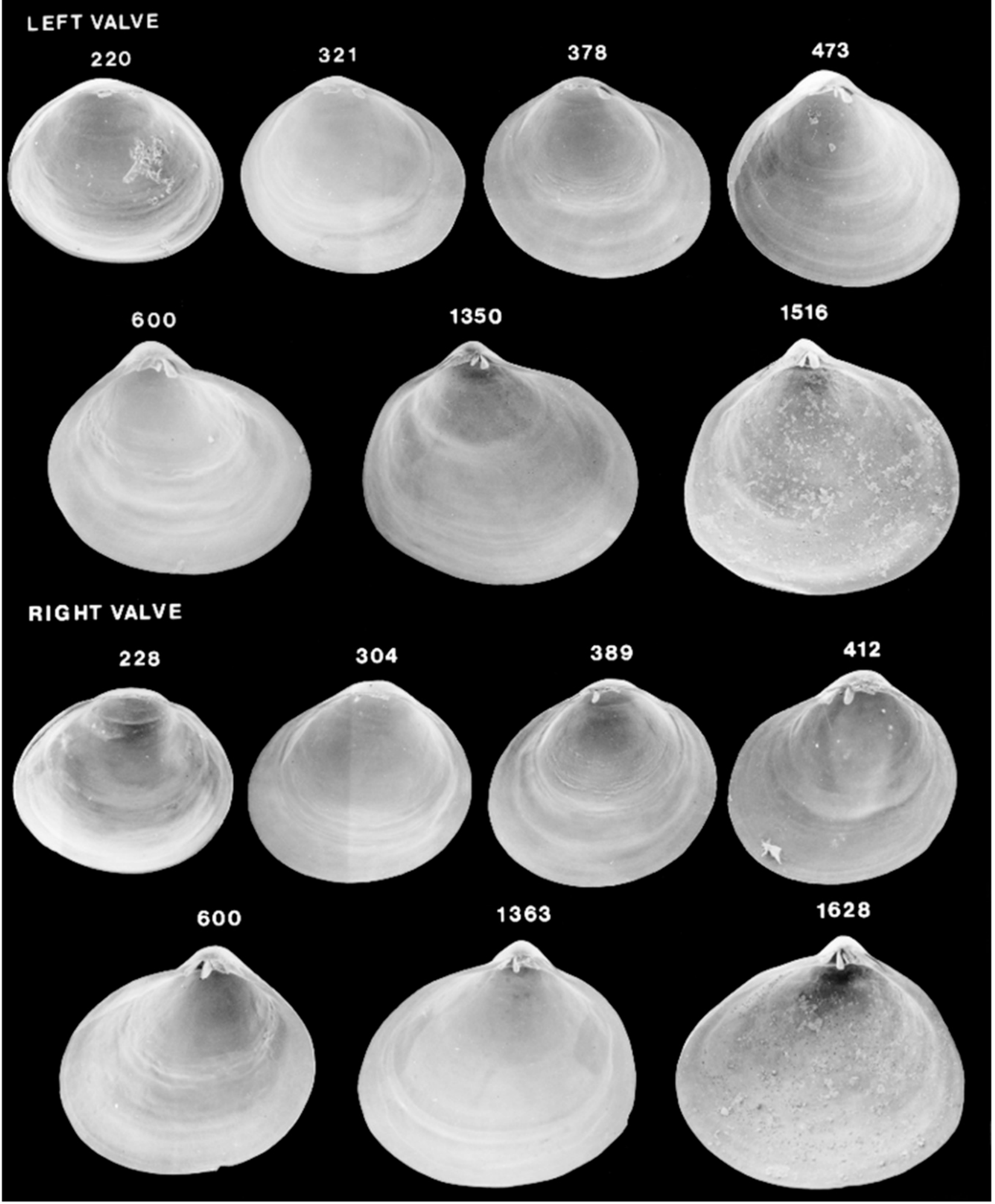

Figure 42. Scanning electron micrographs of disarticulated shell valves of Limecola balthica postlarvae. Numbers indicate the maximum linear shell dimension in micrometers. 


\section{LIMECOLA BALTHICA}

\section{LEFT VALVE}
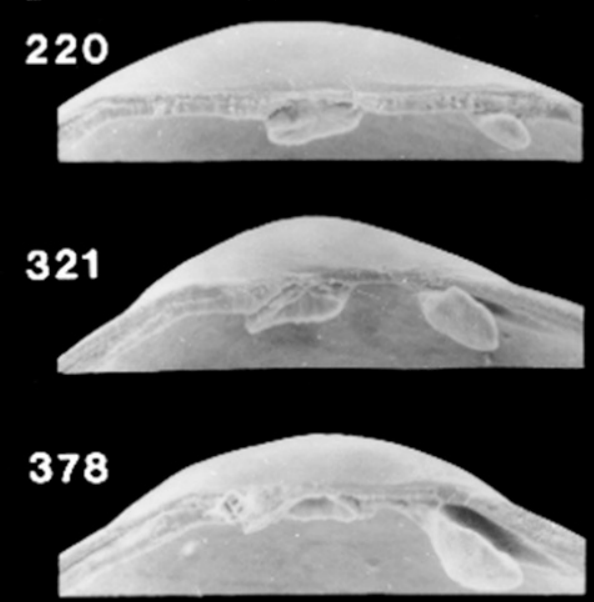

473
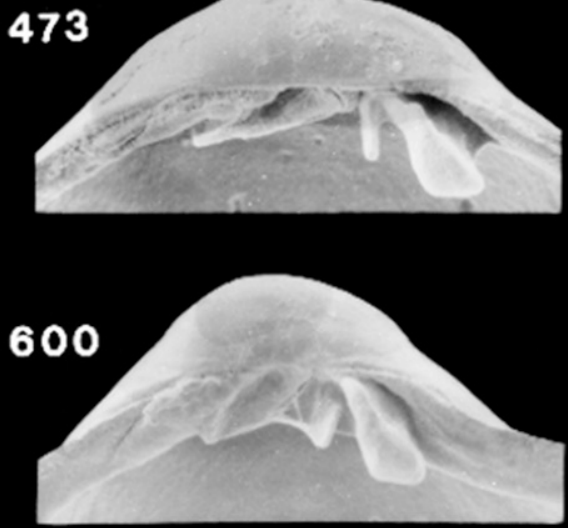

1350

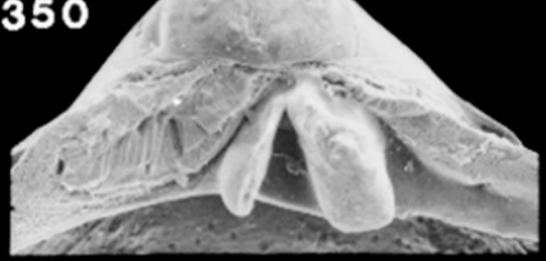

1516

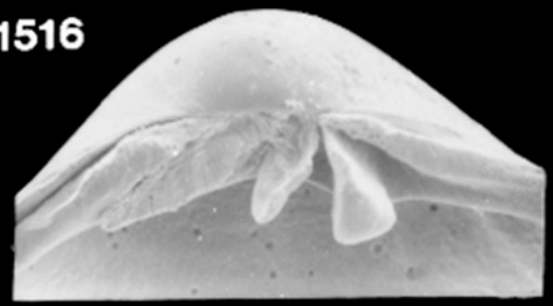

\section{RIGHT VALVE}

228
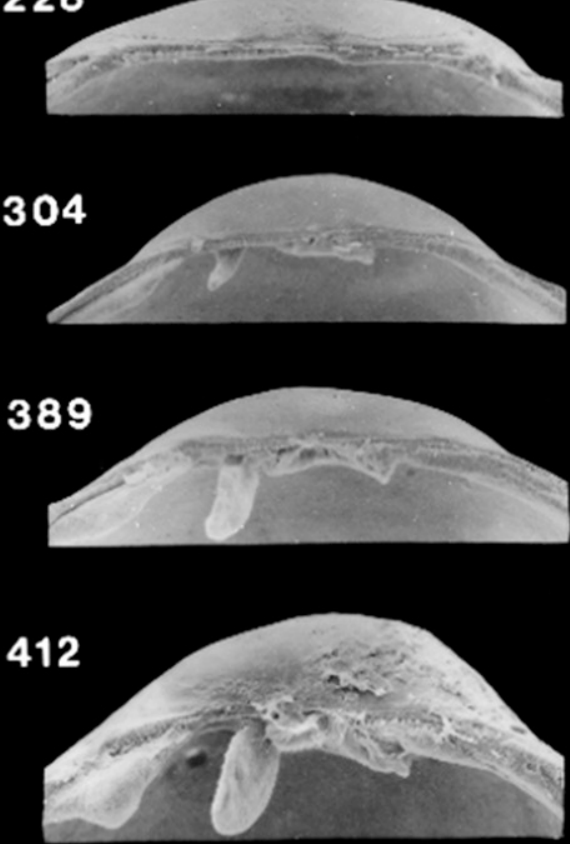

600
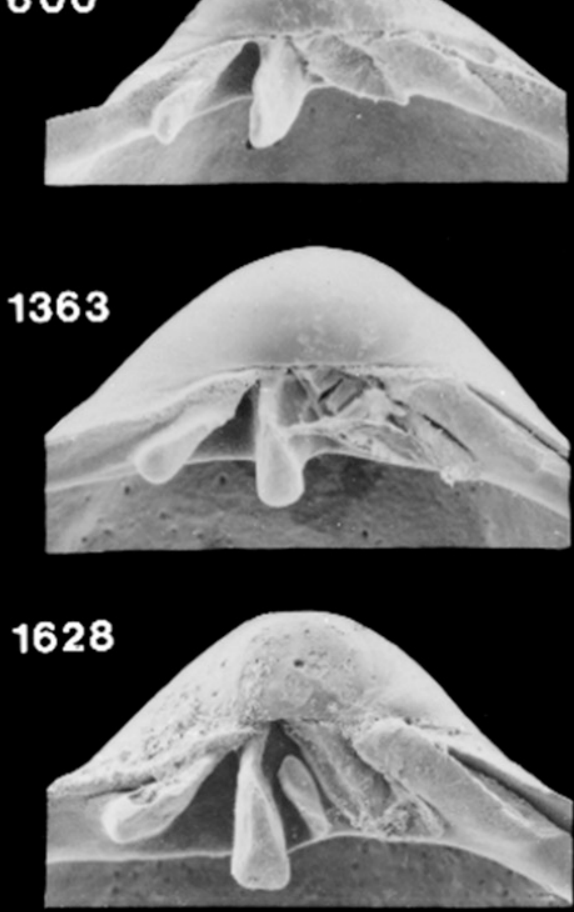


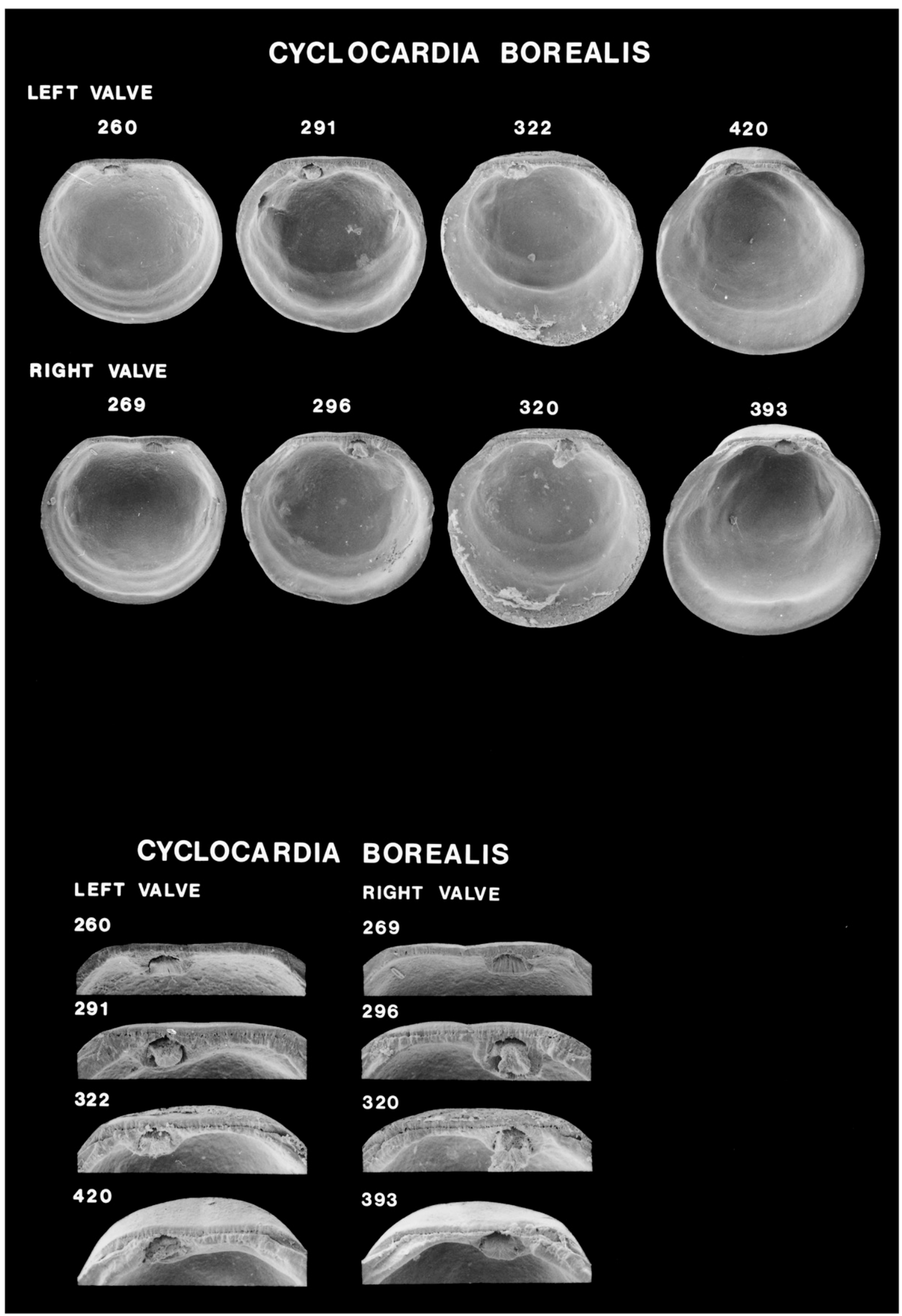

Figure 44. Scanning electron micrographs of disarticulated shell valves of Cyclocardia borealis postlarvae (top) and higher magnification scanning electron micrographs of the hinge of these shell valves (bottom). Numbers indicate the maximum linear shell dimension in micrometers. 


\section{ASTARTE CASTANEA}

\section{LEFT VALVE}
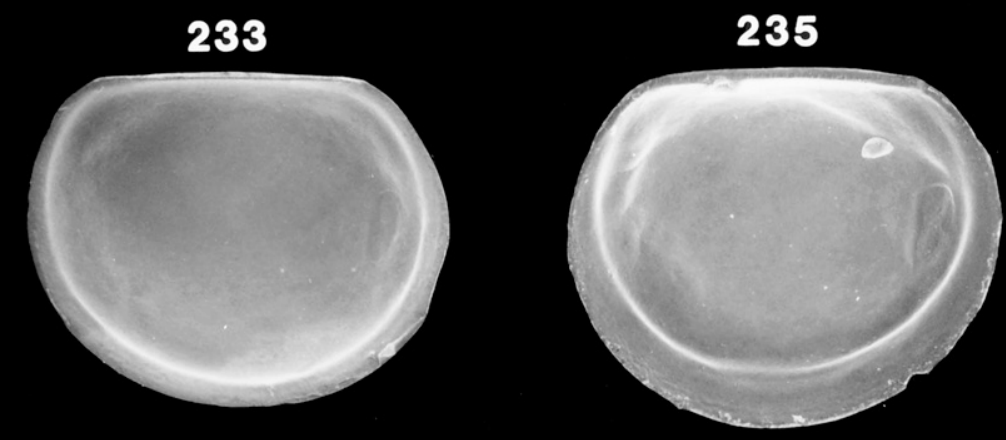

\section{RIGHT VALVE}

\section{5}
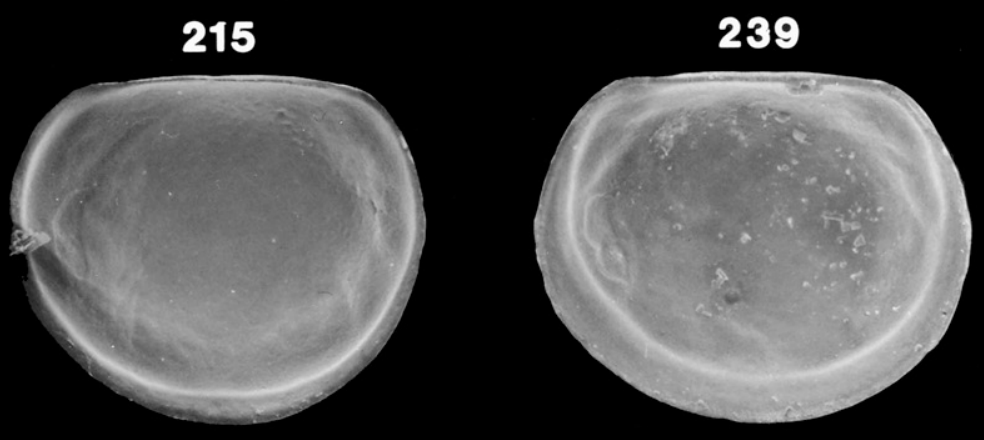

\section{ASTARTE CASTANEA}

\section{LEFT VALVE}

\section{3}

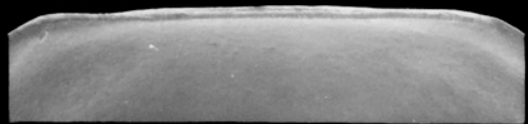

\section{5}

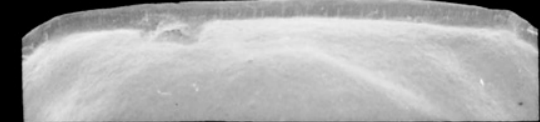

\section{RIGHT VALVE}

215

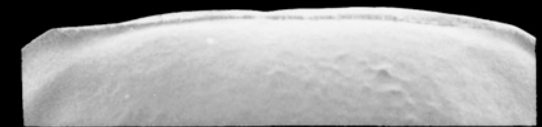

239 


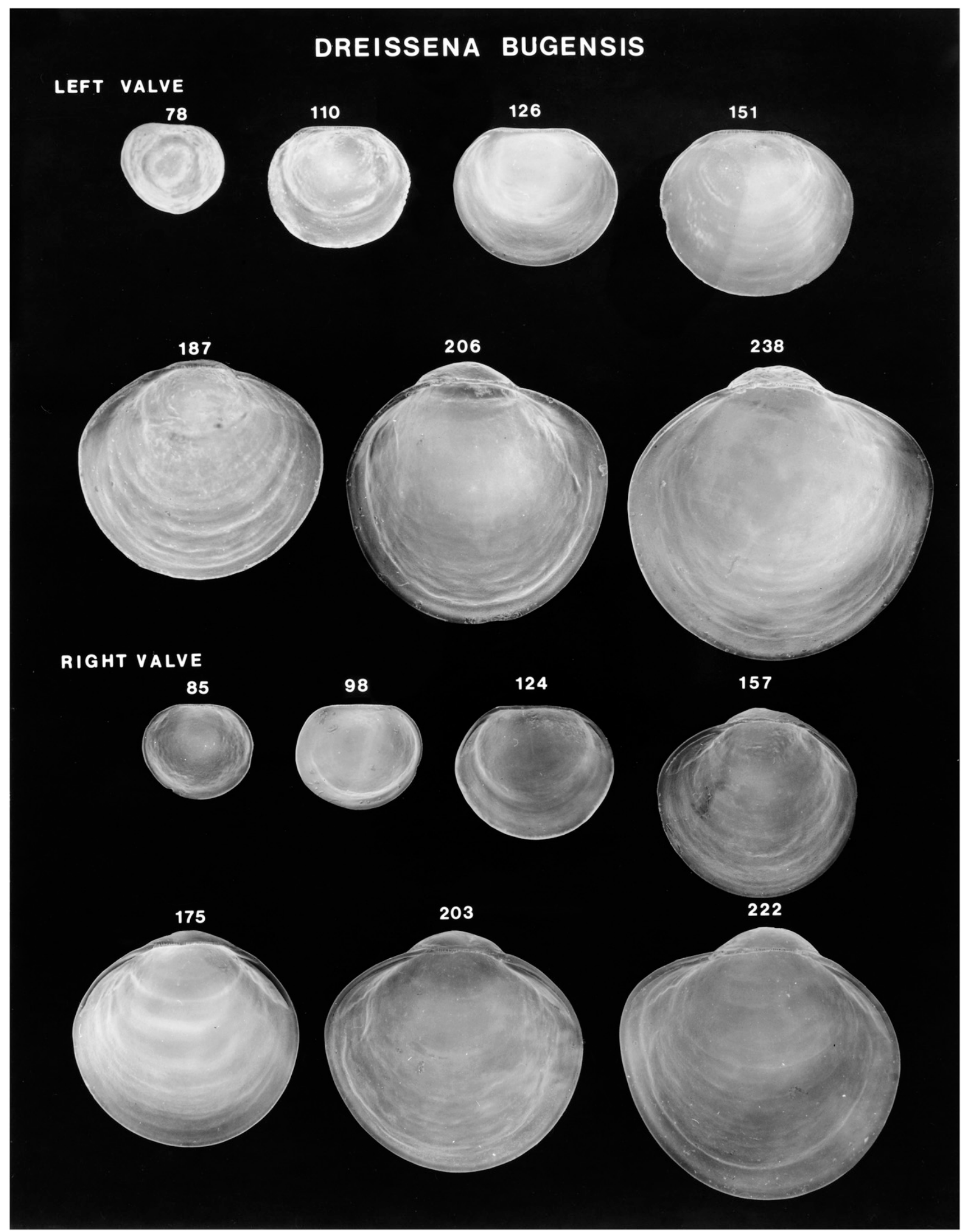

Figure 46. Scanning electron micrographs of disarticulated shell valves of Dreissena bugensis larvae. Numbers indicate the maximum linear shell dimension in micrometers. 


\section{DREISSENA BUGENSIS}

\section{LEFT VALVE}

\section{8}

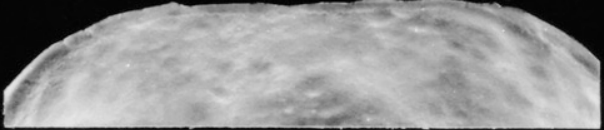

110

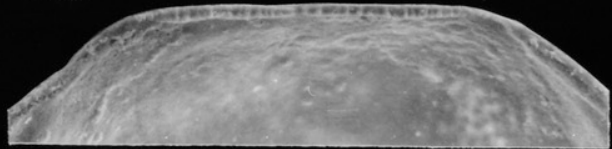

126

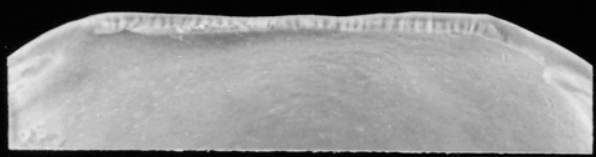

151

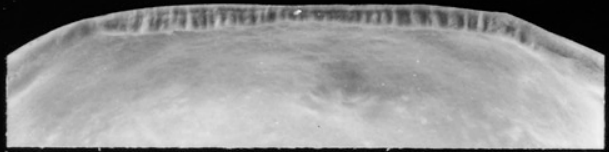

187

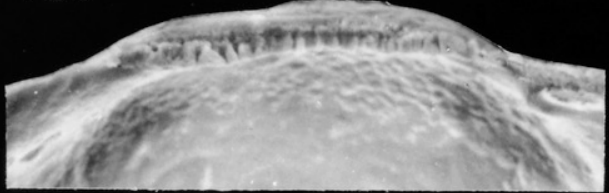

206

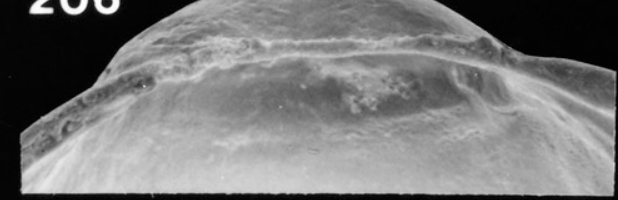

238

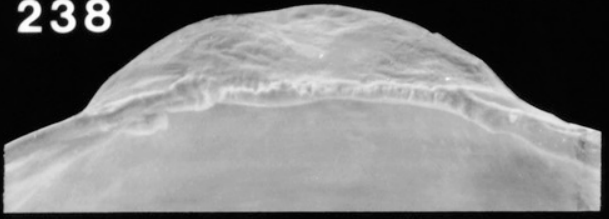

\section{RIGHT VALVE}

85

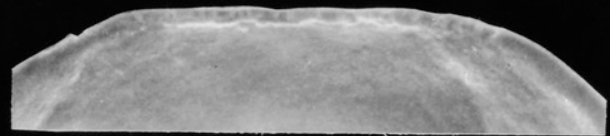

98

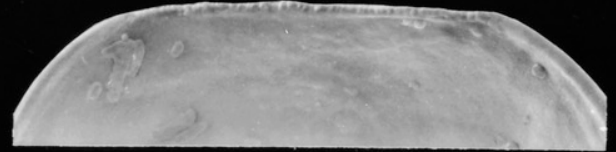

124

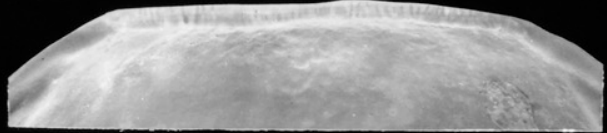

157

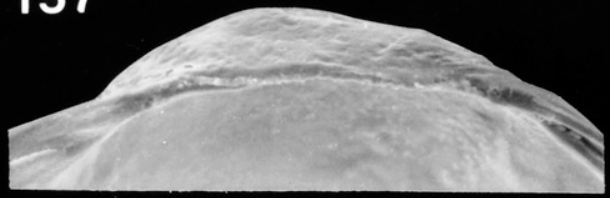

175
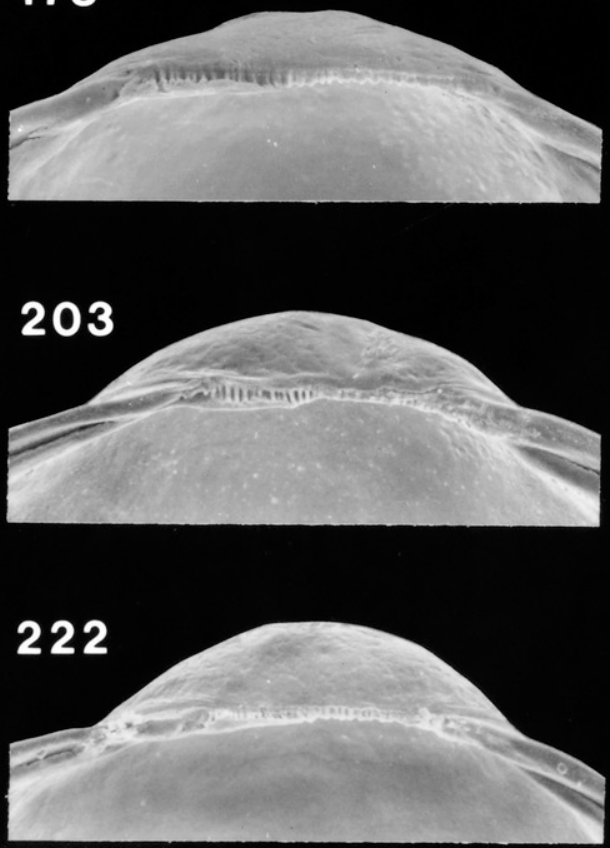


\section{DREISSENA BUGENSIS}

\section{LEFT VALVE}

250

274

332
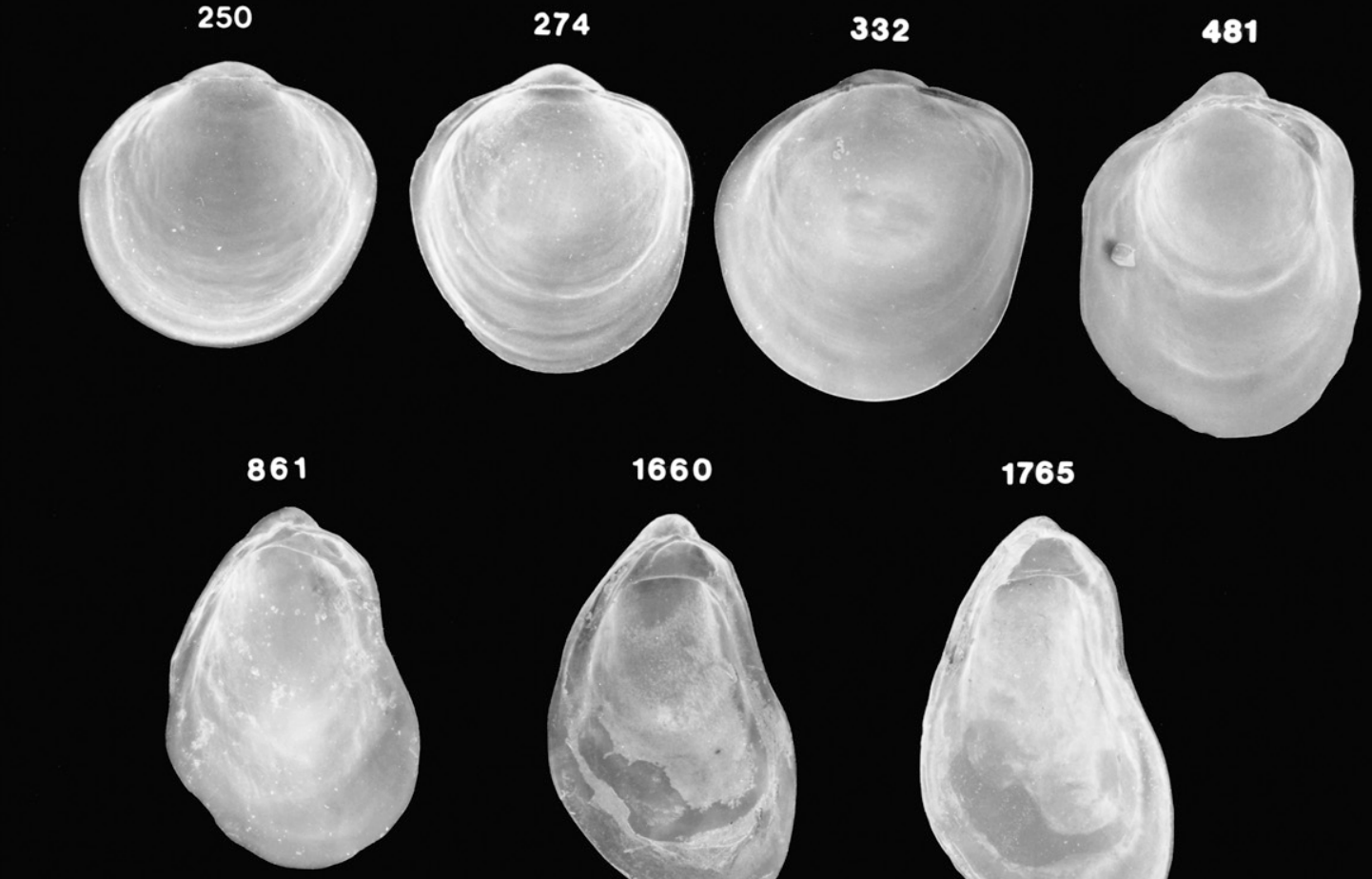

1660

1765

RIGHT VALVE

247
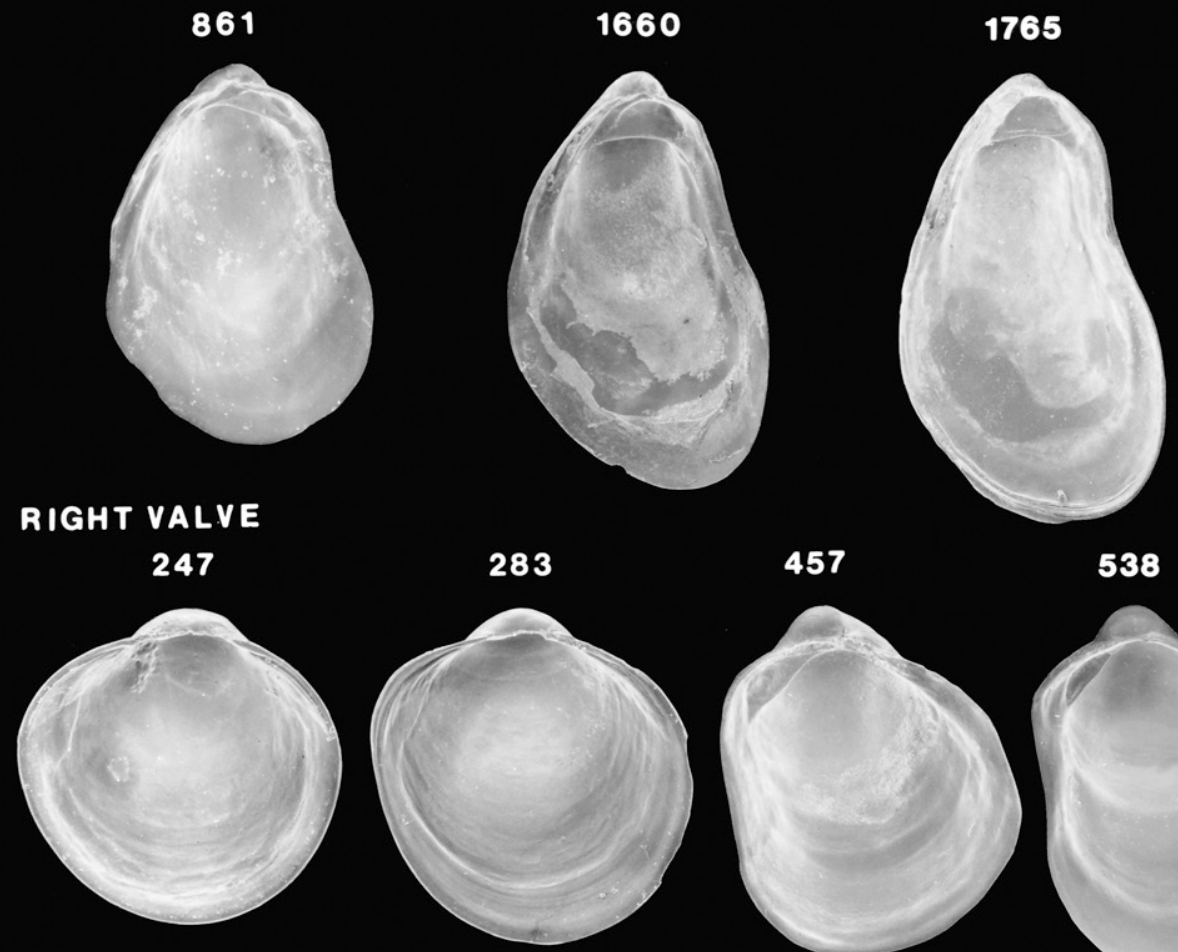

457

538

866

1225
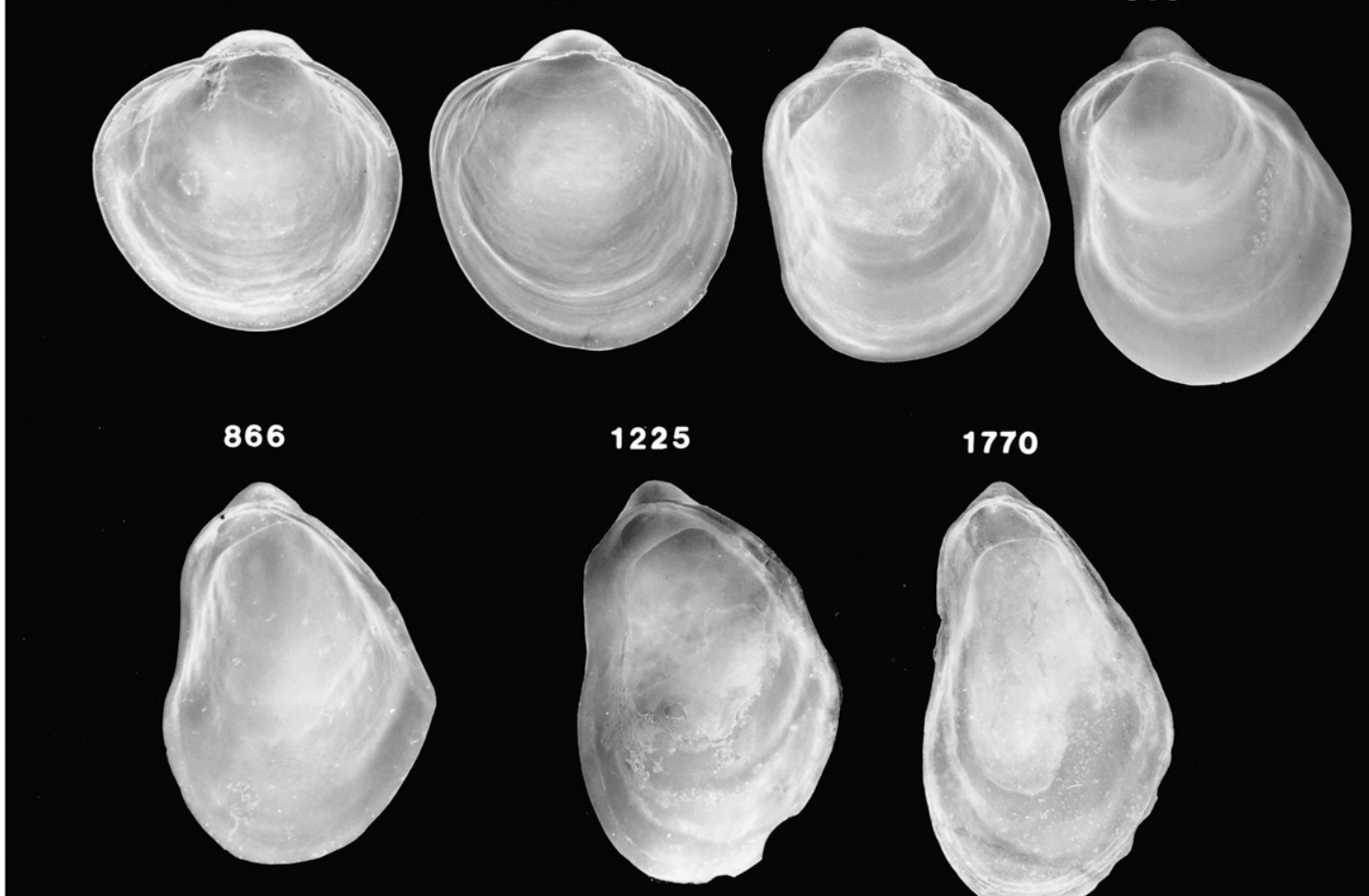

1770 


\section{DREISSENA BUGENSIS}

\section{LEFT VALVE}
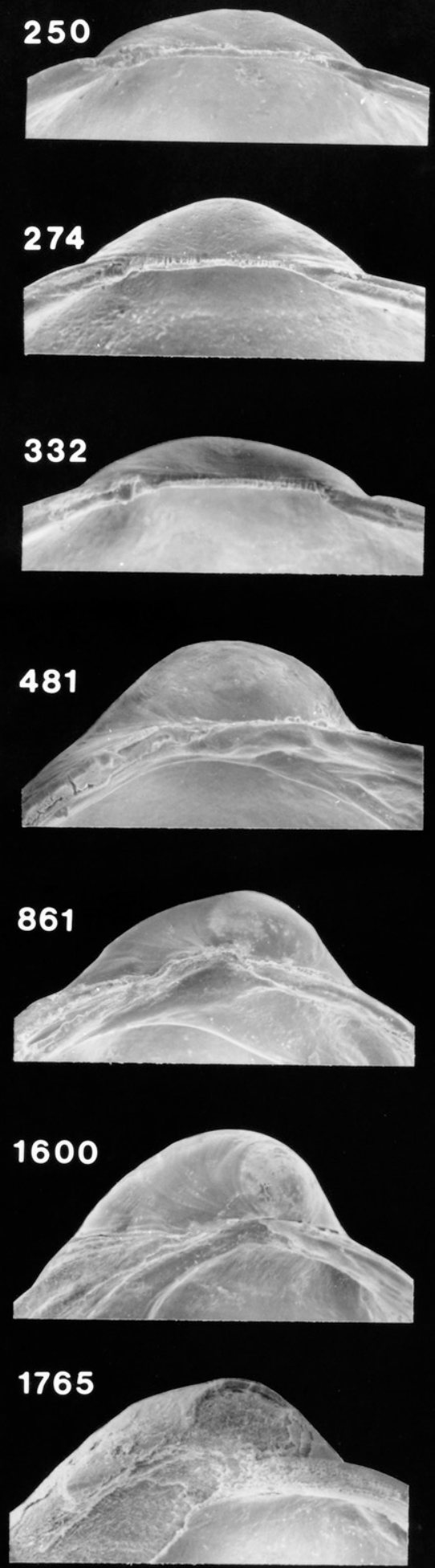

\section{RIGHT VALVE}
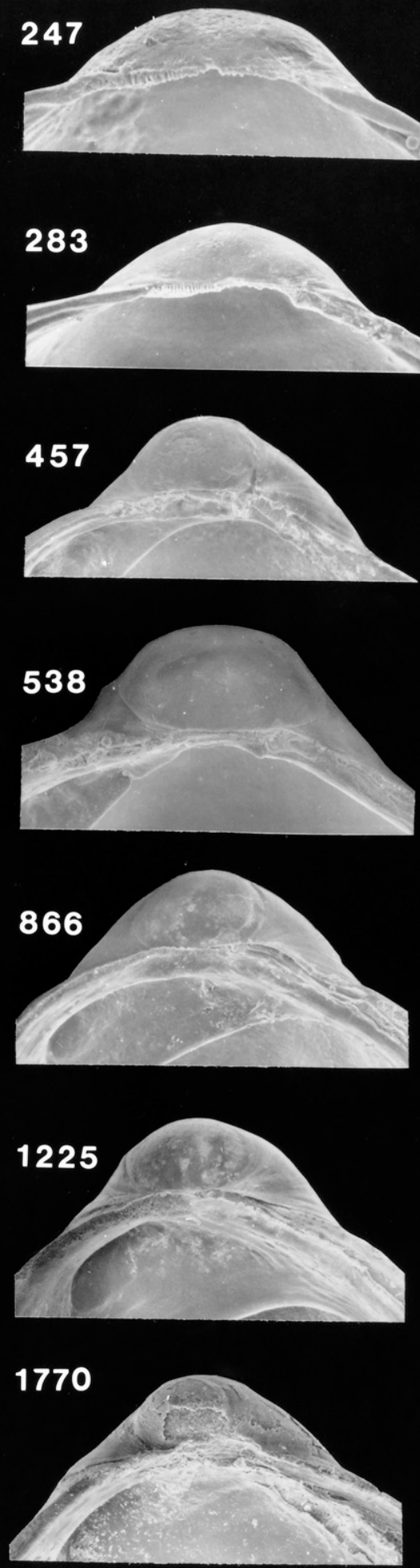

Figure 49. Scanning electron micrographs of the hinge of disarticulated shell valves of Dreissena bugensis postlarvae seen in Figure 48. Numbers indicate the maximum linear shell dimension in micrometers. 


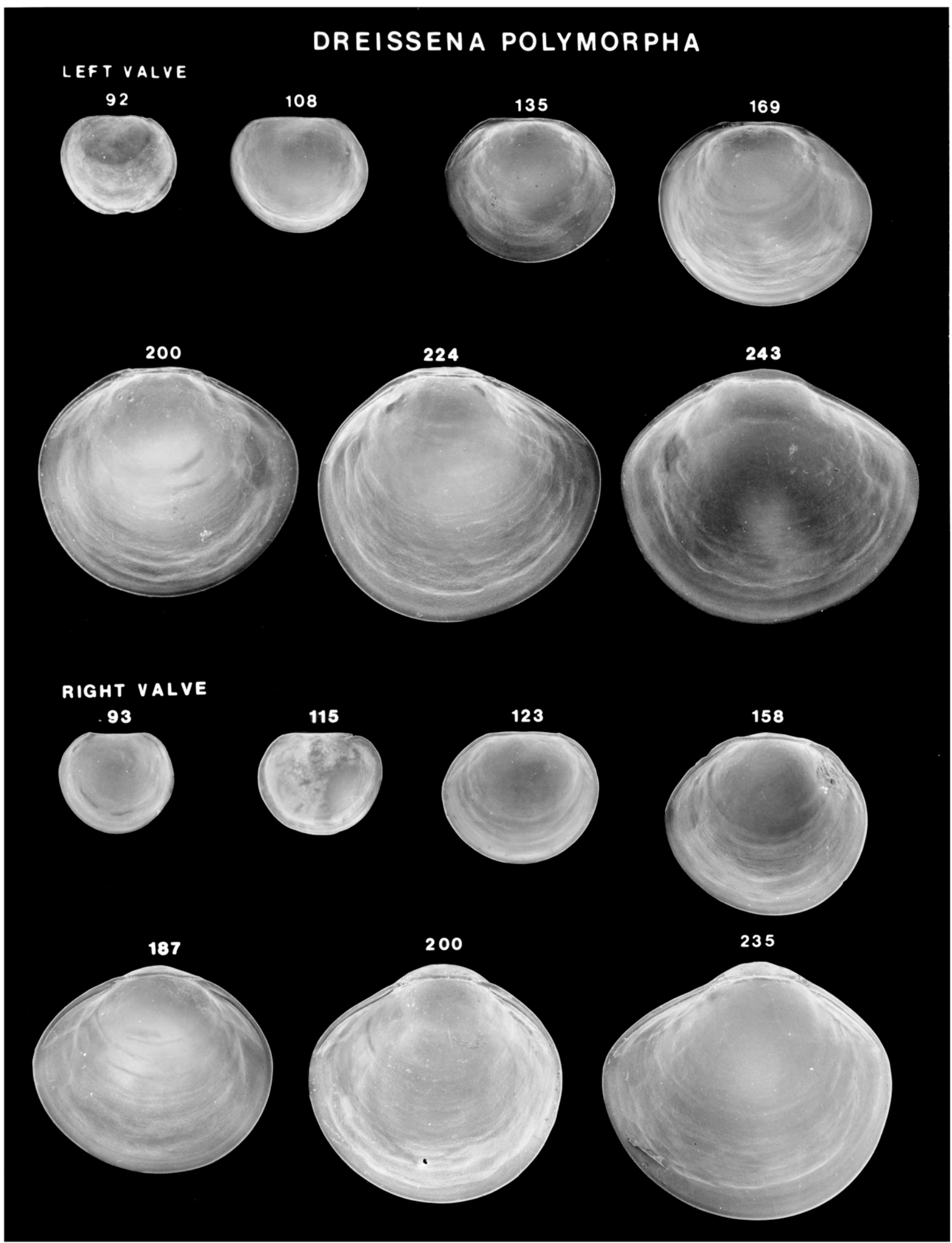

Figure 50. Scanning electron micrographs of disarticulated shell valves of Dreissena polymorpha larvae. Numbers indicate the maximum linear shell dimension in micrometers. 


\section{DREISSENA POLYMORPHA}

\section{LEFT VALVE}

\section{2}

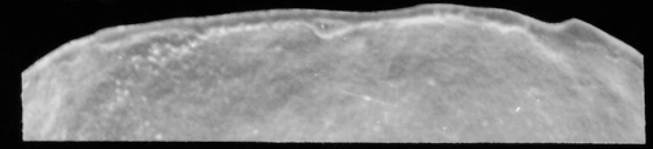

\section{8}

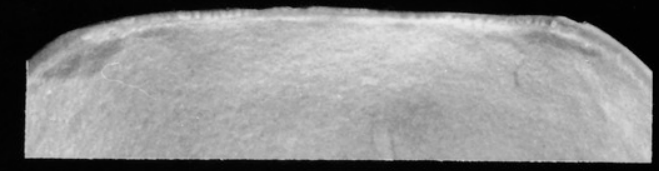

\section{5}

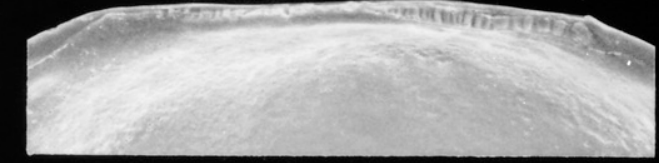

169

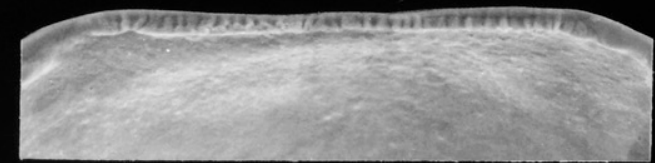

\section{0}

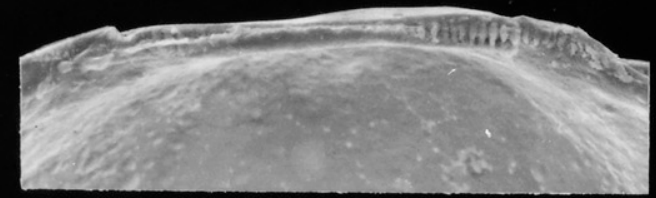

224

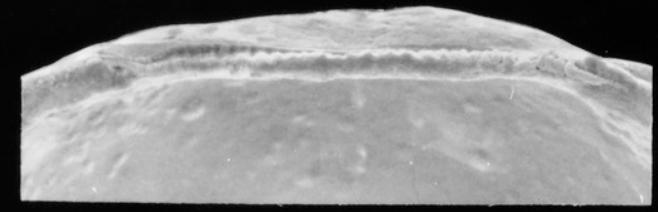

\section{3}

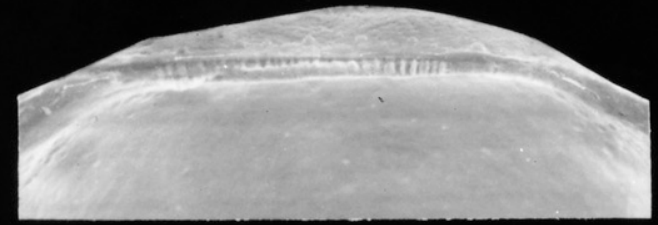

\section{RIGHT VALVE}

\section{3}

115

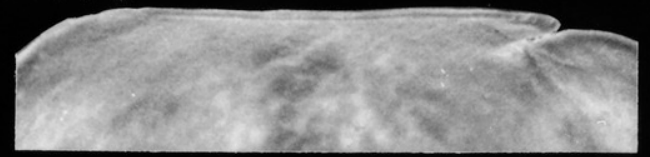

123

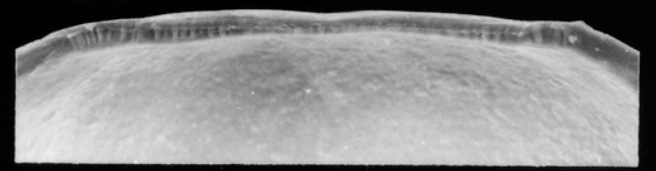

158
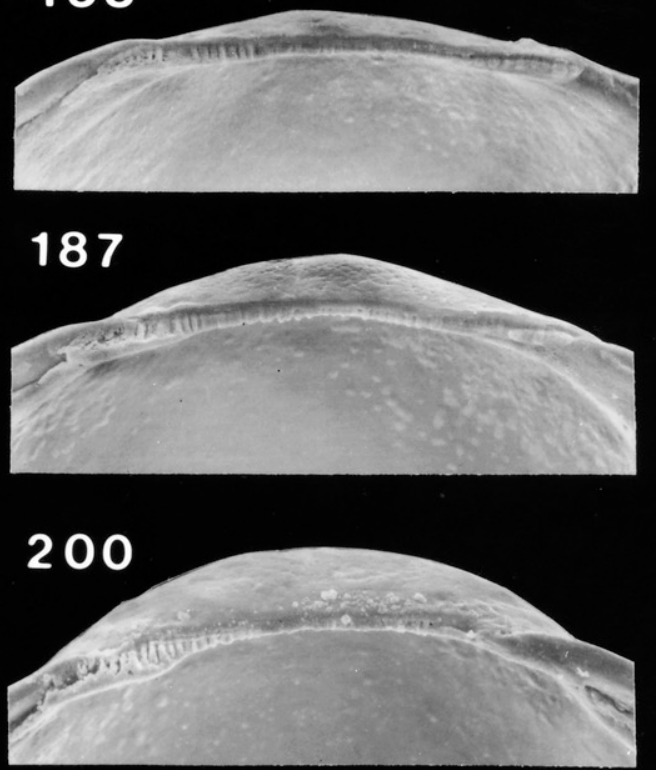

235

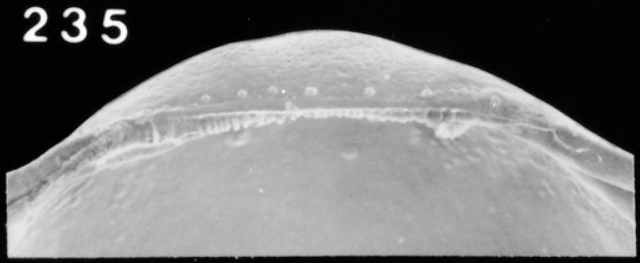




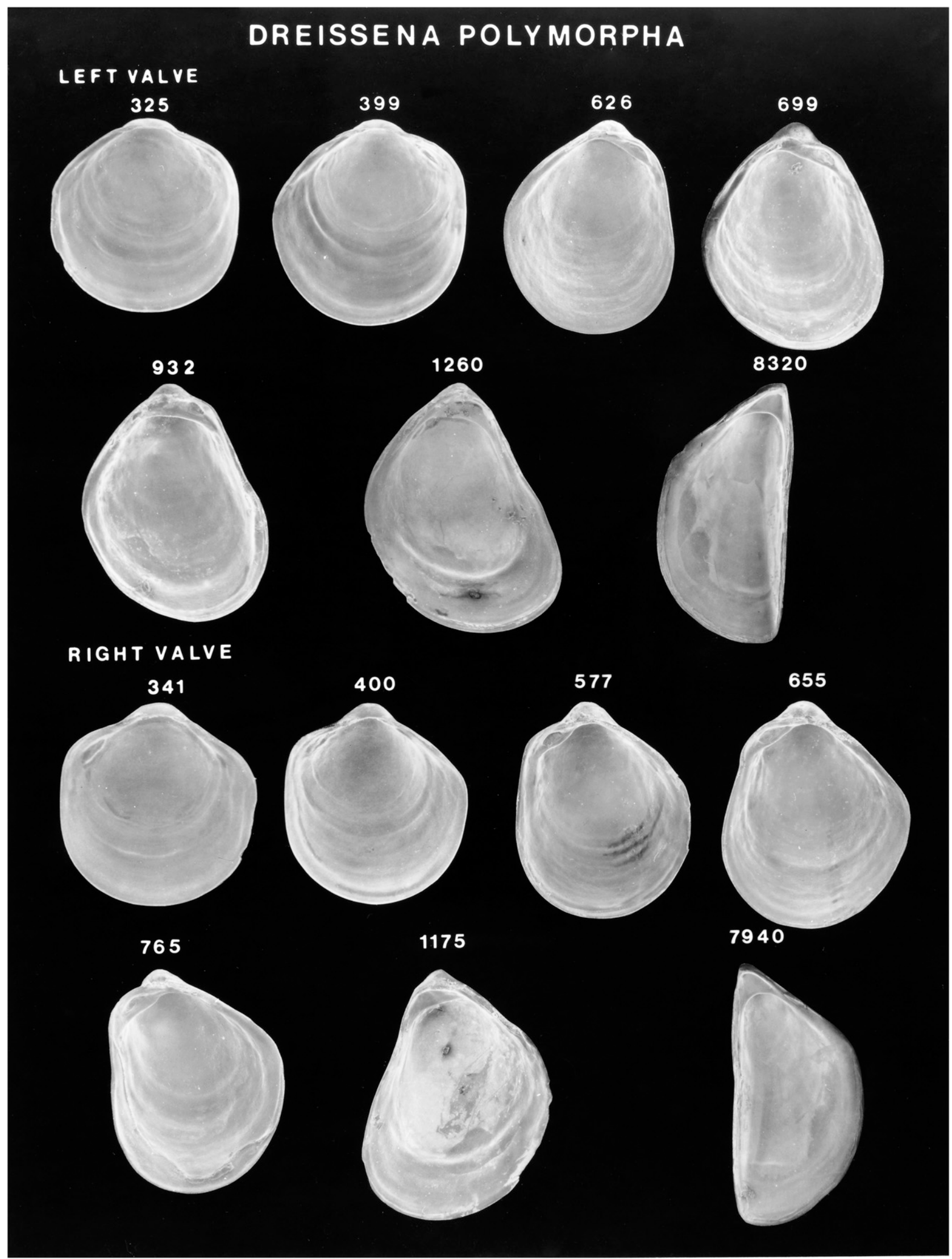

Figure 52. Scanning electron micrographs of disarticulated shell valves of Dreissena polymorpha postlarvae. Numbers indicate the maximum linear shell dimension in micrometers. 


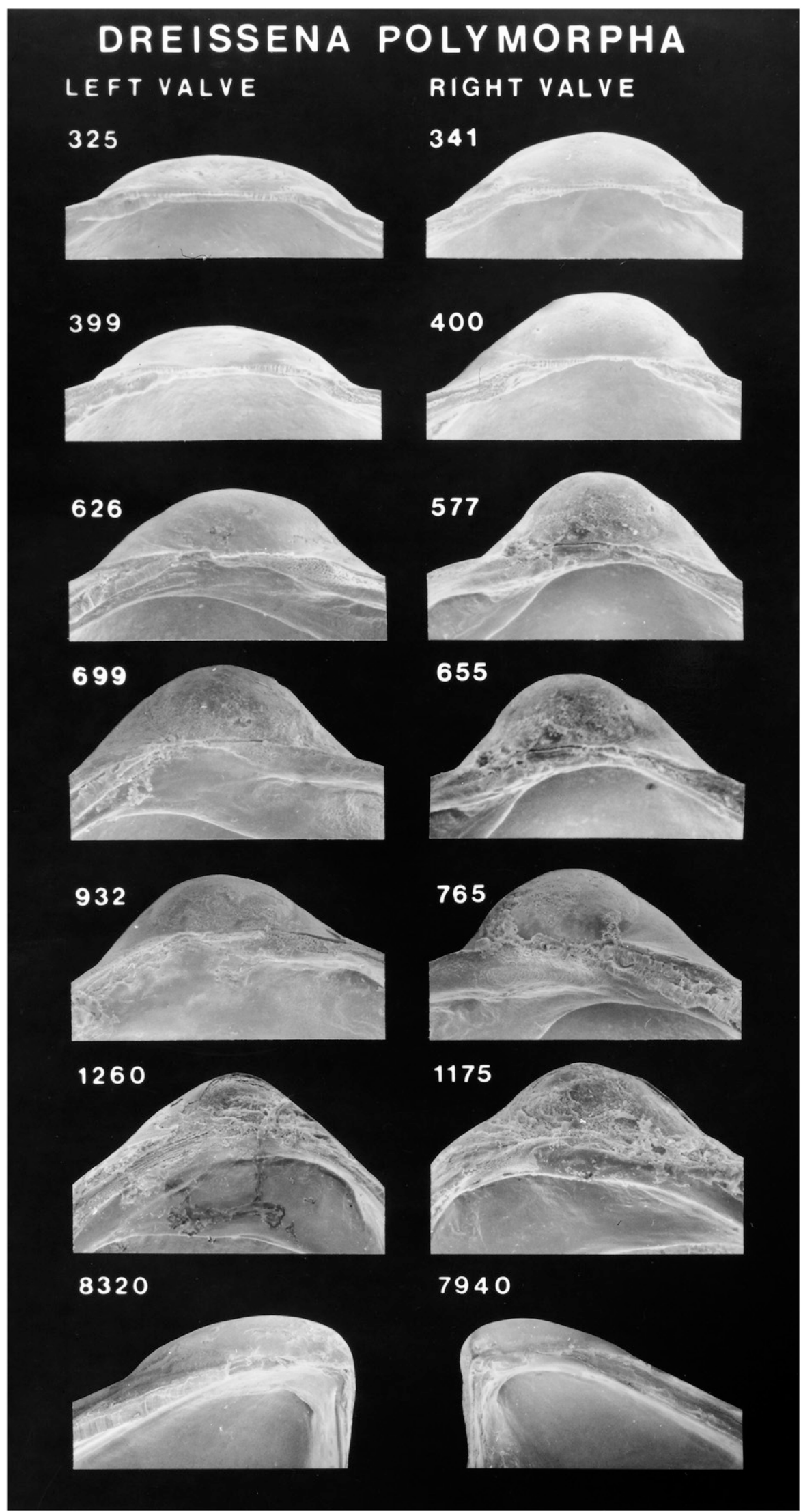

Figure 53. Scanning electron micrographs of the hinge of disarticulated shell valves of Dreissena polymorpha postlarvae seen in Figure 52 . Numbers indicate the maximum linear shell dimension in micrometers. 


\section{MYTILOPSIS LEUCOPHAEATA}
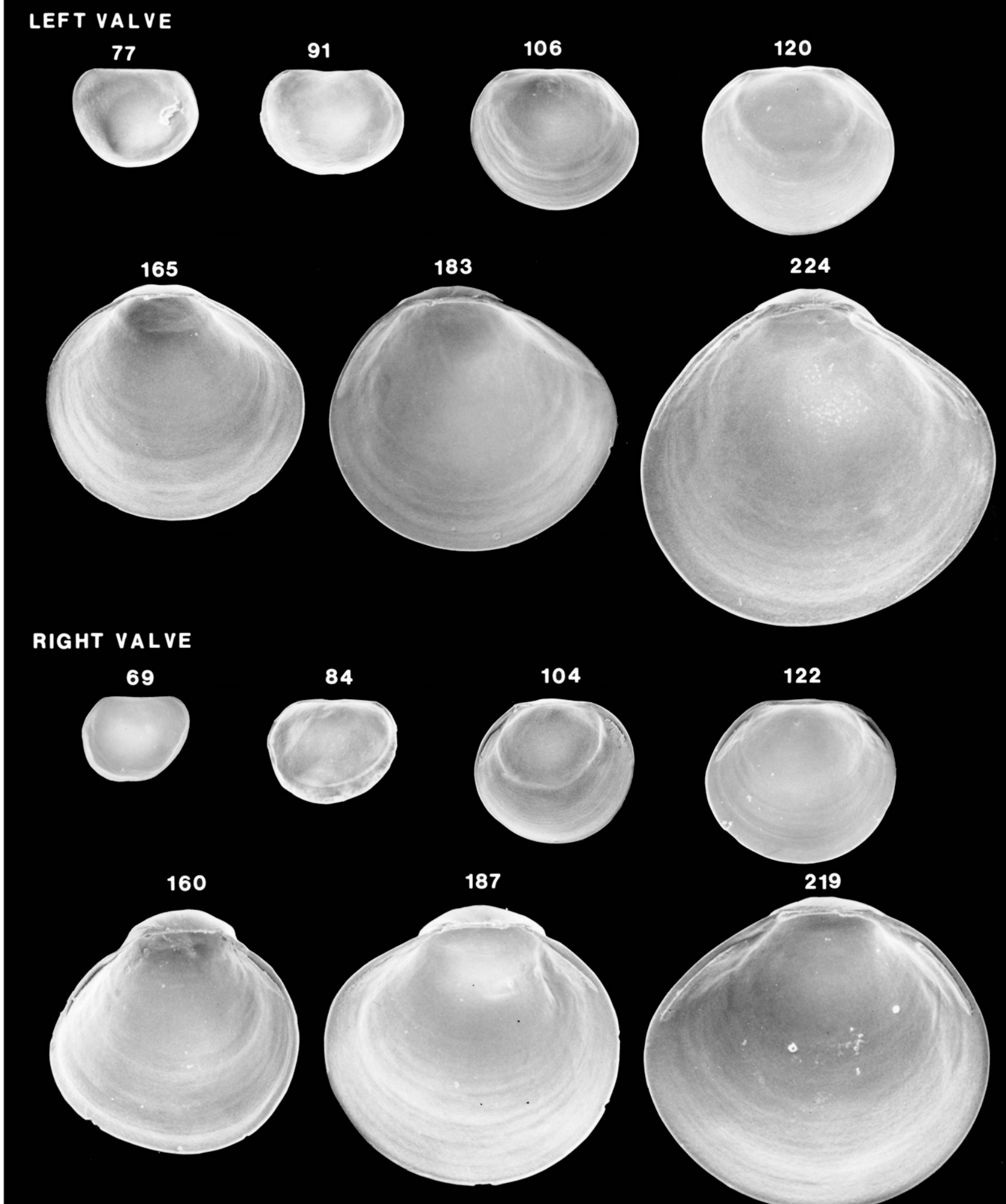

Figure 54. Scanning electron micrographs of disarticulated shell valves of Mytilopsis leucophaeata larvae. Numbers indicate the maximum linear shell dimension in micrometers. 


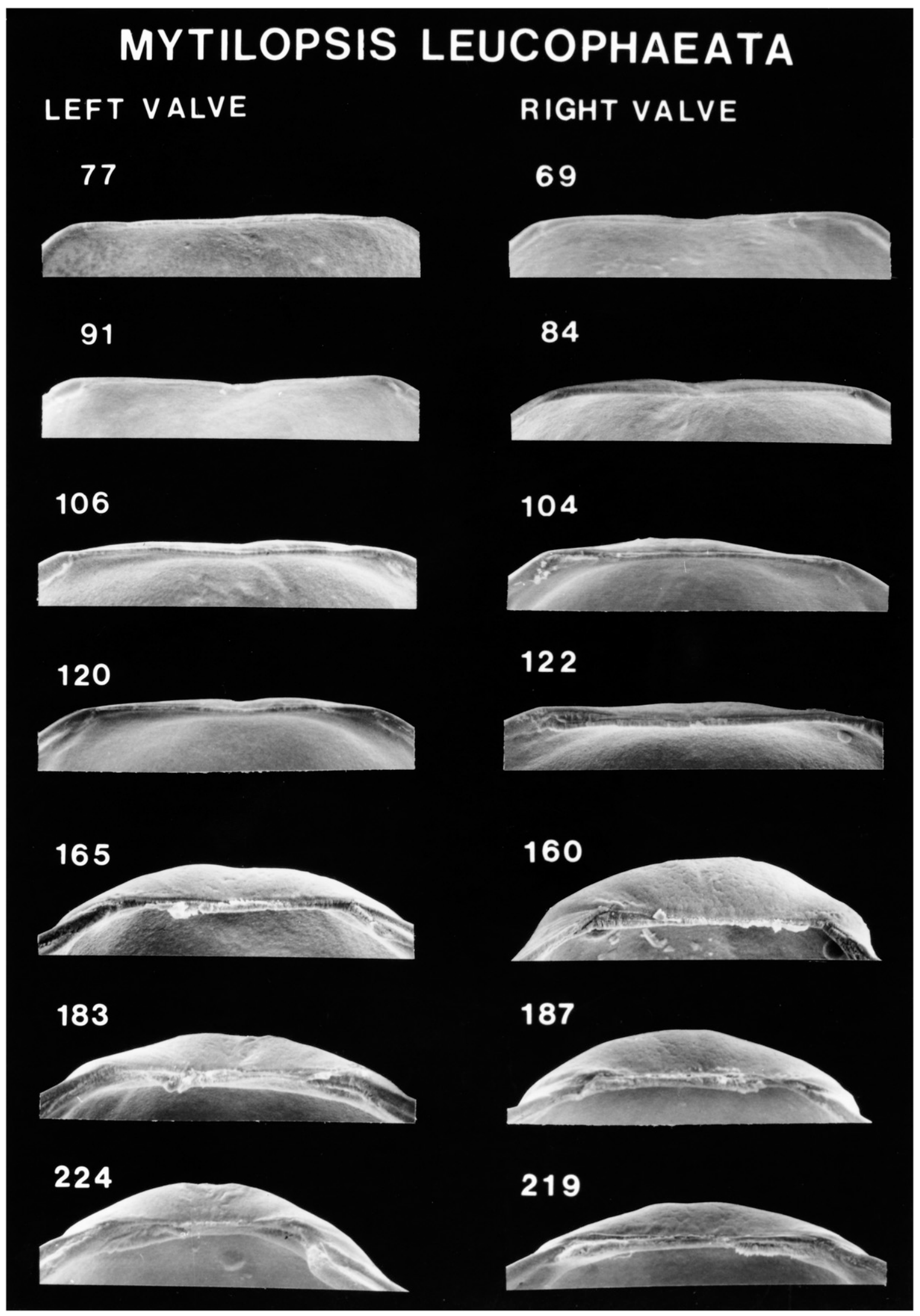

Figure 55. Scanning electron micrographs of the hinge of disarticulated shell valves of Mytilopsis leucophaeata larvae seen in Figure 54. Numbers indicate the maximum linear shell dimension in micrometers. 


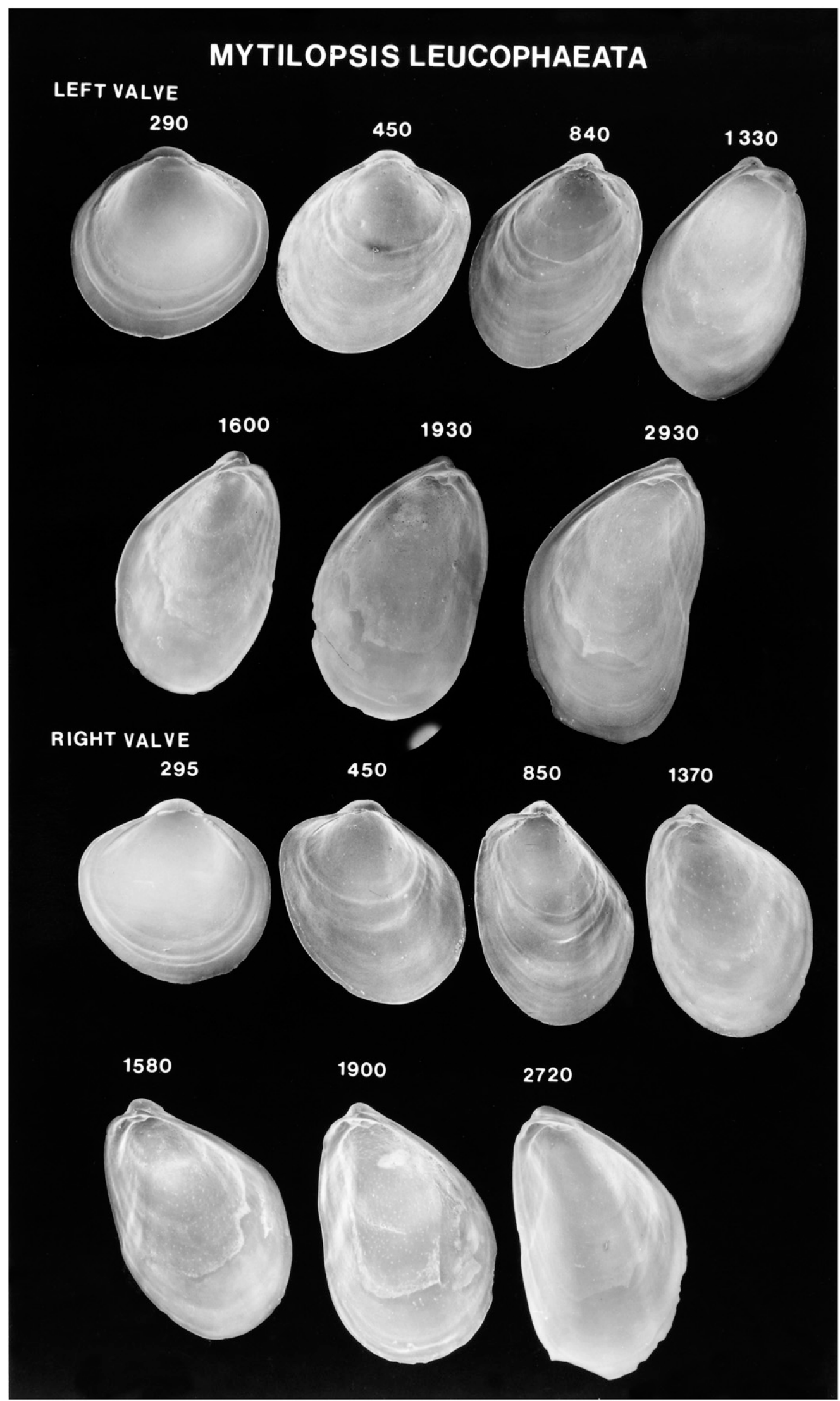

Figure 56. Scanning electron micrographs of disarticulated shell valves of Mytilopsis leucophaeata postlarvae. Numbers indicate the maximum linear shell dimension in micrometers. 


\section{MYTILOPSIS LEUCOPHAEATA}

\section{LEFT VALVE}
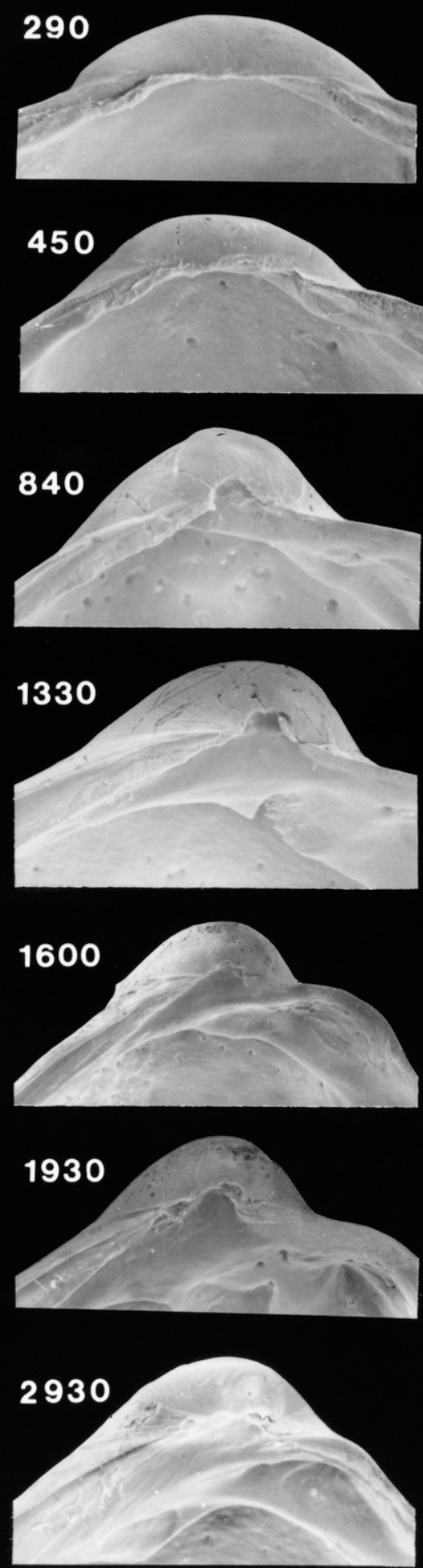

\section{RIGHT VALVE}
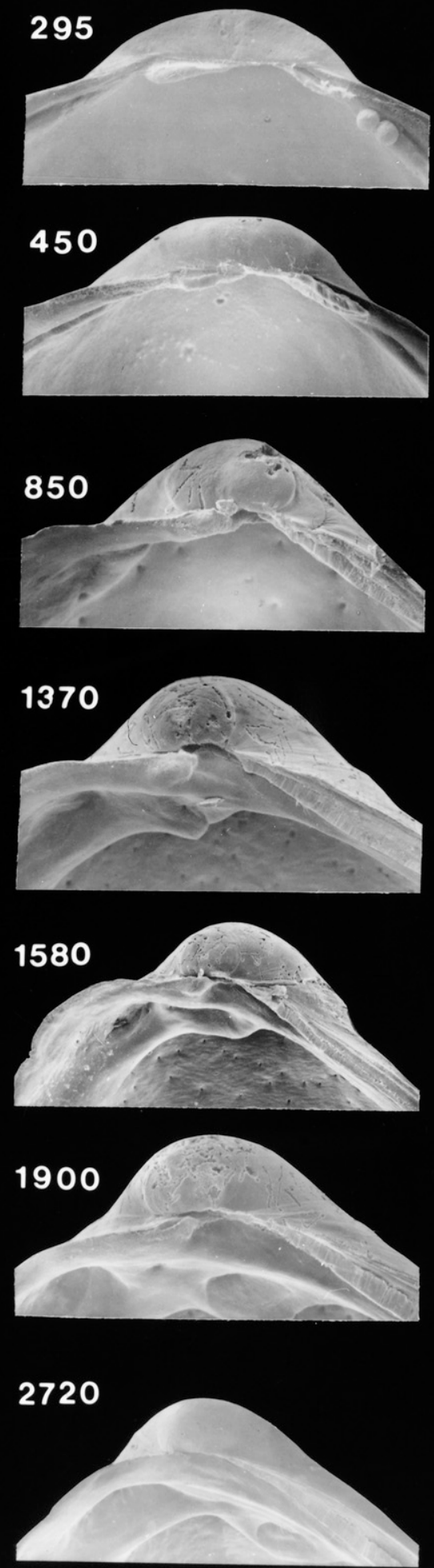

Figure 57. Scanning electron micrographs of the hinge of disarticulated shell valves of Mytilopsis leucophaeata postlarvae seen in Figure 56. Numbers indicate the maximum linear shell dimension in micrometers. 


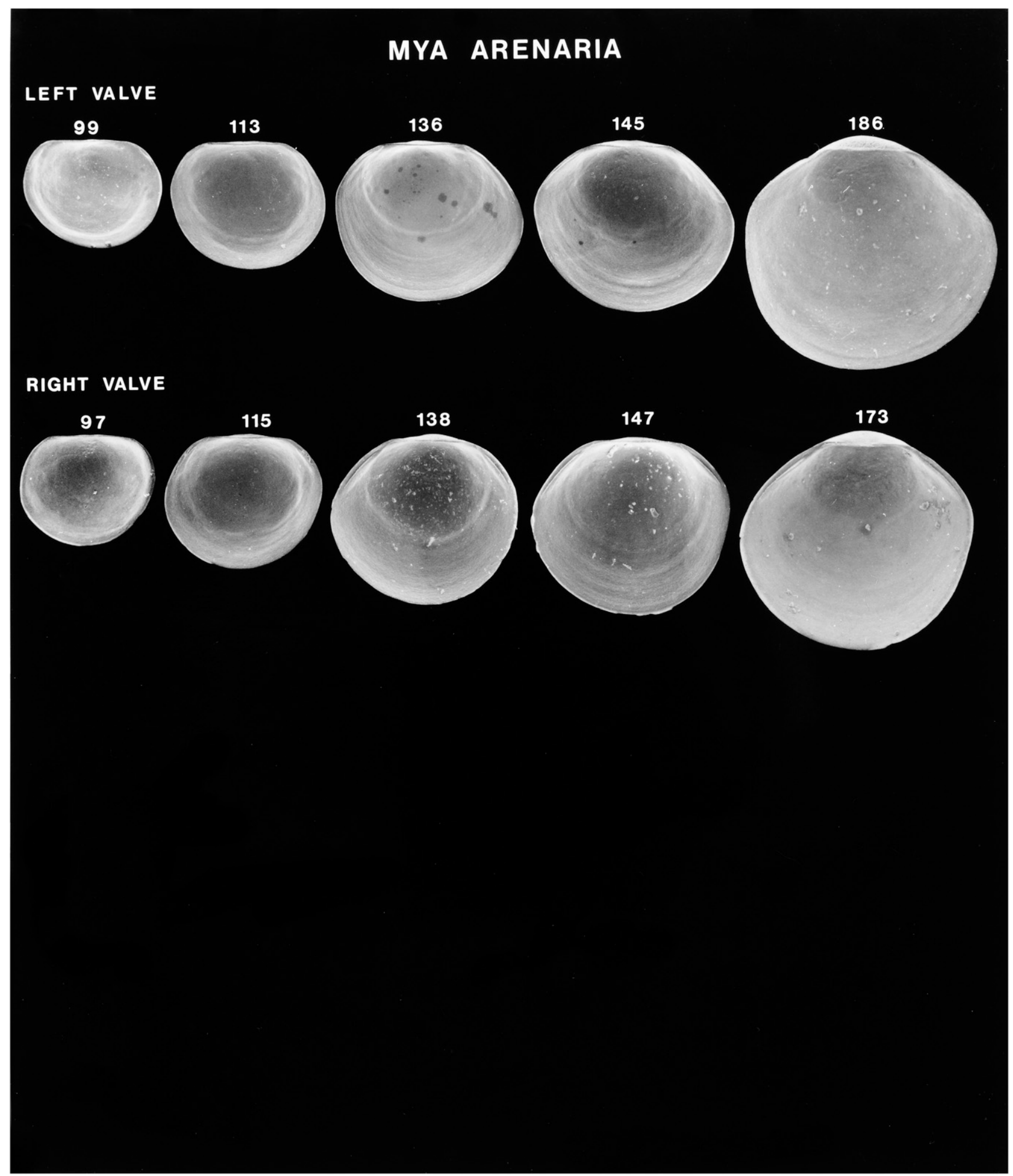

Figure 58. Scanning electron micrographs of disarticulated shell valves of Mya arenaria larvae. Numbers indicate the maximum linear shell dimension in micrometers. 


\section{MYA ARENARIA}

\section{LEFT VALVE}

\section{9}

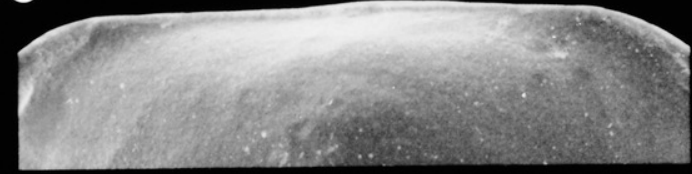

113

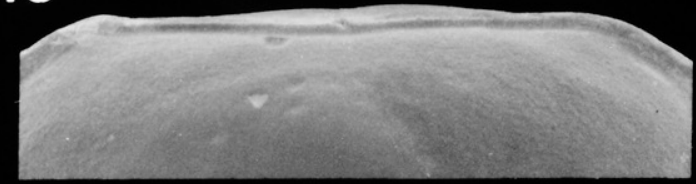

136

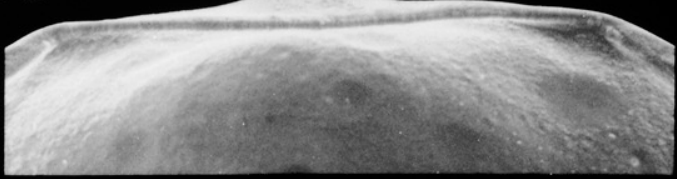

145

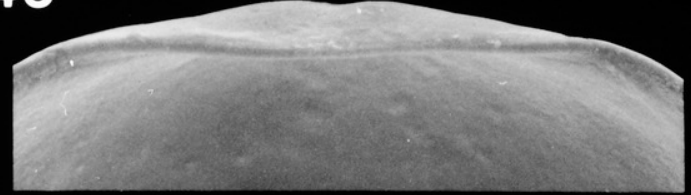

186

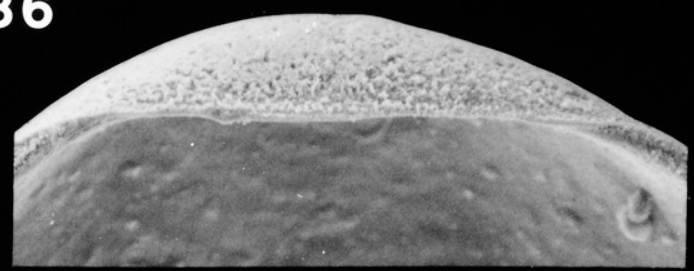

\section{RIGHT VALVE}

\section{7}

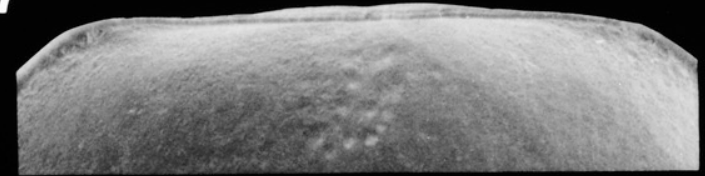

115

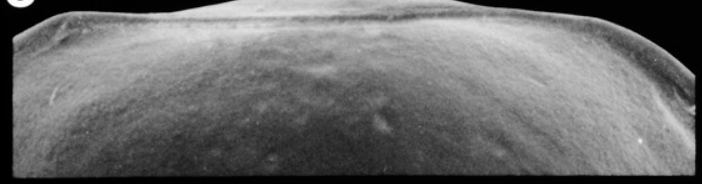

138

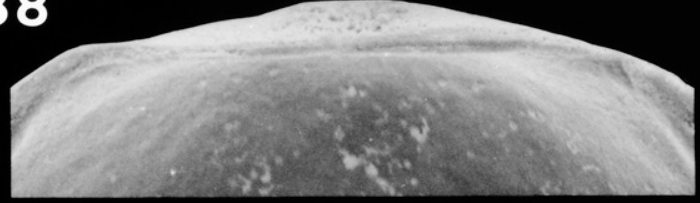

147

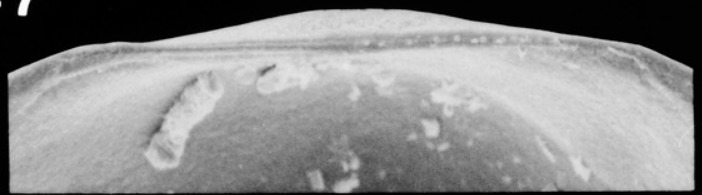

173

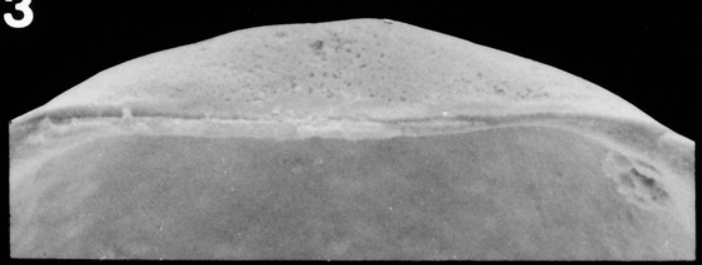

Figure 59. Scanning electron micrographs of the hinge of disarticulated shell valves of Mya arenaria larvae seen in Figure 58. Numbers indicate the maximum linear shell dimension in micrometers. 


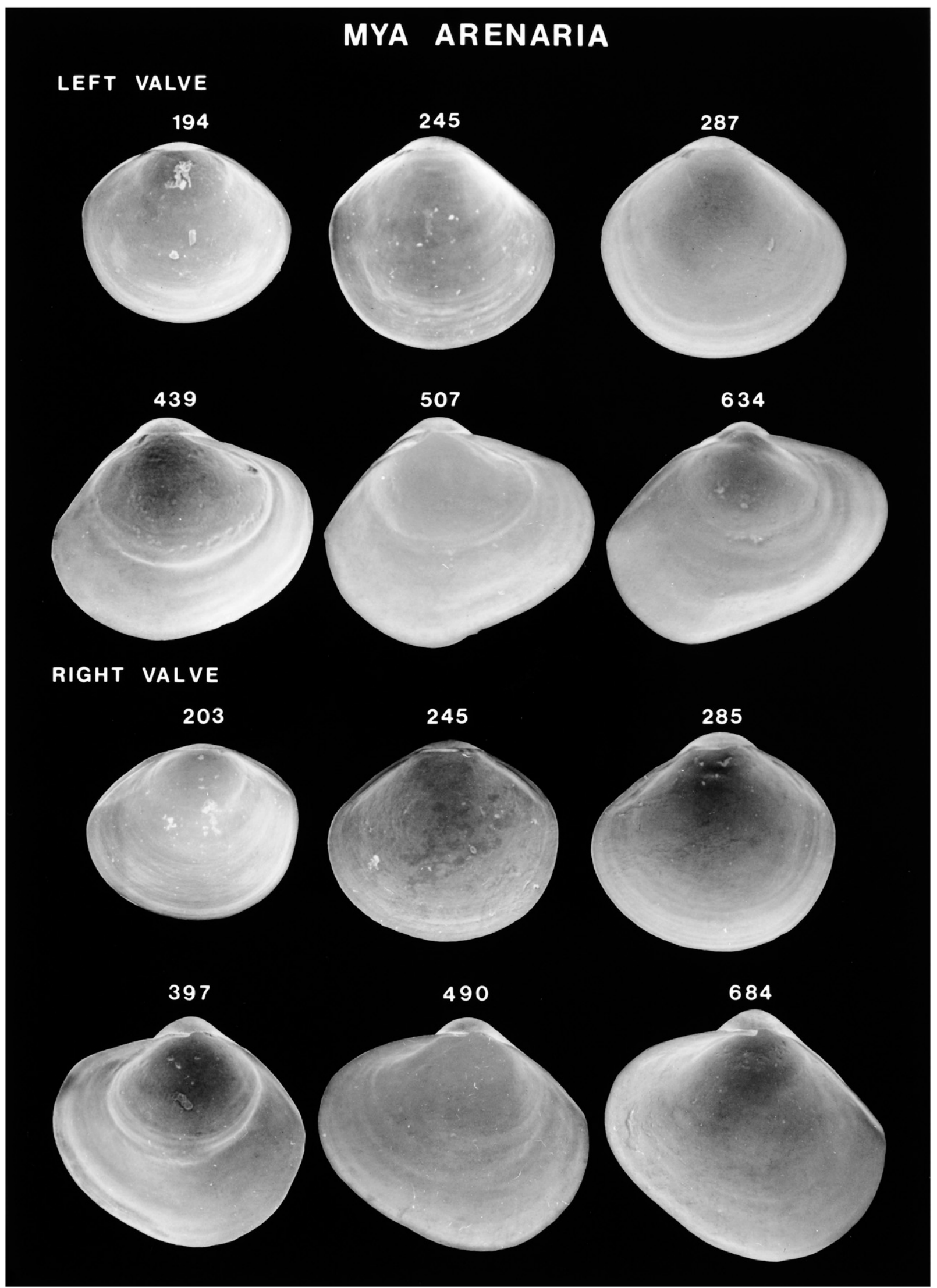

Figure 60. Scanning electron micrographs of disarticulated shell valves of Mya arenaria postlarvae. Numbers indicate the maximum linear shell dimension in micrometers. 


\section{MYA ARENARIA}

\section{LEFT VALVE}
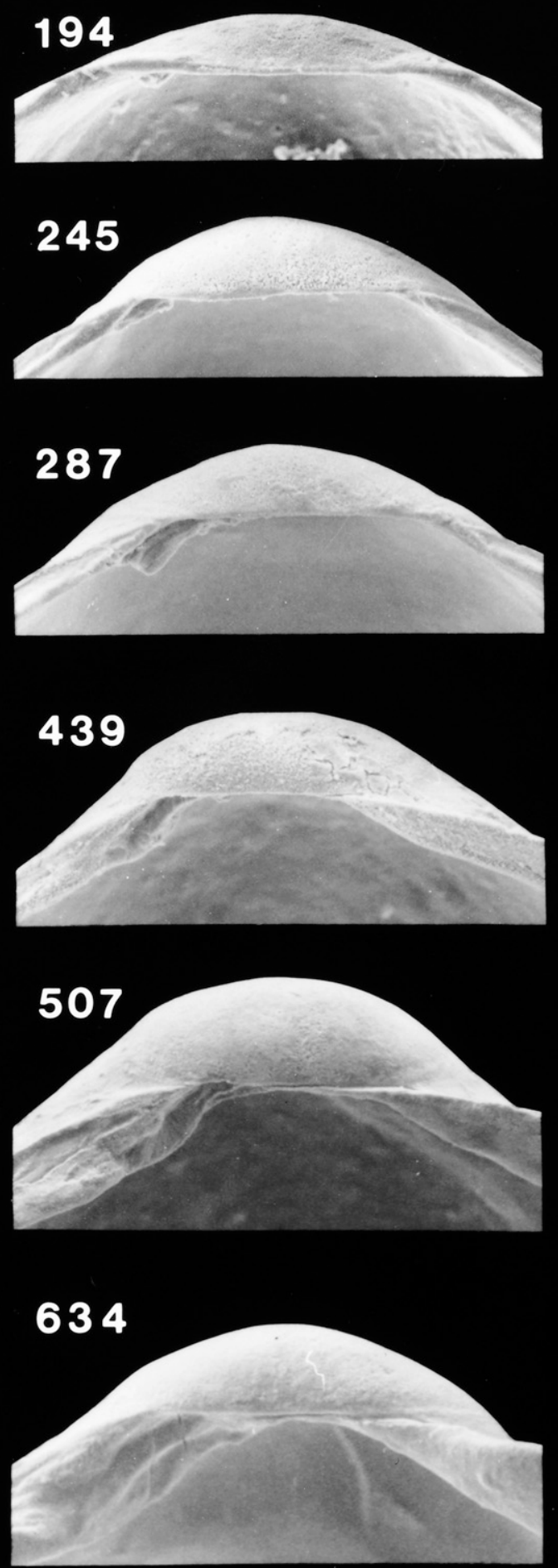

\section{RIGHT VALVE}
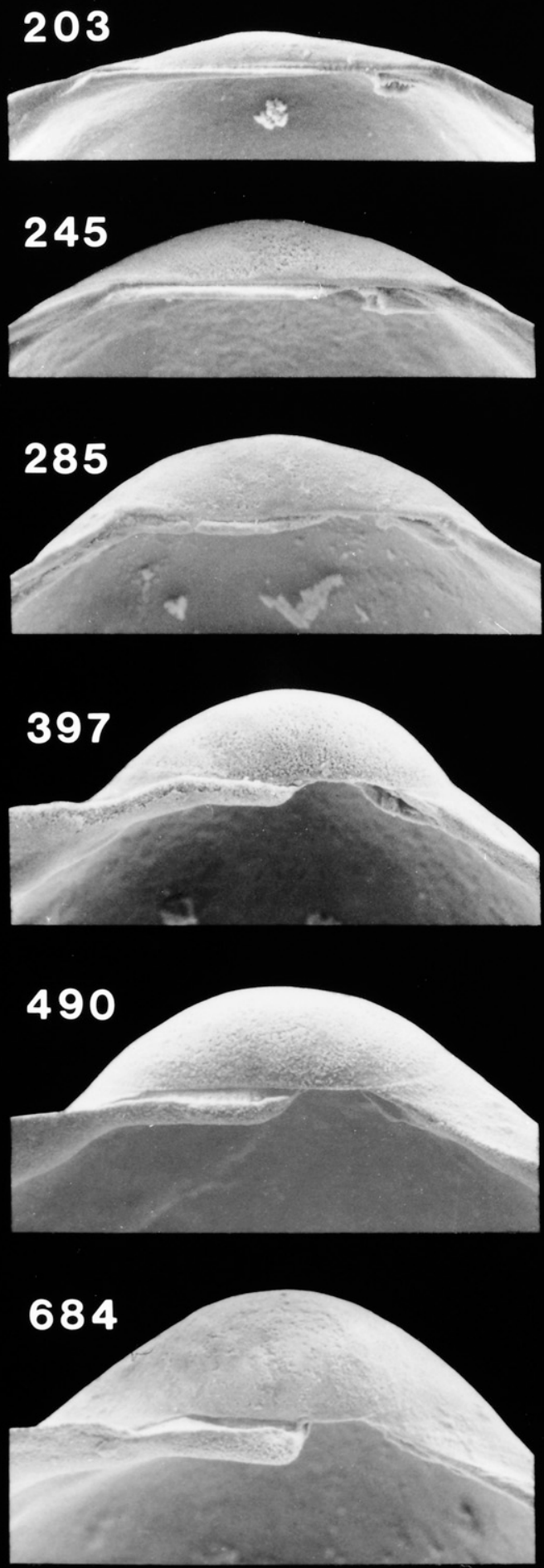


\section{MYA TRUNCATA}

\section{LEFT VALVE}

115

127
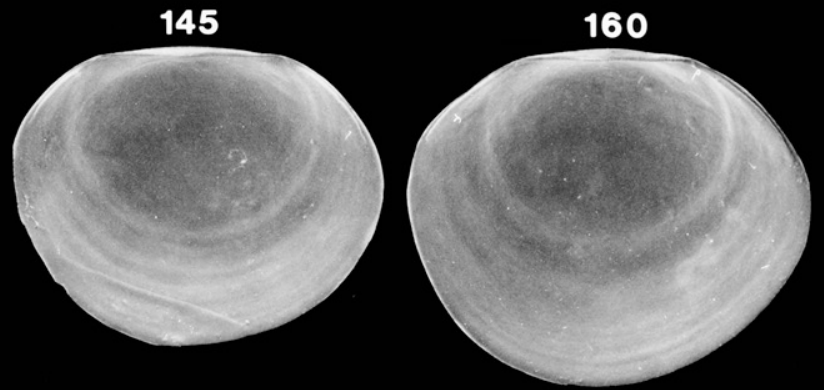

RIGHT VALVE

112

121

141

169

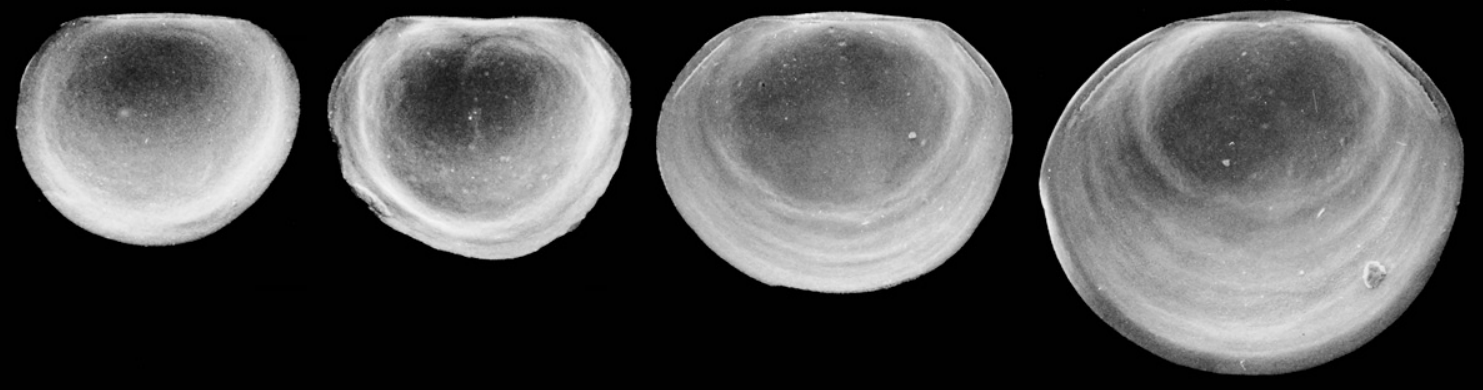

Figure 62. Scanning electron micrographs of disarticulated shell valves of Mya truncata larvae. Numbers indicate the maximum linear shell dimension in micrometers. 


\section{MYA TRUNCATA}

\section{LEFT VALVE}

\section{5}

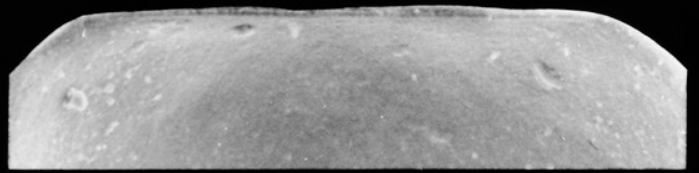

127

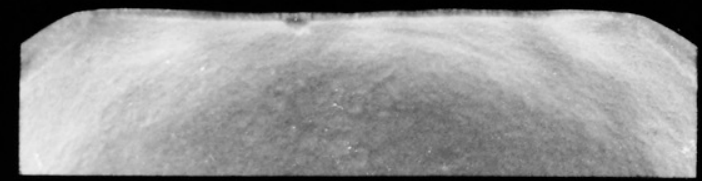

145

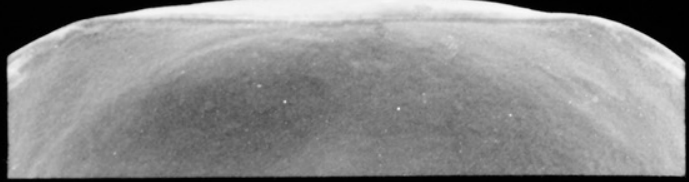

160

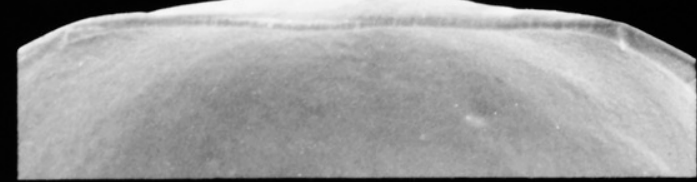

Right VALVE

\section{2}

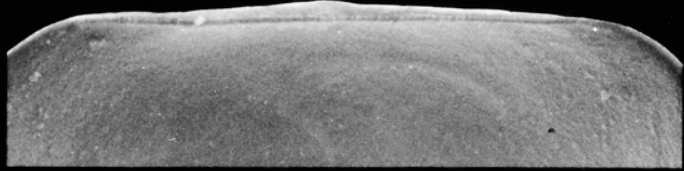

121

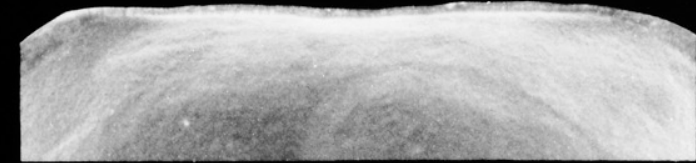

141

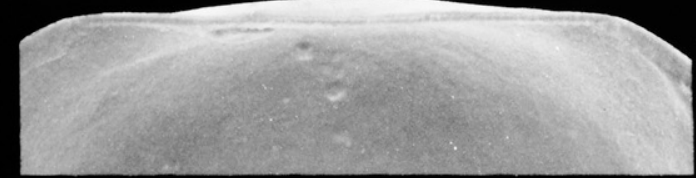

169

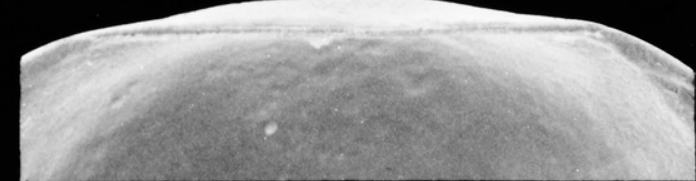

Figure 63. Scanning electron micrographs of the hinge of disarticulated shell valves of Mya truncata larvae seen in Figure 62. Numbers indicate the maximum linear shell dimension in micrometers. 


\section{MYA TRUNCATA}

\section{LEFT VALVE}

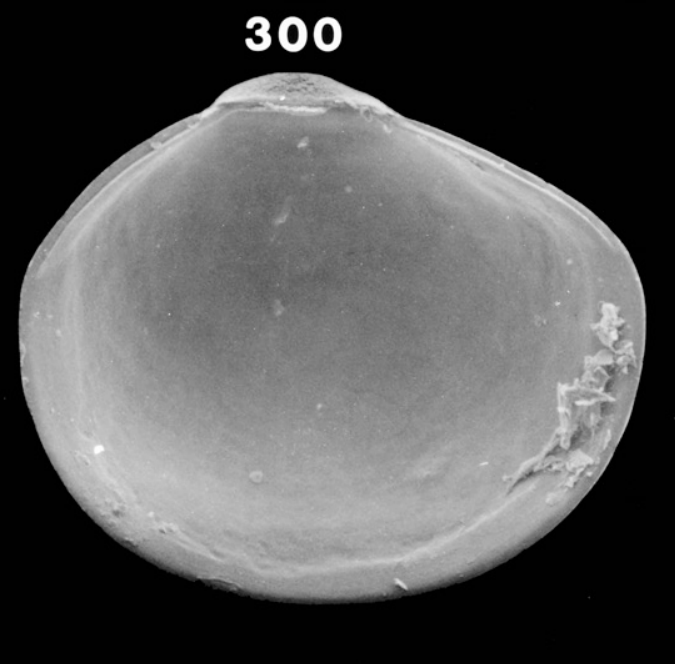

\section{RIGHT VALVE}

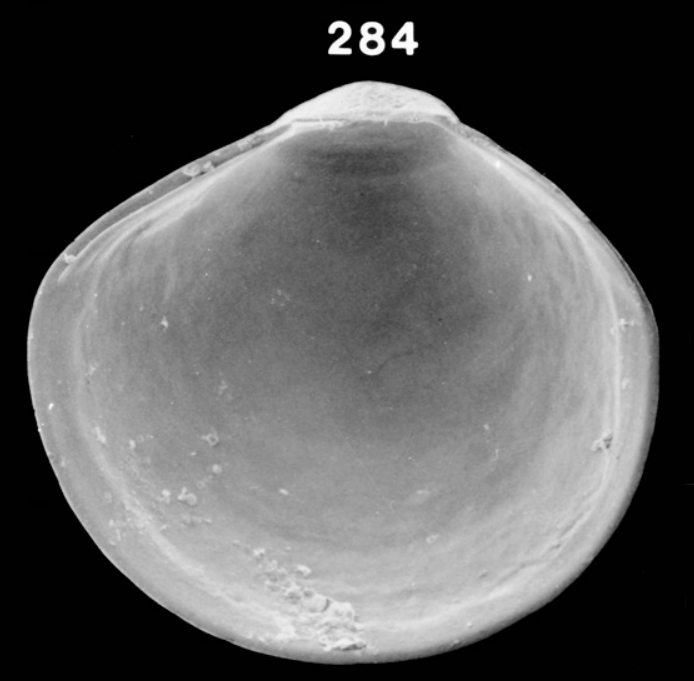

\section{MYA TRUNCATA}

\section{LEFT VALVE}

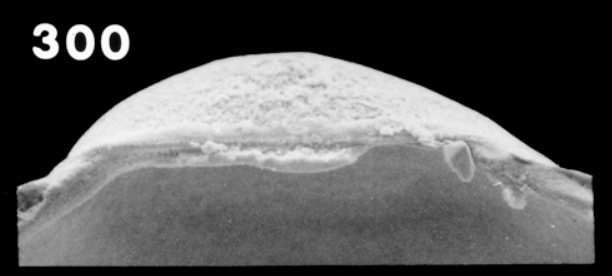

\section{RIGHT VALVE}

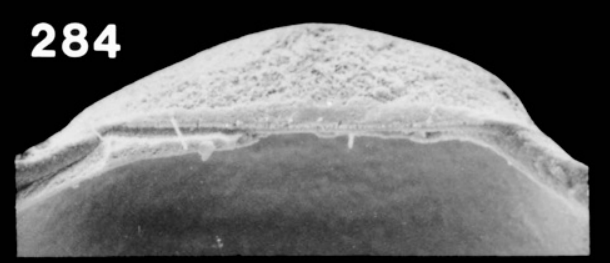

Figure 64. Scanning electron micrographs of disarticulated shell valves of Mya truncata postlarvae (top) and higher magnification scanning electron micrographs of the hinge of these shell valves (bottom). Numbers indicate the maximum linear shell dimension in micrometers. 


\section{CYRTOPLEURA COSTATA}

\section{LEFT VALVE}

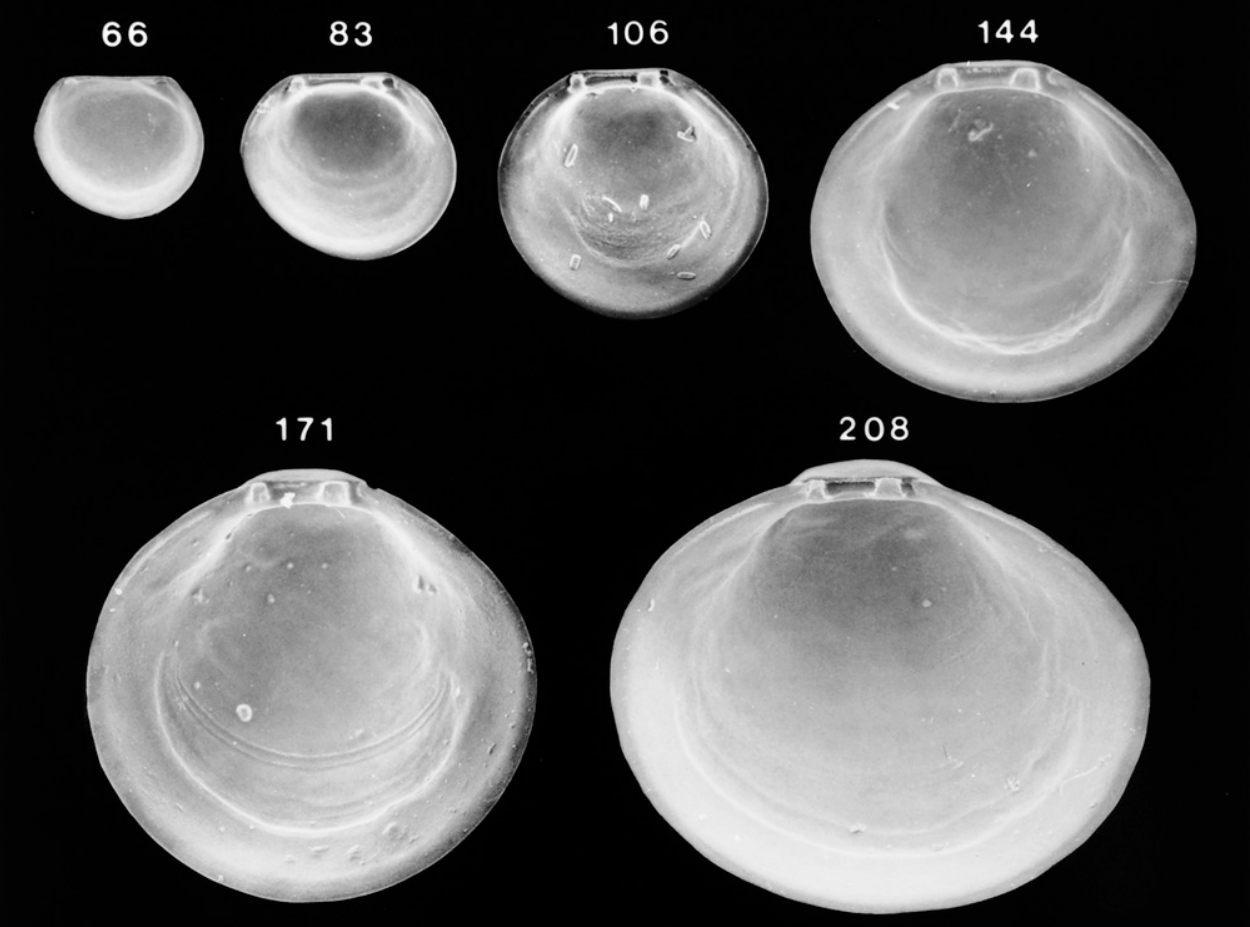

RIGHT VALVE

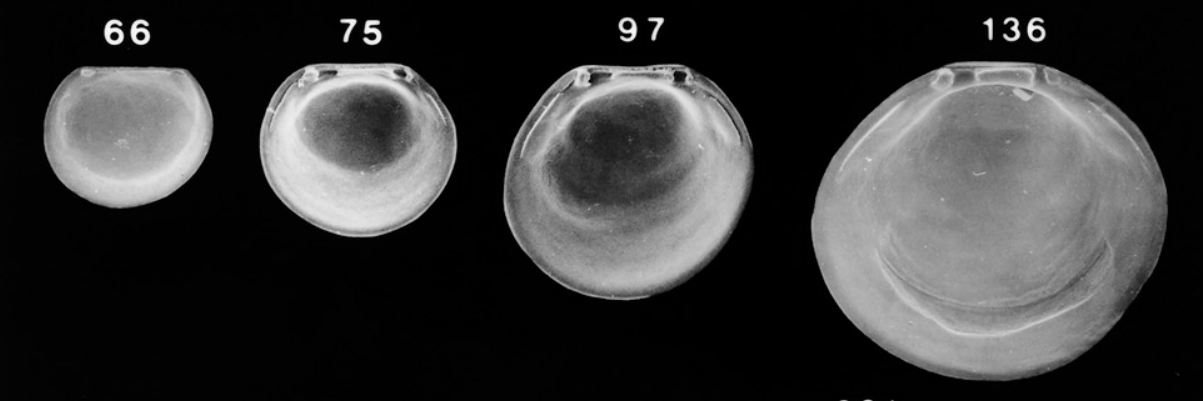

159

221
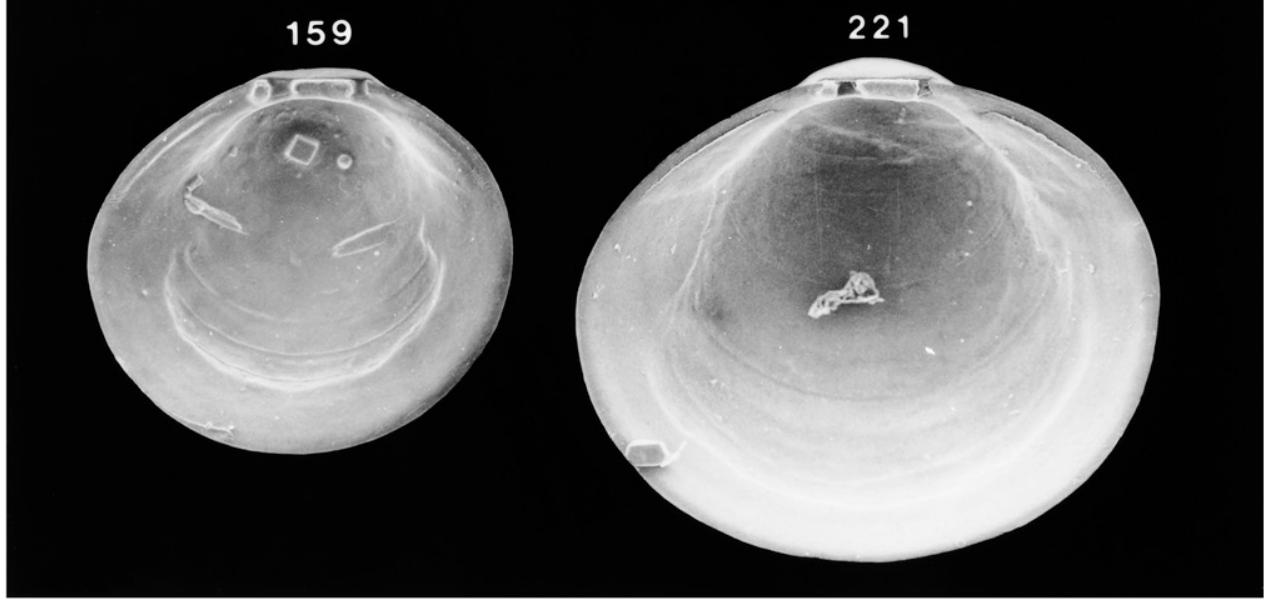

Figure 65. Scanning electron micrographs of disarticulated shell valves of Cyrtopleura costata larvae. Numbers indicate the maximum linear shell dimension in micrometers. 


\section{CYRTOPLEURA COSTATA}

\section{LEFT VALVE}

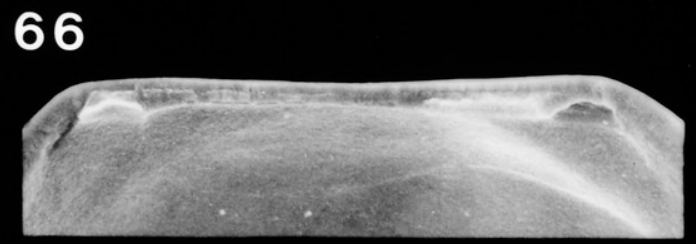

\section{3}

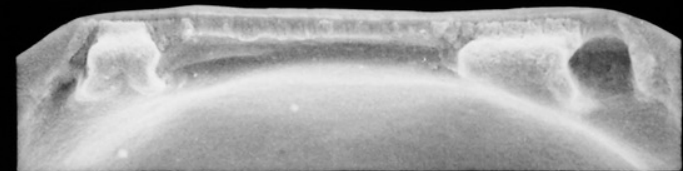

106

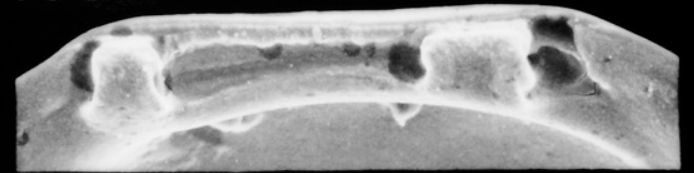

\section{4}

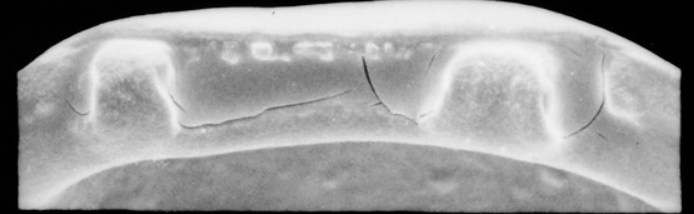

171

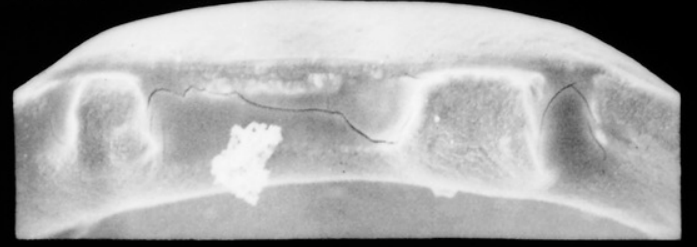

\section{8}

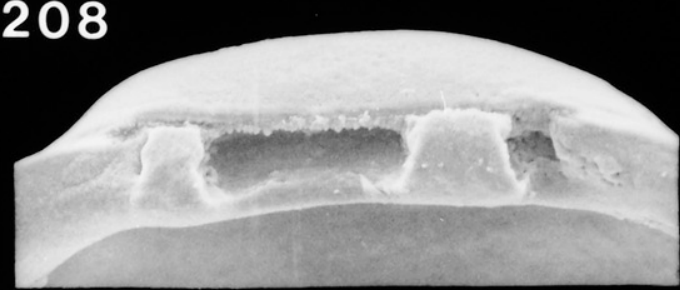

\section{RIGHT VALVE}

\section{6}

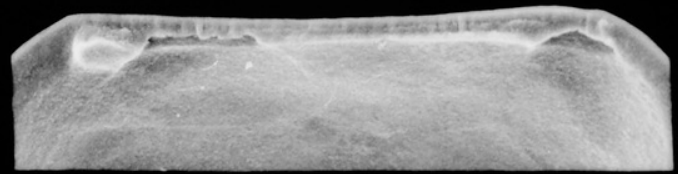

75
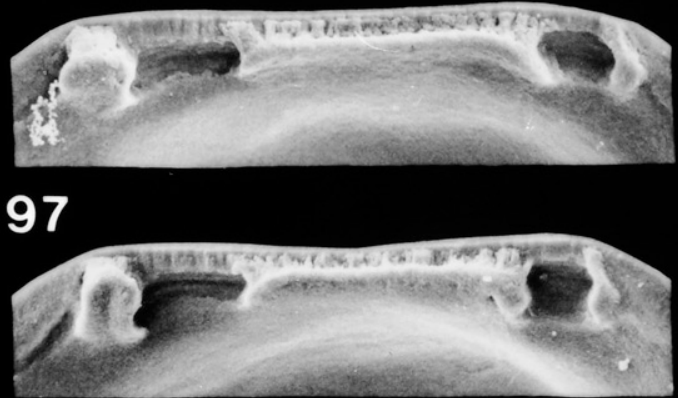

136

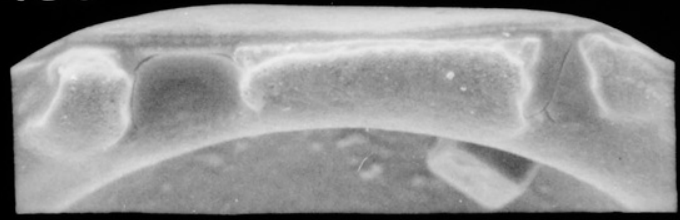

159
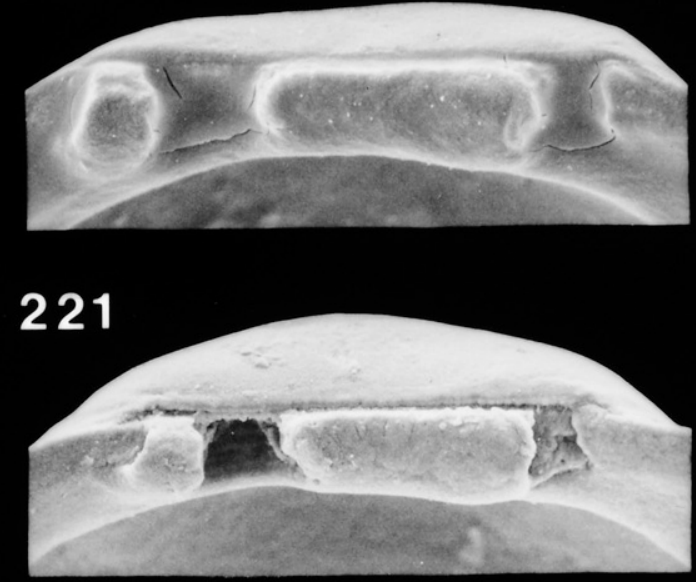


\section{DIPLOTHYRA CURTA}

\section{LEFT VALVE}
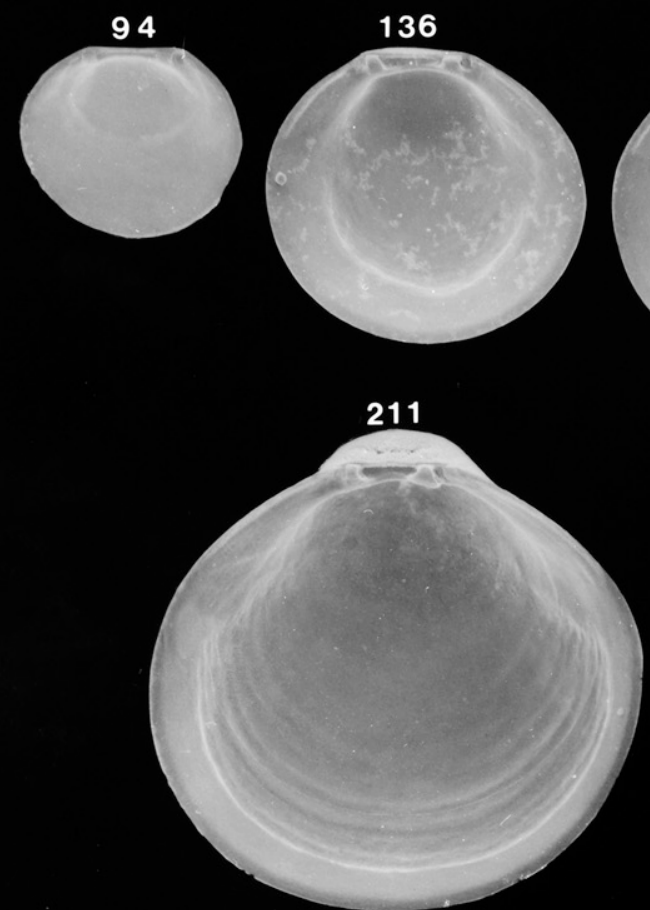

RIGHT VALVE

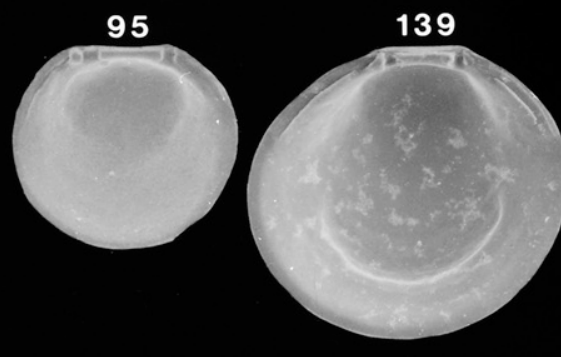

203

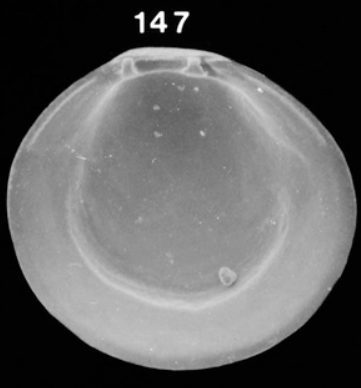

224

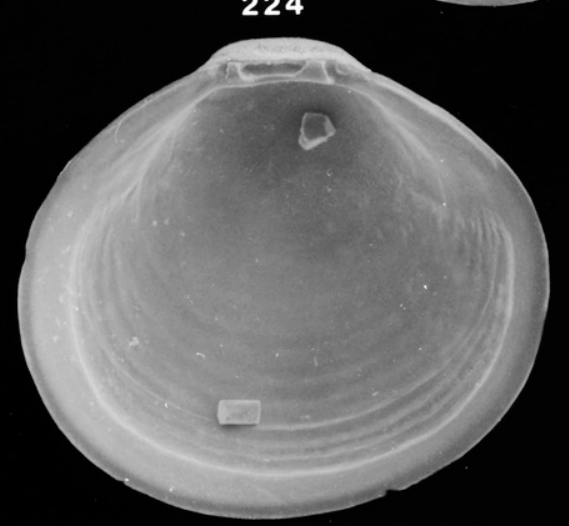

151

161

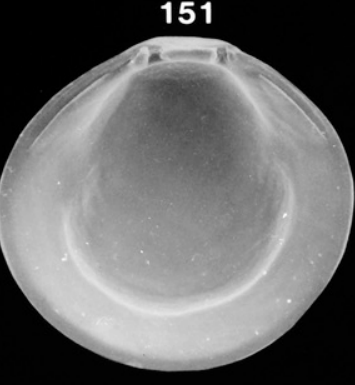

225

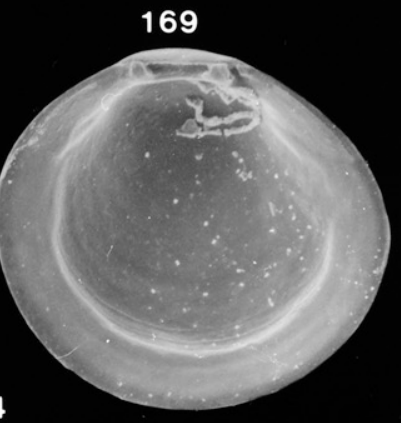




\section{DIPLOTHYRA CURTA}

\section{LEFT VALVE}

94

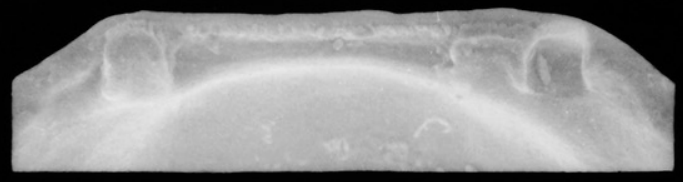

136

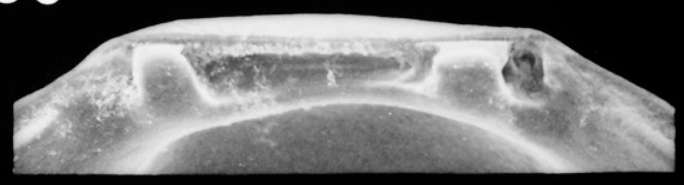

147

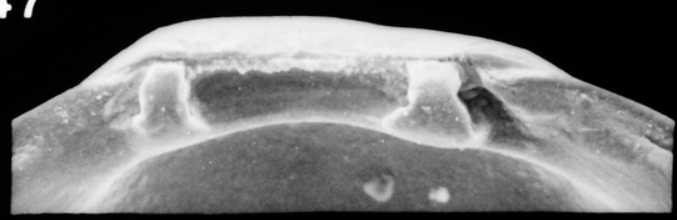

169

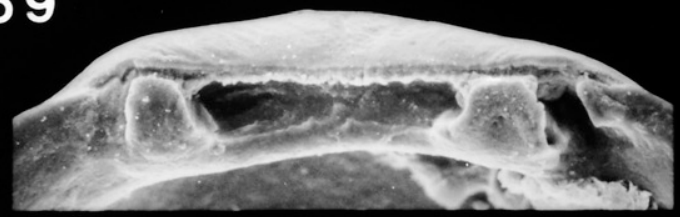

211

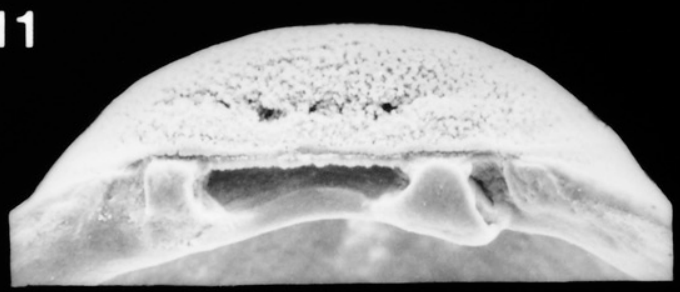

224

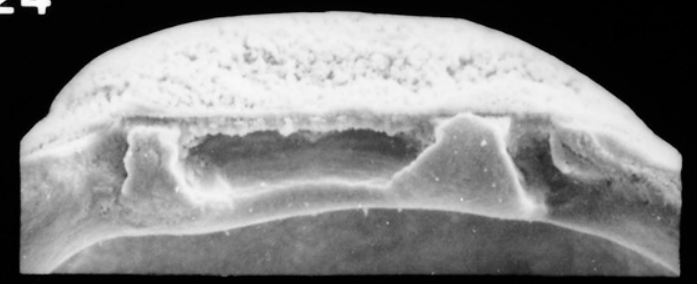

\section{RIGHT VALVE}

95

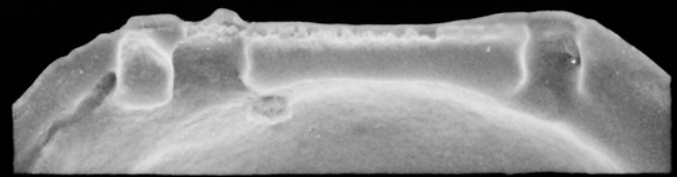

139

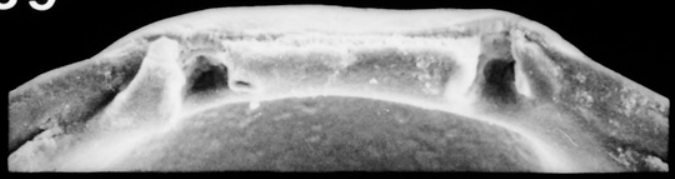

151

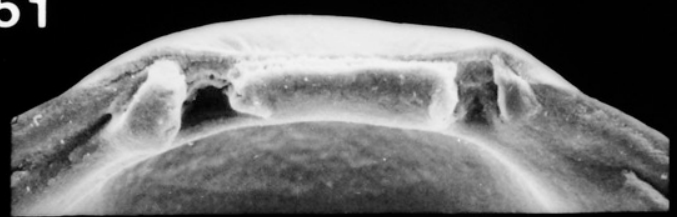

161

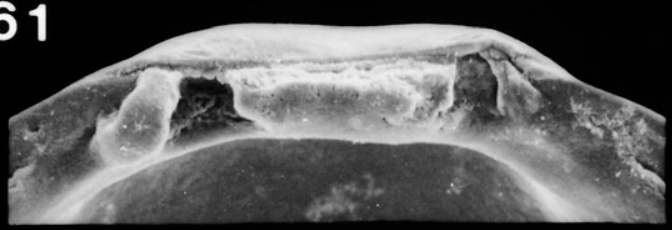

203

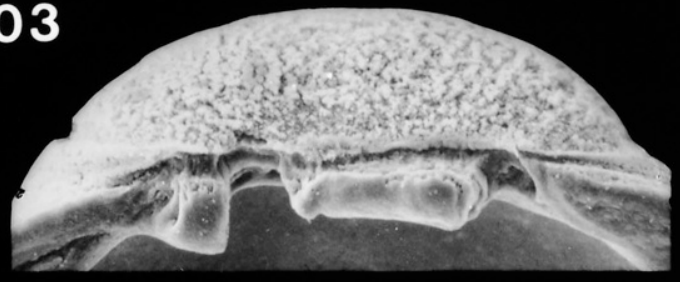

225

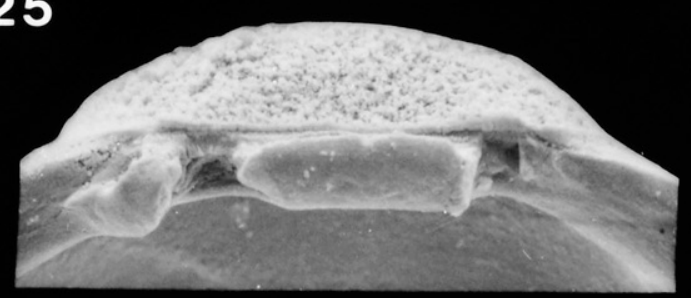




\section{BANKIA GOULDI}

\section{LEFT VALVE}

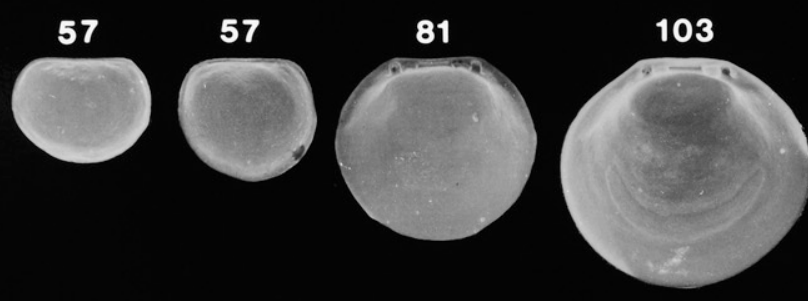

149

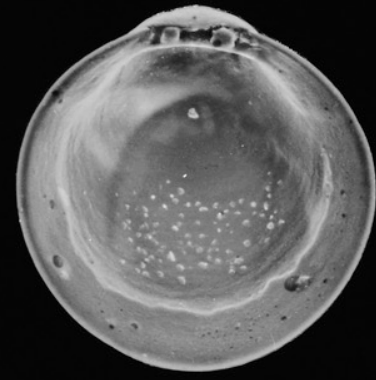

189

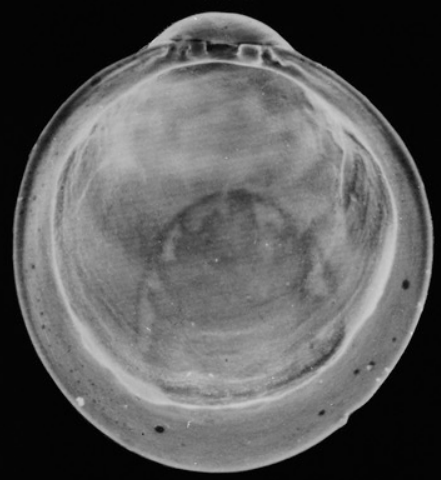

130

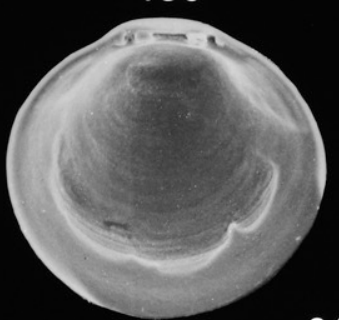

214

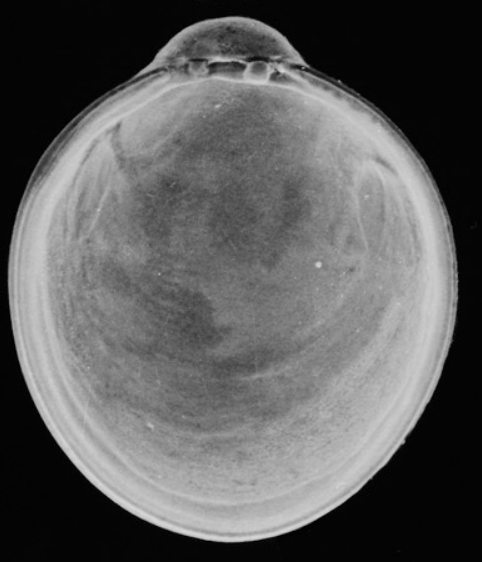

\section{RIGHT VALVE}

\section{2}

62 75

109

132

142

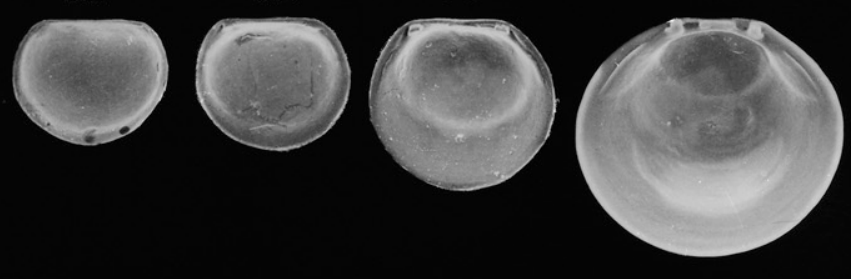

144

192
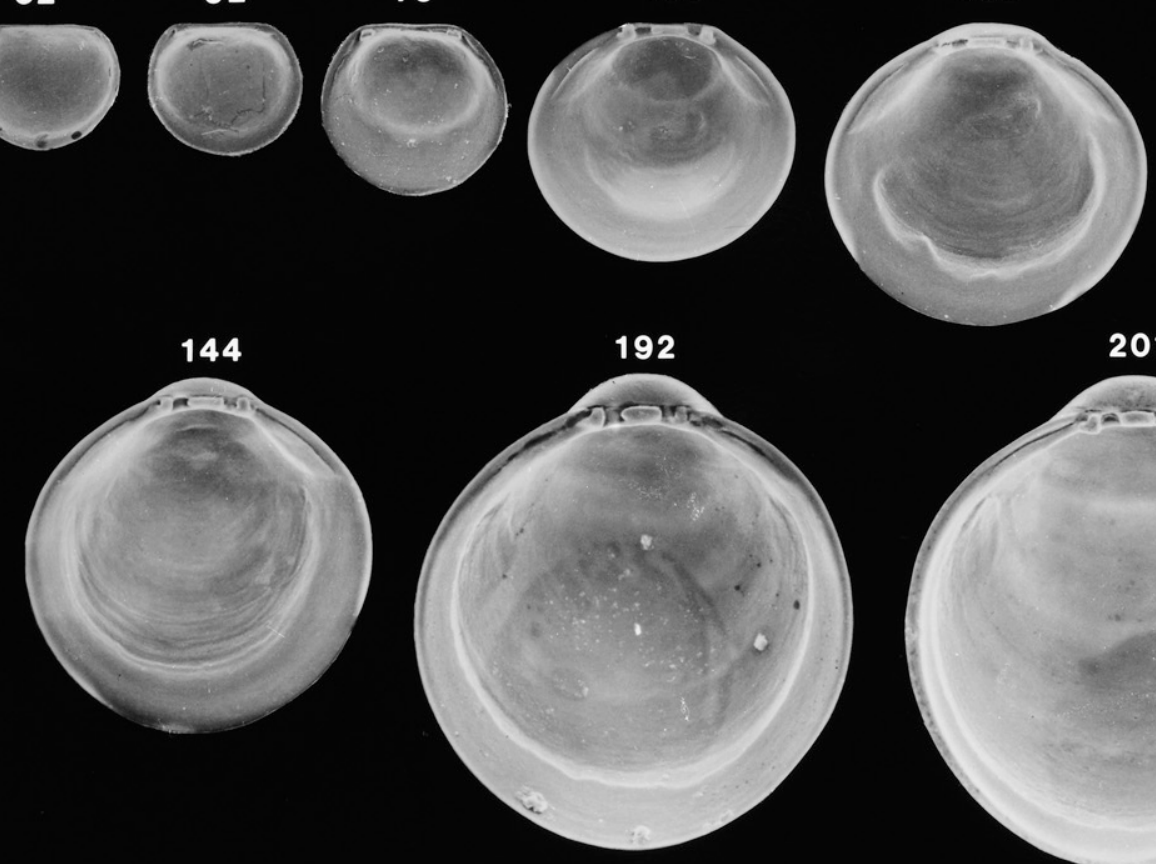

201
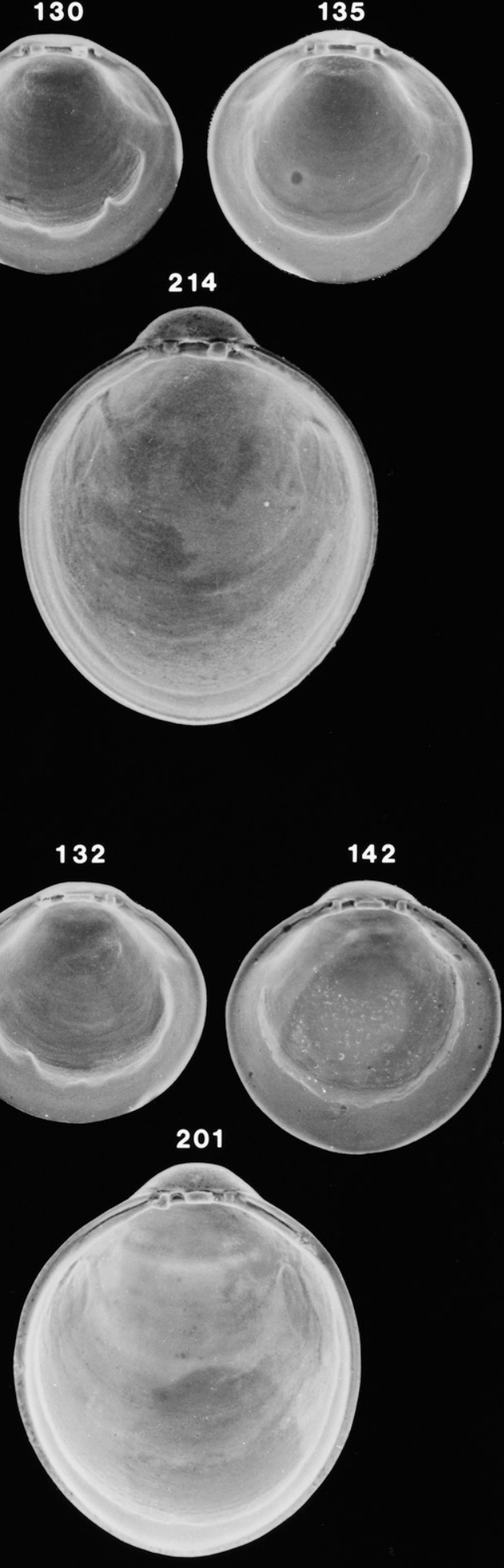

Figure 69. Scanning electron micrographs of disarticulated shell valves of Bankia gouldi larvae. Numbers indicate the maximum linear shell dimension in micrometers. Modified from Tan et al. (1993). 


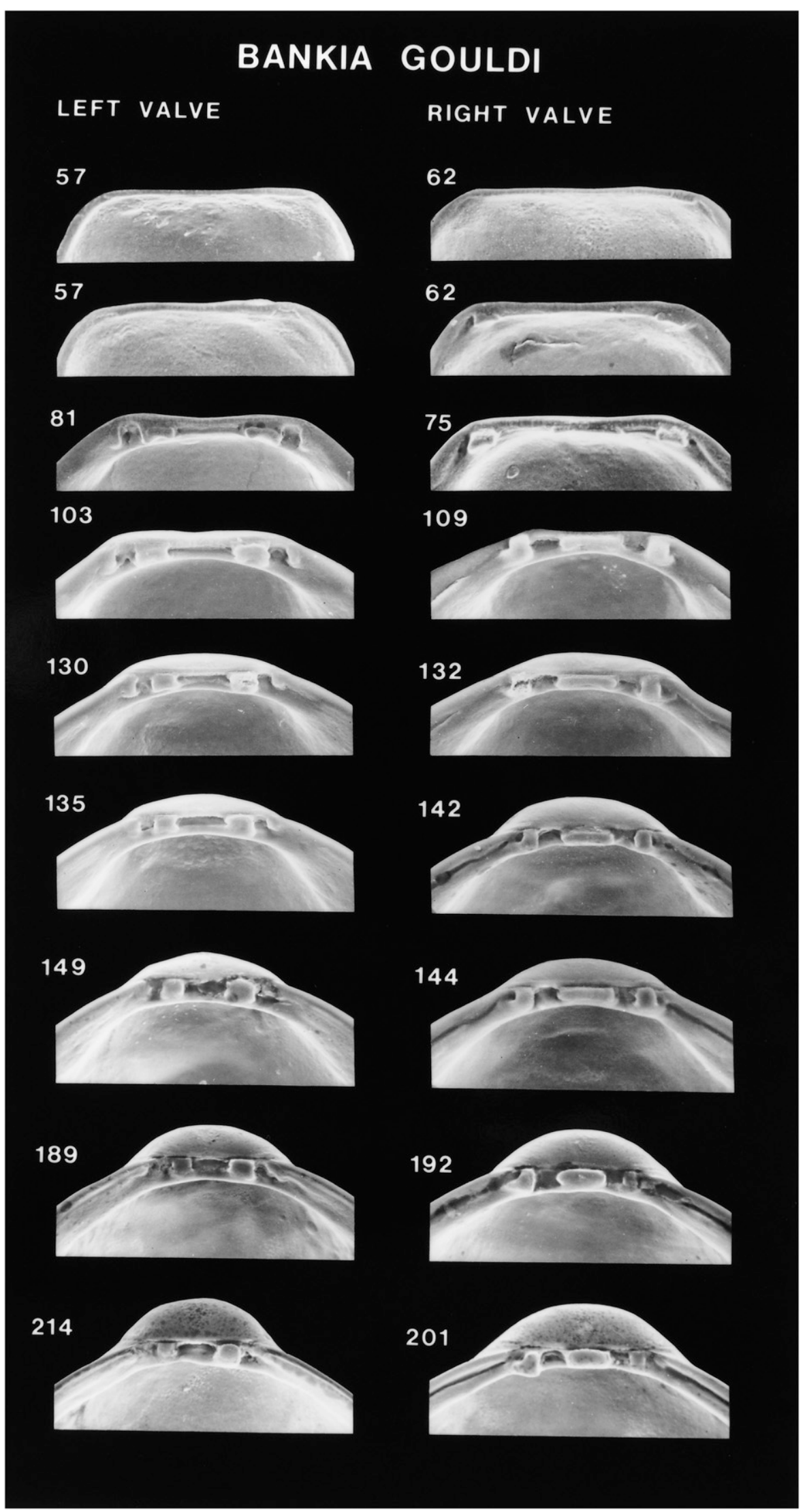

Figure 70. Scanning electron micrographs of the hinge of disarticulated shell valves of Bankia gouldi larvae seen in Figure 69. Numbers indicate the maximum linear shell dimension in micrometers. Modified from Tan et al. (1993). 


\section{BANKIA GOULDI}

\section{LEFT VALVE}
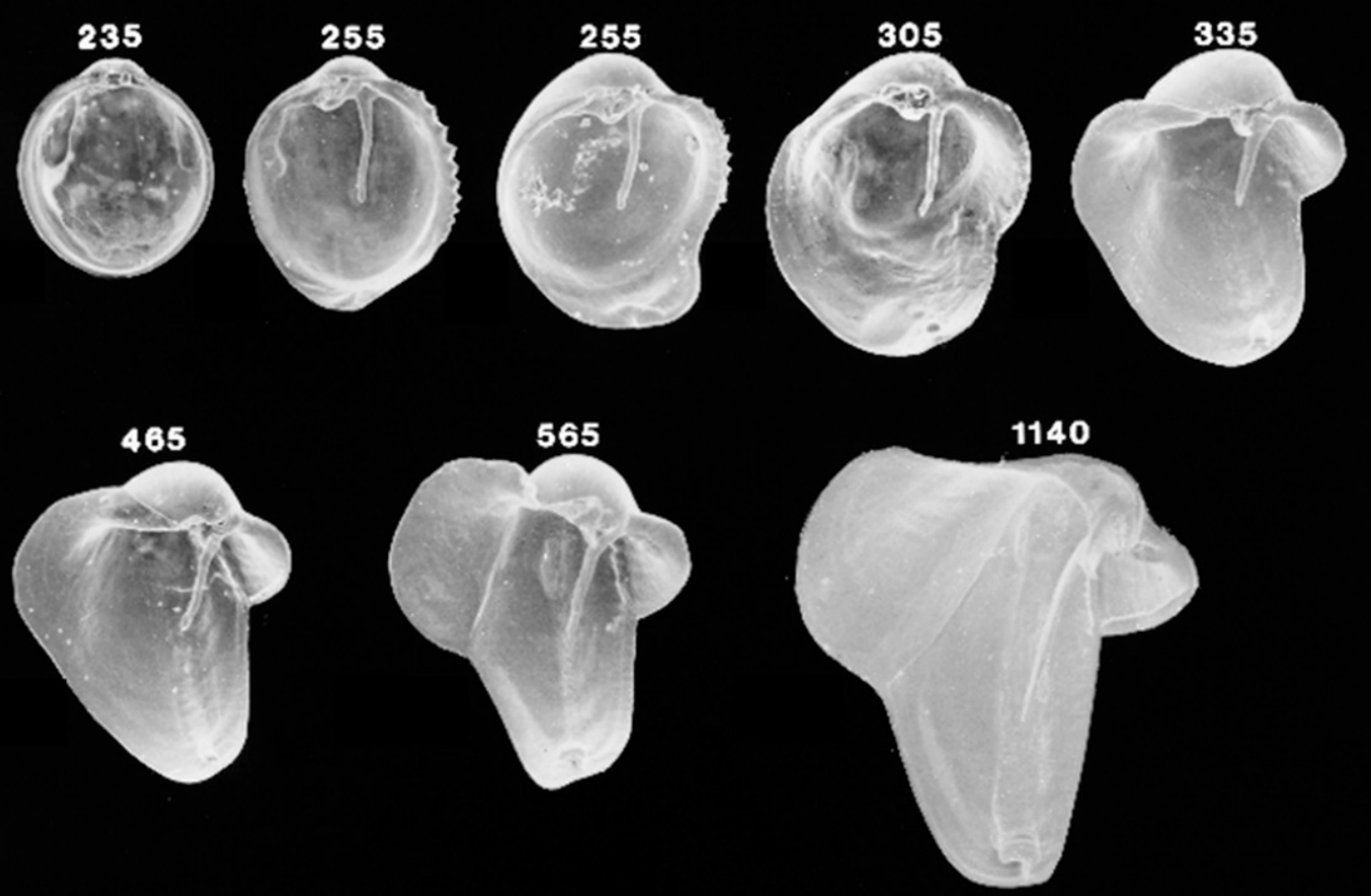

\section{RIGHT VALVE}
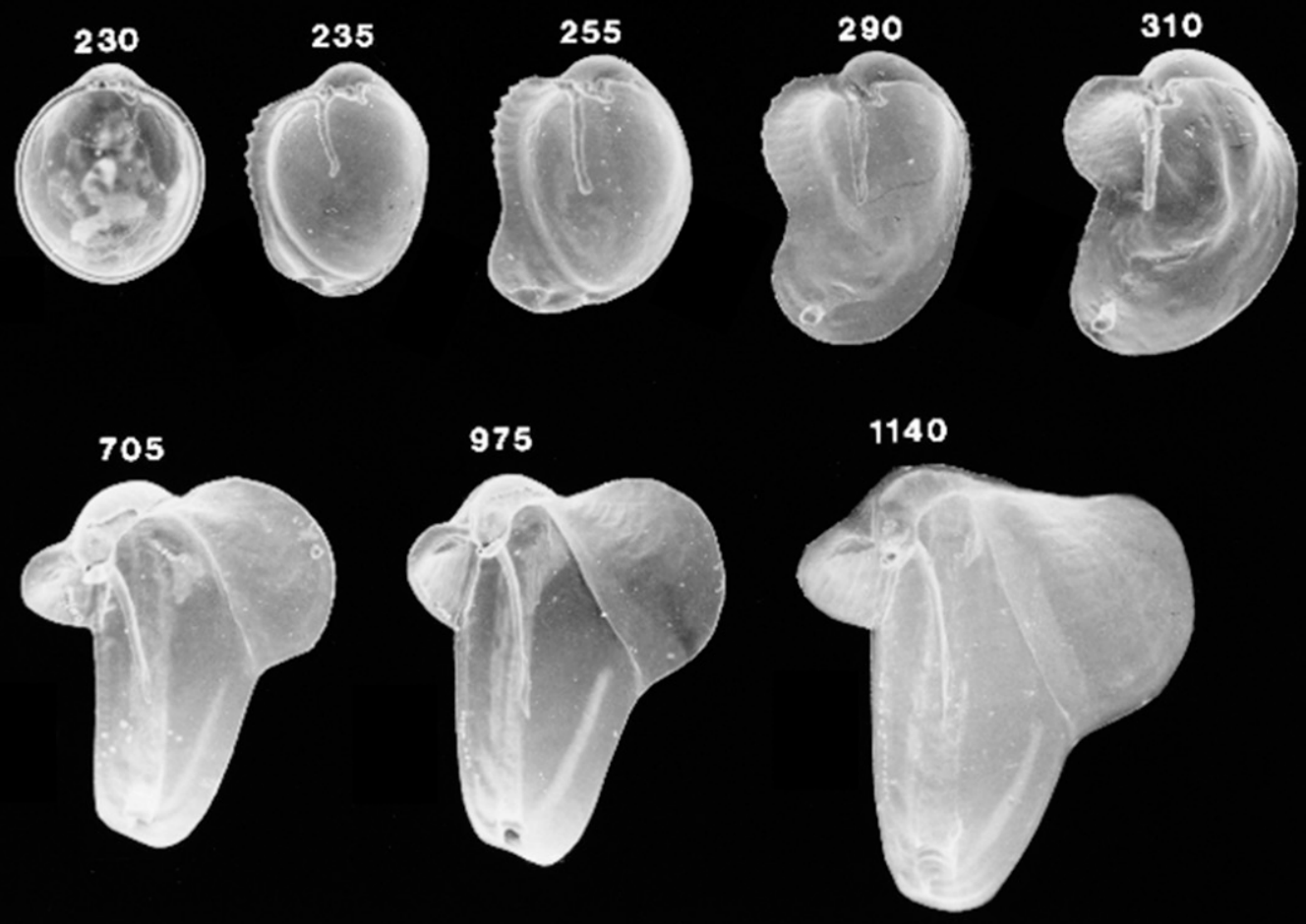

Figure 71. Scanning electron micrographs of disarticulated shell valves of Bankia gouldi postlarvae. Numbers indicate shell height (the greatest dorsoventral dimension) in micrometers. Modified from Tan et al. (1993). 


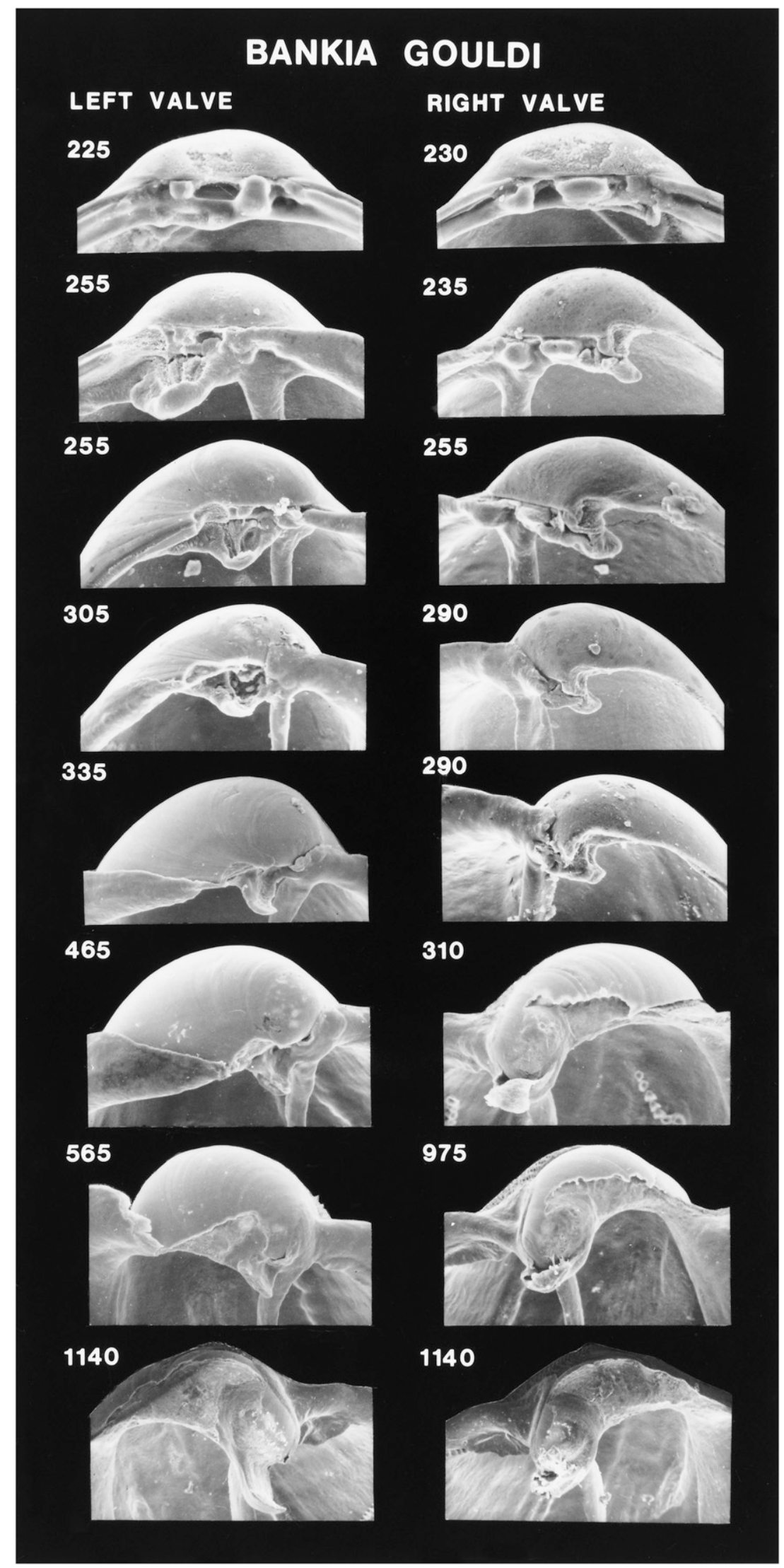

Figure 72. Scanning electron micrographs of the hinge of disarticulated shell valves of Bankia gouldi postlarvae seen in Figure 71. Numbers indicate shell height (the greatest dorsoventral dimension) in micrometers. Modified from Tan et al. (1993). 


\section{TEREDO NAVALIS}

\section{LEFT VALVE}
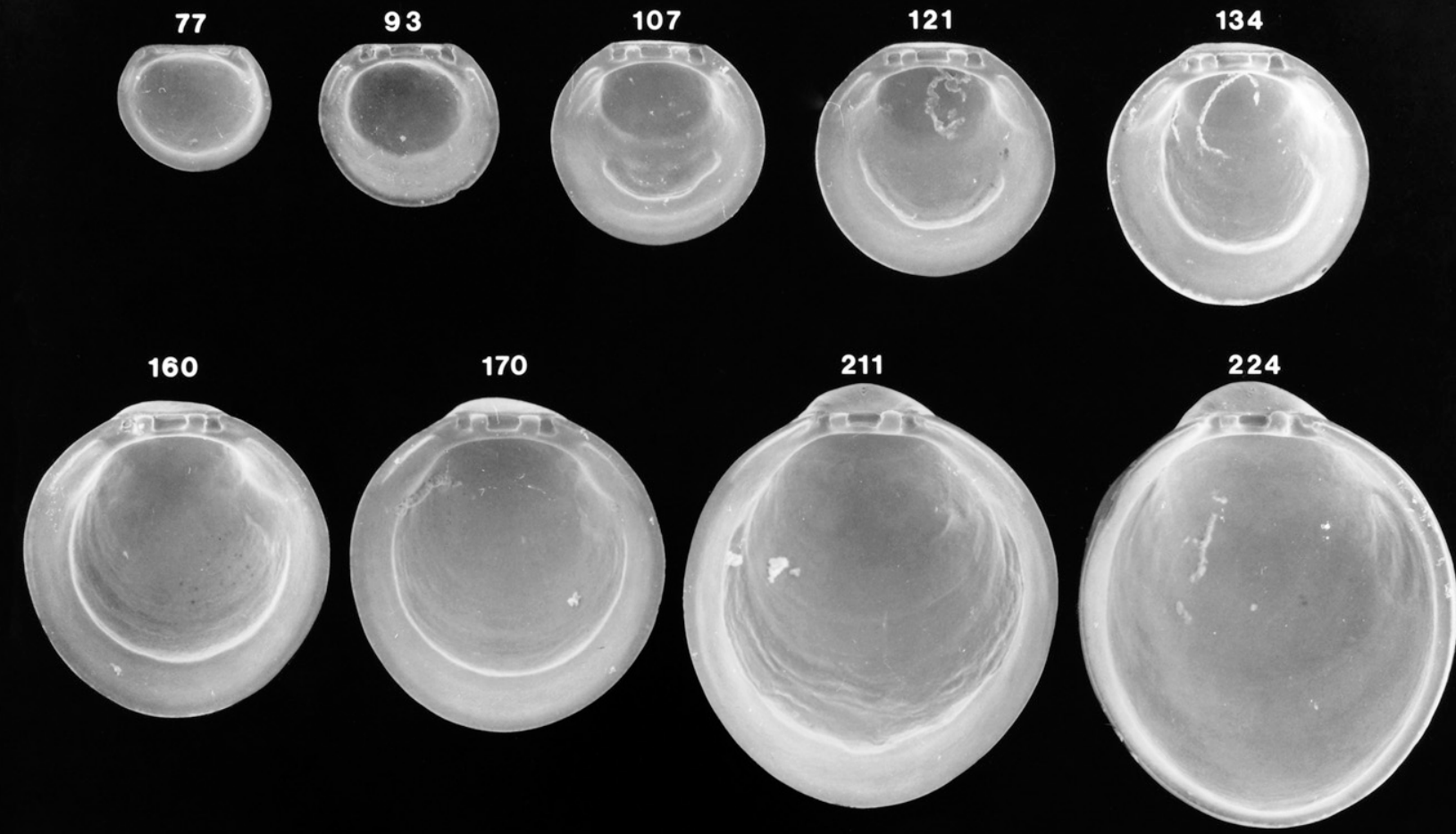

\section{RIGHT VALVE}

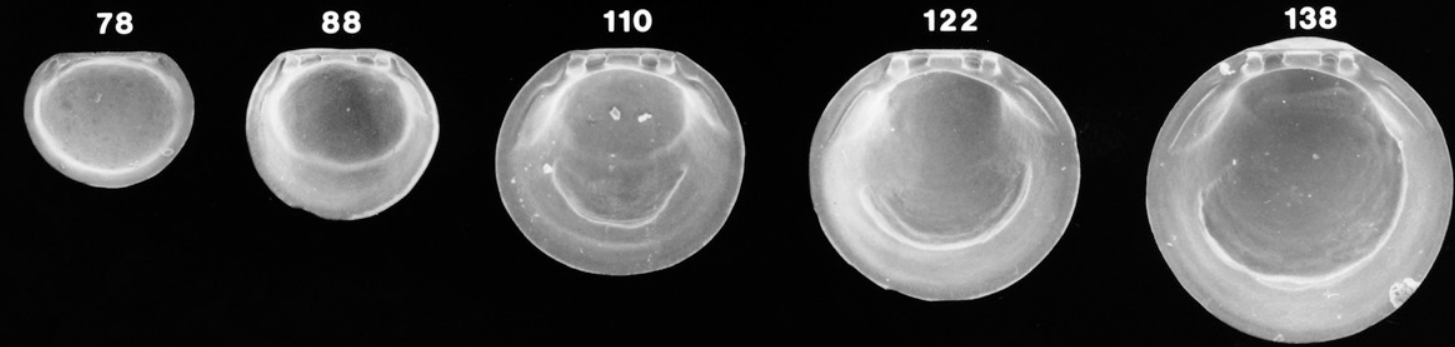

\section{9}

171

190

228

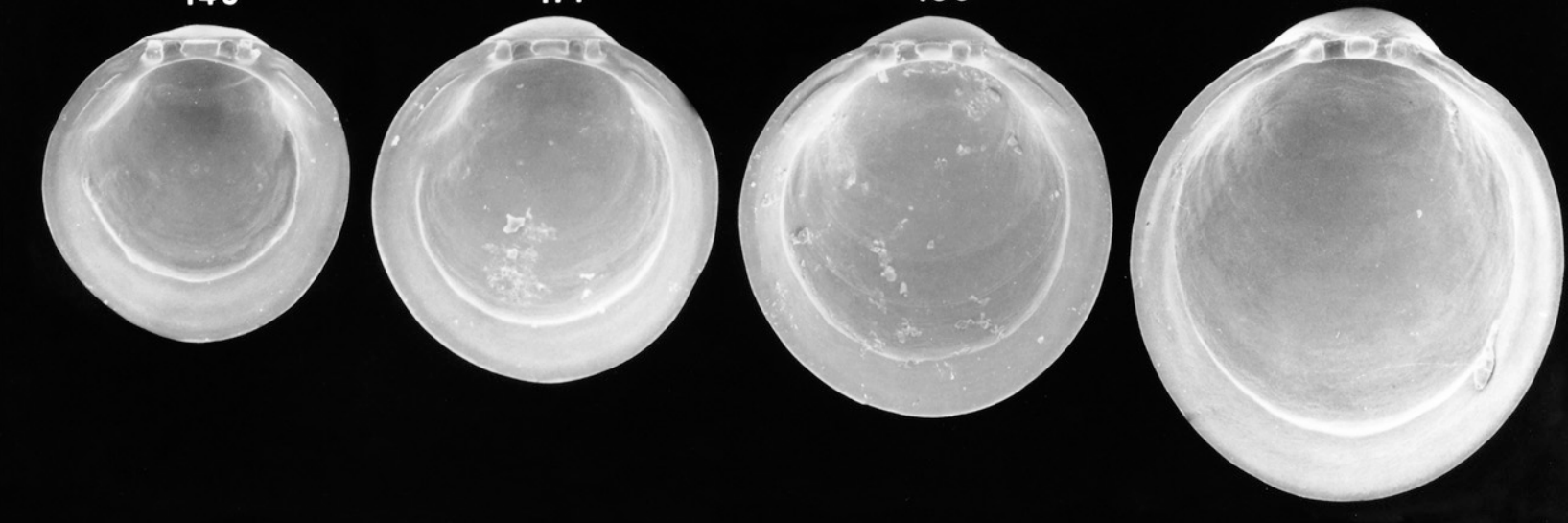

Figure 73. Scanning electron micrographs of disarticulated shell valves of Teredo navalis larvae. Numbers indicate the maximum linear shell dimension in micrometers. Modified from Fuller et al. (1989a). 


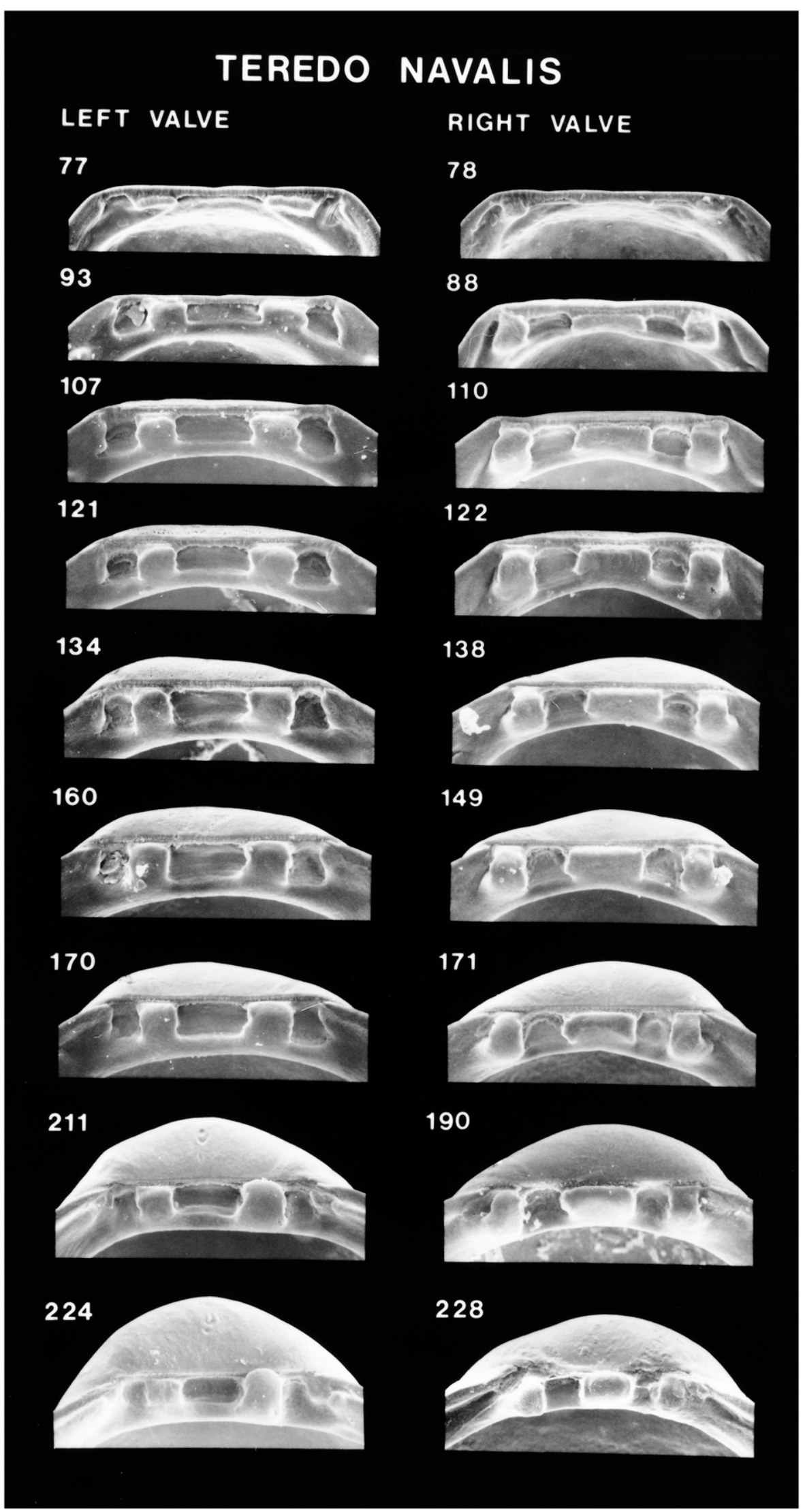

Figure 74. Scanning electron micrographs of the hinge of disarticulated shell valves of Teredo navalis larvae seen in Figure 73 . Numbers indicate the maximum linear shell dimension in micrometers. Modified from Fuller et al. (1989a). 


\section{TEREDO NAVALIS}

\section{LEFT VALVE}
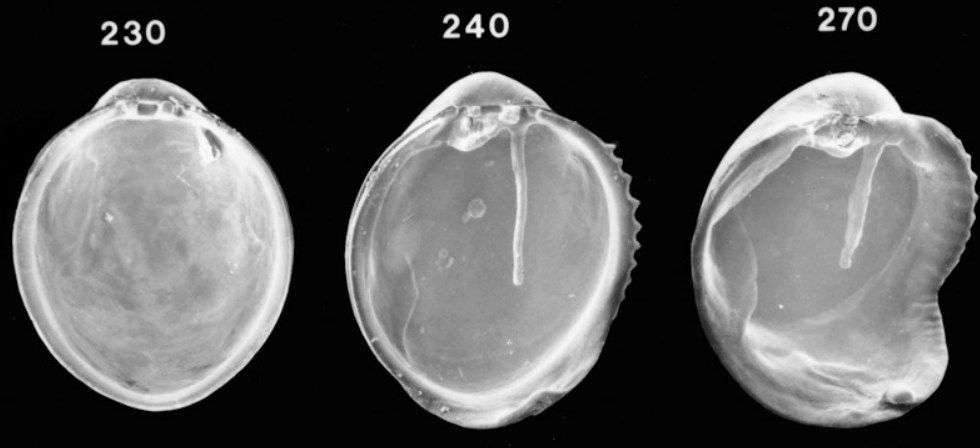

300

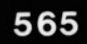

1750
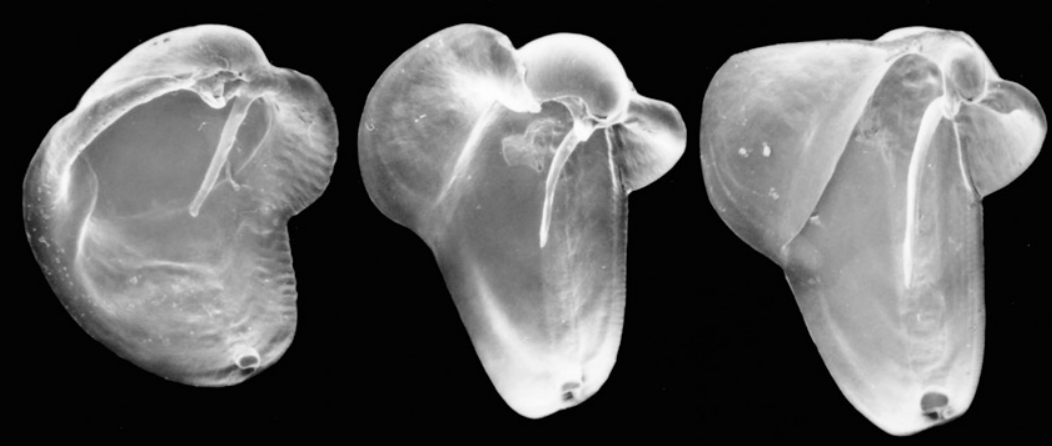

RIGHT VALVE
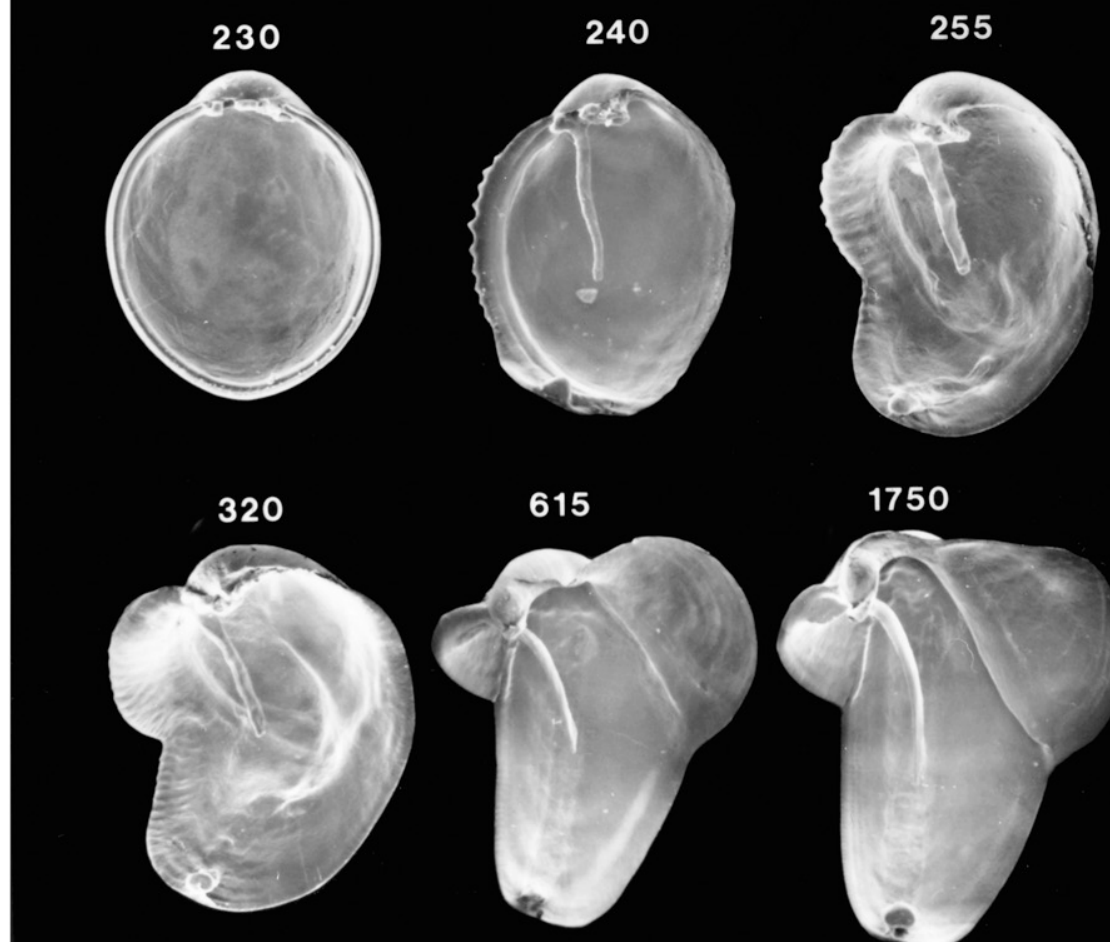

1750

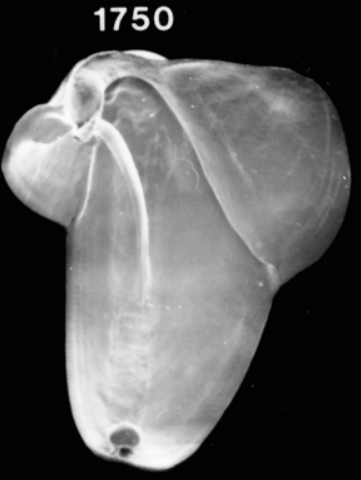

Figure 75. Scanning electron micrographs of disarticulated shell valves of Teredo navalis postlarvae. Numbers indicate shell height (the greatest dorsoventral dimension) in micrometers. Modified from Fuller et al. (1989a). 


\section{TEREDO NAVALIS}

\section{LEFT VALVE}
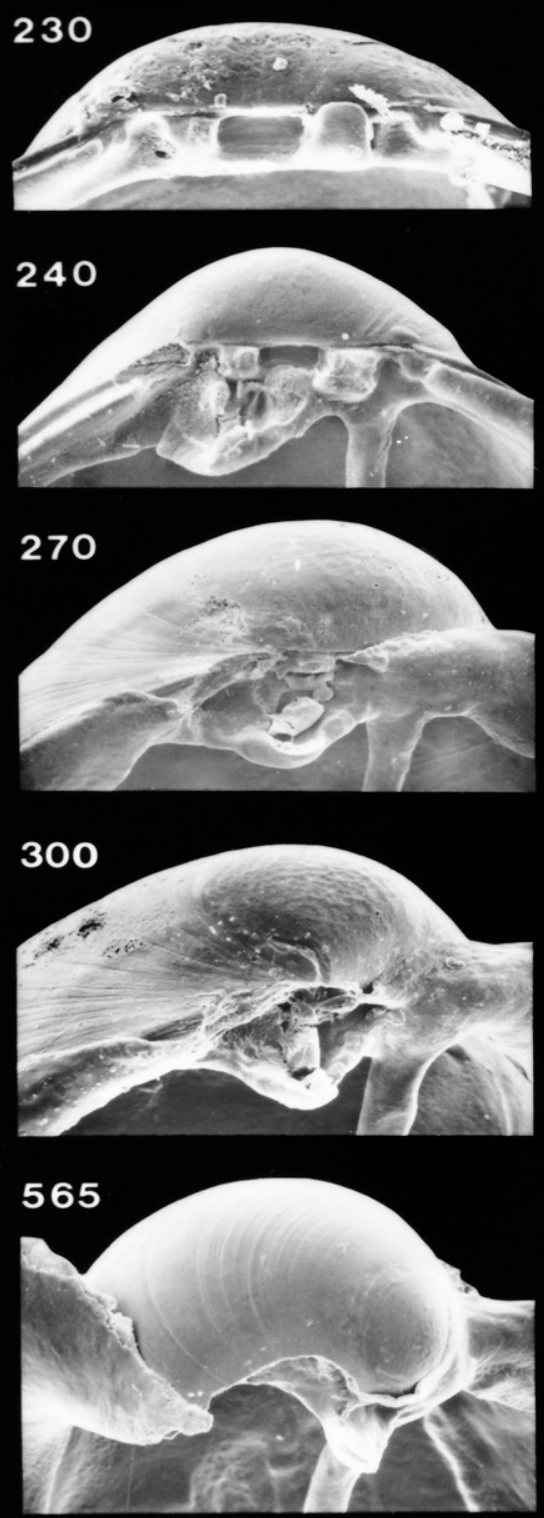

1750

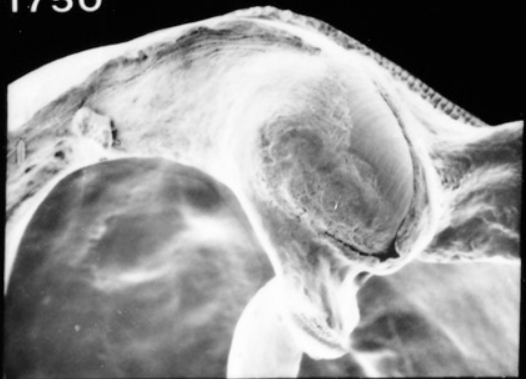

\section{RIGHT VALVE}
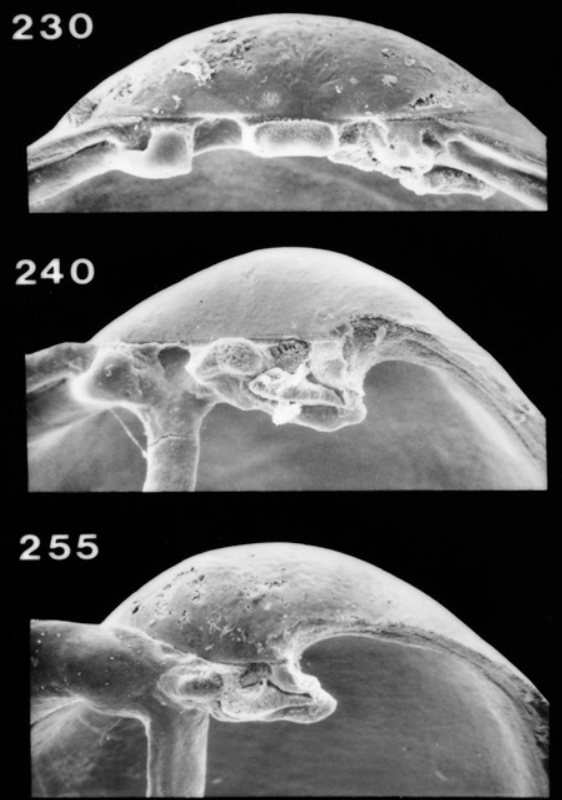

320
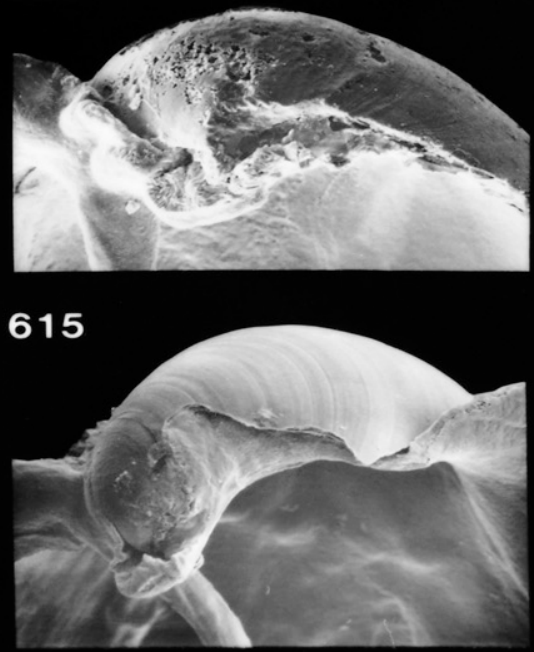

1750

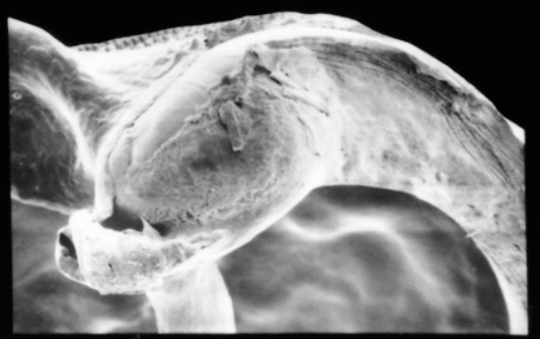




\section{ARCUATULA PAPYRIA}

\section{LEFT VALVE}

92

123

153

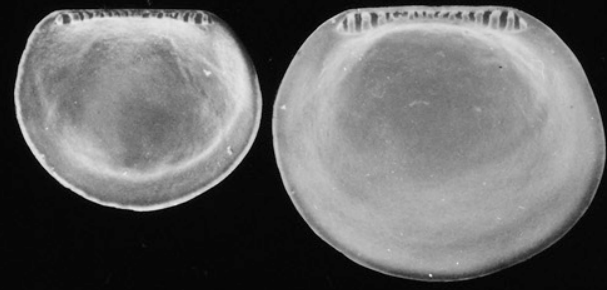

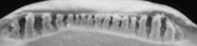

165

189

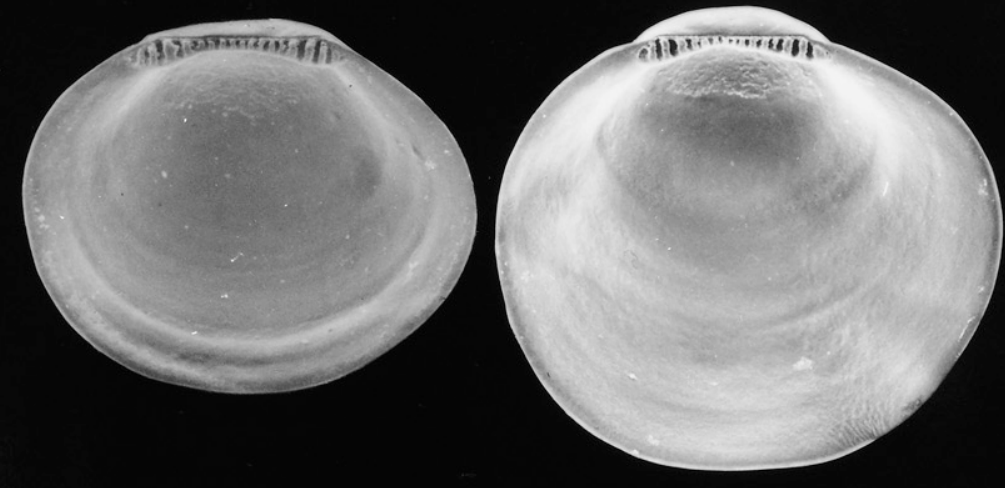

\section{RIGHT VALVE}
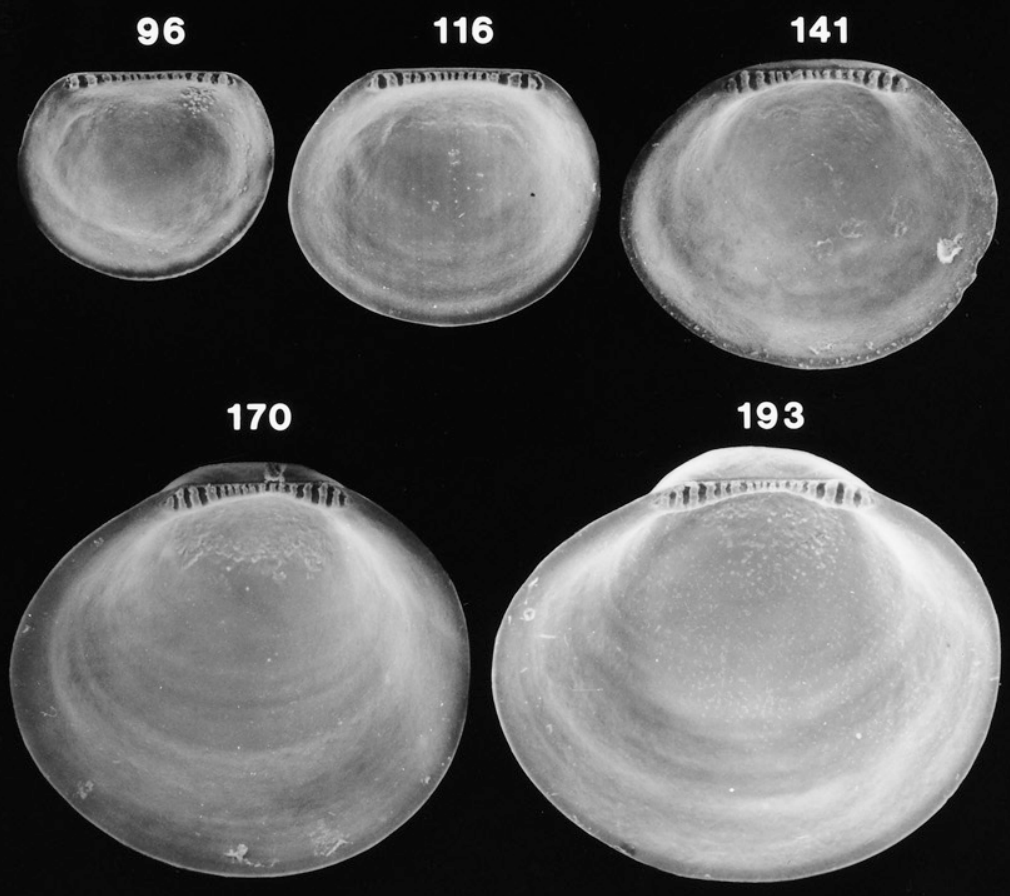

Figure 77. Scanning electron micrographs of disarticulated shell valves of Arcuatula papyria larvae. Numbers indicate the maximum linear shell dimension in micrometers. 


\section{ARCUATULA PAPYRIA}

\section{LEFT VALVE}

92

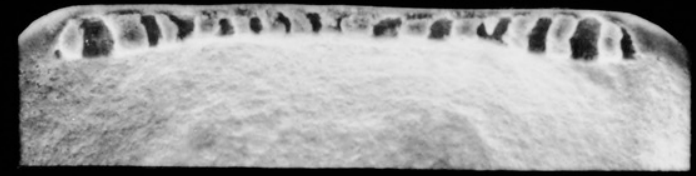

123

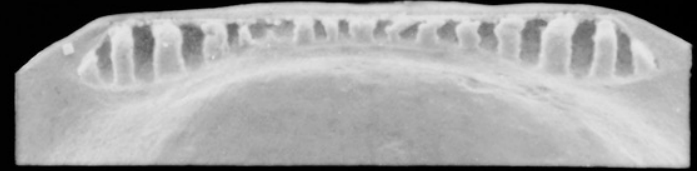

153

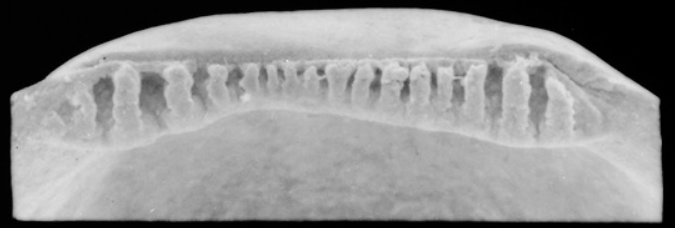

165

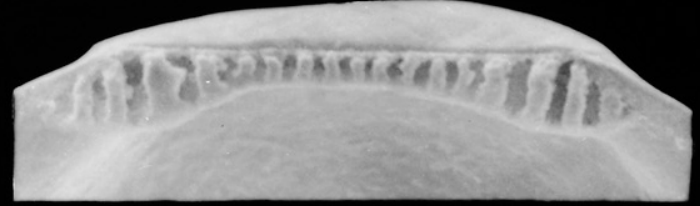

189

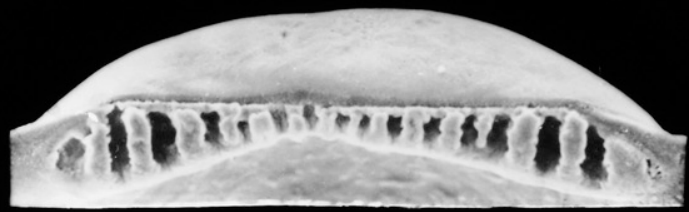

\section{RIGHT VALVE}

96

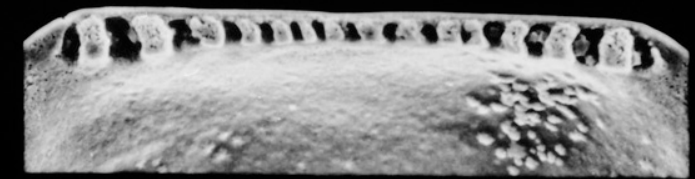

116

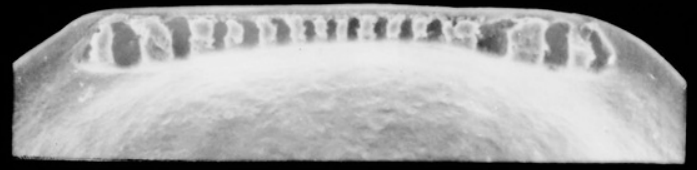

141

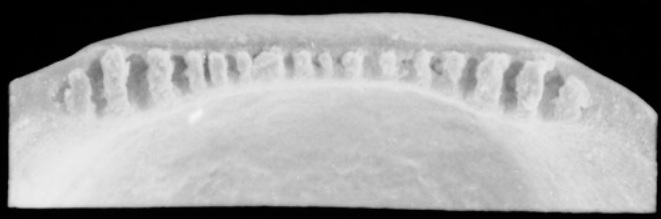

170

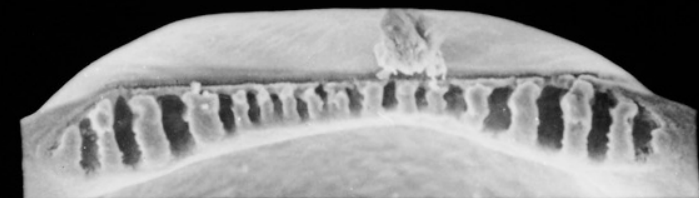

193

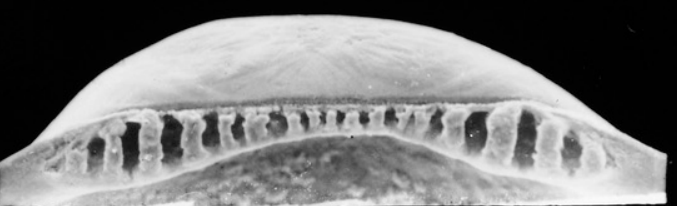

Figure 78. Scanning electron micrographs of the hinge of disarticulated shell valves of Arcuatula papyri larvae seen in Figure 77. Numbers indicate the maximum linear shell dimension in micrometers. 


\section{ARCUATULA PAPYRIA}

\section{LEFT VALVE}

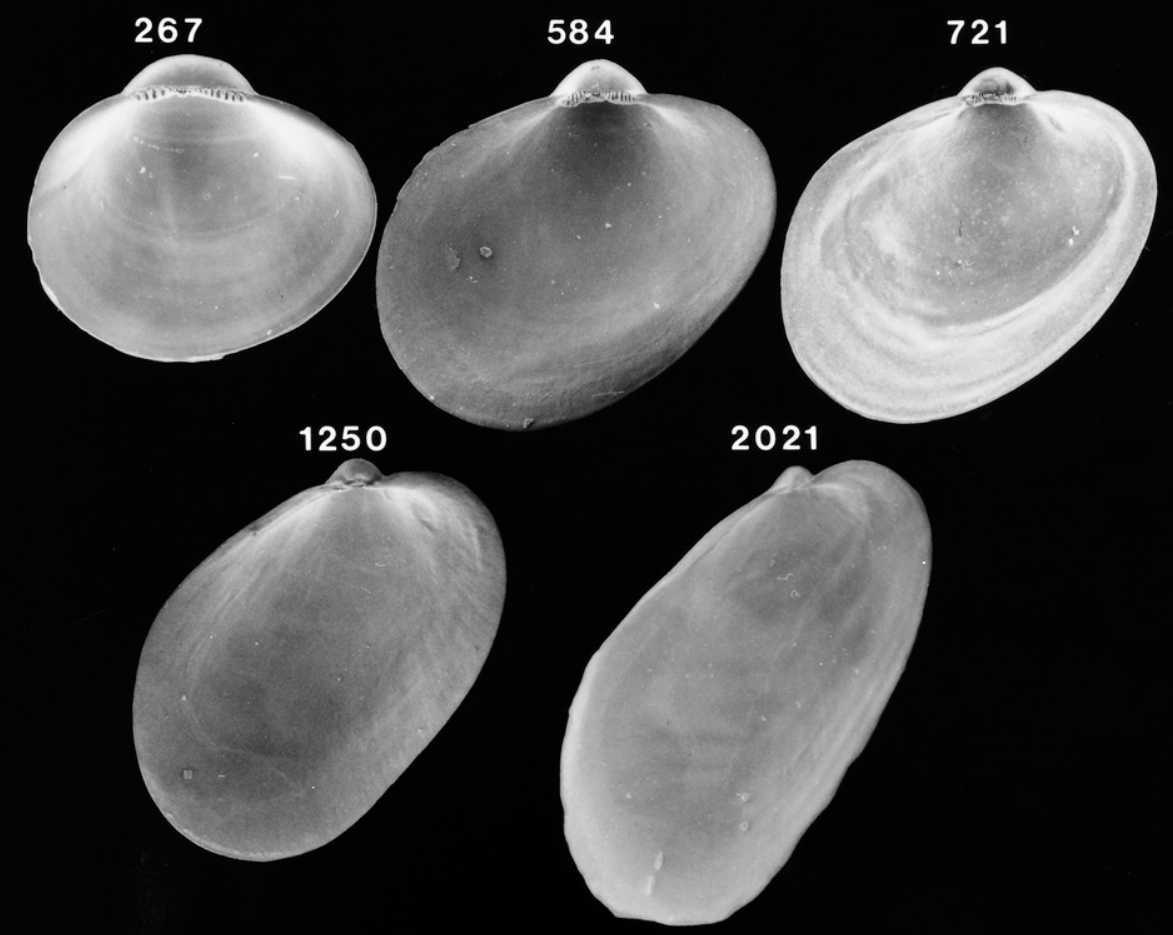

RIGHT VALVE

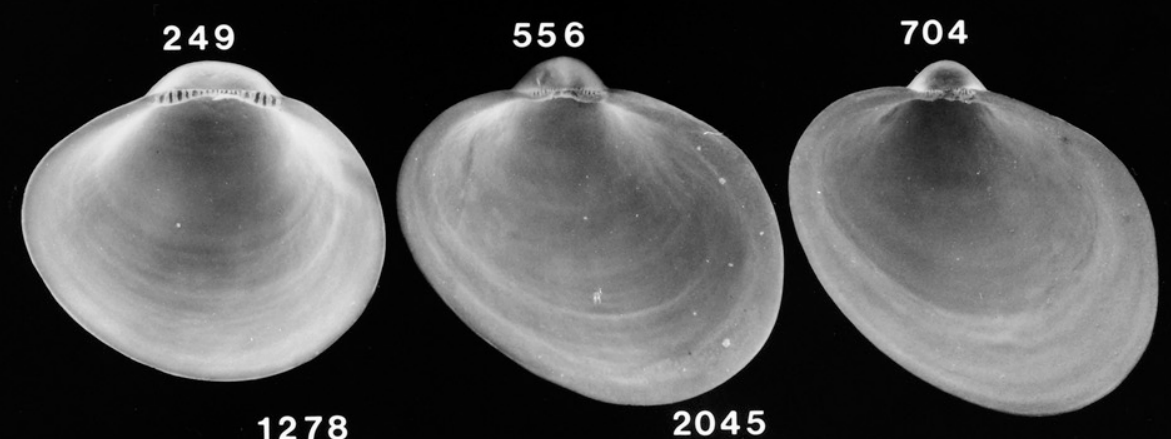

1278

2045
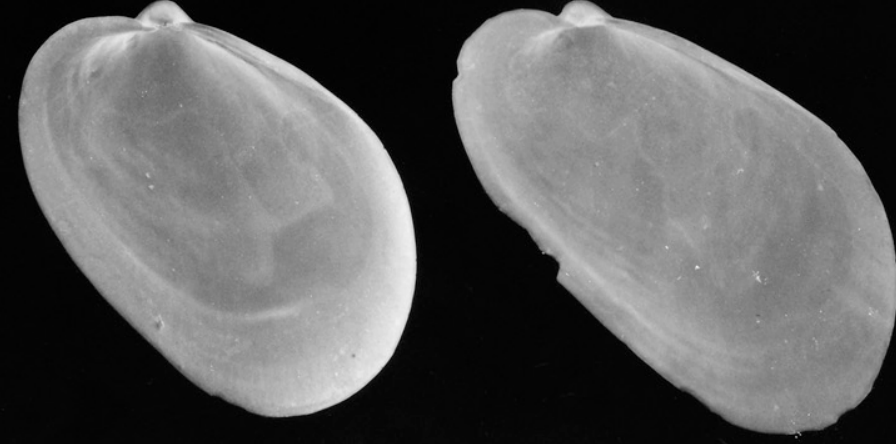

Figure 79. Scanning electron micrographs of disarticulated shell valves of Arcuatula papyri postlarvae. Numbers indicate the maximum linear shel dimension in micrometers. 


\section{ARCUATULA PAPYRIA}

\section{LEFT VALVE}

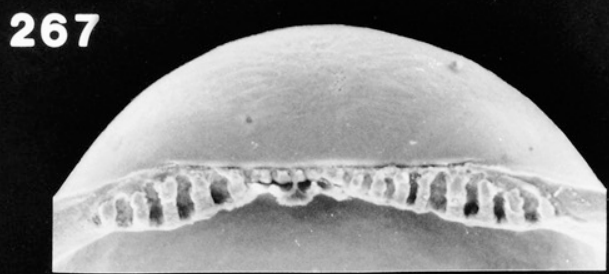

584

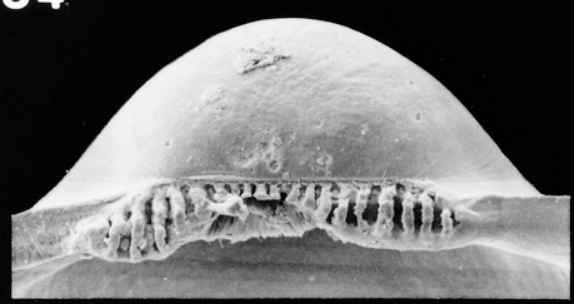

721

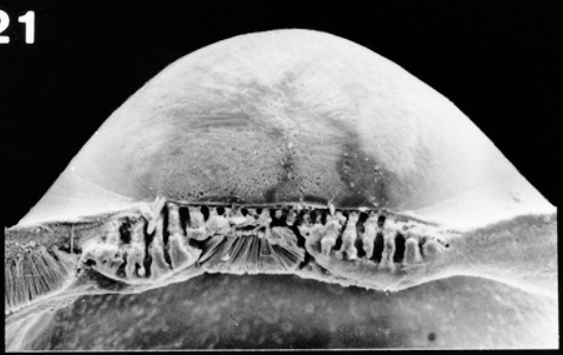

1250

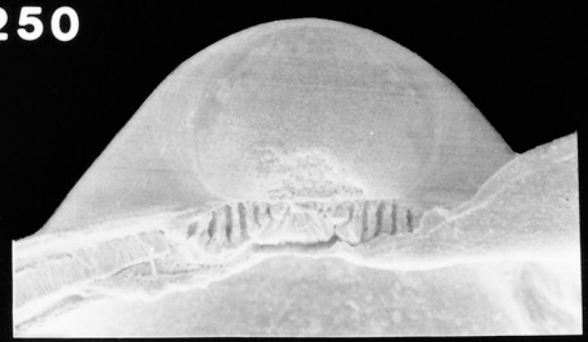

2021

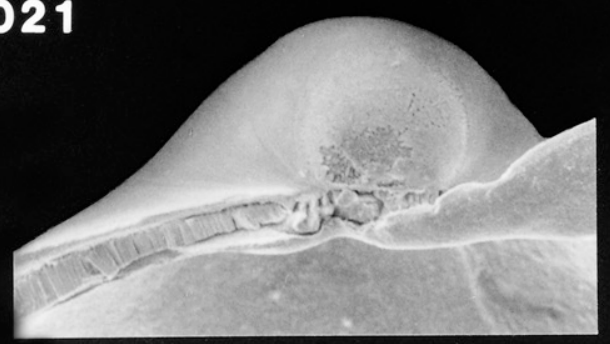

\section{RIGHT VALVE}

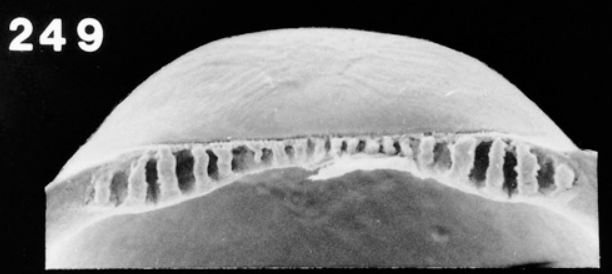

556

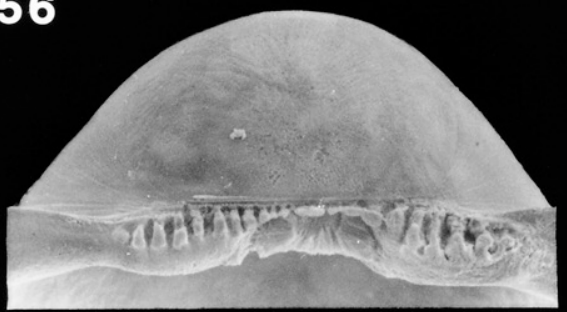

704

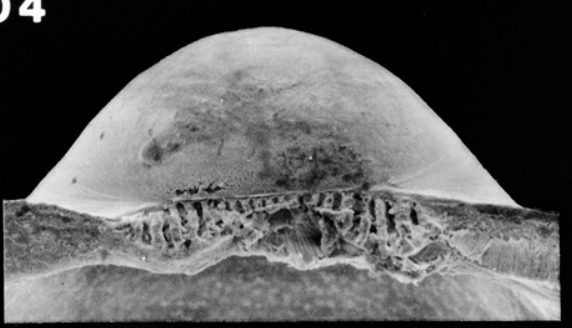

1278

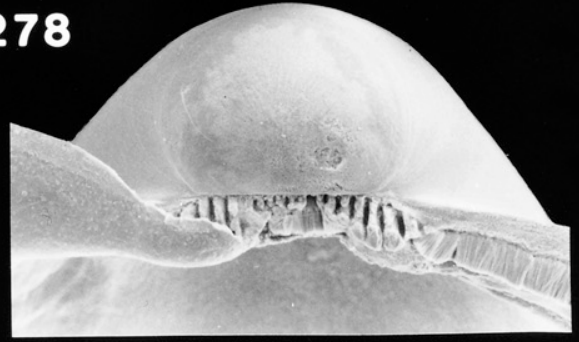

2045

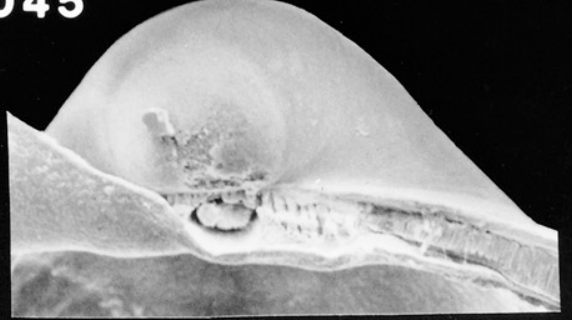

Figure 80. Scanning electron micrographs of the hinge of disarticulated shell valves of Arcuatula papyri postlarvae seen in Figure 79. Numbers indicate the maximum linear shell dimension in micrometers. 


\section{BRACHIDONTES EXUSTUS}

\section{LEFT VALVE}

103

123

142

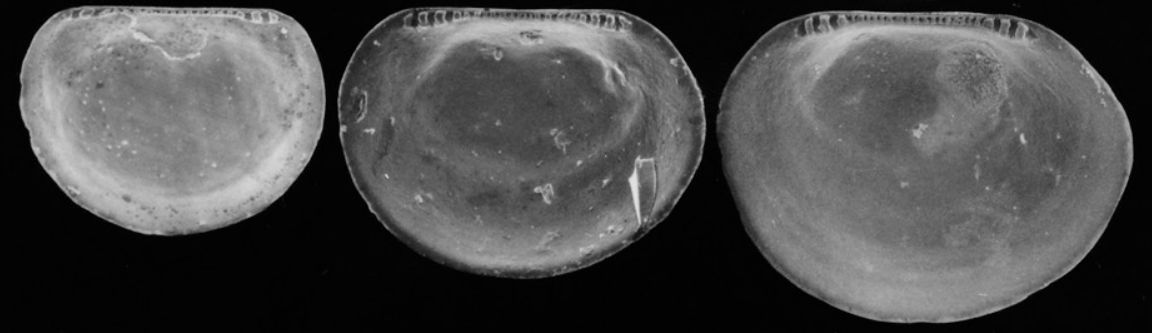

165

177

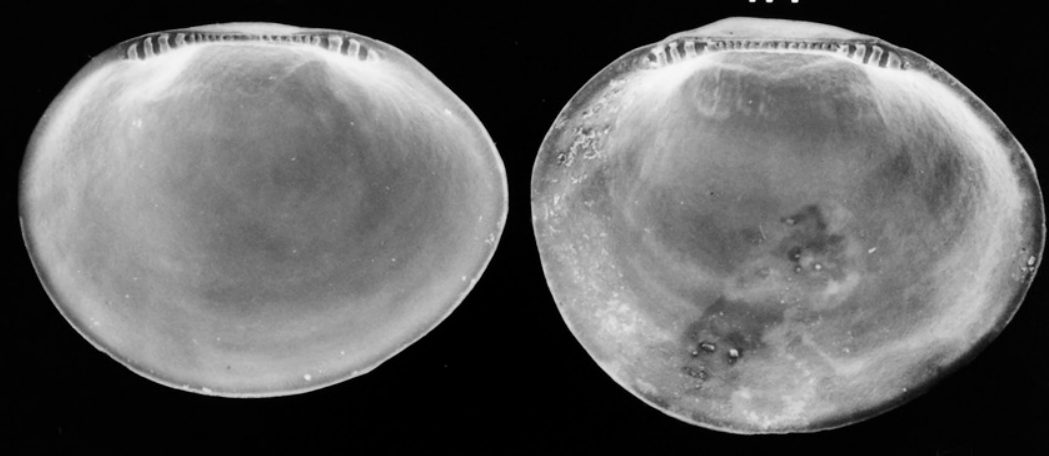

RIGHT VALVE

102

119

134

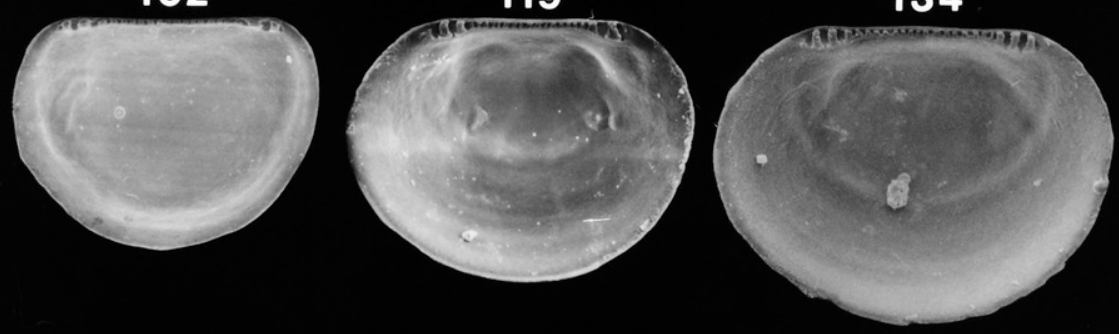

164

183
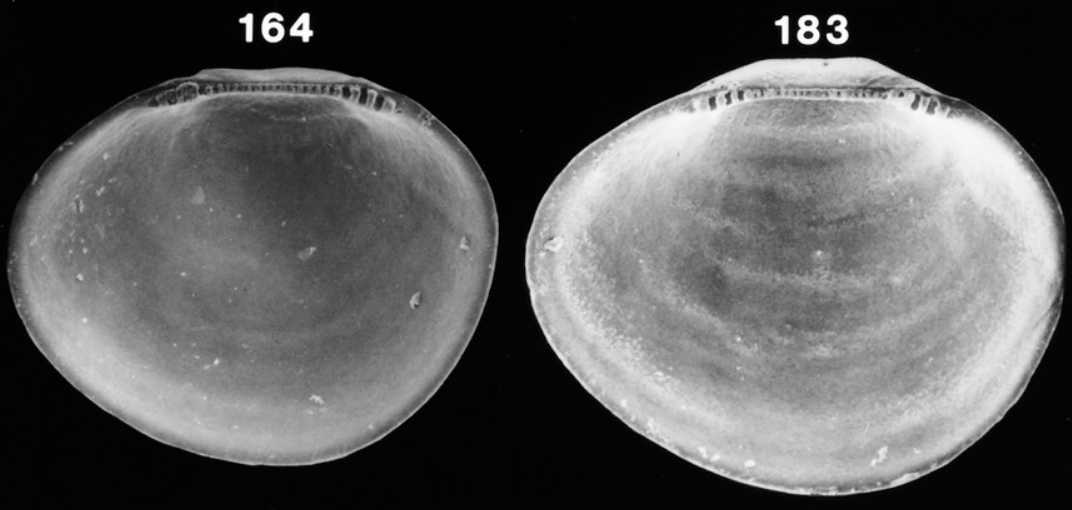

Figure 81. Scanning electron micrographs of disarticulated shell valves of Brachidontes exustus larvae. Numbers indicate the maximum linear shell dimension in micrometers. Modified from Fuller and Lutz (1989). 


\section{BRACHIDONTES EXUSTUS}

\section{LEFT VALVE}

\section{3}

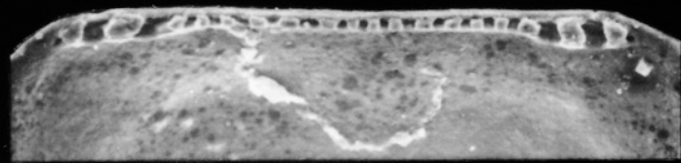

123

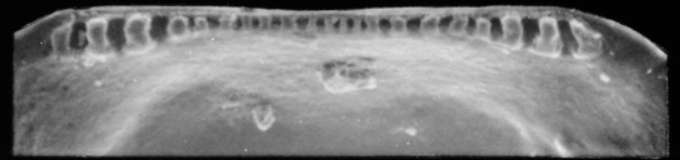

\section{2}

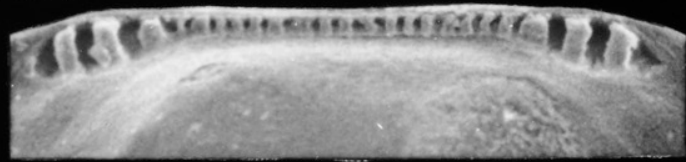

165

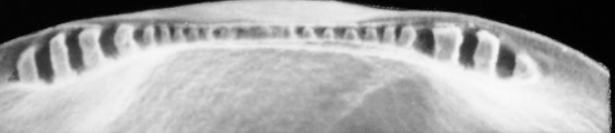

177

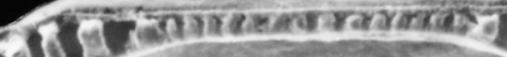

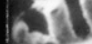

$\operatorname{lon} 20$

\section{RIGHT VALVE}

\section{2}

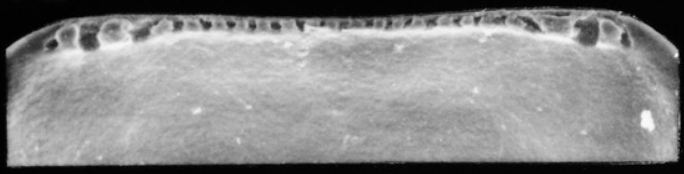

\section{9}

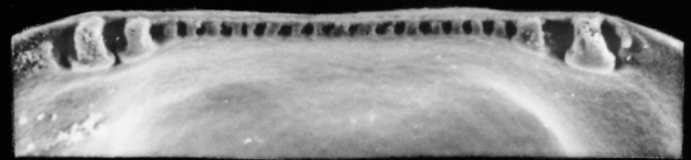

\section{4}

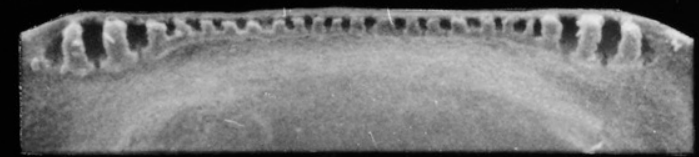

164

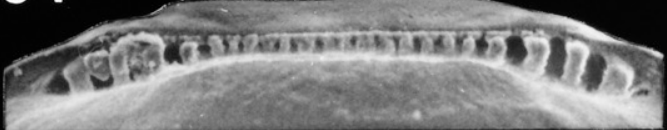

183

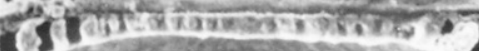

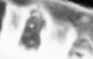

Figure 82. Scanning electron micrographs of the hinge of disarticulated shell valves of Brachidontes exustus larvae seen in Figure 81. Numbers indicate the maximum linear shell dimension in micrometers. Modified from Fuller and Lutz (1989). 


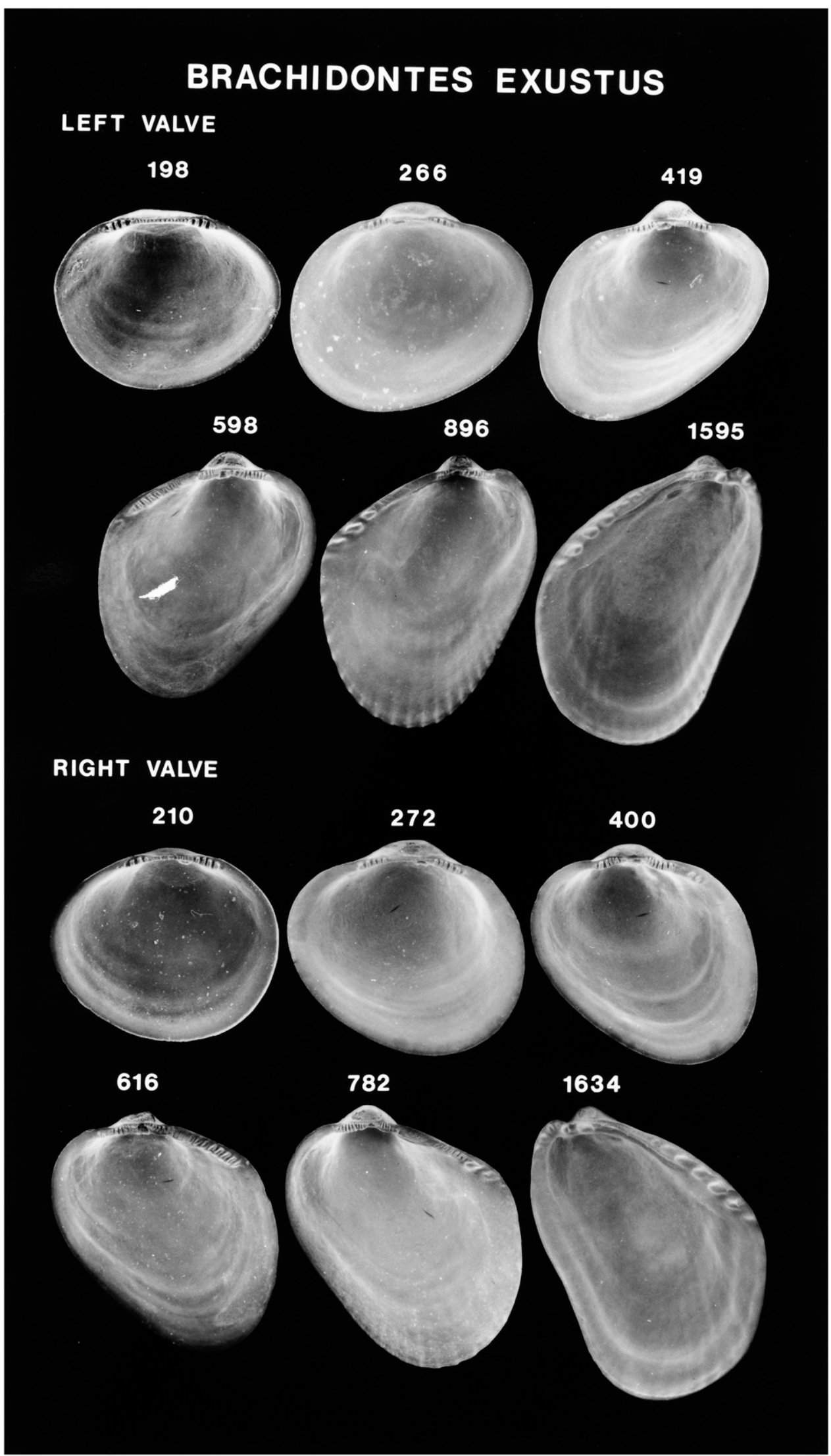

Figure 83. Scanning electron micrographs of disarticulated shell valves of Brachidontes exustus postlarvae. Numbers indicate the maximum linear shell dimension in micrometers. Modified from Fuller and Lutz (1989). 


\section{BRACHIDONTES EXUSTUS}

\section{LEFT VALVE}

198

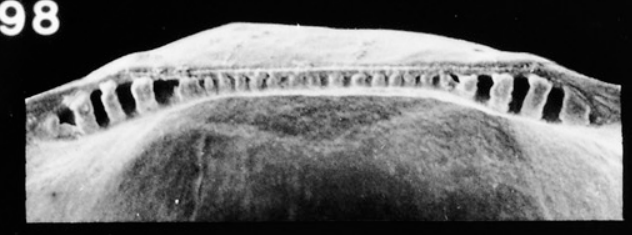

266

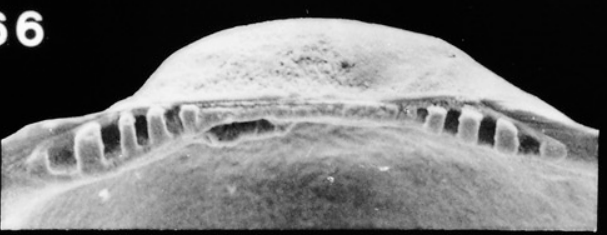

419

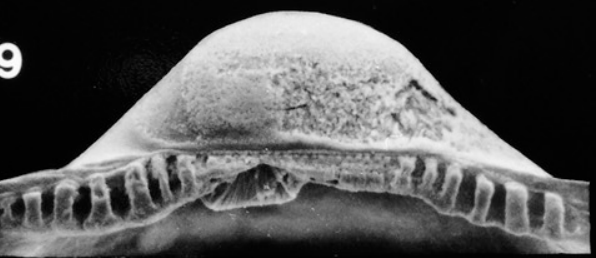

598

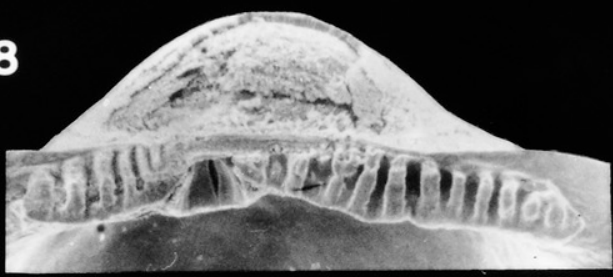

896

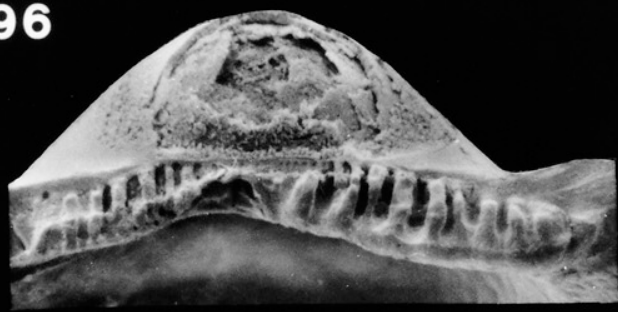

1595

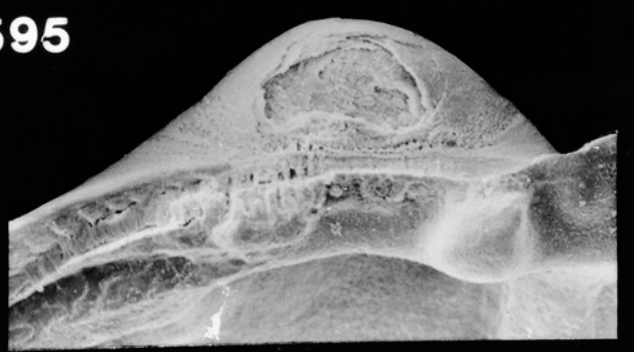

\section{RIGHT VALVE}

\section{0}

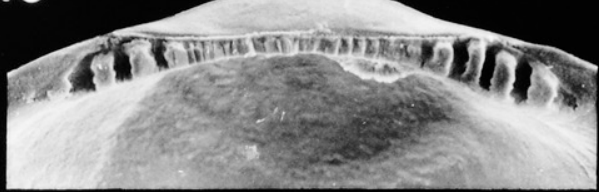

272

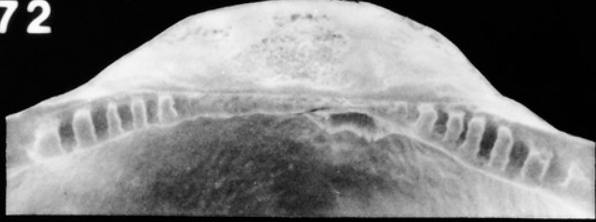

400

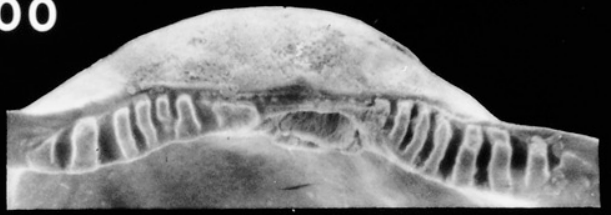

616

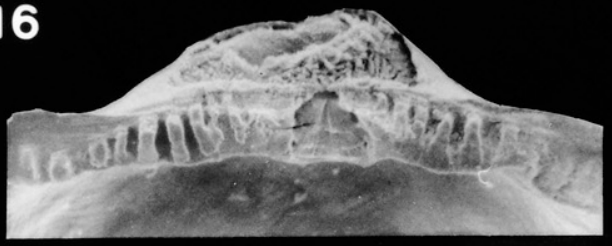

782

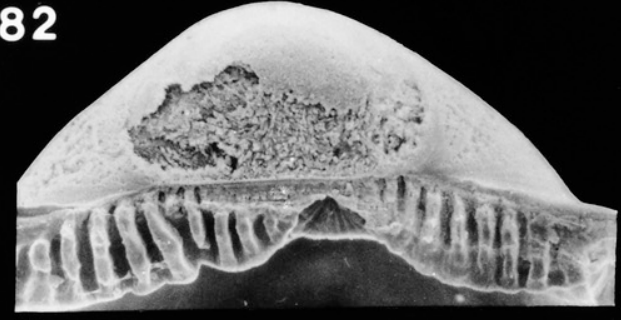

1634

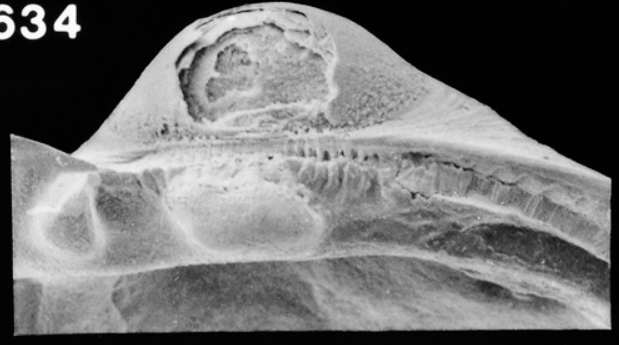

Figure 84. Scanning electron micrographs of the hinge of disarticulated shell valves of Brachidontes exustus postlarvae seen in Figure 83. Numbers indicate the maximum linear shell dimension in micrometers. Modified from Fuller and Lutz (1989). 


\section{GEUKENSIA DEMISSA}

\section{LEFT VALVE}

107

127

135
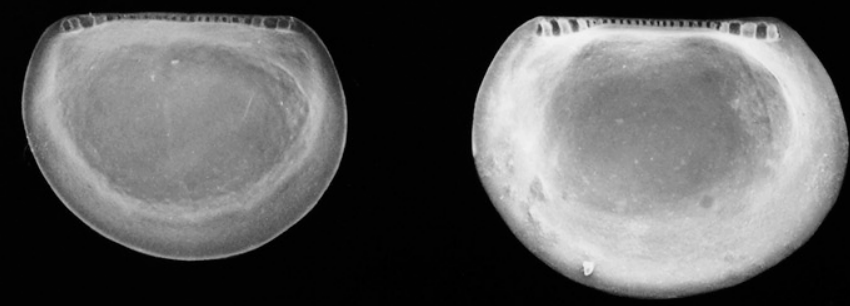

144

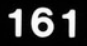

169

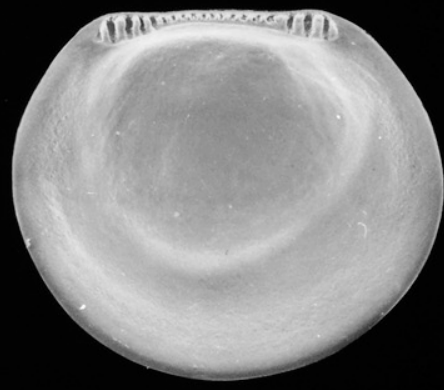

RIGHT VALVE

\section{3}

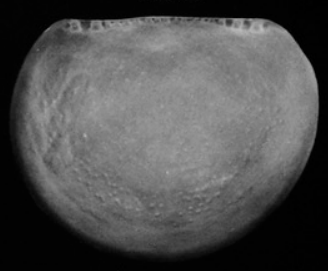

127
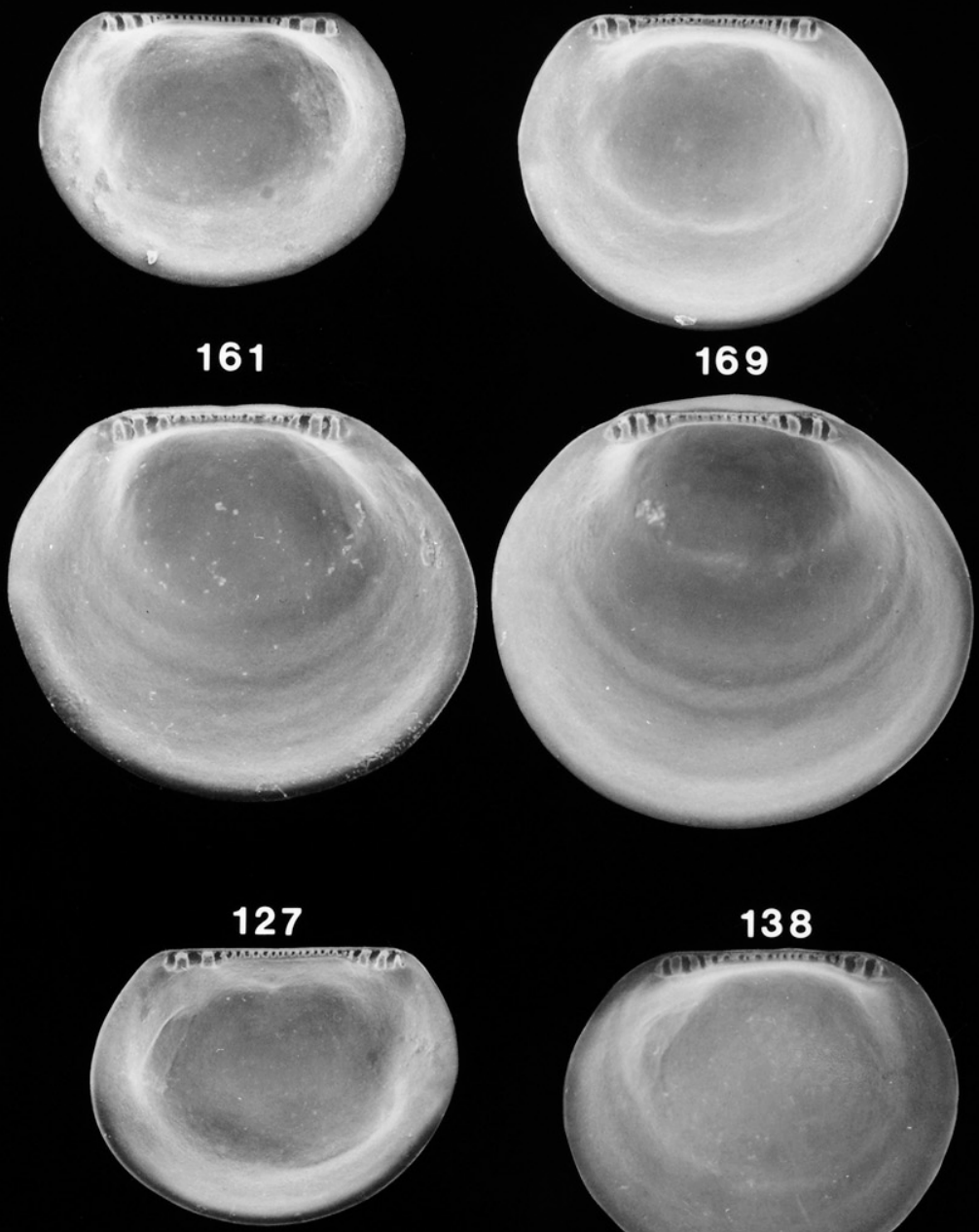

\section{4}

152
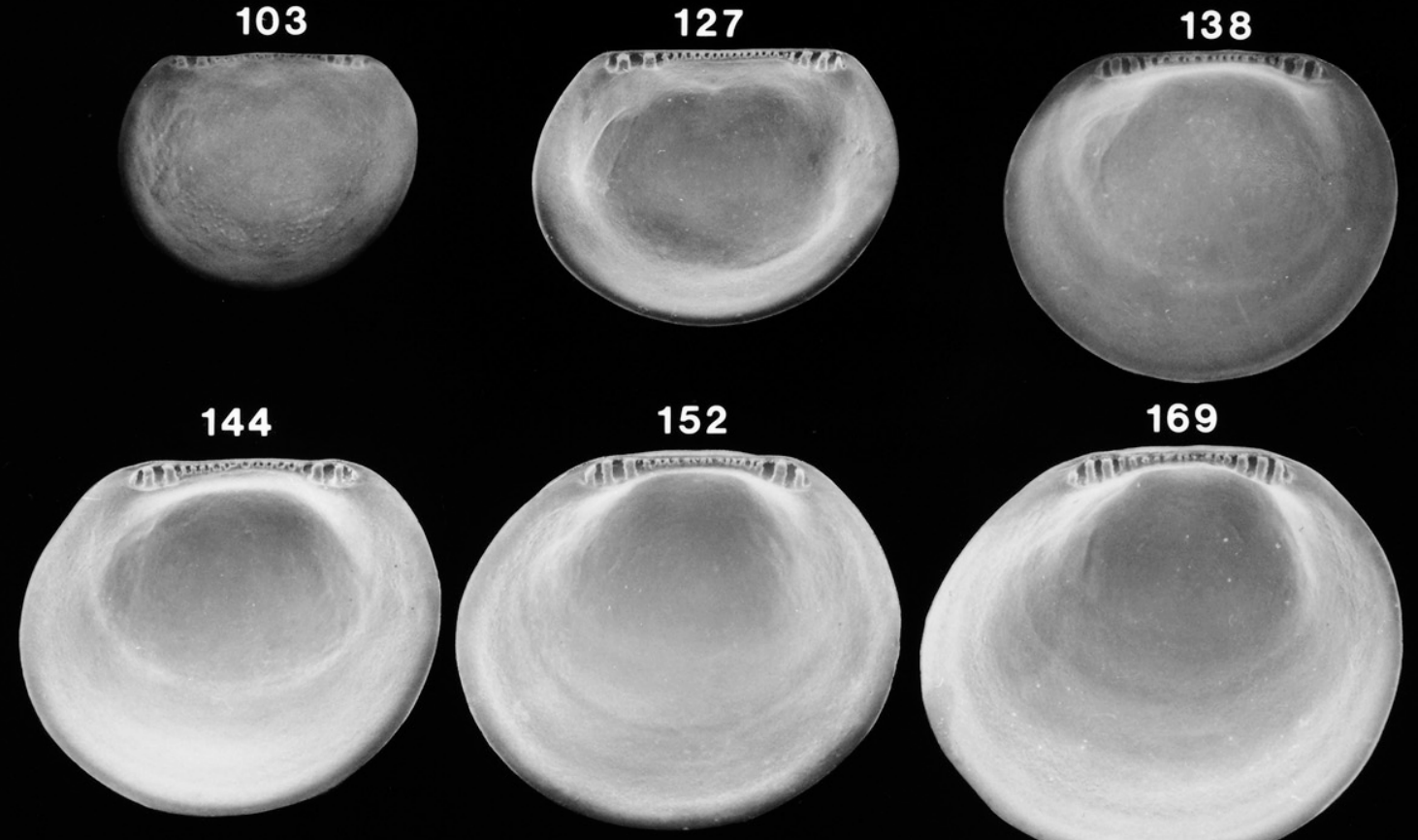

169

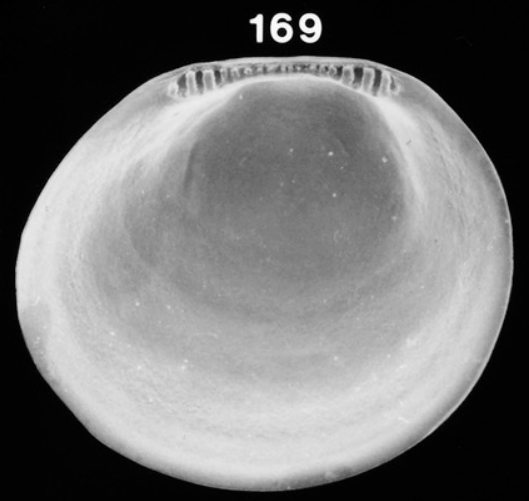

Figure 85. Scanning electron micrographs of disarticulated shell valves of Geukensia demissa larvae. Numbers indicate the maximum linear shell dimension in micrometers. Modified from Fuller and Lutz (1989). 


\section{GEUKENSIA DEMISSA}

\section{LEFT VALVE}

107

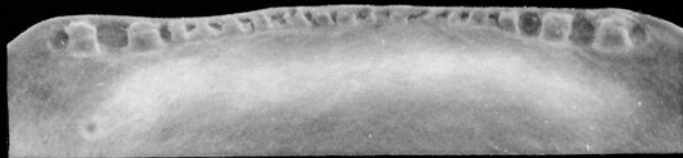

127

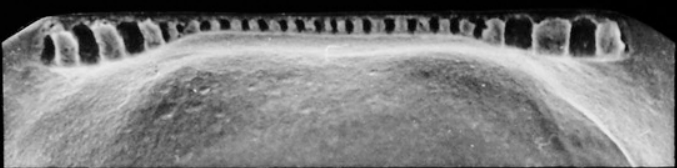

135

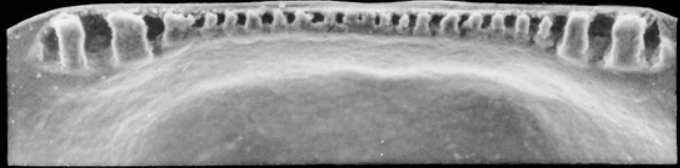

144

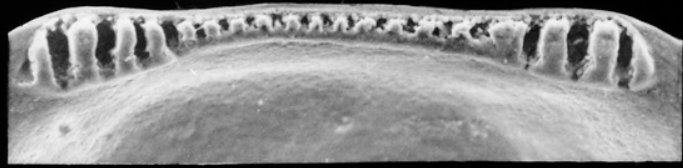

161

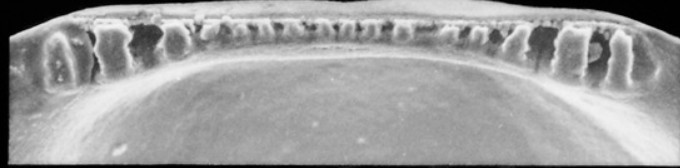

169

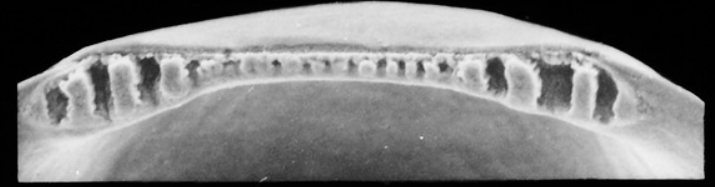

\section{RIGHT VALVE}

\section{3}

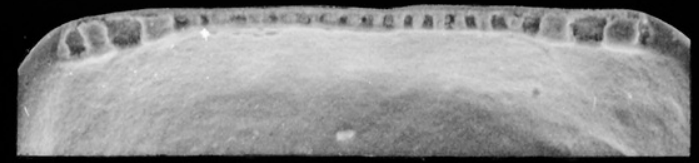

127

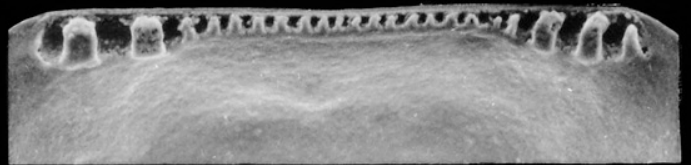

\section{8}

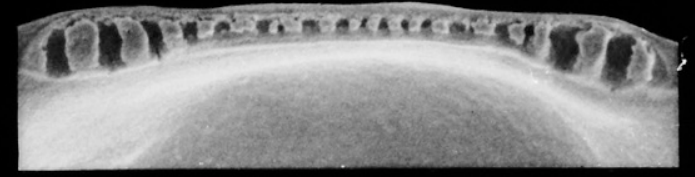

144

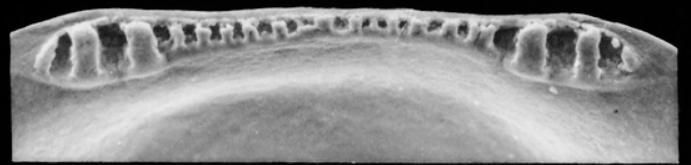

152

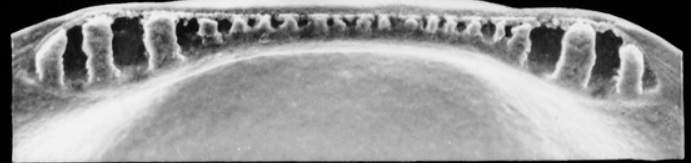

\section{9}

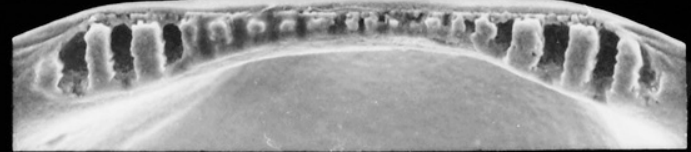




\section{GEUKENSIA DEMISSA}

\section{LEFT VALVE}

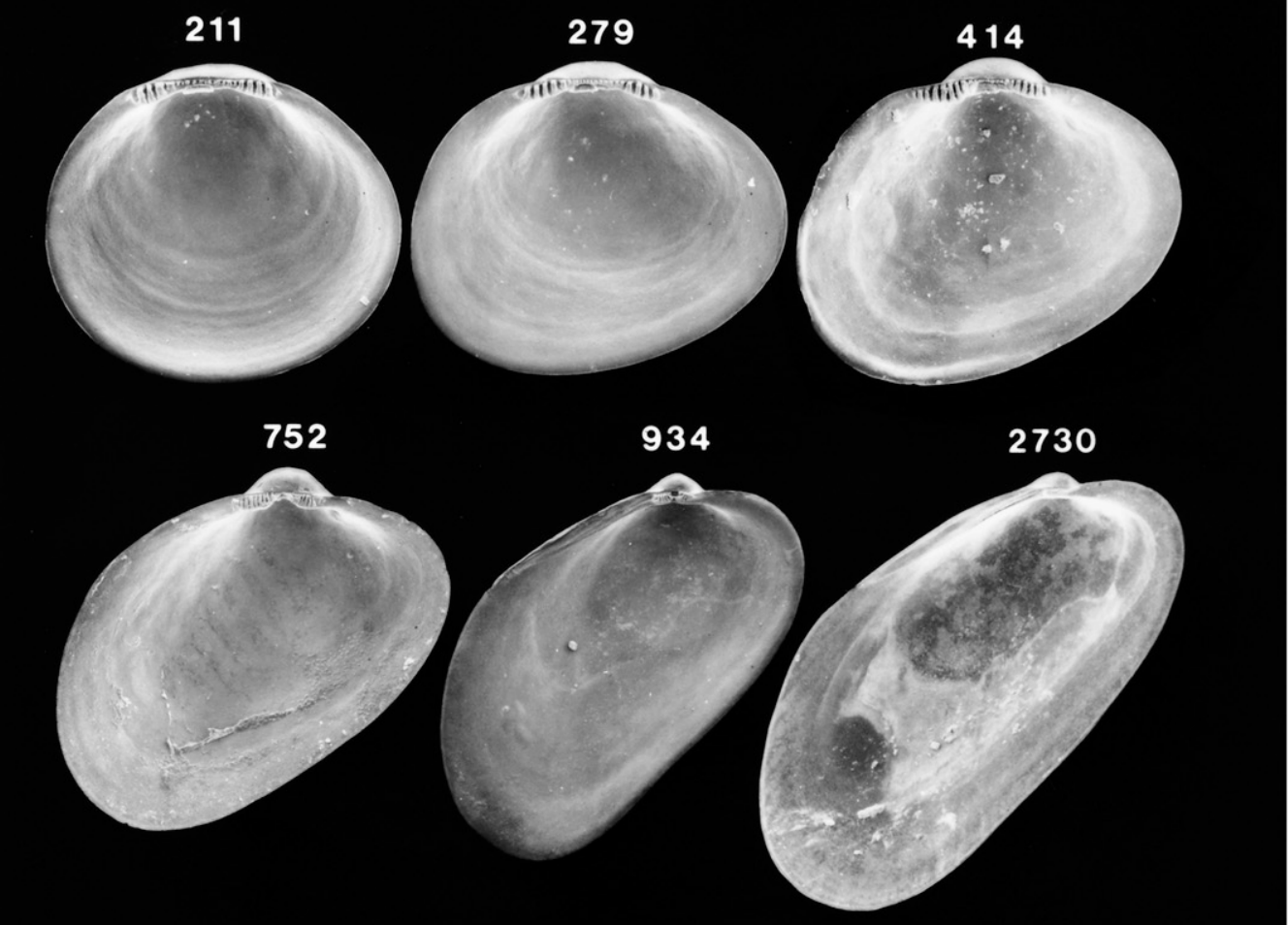

RIGHT VALVE

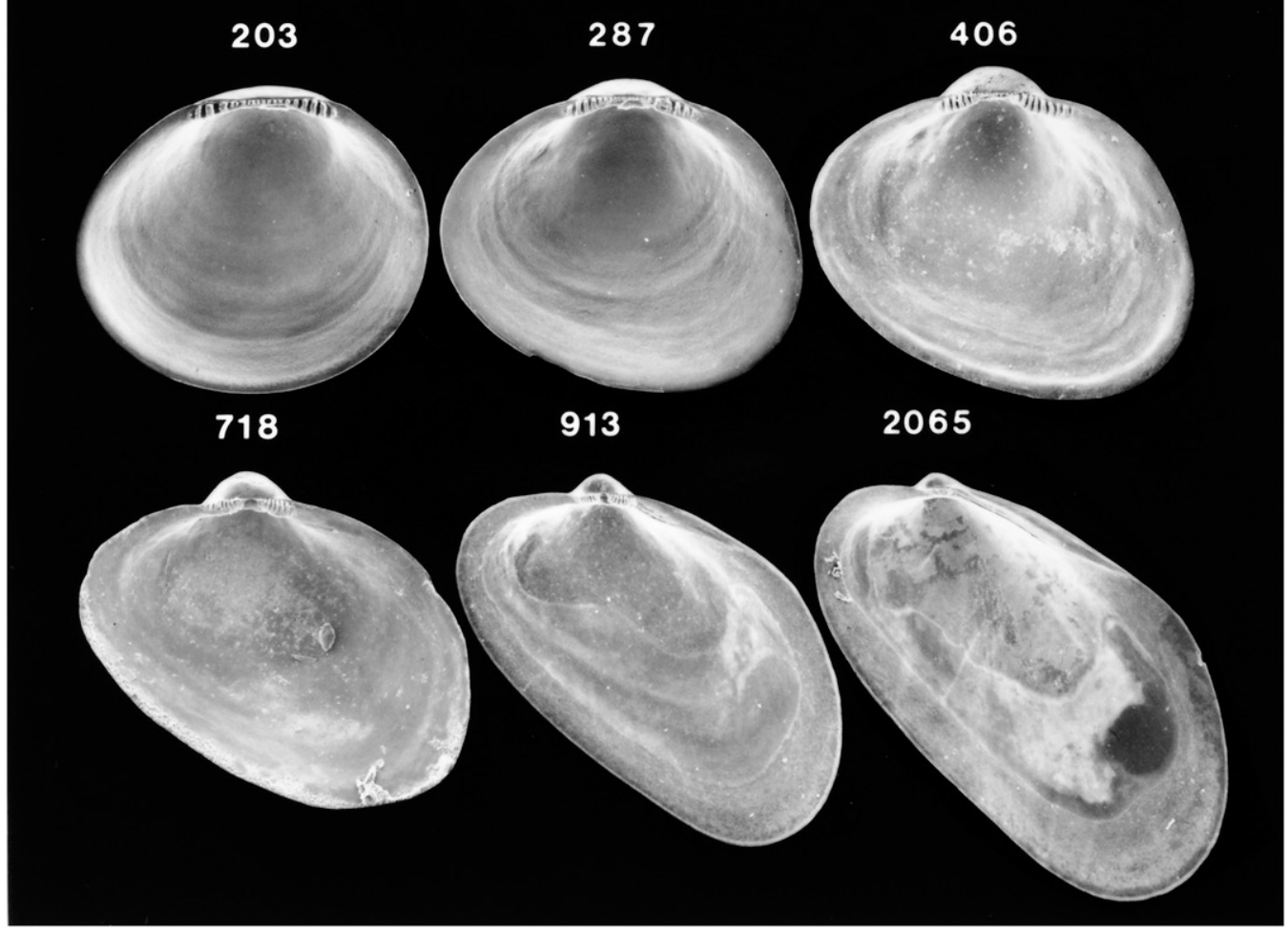

Figure 87. Scanning electron micrographs of disarticulated shell valves of Geukensia demissa postlarvae. Numbers indicate the maximum linear shell dimension in micrometers. Modified from Fuller and Lutz (1989). 


\section{GEUKENSIA DEMISSA}

\section{LEFT VALVE}

\section{1}

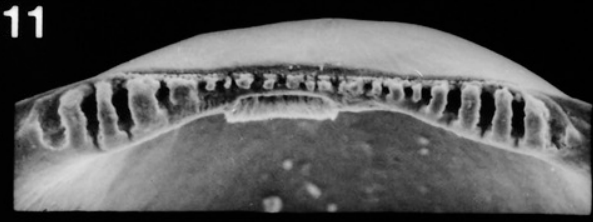

279

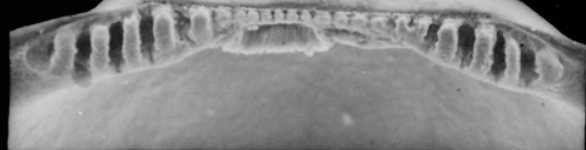

\section{4}
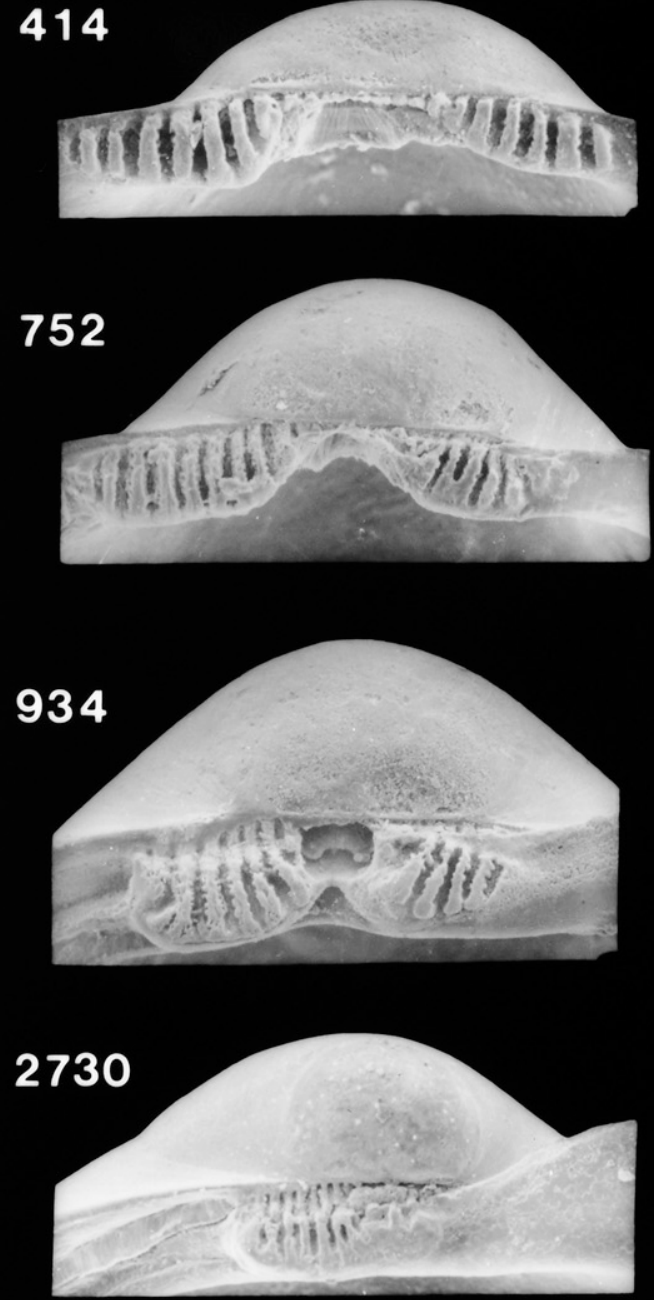

\section{RIGHT VALVE}
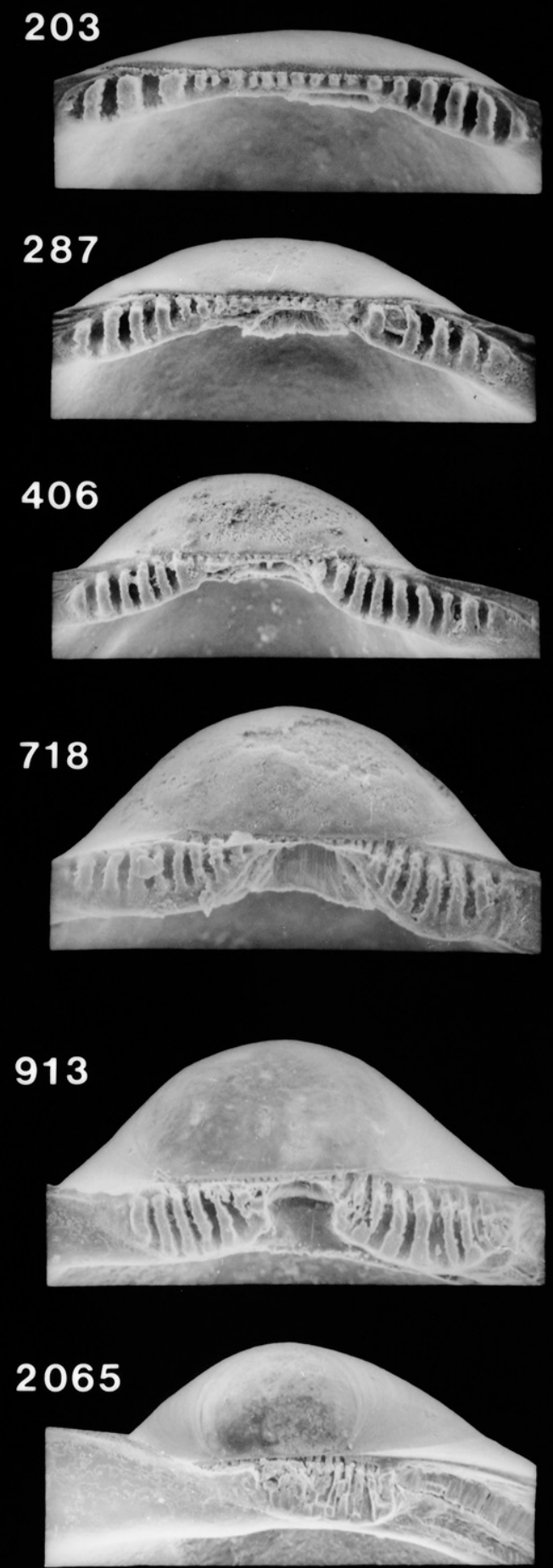

Figure 88. Scanning electron micrographs of the hinge of disarticulated shell valves of Geukensia demissa postlarvae seen in Figure 87. Numbers indicate the maximum linear shell dimension in micrometers. Modified from Fuller and Lutz (1989). 


\section{ISCHADIUM RECURVUM}

\section{LEFT VALVE}

99

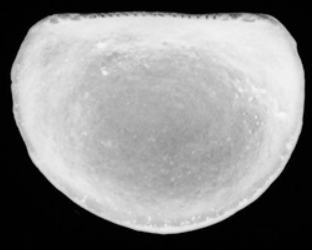

141

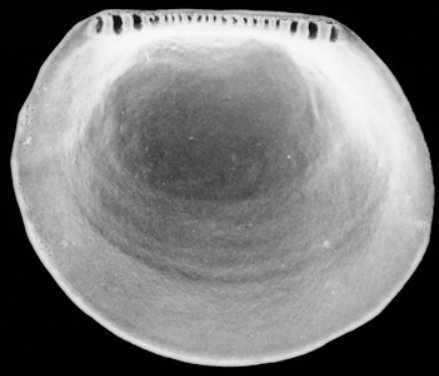

RIGHT VALVE
110

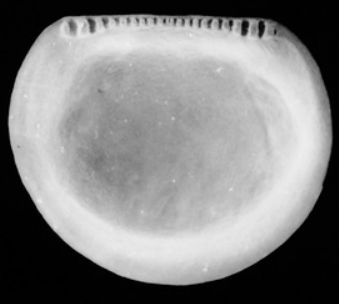

156

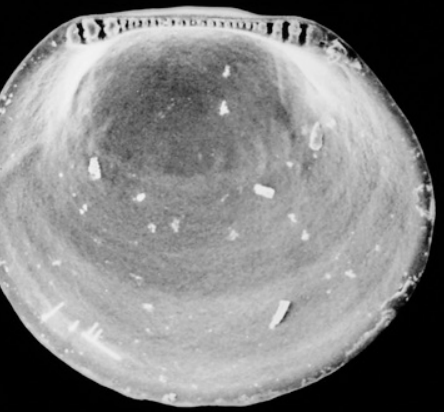

114

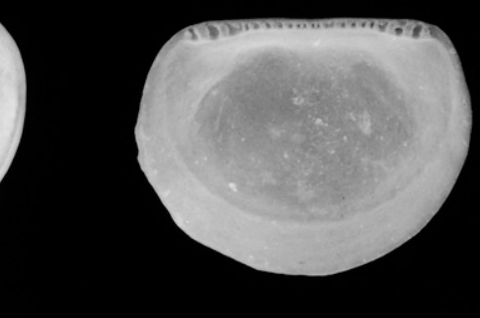

127

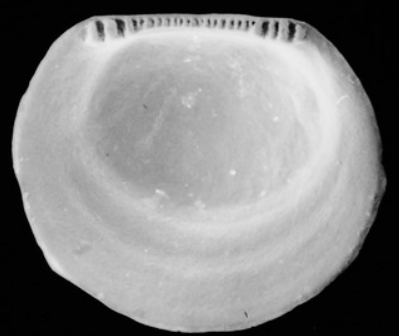

169
102
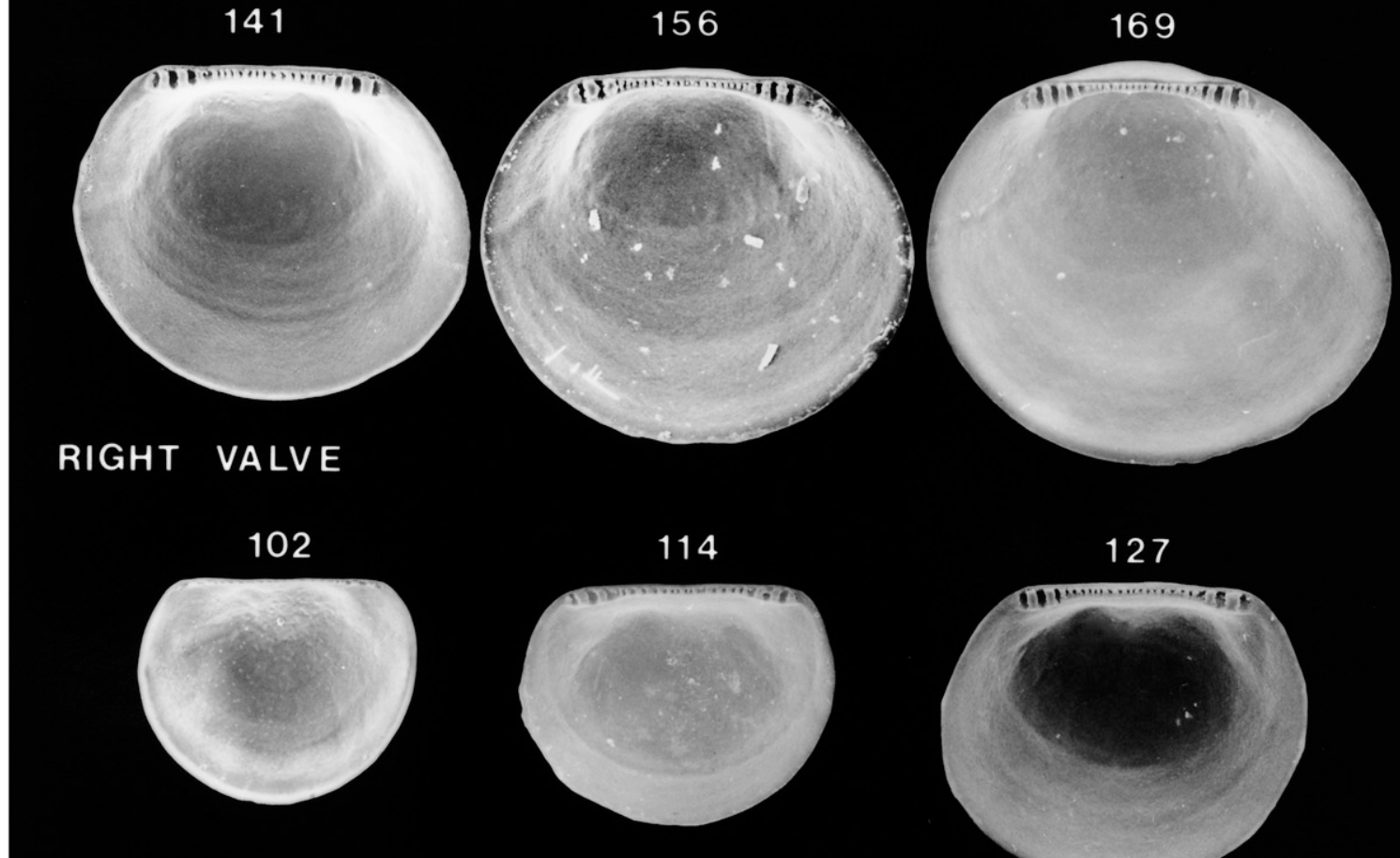

135

150

169
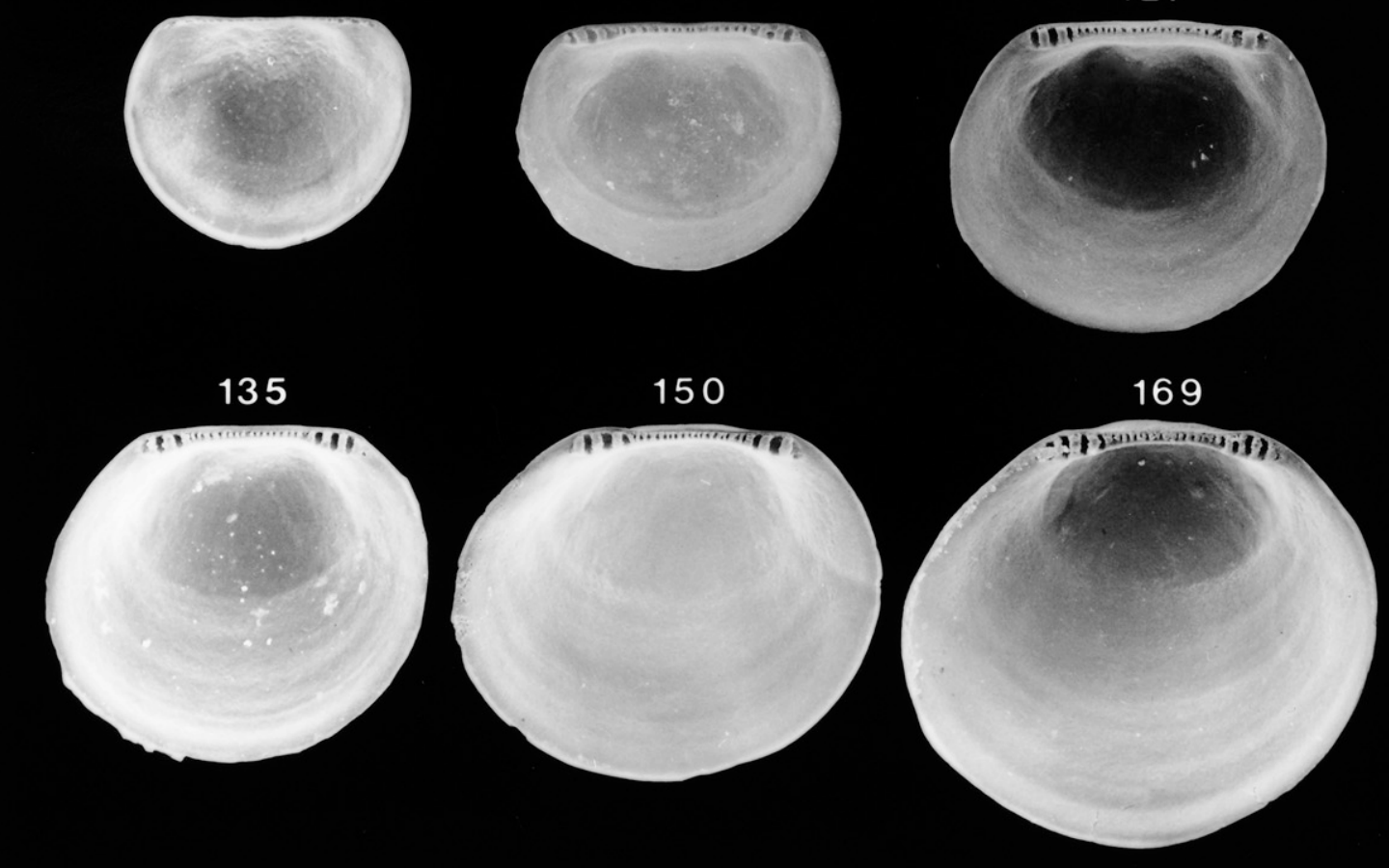

Figure 89. Scanning electron micrographs of disarticulated shell valves of Ischadium recurvum larvae. Numbers indicate the maximum linear shell dimension in micrometers. Modified from Fuller and Lutz (1989). 


\section{ISCHADIUM RECURVUM}

\section{LEFT VALVE}

\section{9}

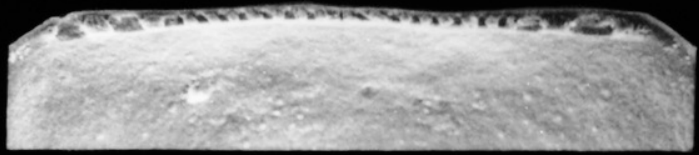

110

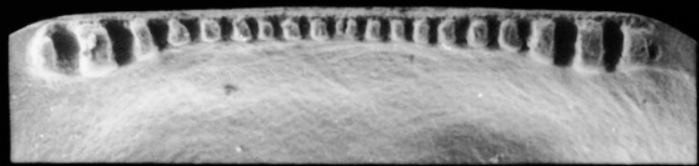

\section{7}

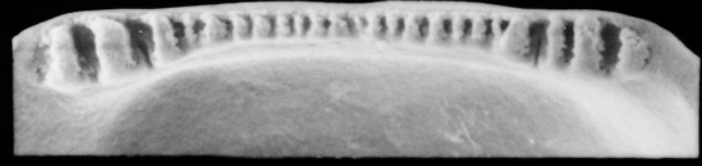

141

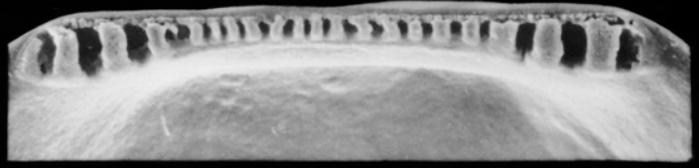

156

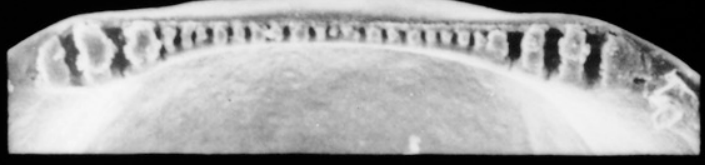

169

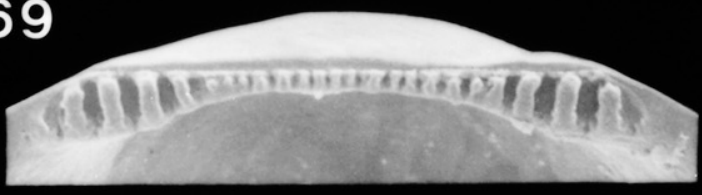

\section{RIGHT VALVE}

102

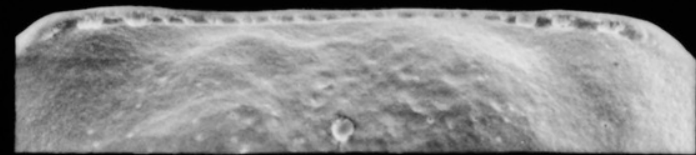

114

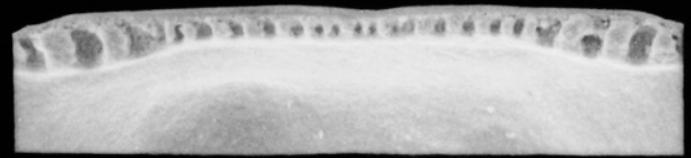

127

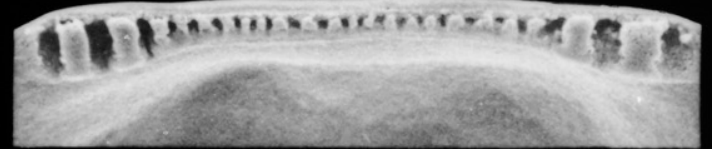

135

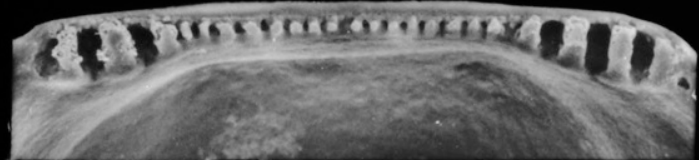

150

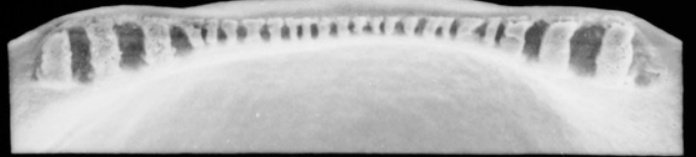

169

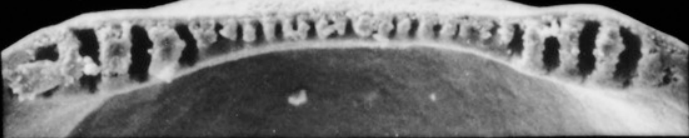

Figure 90. Scanning electron micrographs of the hinge of disarticulated shell valves of Ischadium recurvum larvae seen in Figure 89. Numbers indicate the maximum linear shell dimension in micrometers. Modified from Fuller and Lutz (1989). 


\section{ISCHADIUM RECURVUM}

\section{LEFT VALVE}
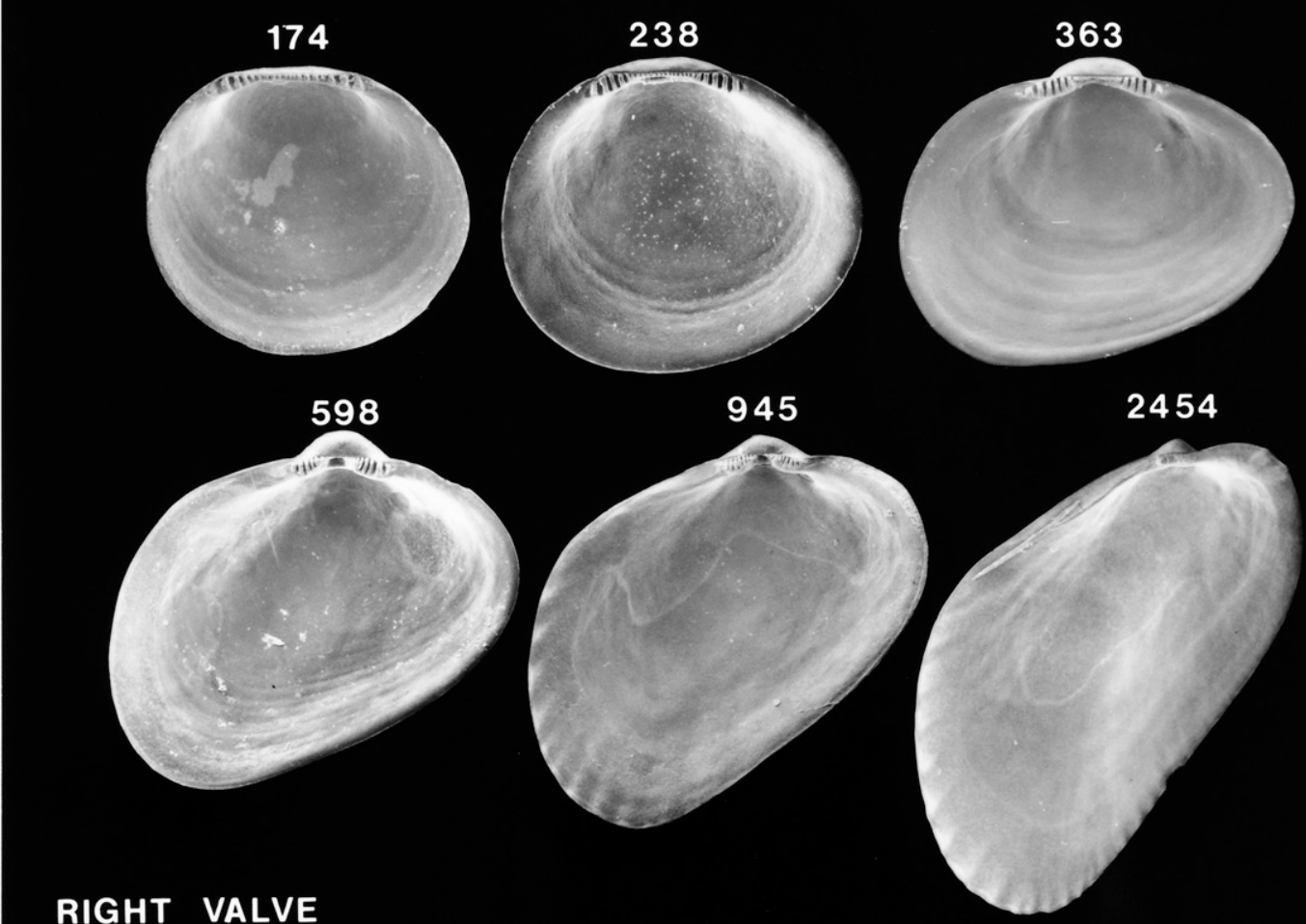

RIGHT VALVE

175

213

330
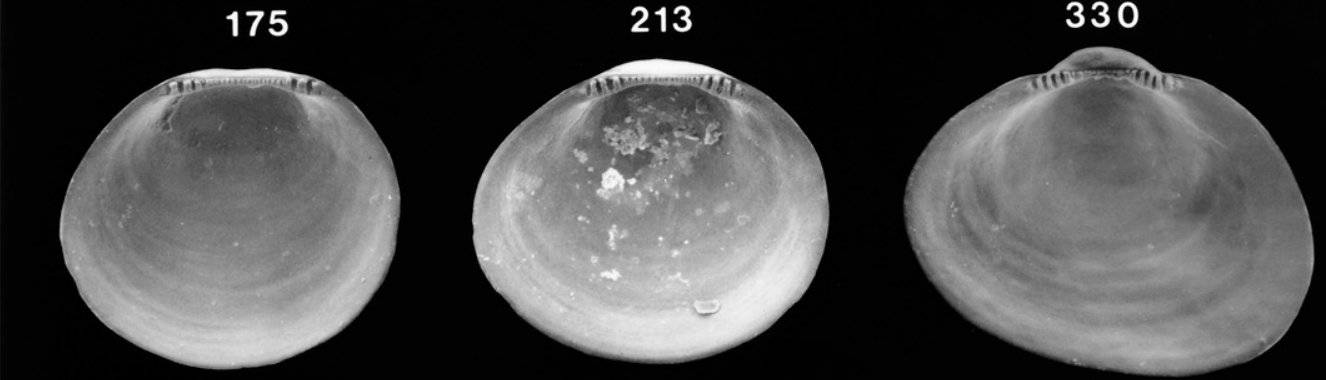

551

2264

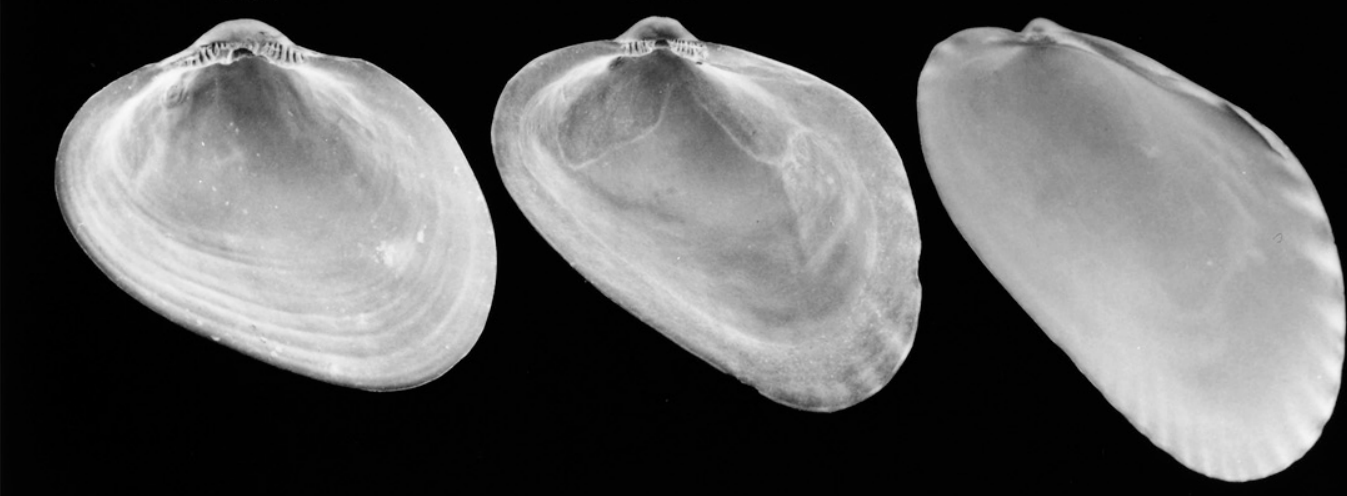

Figure 91. Scanning electron micrographs of disarticulated shell valves of Ischadium recurvum postlarvae. Numbers indicate the maximum linear shell dimension in micrometers. Modified from Fuller and Lutz (1989). 


\section{ISCHADIUM RECURVUM}

\section{LEFT VALVE}

174

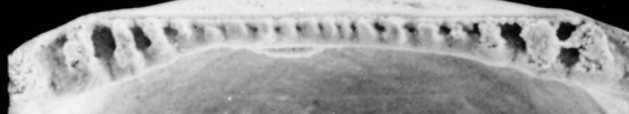

\section{8}
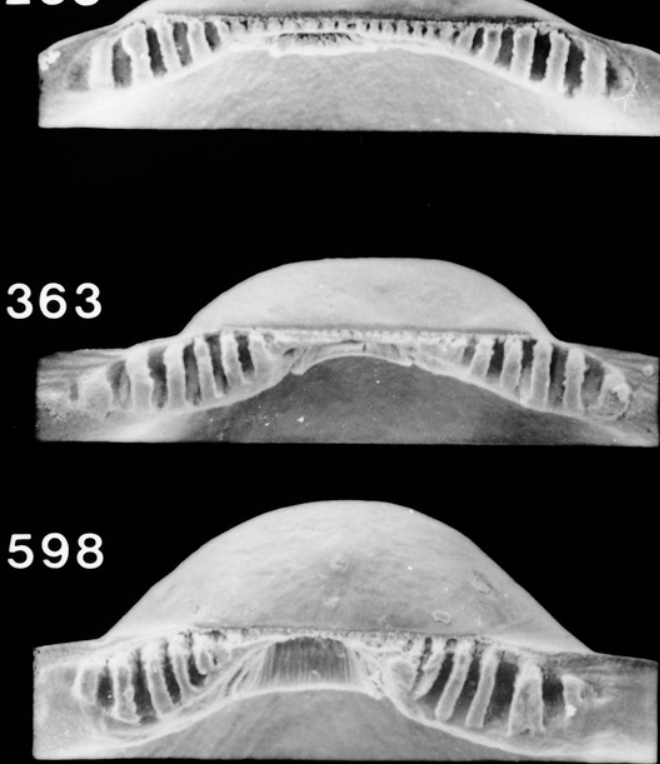

\section{5}

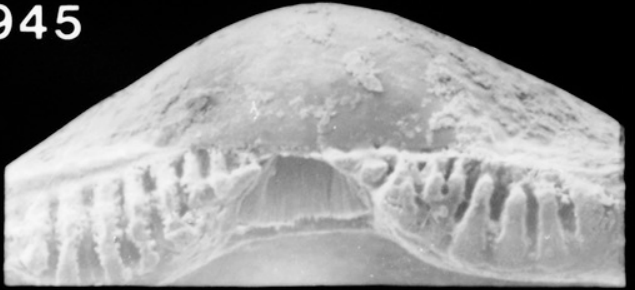

\section{4}

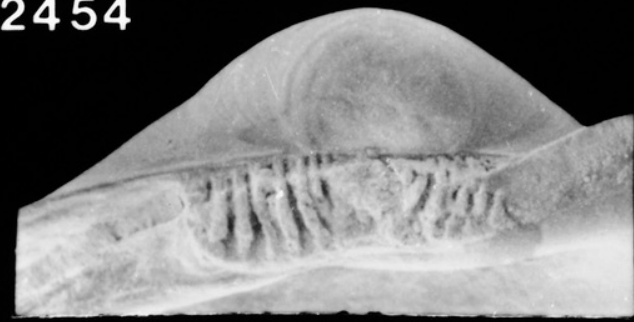

\section{RIGHT VALVE}

175

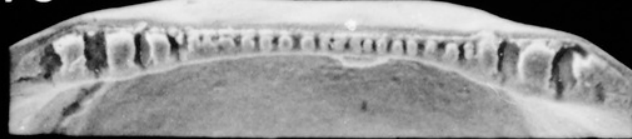

213
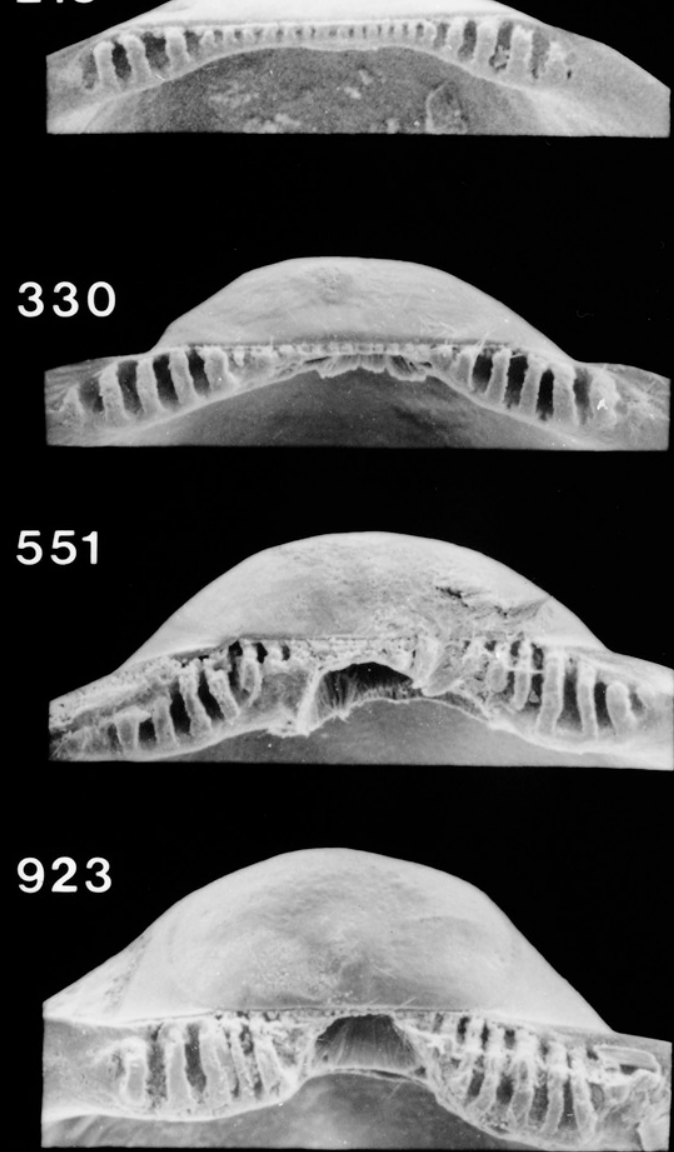

2264

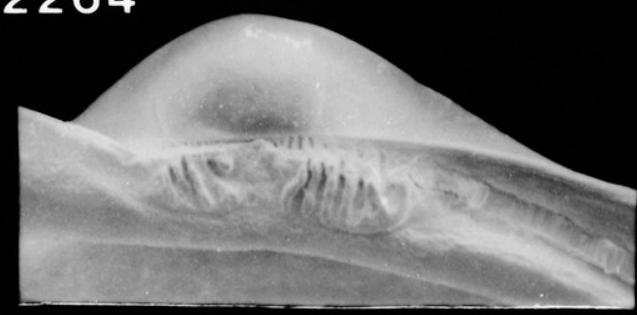

Figure 92. Scanning electron micrographs of the hinge of disarticulated shell valves of Ischadium recurvum postlarvae seen in Figure 91. Numbers indicate the maximum linear shell dimension in micrometers. Modified from Fuller and Lutz (1989). 


\section{LEIOSOLENUS BISULCATUS}

\section{LEFT VALVE}

98

112

124
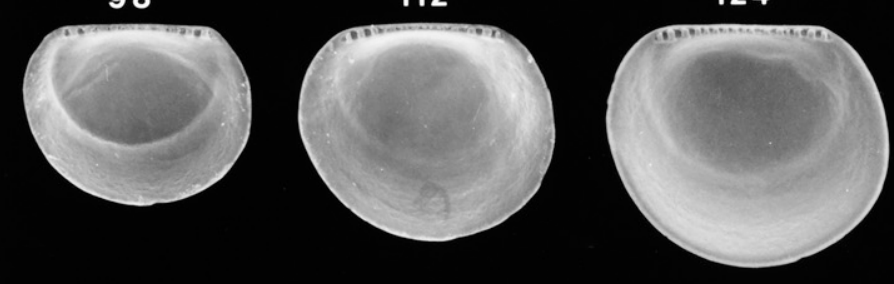

152

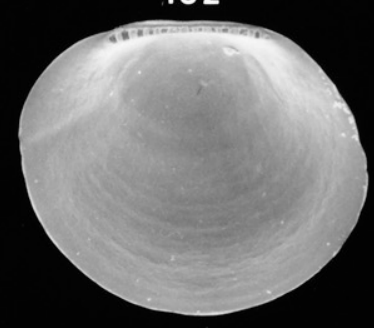

168

201

256

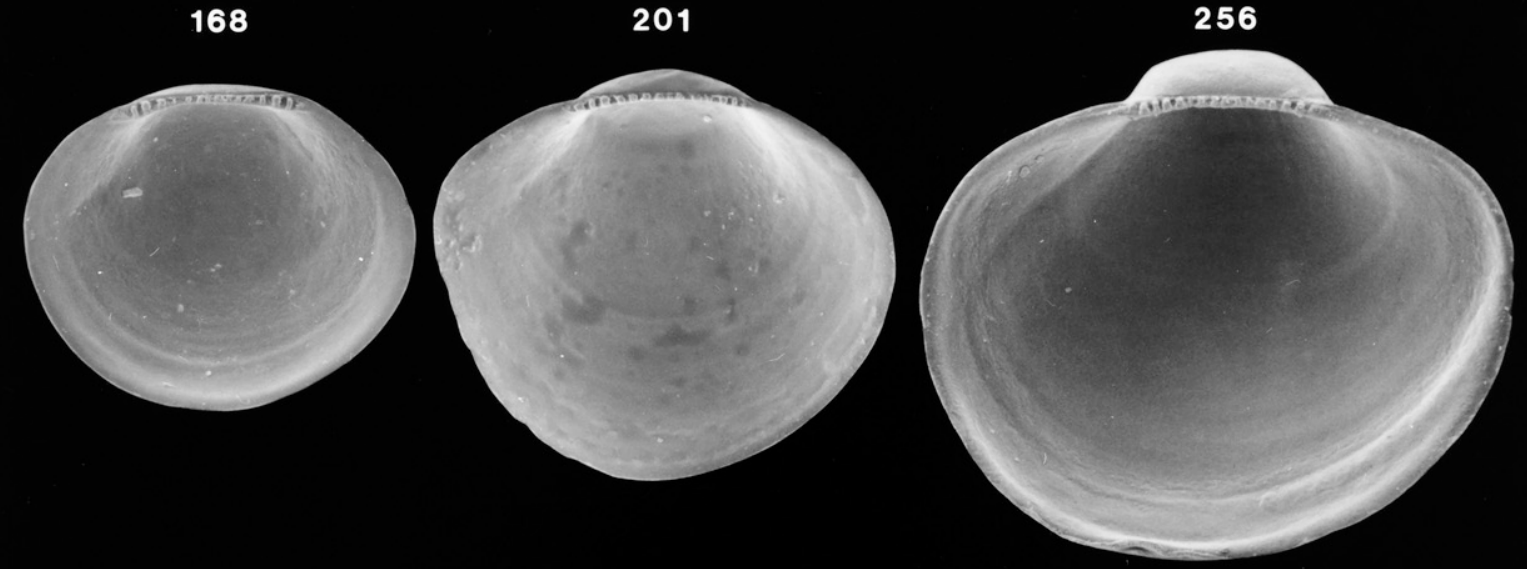

RIGHT VALVE

103

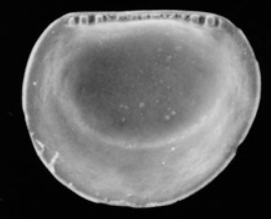

109

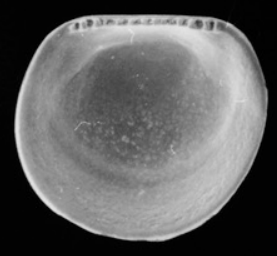

128

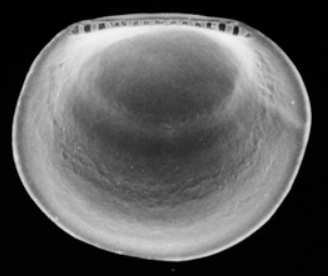

143

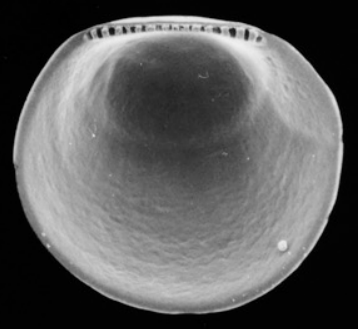

246

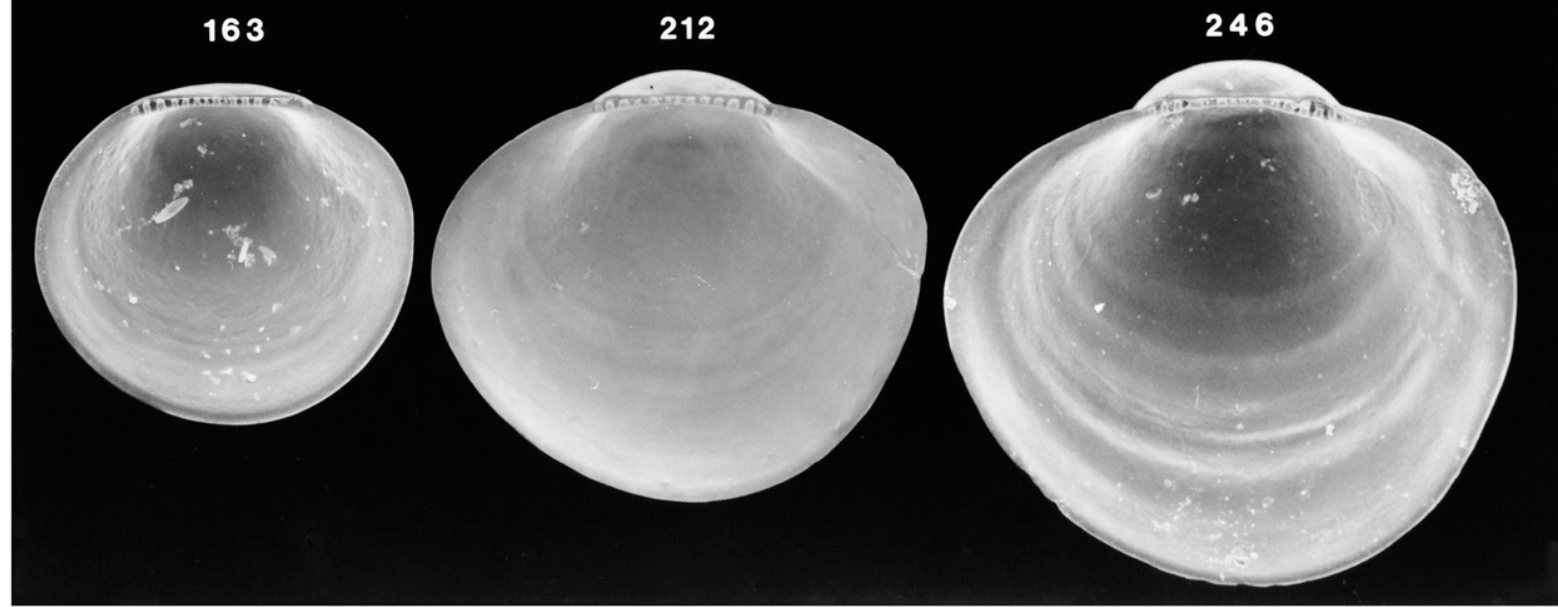

Figure 93. Scanning electron micrographs of disarticulated shell valves of Leiosolenus bisulcatus larvae. Numbers indicate the maximum linear shell dimension in micrometers. 


\section{LEIOSOLENUS BISULCATUS}

\section{LEFT VALVE}

\section{8}

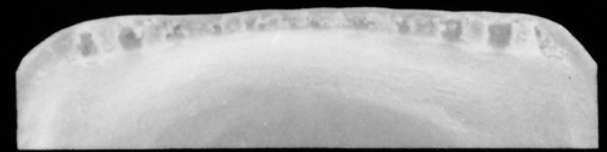

112

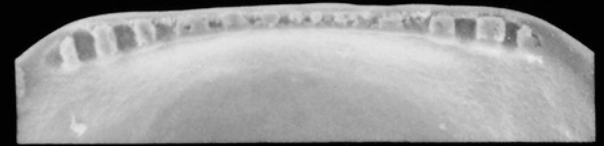

124

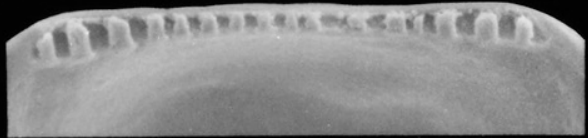

152

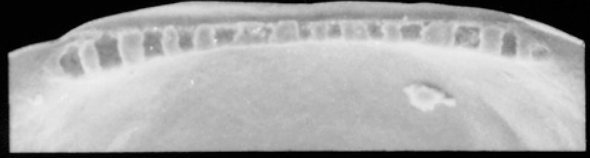

168
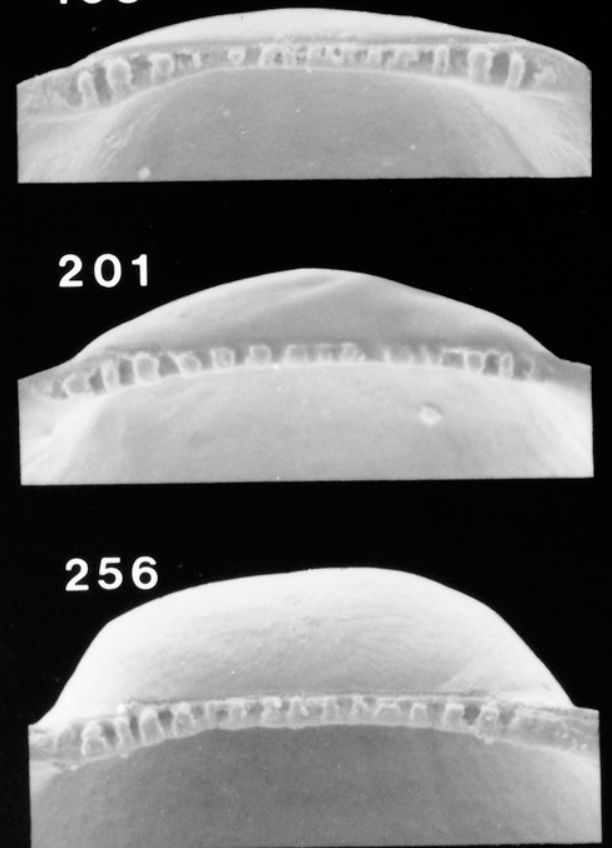

\section{RIGHT VALVE}

103

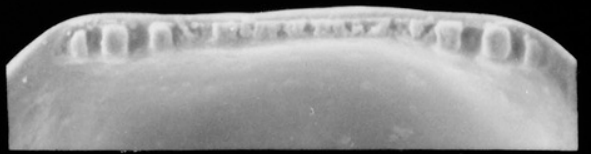

109

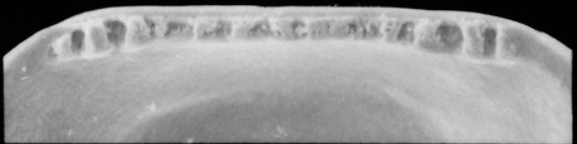

128

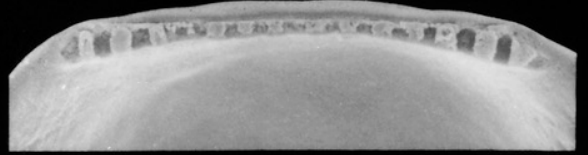

143

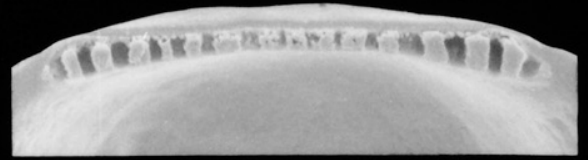

163
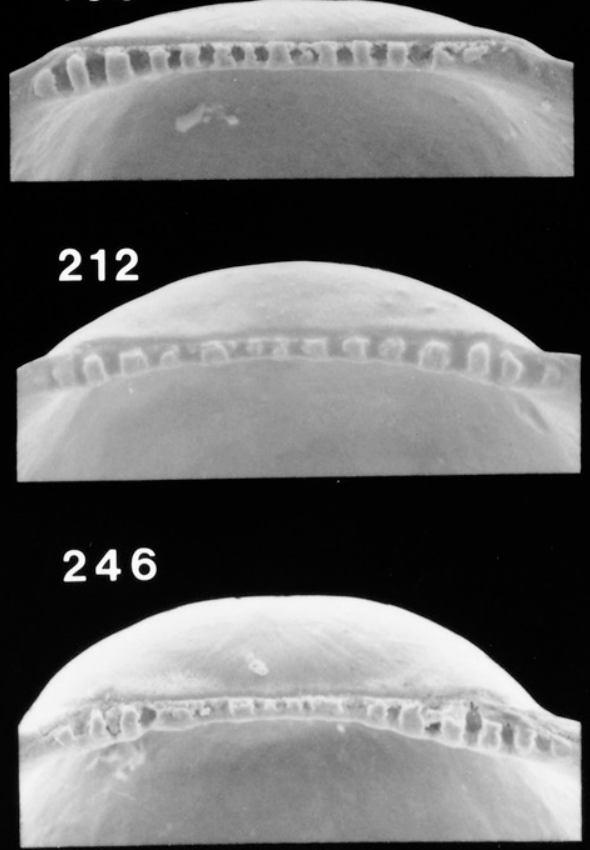

Figure 94. Scanning electron micrographs of the hinge of disarticulated shell valves of Leiosolenus bisulcatus larvae seen in Figure 93. Numbers indicate the maximum linear shell dimension in micrometers. 


\section{MODIOLUS AMERICANUS}

\section{LEFT VALVE}
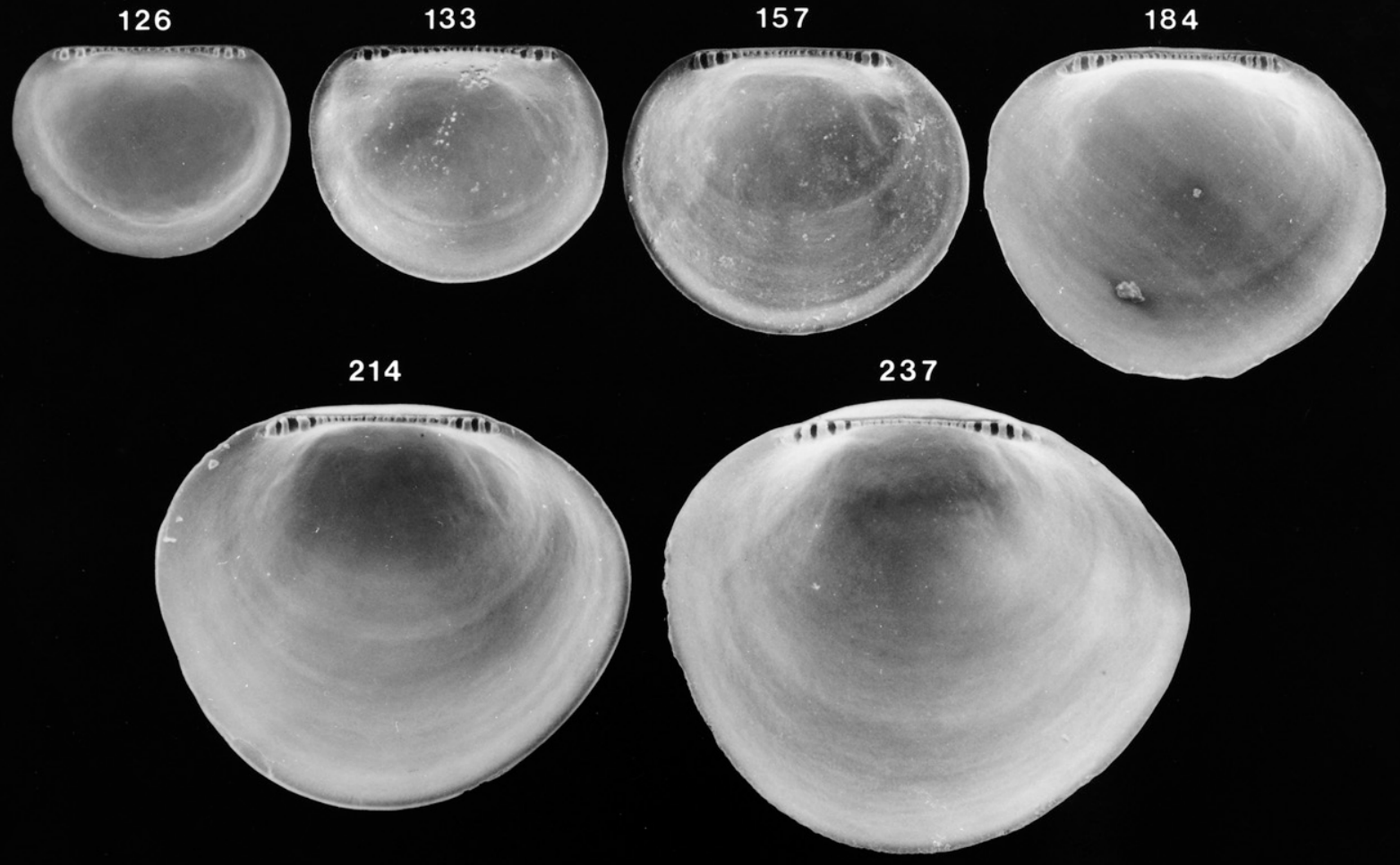

RIGHT VALVE

124

130

158

184
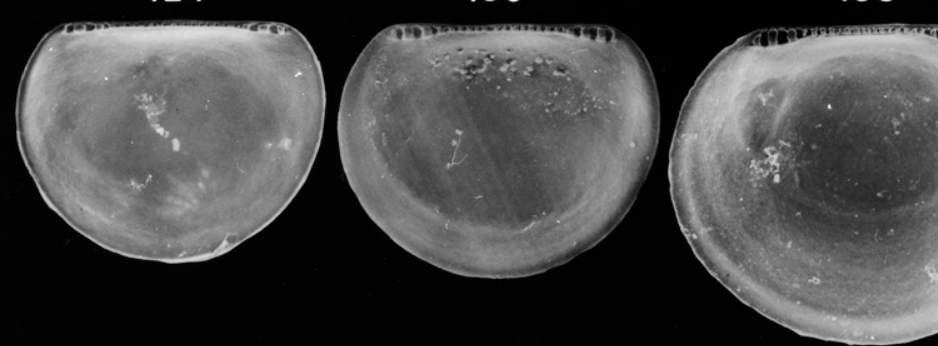

(m)

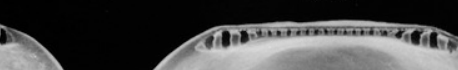

210

235
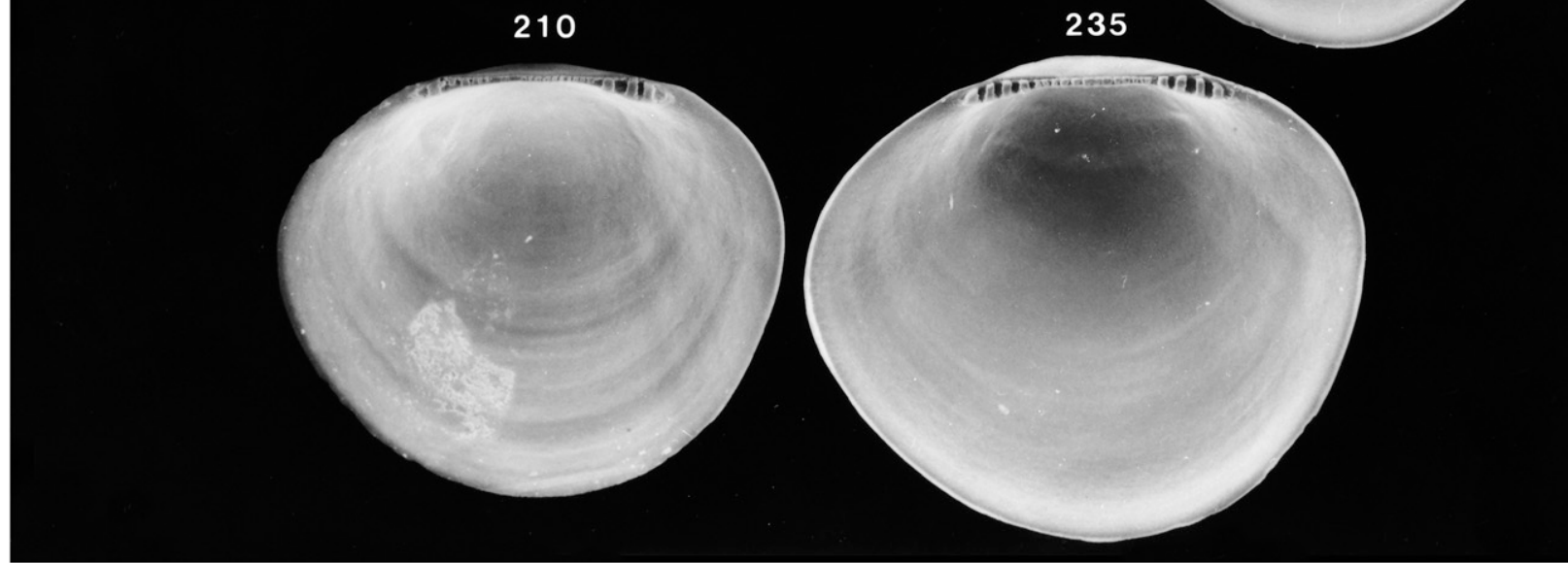

Figure 95. Scanning electron micrographs of disarticulated shell valves of Modiolus americanus larvae. Numbers indicate the maximum linear shell dimension in micrometers. Modified from Fuller and Lutz (1989). 


\section{MODIOLUS AMERICANUS}

\section{LEFT VALVE}

126

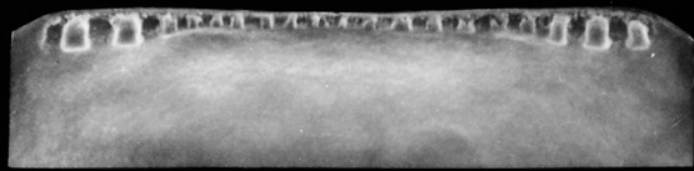

133

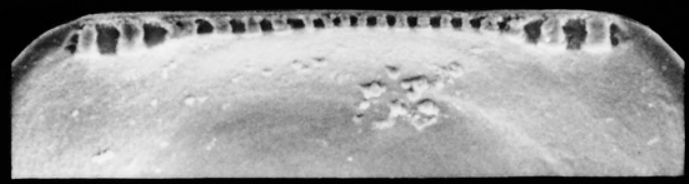

157

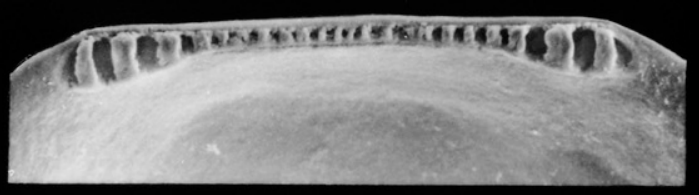

184

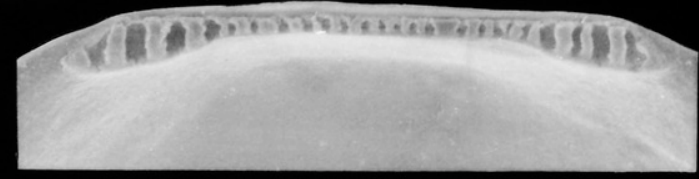

214

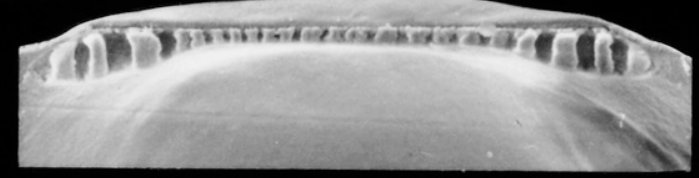

\section{7}

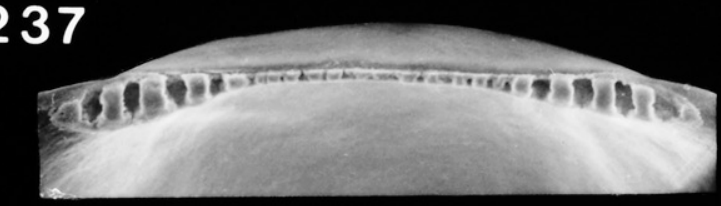

\section{RIGHT VALVE}

124

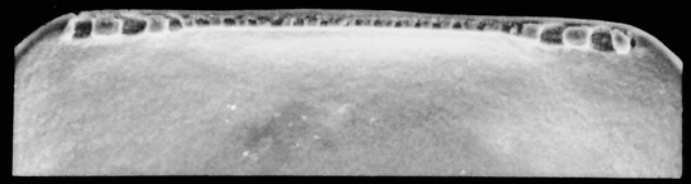

130

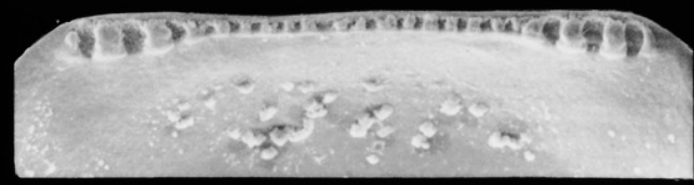

158

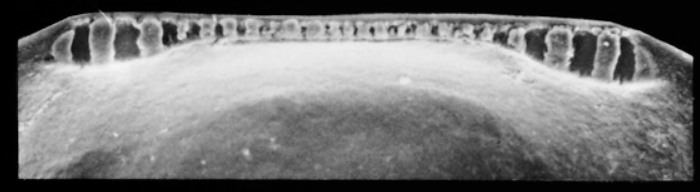

184

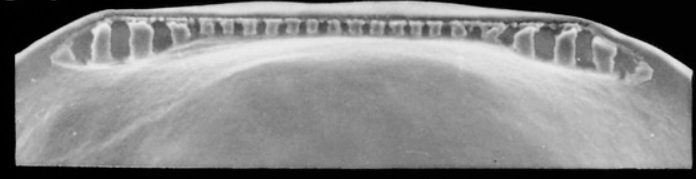

210

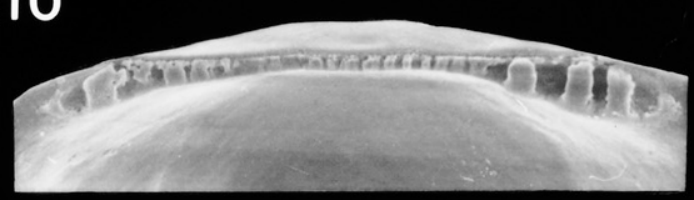

235

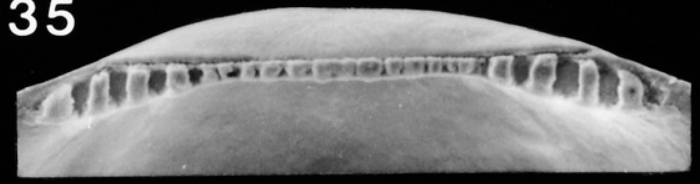




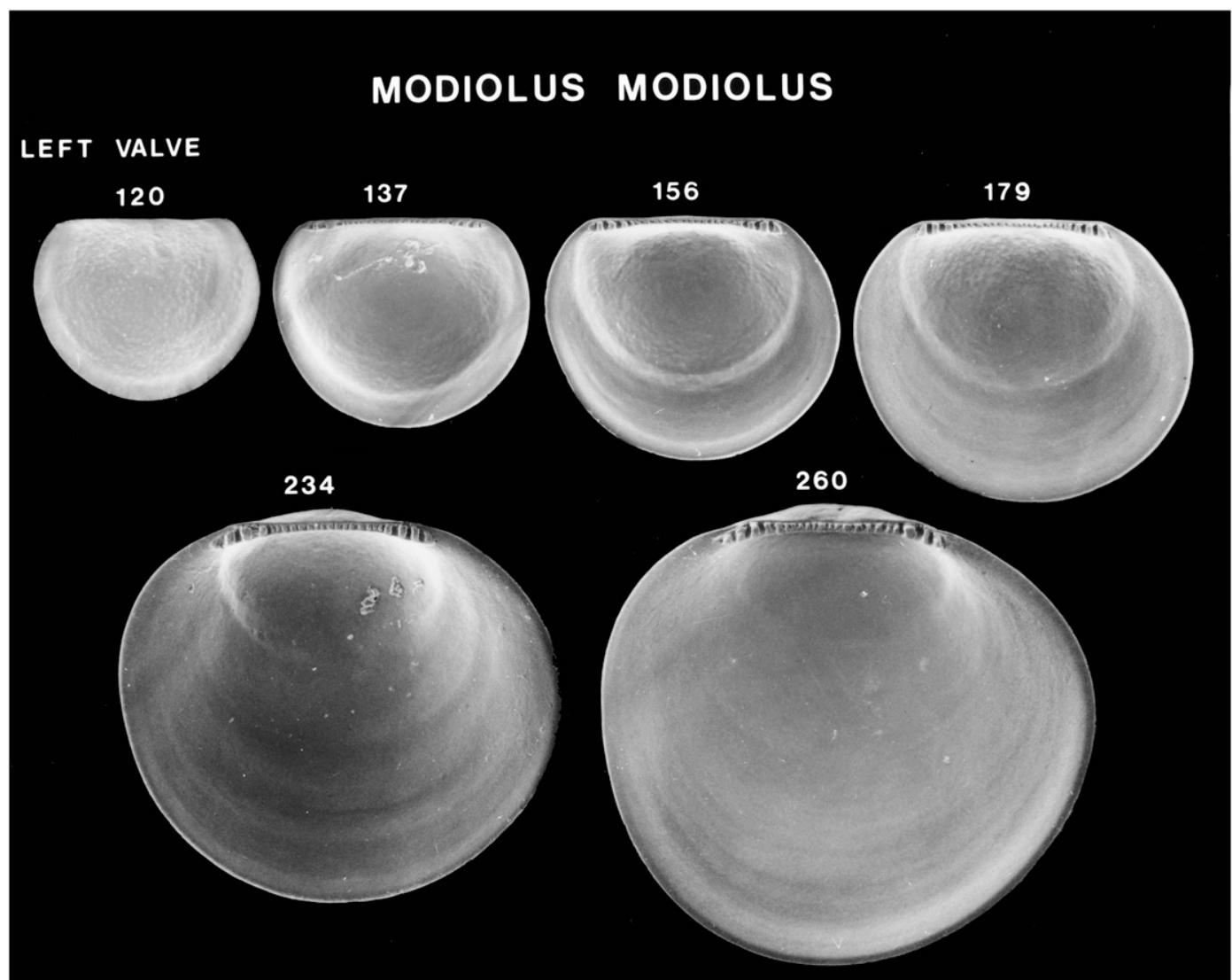

\section{RIGHT VALVE}

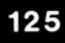

132

152

199

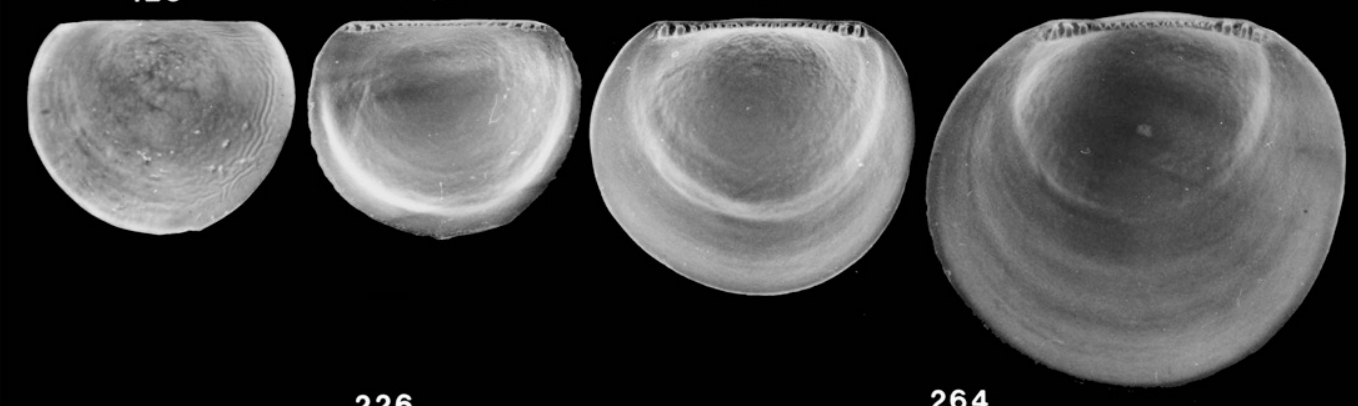

226

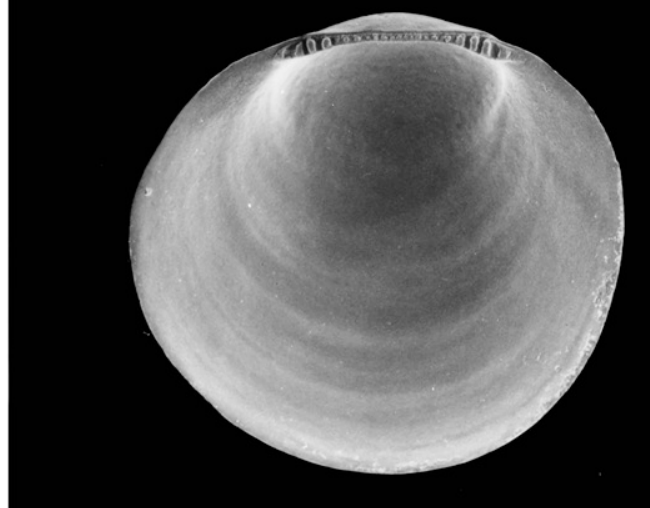

264

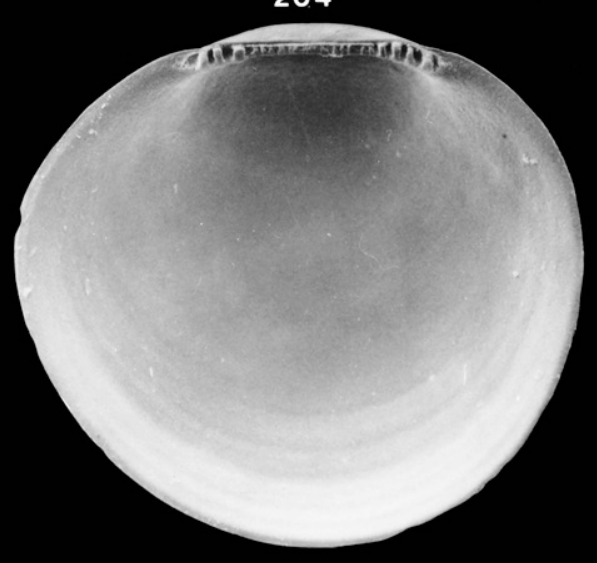

Figure 97. Scanning electron micrographs of disarticulated shell valves of Modiolus modiolus larvae. Numbers indicate the maximum linear shell dimension in micrometers. Modified from Fuller and Lutz (1989). 


\section{MODIOLUS MODIOLUS}

\section{LEFT VALVE}

120

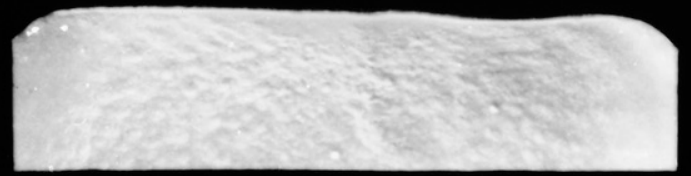

137

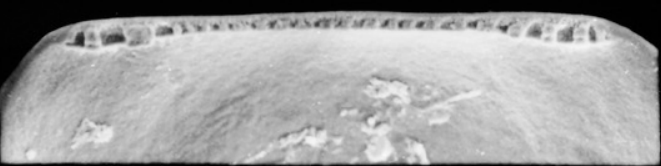

156

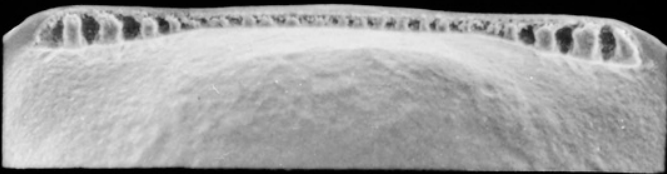

179

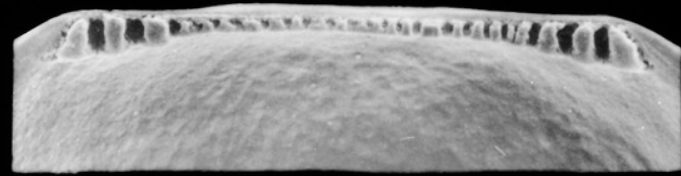

234

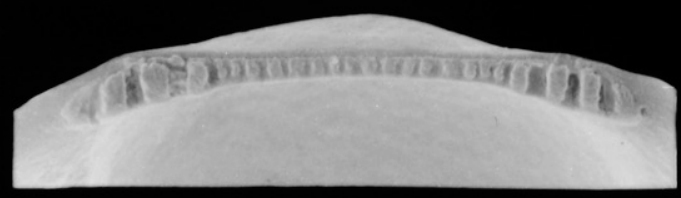

260

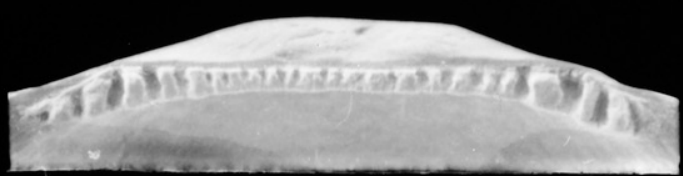

\section{RIGHT VALVE}

\section{5}

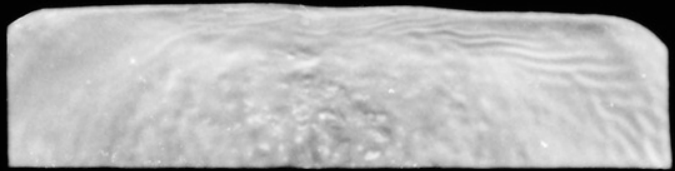

132

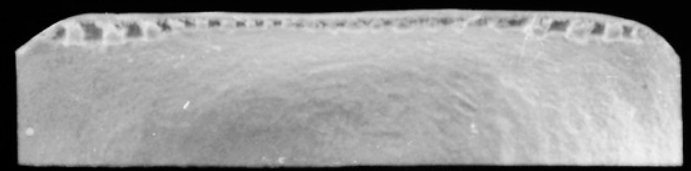

152

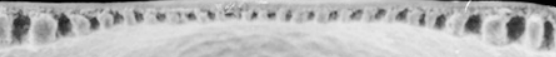

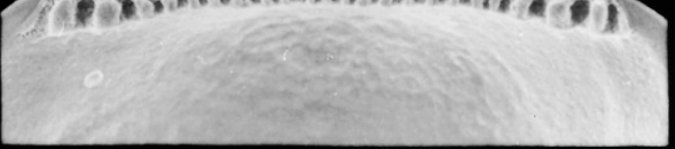

199

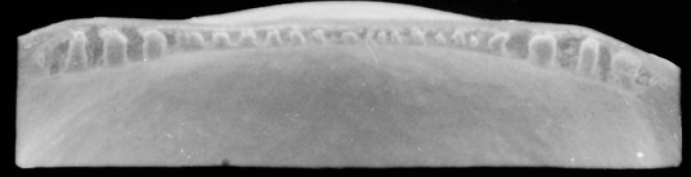

226

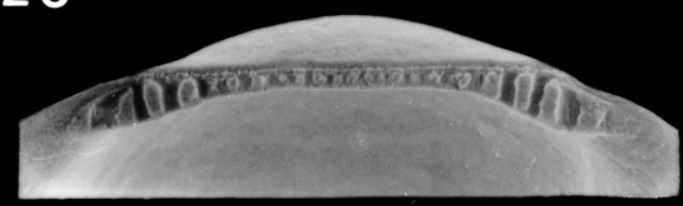

264

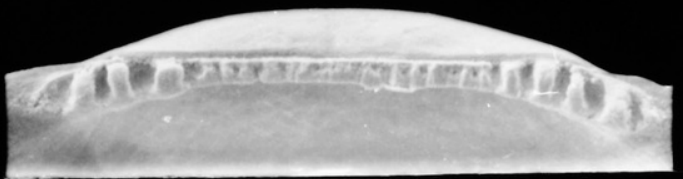




\section{MODIOLUS MODIOLUS}

\section{LEFT VALVE}

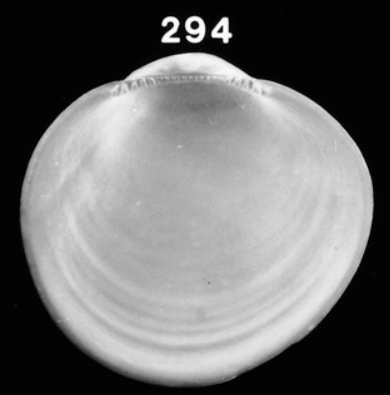

324

542
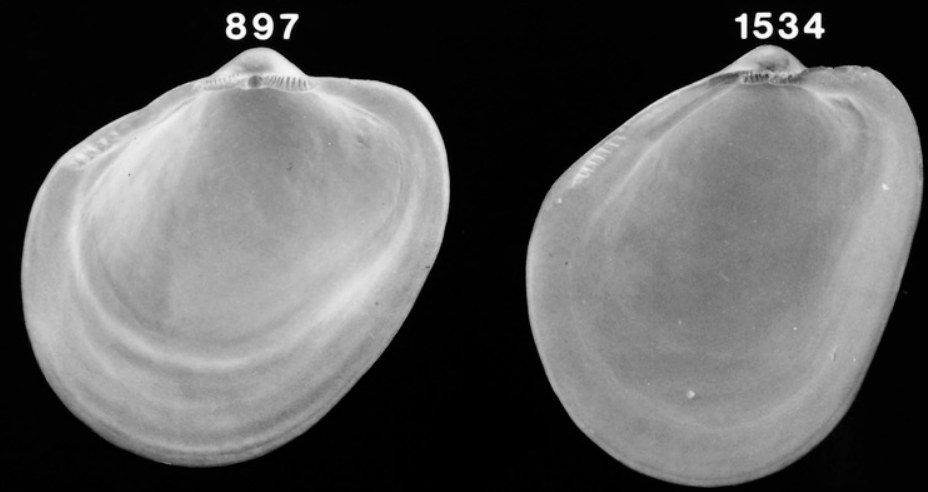

\section{RIGHT VALVE}

\section{3}

324

552

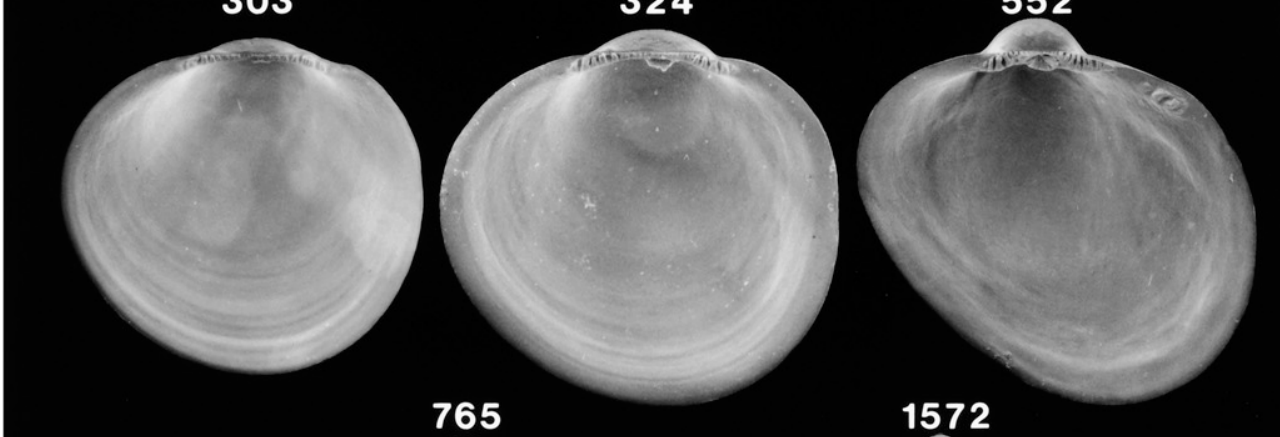

765

1572
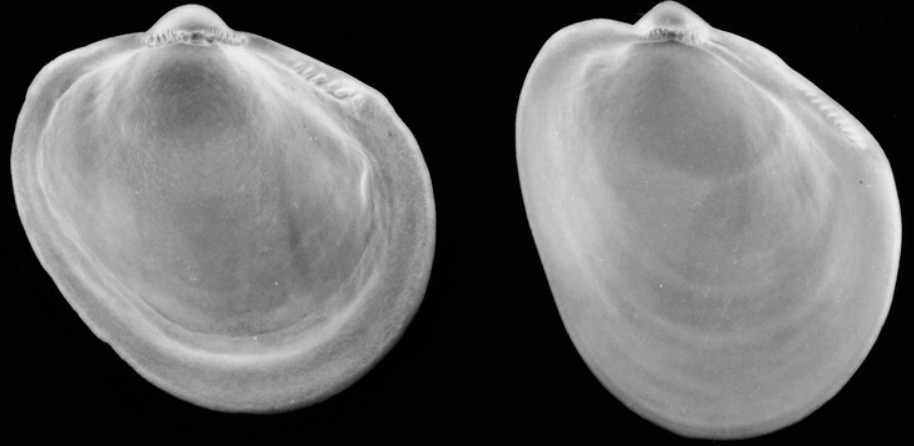

Figure 99. Scanning electron micrographs of disarticulated shell valves of Modiolus modiolus postlarvae. Numbers indicate the maximum linear shell dimension in micrometers. Modified from Fuller and Lutz (1989). 


\section{MODIOLUS MODIOLUS}

\section{LEFT VALVE}

294

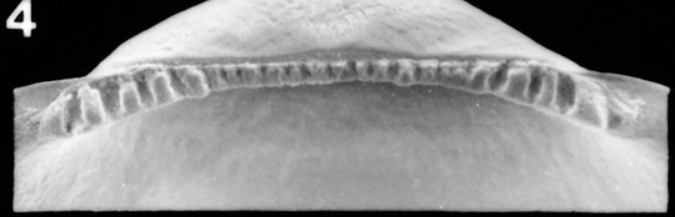

324

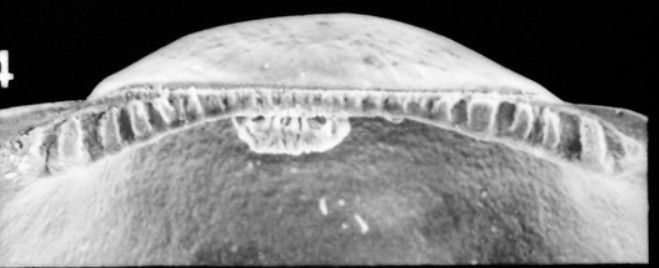

542

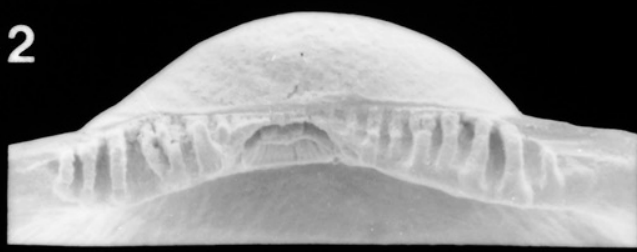

897

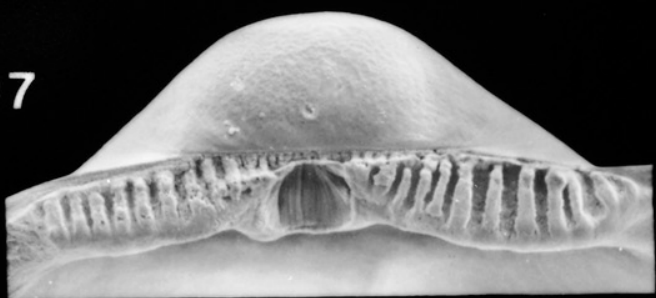

1534

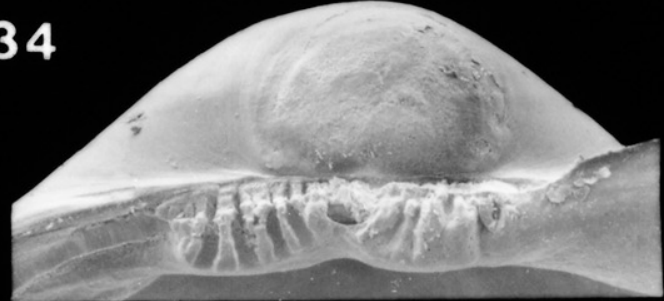

\section{RIGHT VALVE}
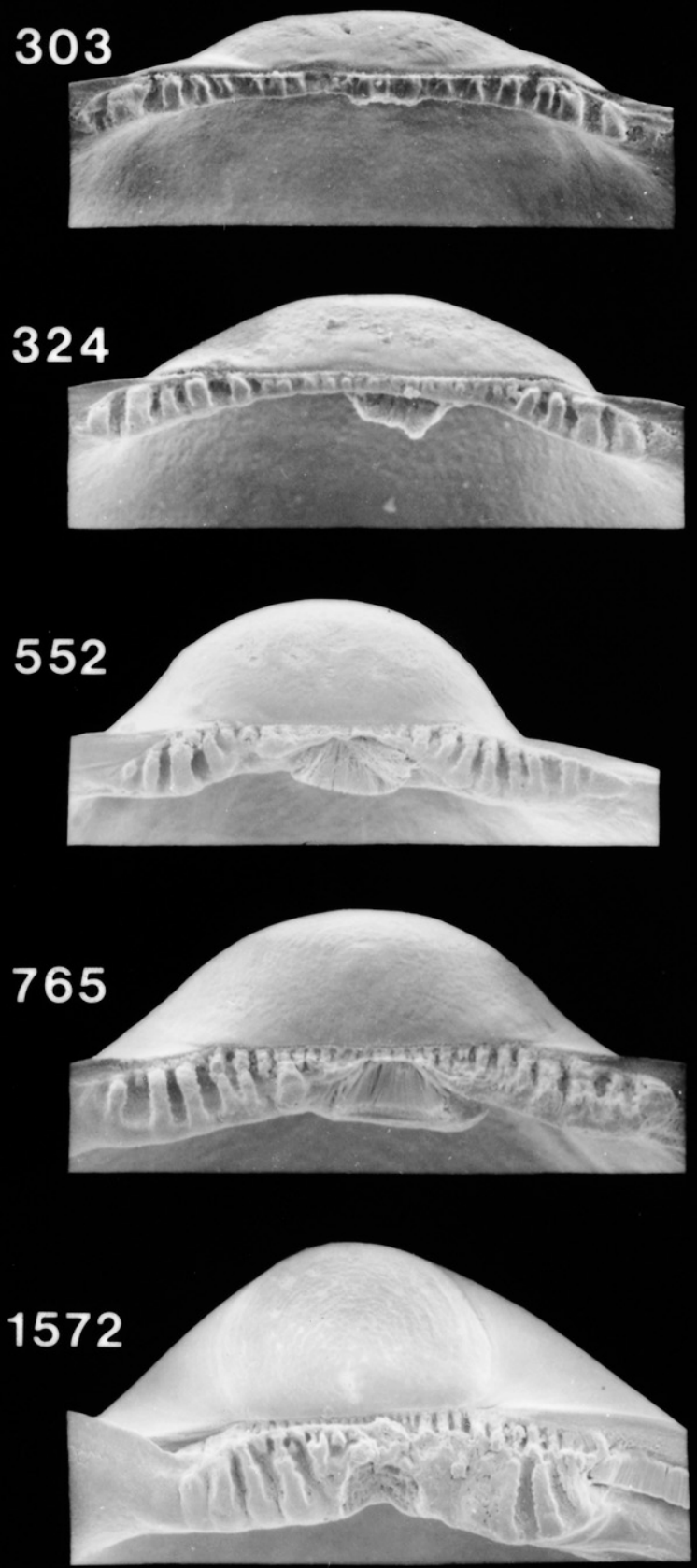


\section{MYTILUS EDULIS}

\section{LEFT VALVE}

106

116

138

150

177
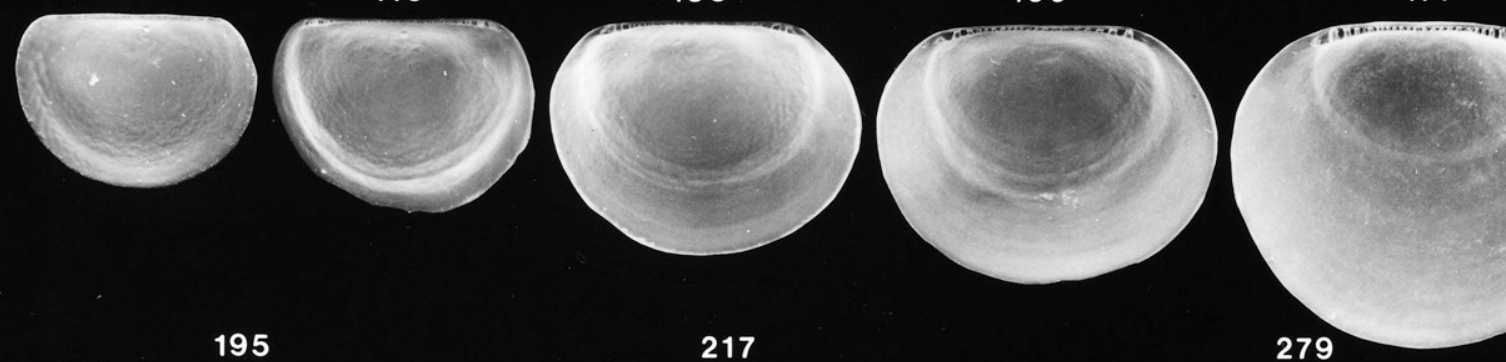

195

217

279
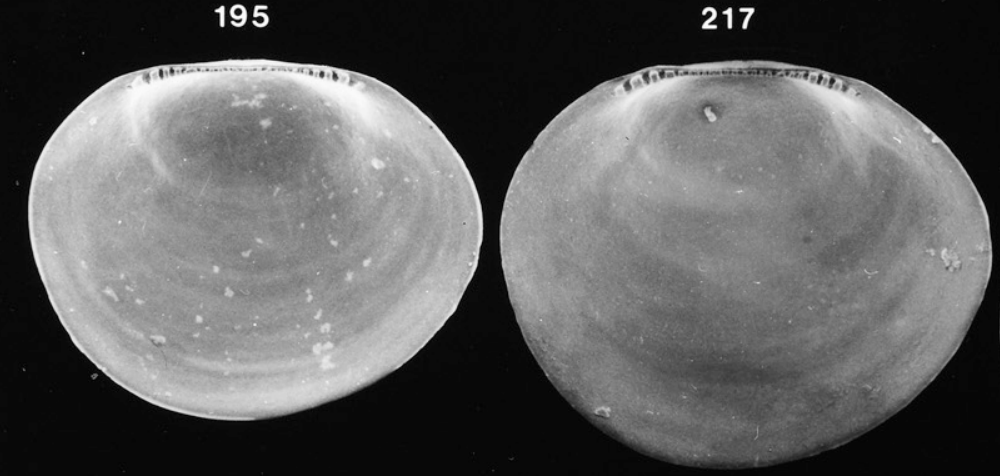

\section{RIGHT VALVE}
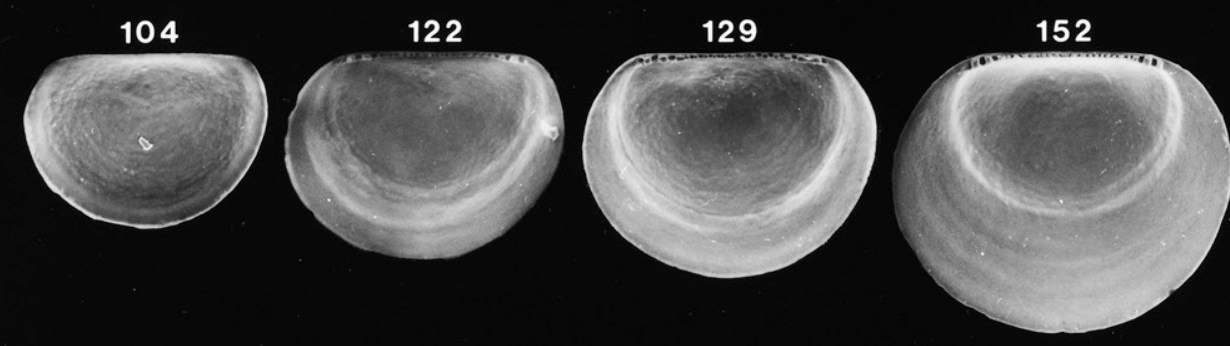

\section{1}

188

225

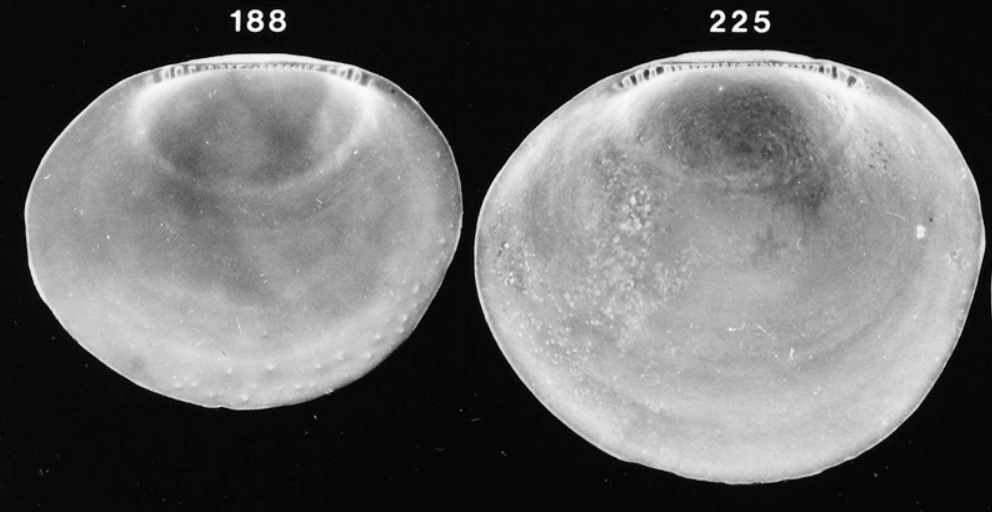




\section{MYTILUS EDULIS}

\section{LEFT VALVE}

\section{6}

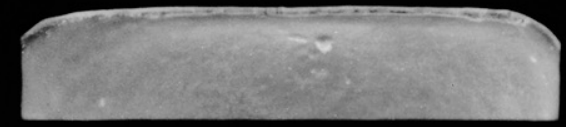

116

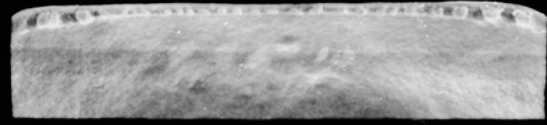

138

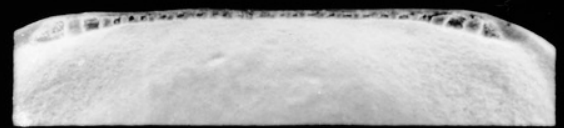

150

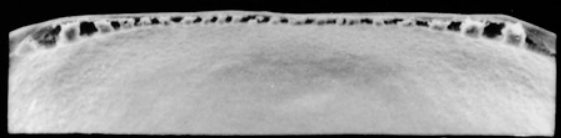

177

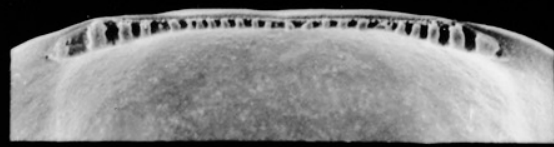

195

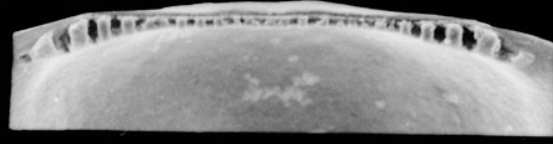

217

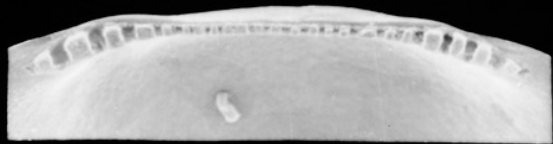

279

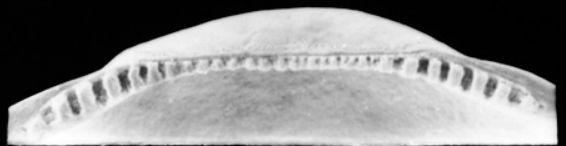

\section{RIGHT VALVE}

104

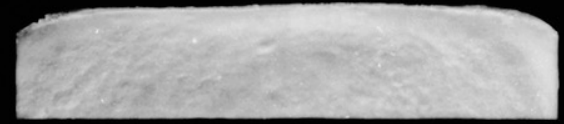

122

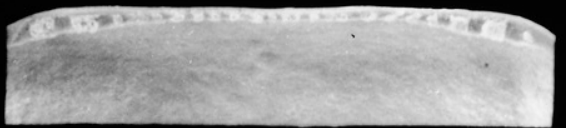

129

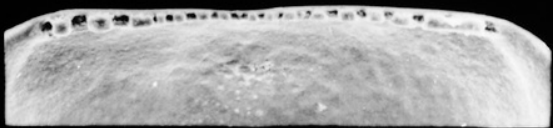

152

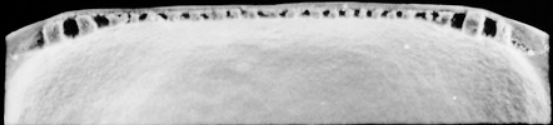

171

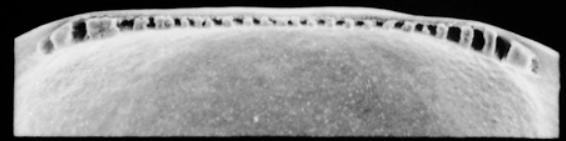

188

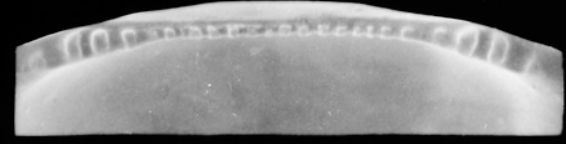

225

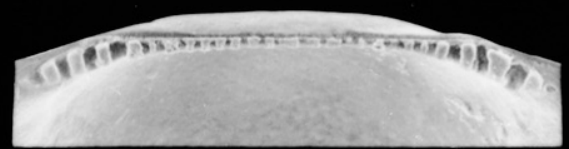

286

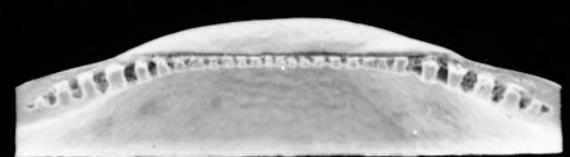

Figure 102. Scanning electron micrographs of the hinge of disarticulated shell valves of Mytilus edulis larvae seen in Figure 101. Numbers indicate the maximum linear shell dimension in micrometers. Modified from Fuller and Lutz (1989). 


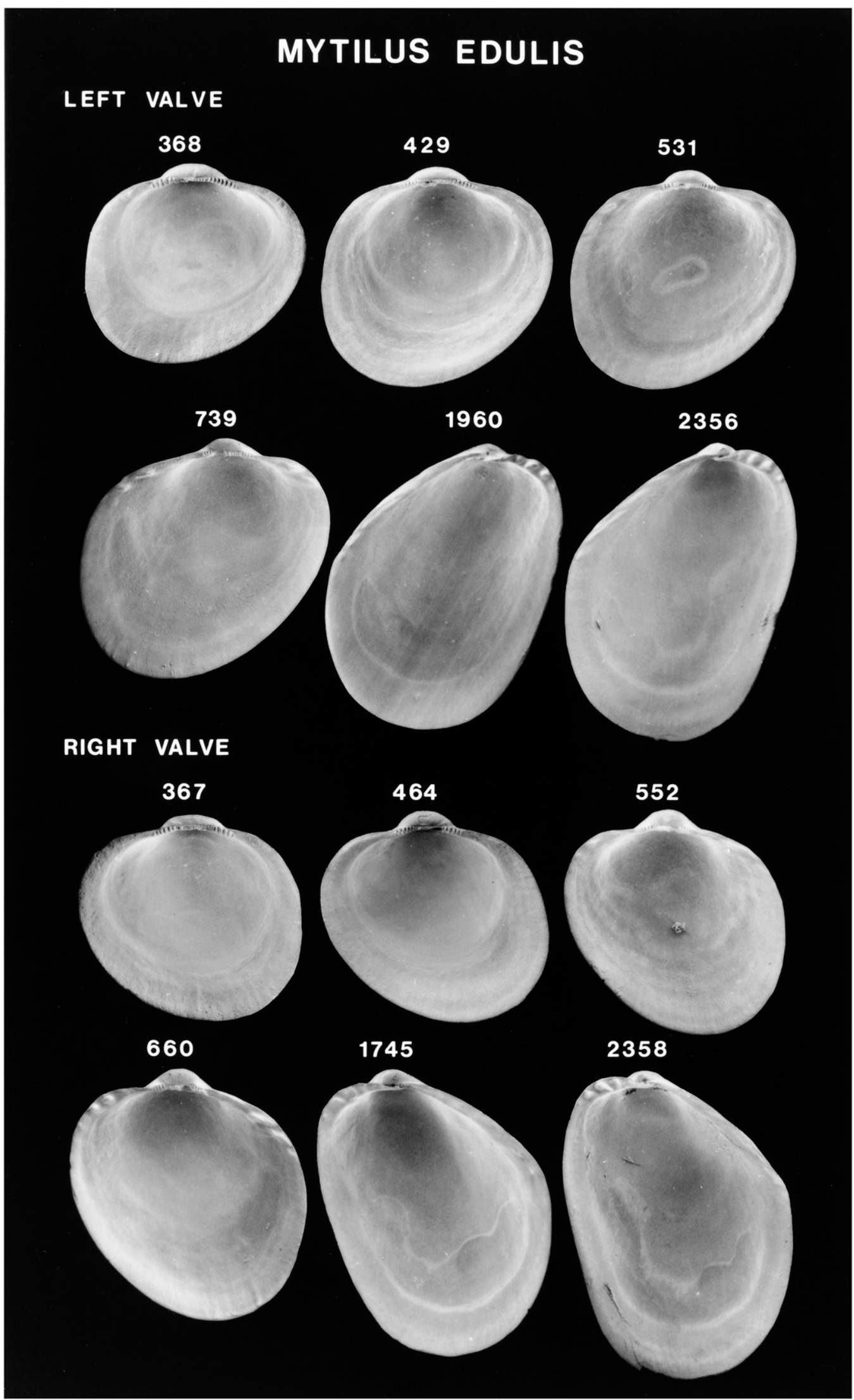

Figure 103. Scanning electron micrographs of disarticulated shell valves of Mytilus edulis postlarvae. Numbers indicate the maximum linear shell dimension in micrometers. Modified from Fuller and Lutz (1989). 


\section{MYTILUS EDULIS}

LEFT VALVE

368

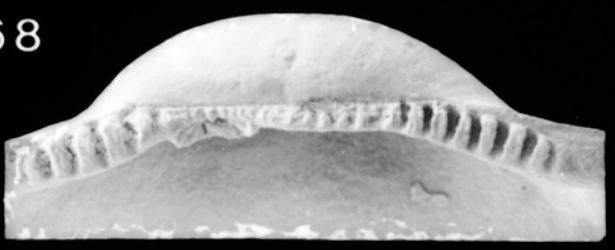

429

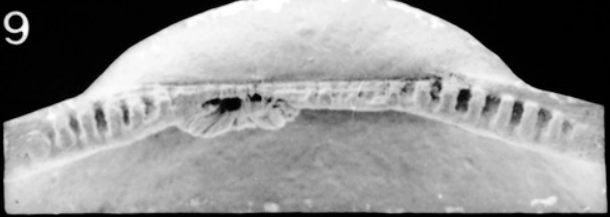

531

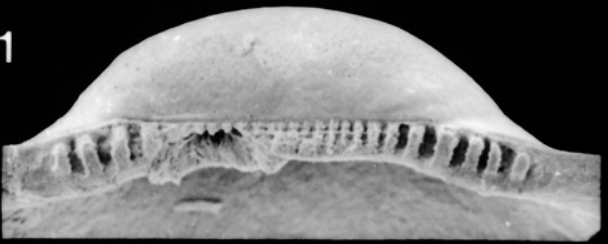

739

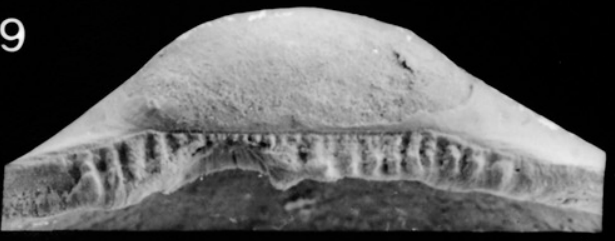

1960

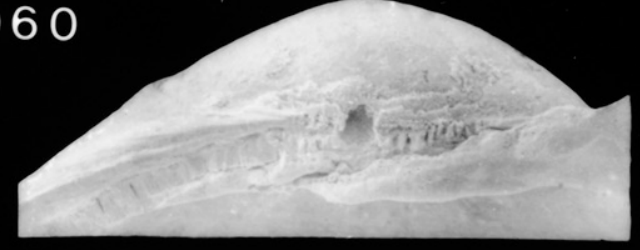

\section{6}

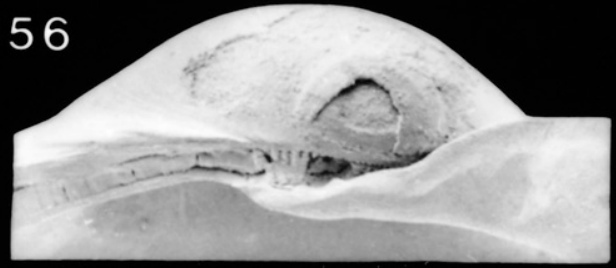

\section{RIGHT VALVE}

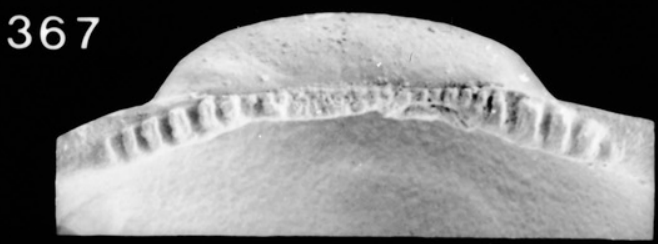

464

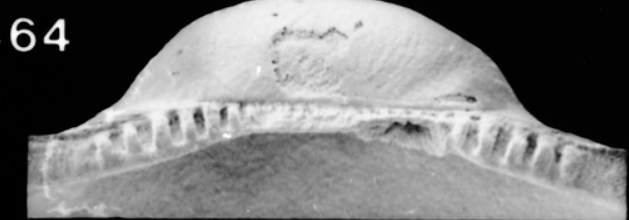

552

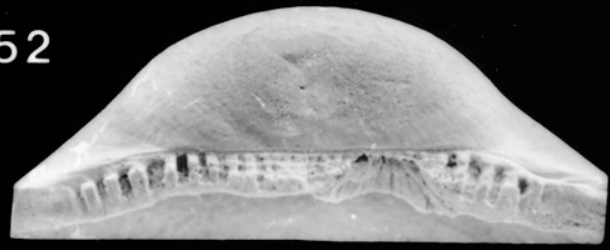

660

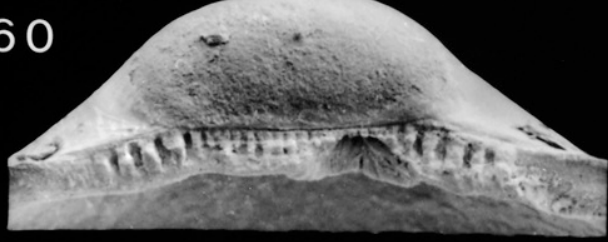

1745

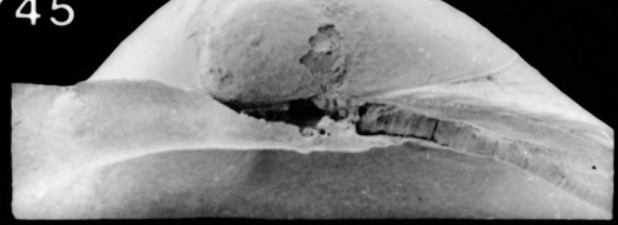

2358

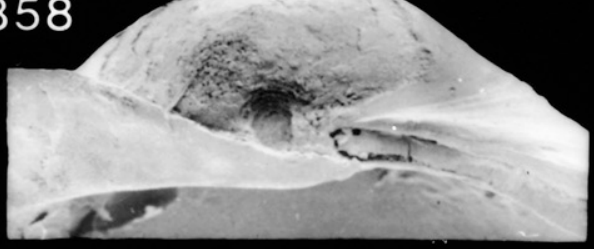




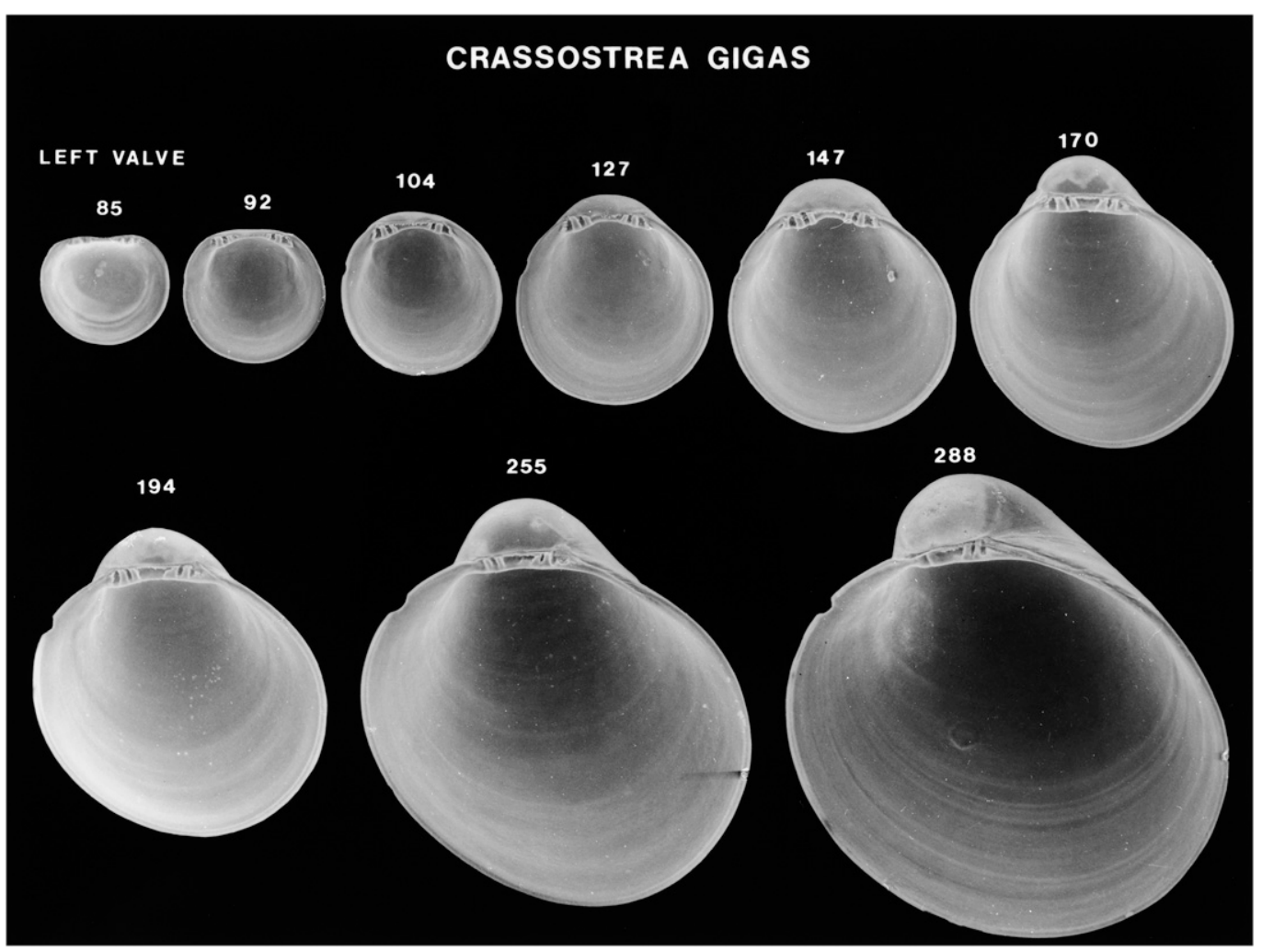

Figure 105. Scanning electron micrographs of disarticulated left shell valves of Crassostrea gigas larvae. Numbers indicate the maximum linear shell dimension in micrometers. Modified from Hu et al. (1993).

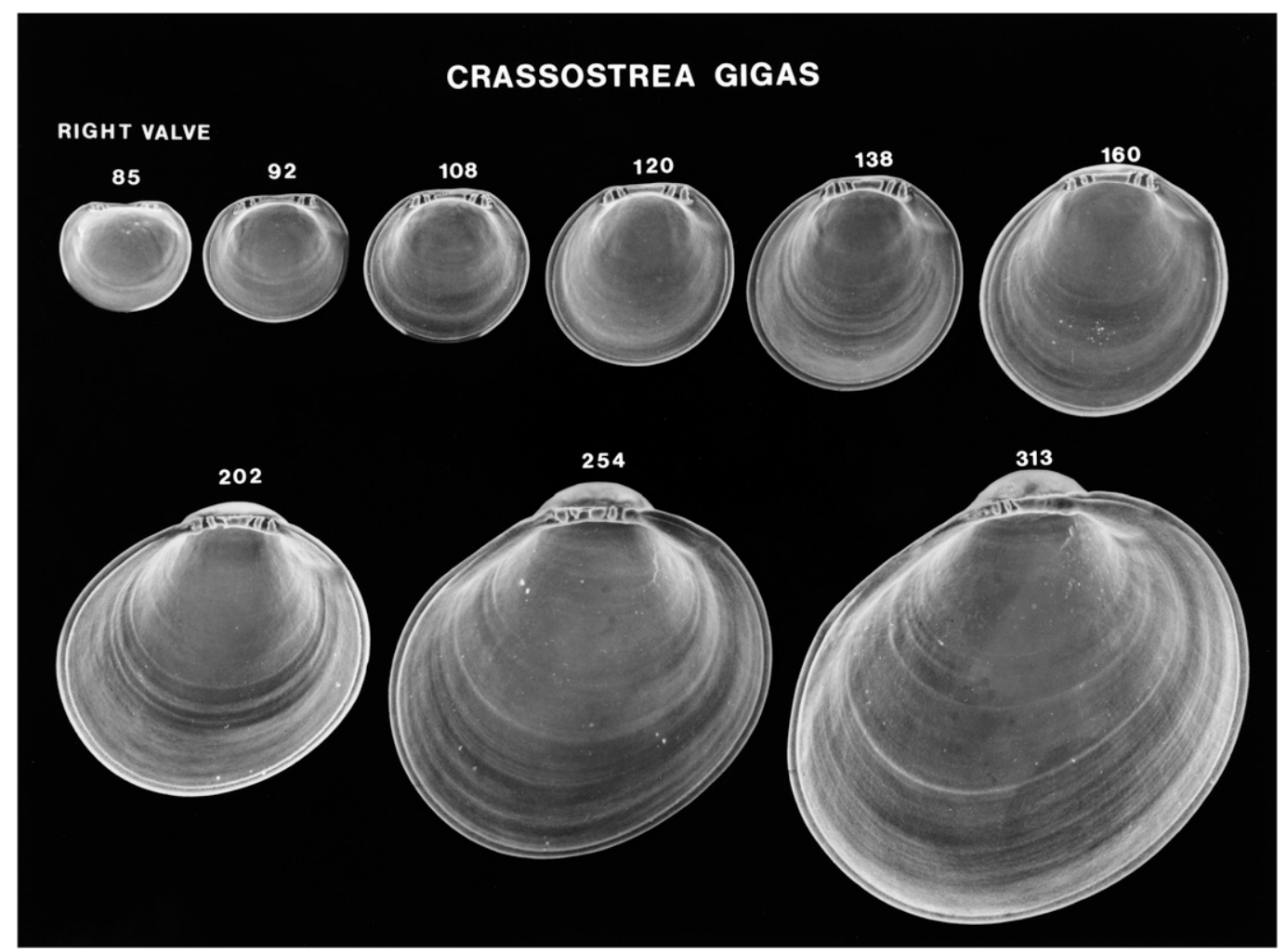

Figure 106. Scanning electron micrographs of disarticulated right shell valves of Crassostrea gigas larvae. Numbers indicate the maximum linear shell dimension in micrometers. Modified from Hu et al. (1993). 


\section{CRASSOSTREA GIGAS}

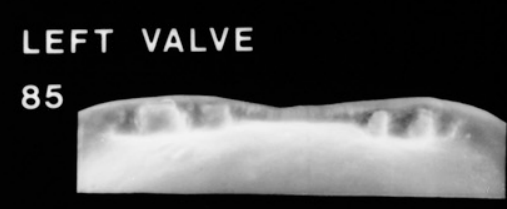

92

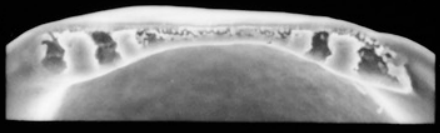

104

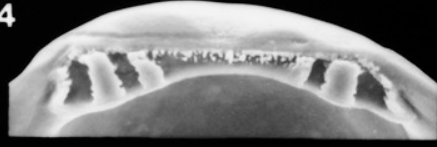

127

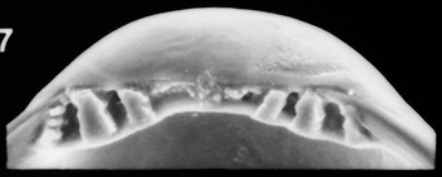

147

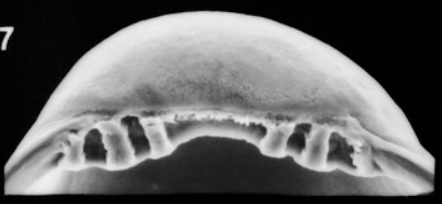

170

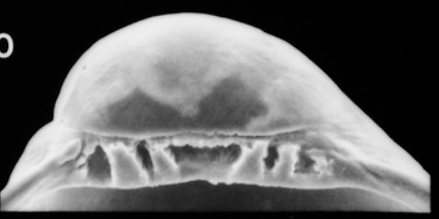

194

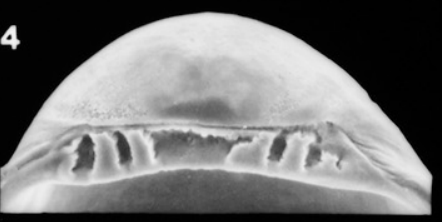

255
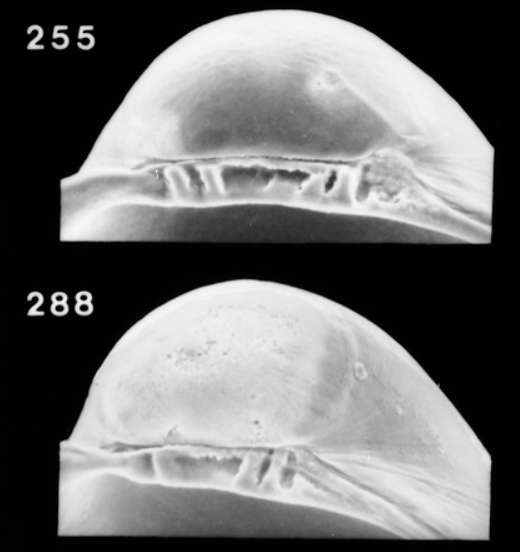

RIGHT VALVE

85

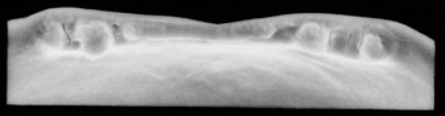

92

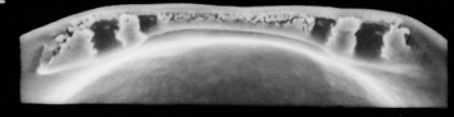

108

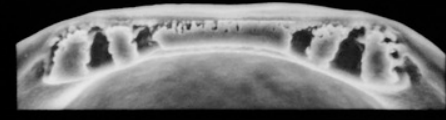

120

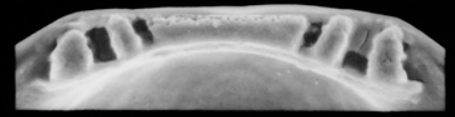

138

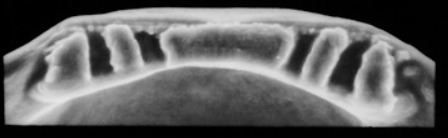

160

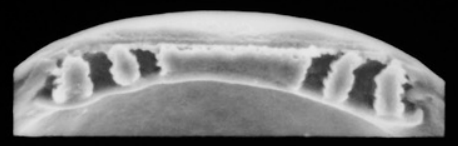

202

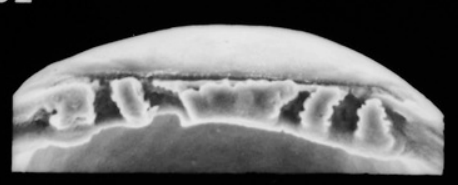

254

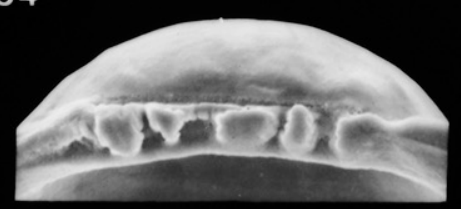

313

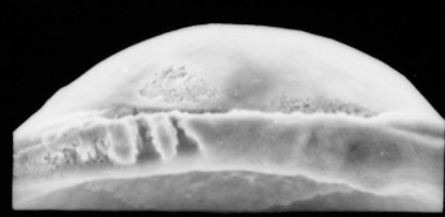

Figure 107. Scanning electron micrographs of the hinge of disarticulated shell valves of Crassostrea gigas larvae seen in Figures 105 and 106. Numbers indicate the maximum linear shell dimension in micrometers. Modified from Hu et al. (1993). 


\section{CRASSOSTREA GIGAS}

\section{LEFT VALVE}

363 475

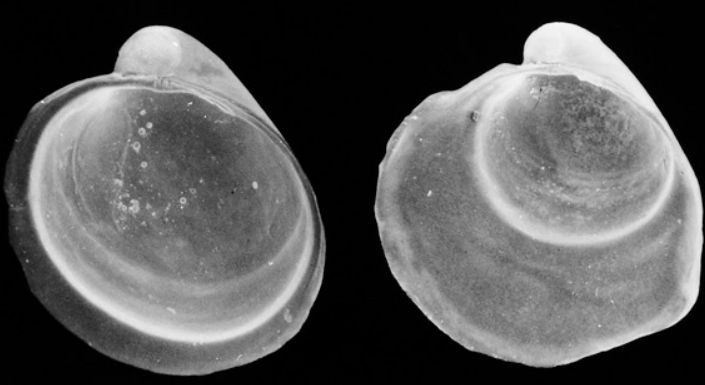

978
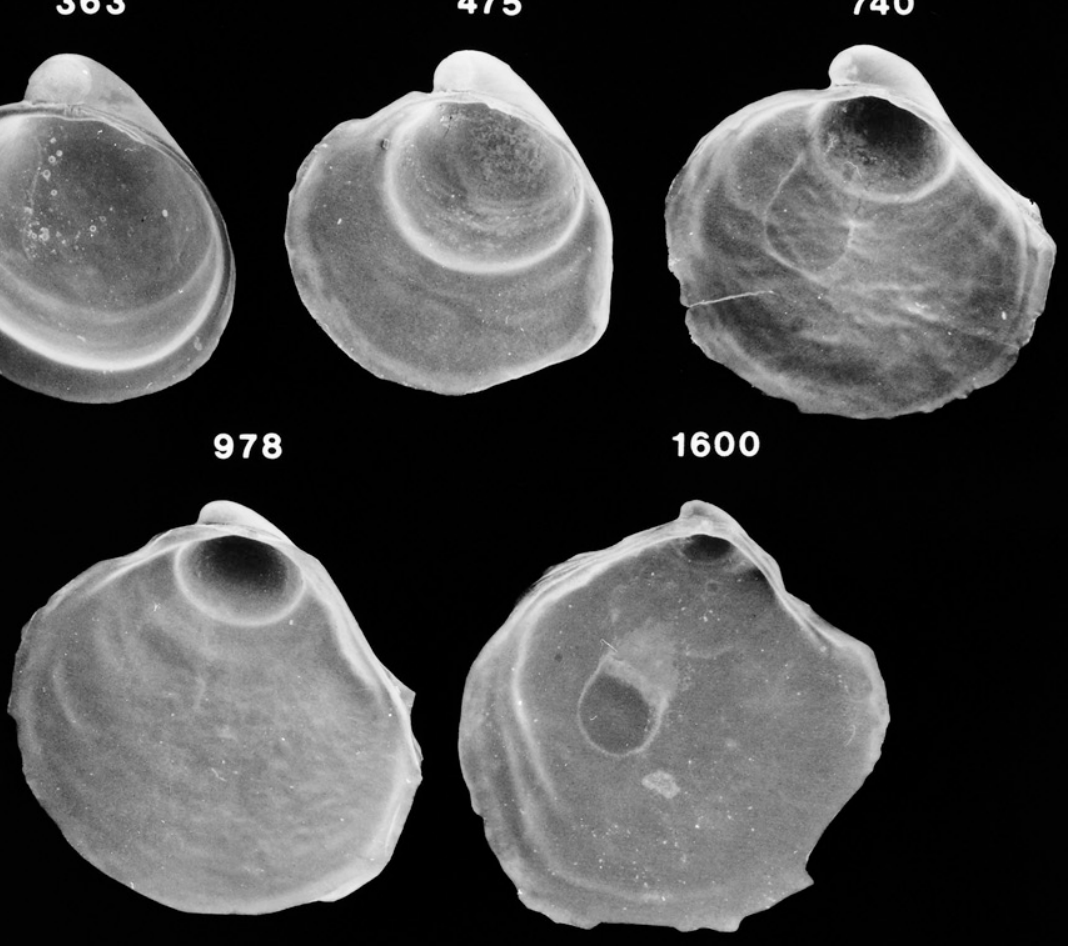

RIght VALVE

350

500

700

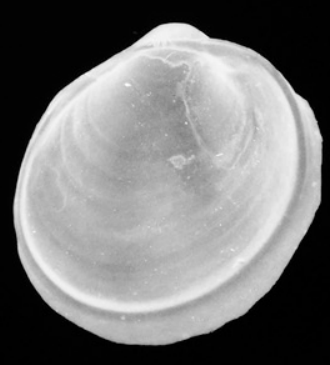

1010
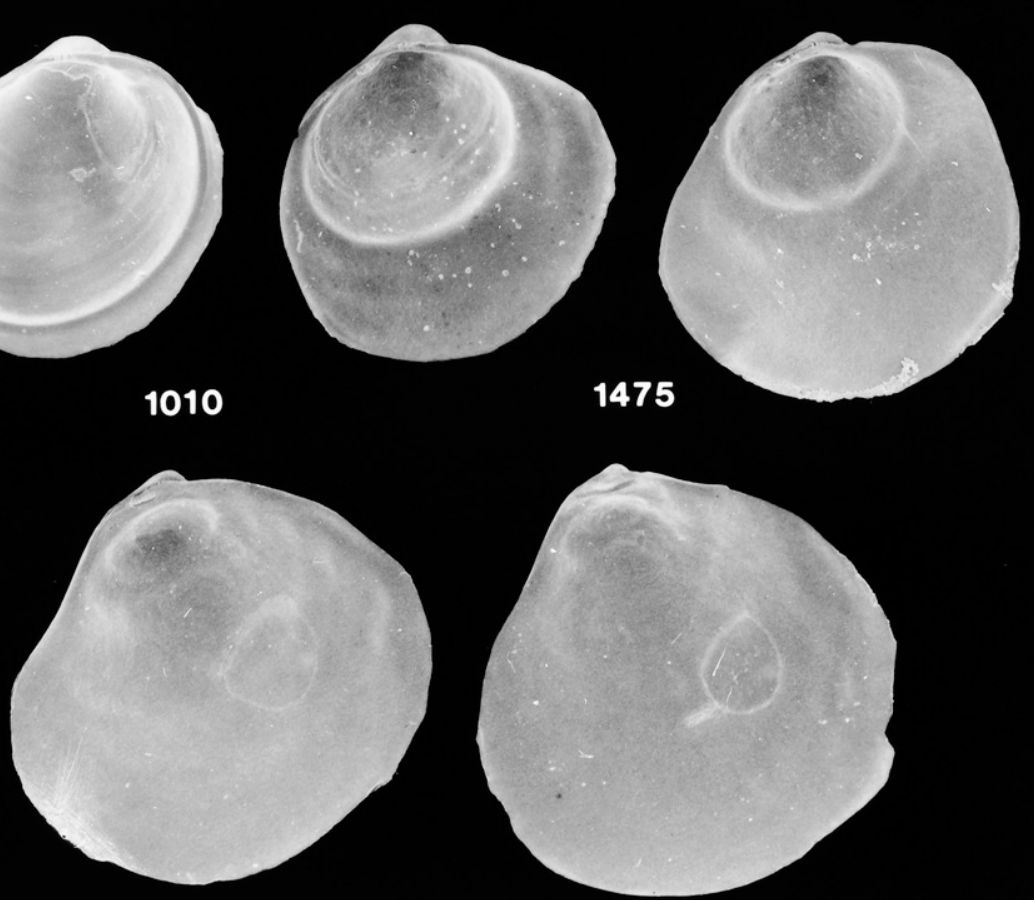

Figure 108. Scanning electron micrographs of disarticulated shell valves of Crassostrea gigas postlarvae. Numbers indicate the maximum linear shel dimension in micrometers. Modified from Hu et al. (1993). 


\section{CRASSOSTREA GIGAS}

\section{LEFT VALVE}

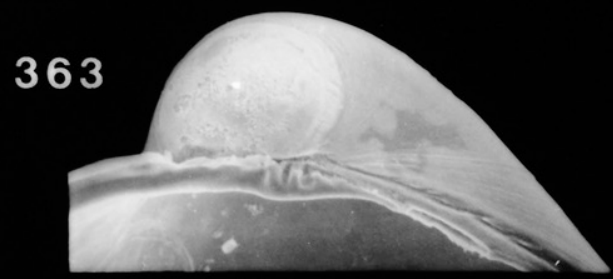

\section{5}

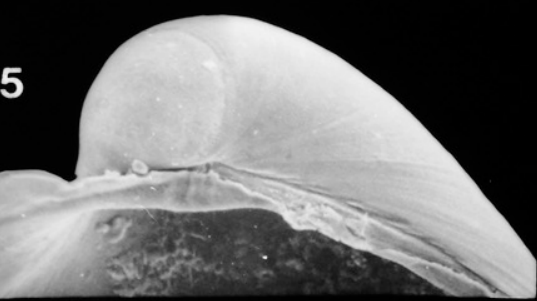

740

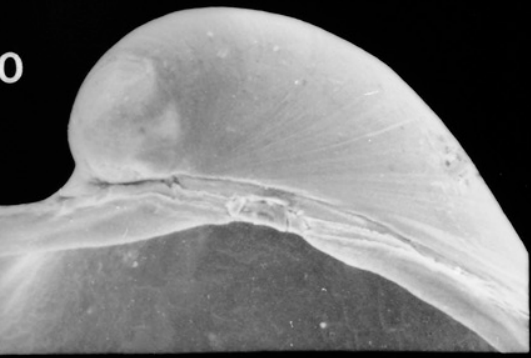

978

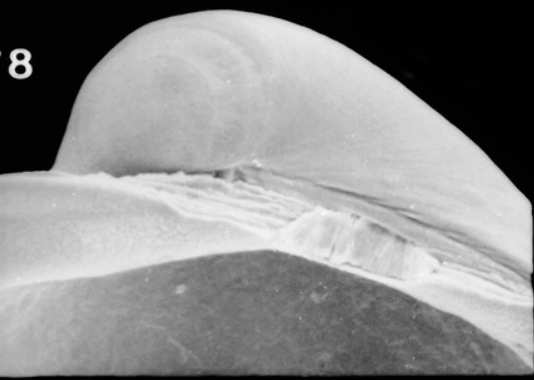

1600

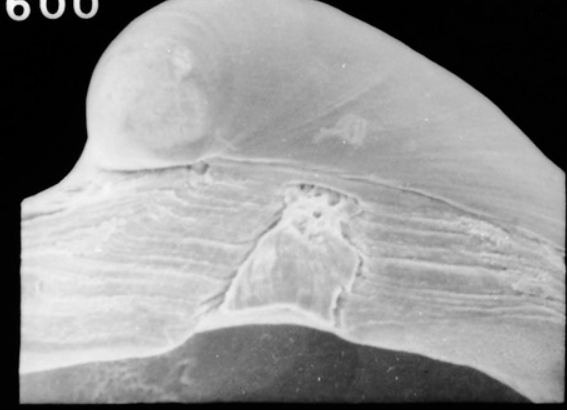

\section{RIGHT VALVE}

350

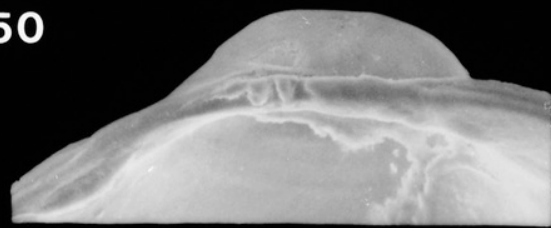

500

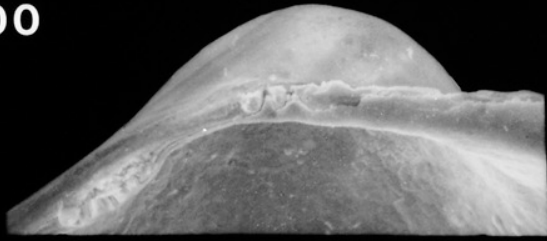

700

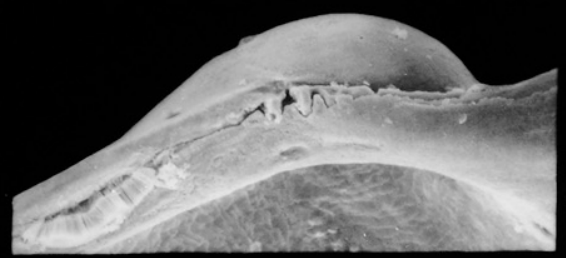

1010

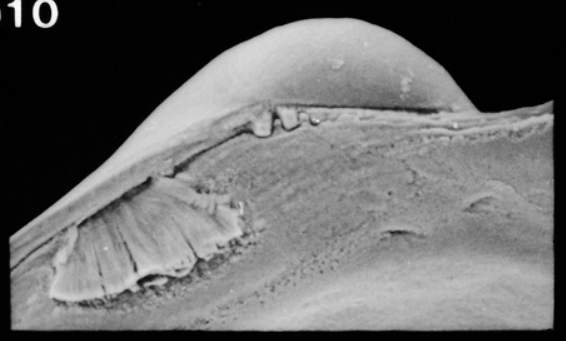

1475

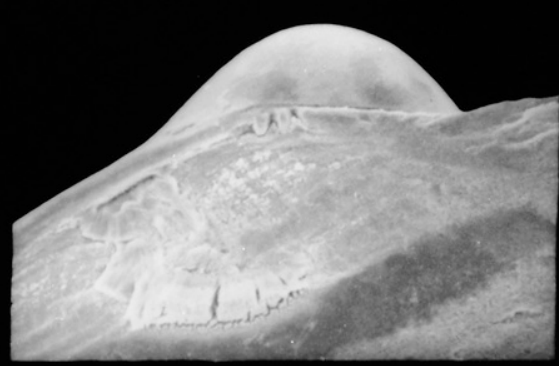

Figure 109. Scanning electron micrographs of the hinge of disarticulated shell valves of Crassostrea gigas postlarvae seen in Figure 108. Numbers indicate the maximum linear shell dimension in micrometers. Modified from Hu et al. (1993). 


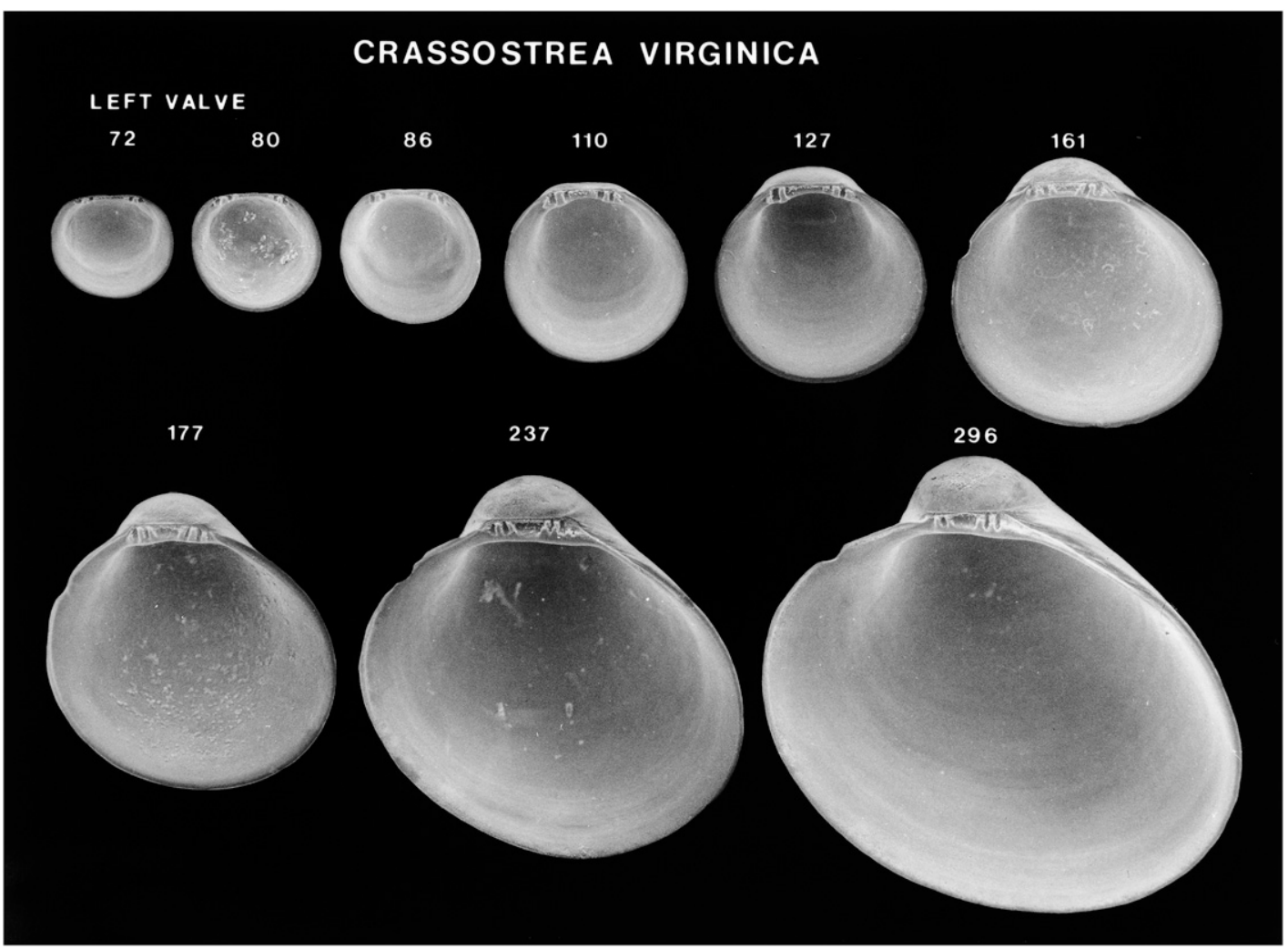

Figure 110. Scanning electron micrographs of disarticulated left shell valves of Crassostrea virginica larvae. Numbers indicate the maximum linear shell dimension in micrometers. Modified from Hu et al. (1993).

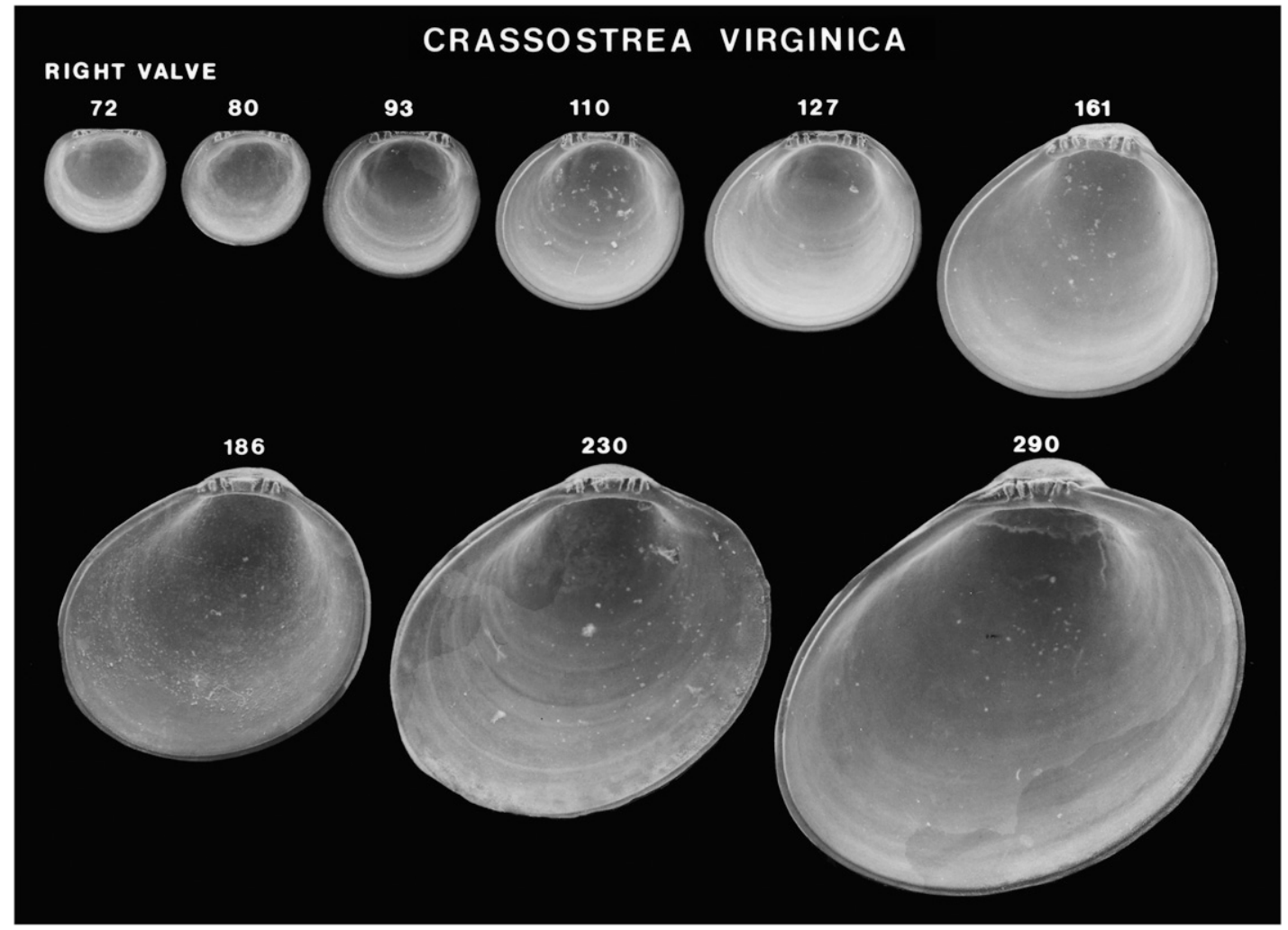

Figure 111. Scanning electron micrographs of disarticulated right shell valves of Crassostrea virginica larvae. Numbers indicate the maximum linear shell dimension in micrometers. Modified from Hu et al. (1993). 


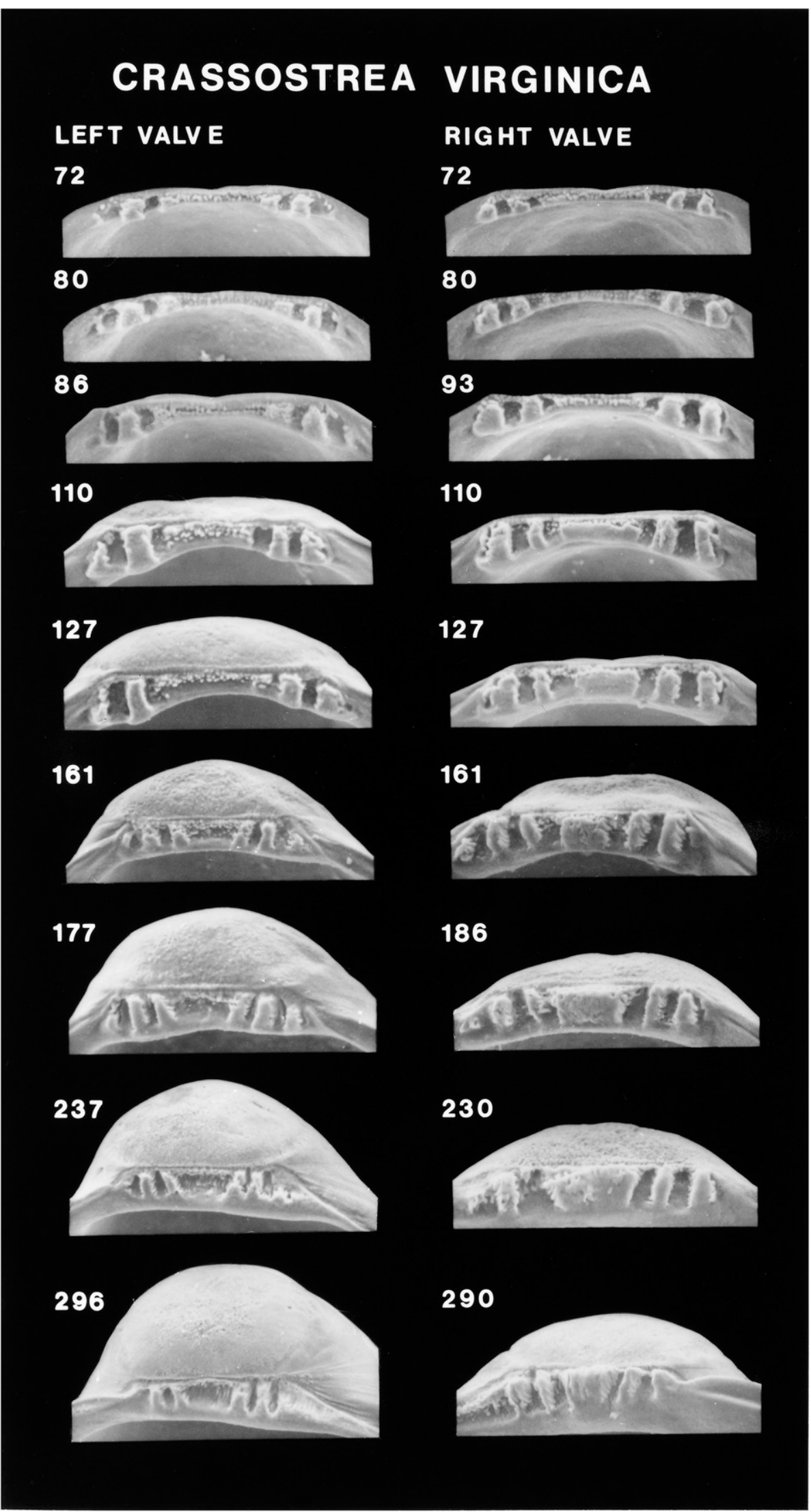

Figure 112. Scanning electron micrographs of the hinge of disarticulated shell valves of Crassostrea virginica larvae seen in Figures 110 and 111. Numbers indicate the maximum linear shell dimension in micrometers. Modified from Hu et al. (1993). 


\section{CRASSOSTREA VIRGINICA}

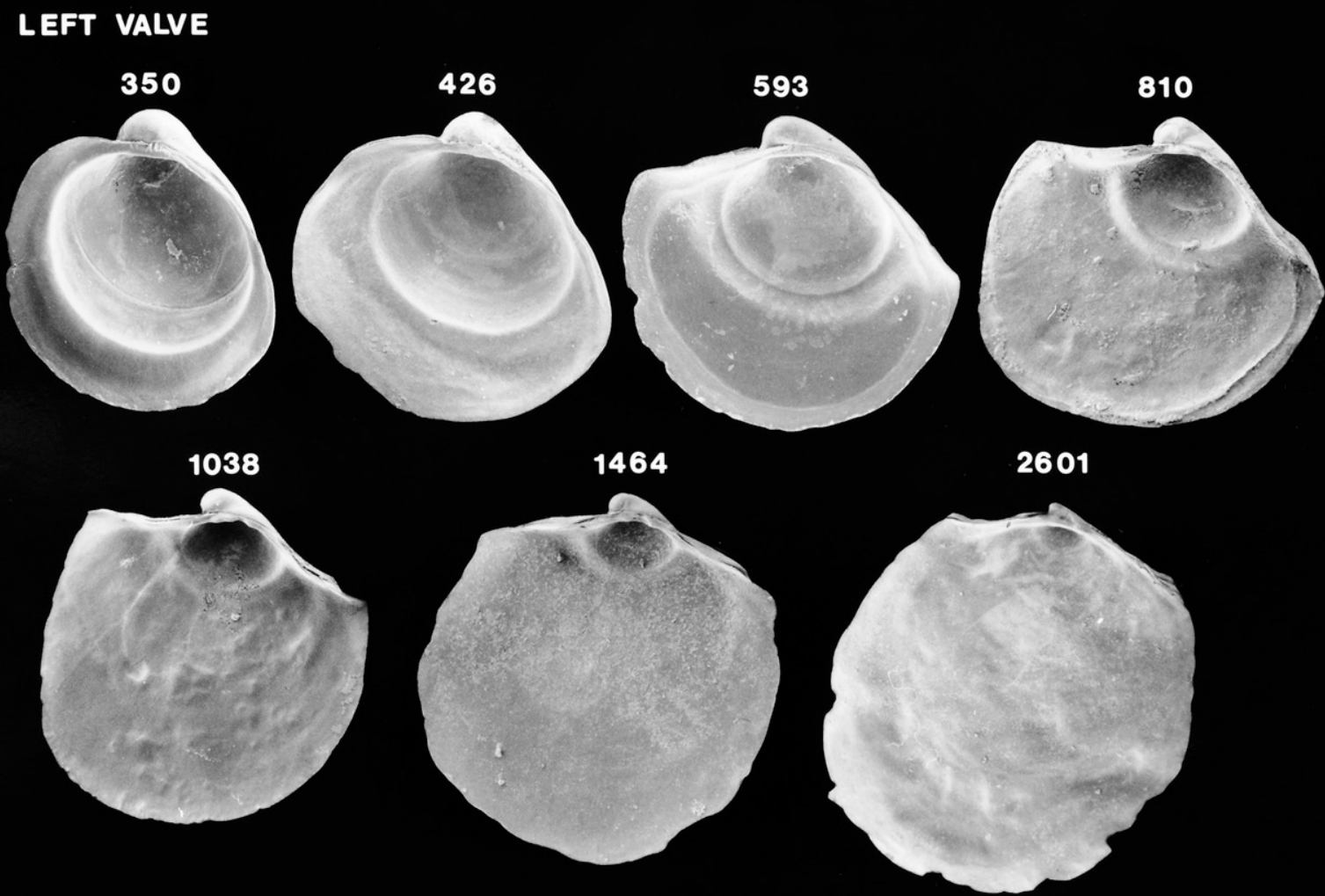

RIGHT VALVE

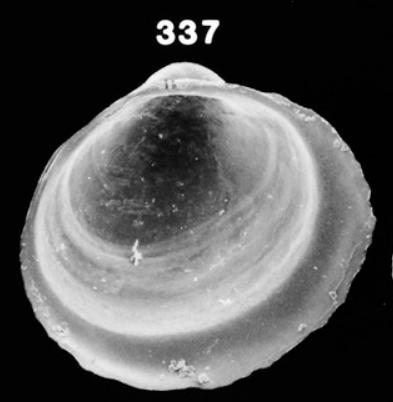

337

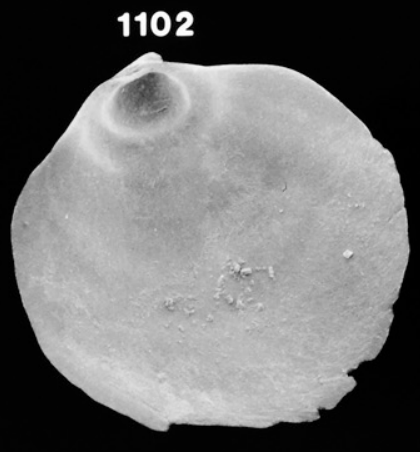

468

540

881

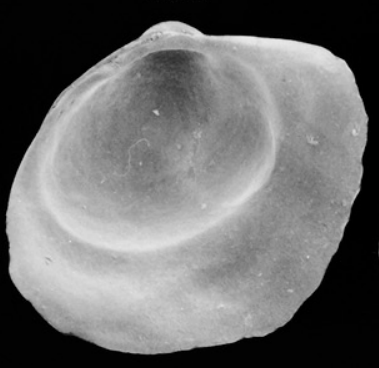

1656
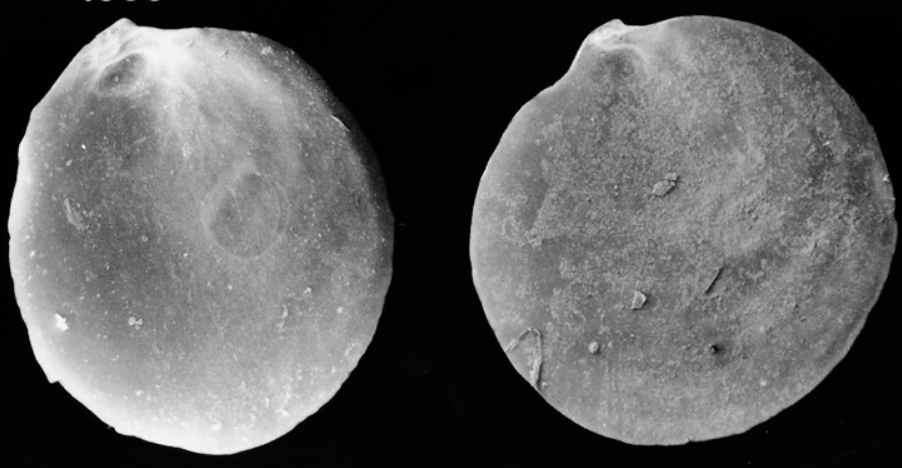

Figure 113. Scanning electron micrographs of disarticulated shell valves of Crassostrea virginica postlarvae. Numbers indicate the maximum linear shell dimension in micrometers. Modified from Hu et al. (1993). 


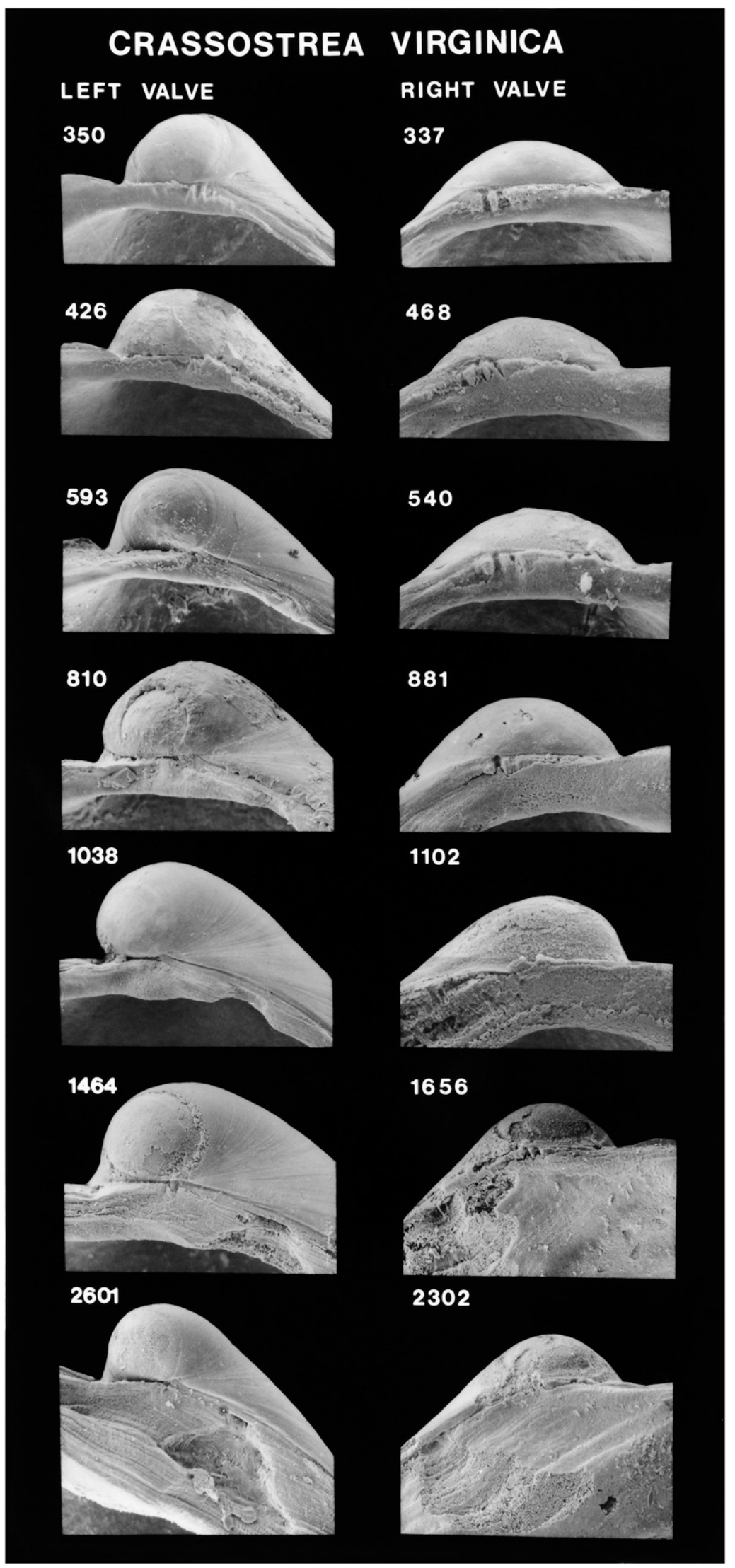

Figure 114. Scanning electron micrographs of the hinge of disarticulated shell valves of Crassostrea virginica postlarvae seen in Figure 113. Numbers indicate the maximum linear shell dimension in micrometers. Modified from Hu et al. (1993). 


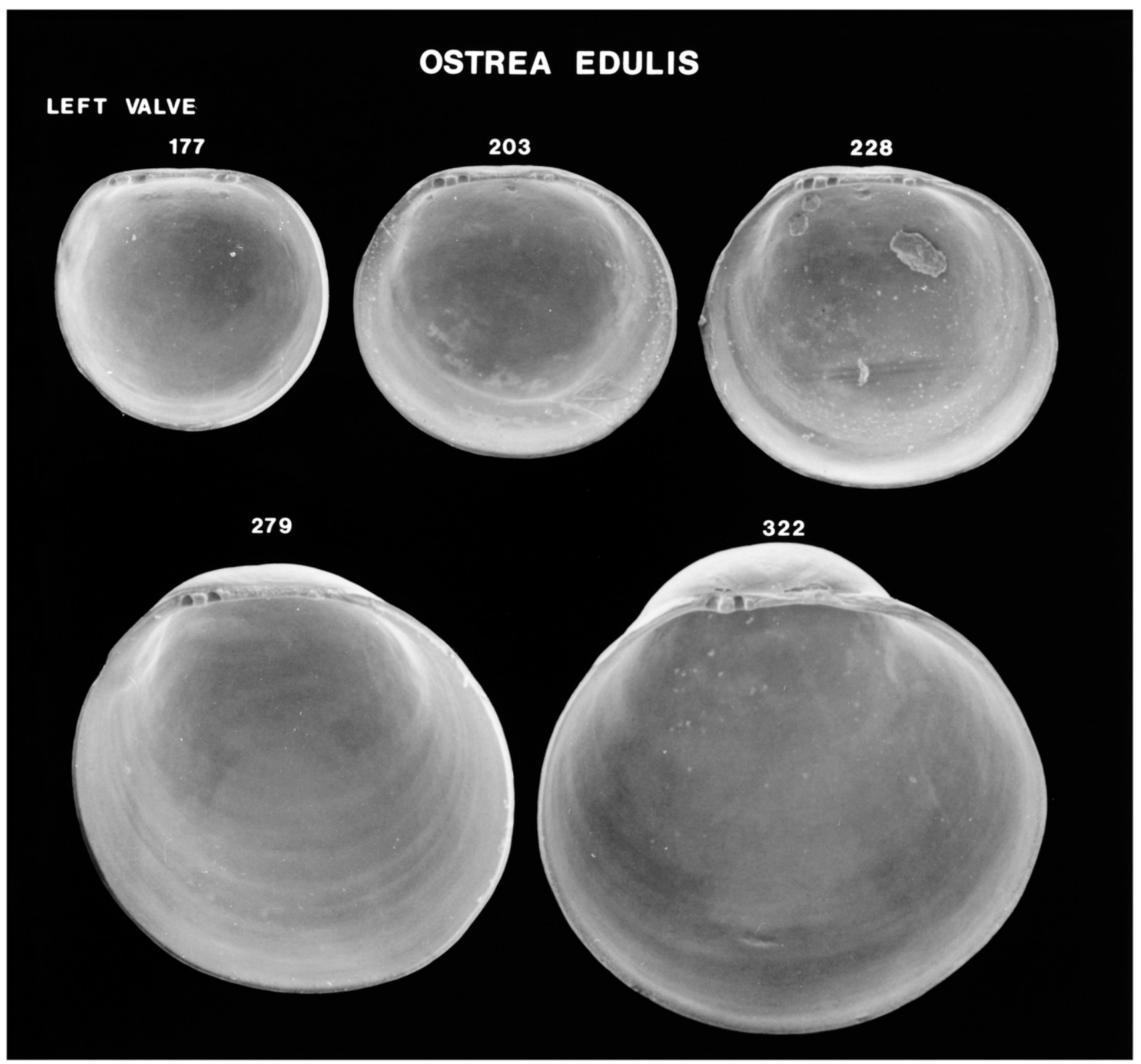

Figure 115. Scanning electron micrographs of disarticulated left shell valves of Ostrea edulis larvae. Numbers indicate the maximum linear shell dimension in micrometers. Modified from Hu et al. (1993). 


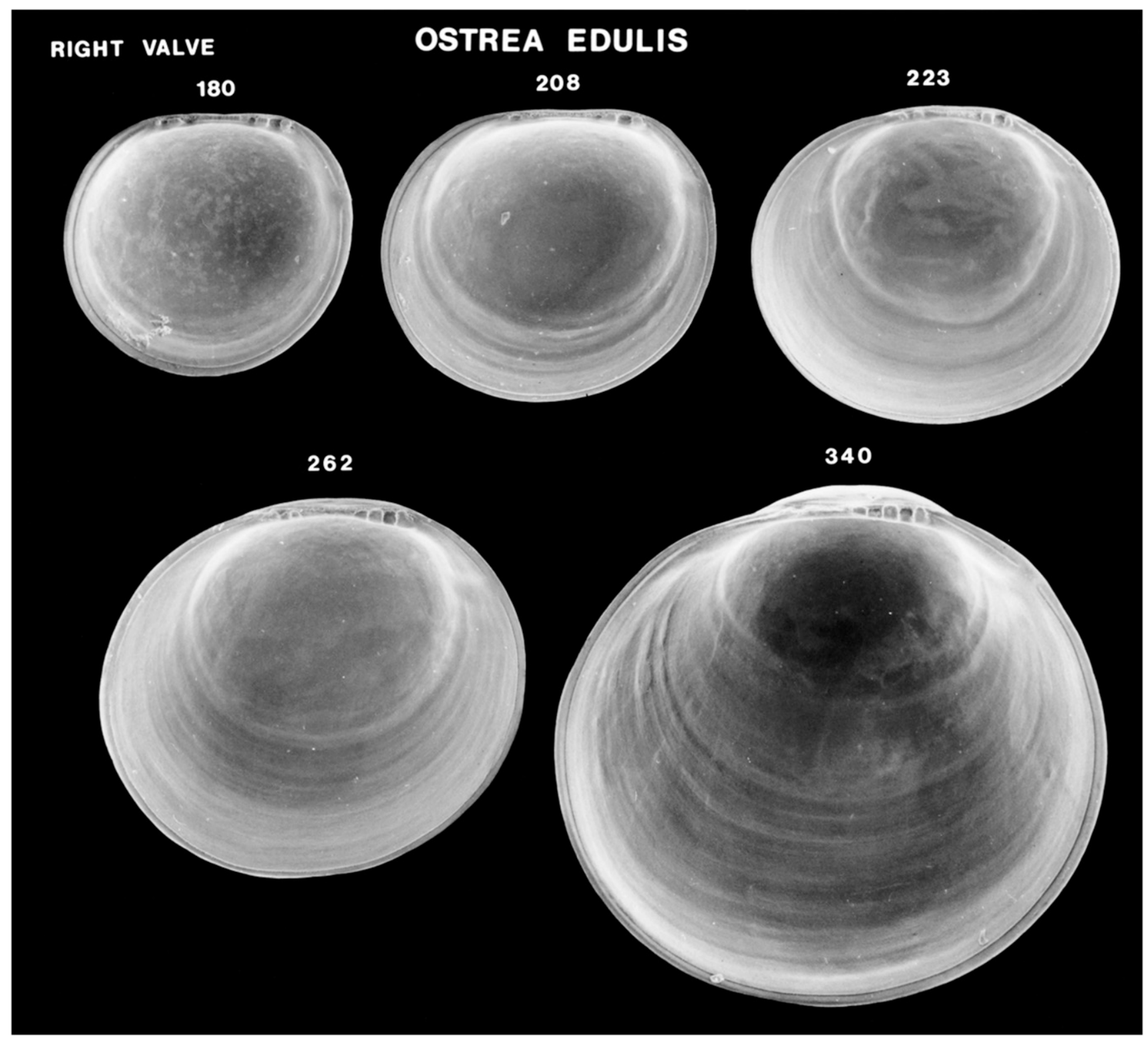

Figure 116. Scanning electron micrographs of disarticulated right shell valves of Ostrea edulis larvae. Numbers indicate the maximum linear shell dimension in micrometers. Modified from Hu et al. (1993). 


\section{OSTREA EDULIS}

\section{LEFT VALVE}

\section{7}

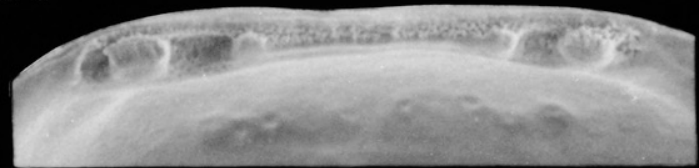

\section{3}

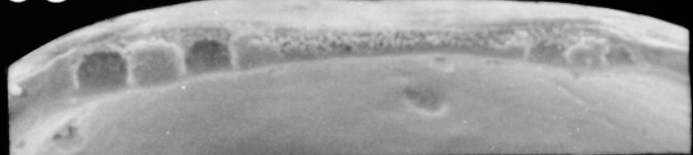

\section{8}
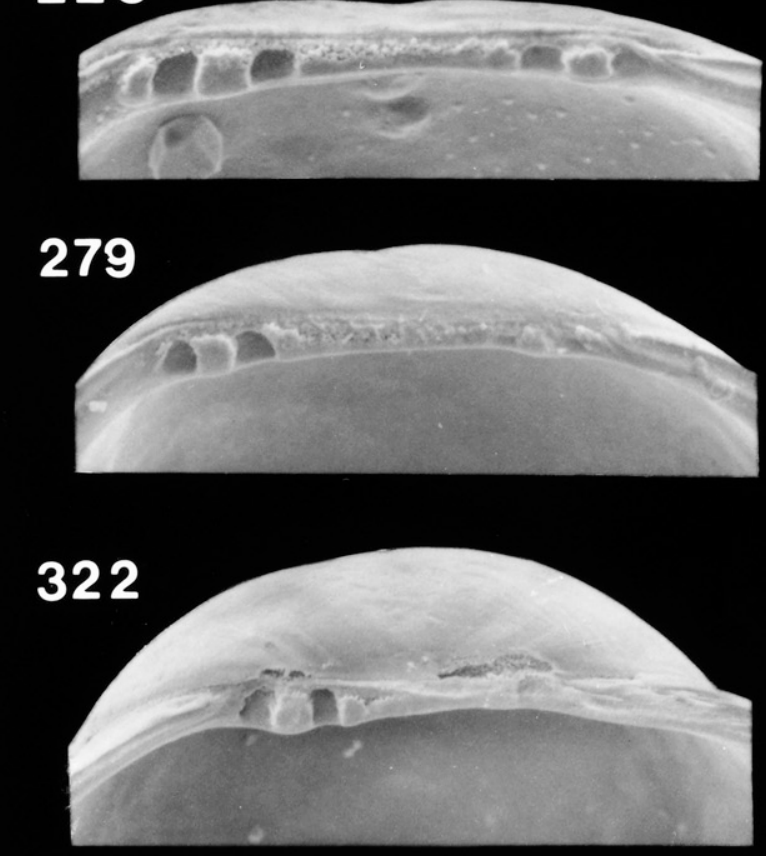

\section{RIGHT VALVE}

\section{0}

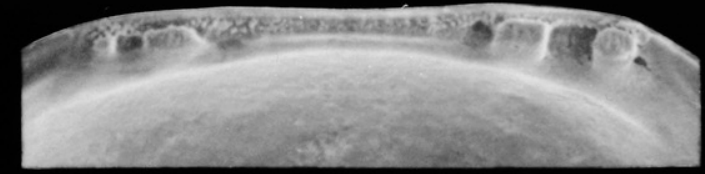

\section{8}

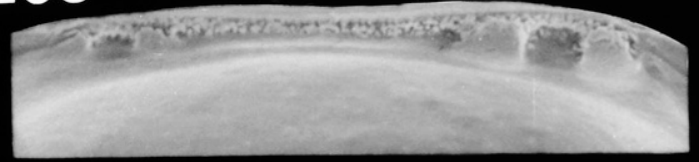

\section{3}

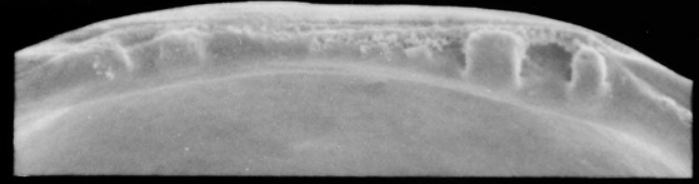

\section{2}

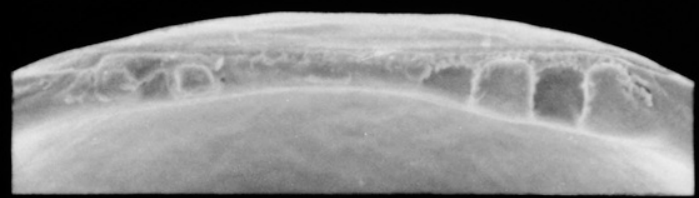

\section{0}

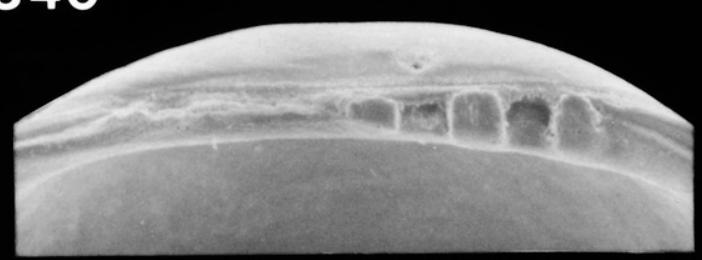

Figure 117. Scanning electron micrographs of the hinge of disarticulated shell valves of Ostrea edulis larvae seen in Figures 115 and 116. Numbers indicate the maximum linear shell dimension in micrometers. Modified from Hu et al. (1993). 


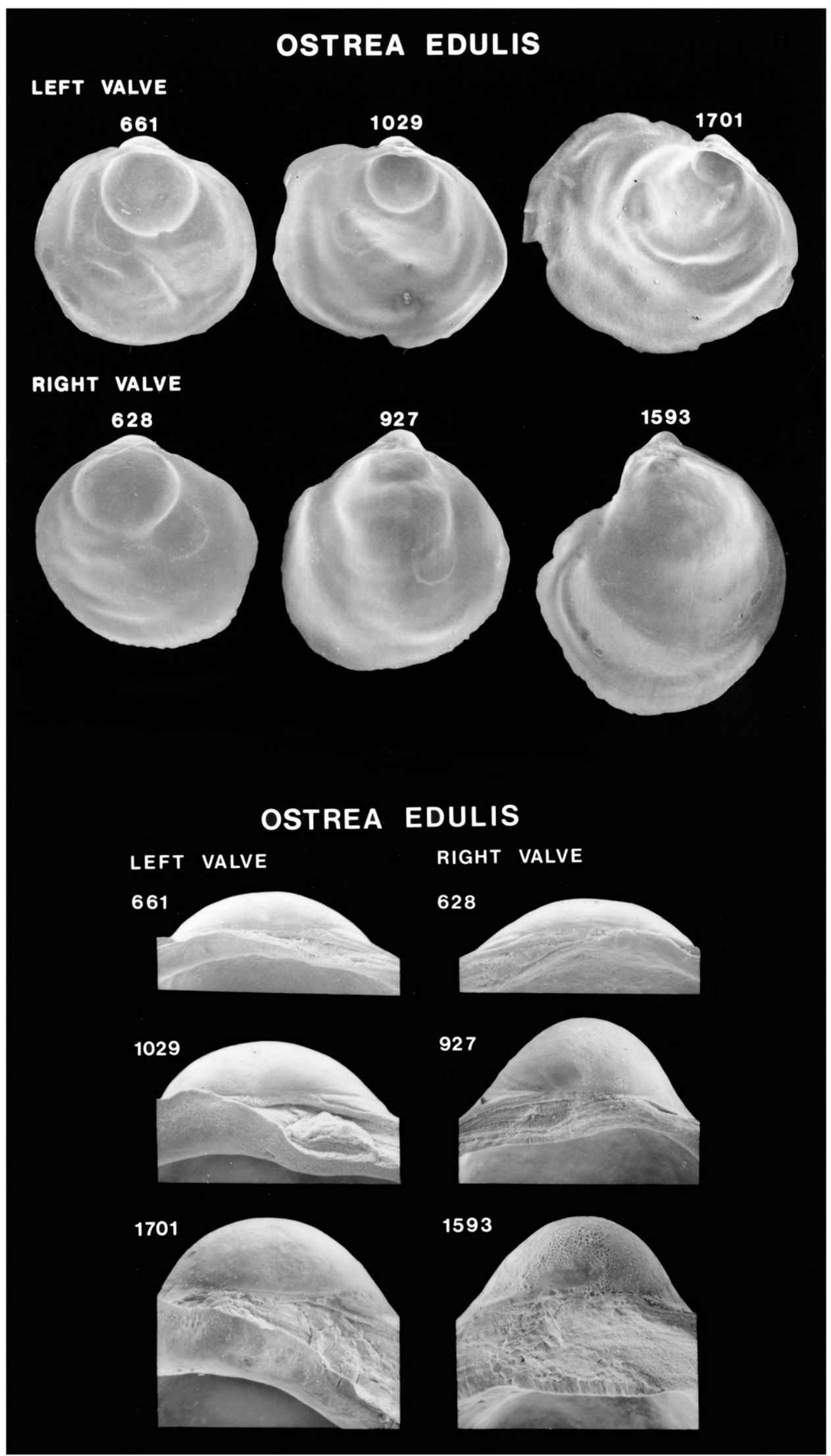

Figure 118. Scanning electron micrographs of disarticulated shell valves of $O$ strea edulis postlarvae (top) and higher magnification scanning electron micrographs of the hinge of these shell valves (bottom). Numbers indicate the maximum linear shell dimension in micrometers. Modified from Hu et al. (1993). 


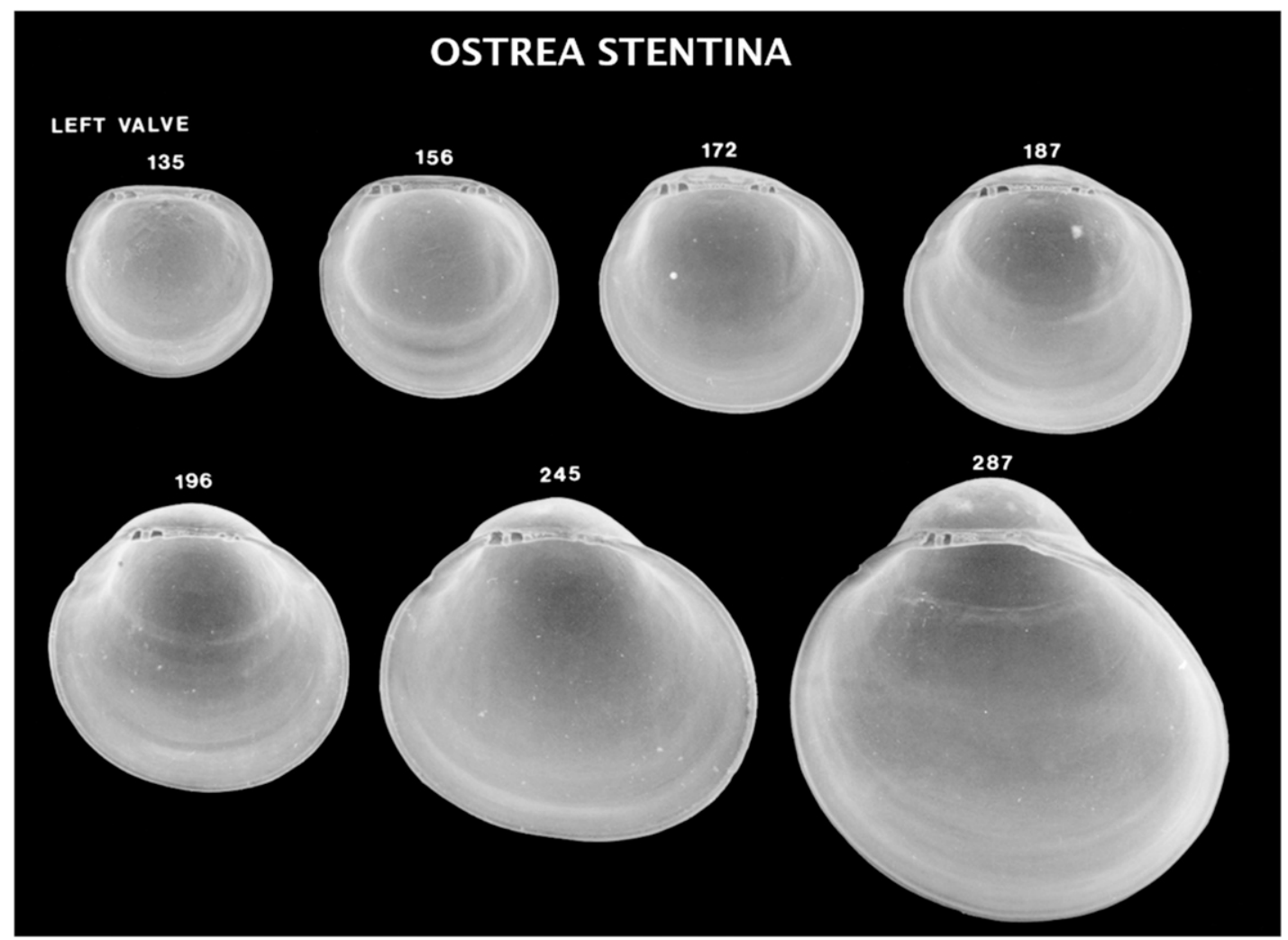

Figure 119. Scanning electron micrographs of disarticulated left shell valves of Ostrea stentina larvae. Numbers indicate the maximum linear shell dimension in micrometers. Modified from Hu et al. (1993).

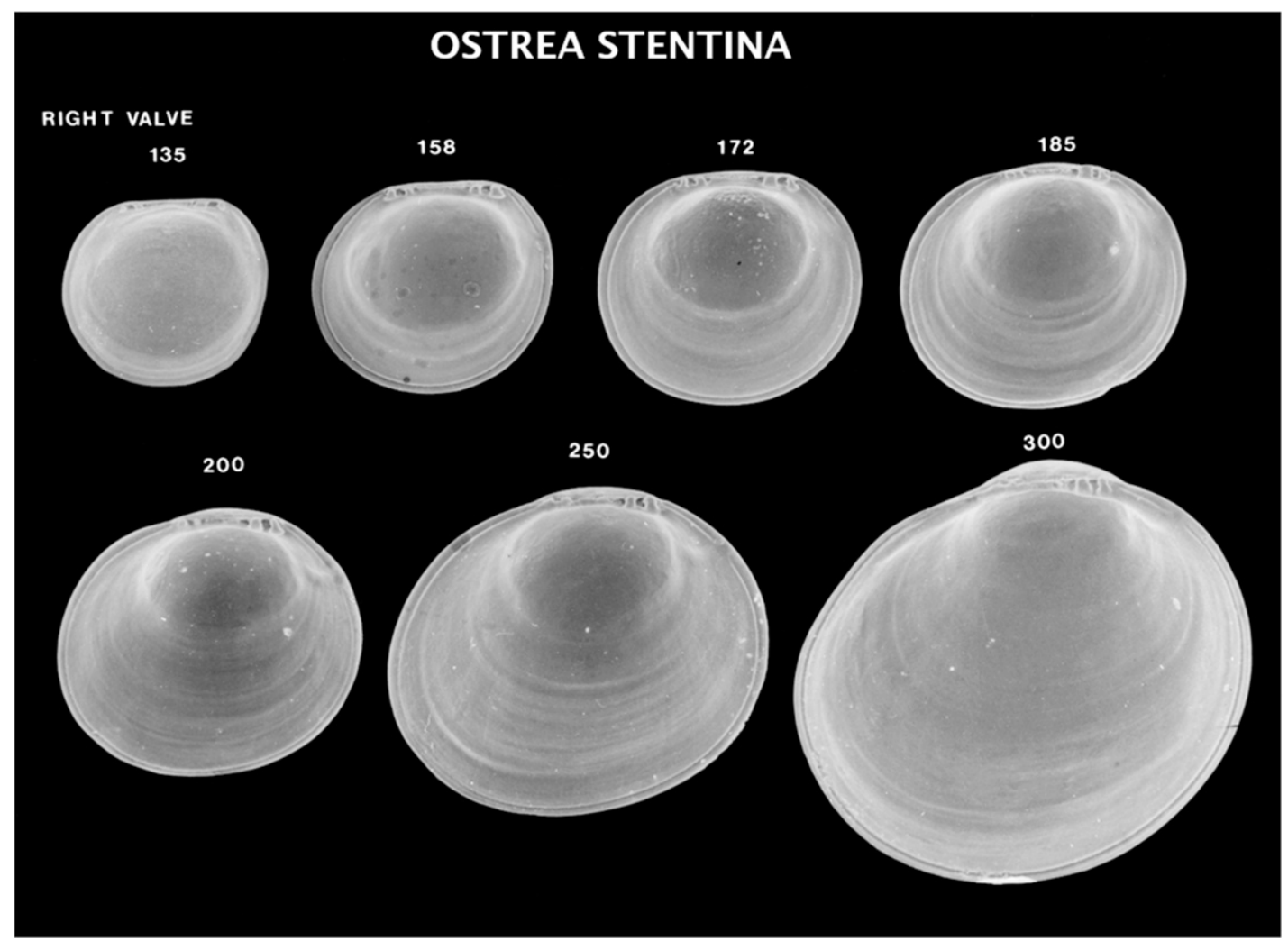

Figure 120. Scanning electron micrographs of disarticulated right shell valves of Ostrea stentina larvae. Numbers indicate the maximum linear shell dimension in micrometers. Modified from Hu et al. (1993). 


\section{OSTREA STENTINA}

\section{LEFT VALVE}

\section{5}

156
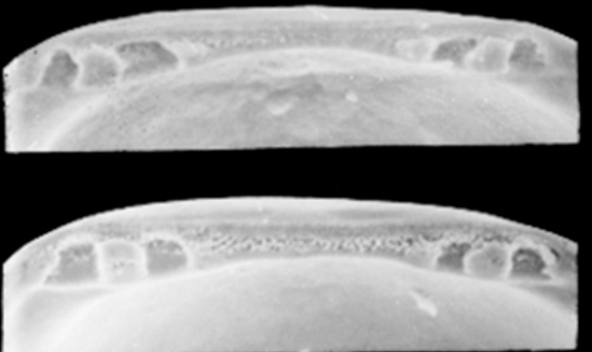

172

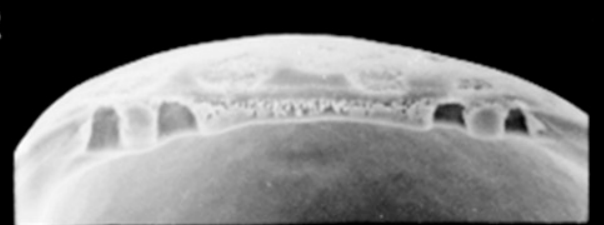

187

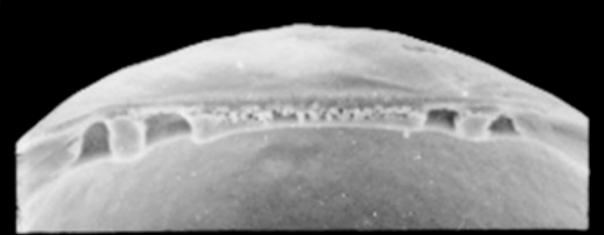

196

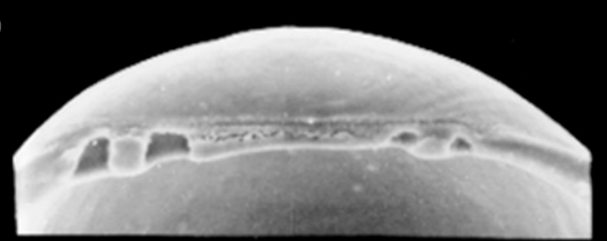

245

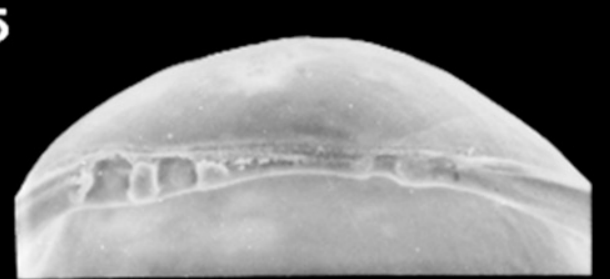

288

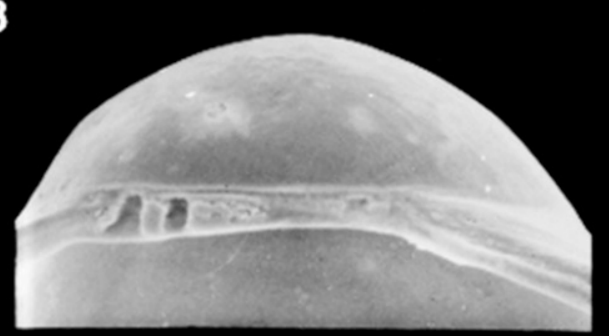

\section{RIGHT VALVE}

135

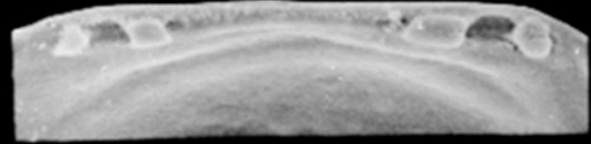

158

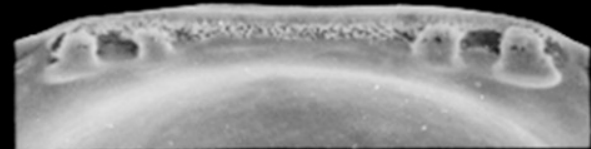

172

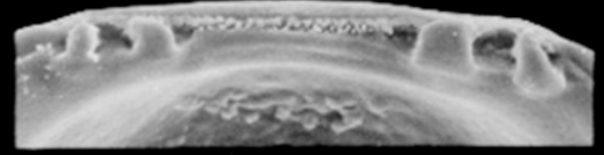

185

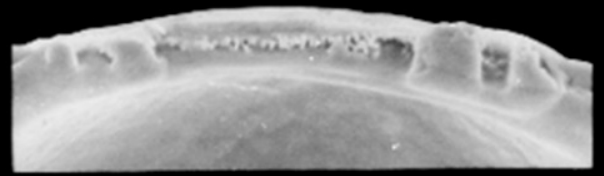

\section{0}

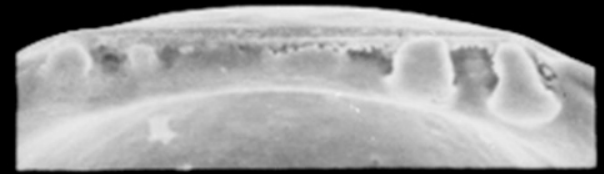

250

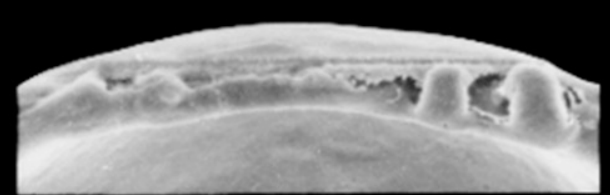

300

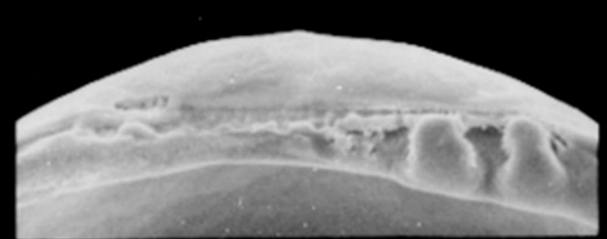

Figure 121. Scanning electron micrographs of the hinge of disarticulated shell valves of Ostrea stentina larvae seen in Figures 119 and 120 . Numbers indicate the maximum linear shell dimension in micrometers. Modified from Hu et al. (1993). 


\section{OSTREA STENTINA}
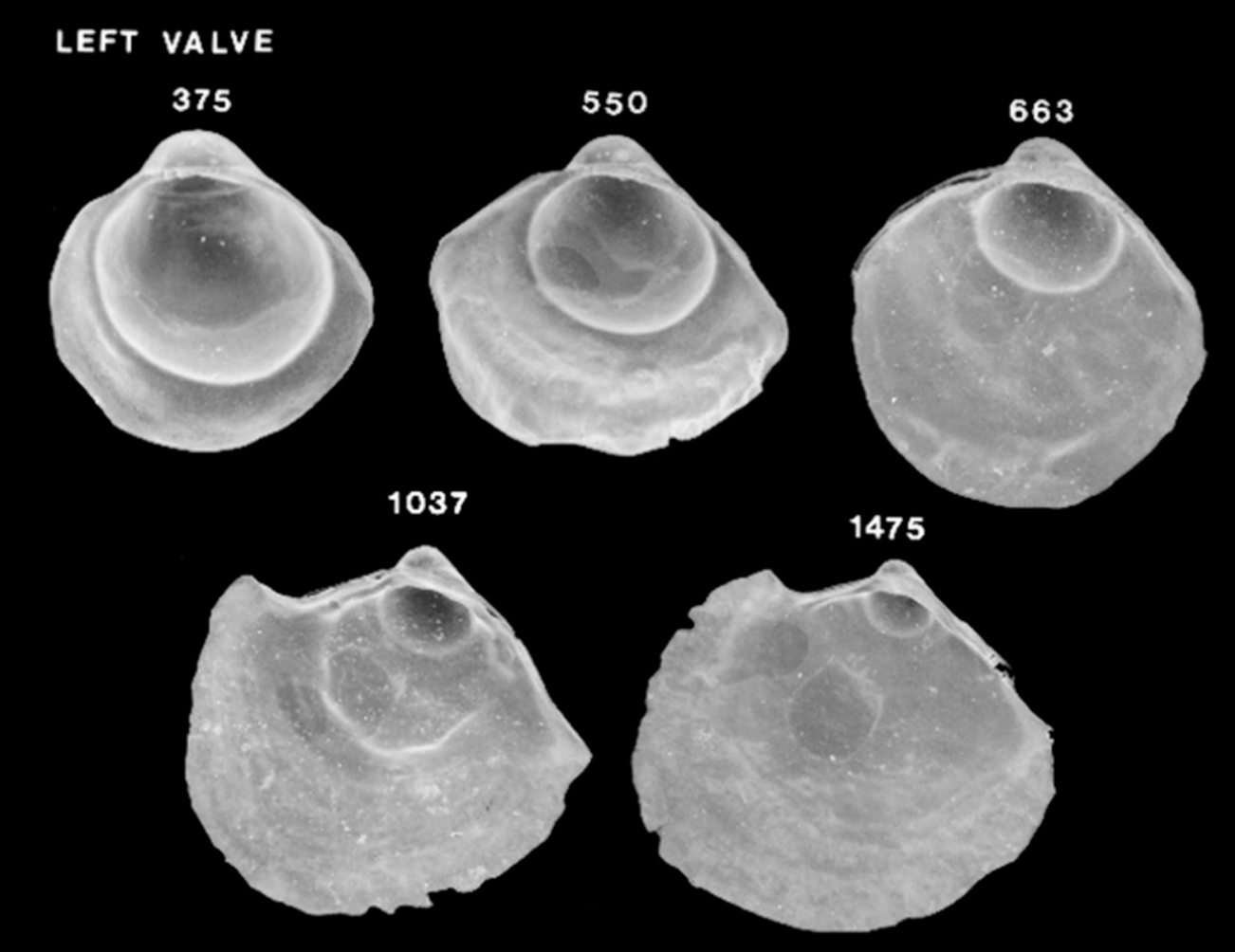

\section{RIGHT VALVE}
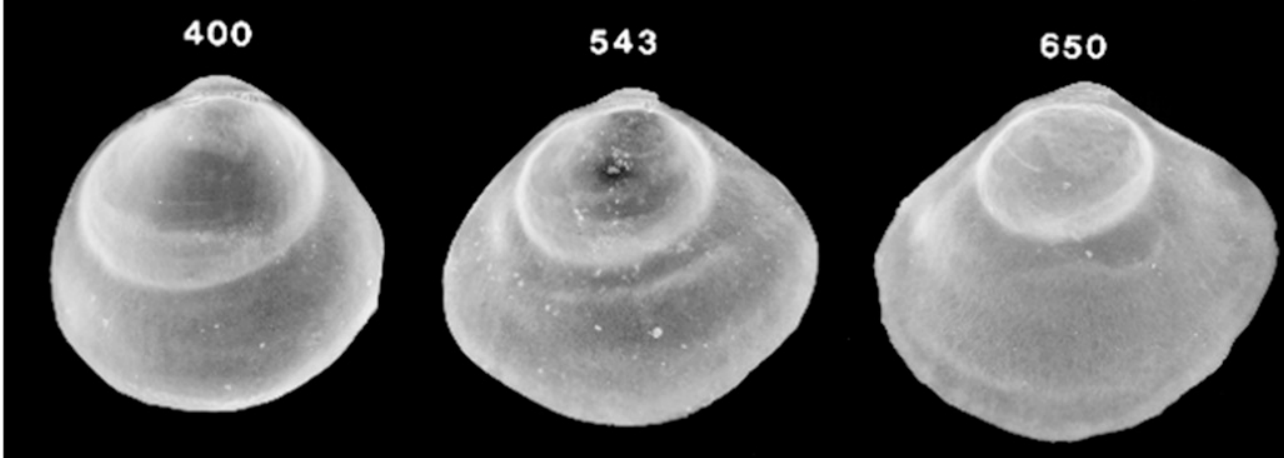

894

1525

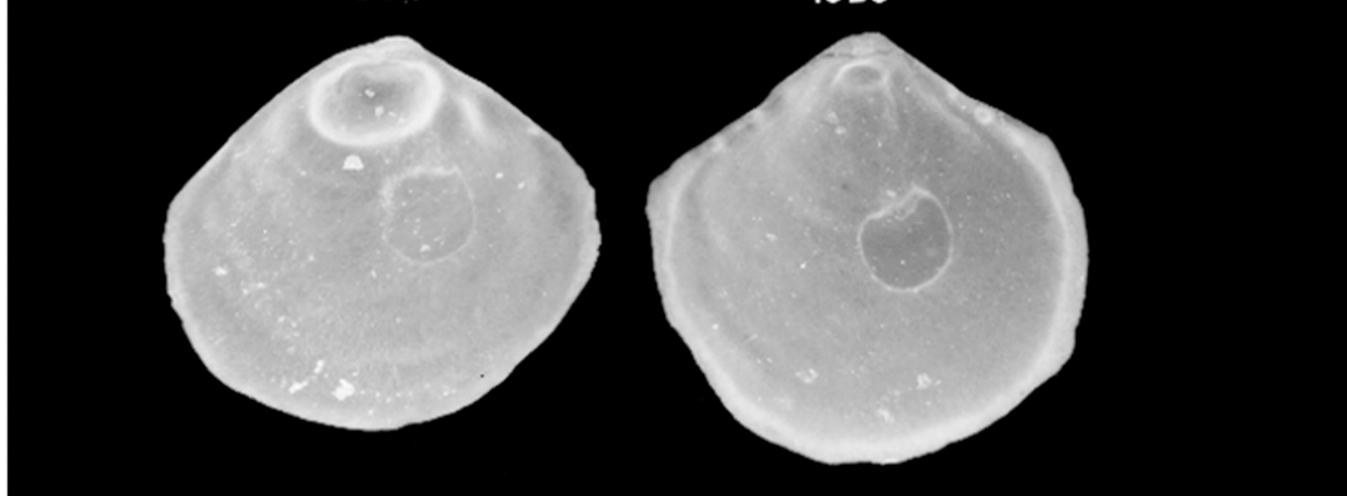

Figure 122. Scanning electron micrographs of disarticulated shell valves of Ostrea stentina postlarvae. Numbers indicate the maximum linear shell dimension in micrometers. Modified from Hu et al. (1993). 


\section{OSTREA STENTINA}

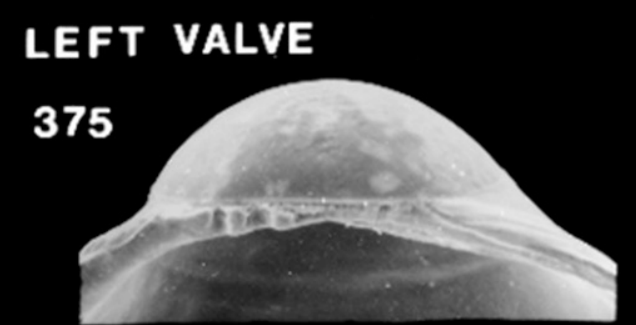

\section{RIGHT VALVE}

400
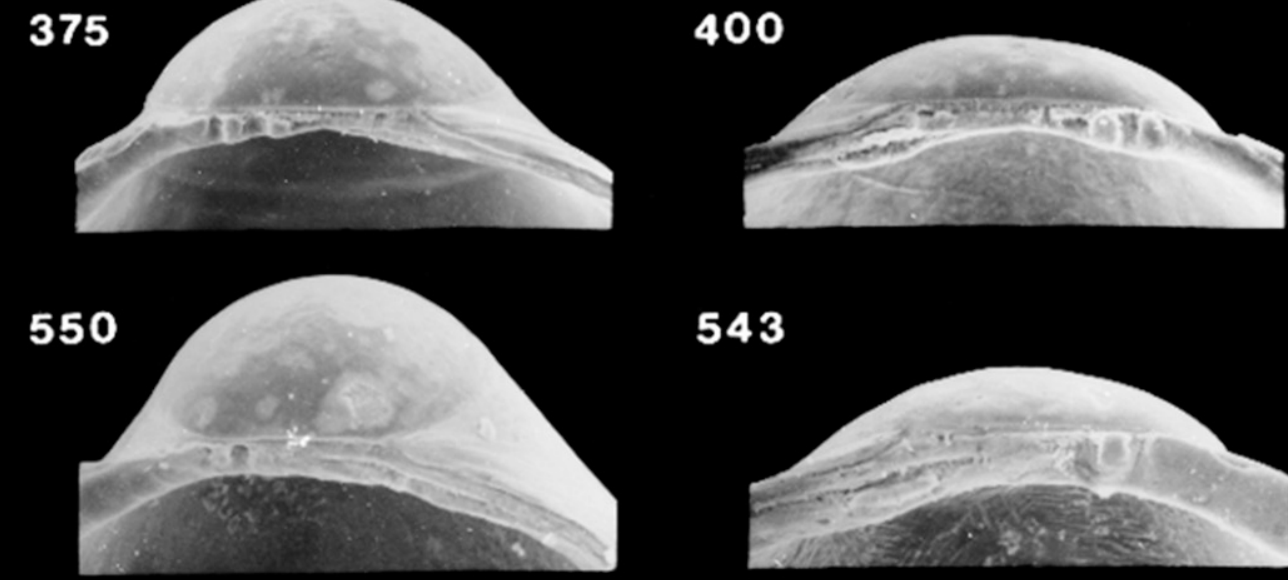

543
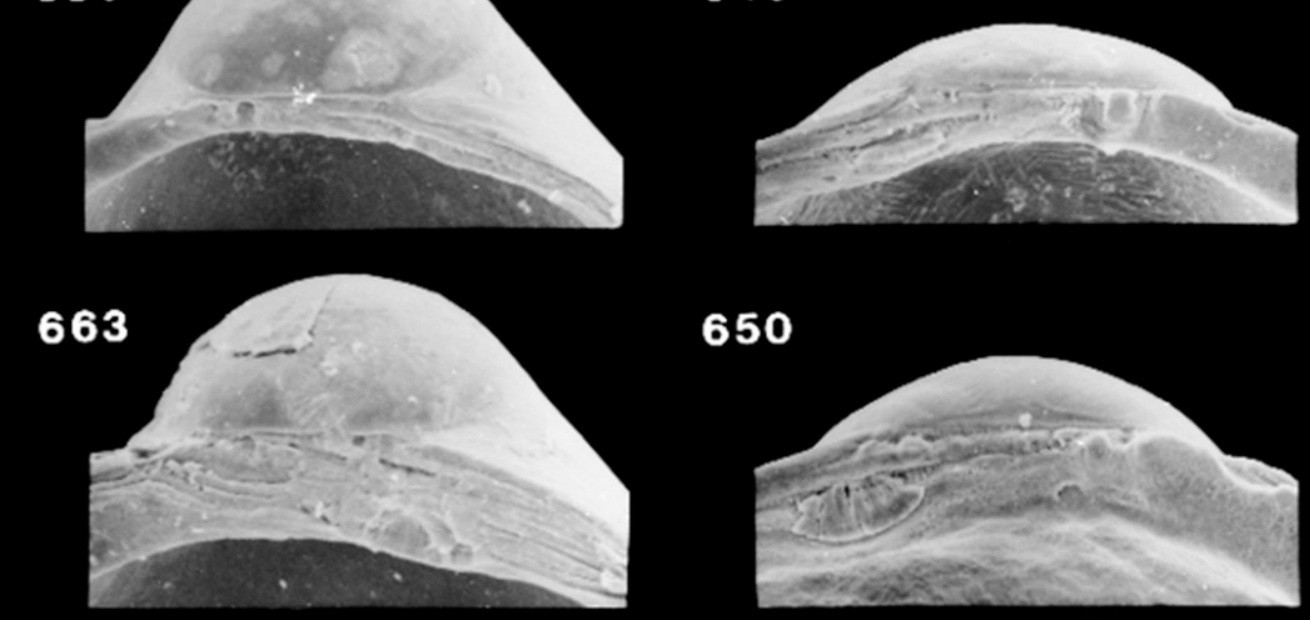

650
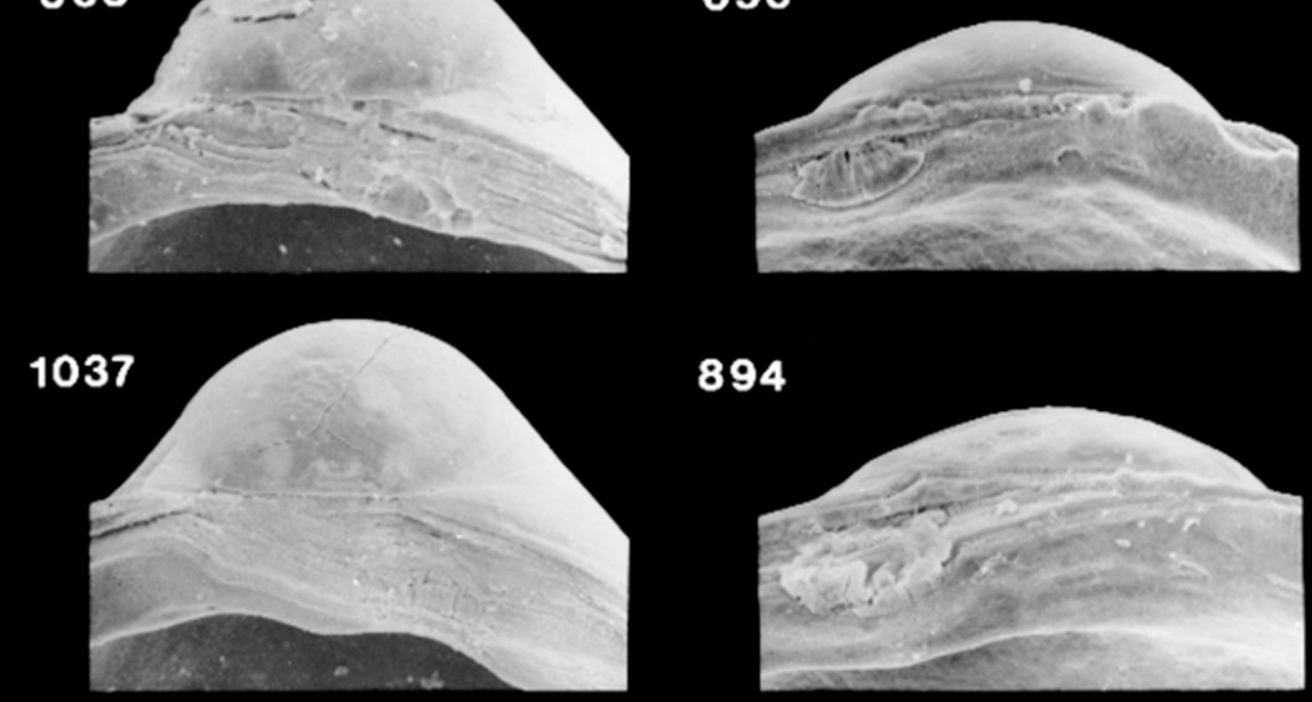

894
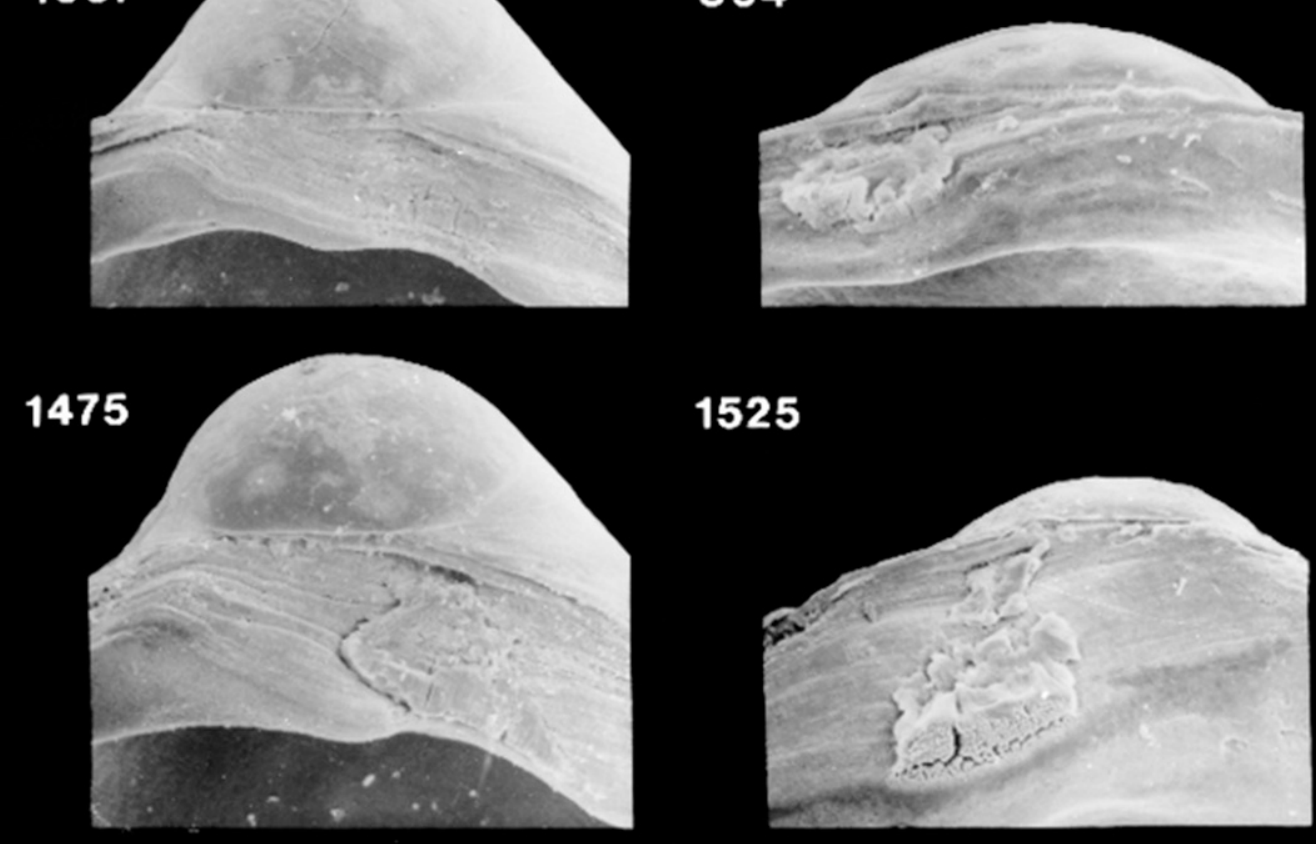

1525

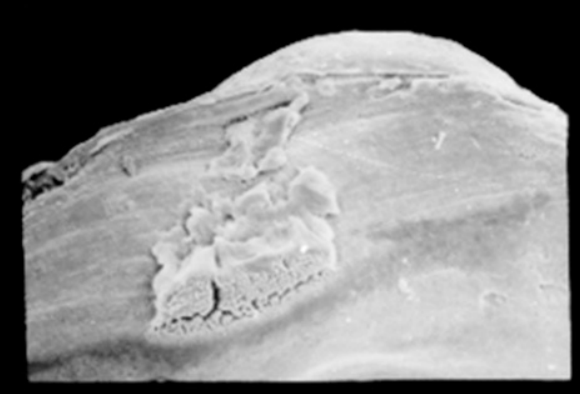

Figure 123. Scanning electron micrographs of the hinge of disarticulated shell valves of Ostrea stentina postlarvae seen in Figure 122 . Numbers indicate the maximum linear shell dimension in micrometers. Modified from Hu et al. (1993). 


\section{ANOMIA SIMPLEX}

\section{LEFT VALVE}

89

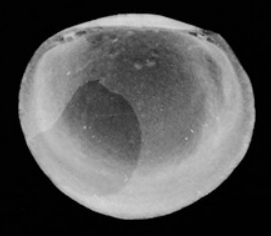

103
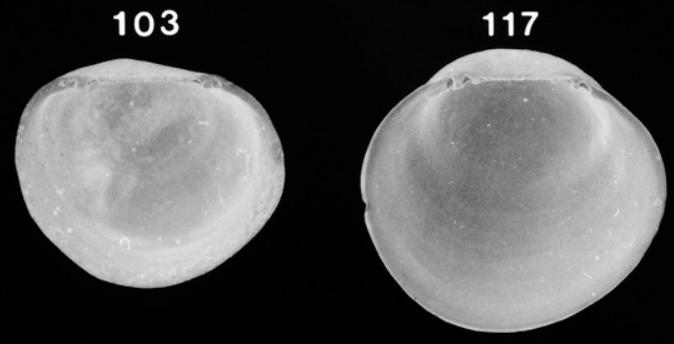

170

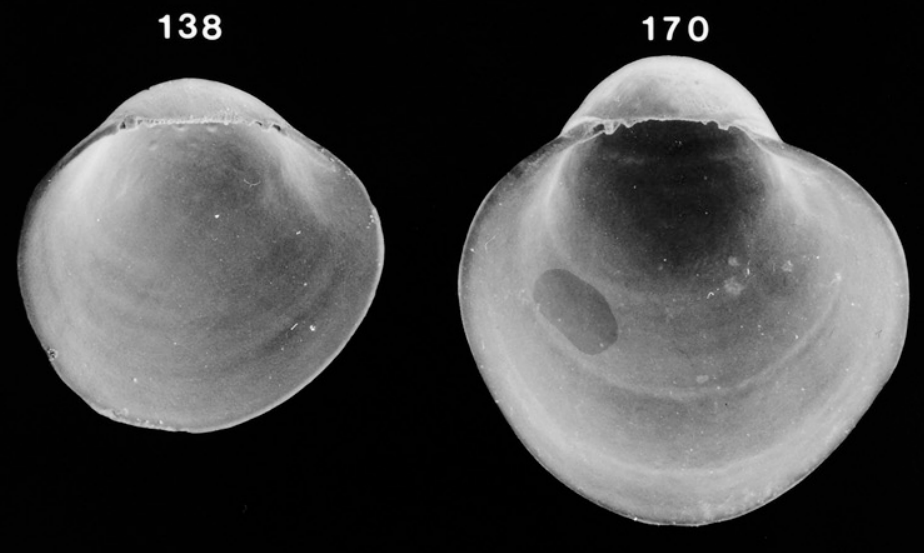

\section{RIGHT VALVE}

84

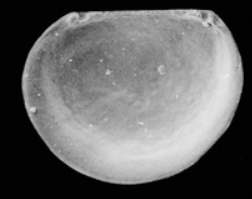

101

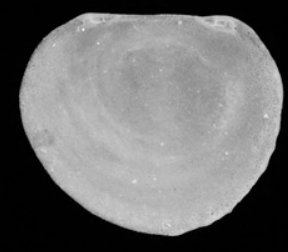

125
154

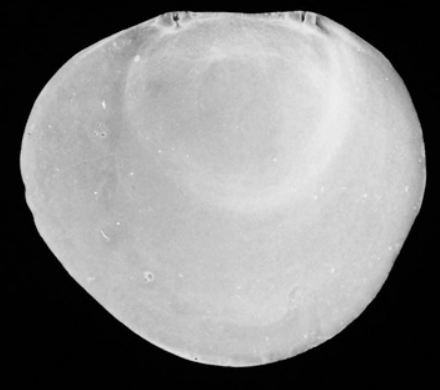

177

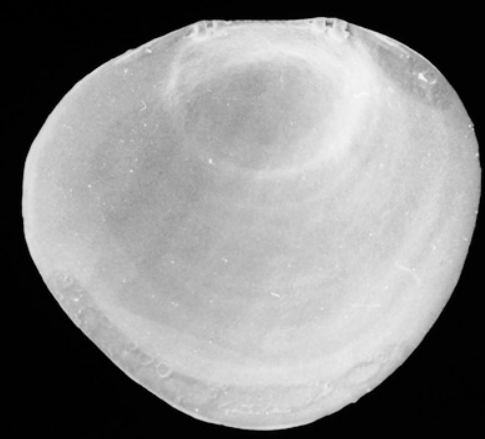

Figure 124. Scanning electron micrographs of disarticulated shell valves of Anomia simplex larvae. Numbers indicate the maximum linear shell dimension in micrometers. 


\section{ANOMIA SIMPLEX}

\section{LEFT VALVE}

89

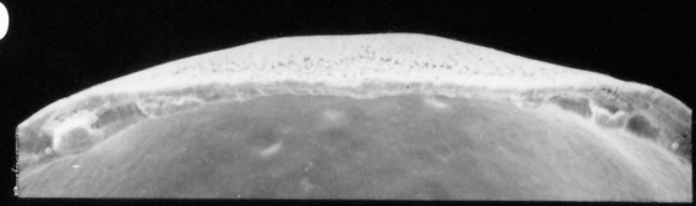

103

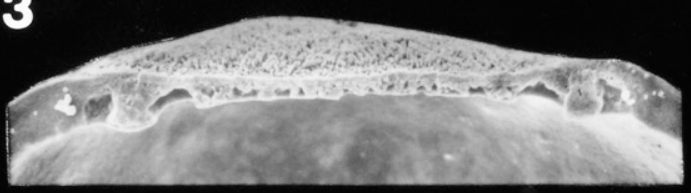

117

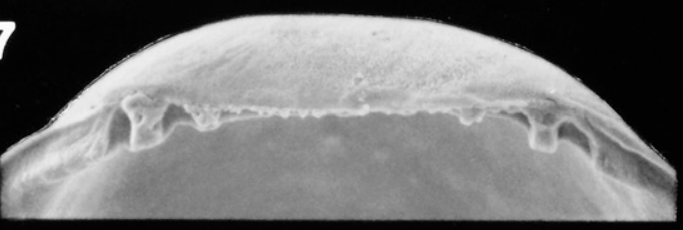

138
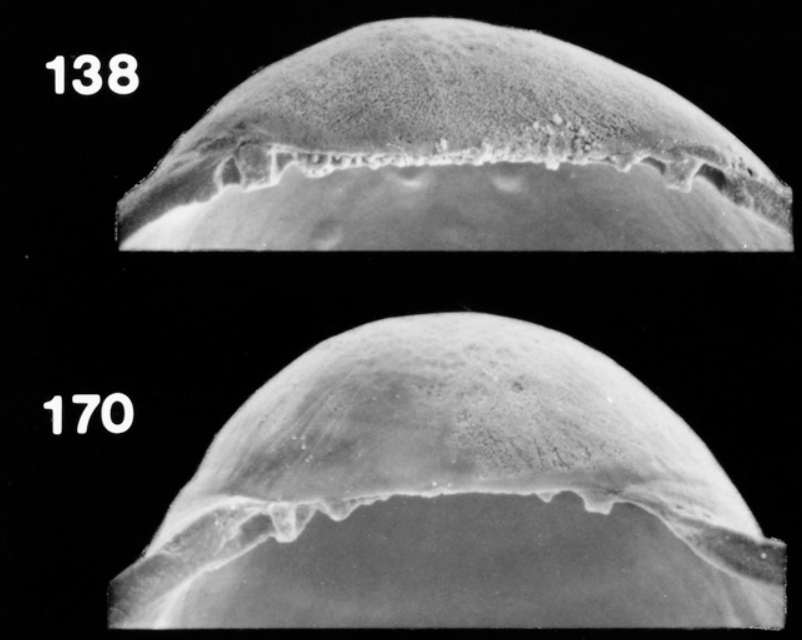

\section{RIGHT VALVE}

\author{
84
}

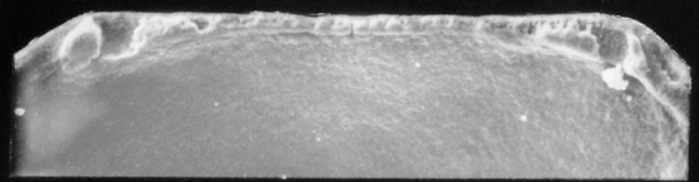

101

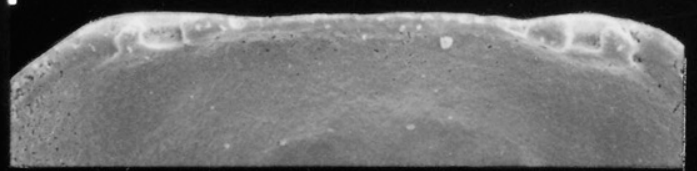

125

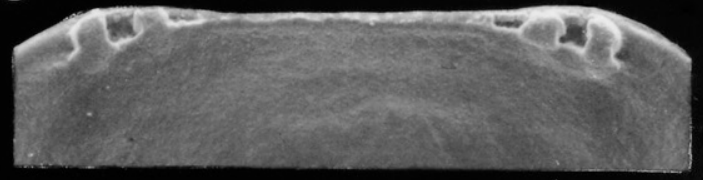

154

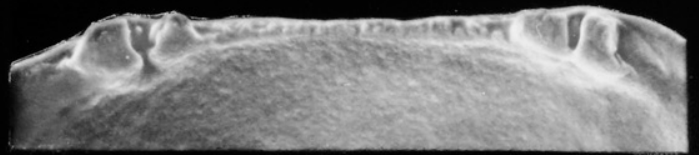

\section{7}

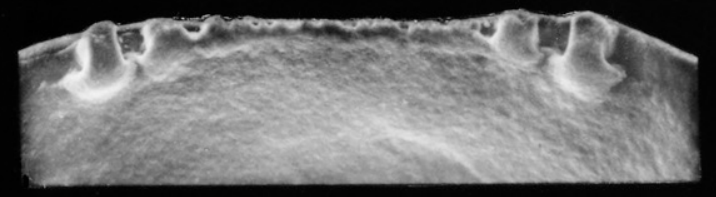

Figure 125. Scanning electron micrographs of the hinge of disarticulated shell valves of Anomia simplex larvae seen in Figure 124. Numbers indicate the maximum linear shell dimension in micrometers. 


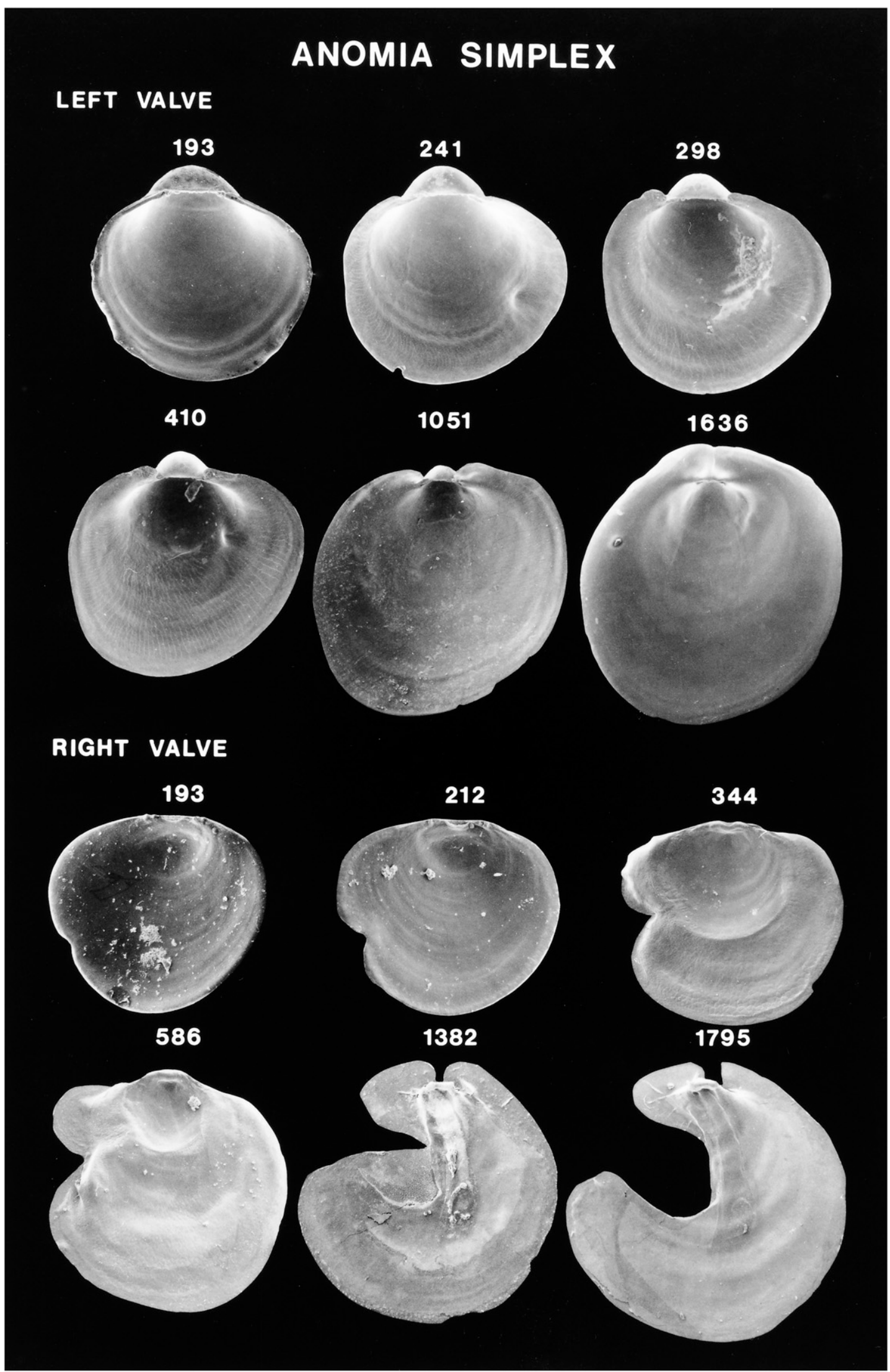

Figure 126. Scanning electron micrographs of disarticulated shell valves of Anomia simplex postlarvae. Numbers indicate the maximum linear shell dimension in micrometers. 


\section{ANOMIA SIMPLEX}

\section{LEFT VALVE}
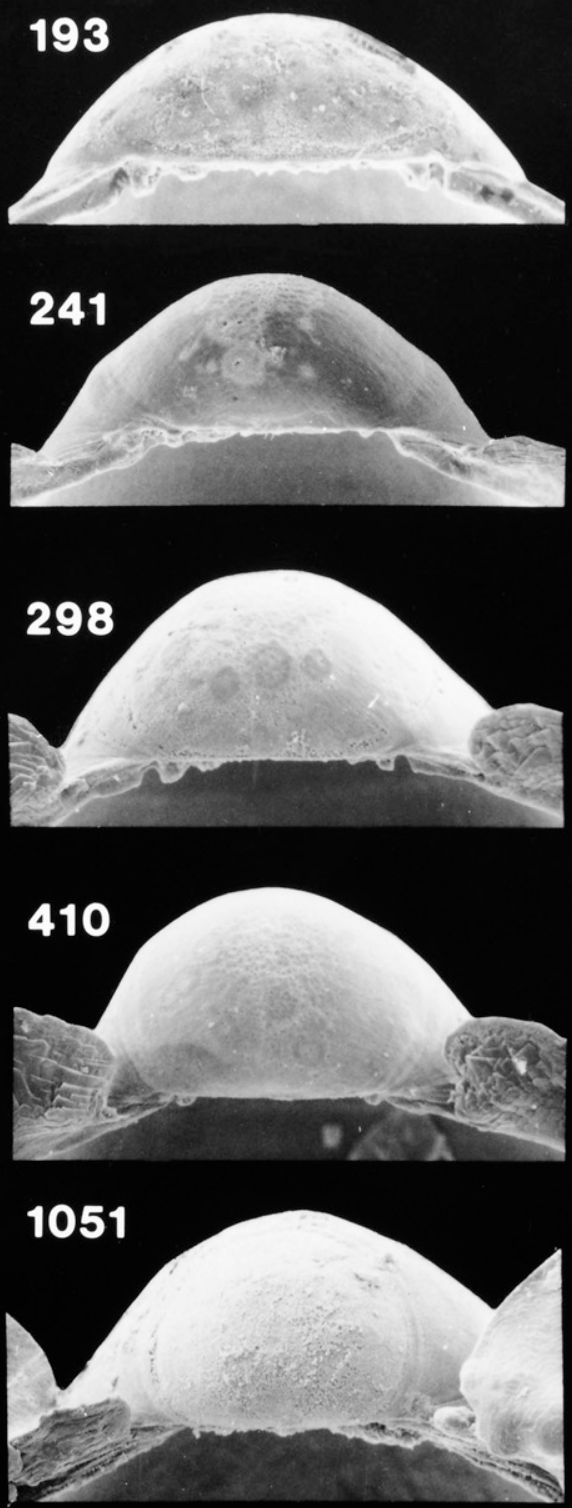

1636

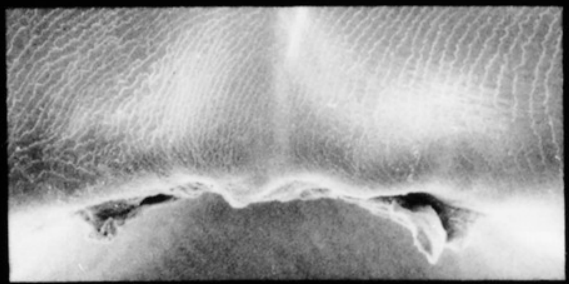

RIGHT VALVE

193

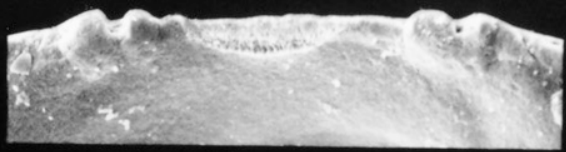

\section{2}

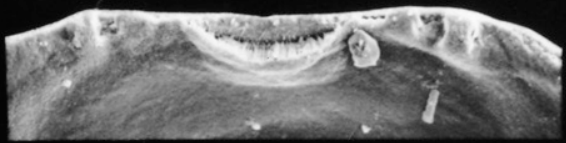

\section{4}

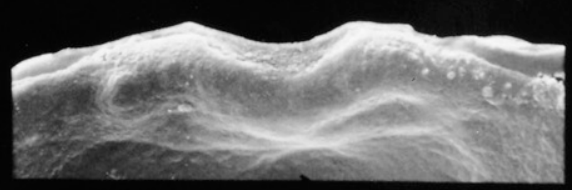

\section{6}

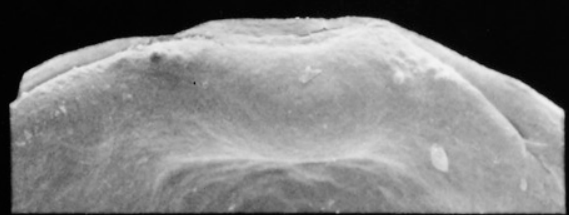

\section{2}

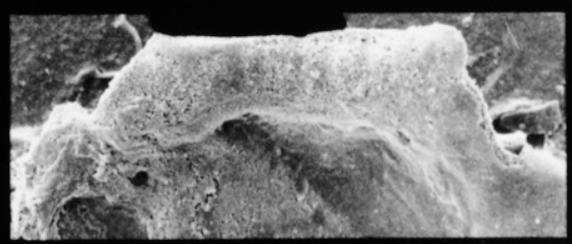

\section{5}

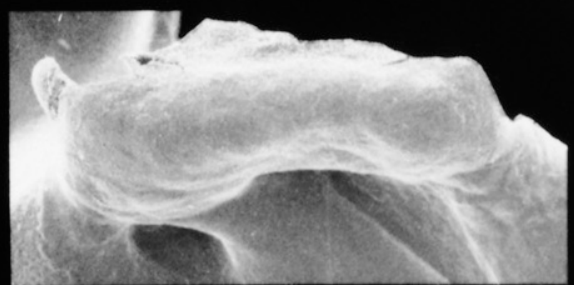

Figure 127. Scanning electron micrographs of the hinge of disarticulated shell valves of Anomia simplex postlarvae seen in Figure 126. Numbers indicate the maximum linear shell dimension in micrometers. 


\section{ARGOPECTEN IRRADIANS}

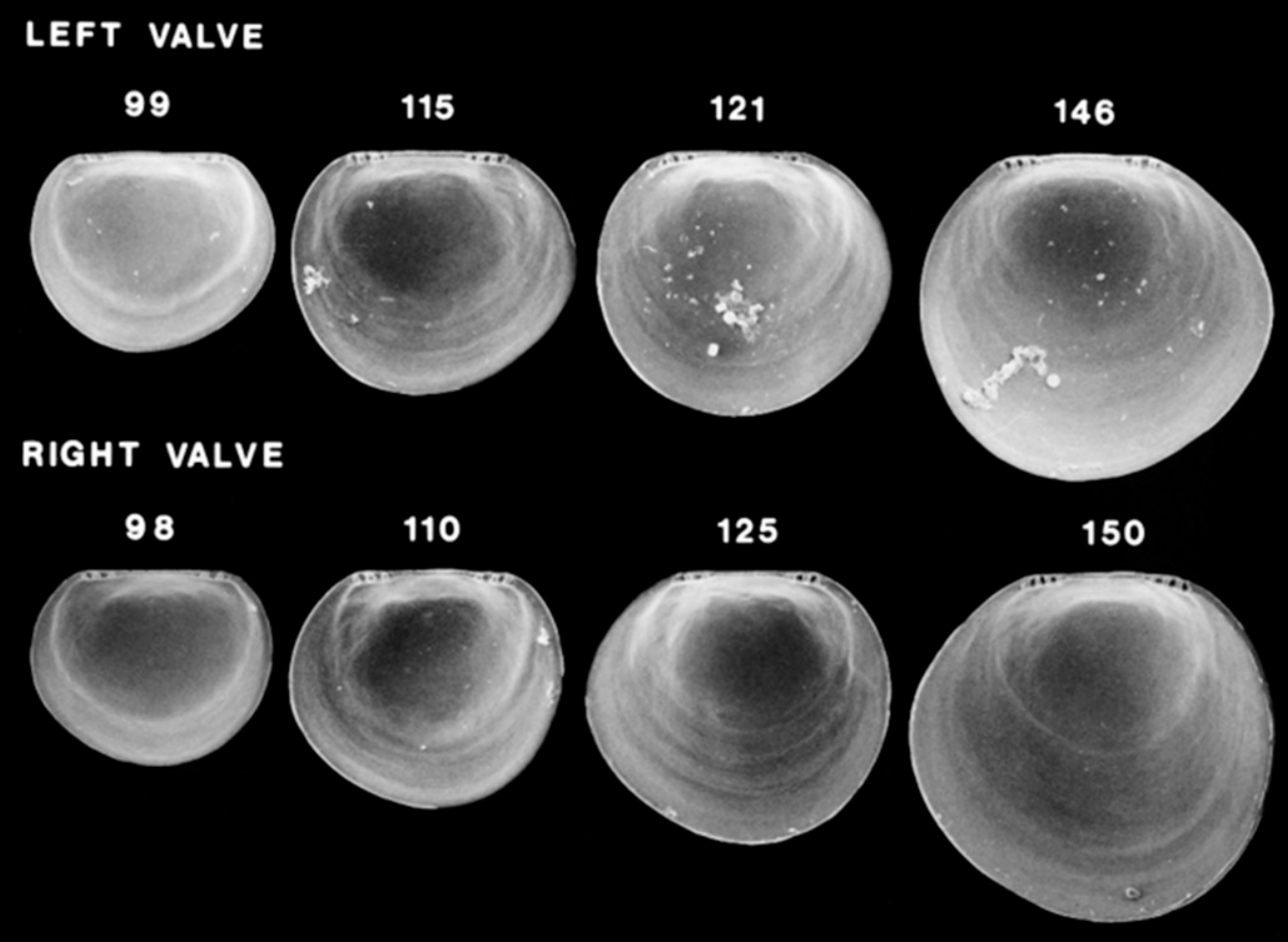

ARGOPECTEN IRRADIANS

\section{LEFT VALVE}

99

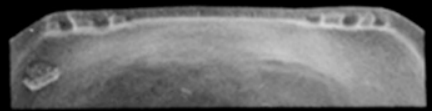

115

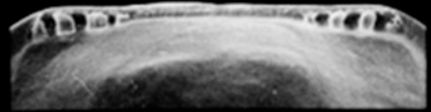

121

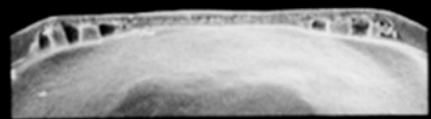

146

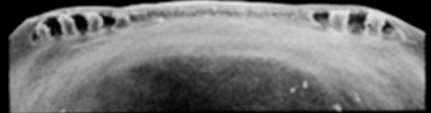

\section{RIGHT VALVE}

98

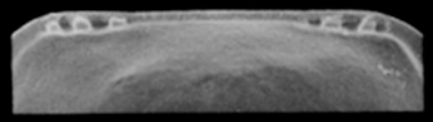

110

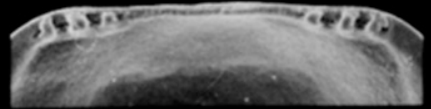

125

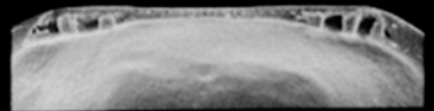

150

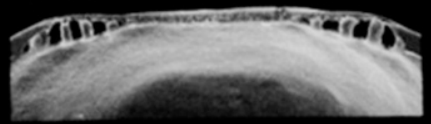




\section{ARGOPECTEN IRRADIANS}

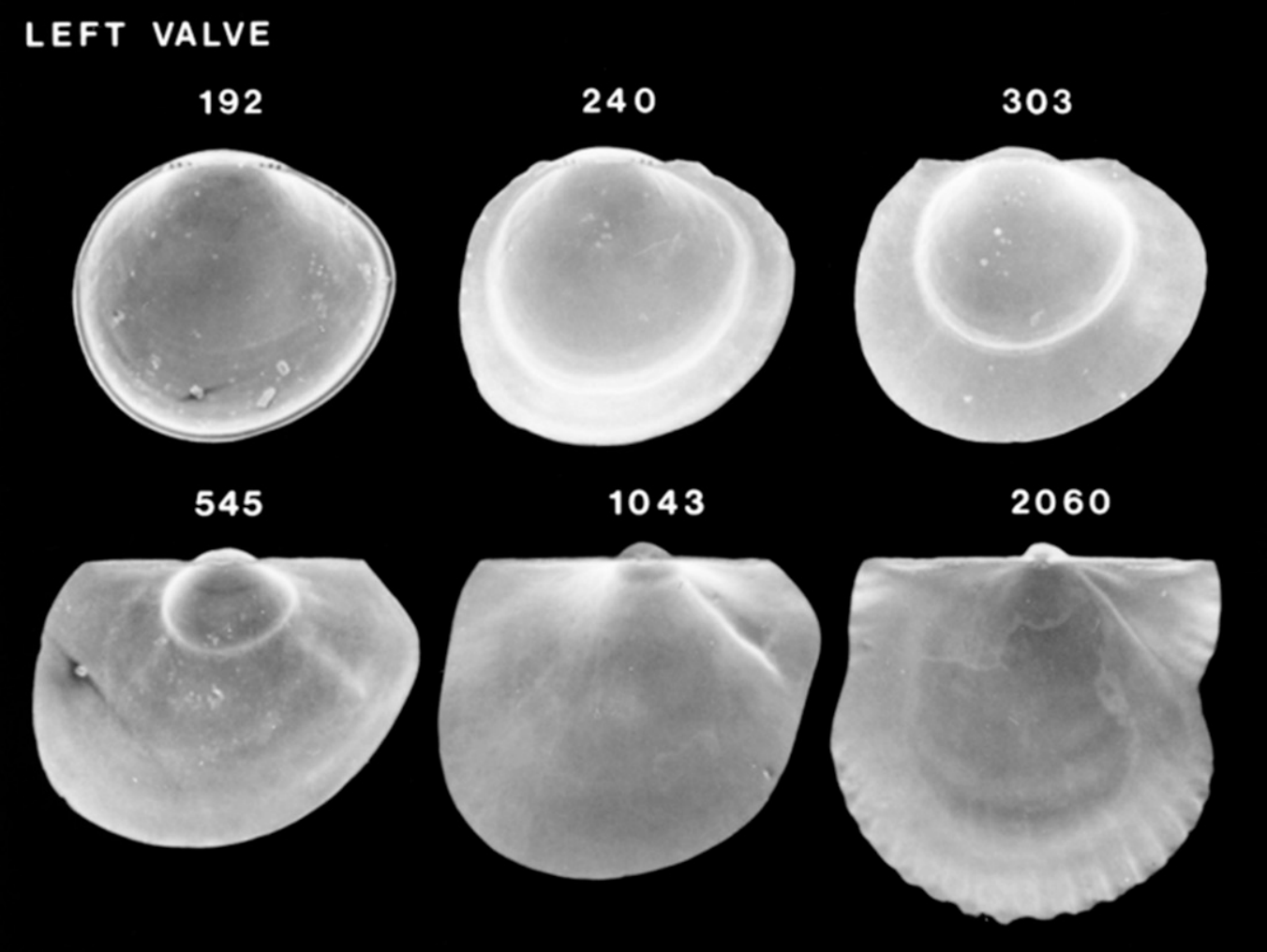

\section{RIGHT VALVE}
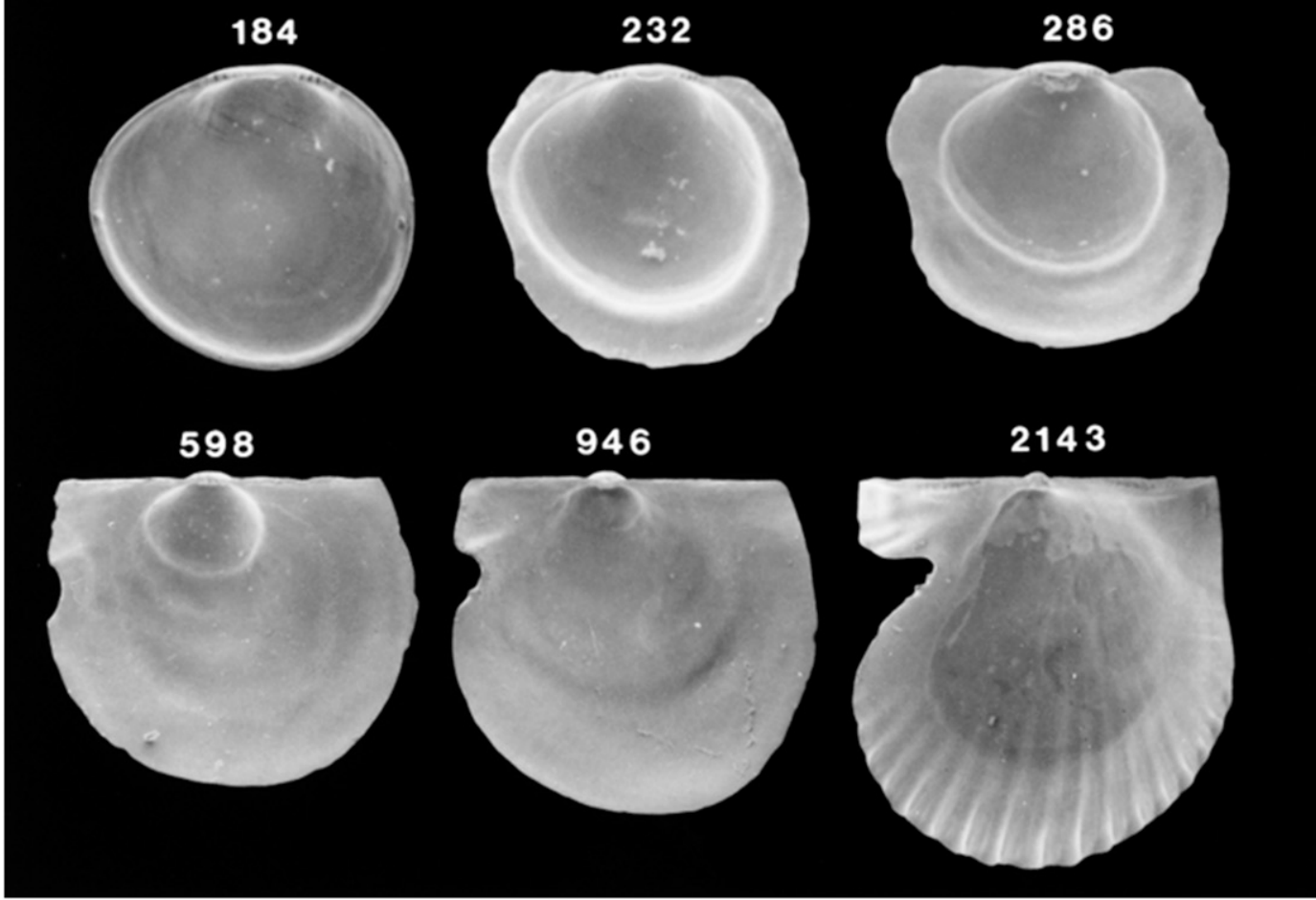

Figure 129. Scanning electron micrographs of disarticulated shell valves of Argopecten irradians postlarvae. Numbers indicate the maximum linear shell dimension in micrometers. 


\section{ARGOPECTEN IRRADIANS}

\section{LEFT VALVE}
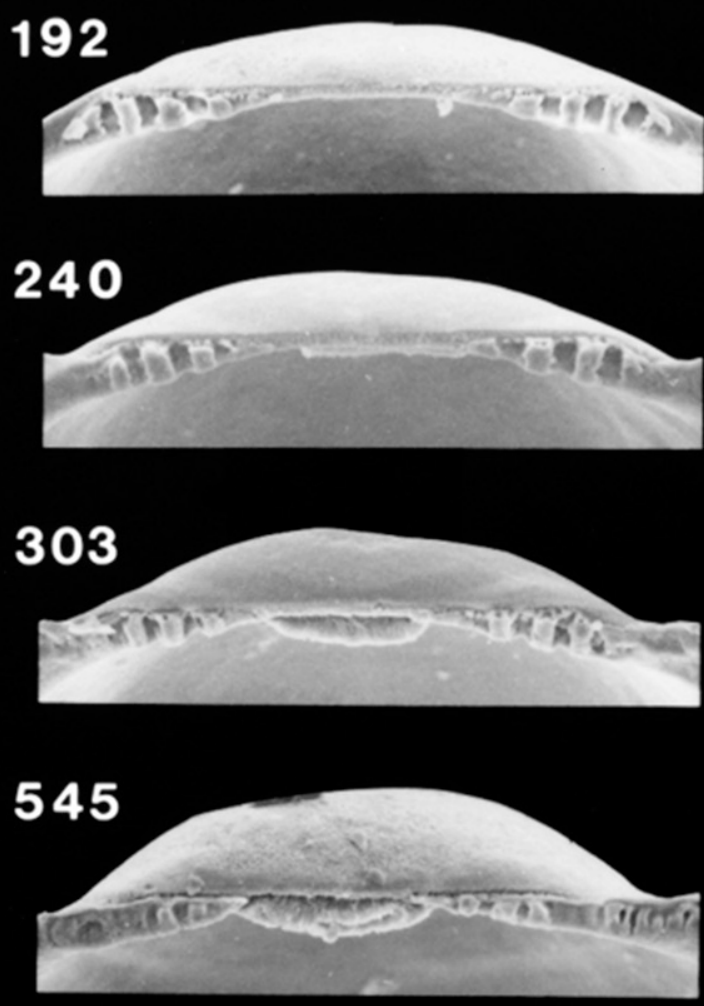

1043

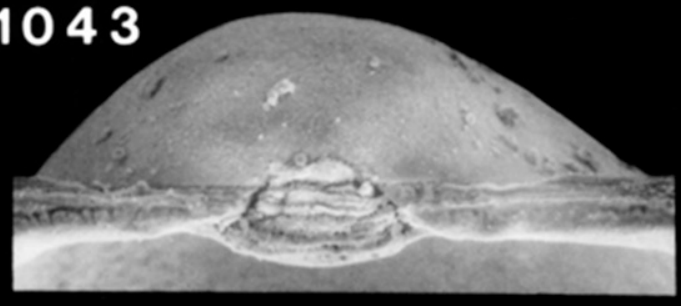

2060

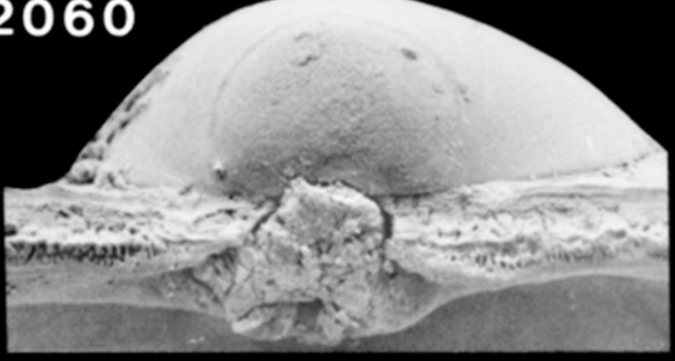

\section{RIGHT VALVE}

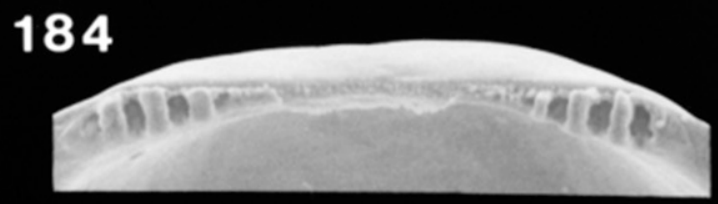

232

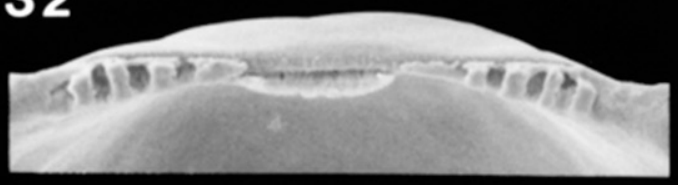

286

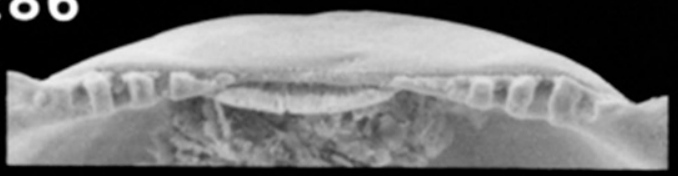

\section{8}

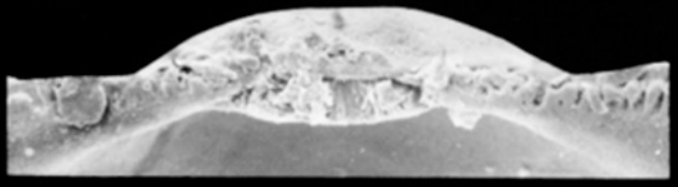

946

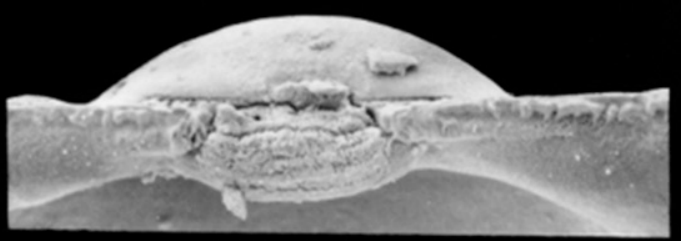

2143

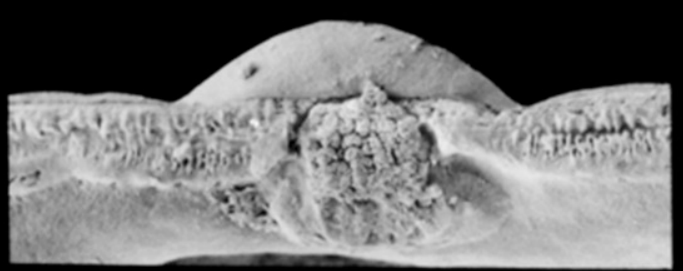




\section{ARGOPECTEN IRRADIANS CONCENTRICUS}

\section{LEFT VALVE}

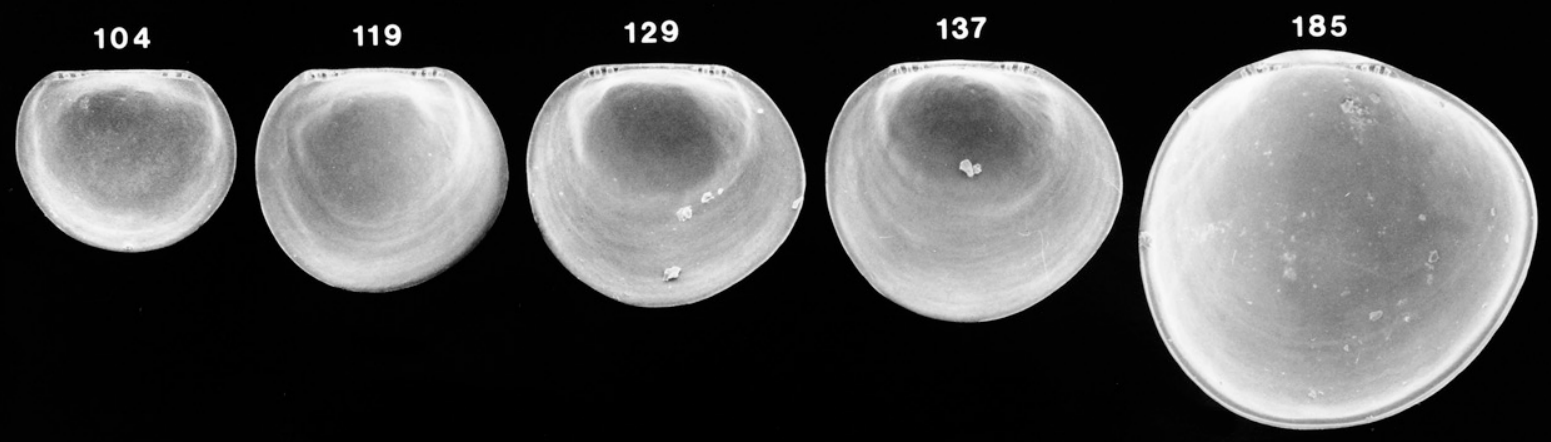

RIGHT VALVE

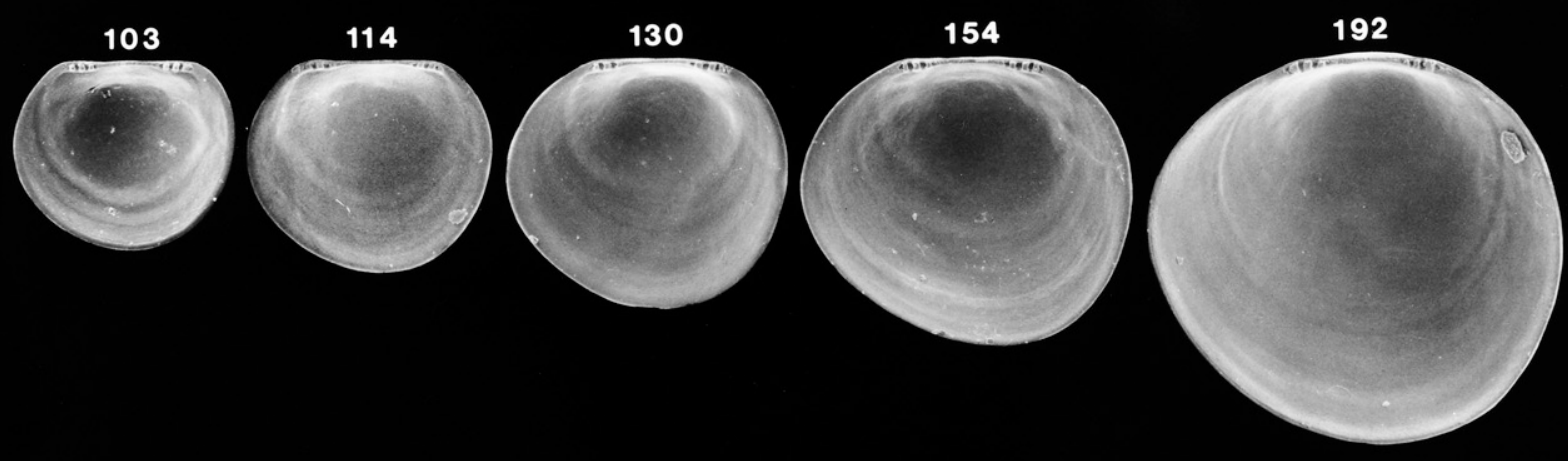

Figure 131. Scanning electron micrographs of disarticulated shell valves of Argopecten irradians concentricus larvae. Numbers indicate the maximum linear shell dimension in micrometers. 


\section{ARGOPECTEN IRRADIANS CONCENTRICUS}

\section{LEFT VALVE}

104

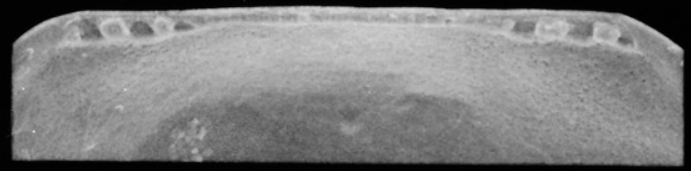

\section{9}

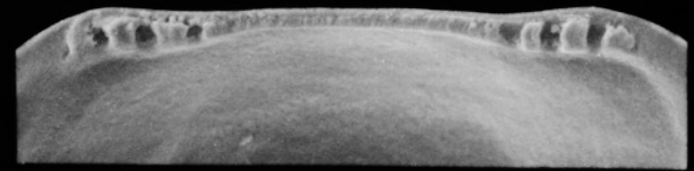

129

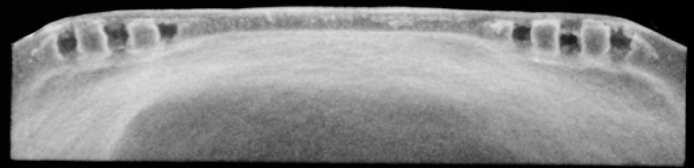

137

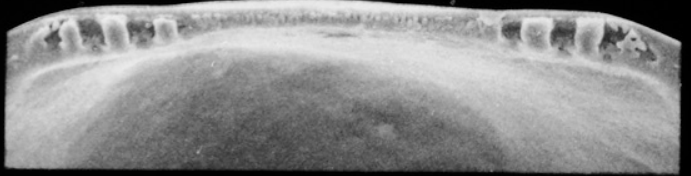

185

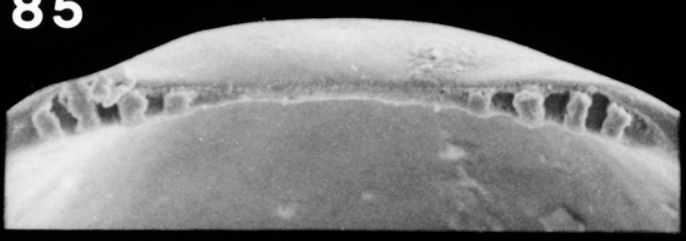

\section{RIGHT VALVE}

103

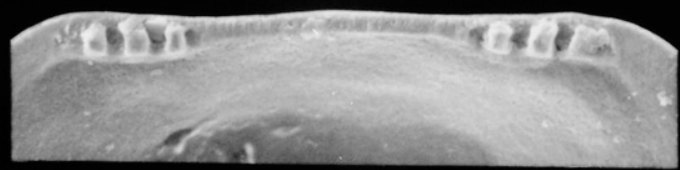

114

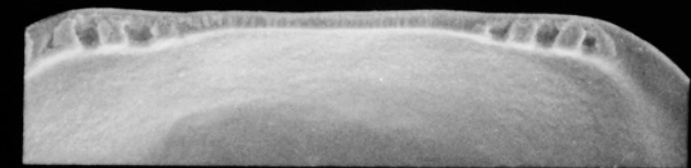

130

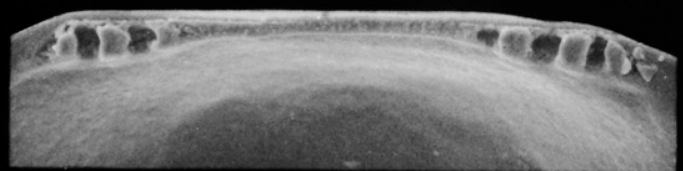

154

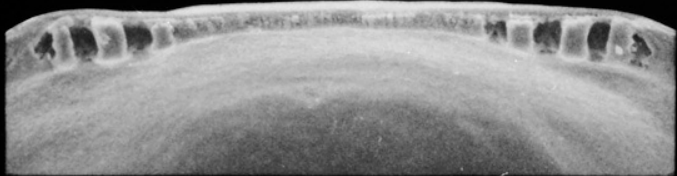

192

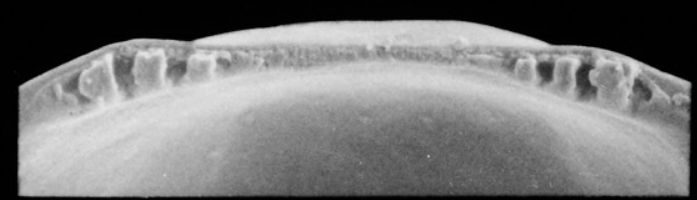




\section{ARGOPECTEN IRRADIANS CONCENTRICUS}

\section{LEFT VALVE}
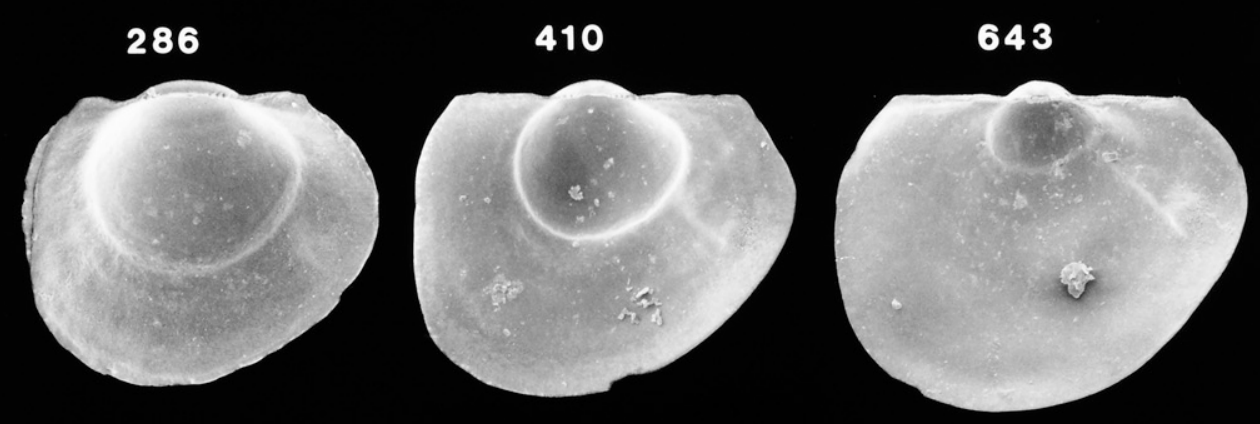

915

1796
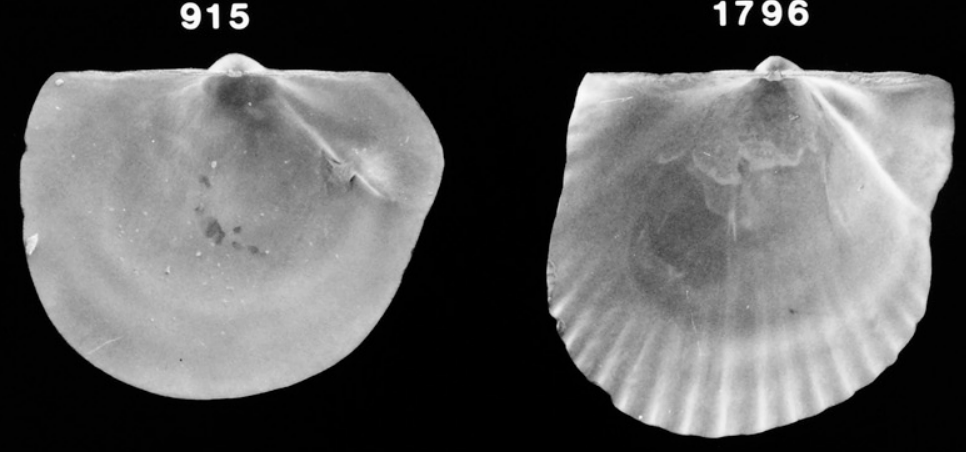

\section{RIGHT VALVE}

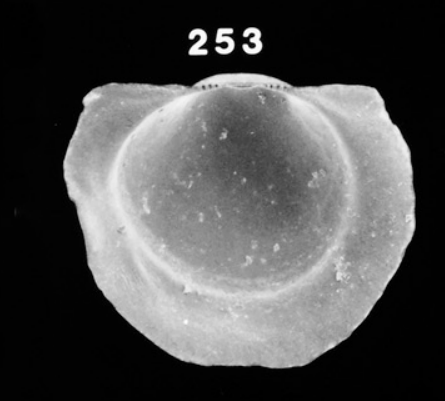

797

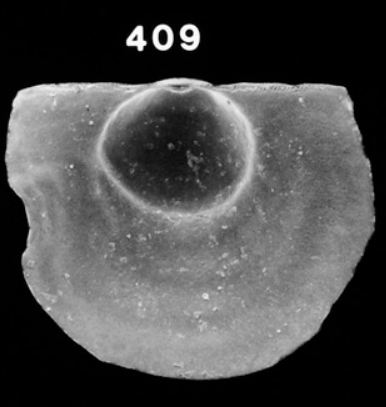

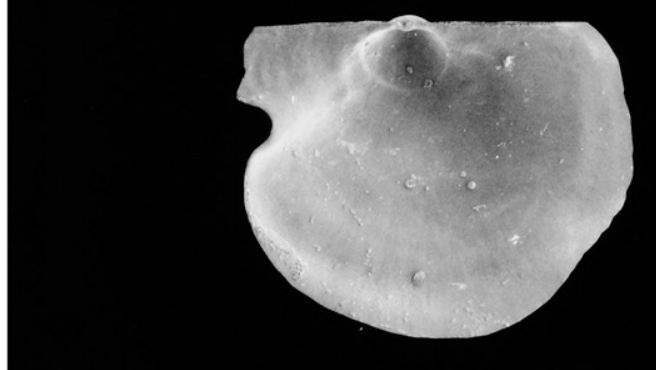

633

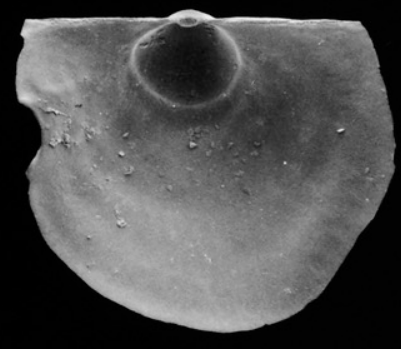

1737

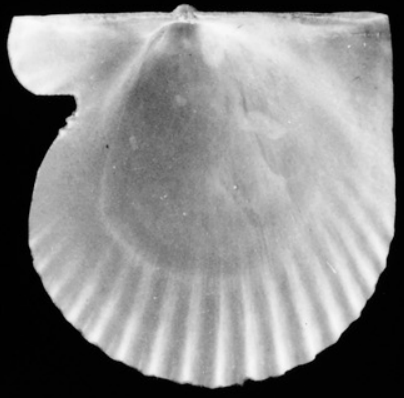

Figure 133. Scanning electron micrographs of disarticulated shell valves of Argopecten irradians concentricus postlarvae. Numbers indicate the maximum linear shell dimension in micrometers. 


\section{ARGOPECTEN IRRADIANS CONCENTRICUS}

\section{LEFT VALVE}

286

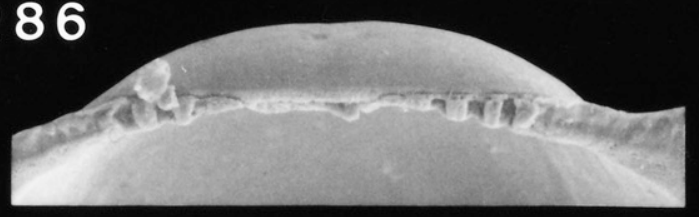

410

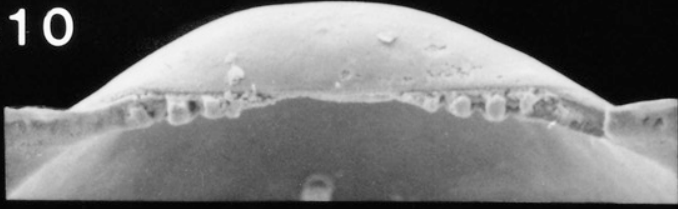

643

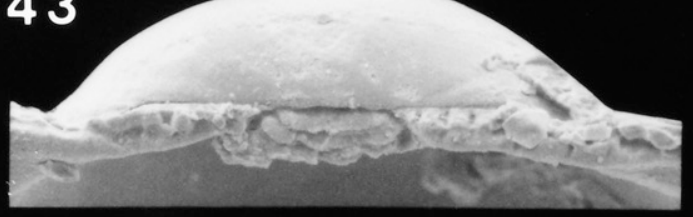

915

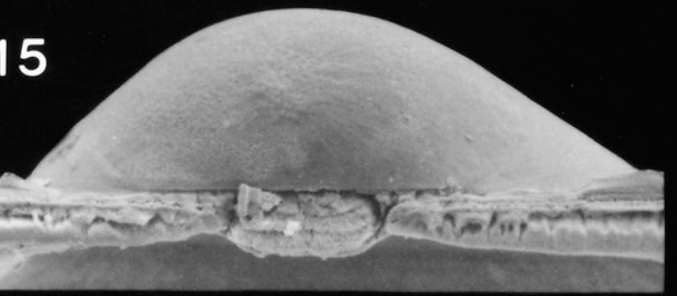

1796

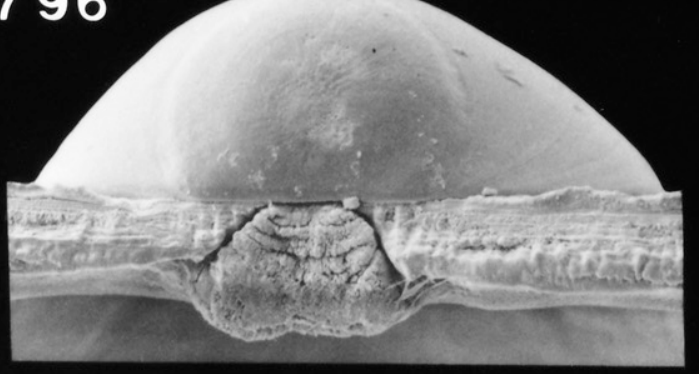

\section{RIGHT VALVE}

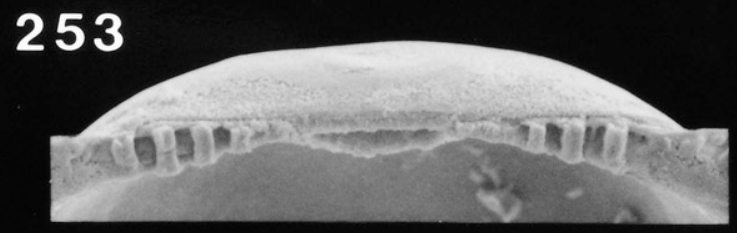

409

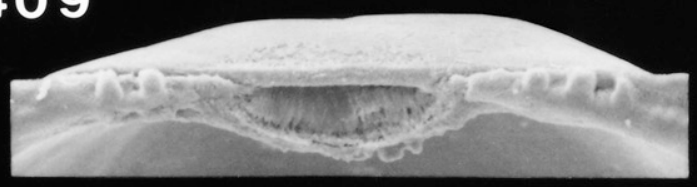

633

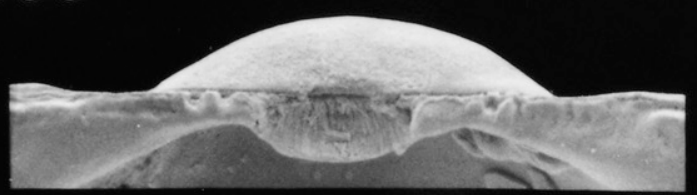

797

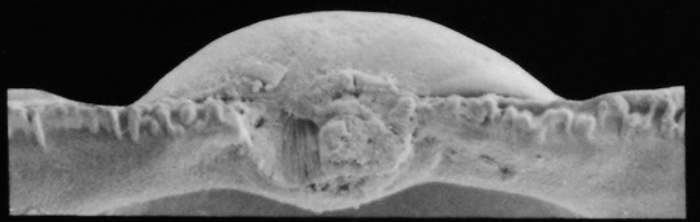

1737

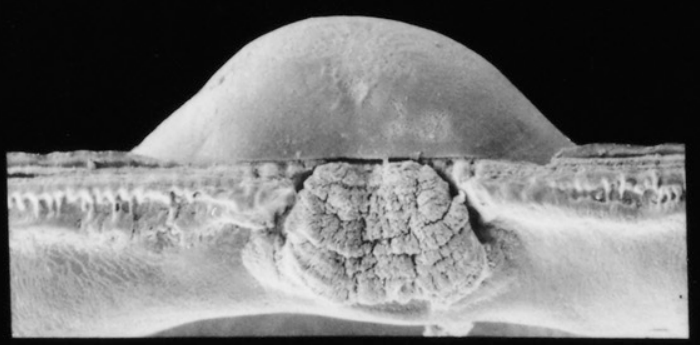

Figure 134. Scanning electron micrographs of the hinge of disarticulated shell valves of Argopecten irradians concentricus postlarvae seen in Figure 133. Numbers indicate the maximum linear shell dimension in micrometers. 


\section{PECTEN MAXIMUS}

\section{LEFT VALVE}

116

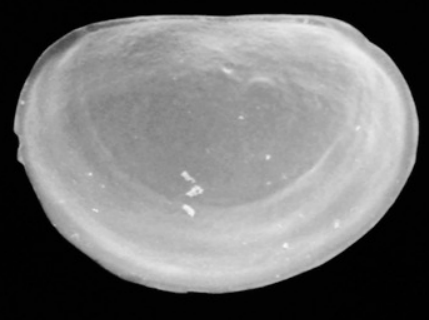

152

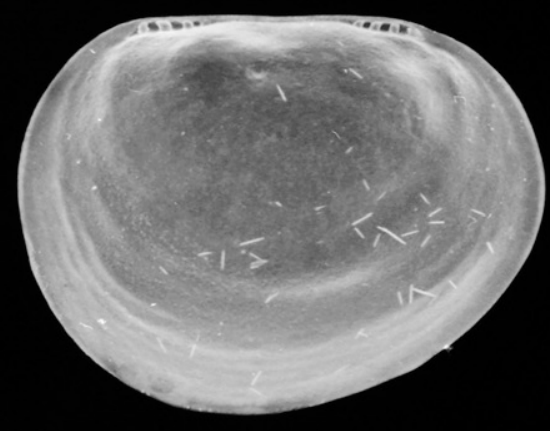

126

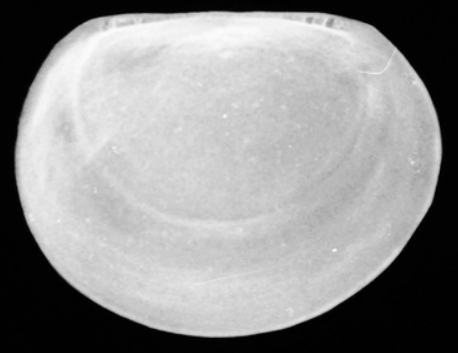

169

\section{RIGHT VALVE}

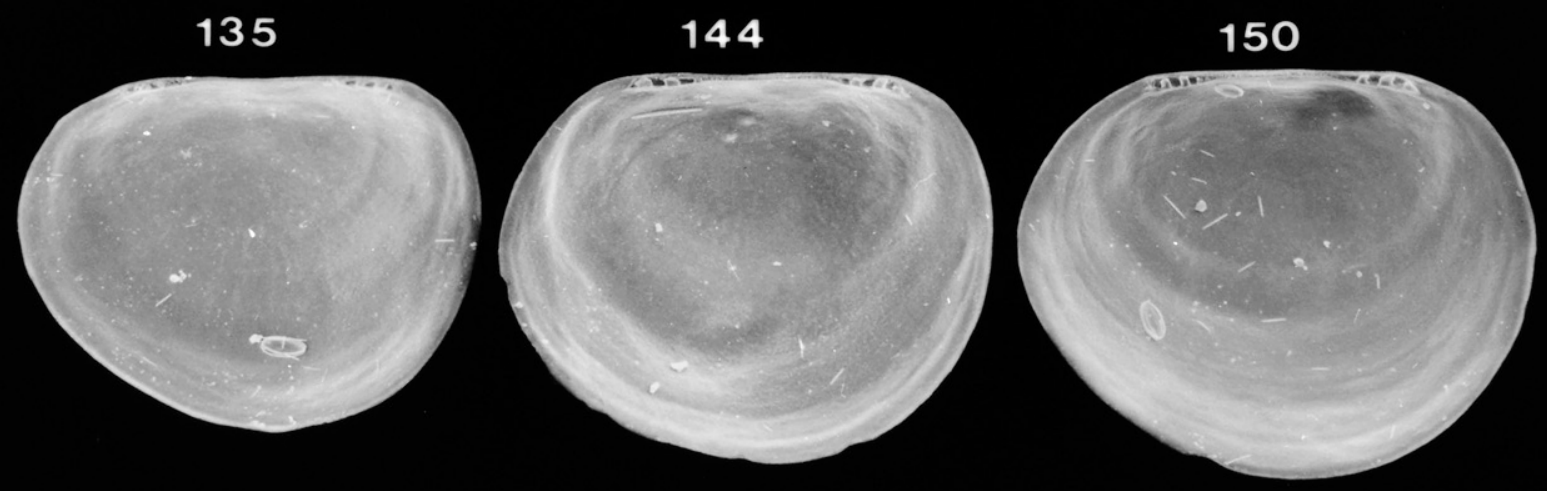

Figure 135. Scanning electron micrographs of disarticulated shell valves of Pecten maximus larvae. Numbers indicate the maximum linear shell dimension in micrometers.

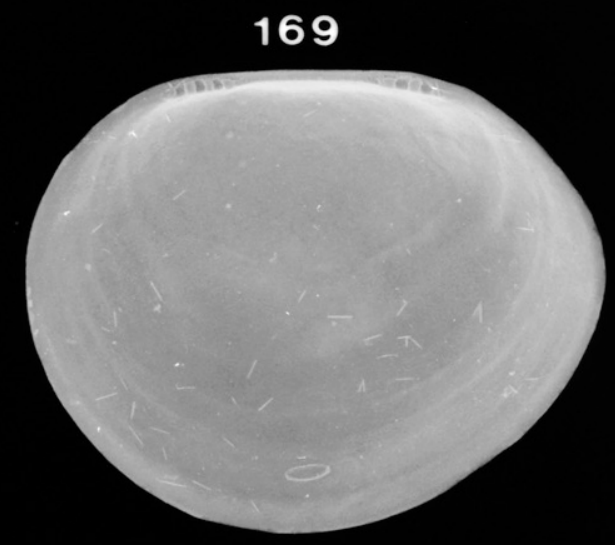




\section{PECTEN MAXIMUS}

\section{LEFT VALVE}

\section{6}

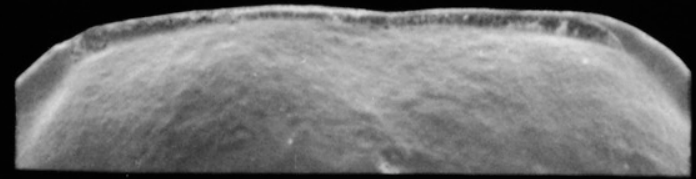

\section{6}

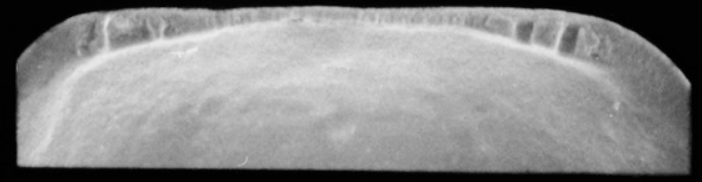

139

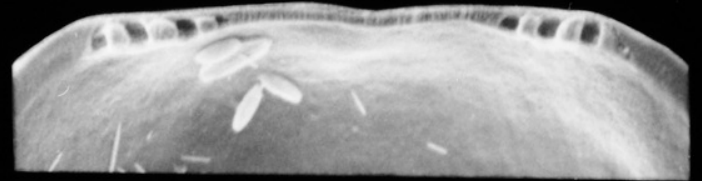

\section{2}

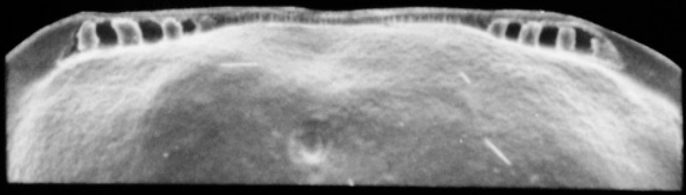

\section{9}

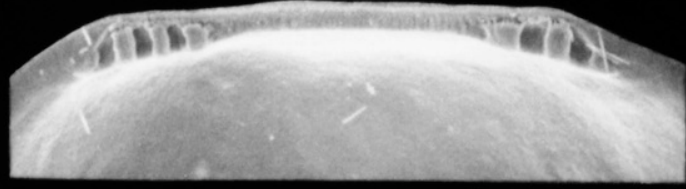

\section{RIGHT VALVE}

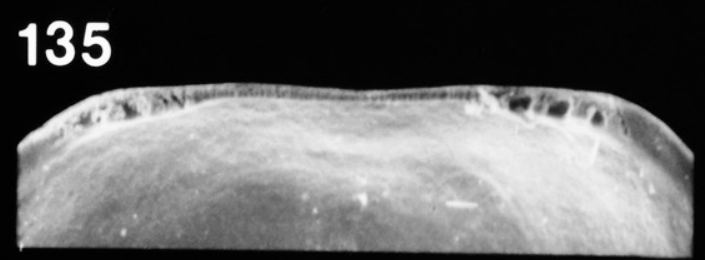

144

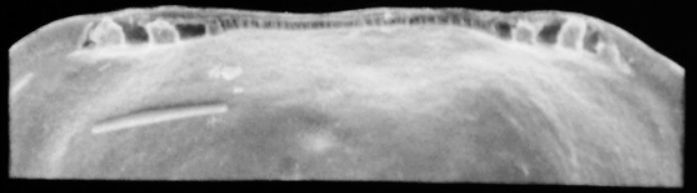

\section{0}

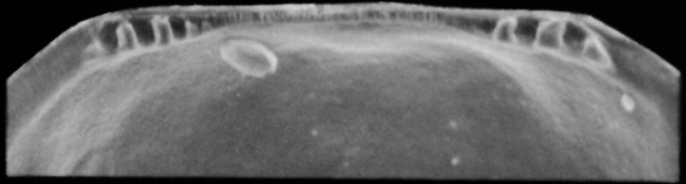




\section{PECTEN MAXIMUS}

\section{LEFT VALVE}
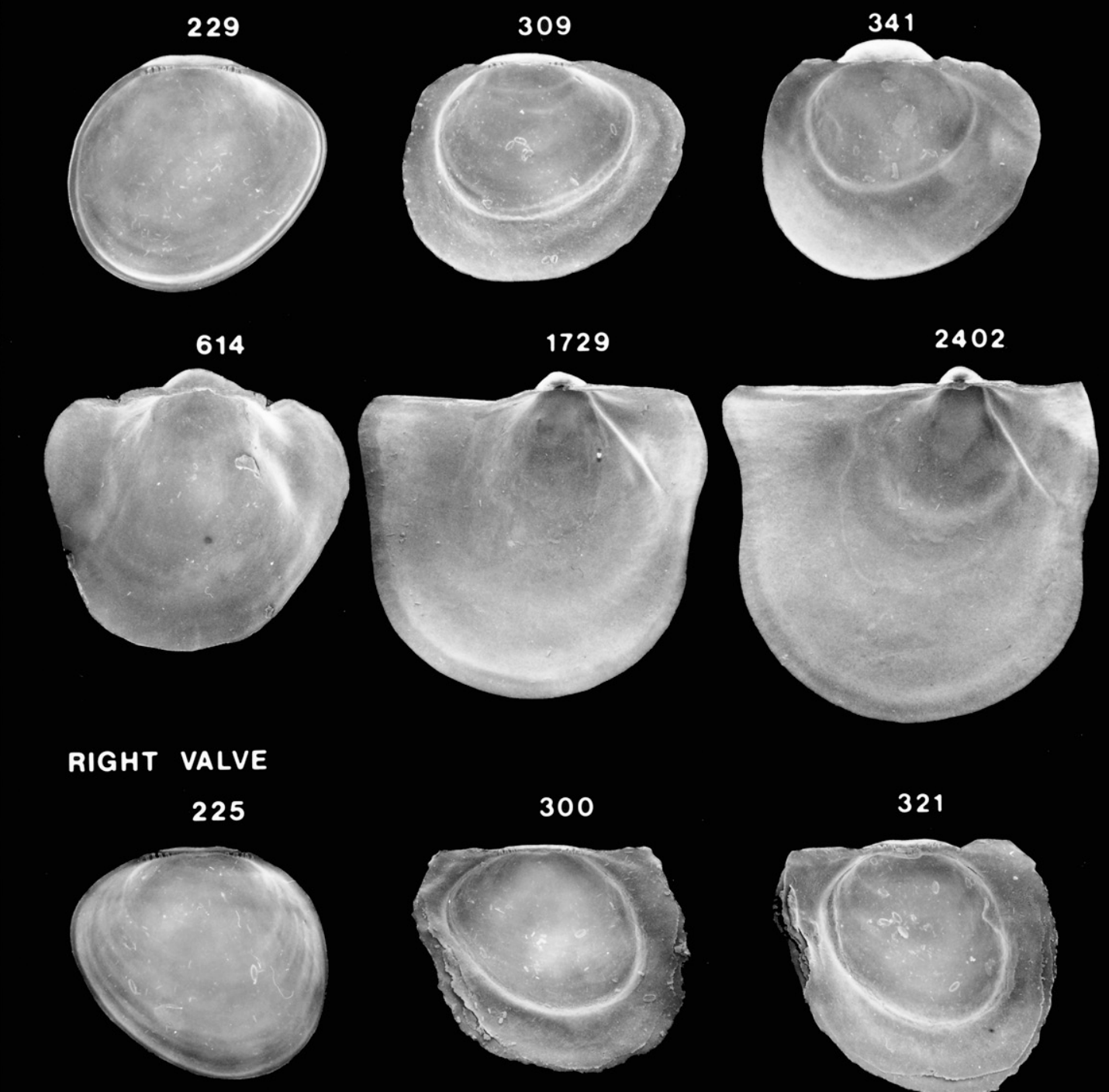

\section{RIGHT VALVE}

225

300

321
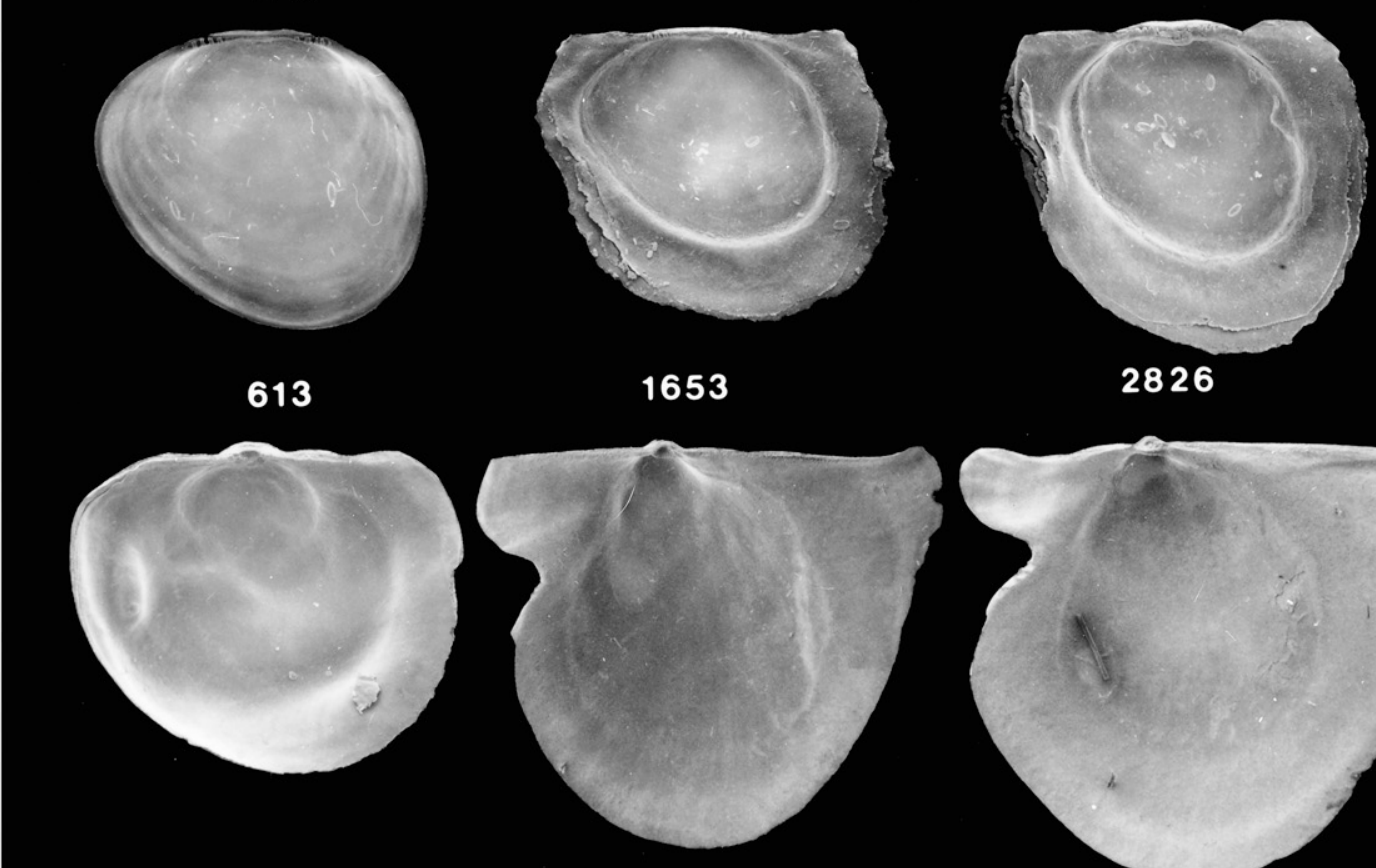

2826 


\section{PECTEN MAXIMUS}

\section{LEFT VALVE}

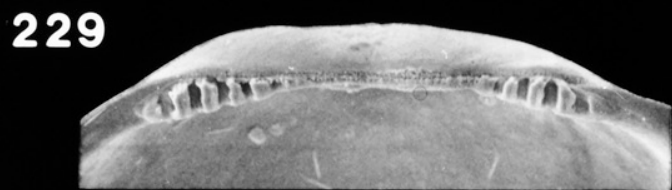

\section{9}

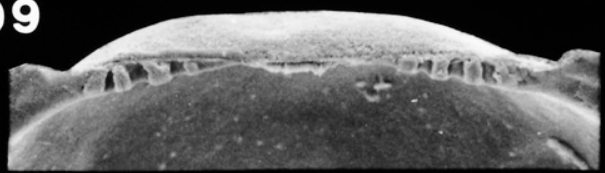

341

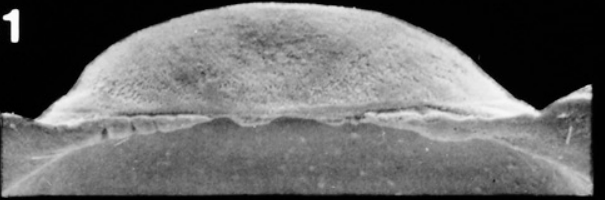

614
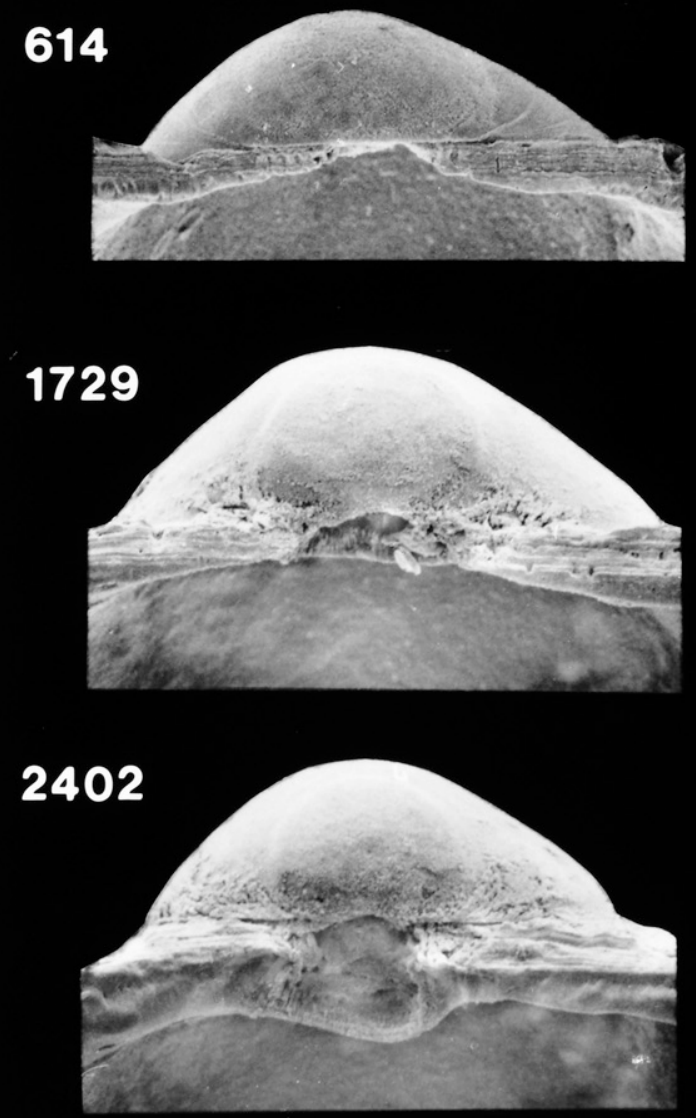

\section{RIGHT VALVE}

225

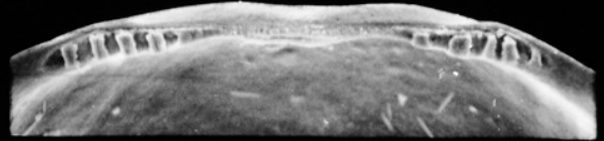

300

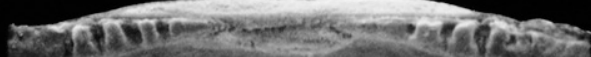

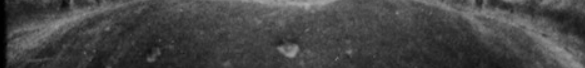

321

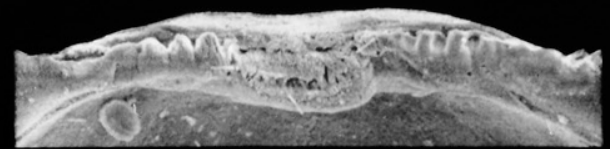

613

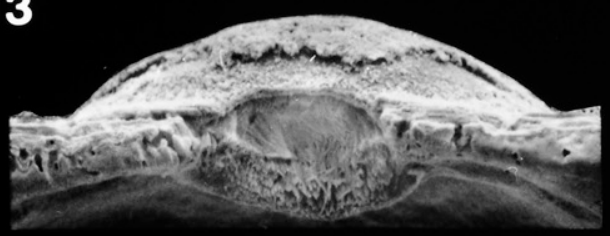

1653

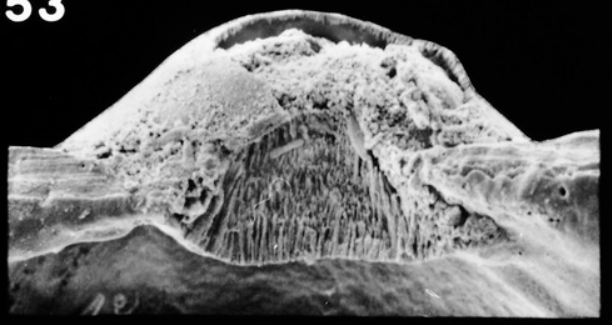

2826

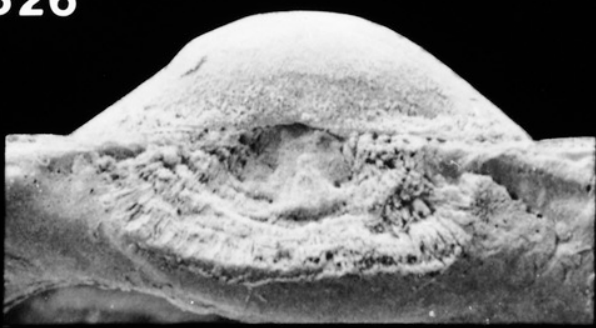




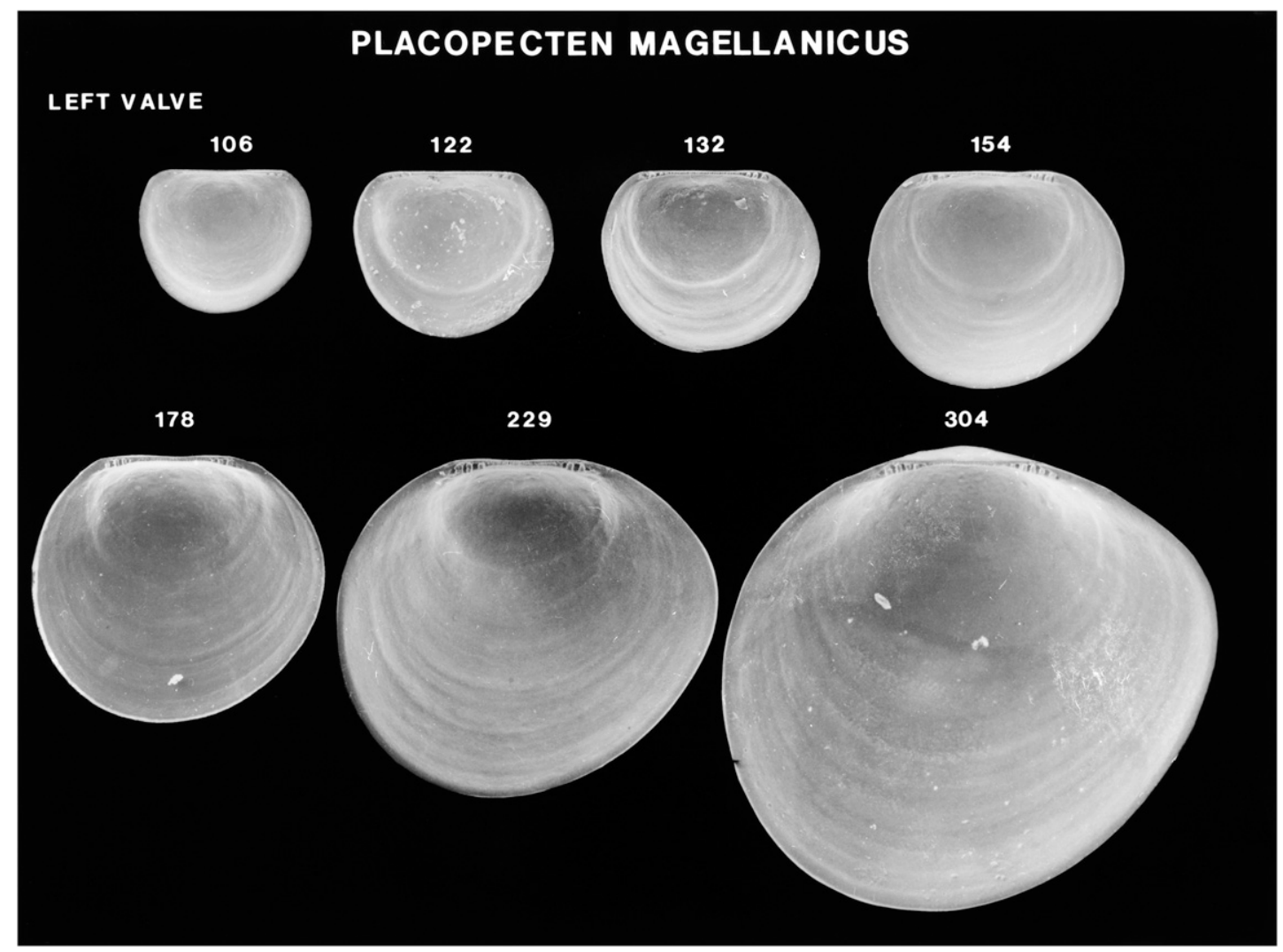

Figure 139. Scanning electron micrographs of disarticulated left shell valves of Placopecten magellanicus larvae. Numbers indicate the maximum linear shell dimension in micrometers.

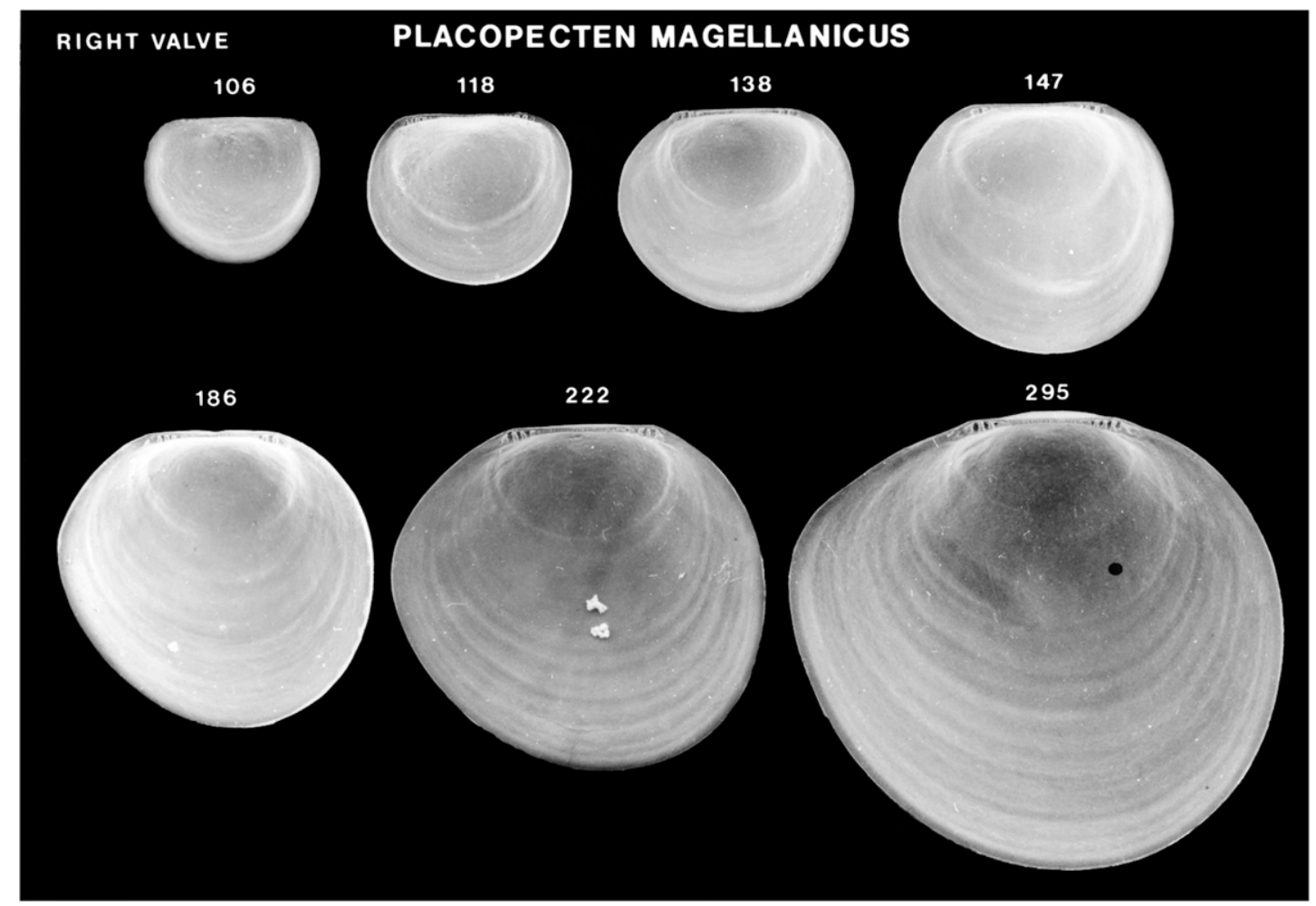

Figure 140. Scanning electron micrographs of disarticulated right shell valves of Placopecten magellanicus larvae. Numbers indicate the maximum linear shell dimension in micrometers. 


\section{PLACOPECTEN MAGELLANICUS}

\section{LEFT VALVE}

\section{6}

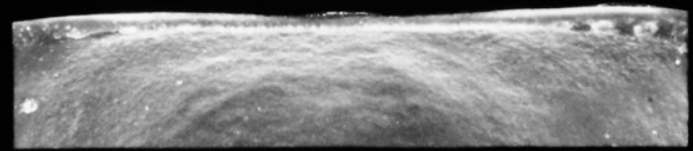

\section{2}

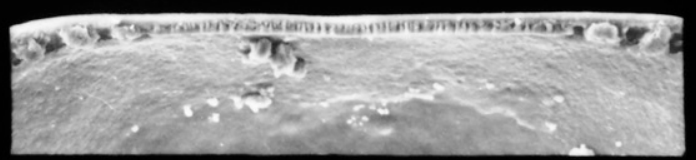

\section{2}

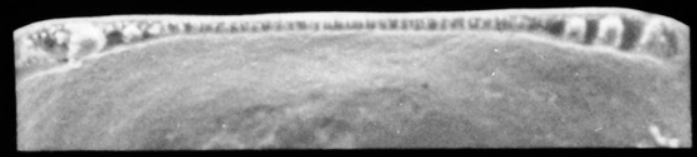

154

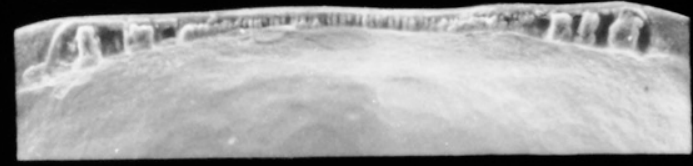

178

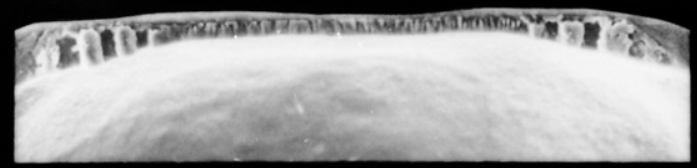

\section{9}

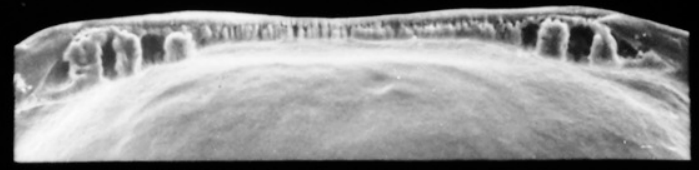

304

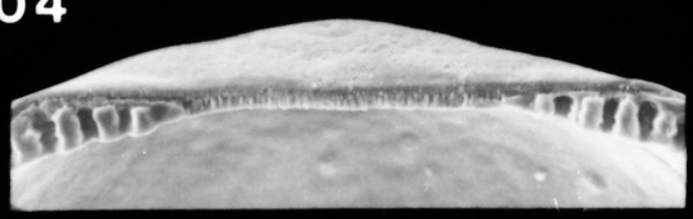

\section{RIGHT VALVE}

\section{6}

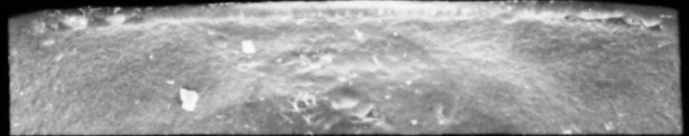

118

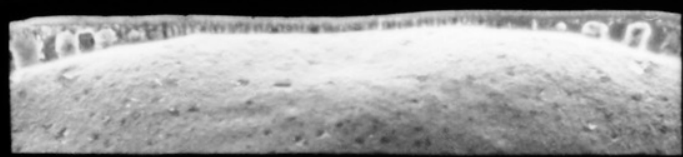

138

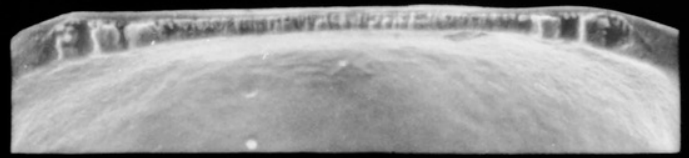

147

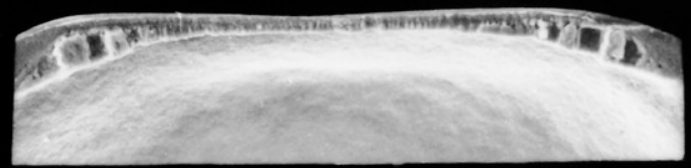

\section{6}

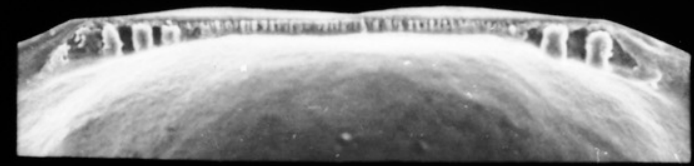

\section{2}

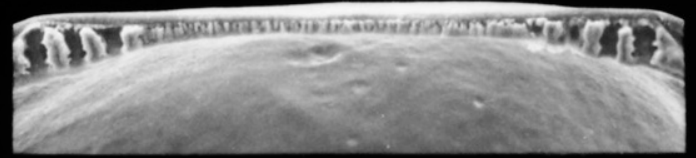

\section{5}

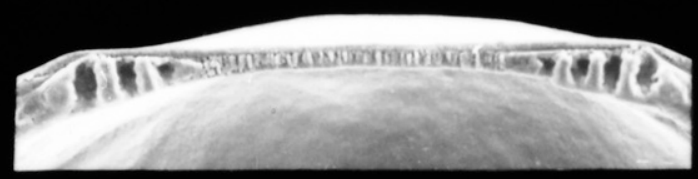




\section{PLACOPECTEN MAGELLANICUS}

\section{LEFT VALVE}
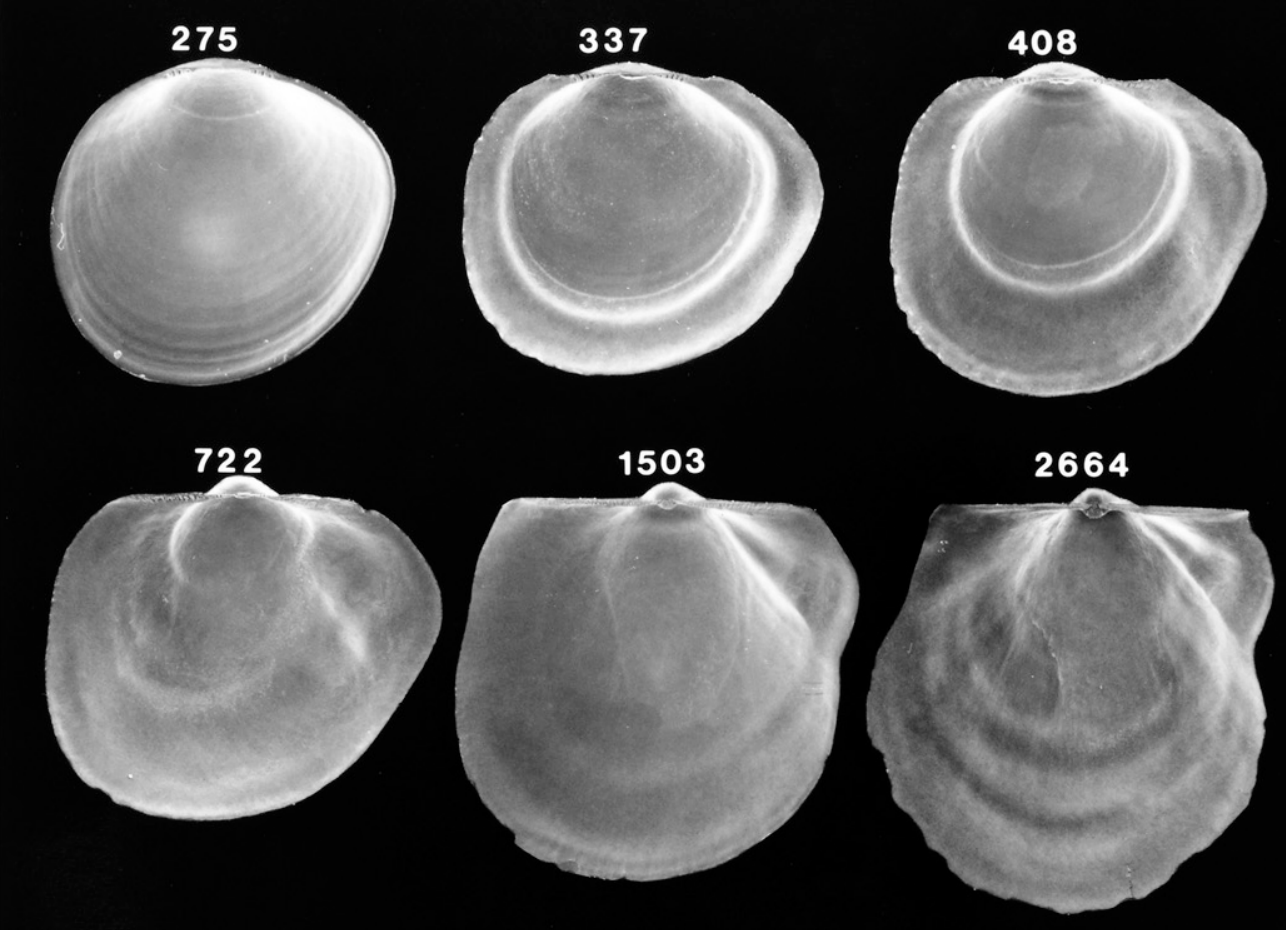

\section{RIGHT VALVE}
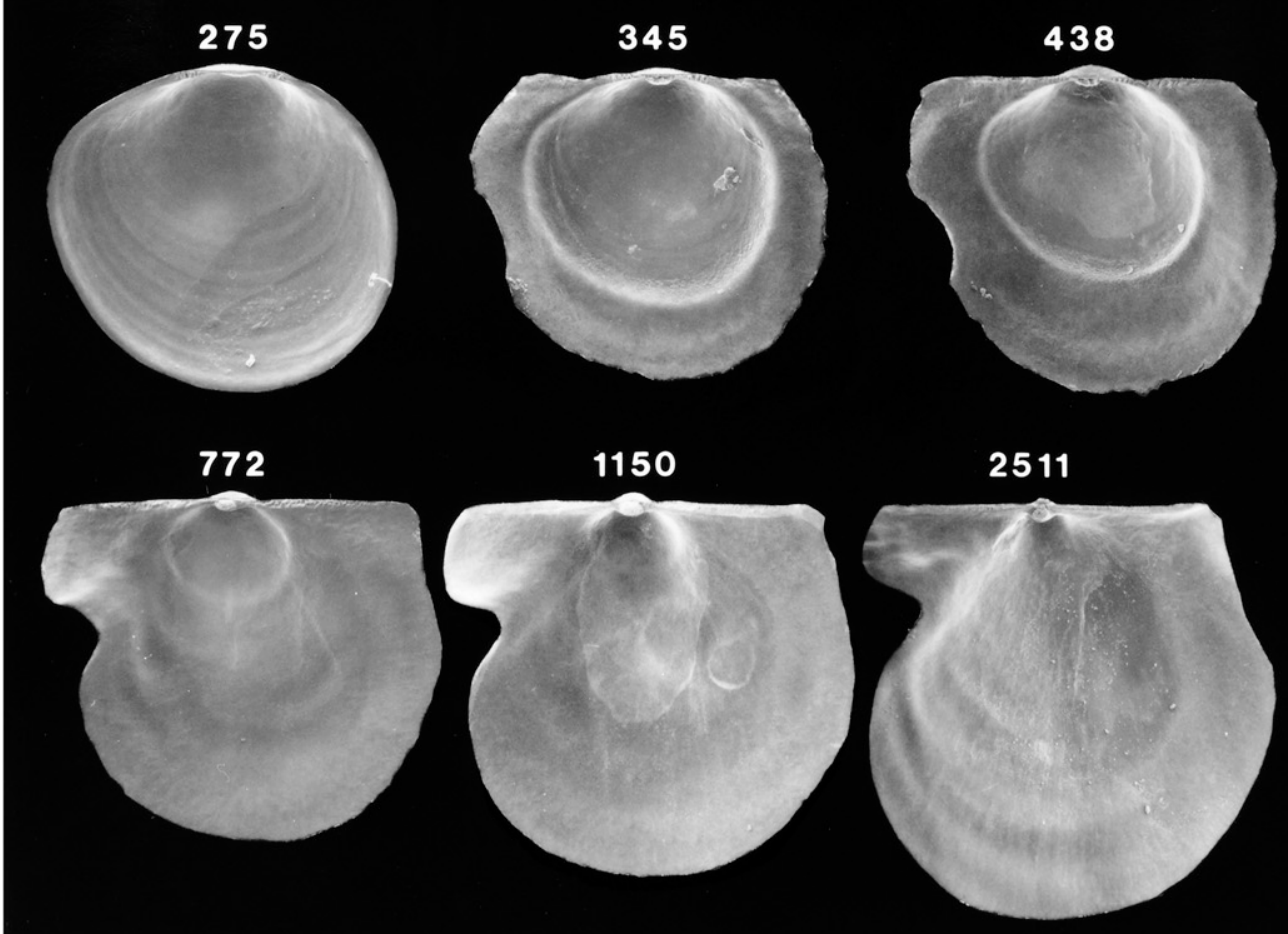

Figure 142. Scanning electron micrographs of disarticulated shell valves of Placopecten magellanicus postlarvae. Numbers indicate the maximum linear shell dimension in micrometers. 


\section{PLACOPECTEN MAGELLANICUS}

\section{LEFT VALVE}
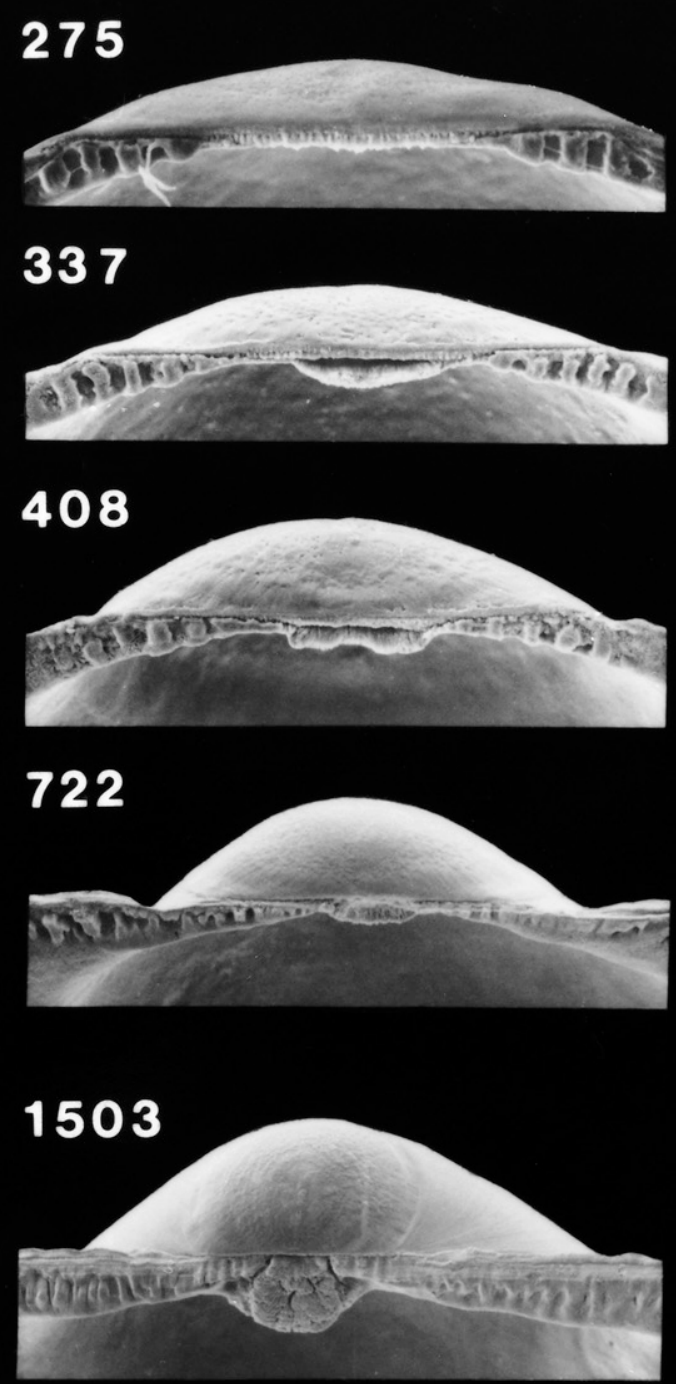

2664

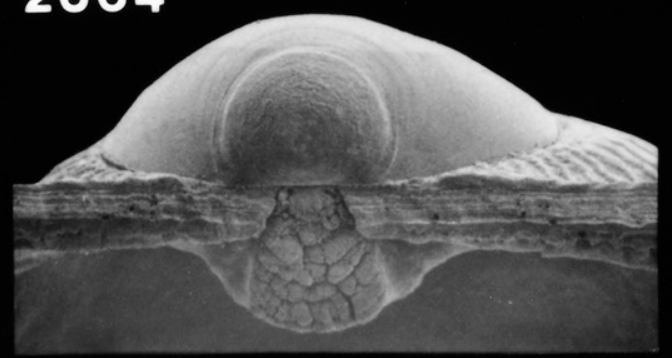

\section{RIGHT VALVE}

275

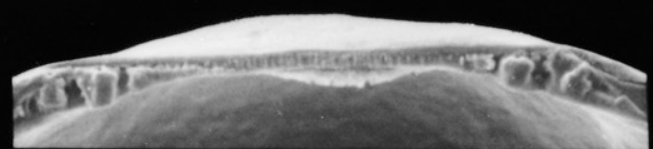

345

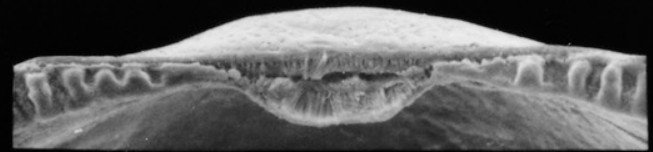

438

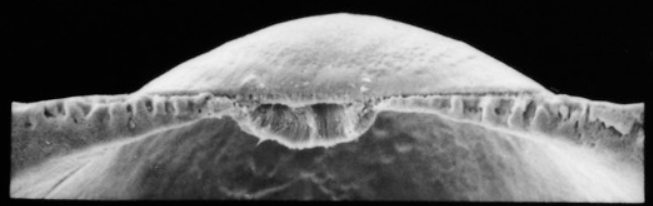

772

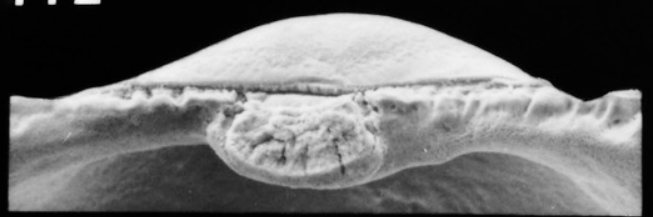

1150

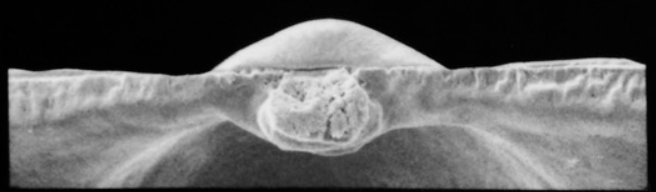

2511

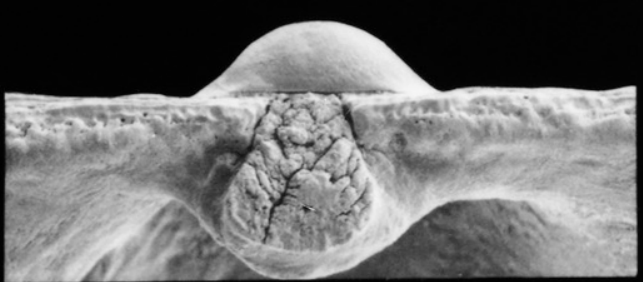




\section{LYONSIA HYALINA}

\section{LEFT VAL VE}

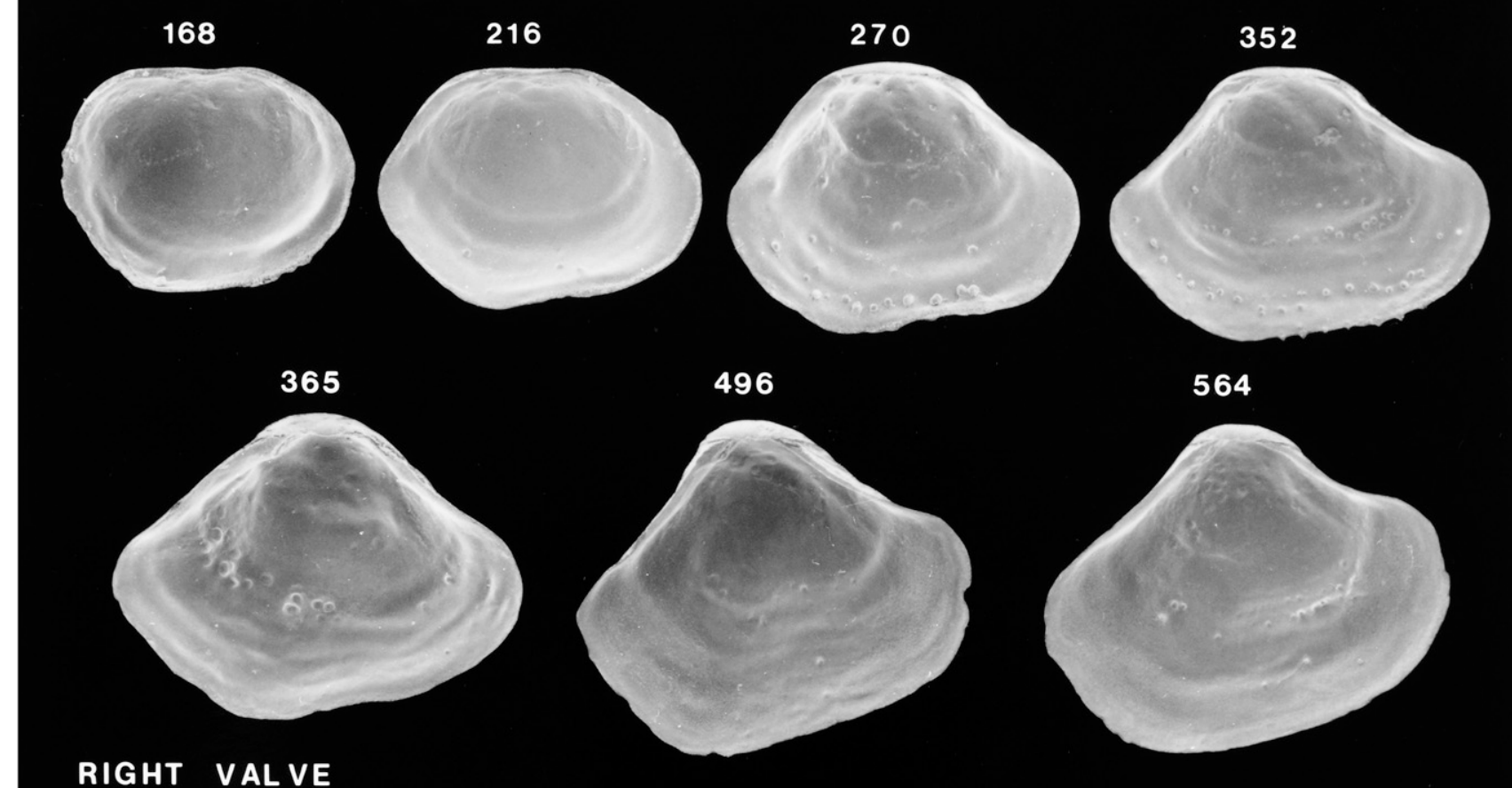

RIGHT VAL VE
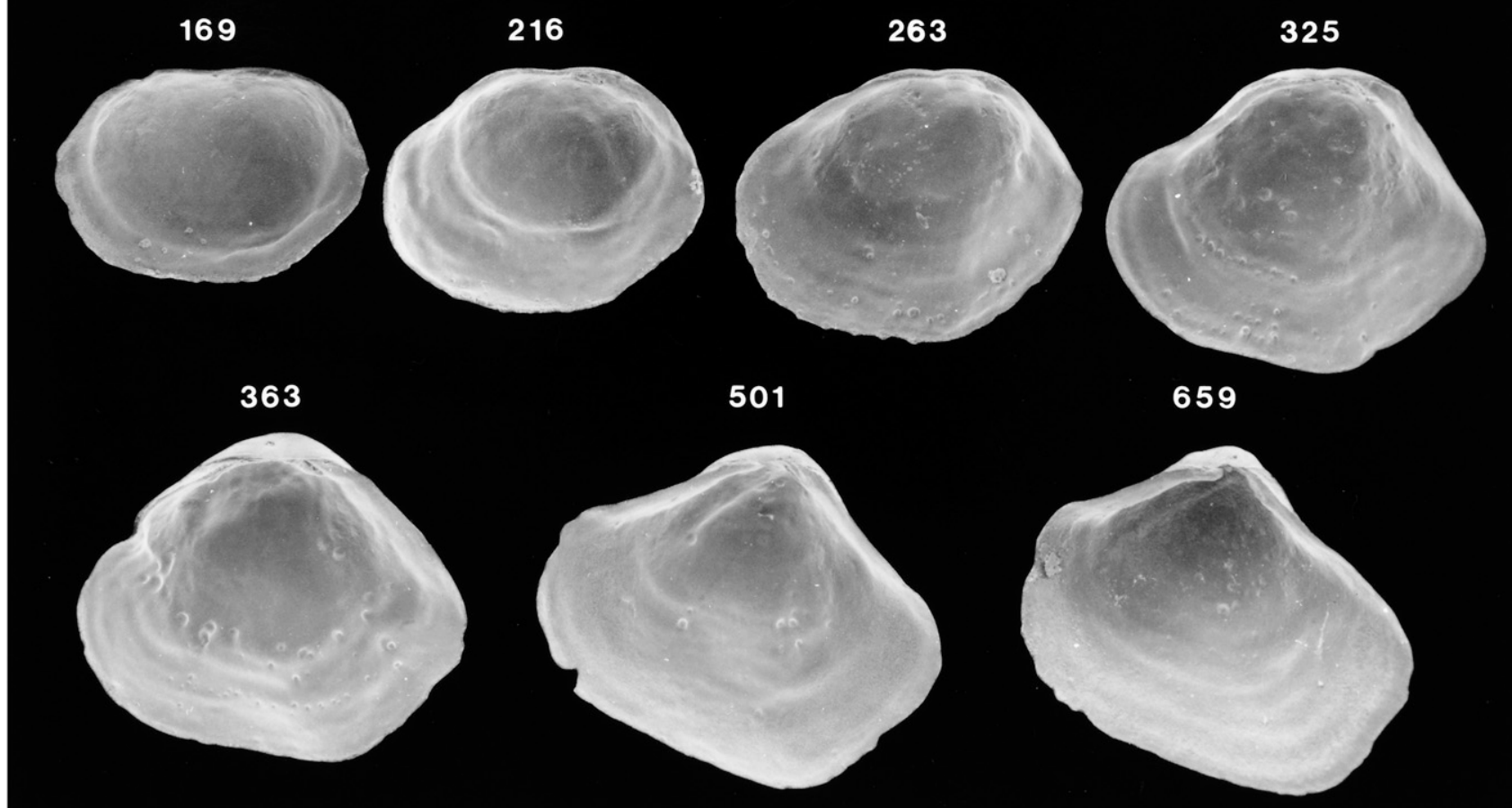

Figure 144. Scanning electron micrographs of disarticulated shell valves of Lyonsia hyalina postlarvae. Numbers indicate the maximum linear shell dimension in micrometers. 


\section{LYONSIA HYALINA}

\section{LEFT VALVE}

\section{8}

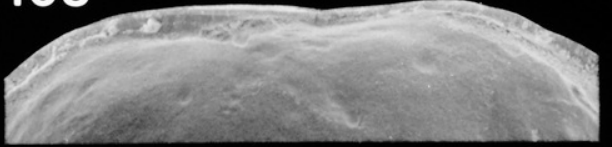

216

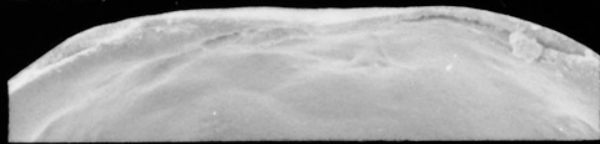

\section{0}

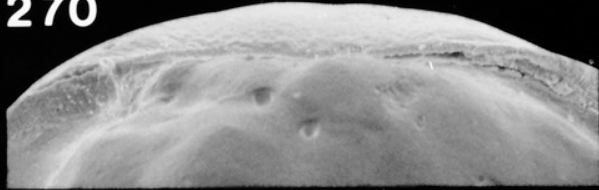

352
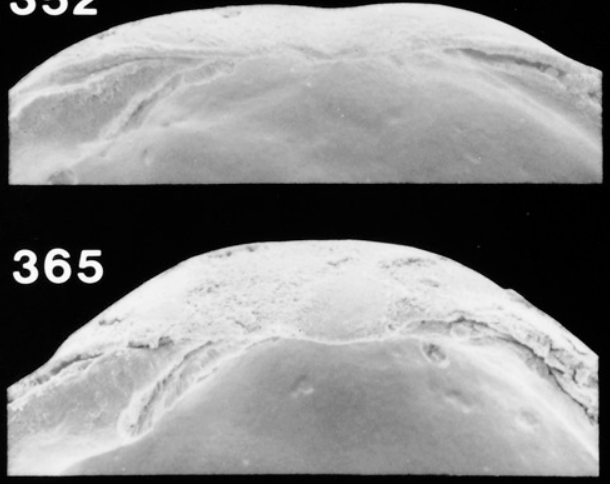

\section{6}

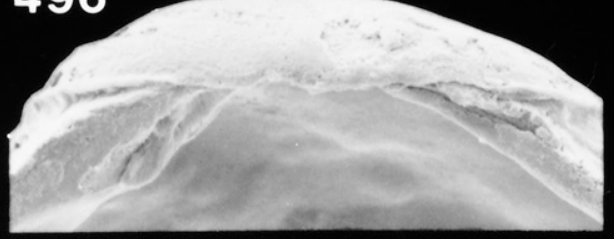

564

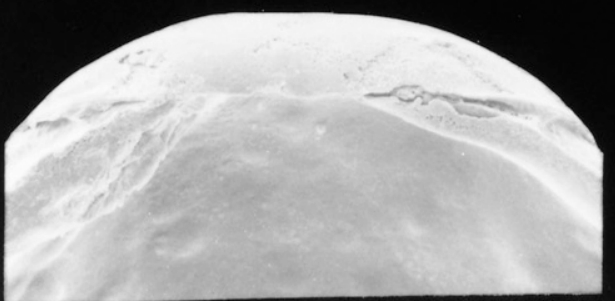

\section{RIGHT VALVE}

\section{9}

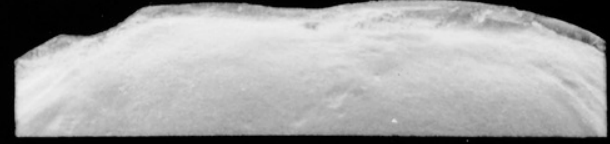

\section{6}

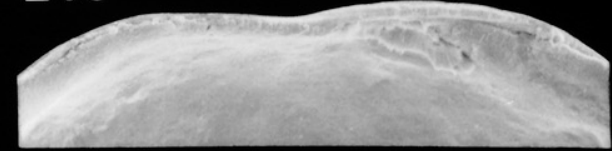

\section{3}

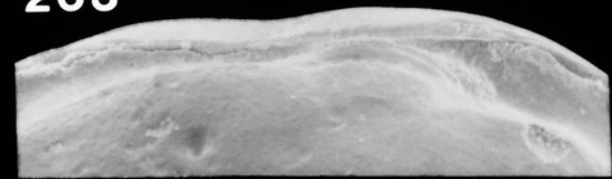

325
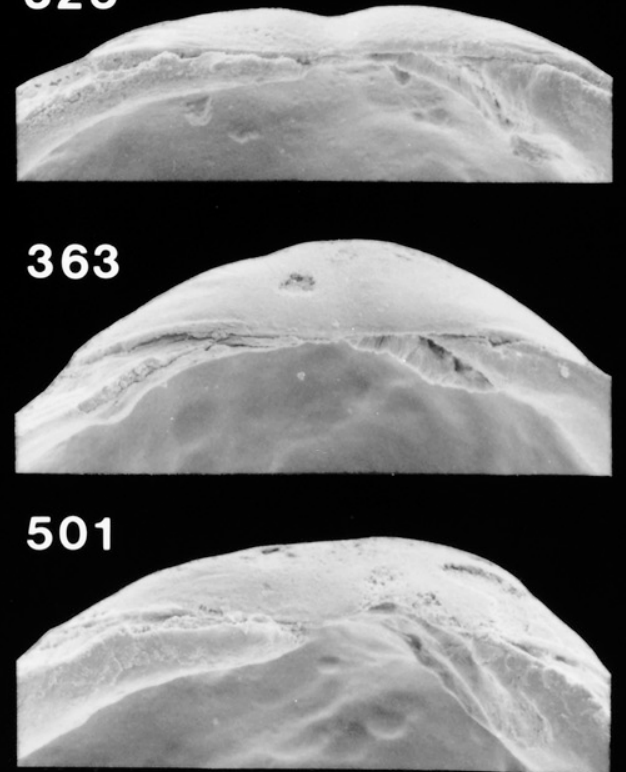

\section{9}

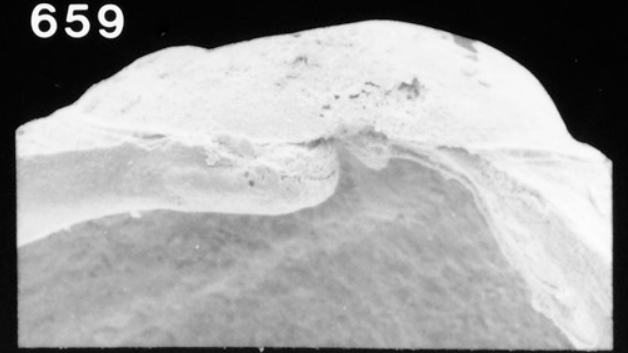




\section{PERIPLOMA LEANUM}

\section{LEFT VALVE}

\section{1}
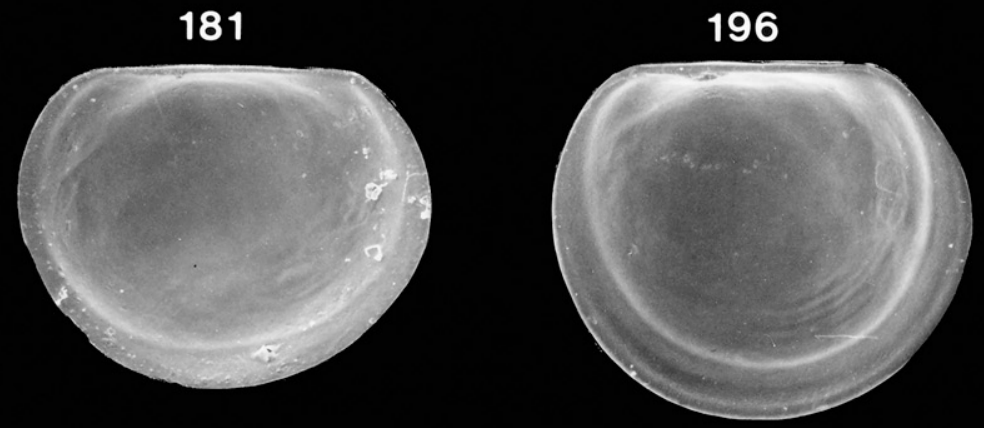

\section{RIGHT VALVE}

177

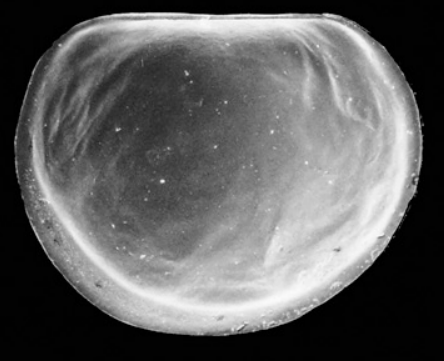

197

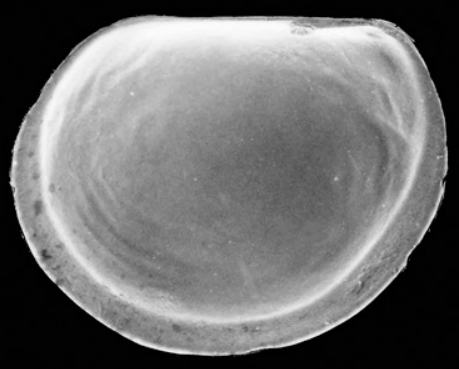

\section{PERIPLOMA LEANUM}

LEFT VALVE

181

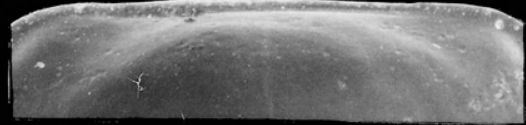

196

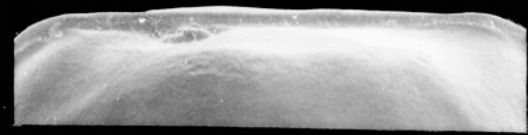

RIGHT VALVE

177

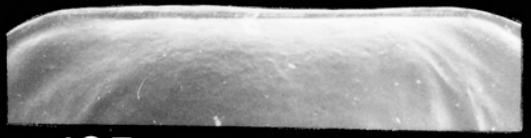

197

Figure 146. Scanning electron micrographs of disarticulated shell valves of Periploma leanum postlarvae (top) and higher magnification scanning electron micrographs of the hinge of these shell valves (bottom). Numbers indicate the maximum linear shell dimension in micrometers. 


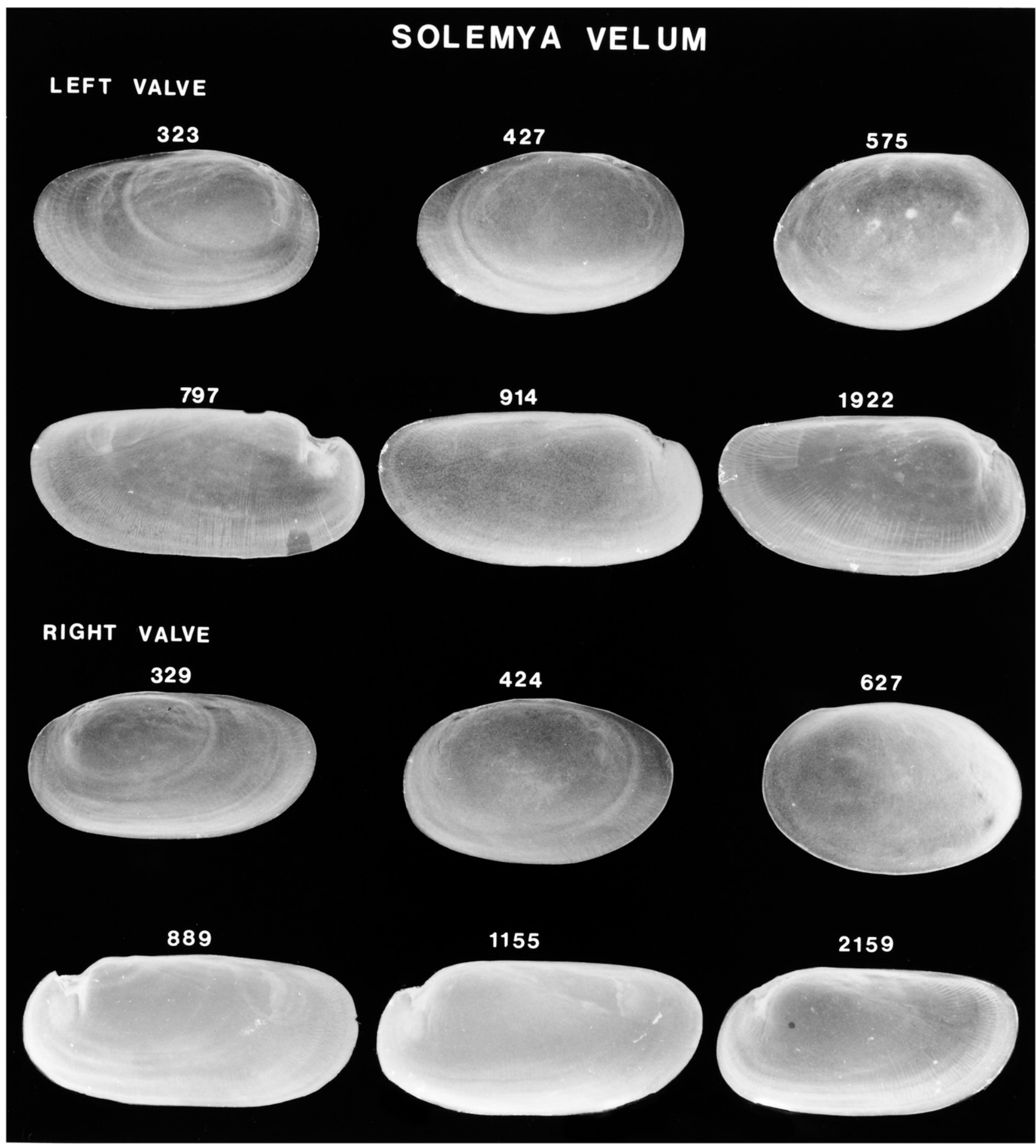

Figure 147. Scanning electron micrographs of disarticulated shell valves of Solemya velum postlarvae. Numbers indicate the maximum linear shell dimension in micrometers. Modified from Gustafson and Lutz (1992). 


\section{SOLEMYA VELUM}

\section{LEFT VALVE}

\section{3}

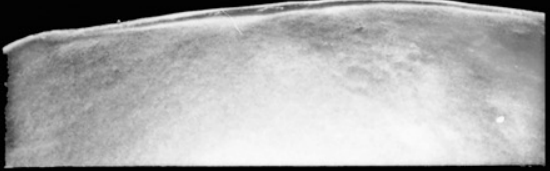

427

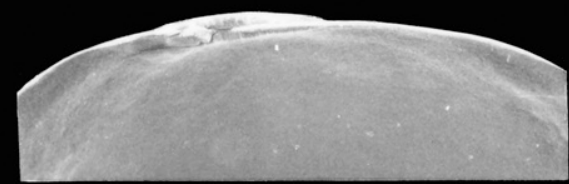

575

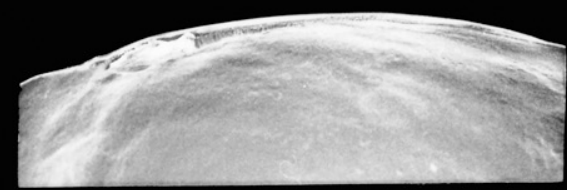

797

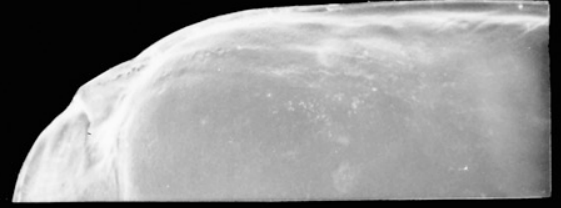

914

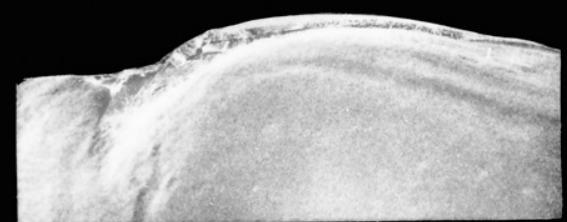

1922

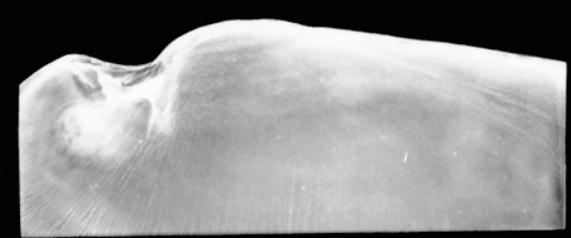

\section{RIGHT VALVE}

\section{9}

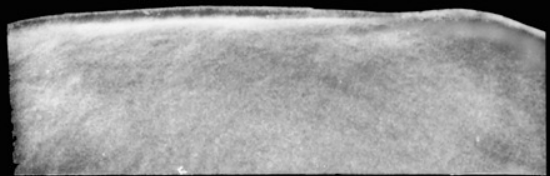

424

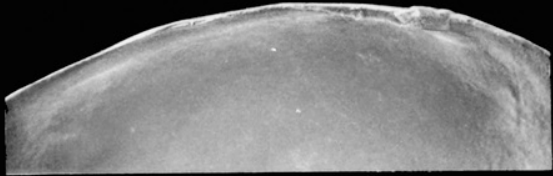

627

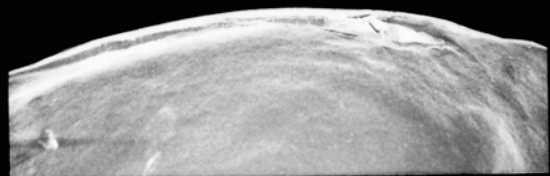

889

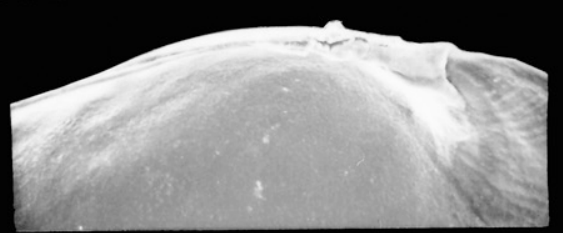

\section{5}

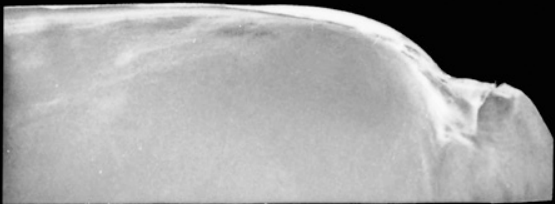

\section{9}

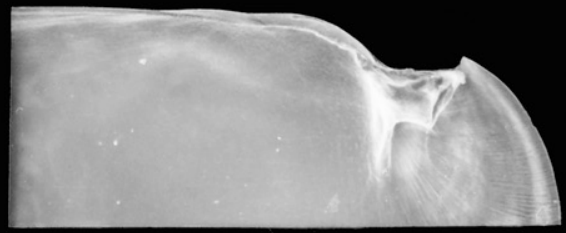

Figure 148. Scanning electron micrographs of the hinge of disarticulated shell valves of Solemya velum postlarvae seen in Figure 147. Numbers indicate the maximum linear shell dimension in micrometers. Modified from Gustafson and Lutz (1992). 


\section{ARCTICA ISLANDICA}

\section{LEFT VALVE}

107

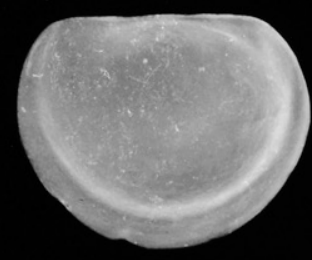

160

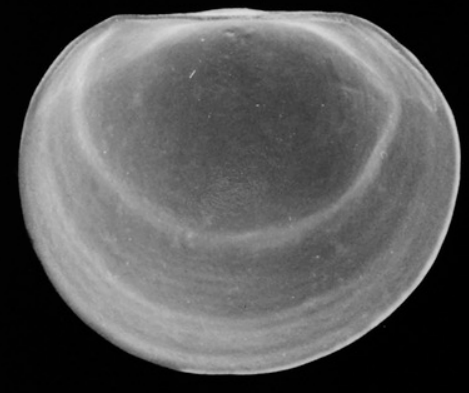

123

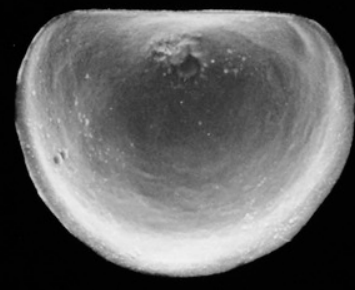

179
145

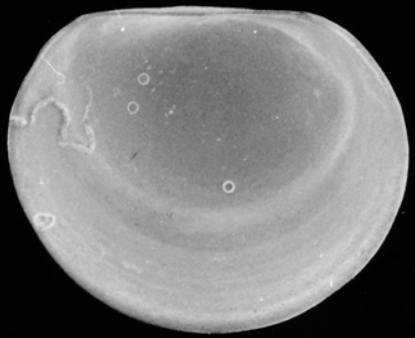

199

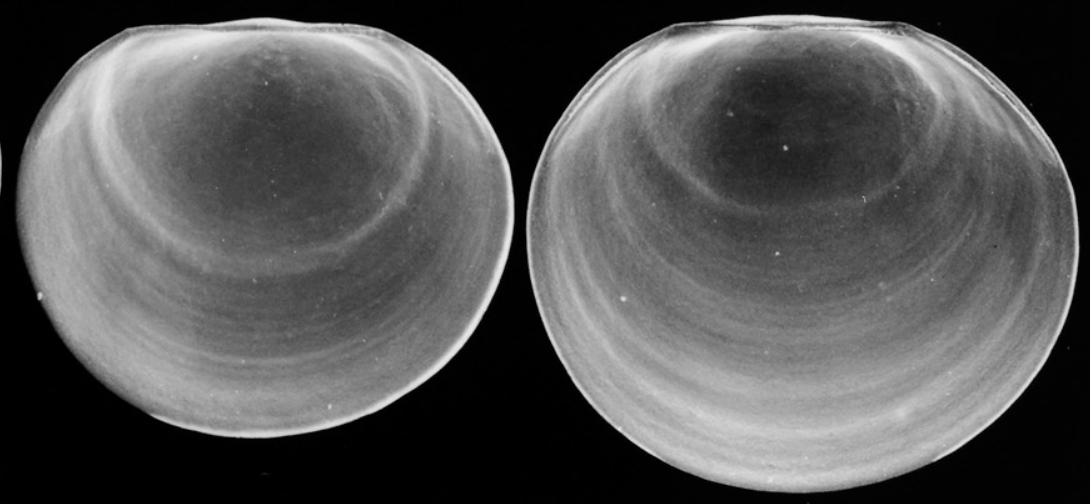

RIGHT VALVE

117

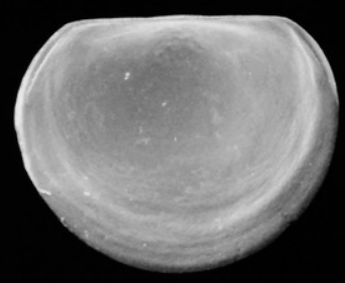

163
130

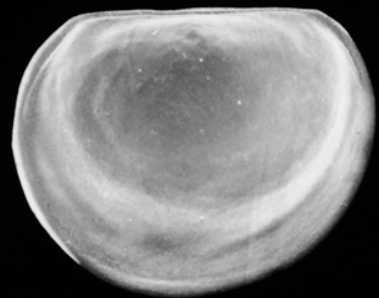

174
148

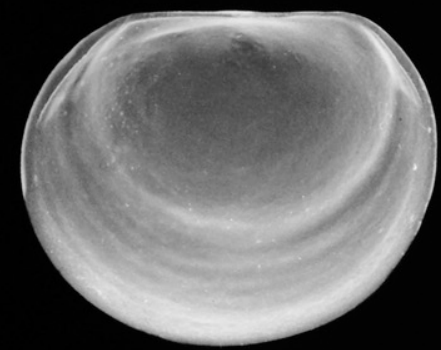

193
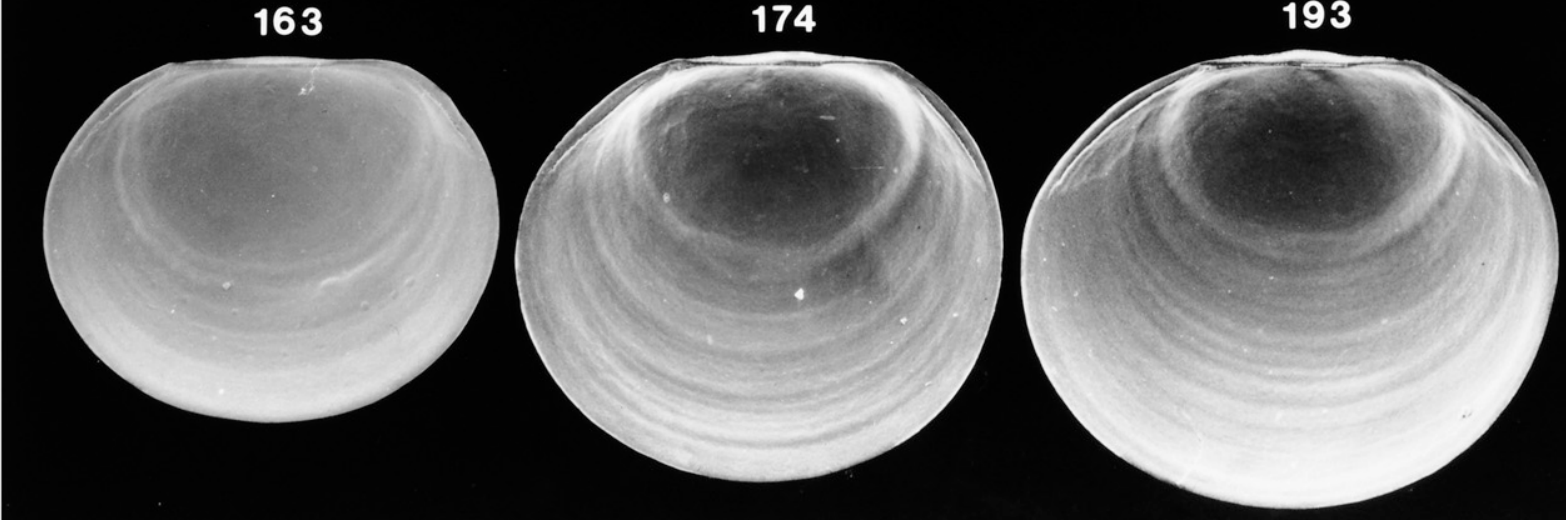

Figure 149. Scanning electron micrographs of disarticulated shell valves of Arctica islandica larvae. Numbers indicate the maximum linear shell dimension in micrometers. Modified from Lutz et al. (1982). 


\section{ARCTICA ISLANDICA}

\section{LEFT VALVE}

\section{7}

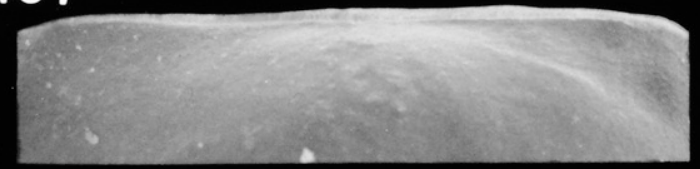

\section{3}

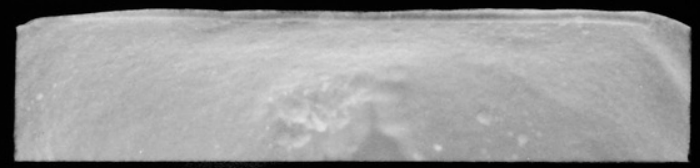

\section{5}

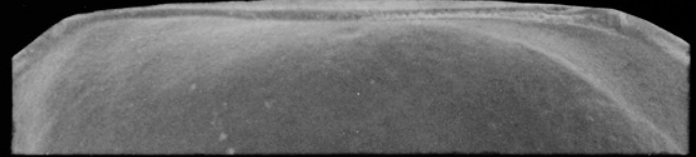

160

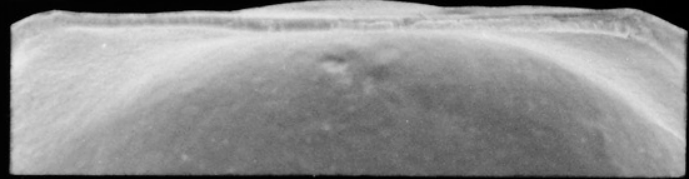

\section{9}

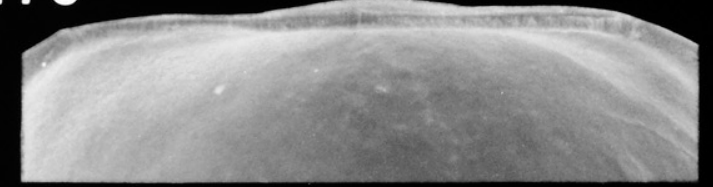

199

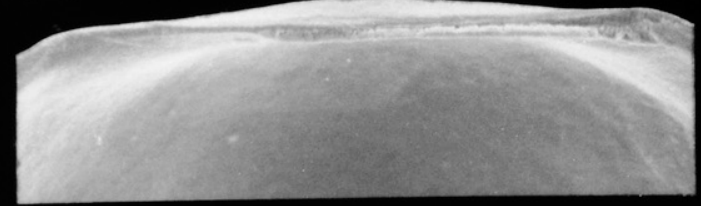

\section{RIGHT VALVE}

117

130

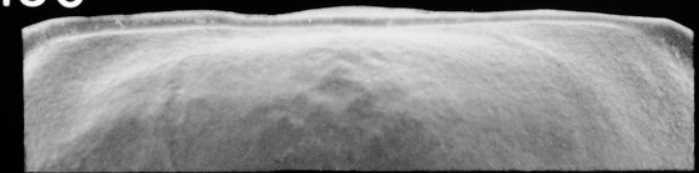

148

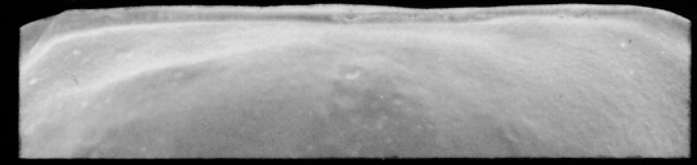

163

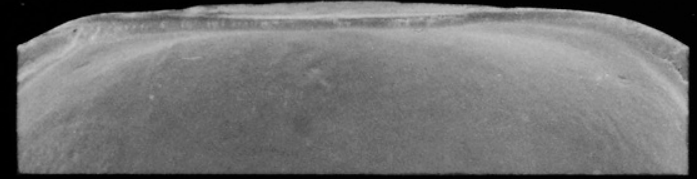

174

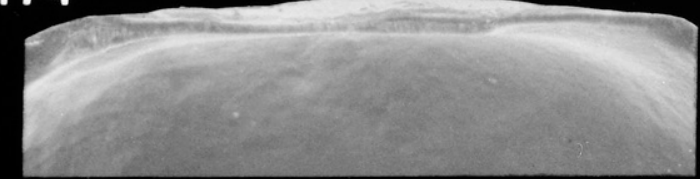

193

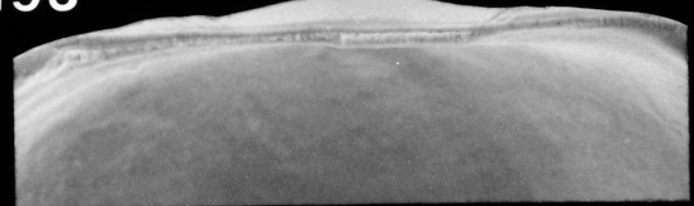

Figure 150. Scanning electron micrographs of the hinge of disarticulated shell valves of Arctica islandica larvae seen in Figure 149. Numbers indicate the maximum linear shell dimension in micrometers. Modified from Lutz et al. (1982). 


\section{ARCTICA ISLANDICA}
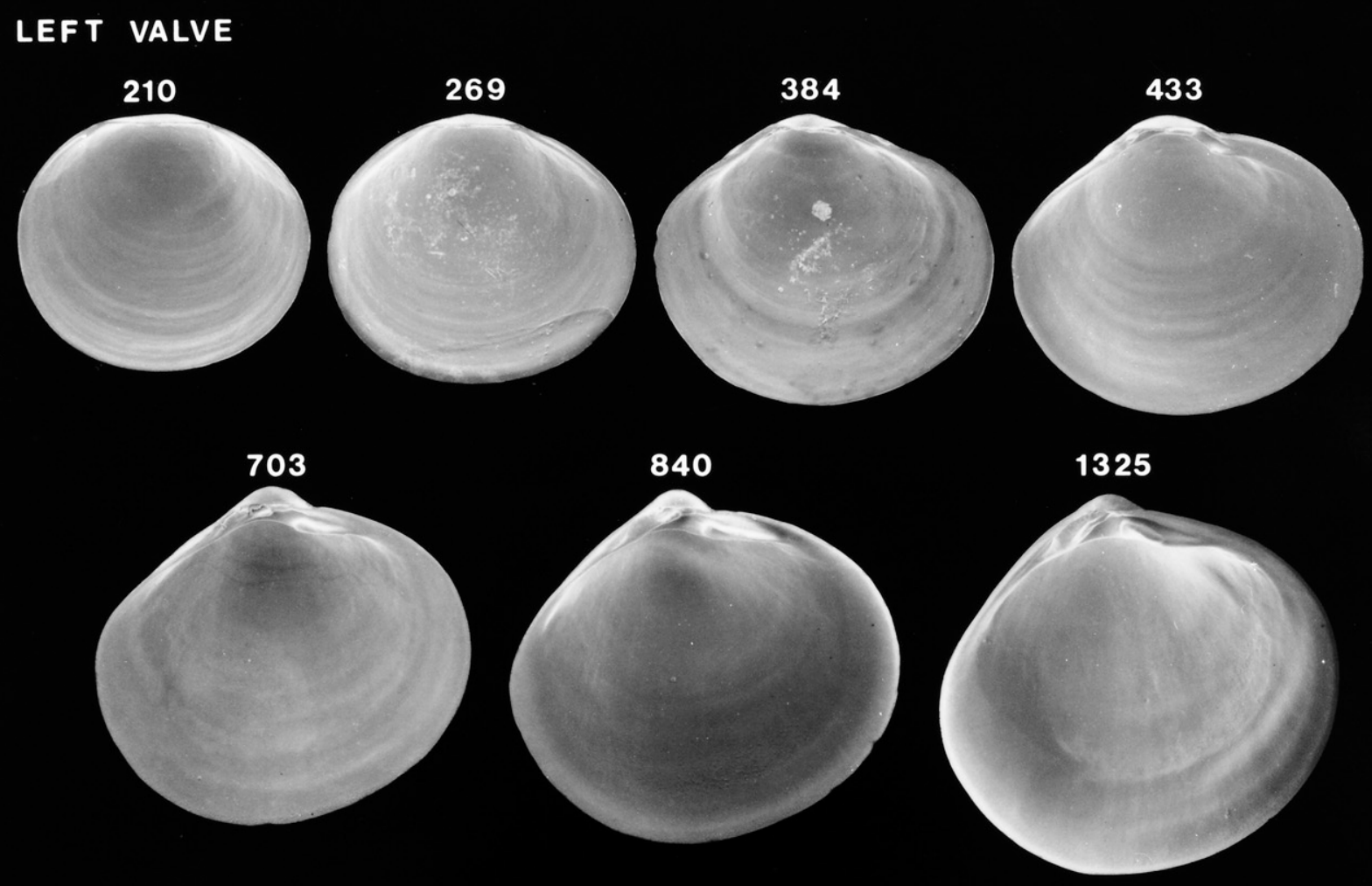

\section{RIGHT VALVE}
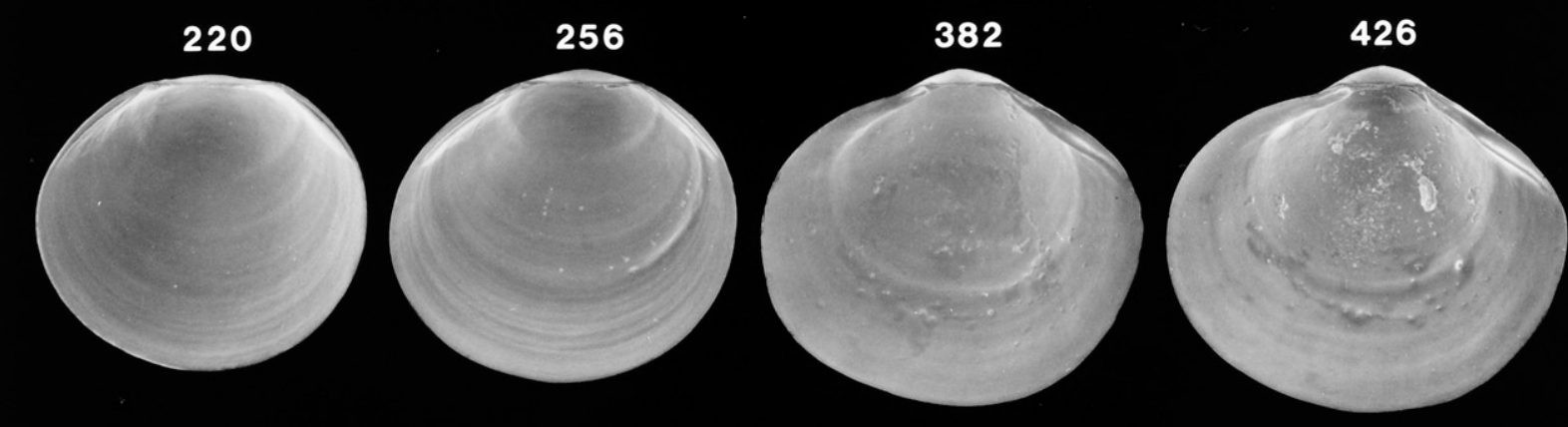

639

753

1179
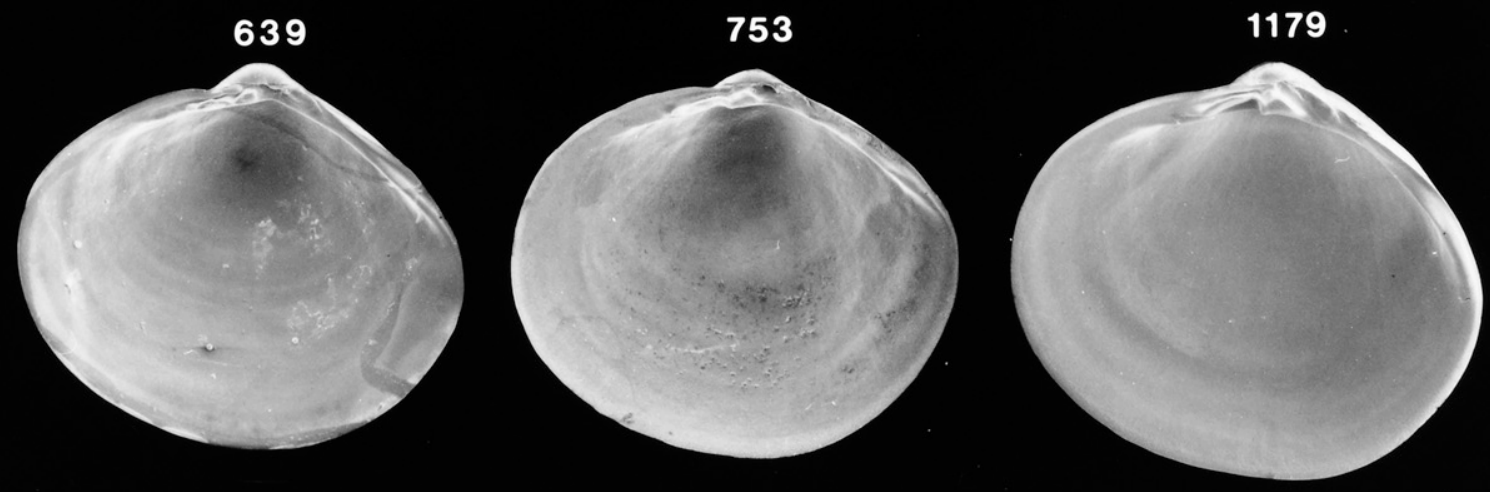

Figure 151. Scanning electron micrographs of disarticulated shell valves of Arctica islandica postlarvae. Numbers indicate the maximum linear shell dimension in micrometers. Modified from Lutz et al. (1982). 


\section{ARCTICA ISLANDICA}

\section{LEFT VALVE}

\section{0}

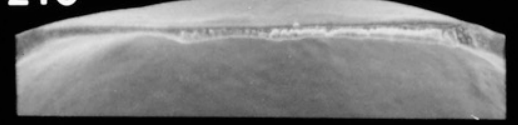

\section{9}
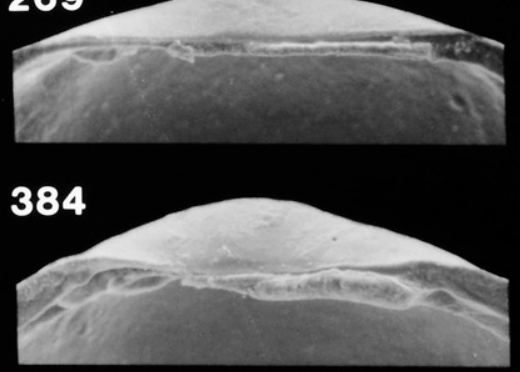

\section{3}

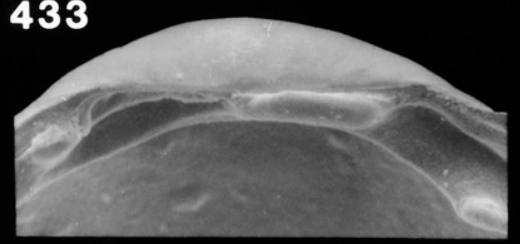

\section{3}
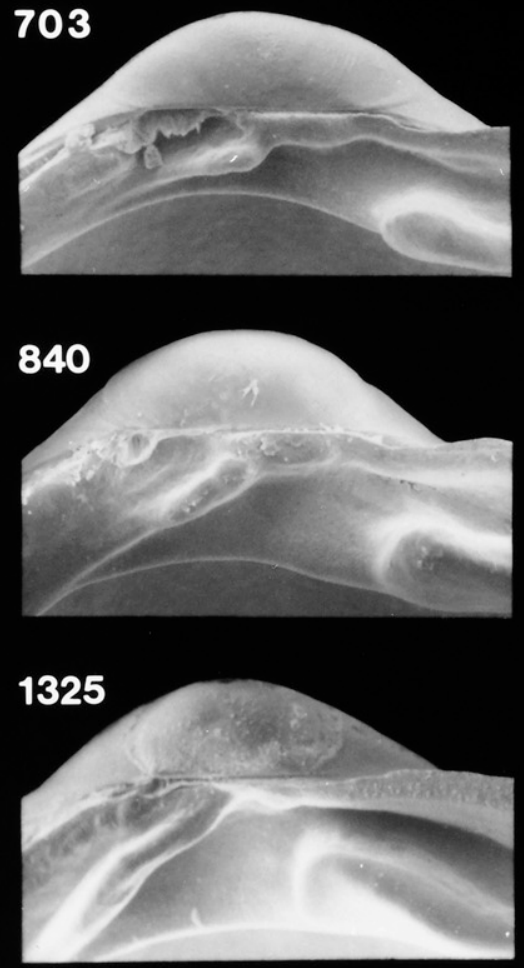

\section{RIGHT VALVE}

\section{0}

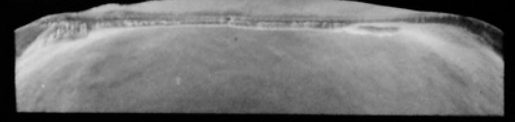

\section{6}
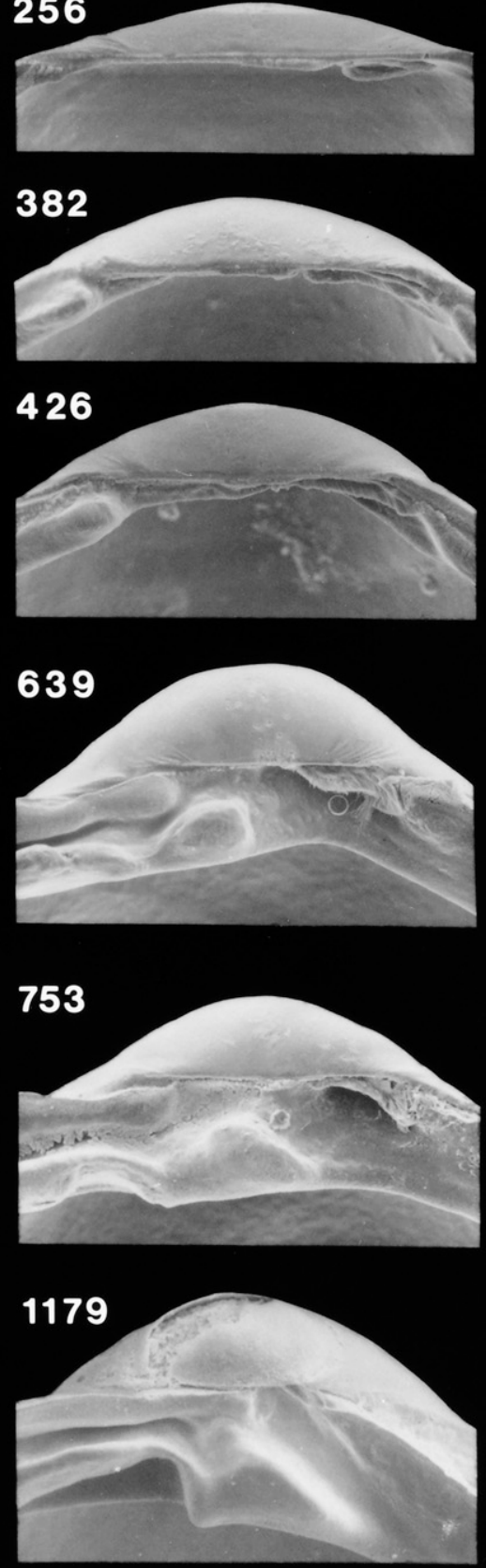


\section{MULINIA LATERALIS}

\section{LEFT VALVE}
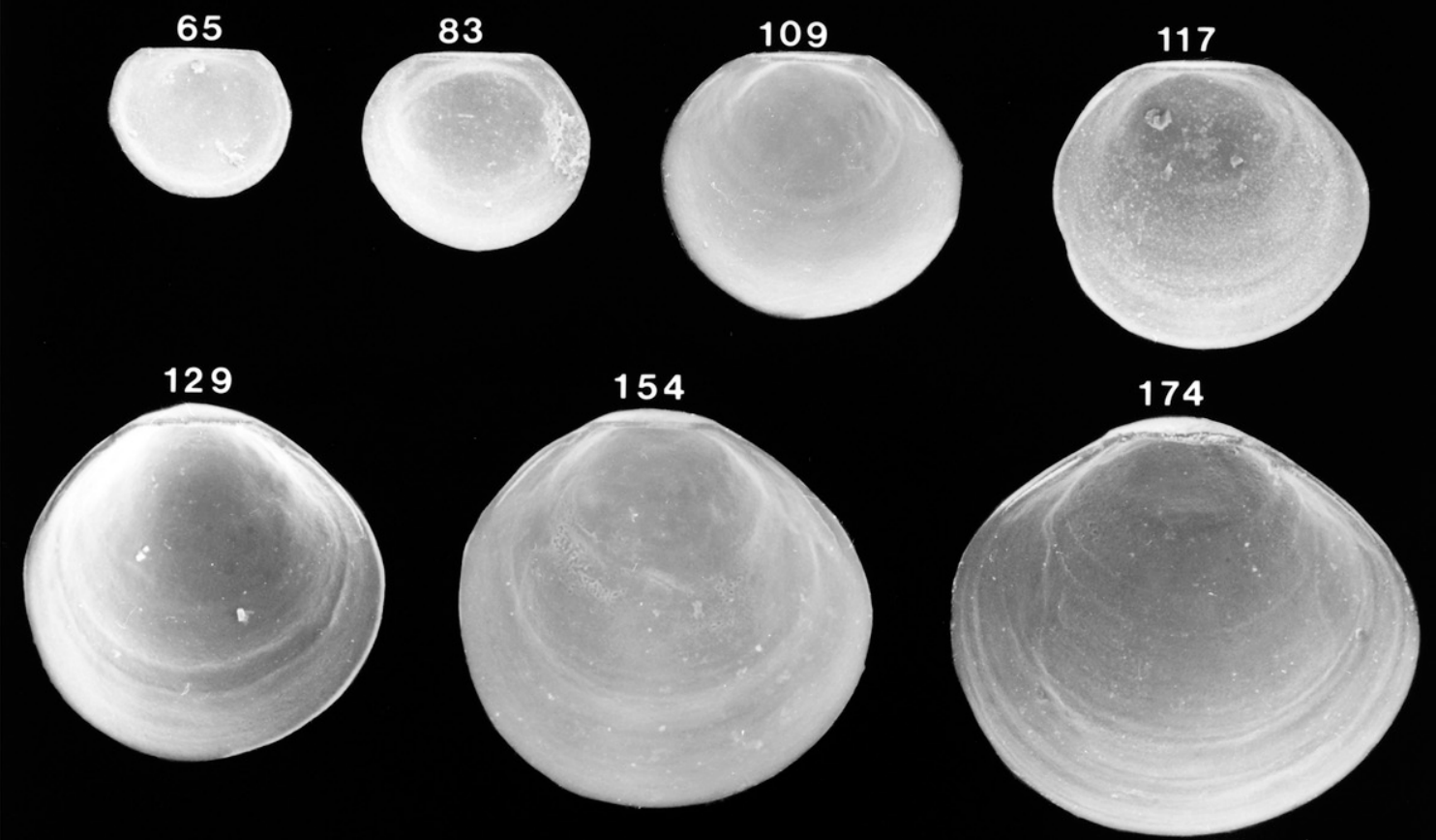

\section{RIGHT VALVE}

68

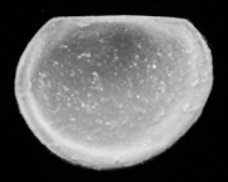

88

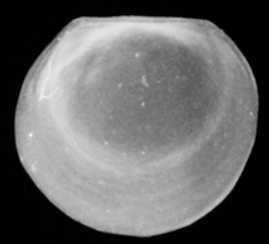

108
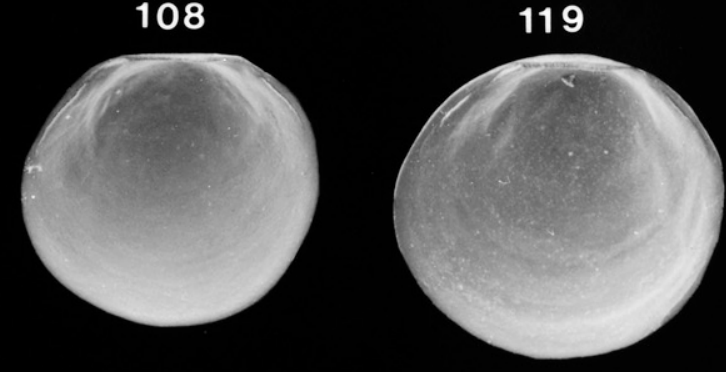

176

149
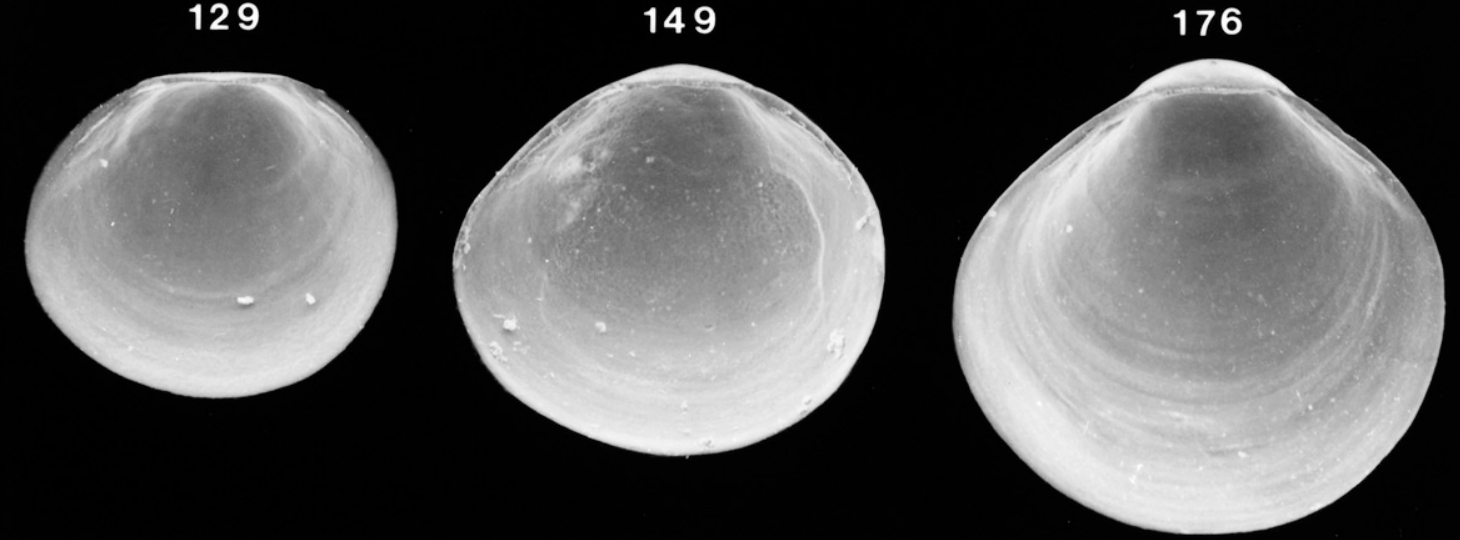

Figure 153. Scanning electron micrographs of disarticulated shell valves of Mulinia lateralis larvae. Numbers indicate the maximum linear shell dimension in micrometers. 


\section{MULINIA LATERALIS}

\section{LEFT VALVE}

\section{5}

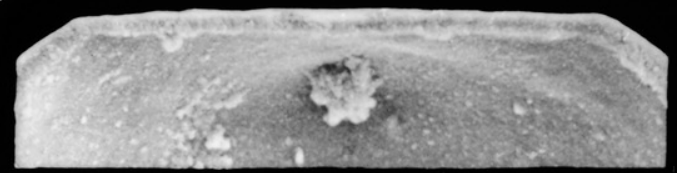

83

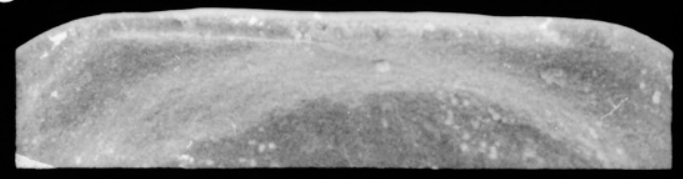

109

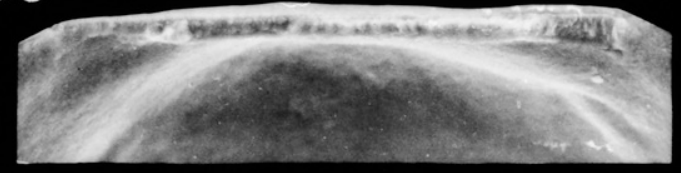

117

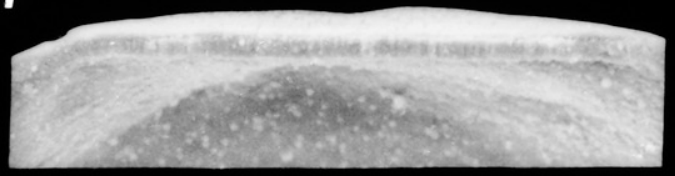

129

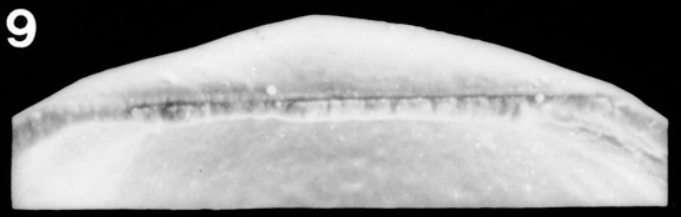

154

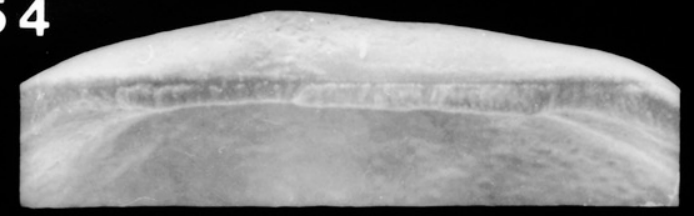

174

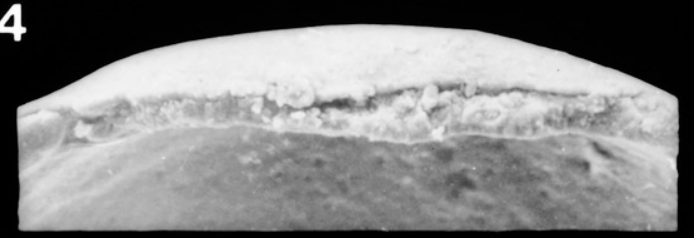

\section{RIGHT VALVE}

\section{8}

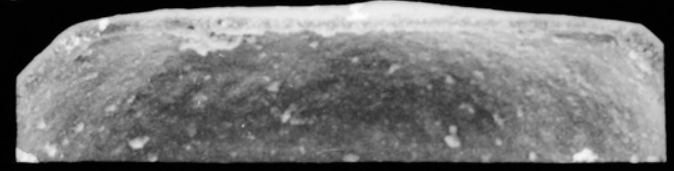

88

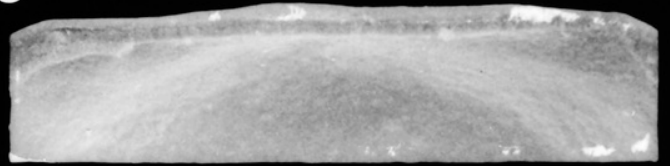

108

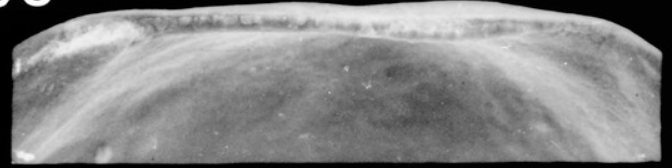

119

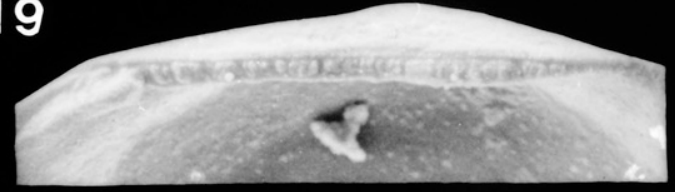

129

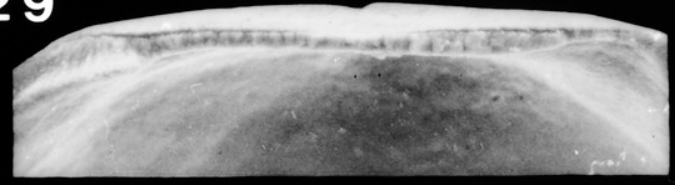

149

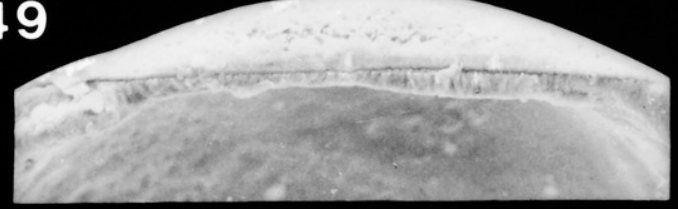

176

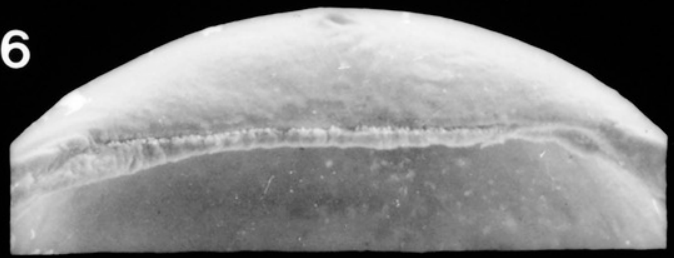

Figure 154. Scanning electron micrographs of the hinge of disarticulated shell valves of Mulinia lateralis larvae seen in Figure 153. Numbers indicate the maximum linear shell dimension in micrometers. 


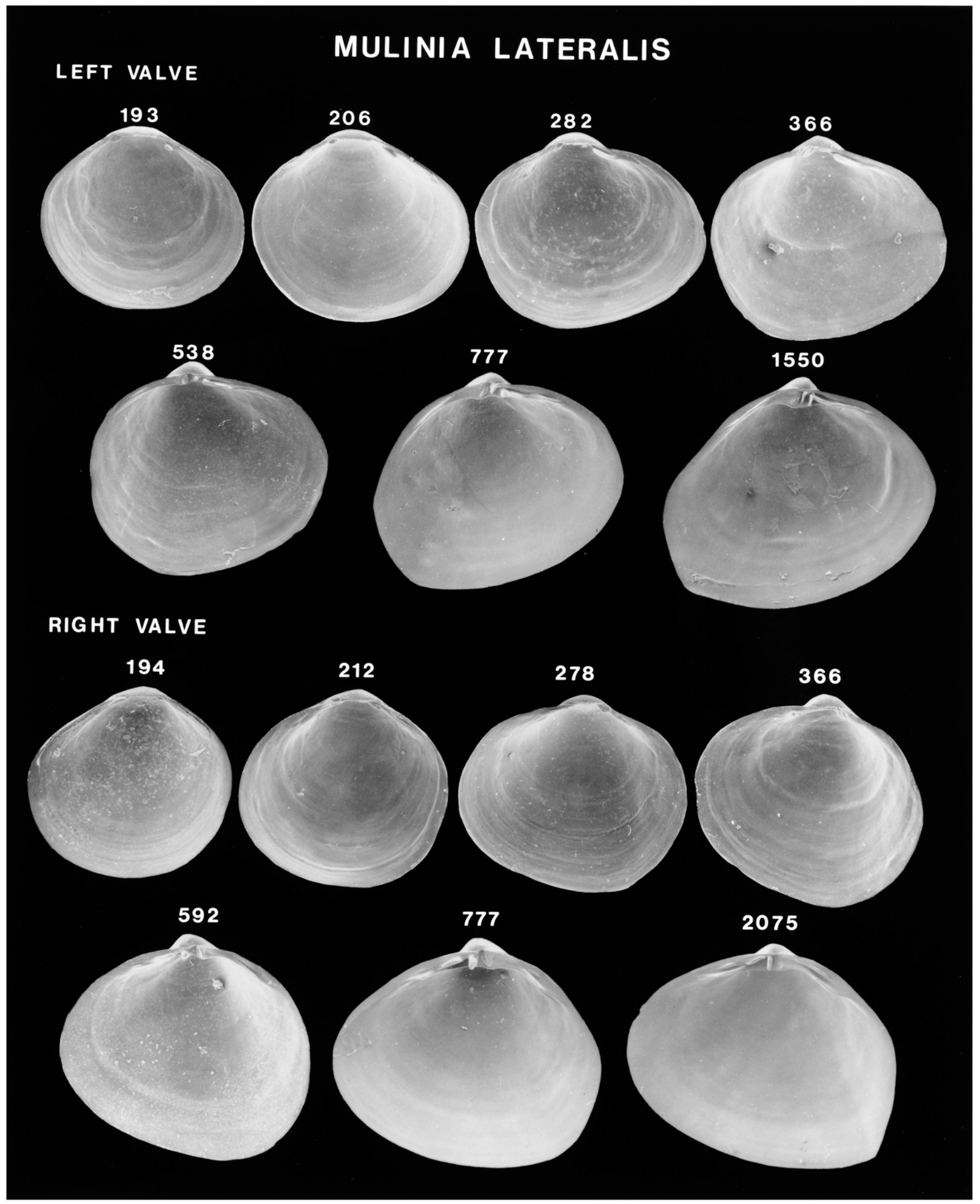

Figure 155. Scanning electron micrographs of disarticulated shell valves of Mulinia lateralis postlarvae. Numbers indicate the maximum linear shell dimension in micrometers. 


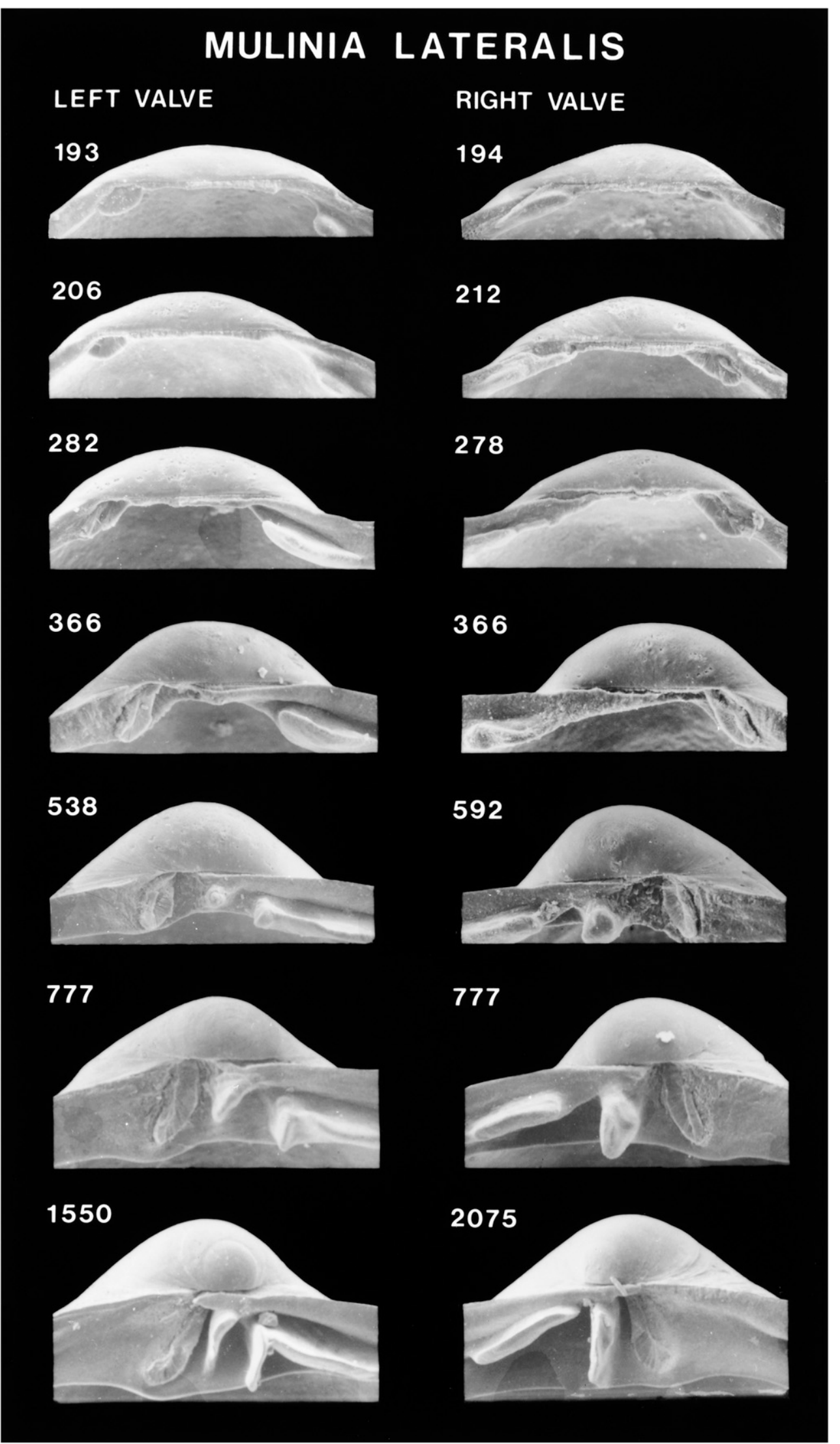

Figure 156. Scanning electron micrographs of the hinge of disarticulated shell valves of Mulinia lateralis postlarvae seen in Figure 155. Numbers indicate the maximum linear shell dimension in micrometers. 


\section{RANGIA CUNEATA}

\section{LEFT VALVE}

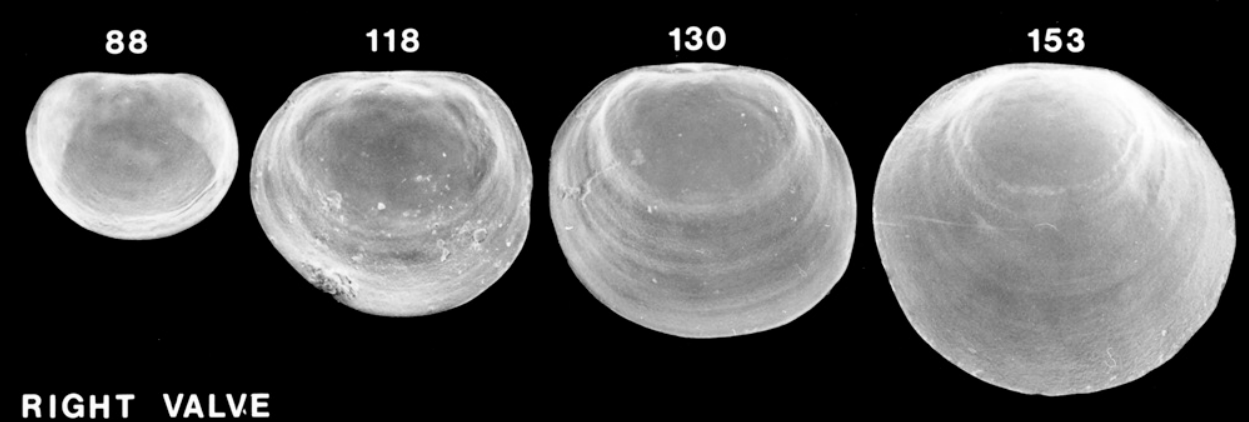

\section{RIGHT VALVE}

92

\section{3}
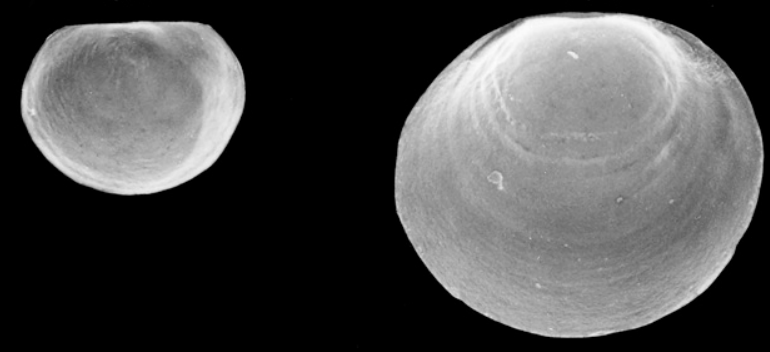

\section{RANGIA CUNEATA}

\section{LEFT VALVE}

\section{8}

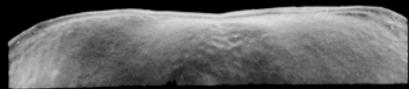

118

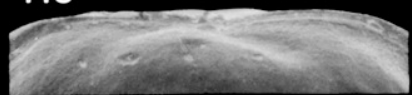

130

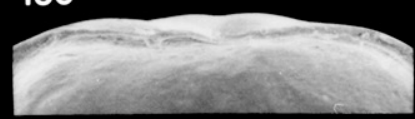

153

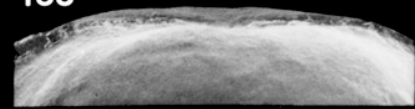

\section{RIGHT VALVE}

\section{2}

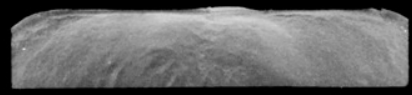

153

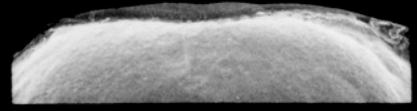




\section{RANGIA CUNEATA}

\section{LEFT VALVE}
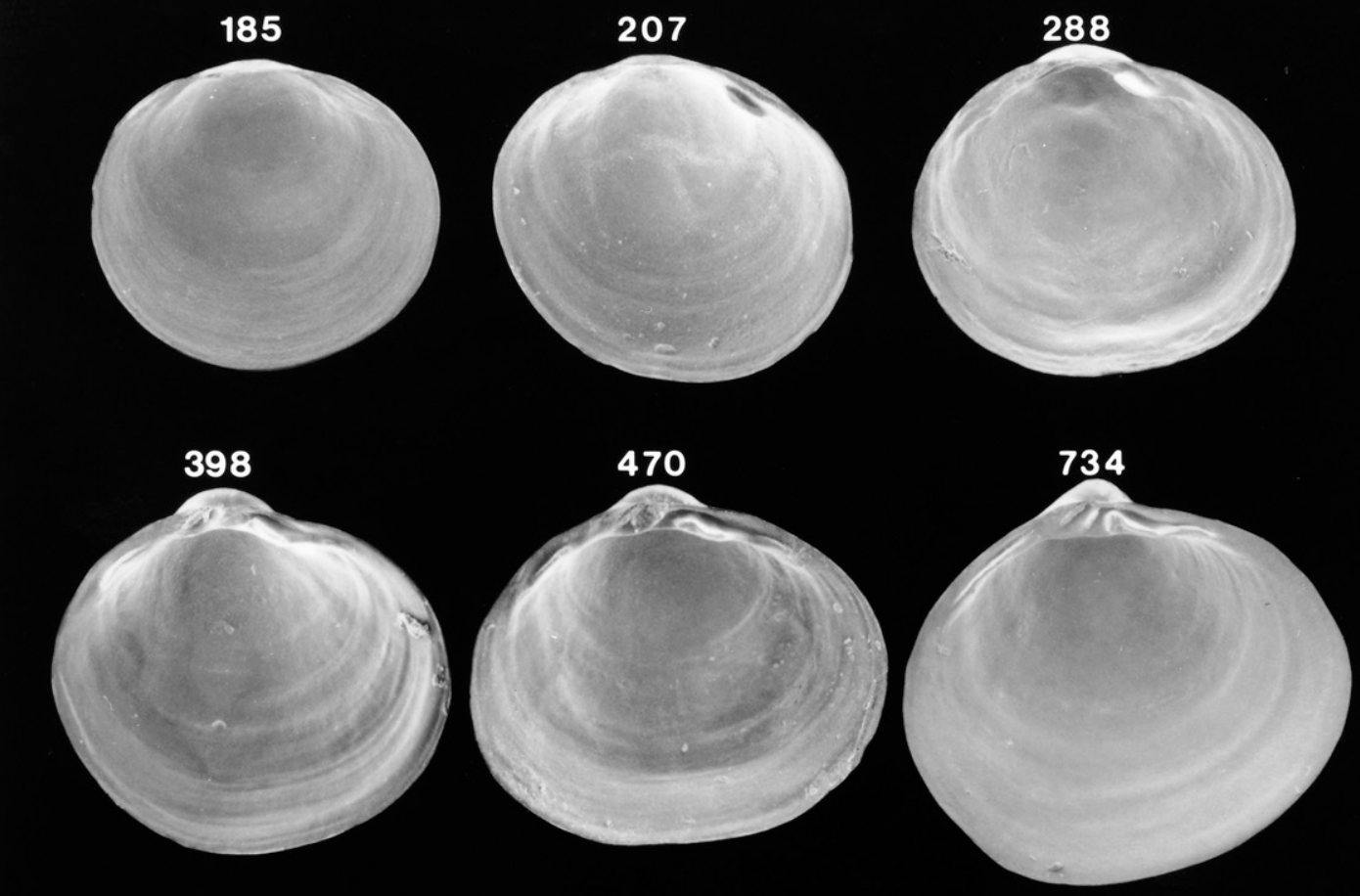

\section{RIGHT VALVE}
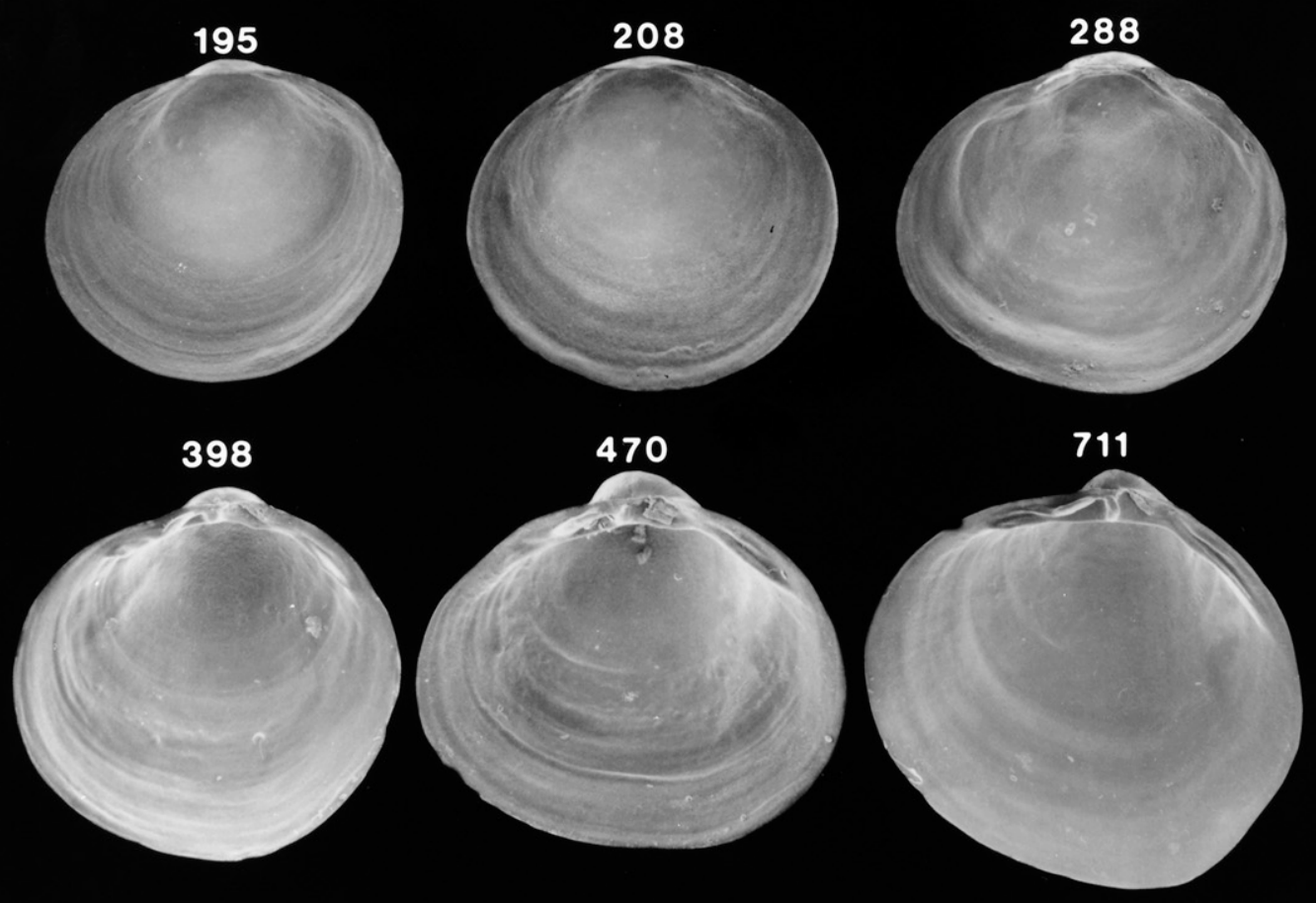

Figure 158. Scanning electron micrographs of disarticulated shell valves of Rangia cuneata postlarvae. Numbers indicate the maximum linear shell dimension in micrometers. 


\section{RANGIA CUNEATA}

\section{LEFT VALVE}
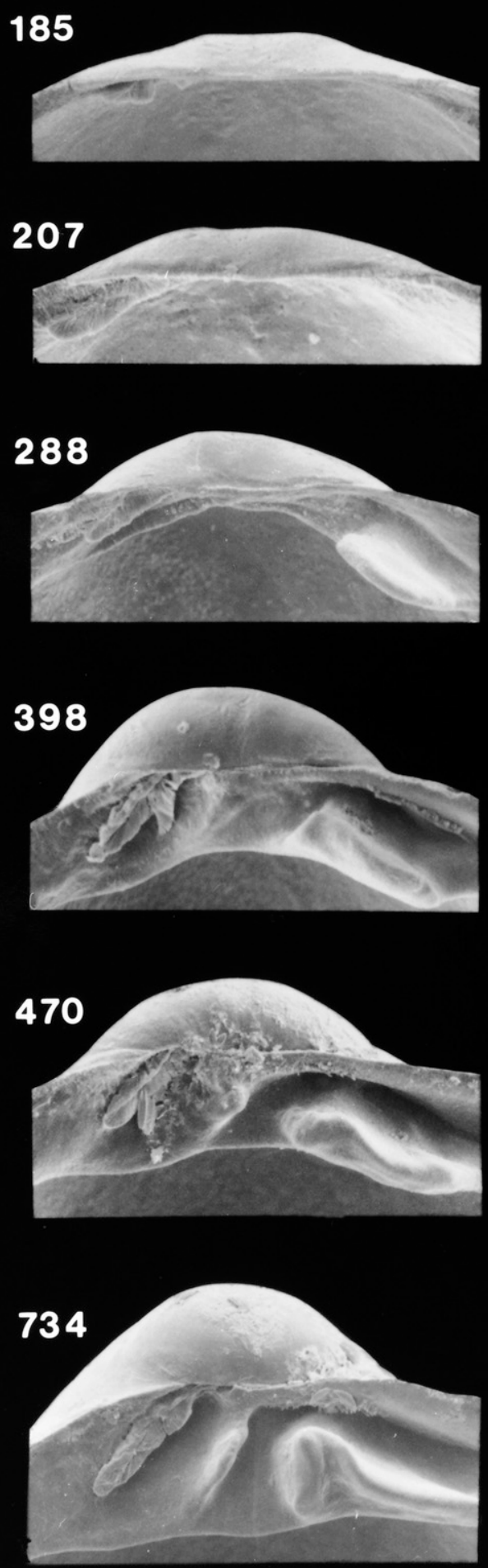

\section{RIGHT VALVE}
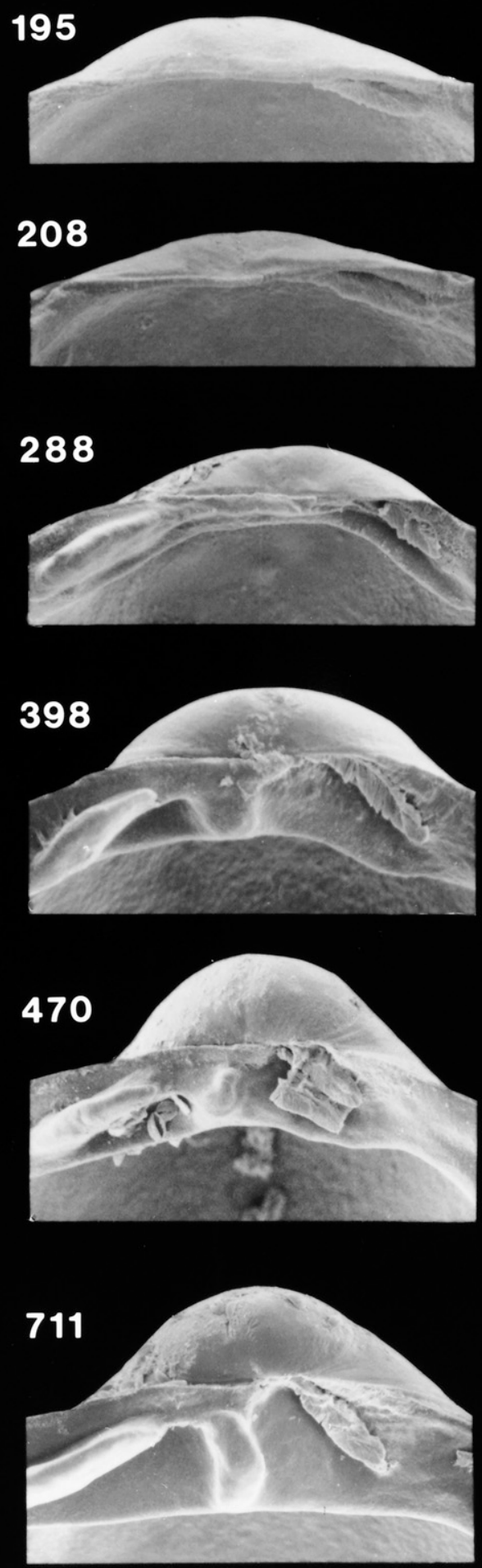

Figure 159. Scanning electron micrographs of the hinge of disarticulated shell valves of Rangia cuneata postlarvae seen in Figure 158. Numbers indicate the maximum linear shell dimension in micrometers. 


\section{SPISULA SOLIDISSIMA}

\section{LEFT VALVE}
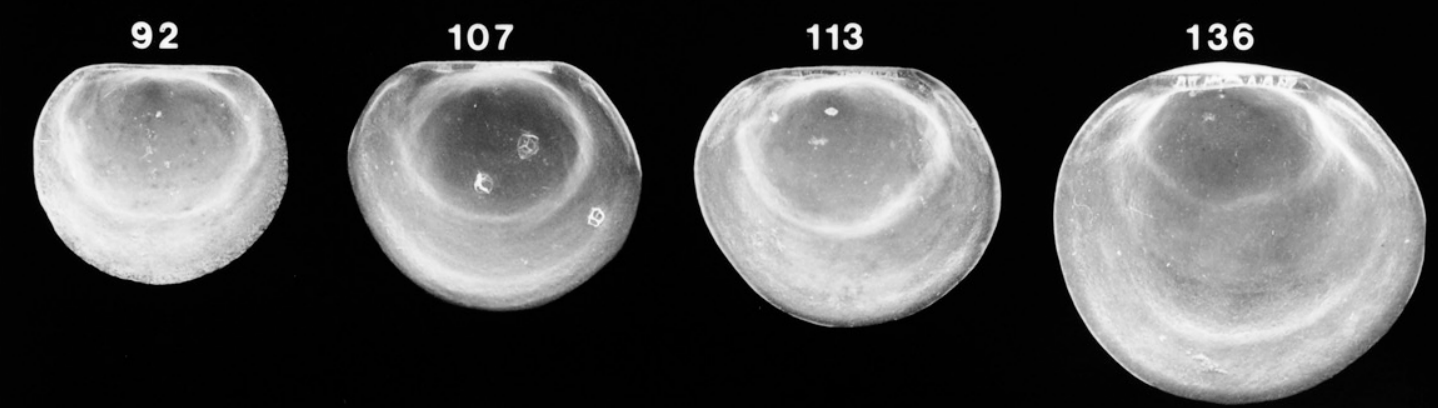

143

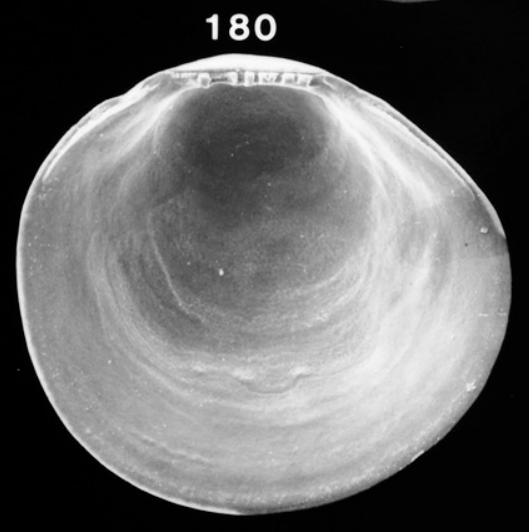

RIGHT VALVE

85

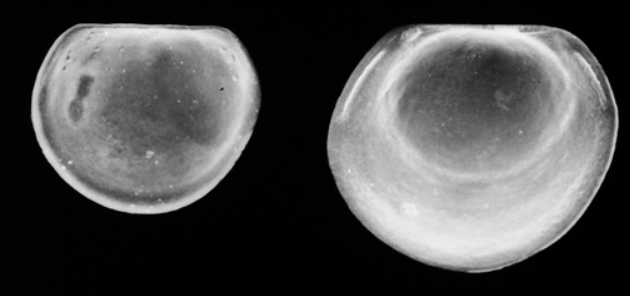

165

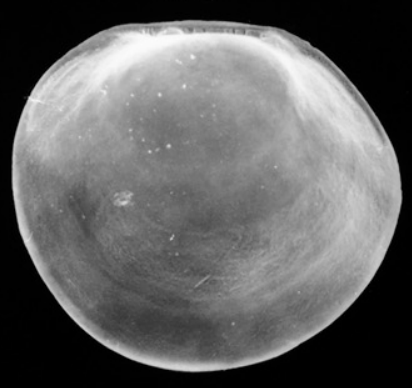

\section{E}




\section{SPISULA SOLIDISSIMA}

\section{LEFT VALVE}

92

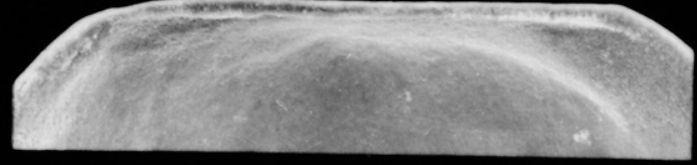

\section{7}

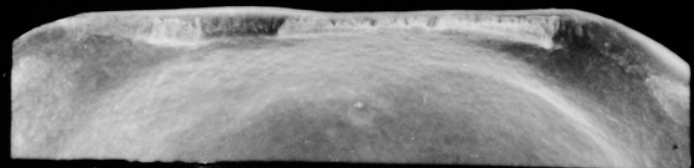

\section{3}

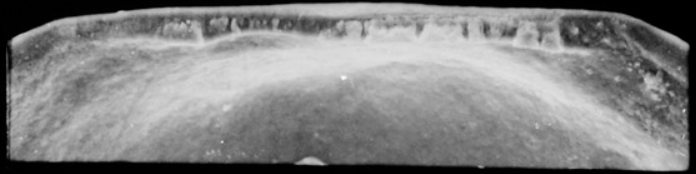

136

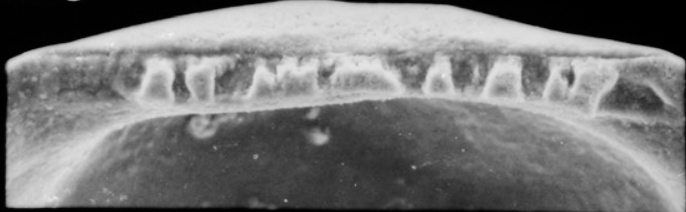

143

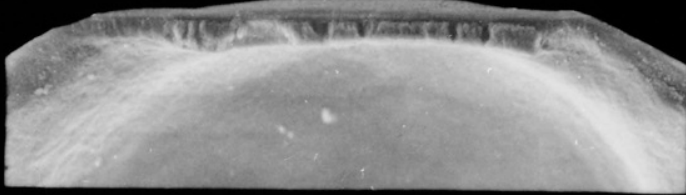

180

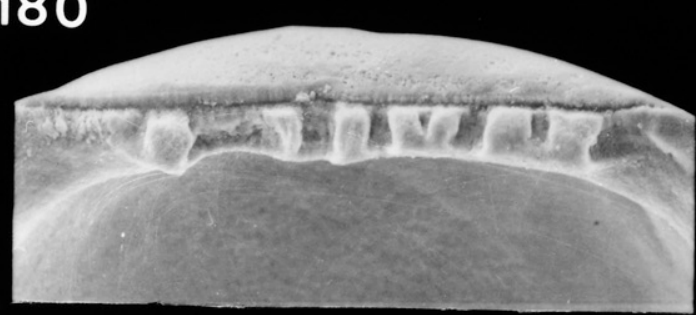

\section{RIGHT VALVE}

85

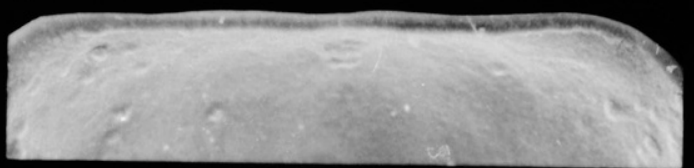

107

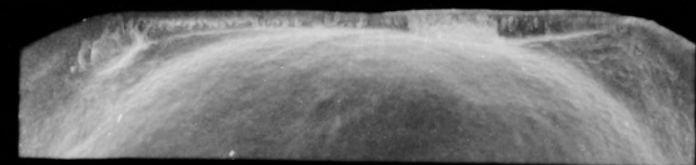

120

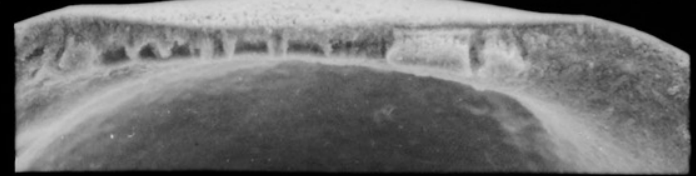

\section{5}
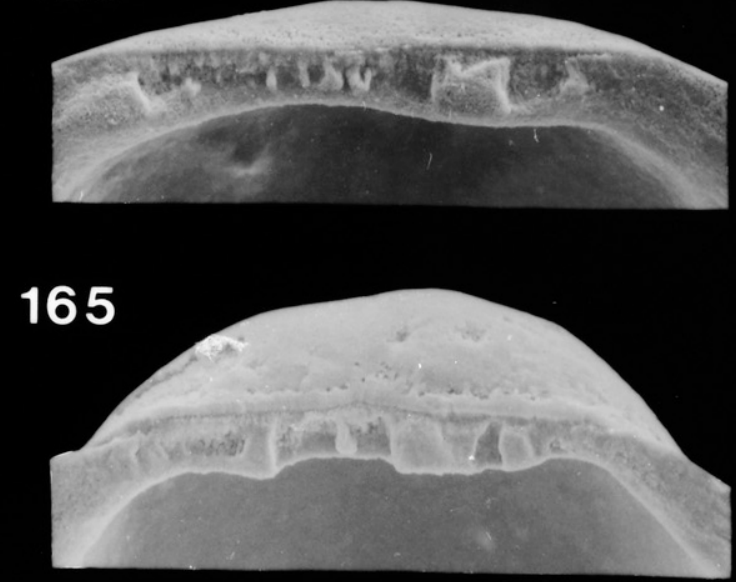

184

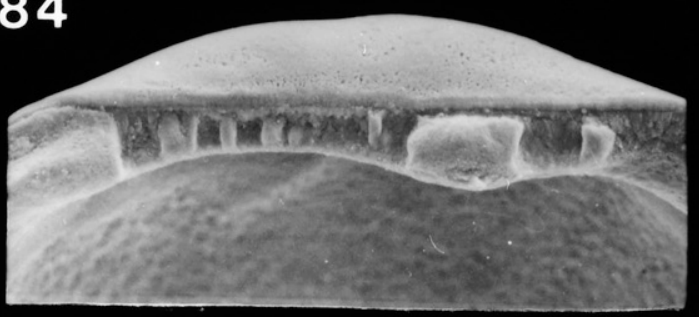




\section{SPISULA SOLIDISSIMA}

\section{LEFT VALVE}
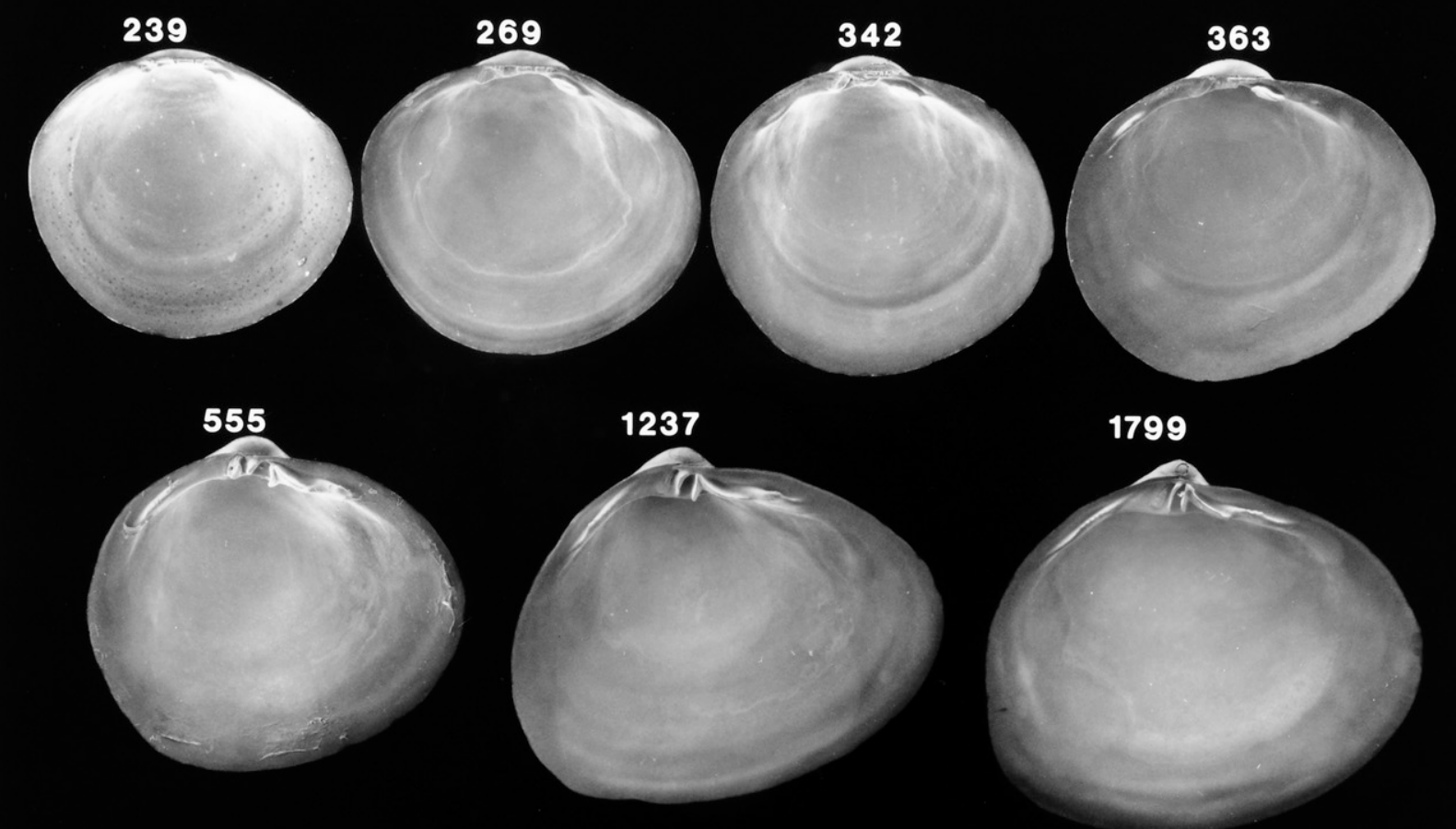

\section{RIGHT VALVE}
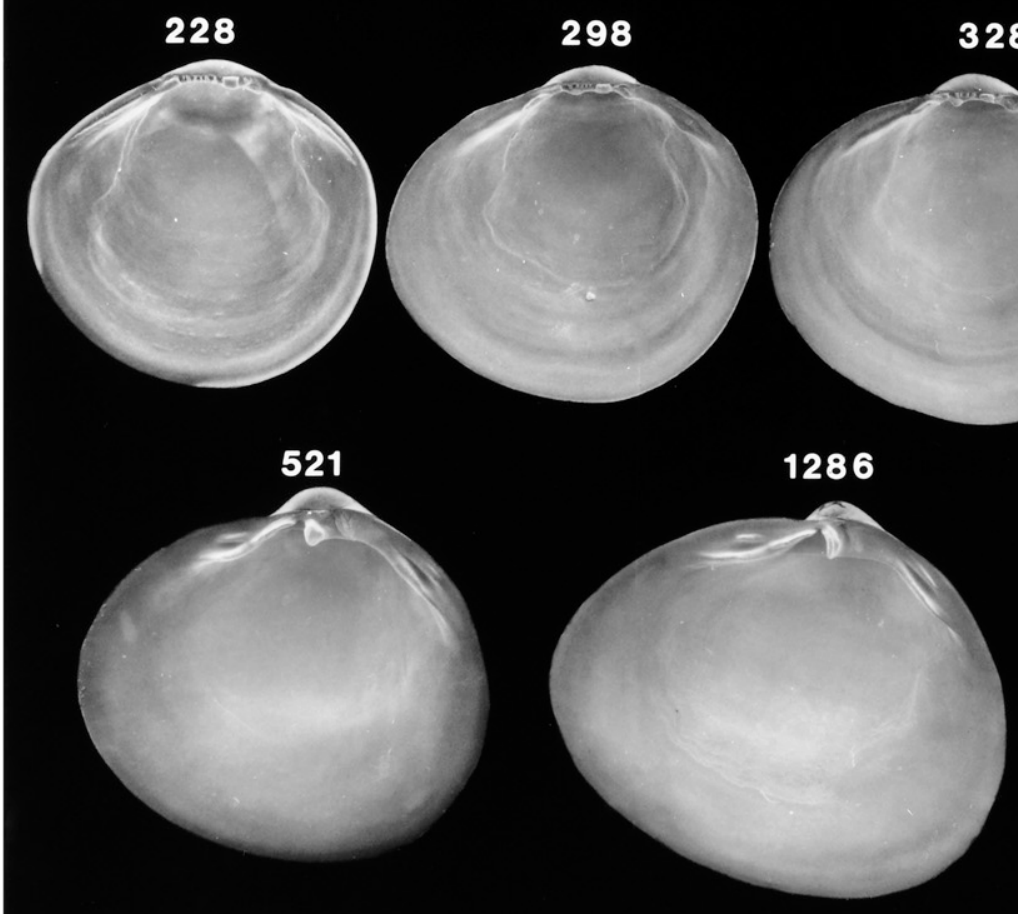

328

388 


\section{SPISULA SOLIDISSIMA}

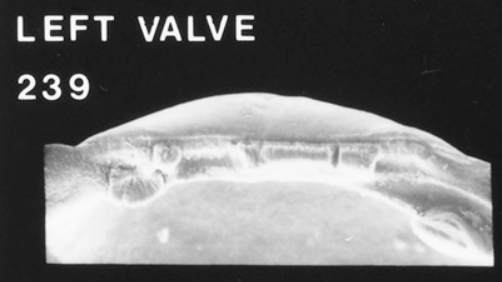

RIGHT VALVE
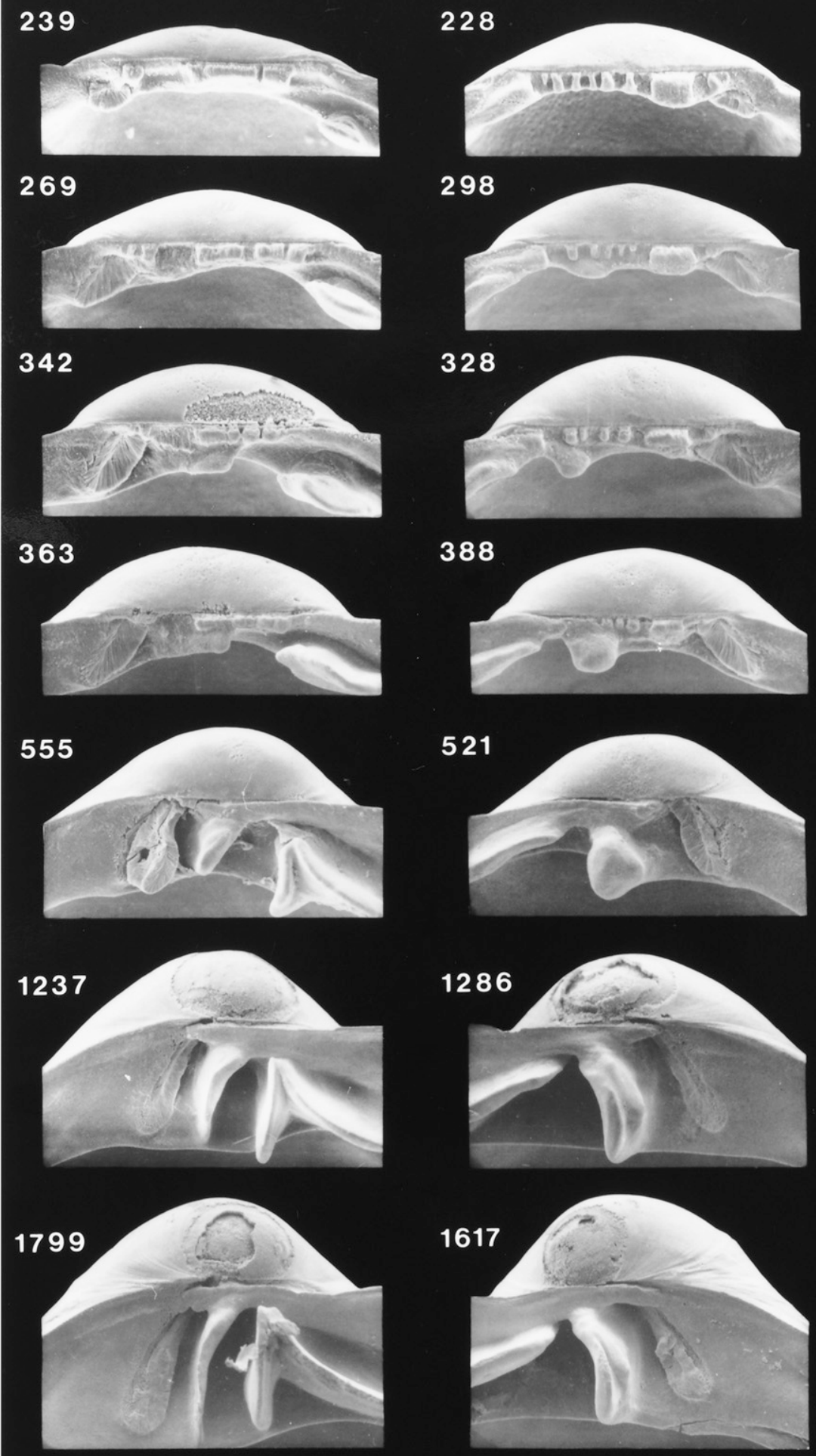

Figure 163. Scanning electron micrographs of the hinge of disarticulated shell valves of Spisula solidissima postlarvae seen in Figure 162. Numbers indicate the maximum linear shell dimension in micrometers. 


\section{MESODESMA ARCTATUM}

\section{LEFT VALVE}

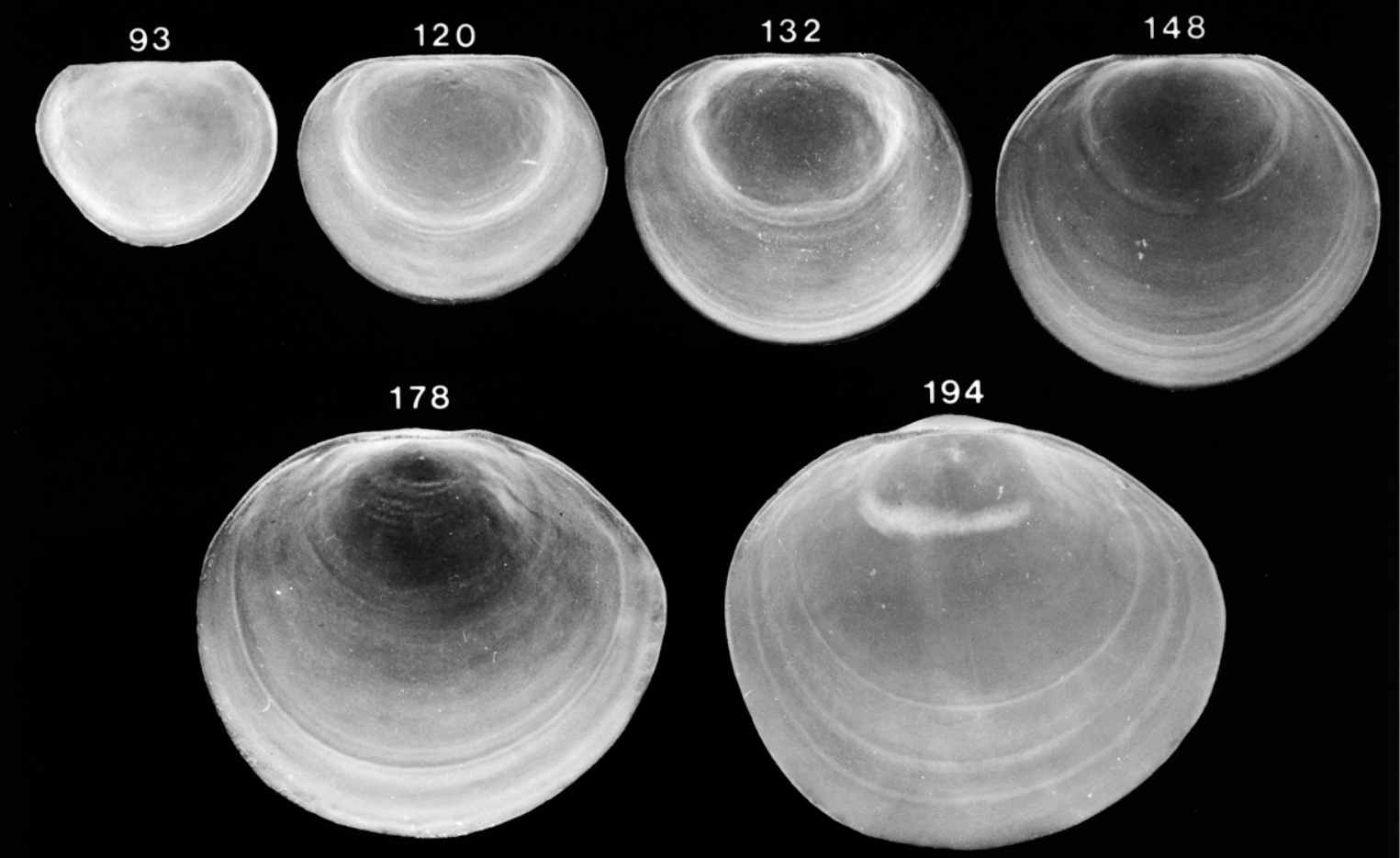

\section{RIGHT VALVE}

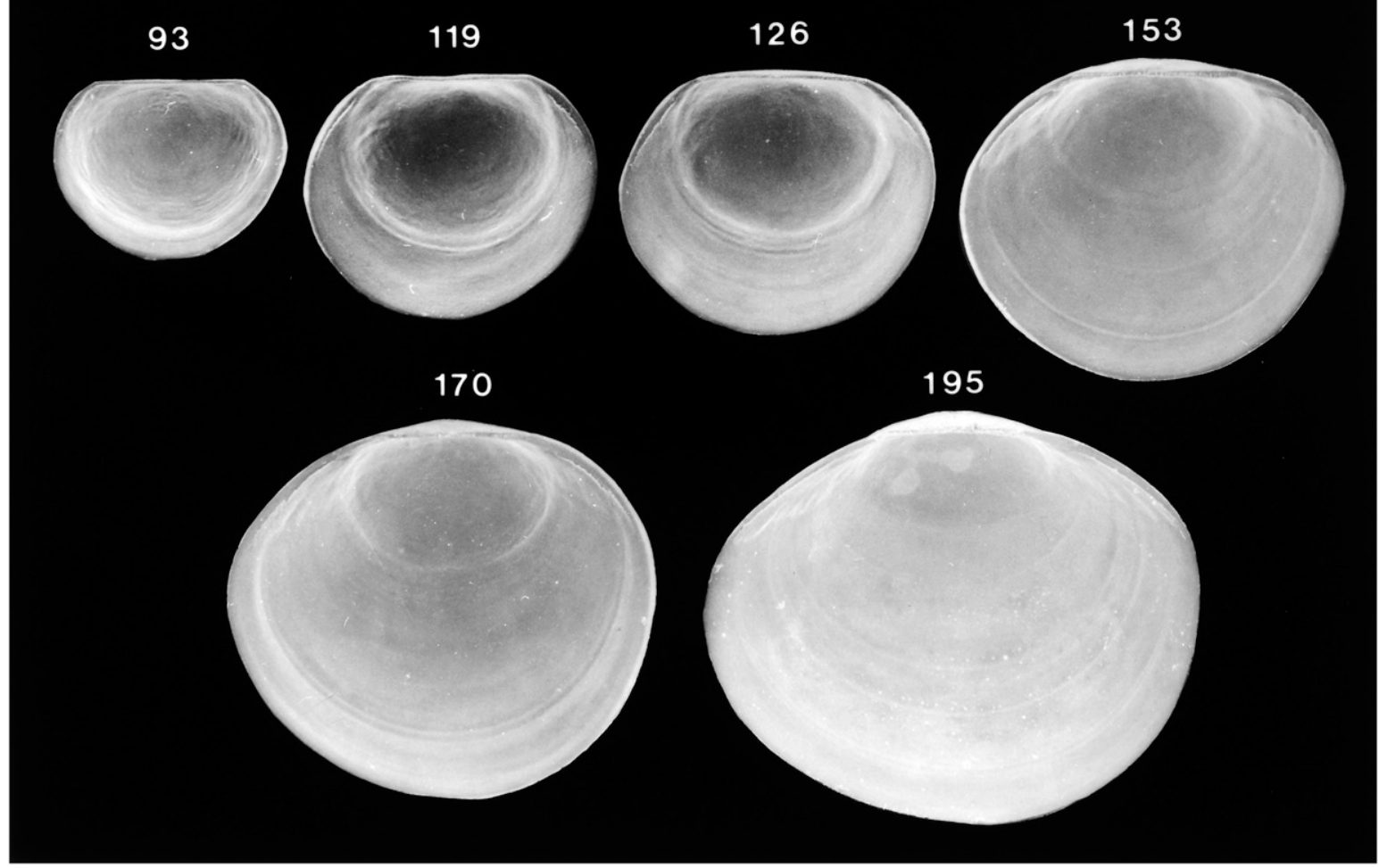

Figure 164. Scanning electron micrographs of disarticulated shell valves of Mesodesma arctatum larvae. Numbers indicate the maximum linear shell dimension in micrometers. 


\section{MESODESMA ARCTATUM}

\section{LEFT VALVE}

\section{3}

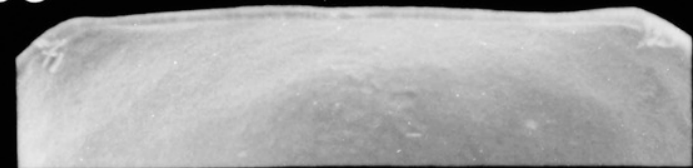

120

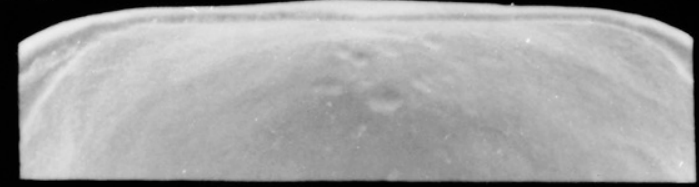

132

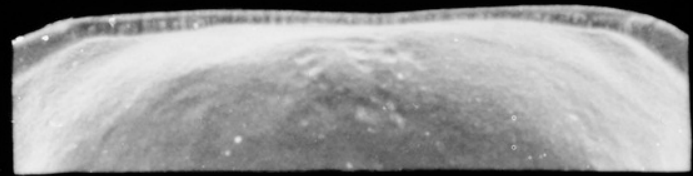

148

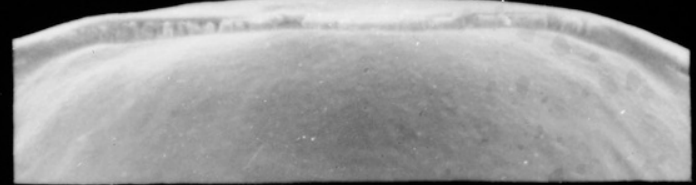

178

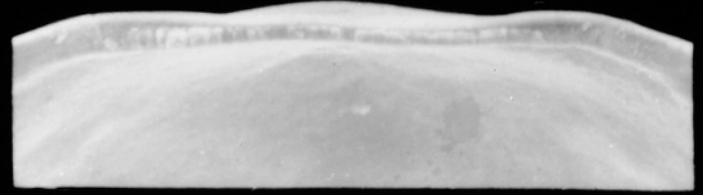

194

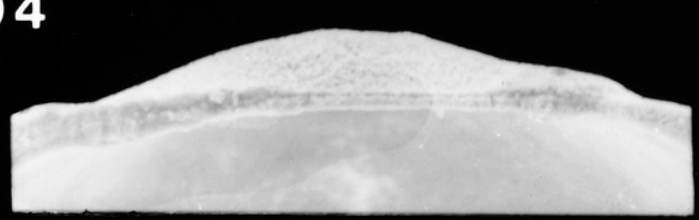

\section{RIGHT VALVE}

\section{3}

119

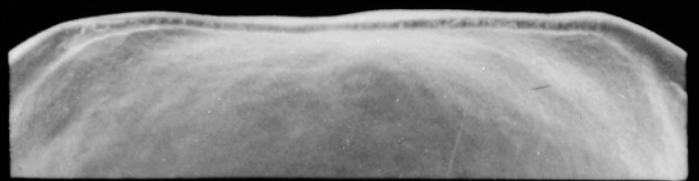

126

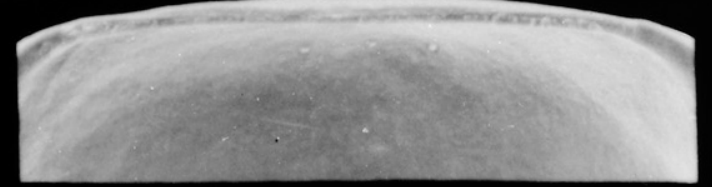

153

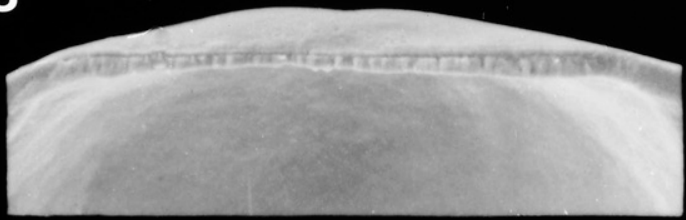

170

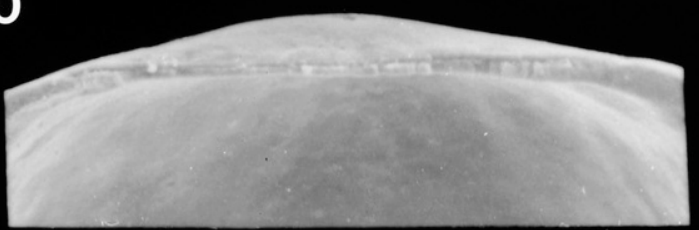

195

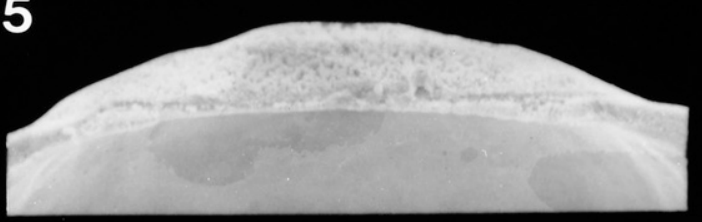




\section{MESODESMA ARCTATUM}

\section{LEFT VALVE}

229

324

455

590

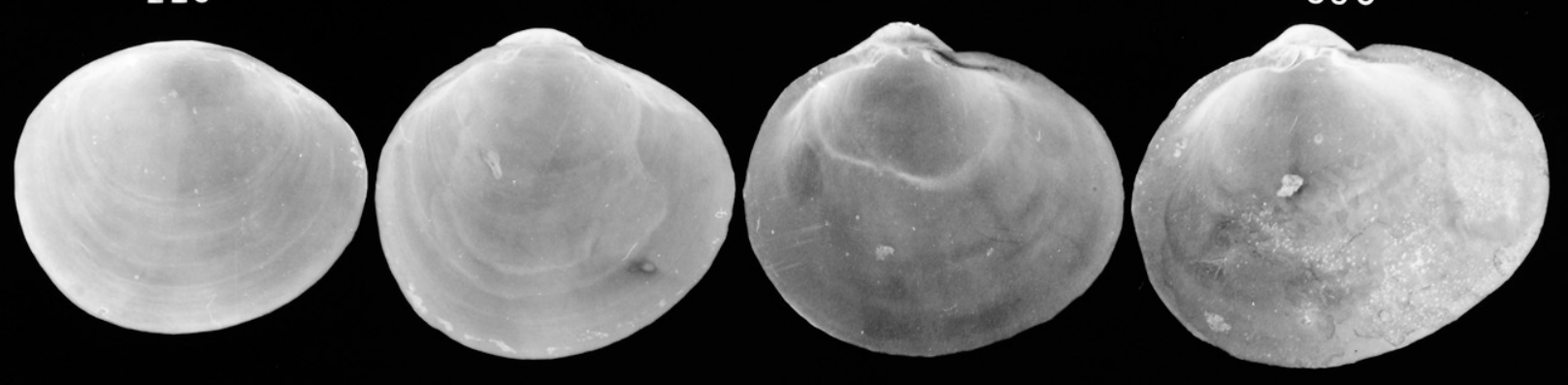

703

1091

1765
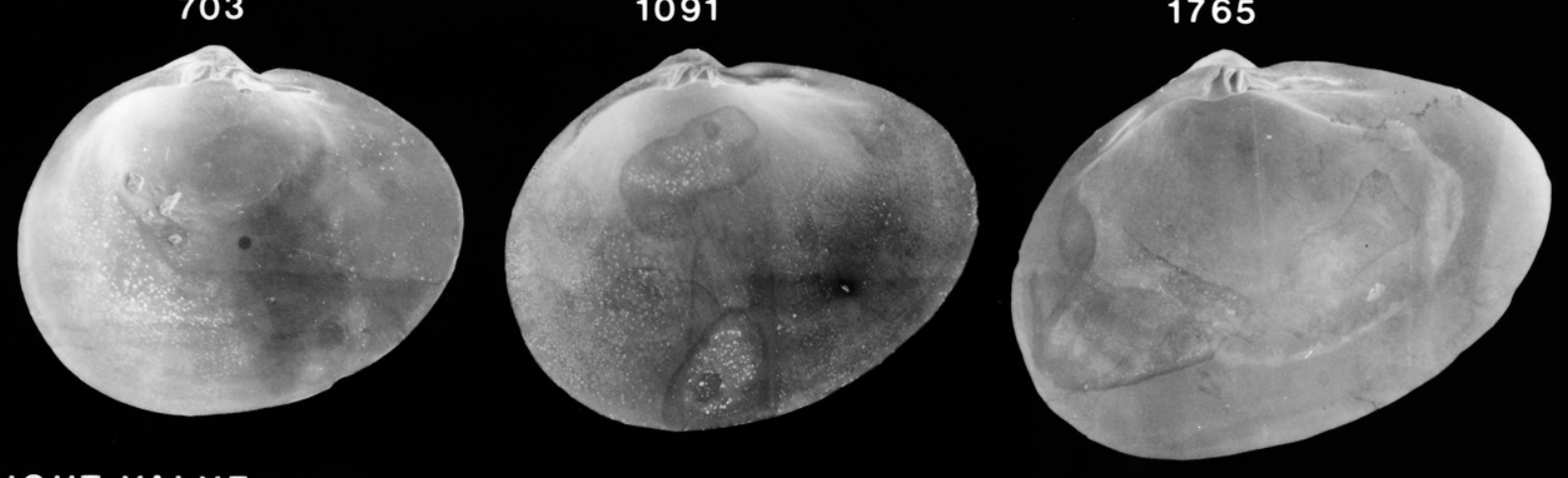

RIGHT VALVE

227

324

430

573

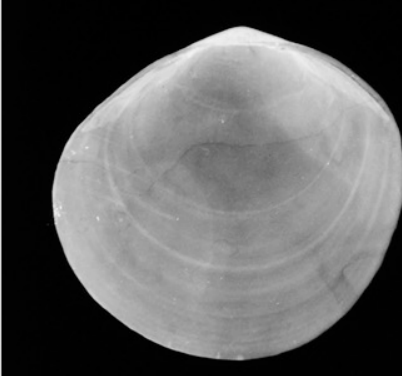

695
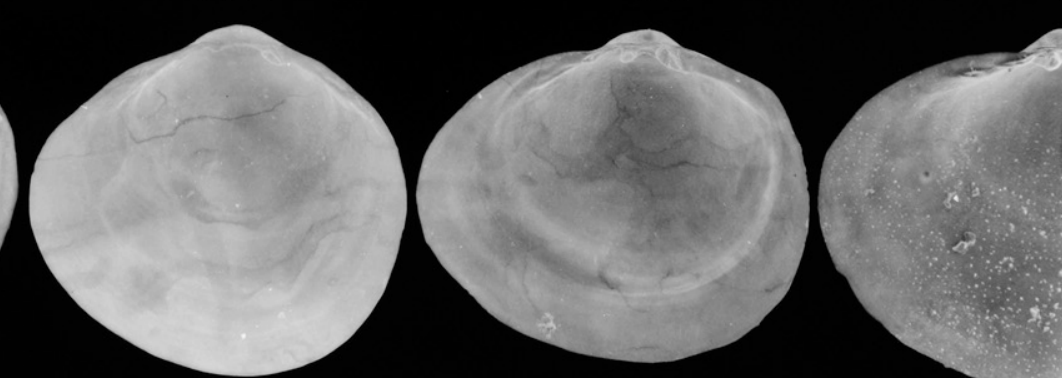


\section{MESODESMA ARCTATUM}

\section{LEFT VALVE}

\section{9}

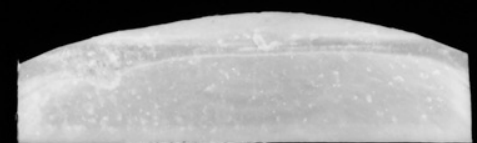

\section{4}

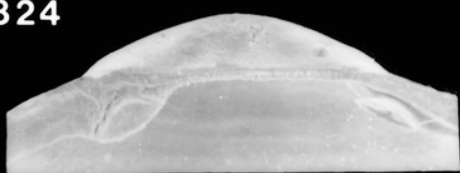

455

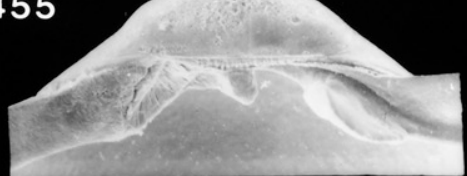

590

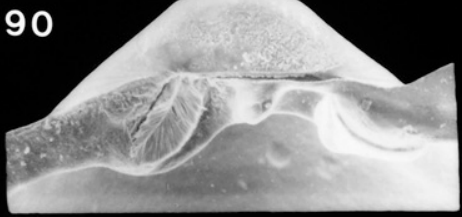

703

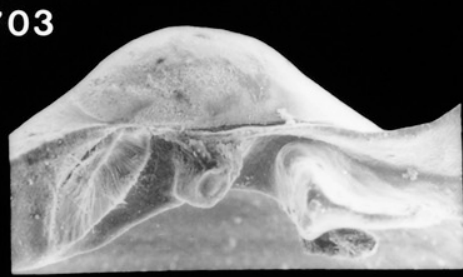

1091

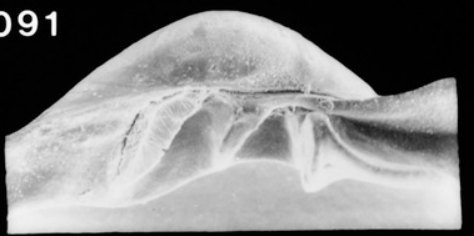

1765

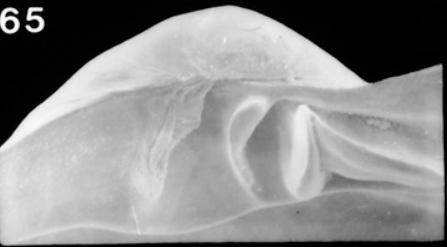

\section{RIGHT VALVE}

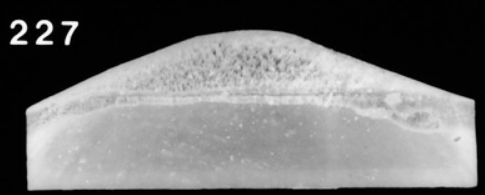

\section{4}

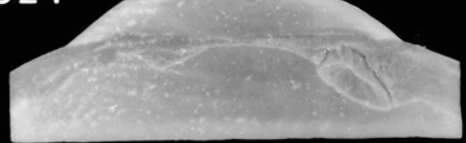

430

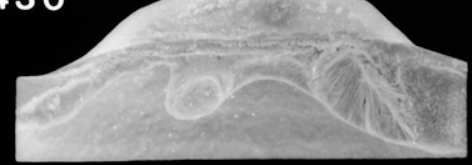

573

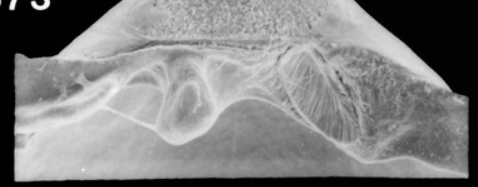

695

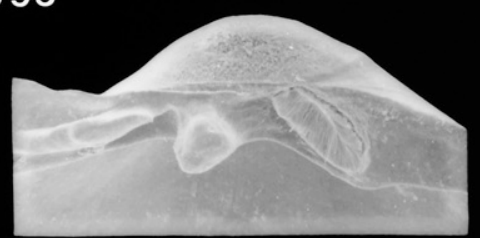

1079

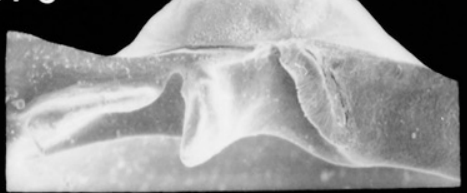

1664

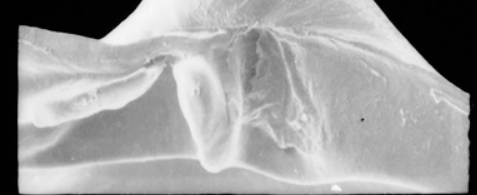




\section{CHIONE CANCELLATA}

\section{LEFT VALVE}

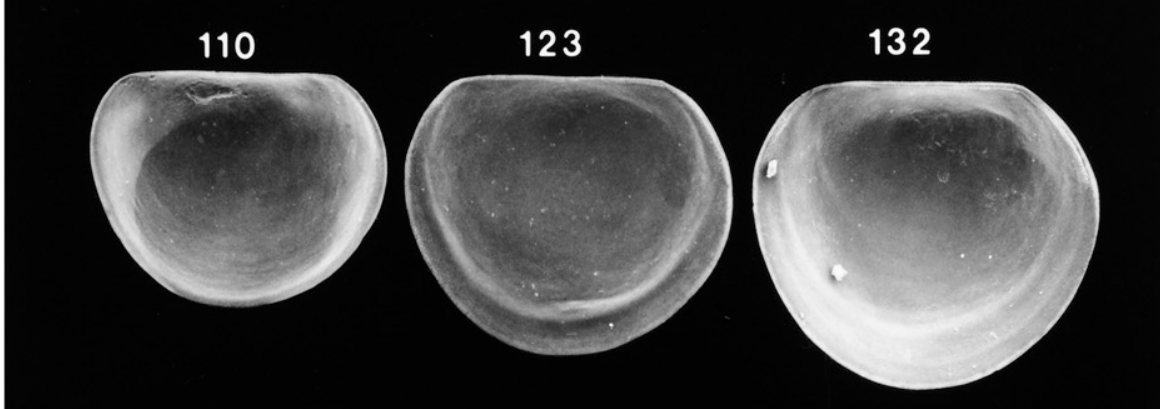

161
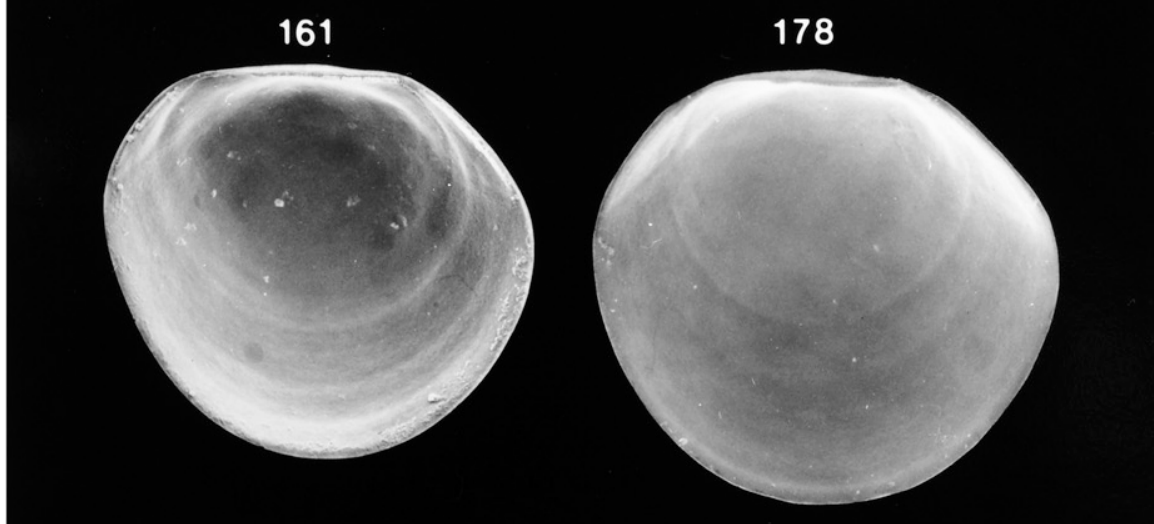

RIGHT VALVE

107

121

134

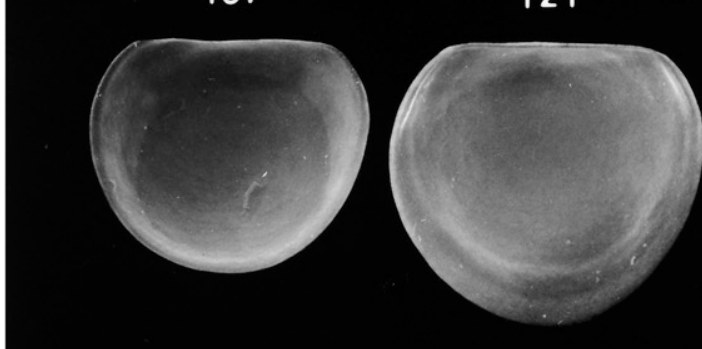

156

186

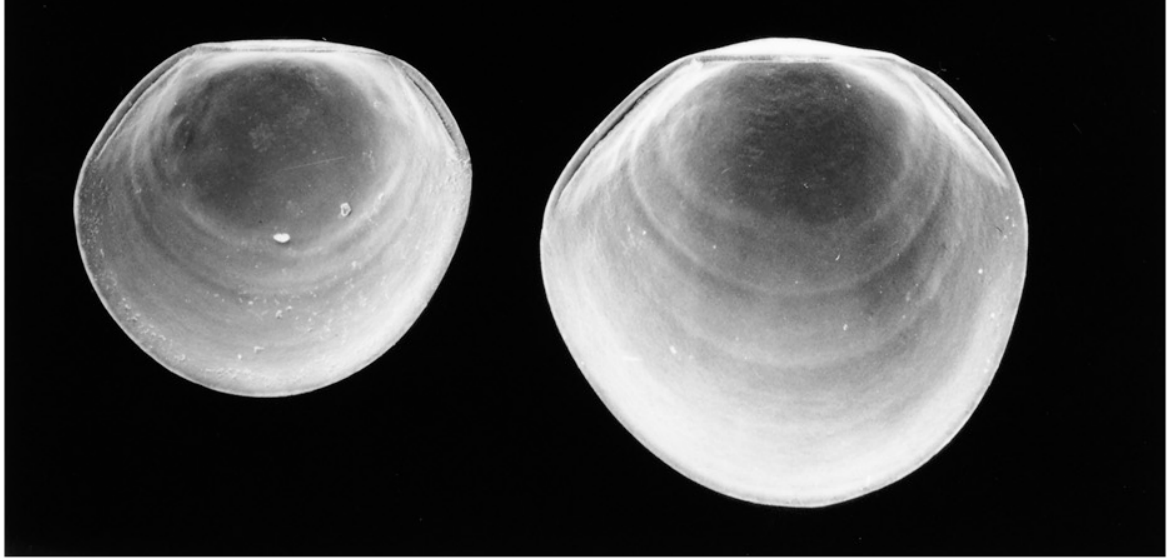

Figure 168. Scanning electron micrographs of disarticulated shell valves of Chione cancellata larvae. Numbers indicate the maximum linear shell dimension in micrometers. Modified from Goodsell et al. (1992). 


\section{CHIONE CANCELLATA}

\section{LEFT VALVE}

\section{0}

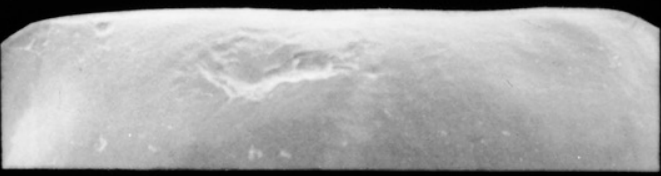

123

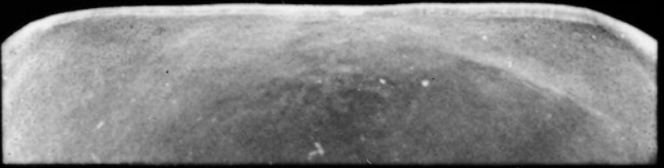

132

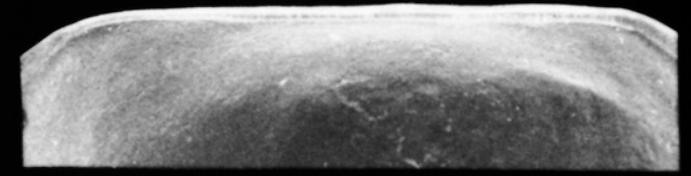

161

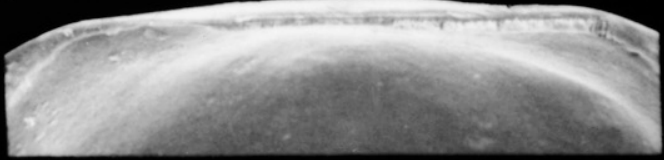

178

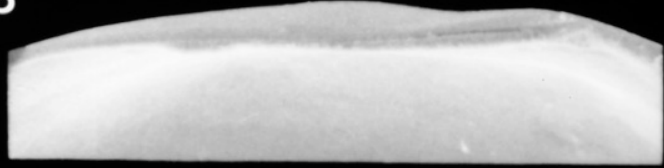

\section{RIGHT VALVE}

107

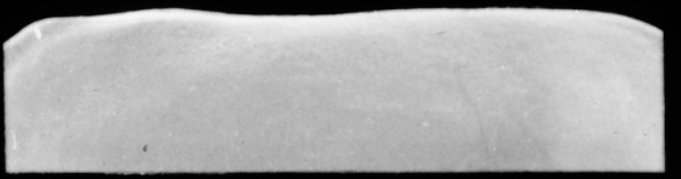

121

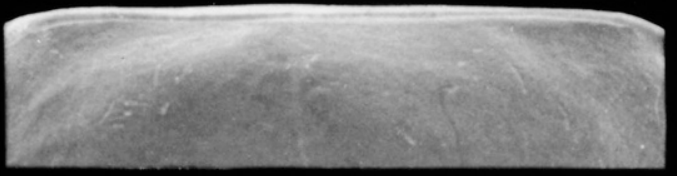

134

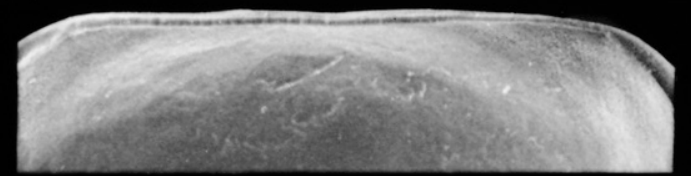

156

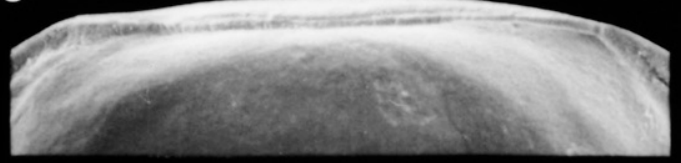

186

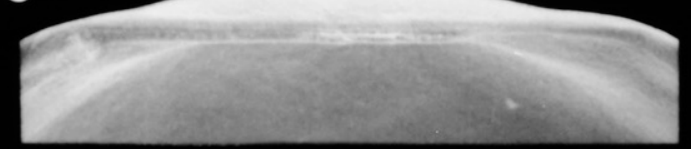

Figure 169. Scanning electron micrographs of the hinge of disarticulated shell valves of Chione cancellata larvae seen in Figure 168 . Numbers indicate the maximum linear shell dimension in micrometers. Modified from Goodsell et al. (1992). 


\section{CHIONE CANCELLATA}

\section{LEFT VALVE}
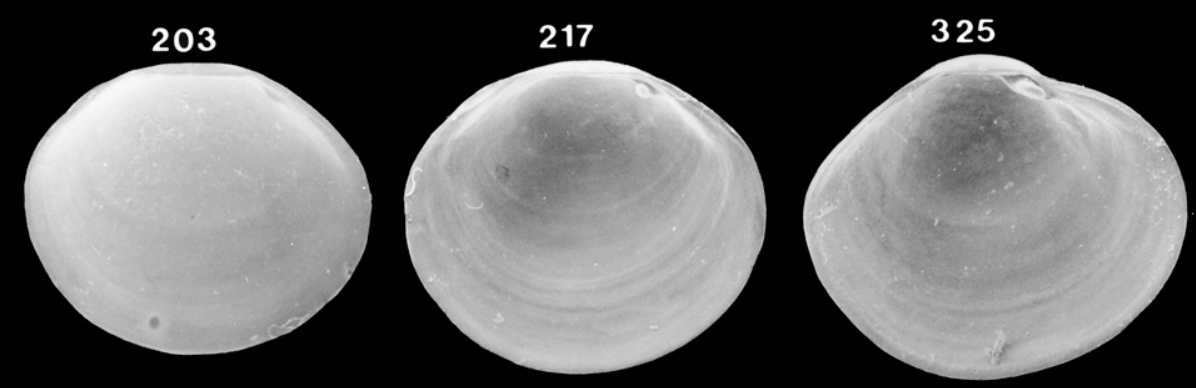

\section{RIGHT VALVE}
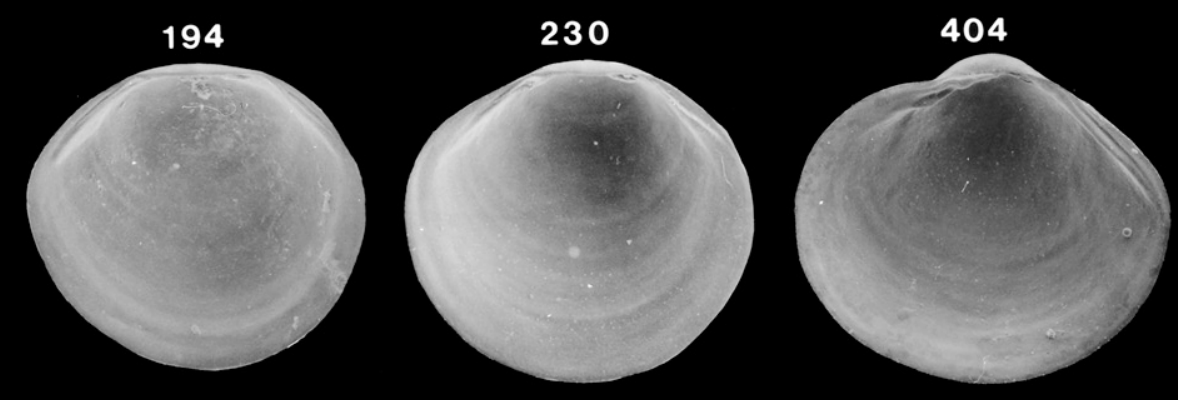

\section{CHIONE CANCELLATA}

\section{LEFT VALVE}

\section{3}

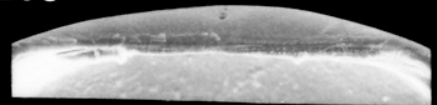

217

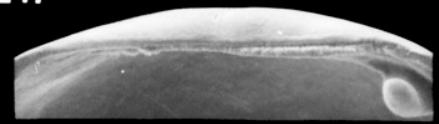

325

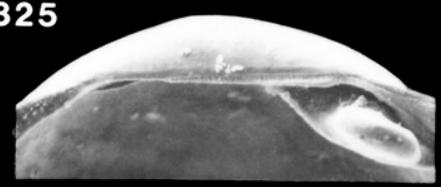

\section{RIGHT VALVE}

194

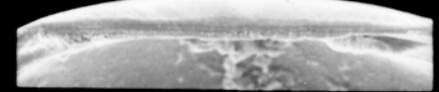

230
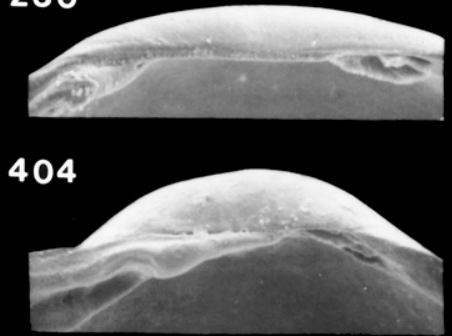

Figure 170. Scanning electron micrographs of disarticulated shell valves of Chione cancellata postlarvae (top) and higher magnification scanning electron micrographs of the hinge of these shell valves (bottom). Numbers indicate the maximum linear shell dimension in micrometers. Modified from Goodsell et al. (1992). 


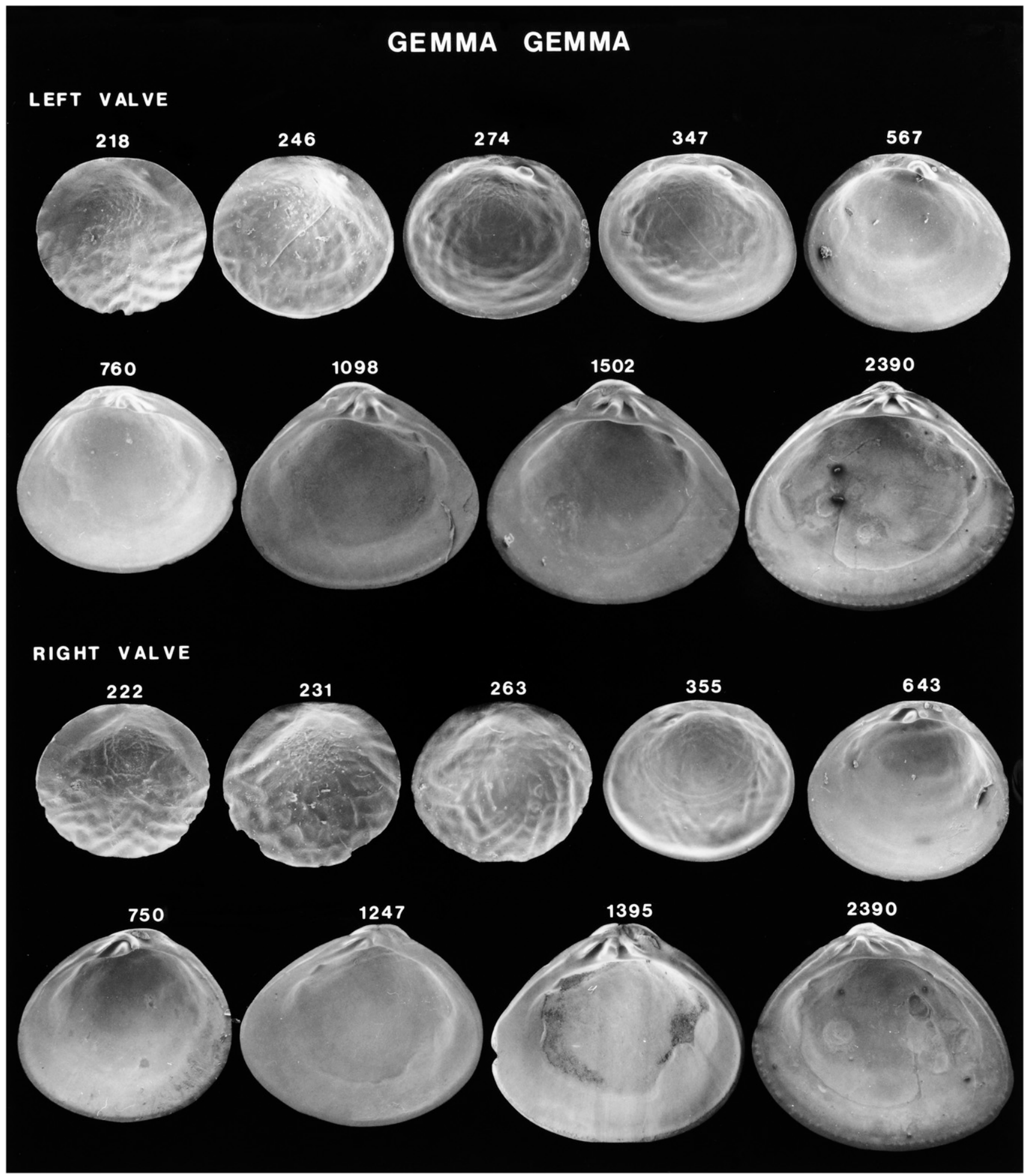

Figure 171. Scanning electron micrographs of disarticulated shell valves of Gemma gemma postlarvae. Numbers indicate the maximum linear shell dimension in micrometers. 


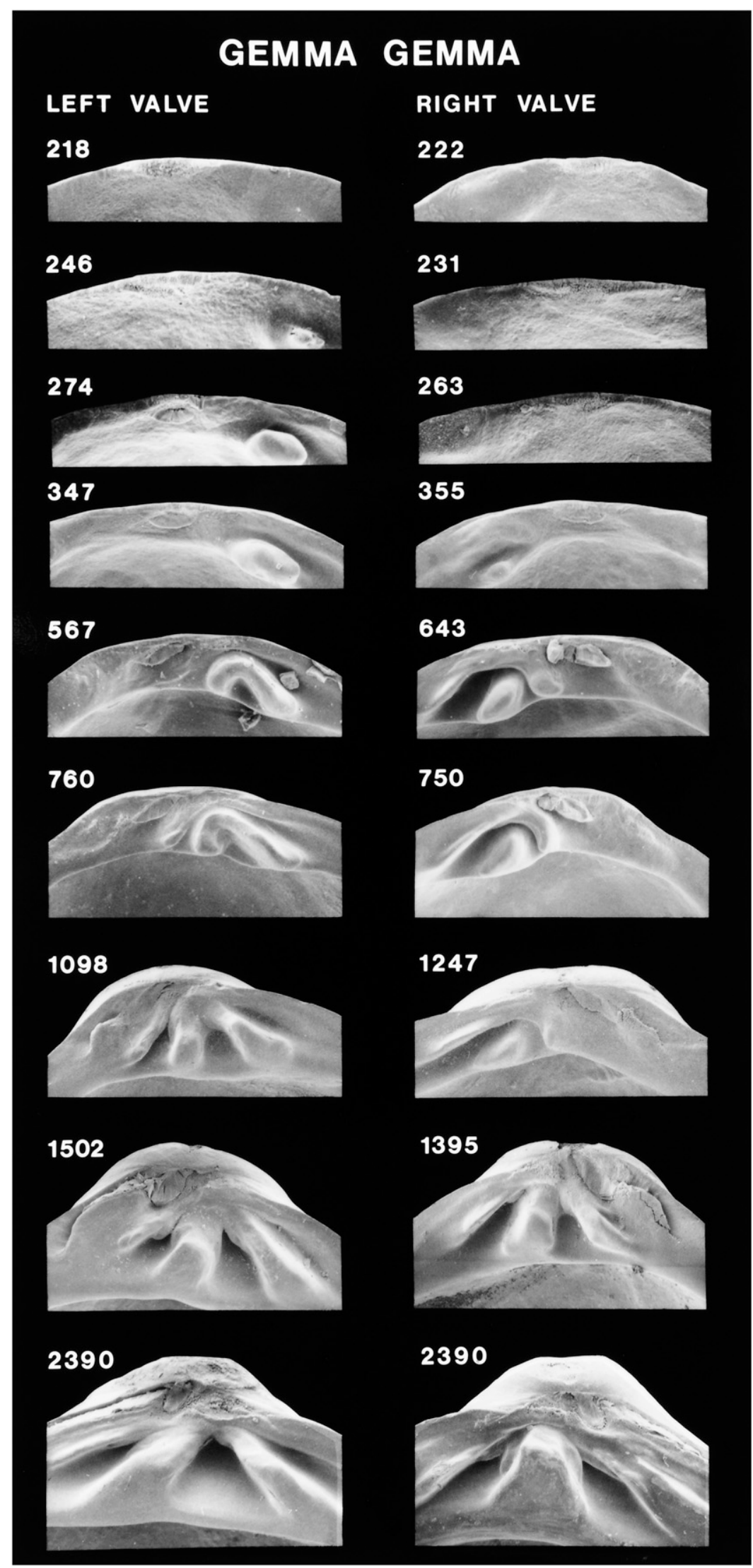

Figure 172. Scanning electron micrographs of the hinge of disarticulated shell valves of Gemma gemma postlarvae seen in Figure 171. Numbers indicate the maximum linear shell dimension in micrometers. 


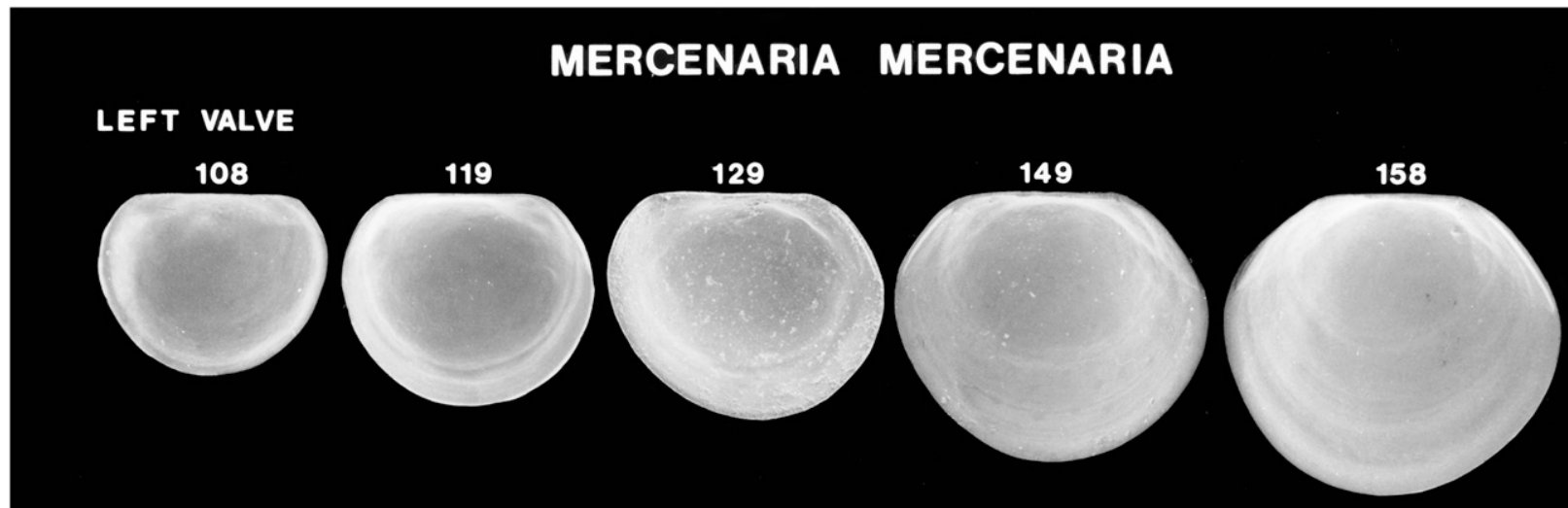

\section{RIGHT VALVE}
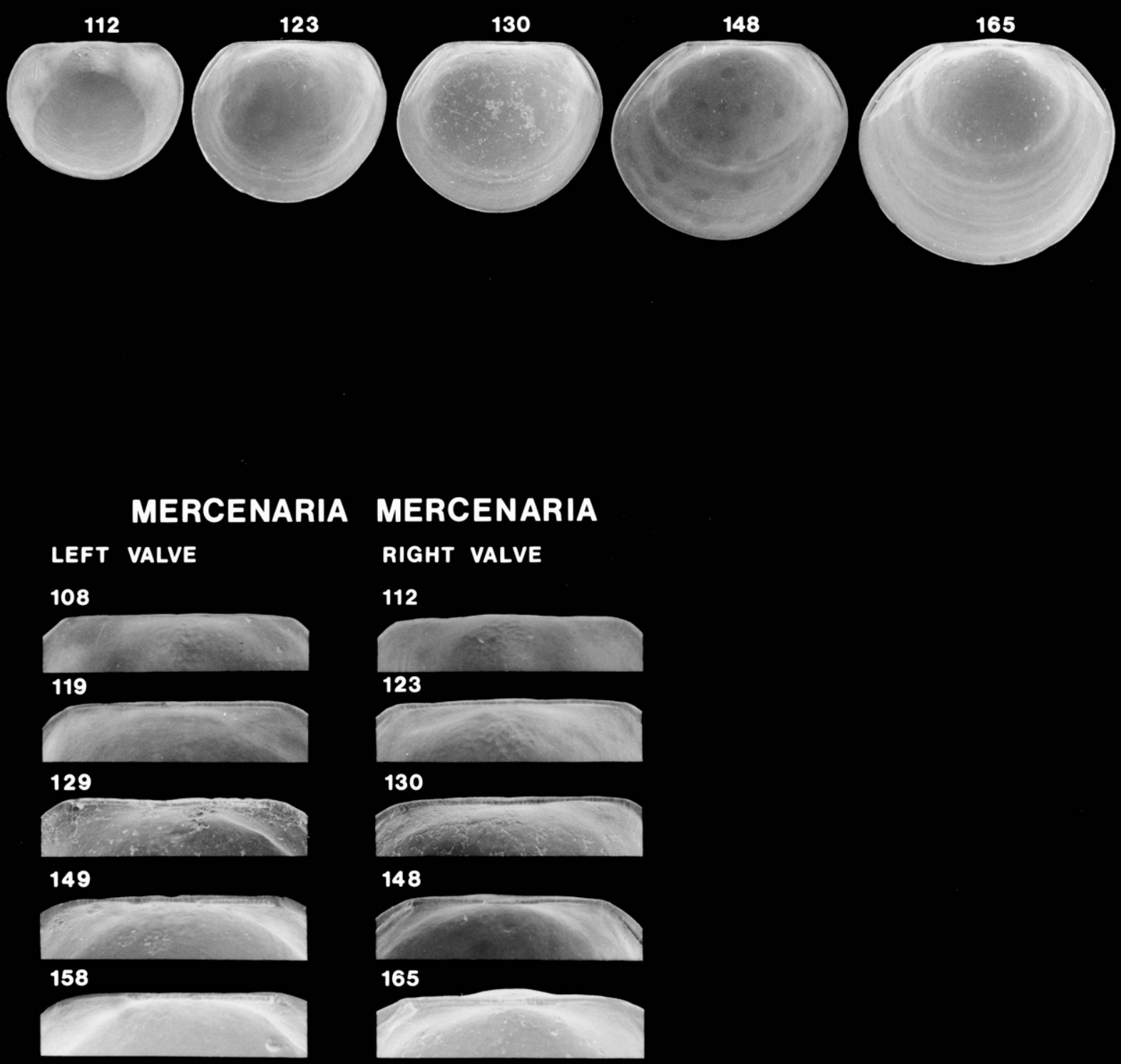

Figure 173. Scanning electron micrographs of disarticulated shell valves of Mercenaria mercenaria larvae (top) and higher magnification scanning electron micrographs of the hinge of these shell valves (bottom). Numbers indicate the maximum linear shell dimension in micrometers. Modified from Goodsell et al. (1992). 


\section{MERCENARIA MERCENARIA}

\section{LEFT VALVE}
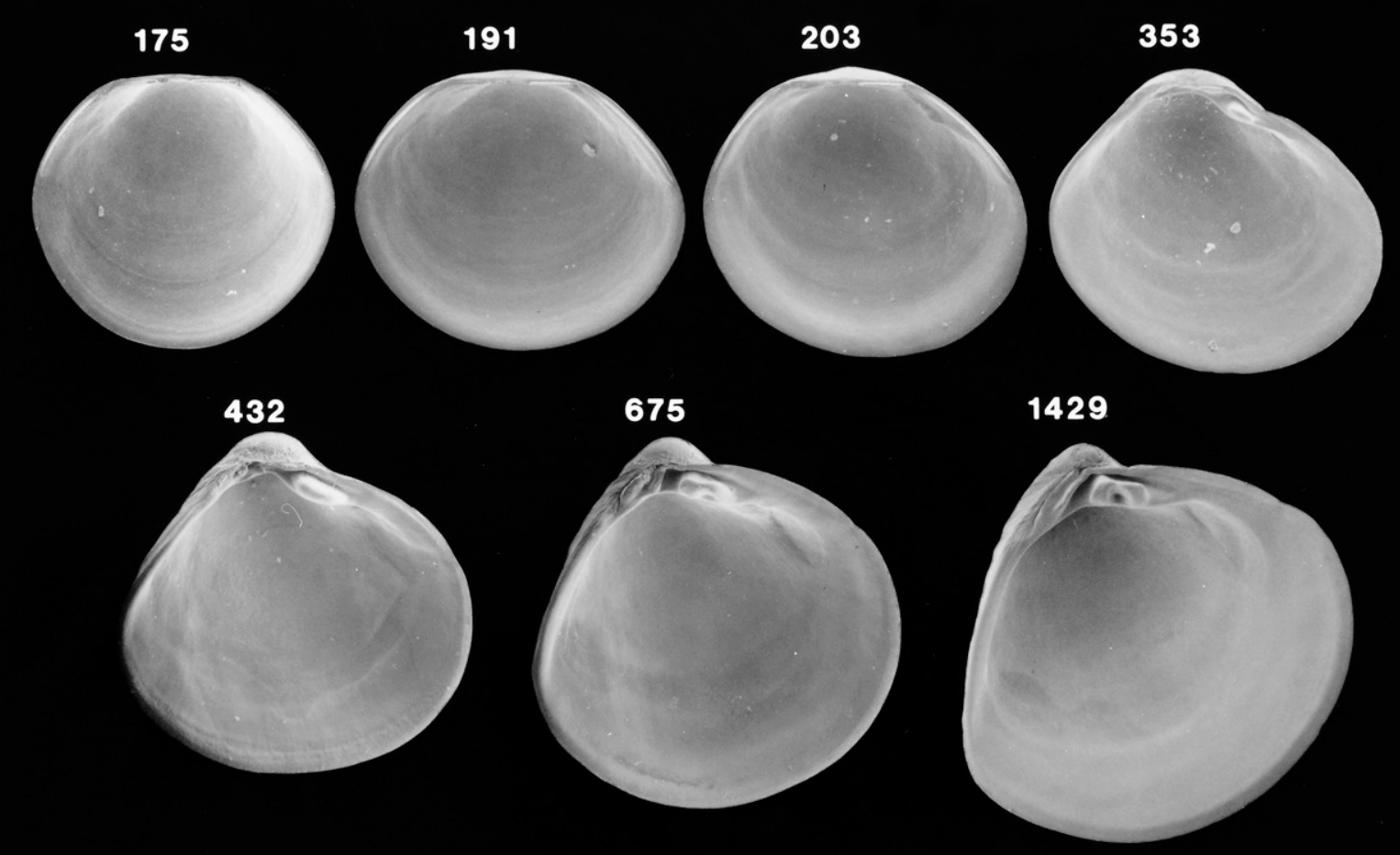

\section{Right VALVE}

170

184

201

271
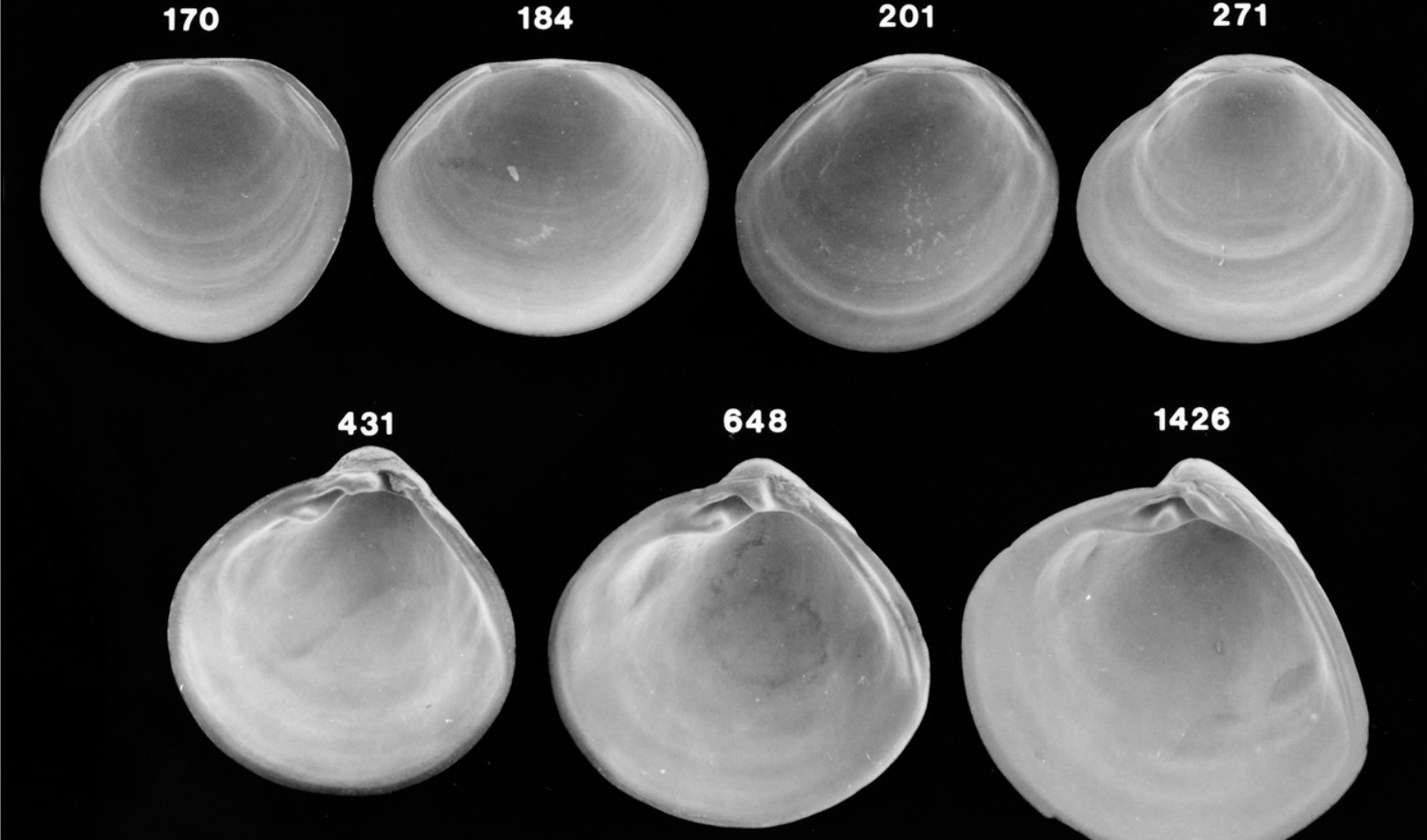


\section{MERCENARIA MERCENARIA}

\section{LEFT VALVE}

\section{5}

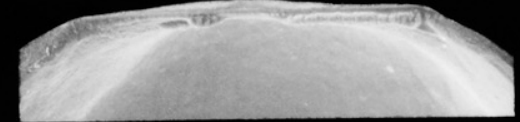

191

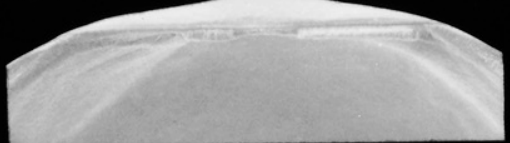

203

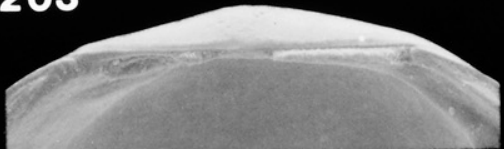

353

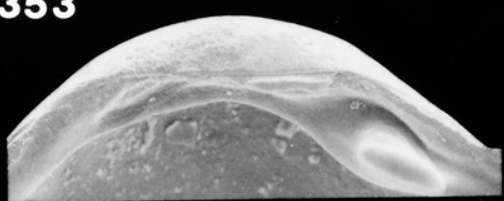

432

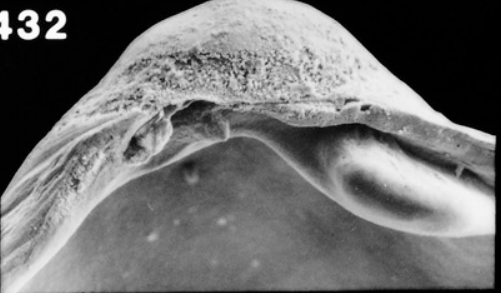

675

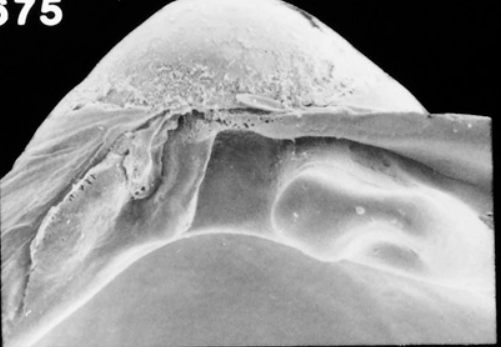

1429

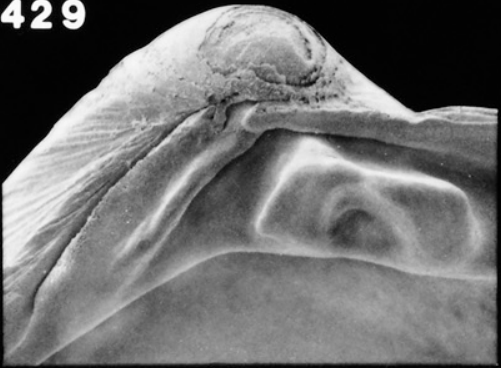

RIGHT VALVE

\section{0}

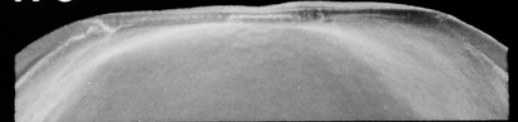

184
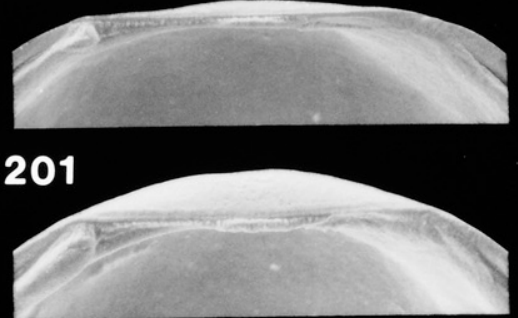

271

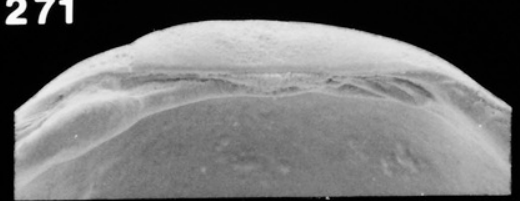

431

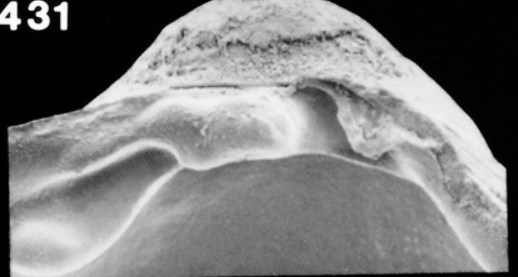

648

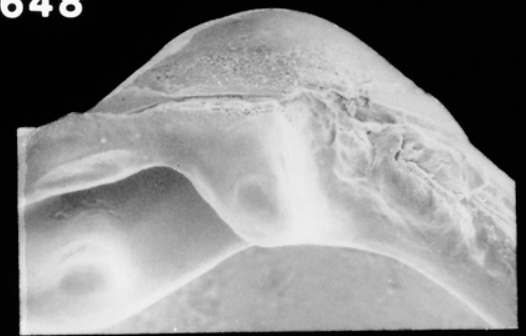

1426

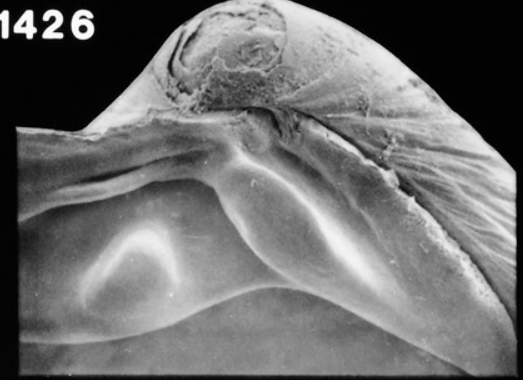

Figure 175. Scanning electron micrographs of the hinge of disarticulated shell valves of Mercenaria mercenaria postlarvae seen in Figure 174. Numbers indicate the maximum linear shell dimension in micrometers. Modified from Goodsell et al. (1992). 


\section{MERCENARIA CAMPECHIENSIS}

\section{LEFT VALVE}

110

152

171
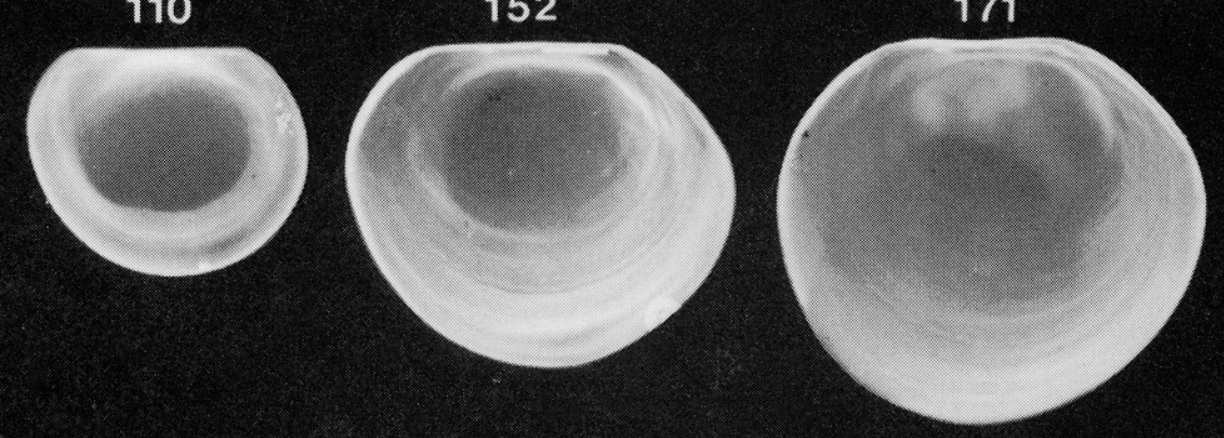

RIGHT VALVE

117
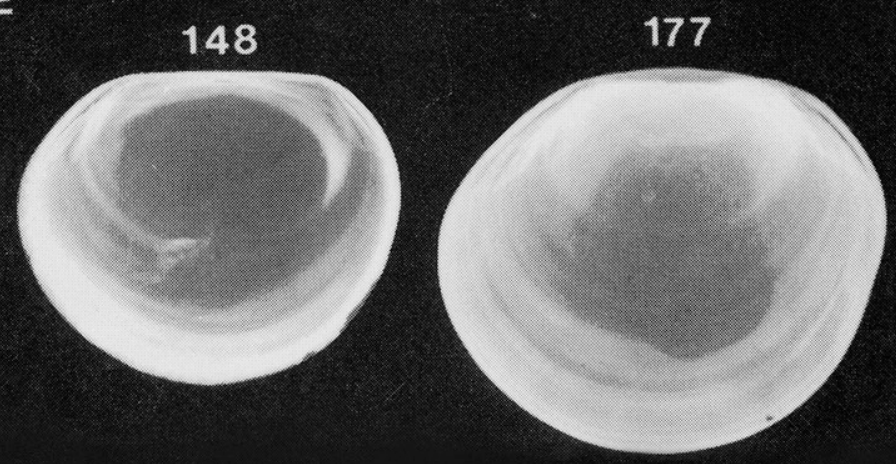

MERCENARIA CAMPECHIENSIS

LEFT VALVE 110

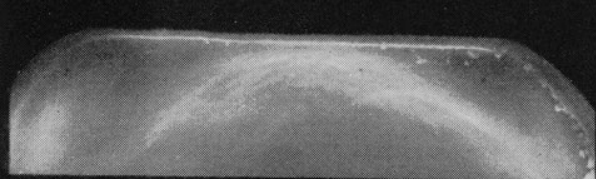

152

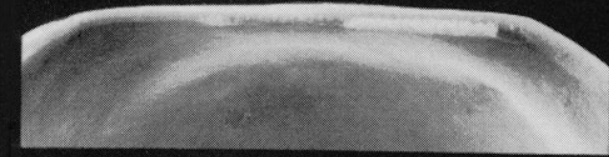

171

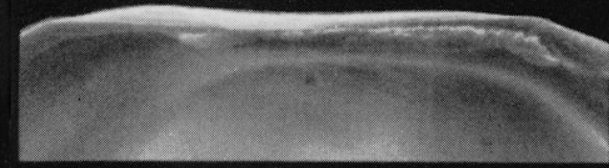

\section{RIGHT VALVE}

117

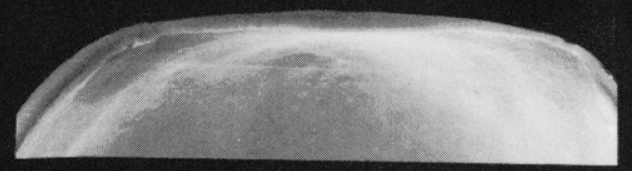

148

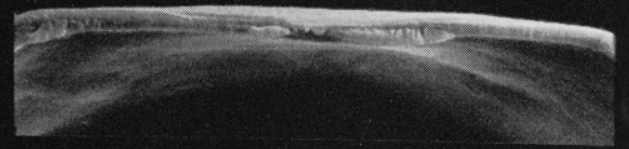

177 


\section{MERCENARIA CAMPECHIENSIS}

\section{LEFT VALVE}
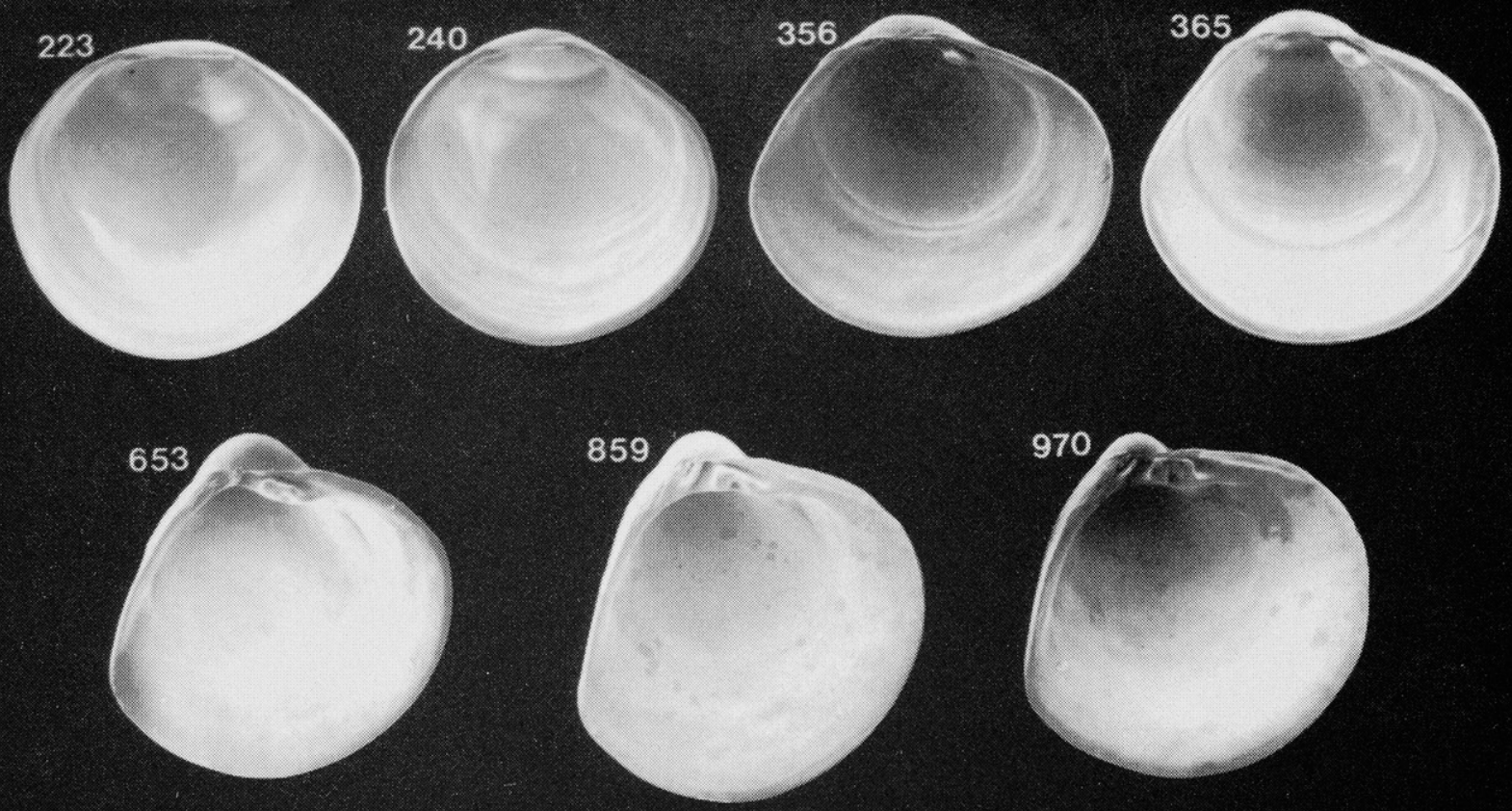

\section{RIGHT VALVE}

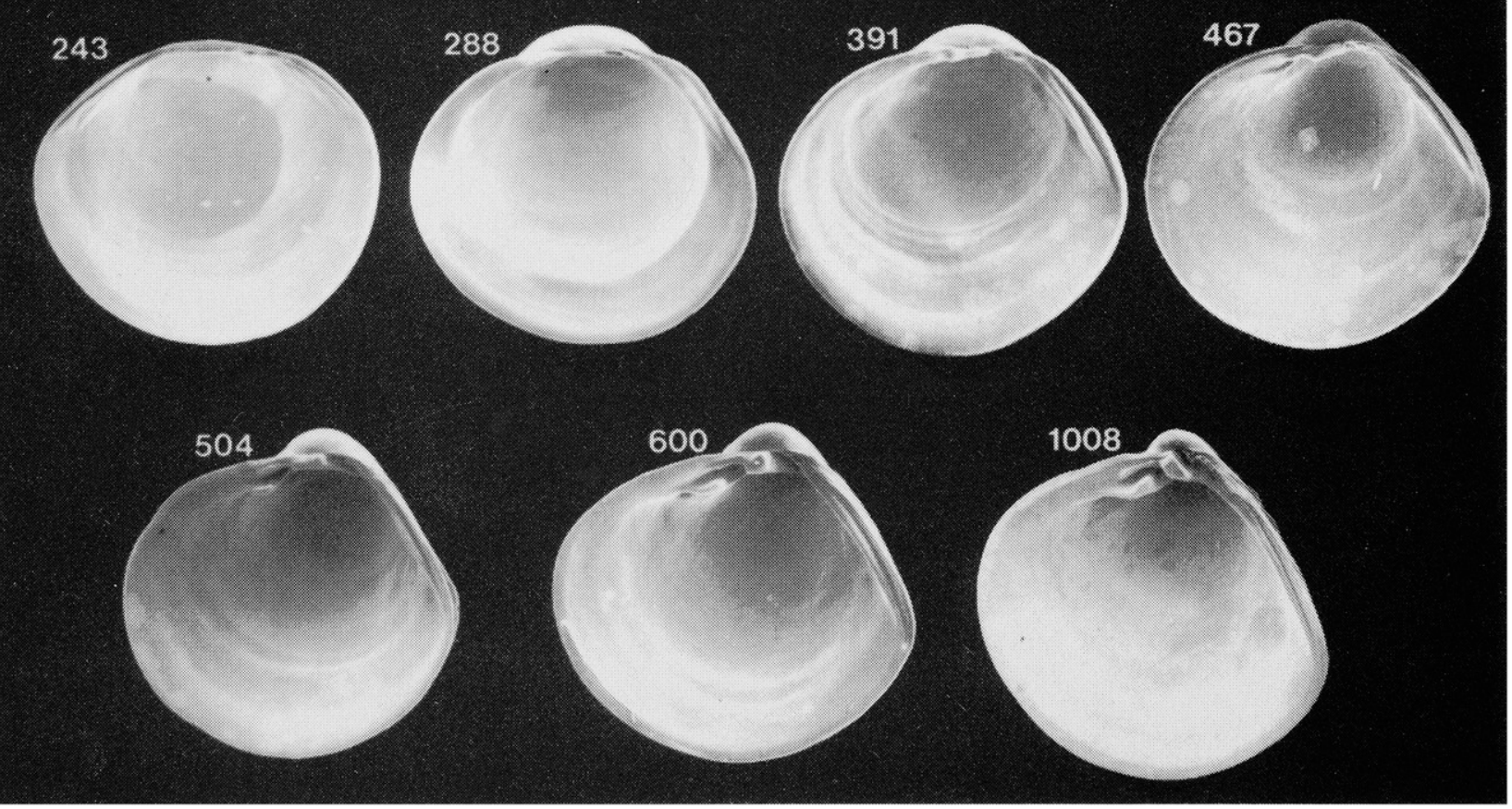

Figure 177. Scanning electron micrographs of disarticulated shell valves of Mercenaria campechiensis postlarvae. Numbers indicate the maximum linear shell dimension in micrometers. Modified from Goodsell et al. (1992). 


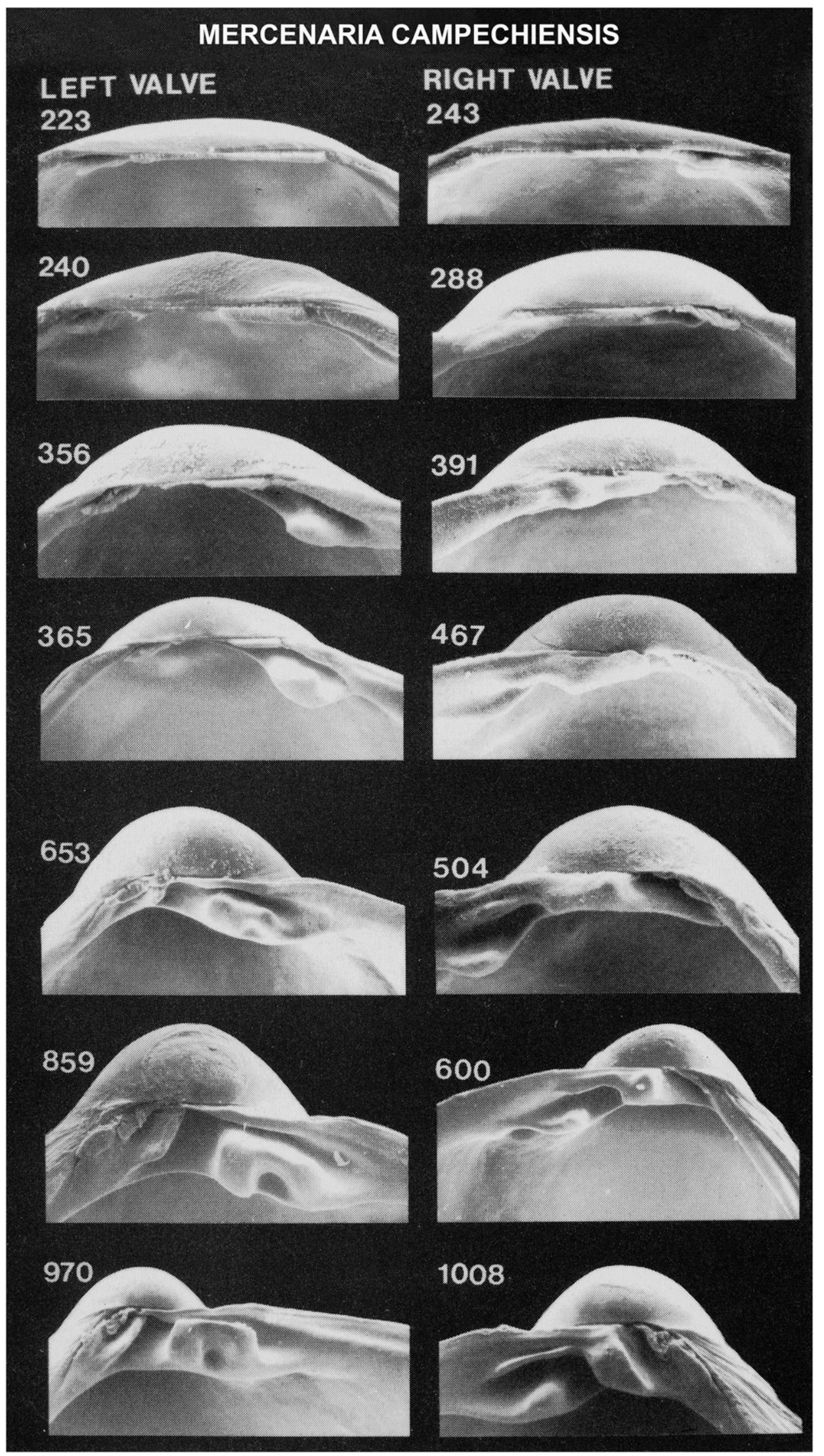

Figure 178. Scanning electron micrographs of the hinge of disarticulated shell valves of Mercenaria campechiensis postlarvae seen in Figure 177. Numbers indicate the maximum linear shell dimension in micrometers. Modified from Goodsell et al. (1992). 


\section{MERCENARIA CAMPECHIENSIS TEXANA}

\section{LEFT VALVE}

114

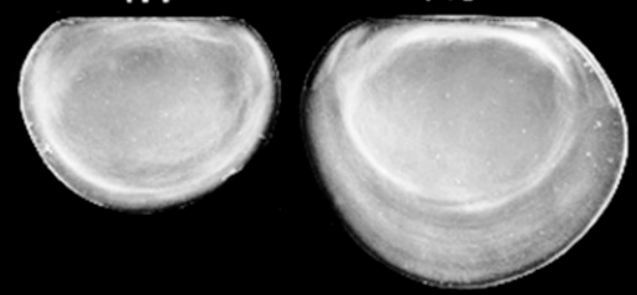

154

177
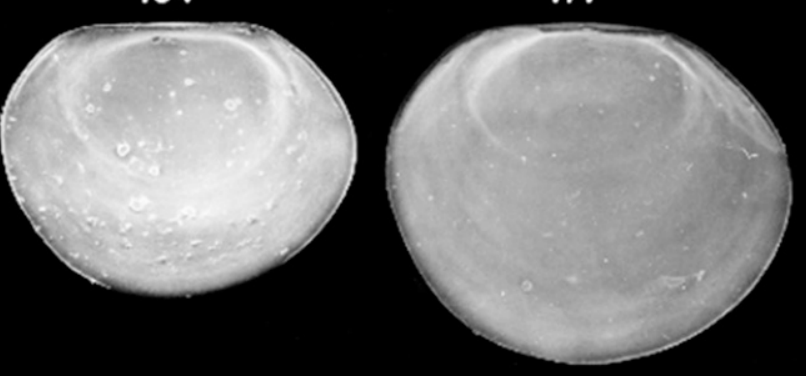

RIGHT VALVE

119

136

146

189
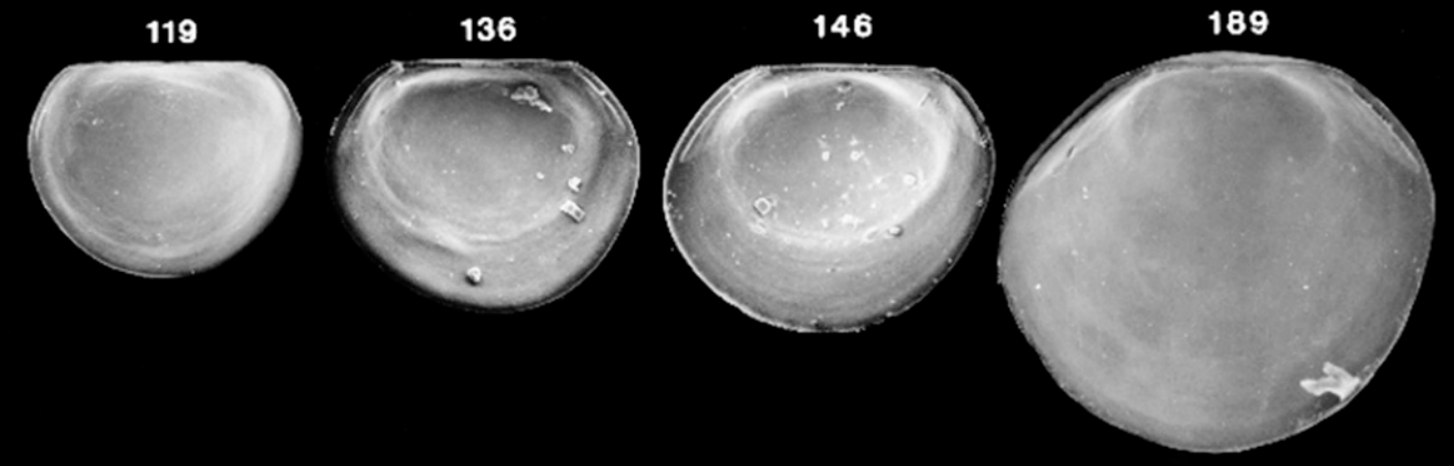

\section{MERCENARIA CAMPECHIENSIS TEXANA}

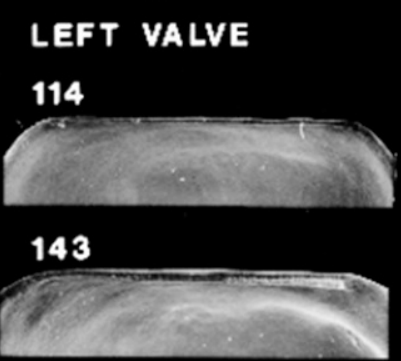

154

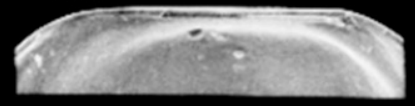

177

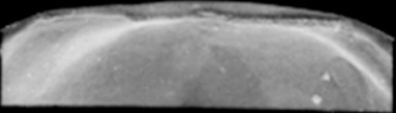

RIGHT VALVE

119

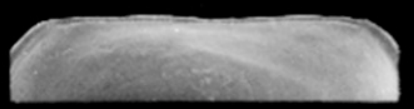

136

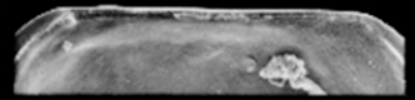

146

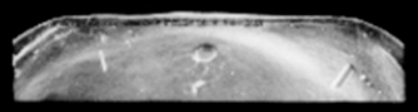

189

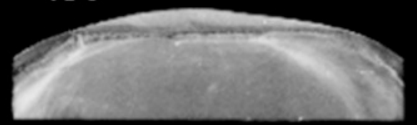

Figure 179. Scanning electron micrographs of disarticulated shell valves of Mercenaria campechiensis texana larvae (top) and higher magnification scanning electron micrographs of the hinge of these shell valves (bottom). Numbers indicate the maximum linear shell dimension in micrometers. Modified from Goodsell et al. (1992). 


\section{MERCENARIA CAMPECHIENSIS TEXANA}

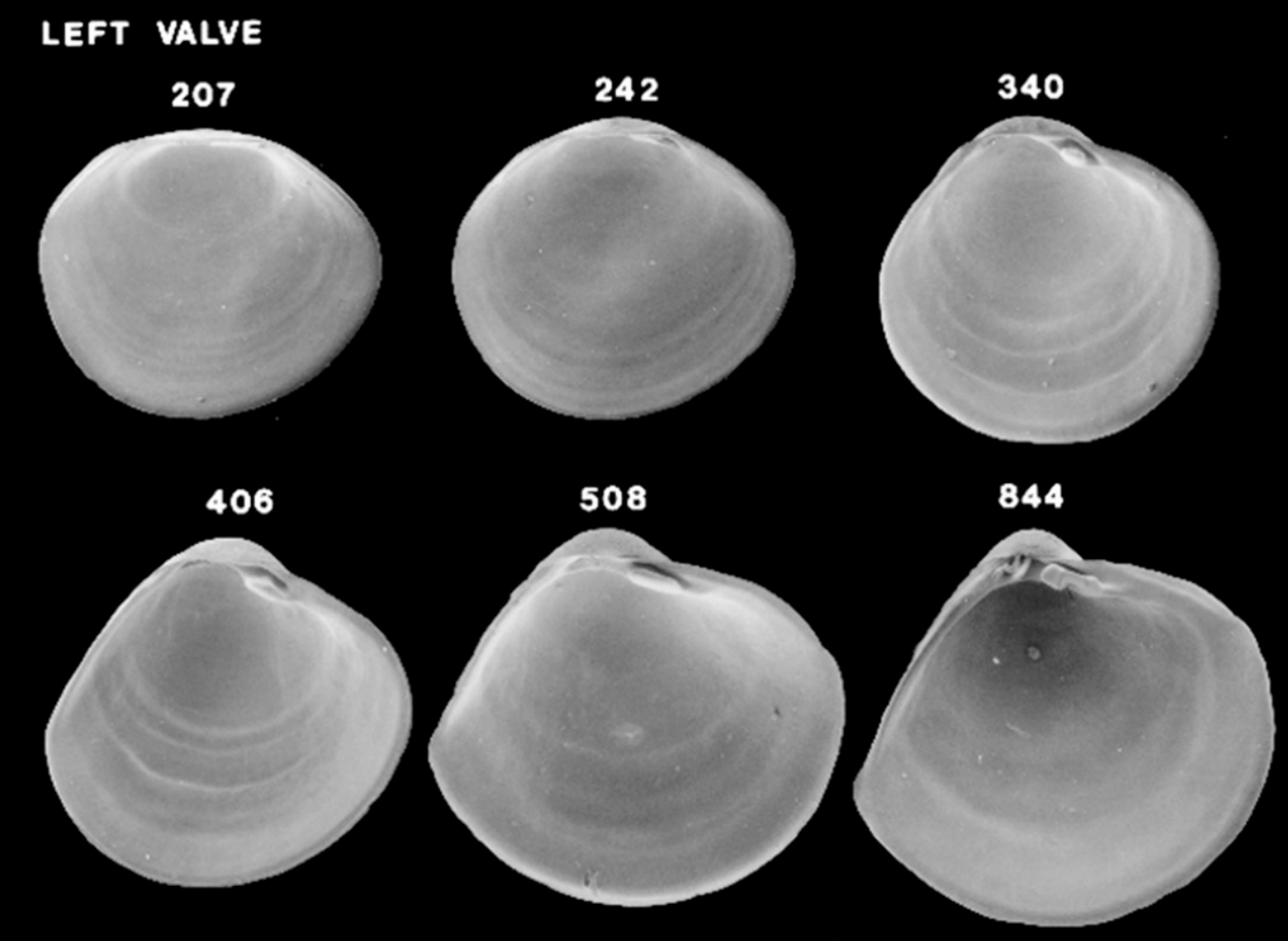

\section{RIGHT VALVE}

202

243

302
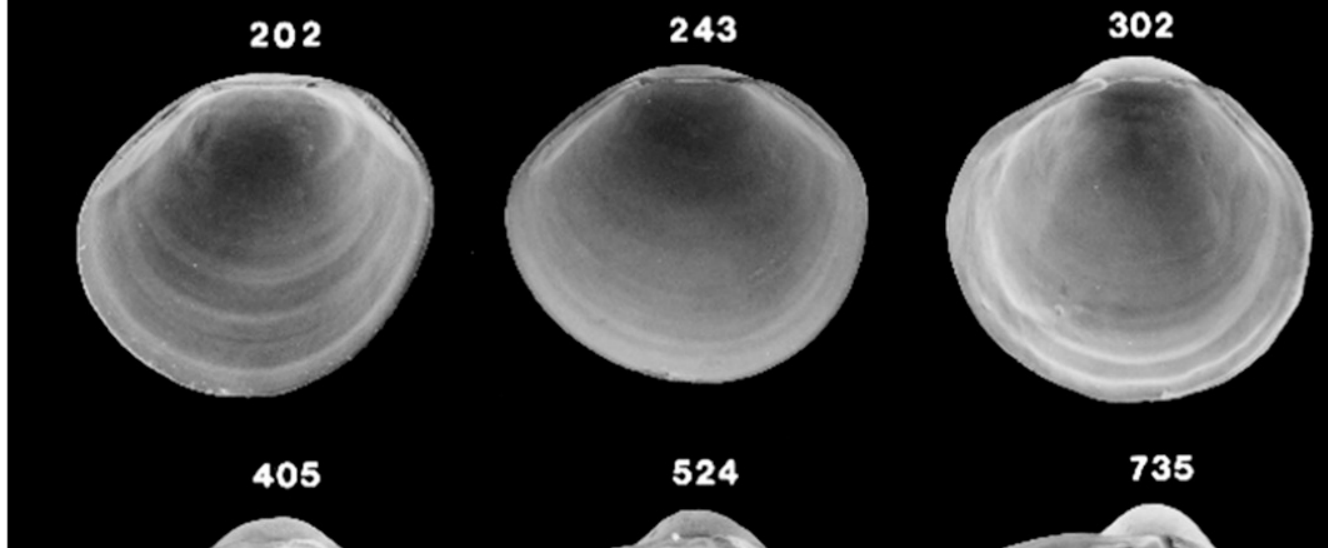

524

735

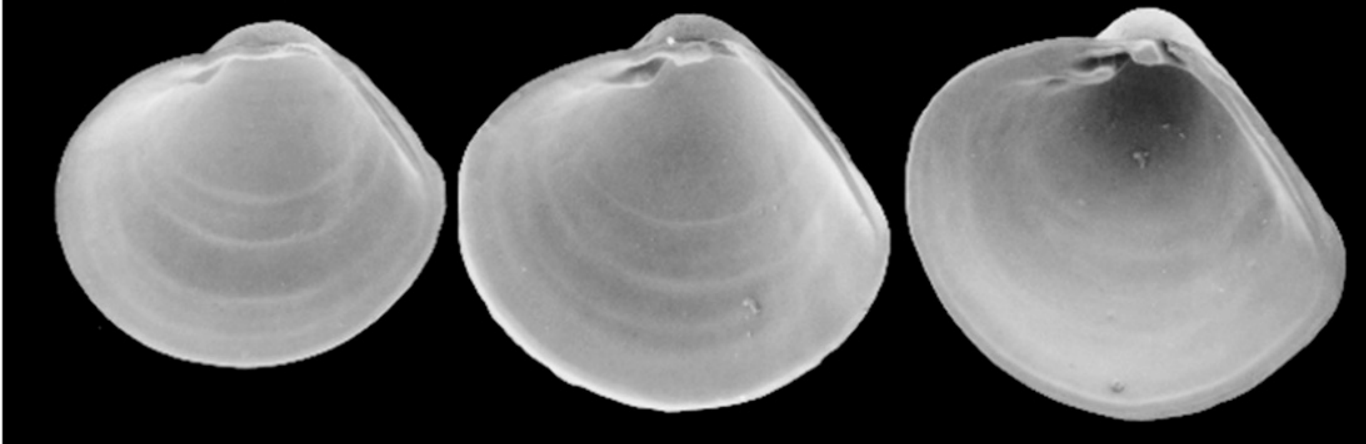

Figure 180. Scanning electron micrographs of disarticulated shell valves of Mercenaria campechiensis texana postlarvae. Numbers indicate the maximum linear shell dimension in micrometers. Modified from Goodsell et al. (1992). 


\section{MERCENARIA CAMPECHIENSIS TEXANA}

\section{LEFT VALVE}

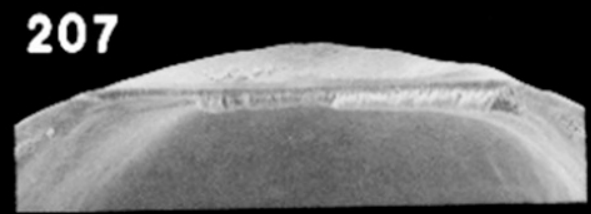

\section{2}

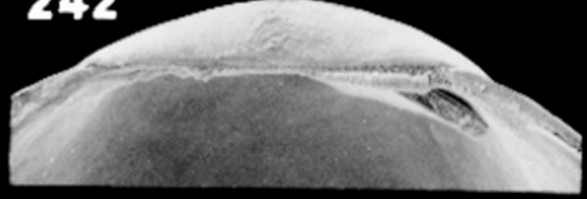

\section{0}

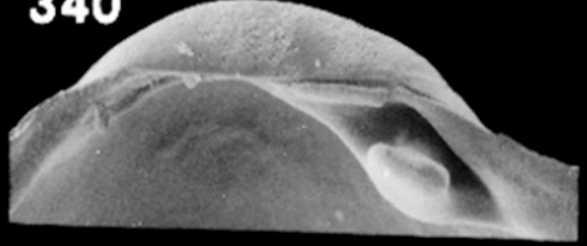

\section{6}

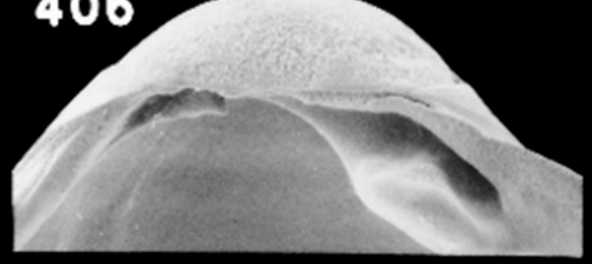

\section{8}
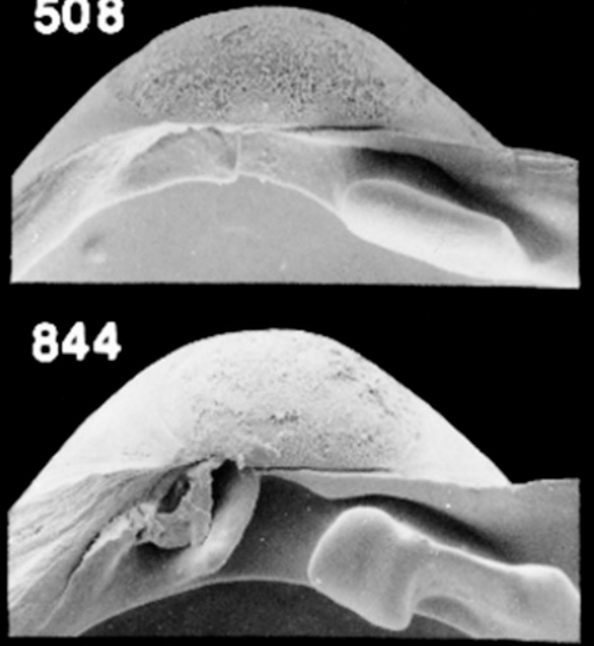

\section{RIGHT VALVE}
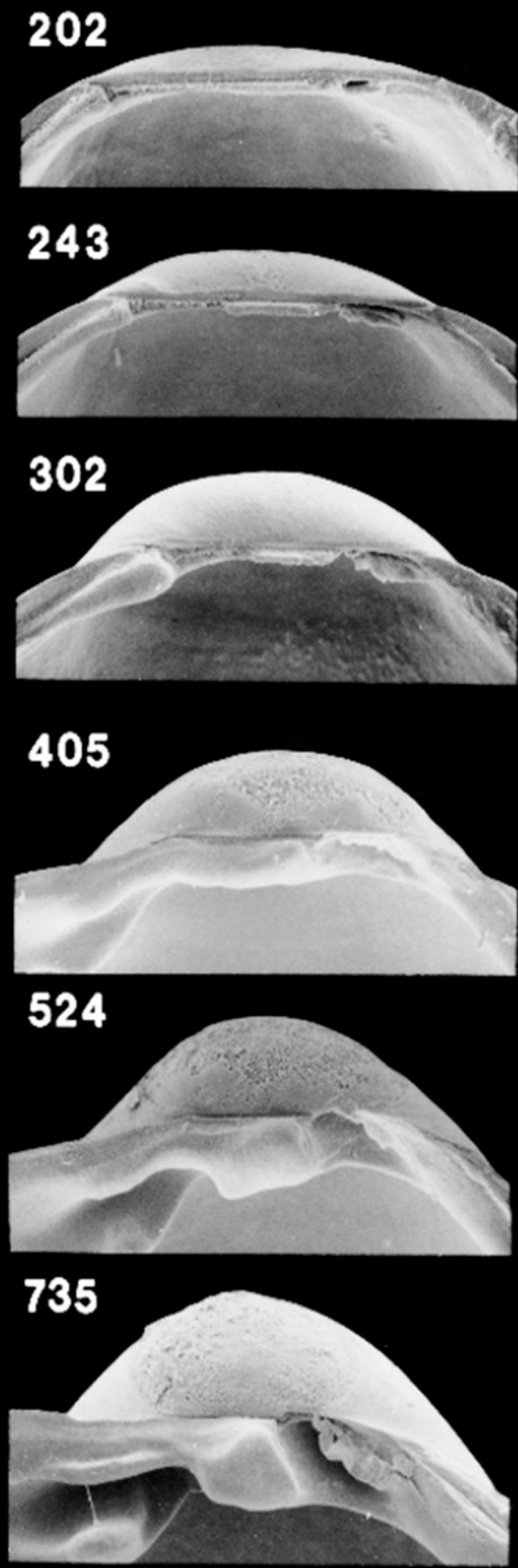


\section{PETRICOLA PHOLADIFORMIS}

\section{LEFT VALVE}
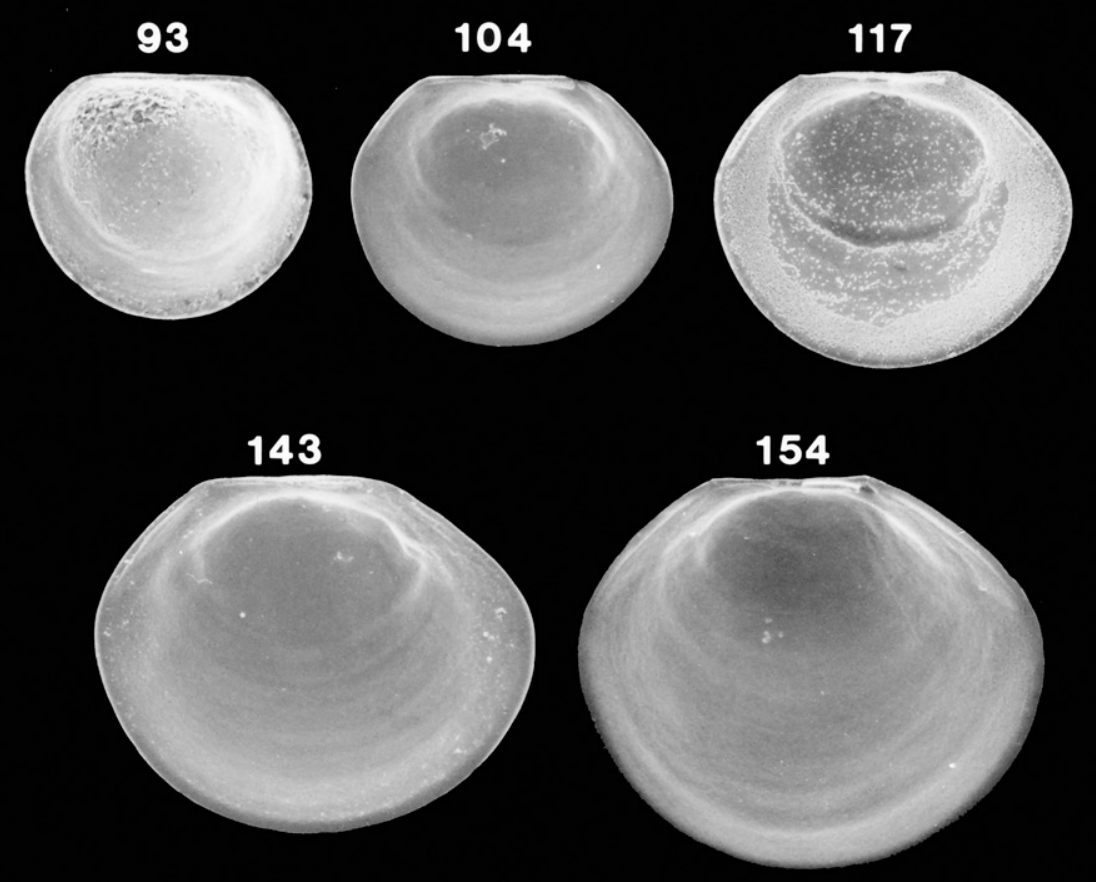

\section{RIGHT VALVE}
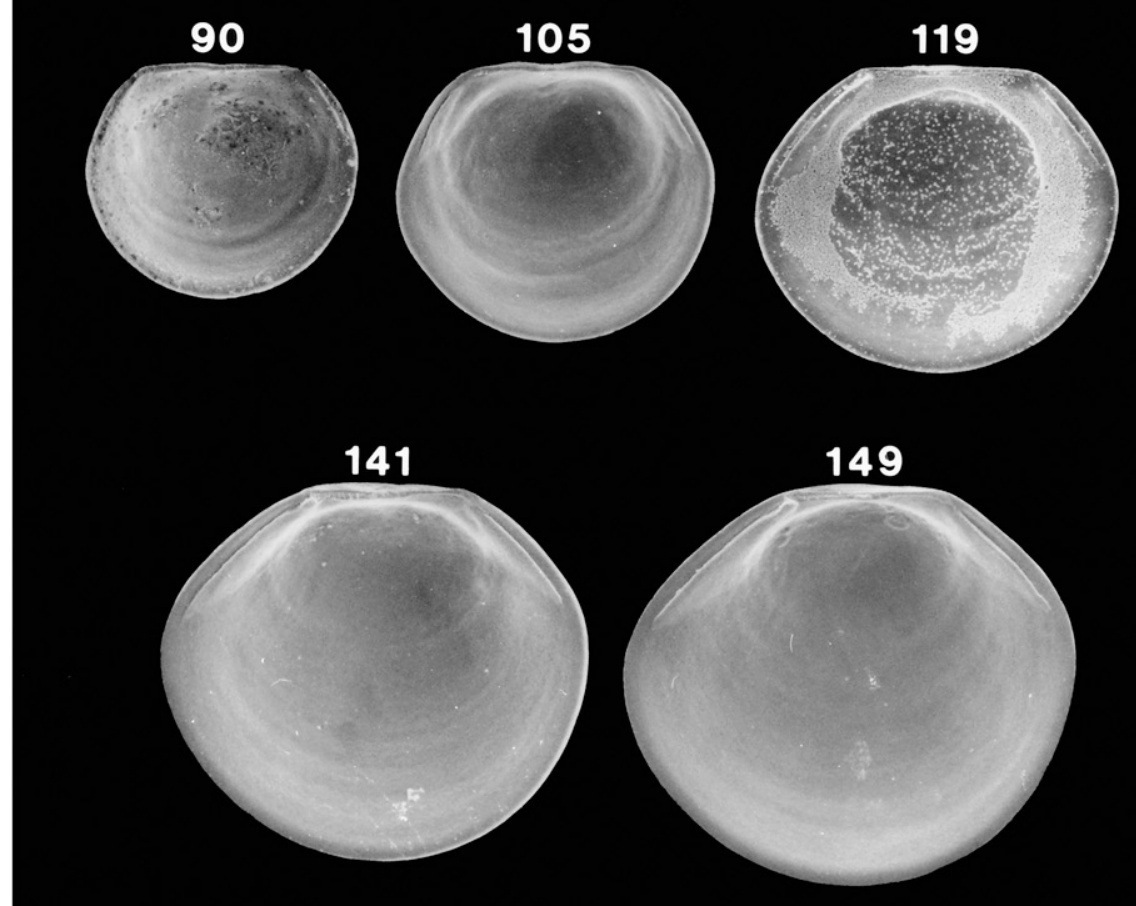

Figure 182. Scanning electron micrographs of disarticulated shell valves of Petricola pholadiformis larvae. Numbers indicate the maximum linear shell dimension in micrometers. 


\section{PETRICOLA PHOLADIFORMIS}

\section{LEFT VALVE}

\section{3}

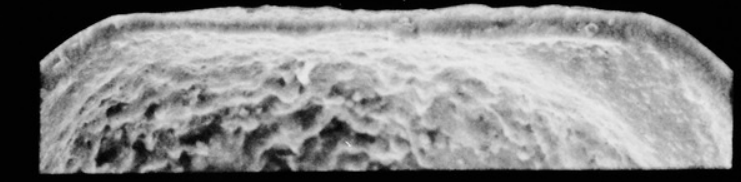

104

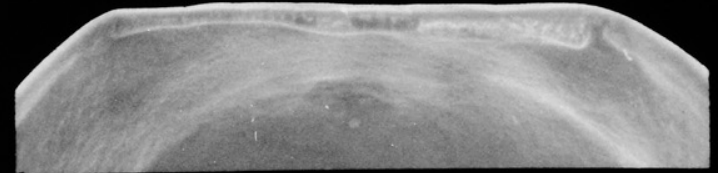

\section{7}

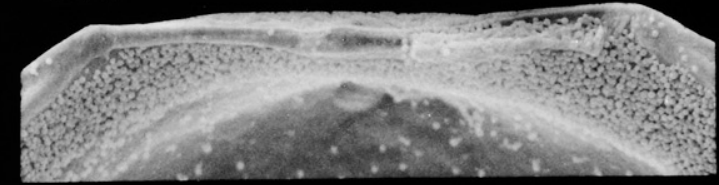

143

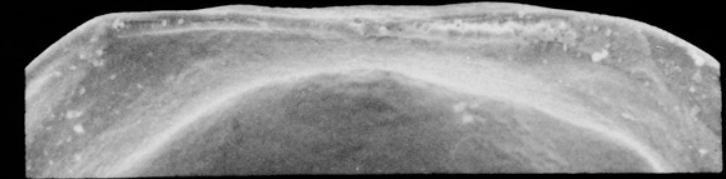

154

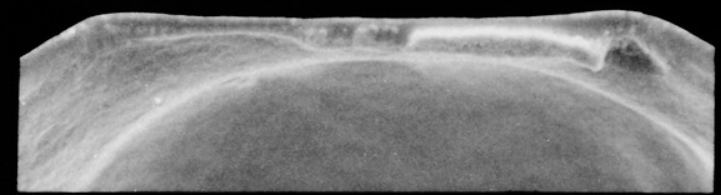

\section{RIGHT VALVE}

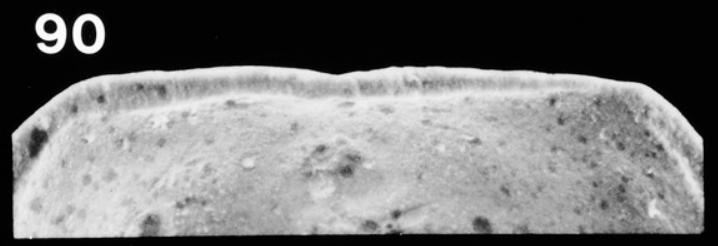

\section{5}

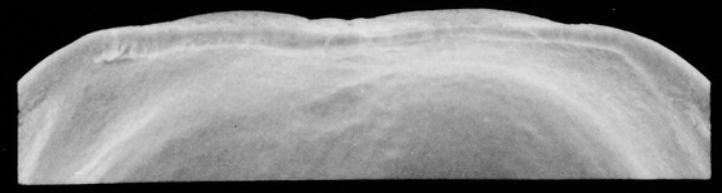

\section{9}

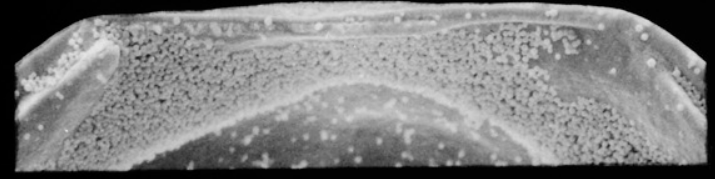

\section{1}

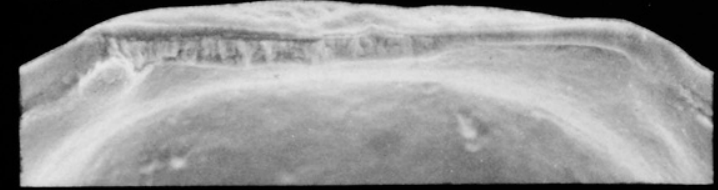

149

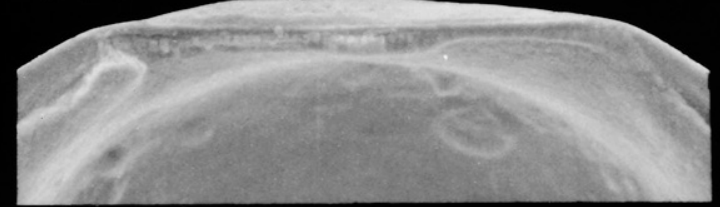

Figure 183. Scanning electron micrographs of the hinge of disarticulated shell valves of Petricola pholadiformis larvae seen in Figure 182. Numbers indicate the maximum linear shell dimension in micrometers. 


\section{PETRICOLA PHOLADIFORMIS}

\section{LEFT VALVE}
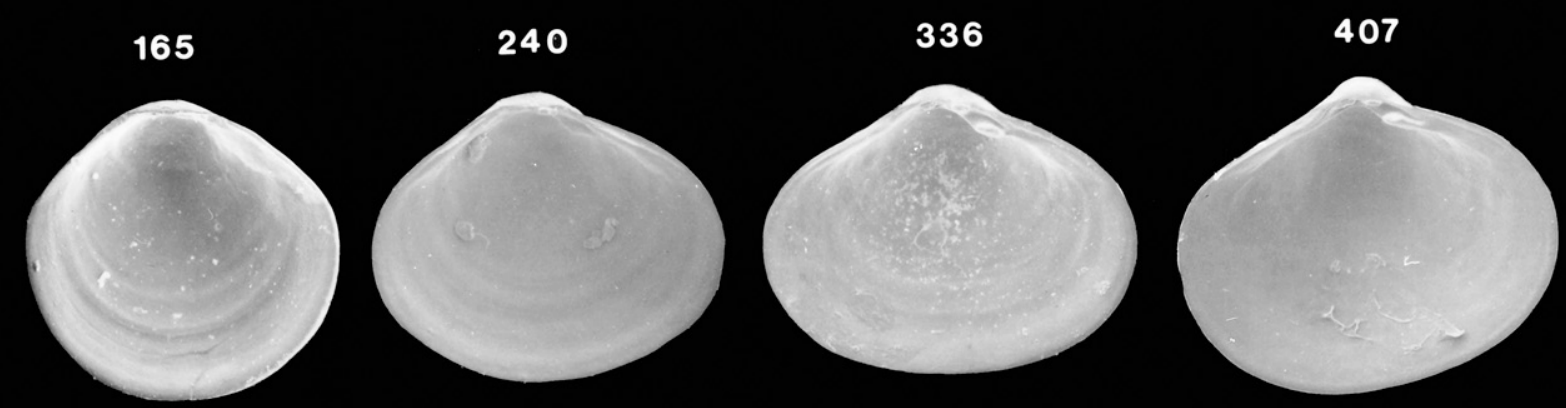

548

1186

2425
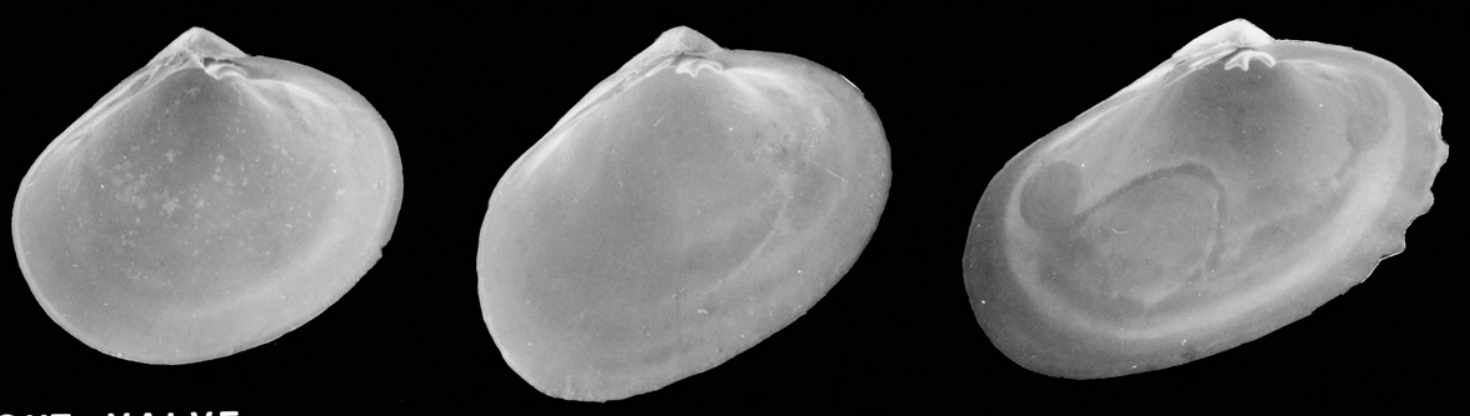

\section{RIGHT VALVE}

180

217

310

405
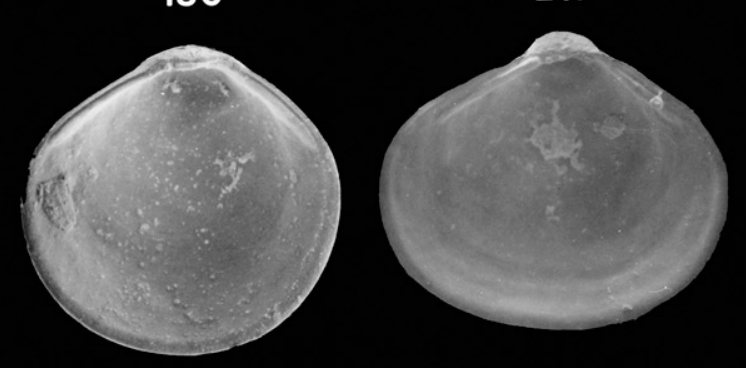

568
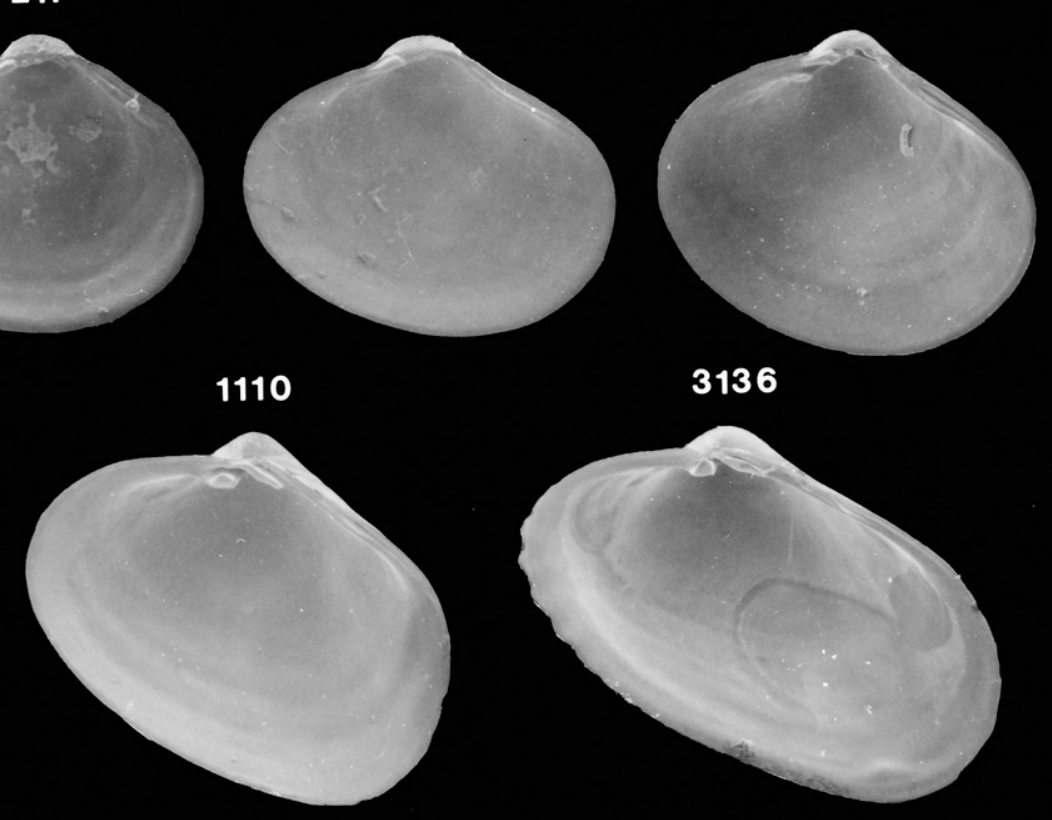

3136
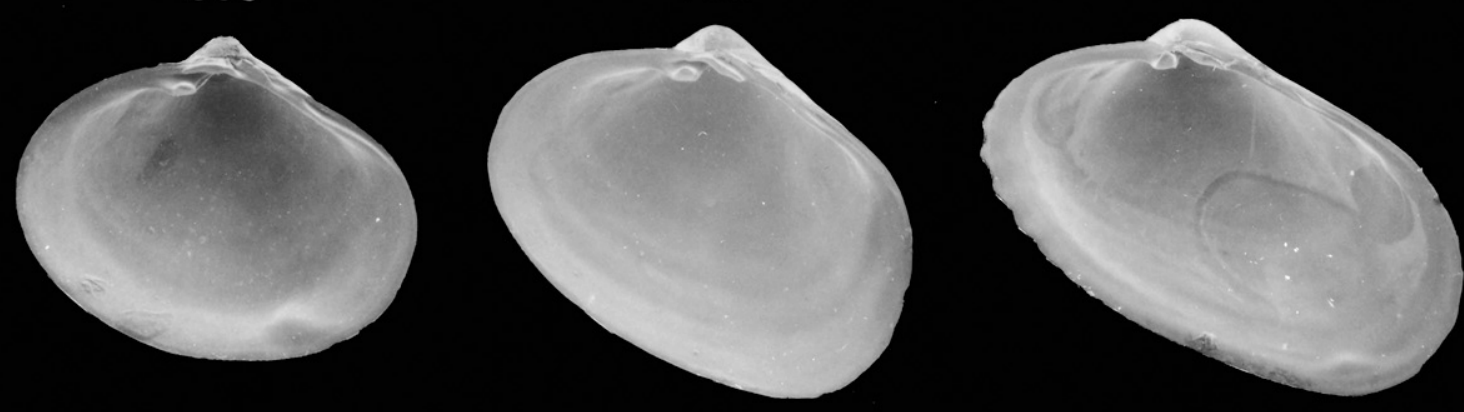

Figure 184. Scanning electron micrographs of disarticulated shell valves of Petricola pholadiformis postlarvae. Numbers indicate the maximum linear shell dimension in micrometers. 


\section{PETRICOLA PHOLADIFORMIS}

\section{LEFT VALVE}

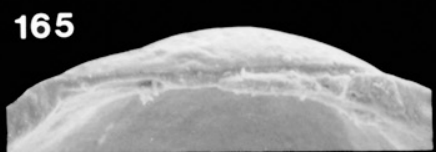

\section{0}

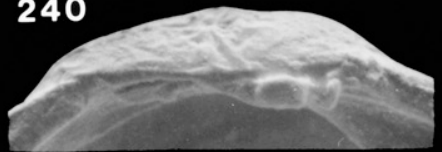

336

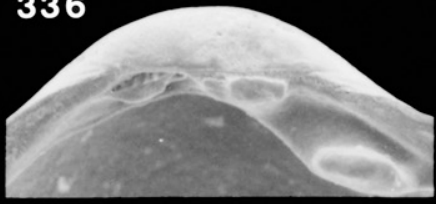

407
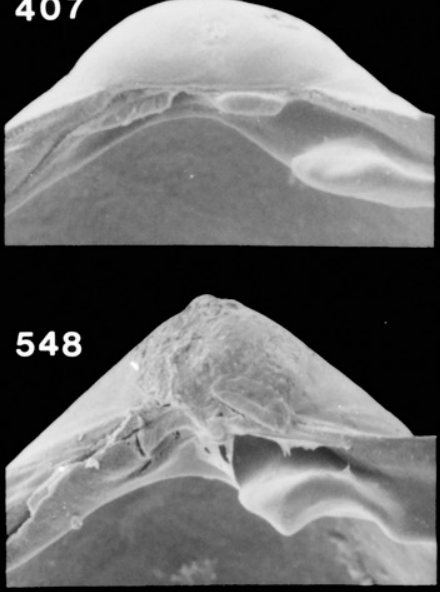

1186

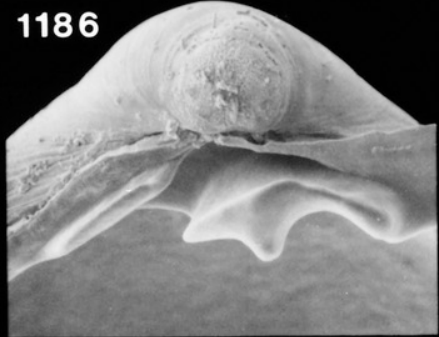

\section{5}

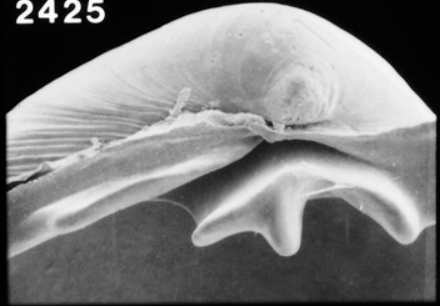

RIGHT VALVE

180
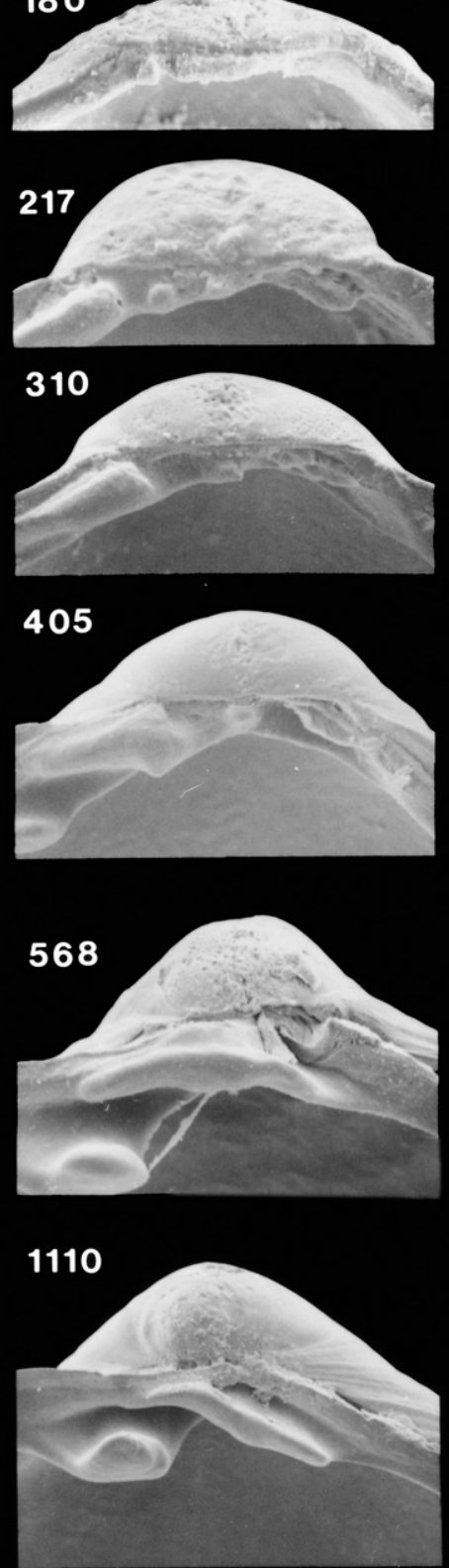

\section{6}

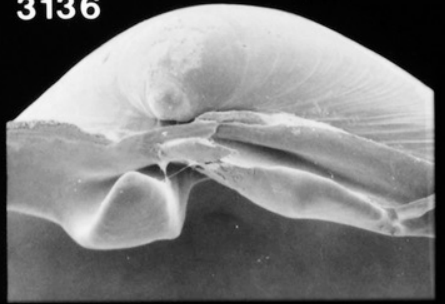

Figure 185. Scanning electron micrographs of the hinge of disarticulated shell valves of Petricola pholadiformis postlarvae seen in Figure 184. Numbers indicate the maximum linear shell dimension in micrometers. 


\section{PITAR MORRHUANUS}

\section{LEFT VAL VE}
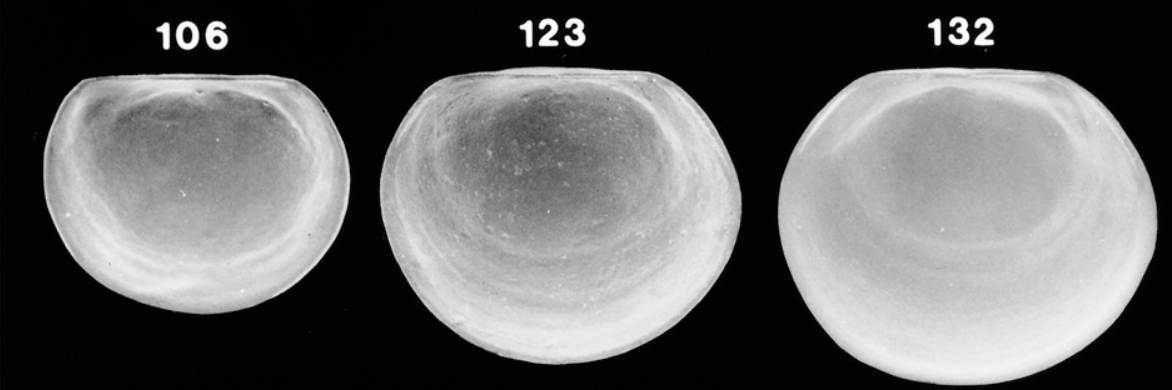

140

168

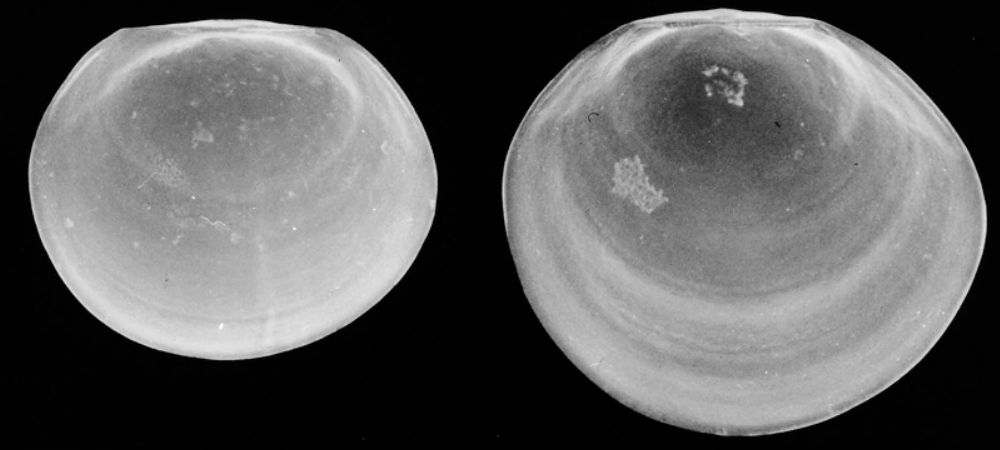

RIGHT VALVE

110

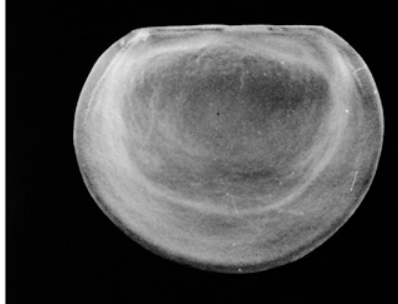

142
118

132

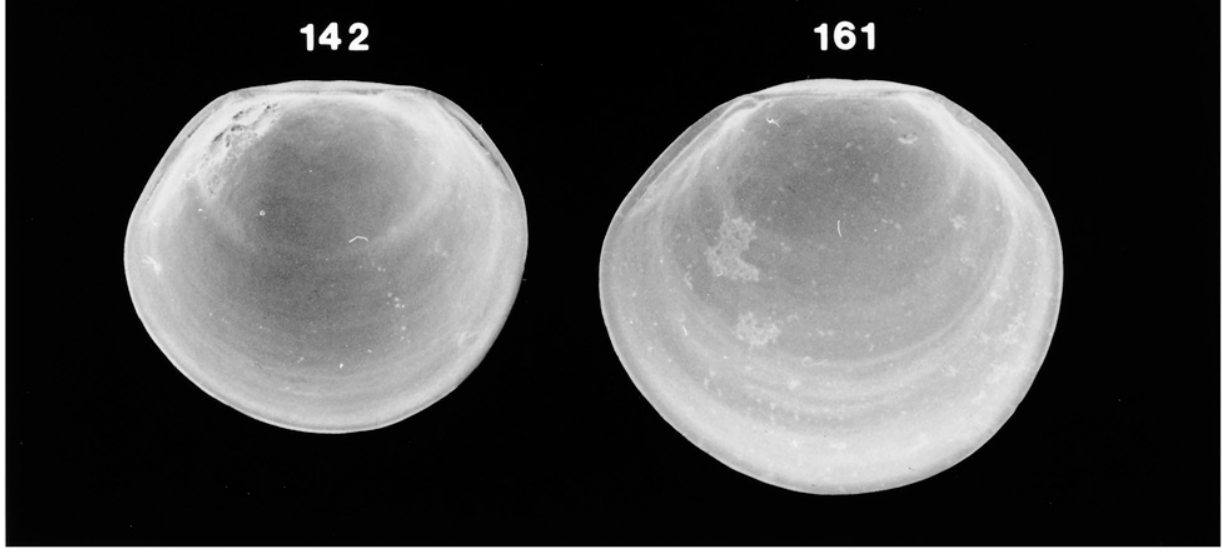

Figure 186. Scanning electron micrographs of disarticulated shell valves of Pitar morrhuanus larvae. Numbers indicate the maximum linear shell dimension in micrometers. Modified from Goodsell et al. (1992). 


\section{PITAR MORRHUANUS}

\section{LEFT VALVE}

\section{6}

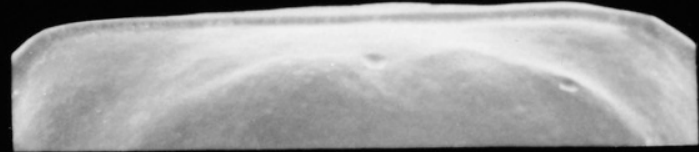

\section{3}

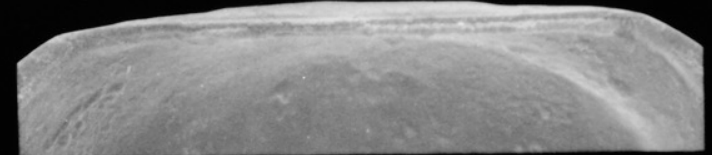

132

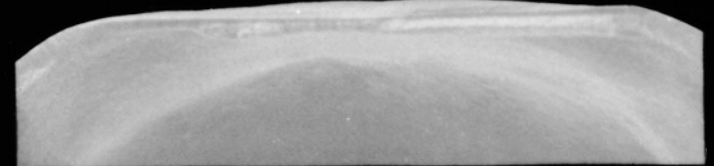

140

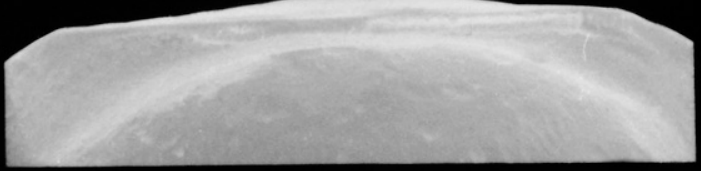

\section{8}

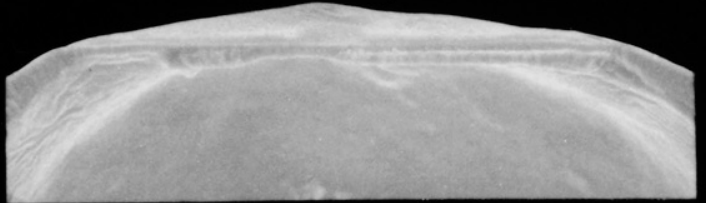

\section{RIGHT VALVE}

\section{0}

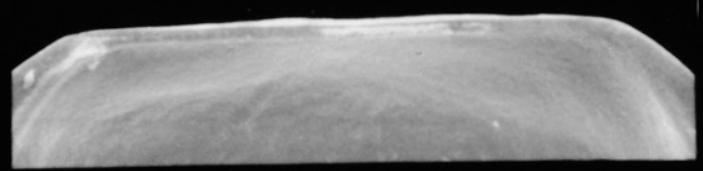

\section{8}

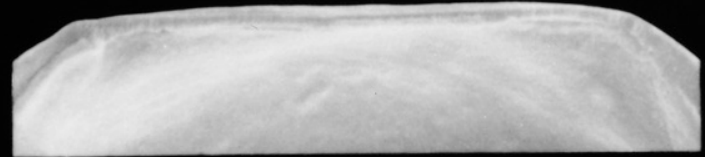

\section{2}

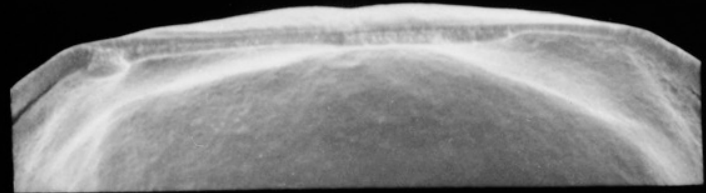

142

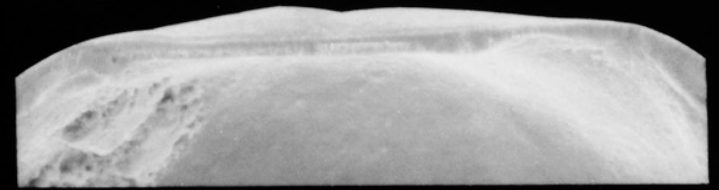

161

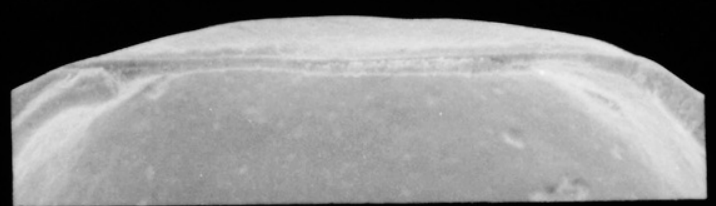

Figure 187. Scanning electron micrographs of the hinge of disarticulated shell valves of Pitar morrhuanus larvae seen in Figure 186. Numbers indicate the maximum linear shell dimension in micrometers. Modified from Goodsell et al. (1992). 


\section{PITAR MORRHUANUS}

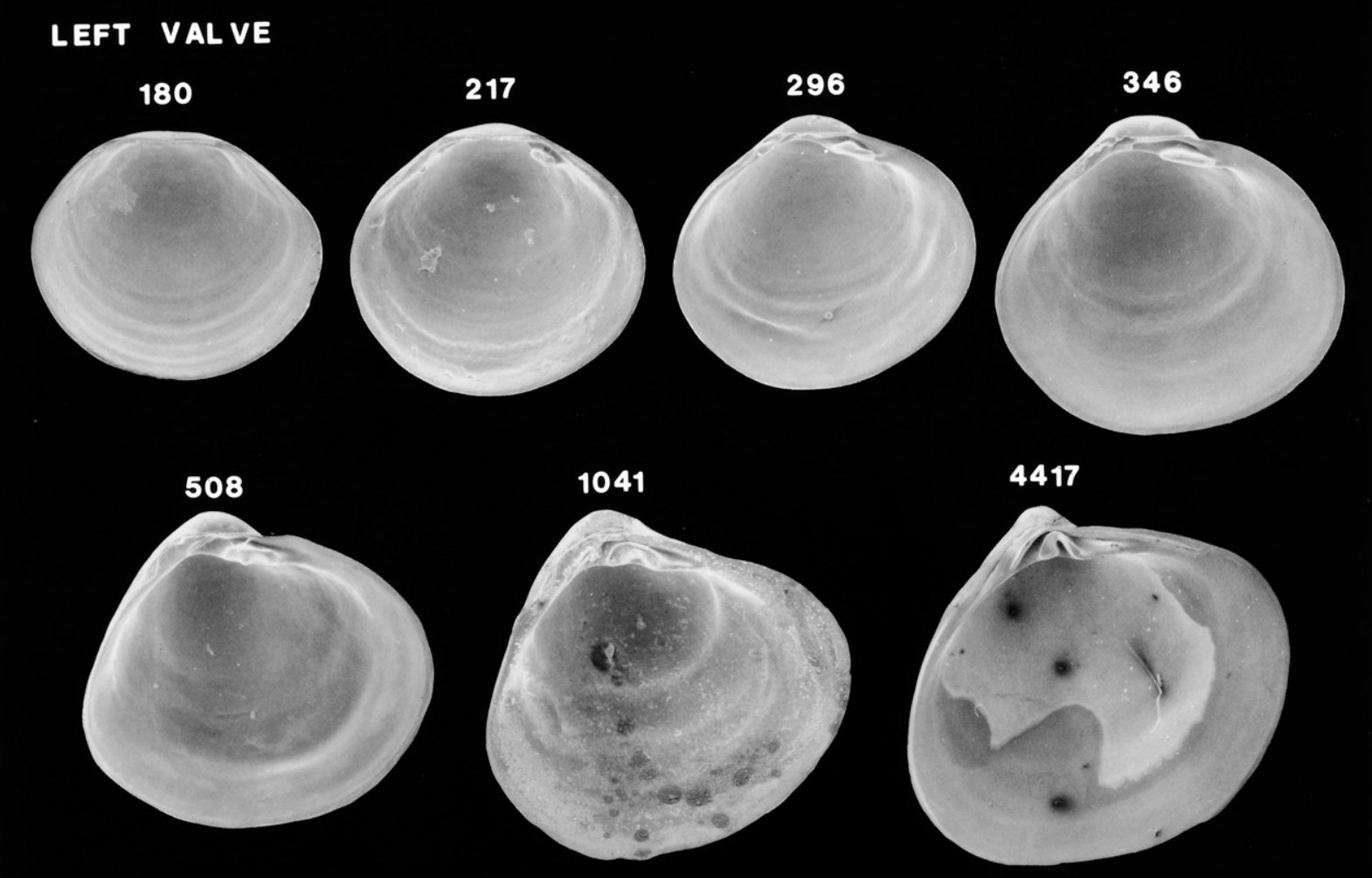

RIGHT VALVE

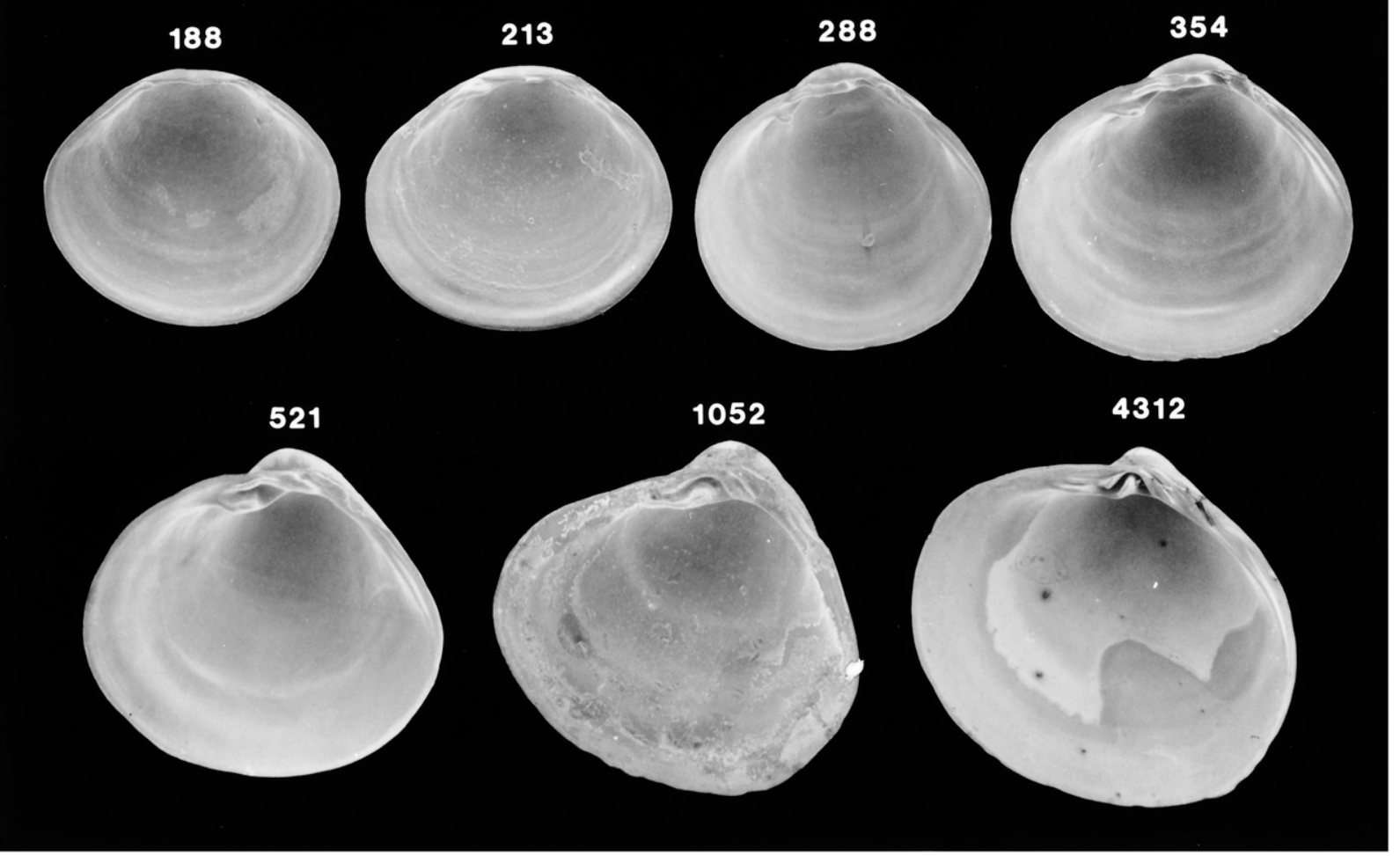

Figure 188. Scanning electron micrographs of disarticulated shell valves of Pitar morrhuanus postlarvae. Numbers indicate the maximum linear shell dimension in micrometers. Modified from Goodsell et al. (1992). 


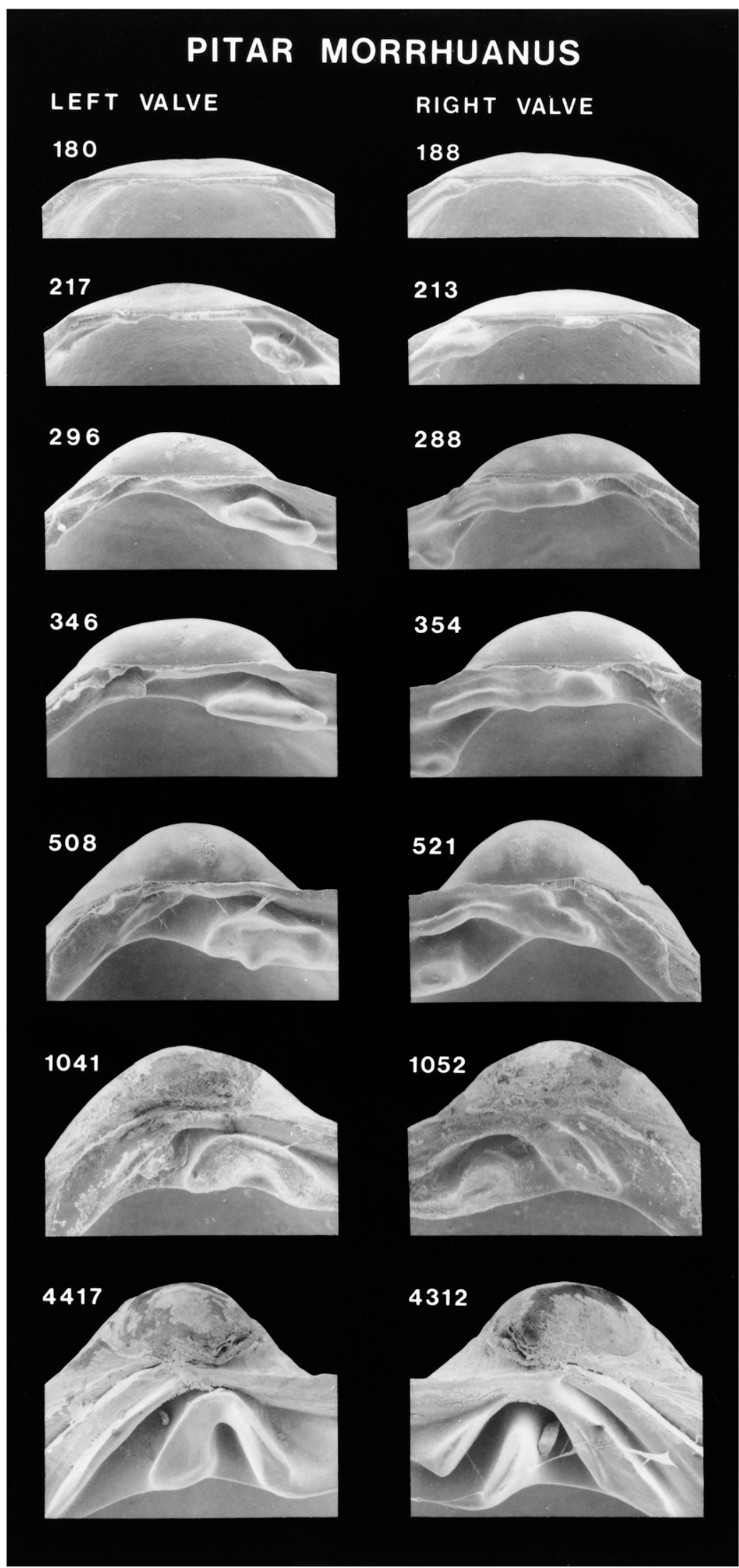

Figure 189. Scanning electron micrographs of the hinge of disarticulated shell valves of Pitar morrhuanus postlarvae seen in Figure 188. Numbers indicate the maximum linear shell dimension in micrometers. Modified from Goodsell et al. (1992). 


\section{RUDITAPES PHILIPPINARUM}

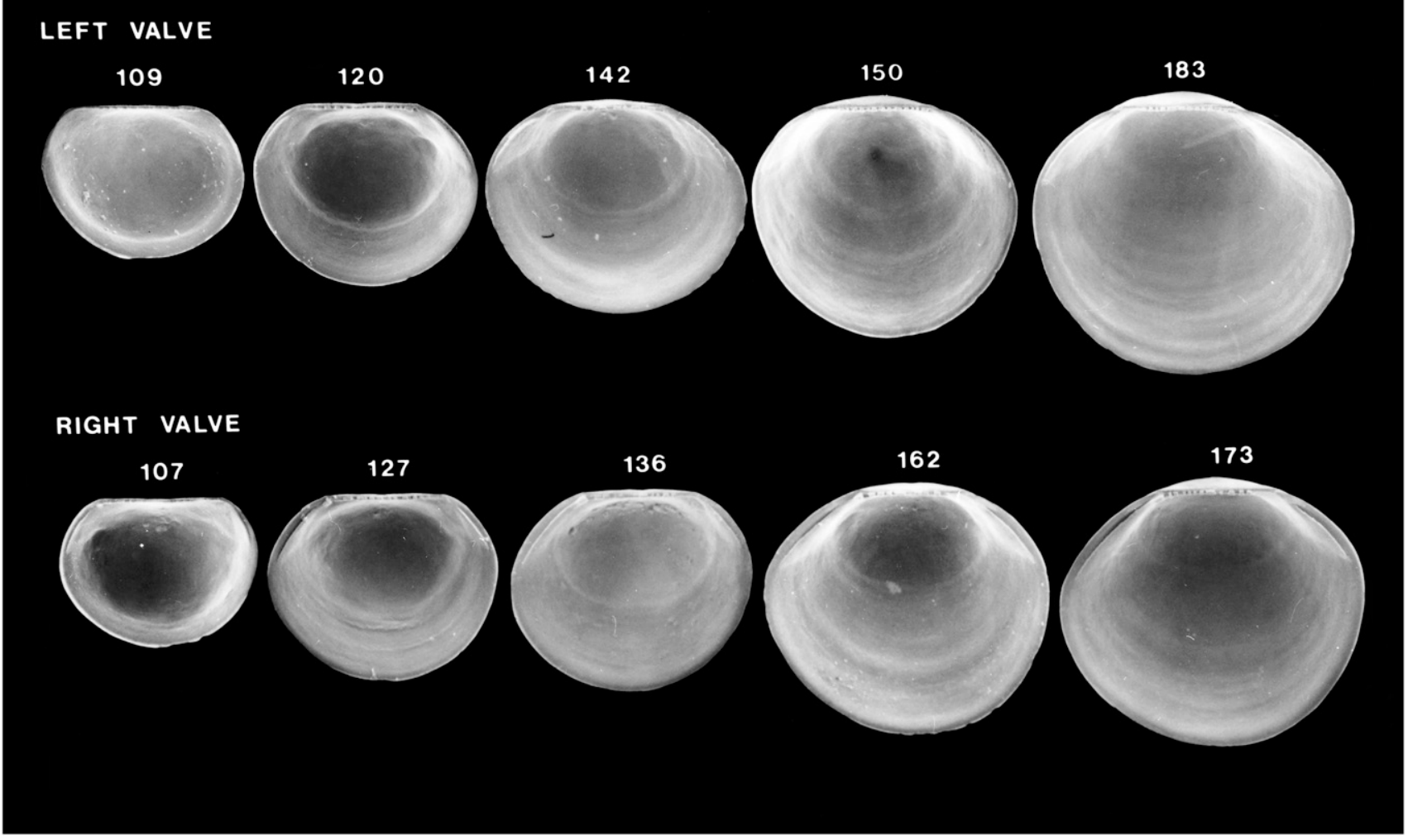

Figure 190. Scanning electron micrographs of disarticulated shell valves of Ruditapes philippinarum larvae. Numbers indicate the maximum linear shell dimension in micrometers. 


\section{RUDITAPES PHILIPPINARUM}

\section{LEFT VALVE}

\section{9}

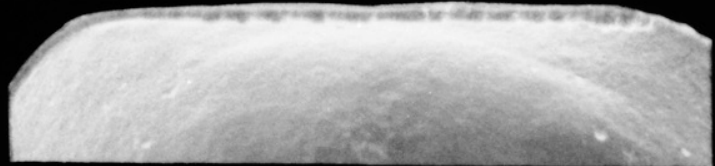

\section{0}

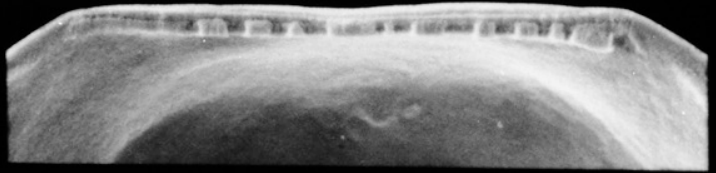

142

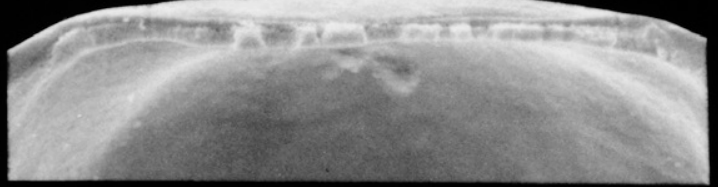

150

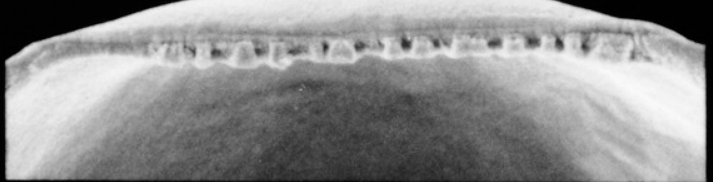

\section{3}

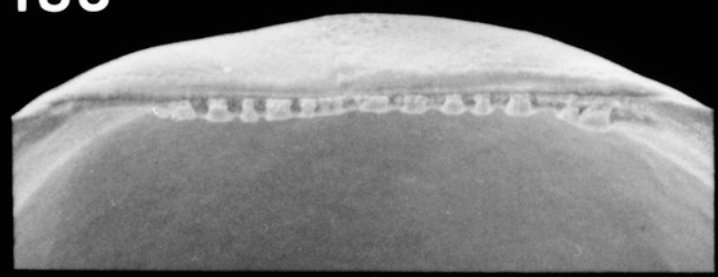

\section{RIGHT VALVE}

\section{7}

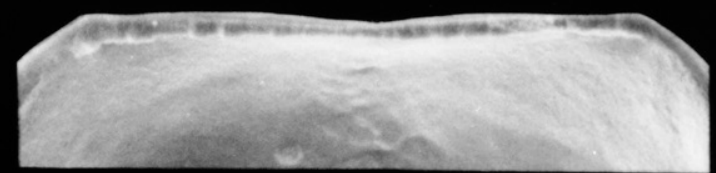

127

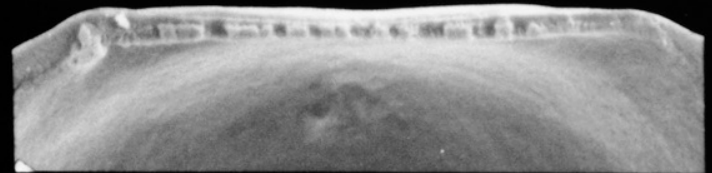

\section{6}

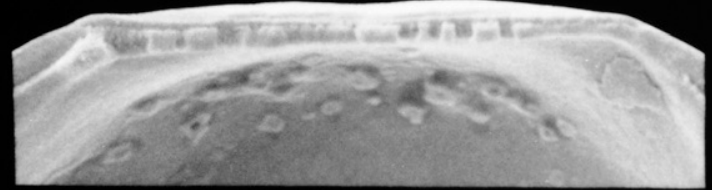

\section{2}

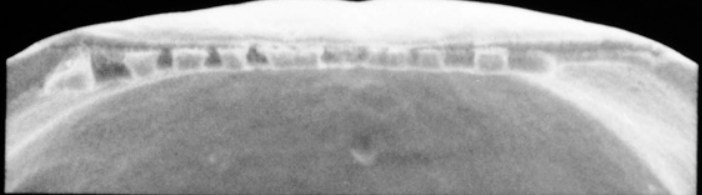

\section{3}

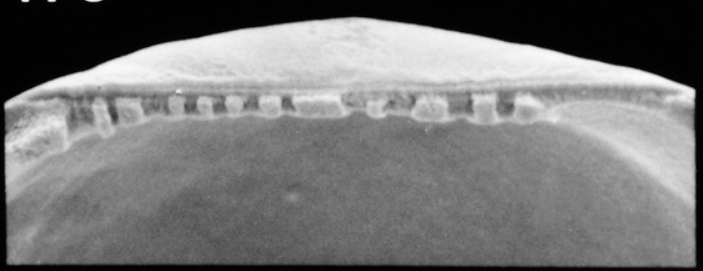

Figure 191. Scanning electron micrographs of the hinge of disarticulated shell valves of Ruditapes philippinarum larvae seen in Figure 190. Numbers indicate the maximum linear shell dimension in micrometers. 


\section{RUDITAPES PHILIPPINARUM}

\section{LEFT VALVE}
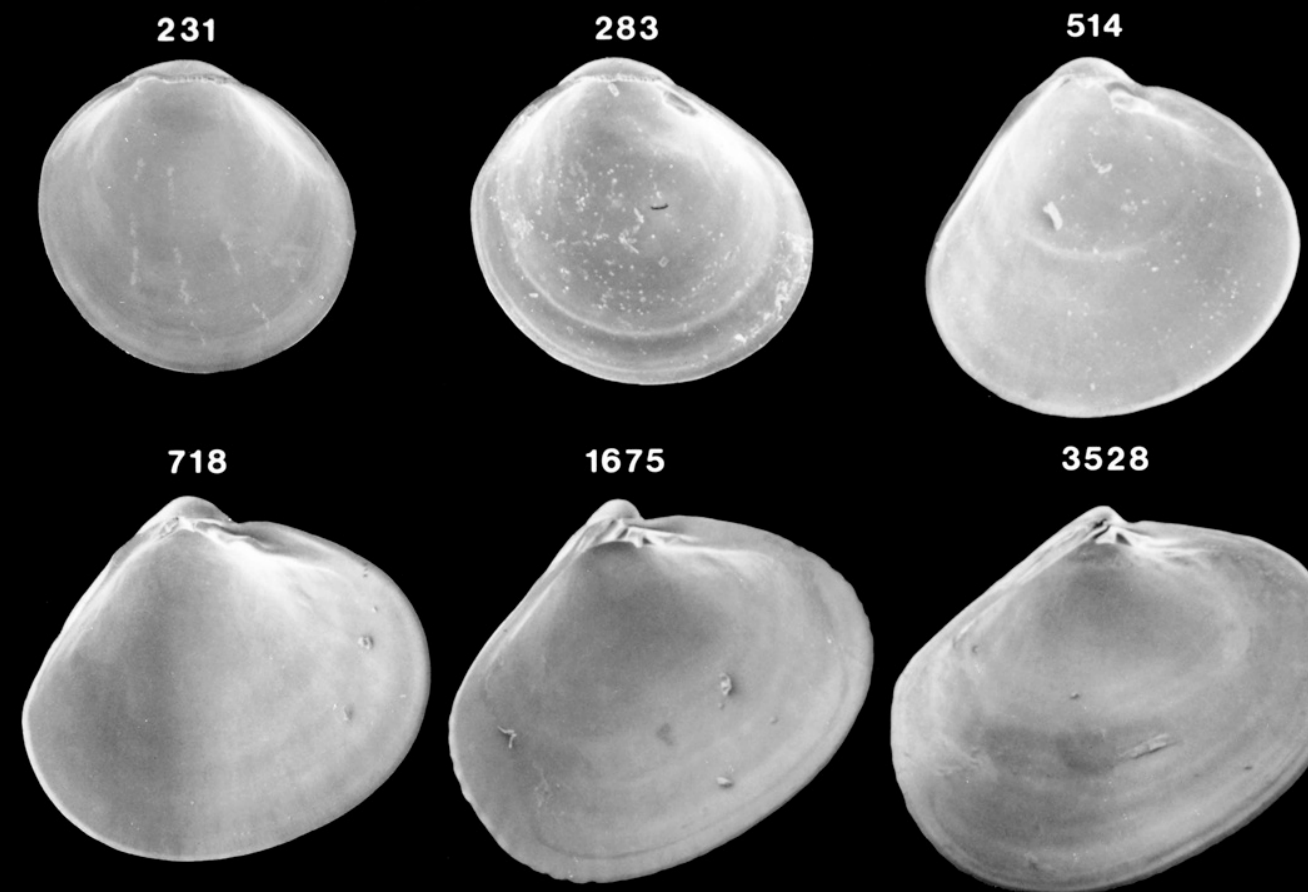

3528

\section{RIGHT VALVE}
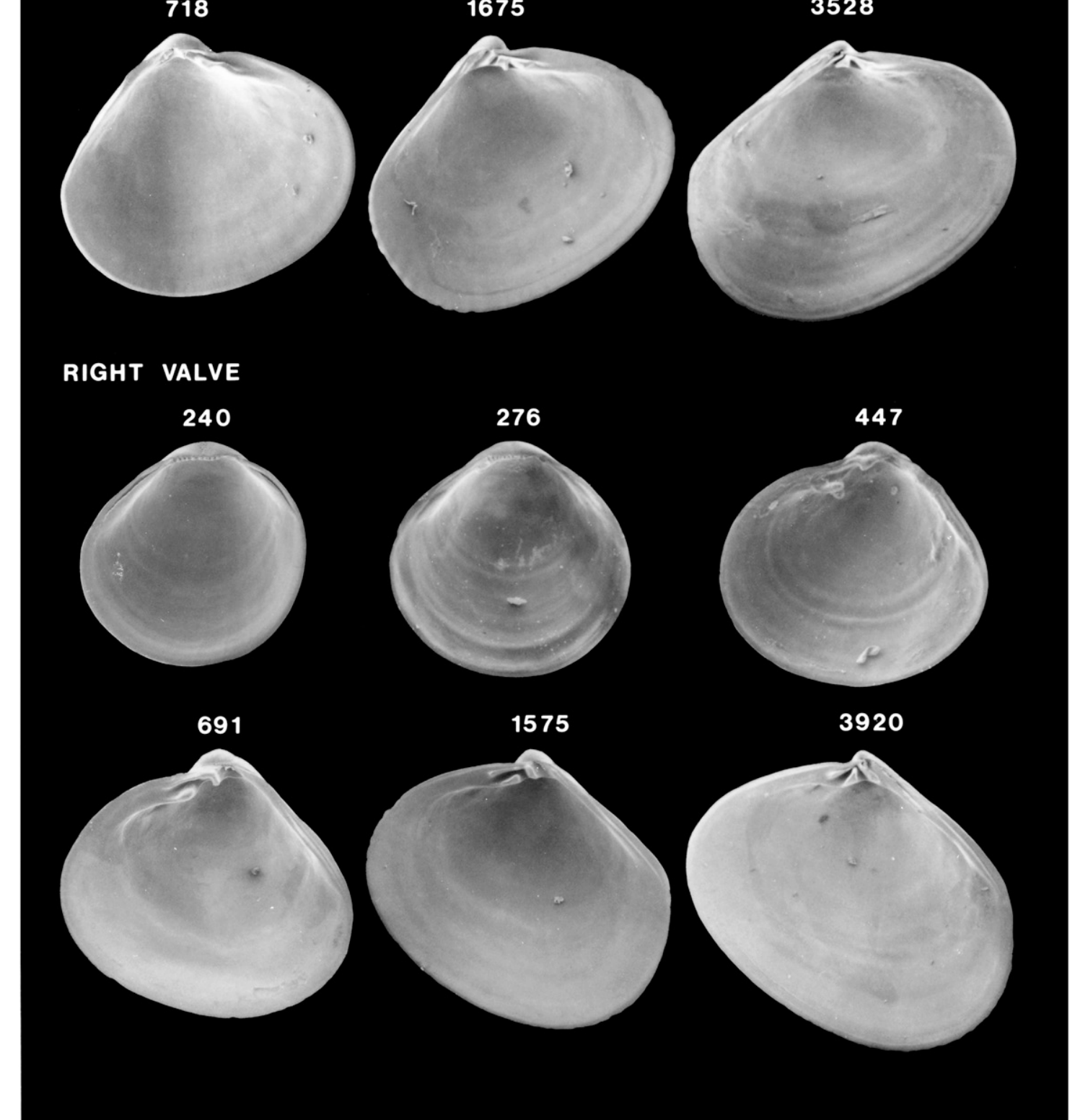

Figure 192. Scanning electron micrographs of disarticulated shell valves of Ruditapes philippinarum postlarvae. Numbers indicate the maximum linear shell dimension in micrometers. 


\section{RUDITAPES PHILIPPINARUM}

\section{LEFT VALVE}
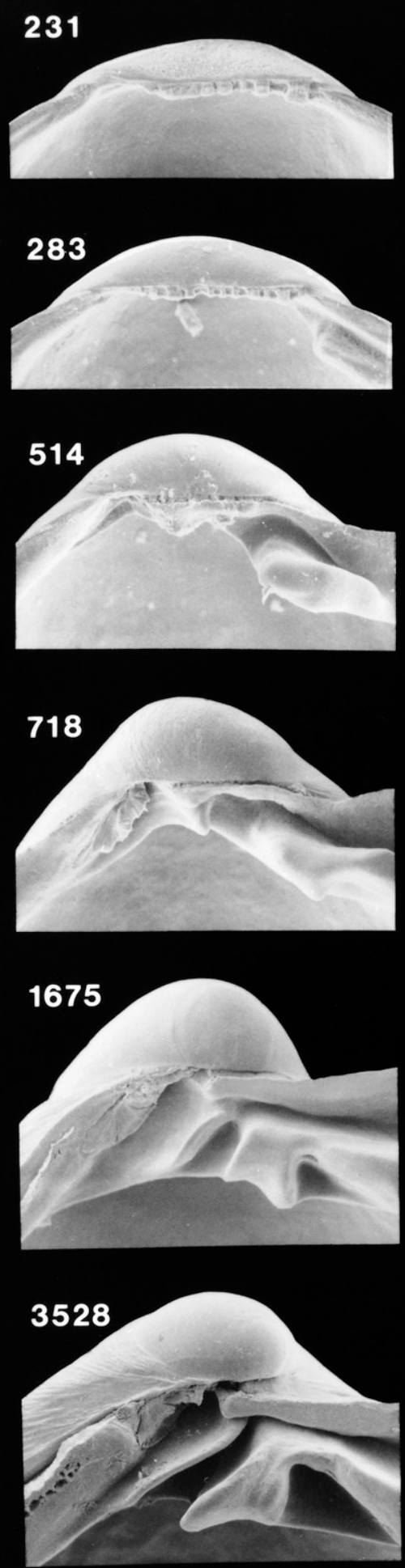

\section{RIGHT VALVE}
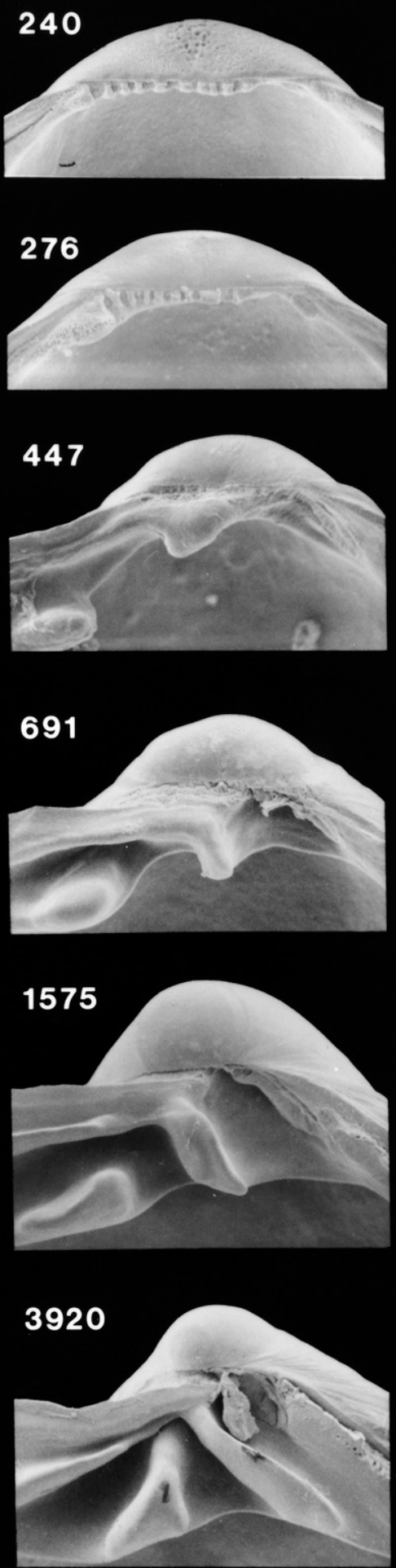

Figure 193. Scanning electron micrographs of the hinge of disarticulated shell valves of Ruditapes philippinarum postlarvae seen in Figure 192. Numbers indicate the maximum linear shell dimension in micrometers. 


\section{CORBICULA FLUMINEA}

\section{LEFT VALVE}
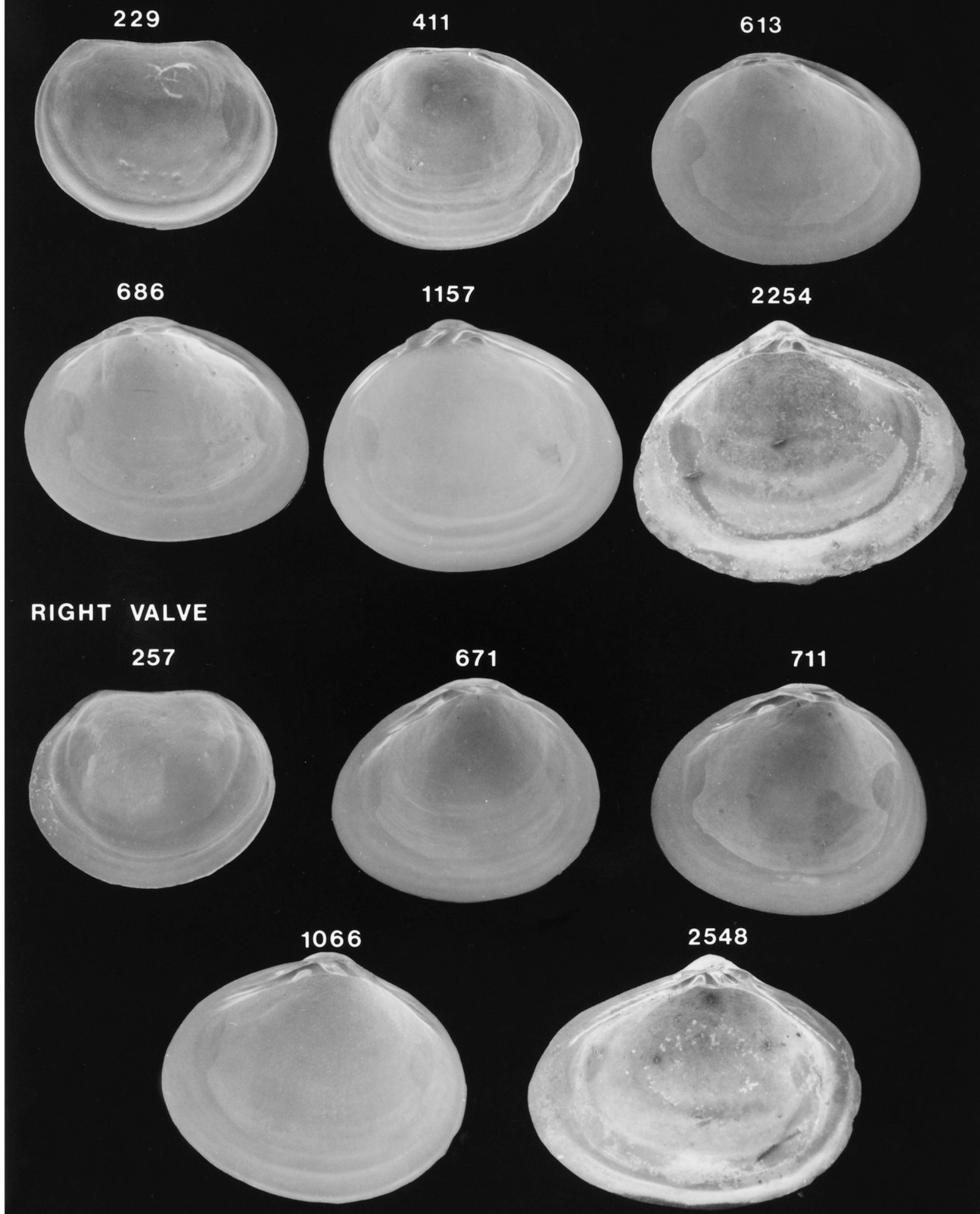

Figure 194. Scanning electron micrographs of disarticulated shell valves of Corbicula fluminea postlarvae. Numbers indicate the maximum linear shell dimension in micrometers. Modified from Kennedy et al. (1991). 


\section{CORBICULA FLUMINEA}

\section{LEFT VALVE}

\section{9}

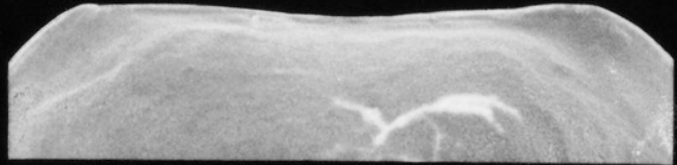

411

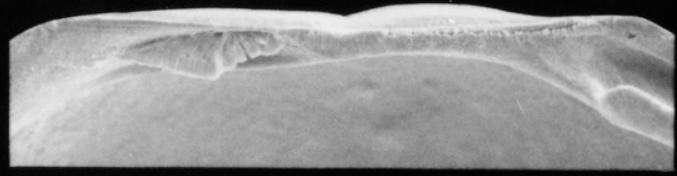

613

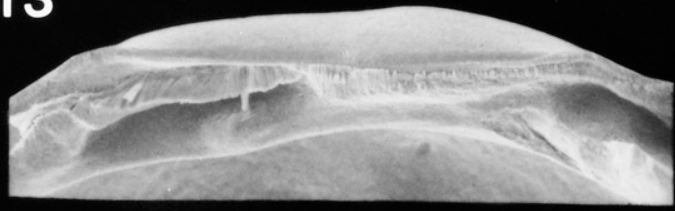

686

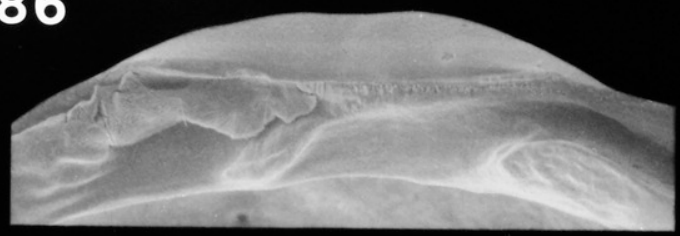

1157

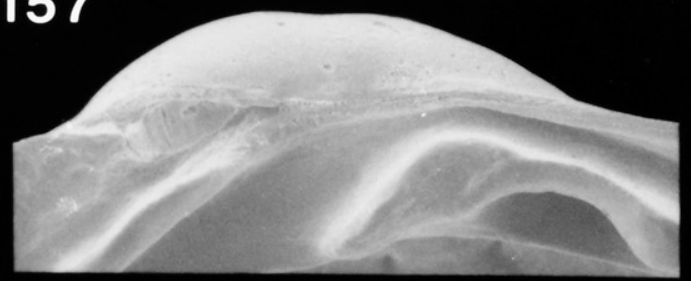

2254

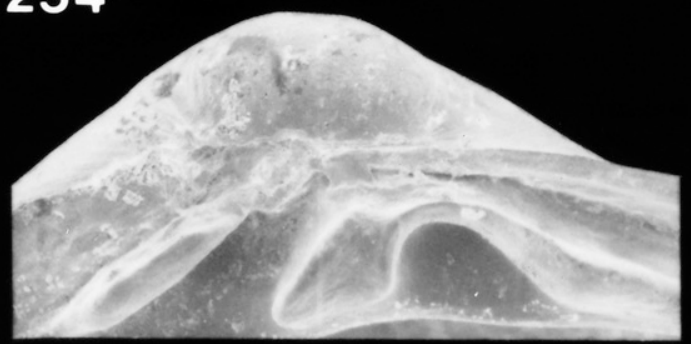

RIGHT VALVE

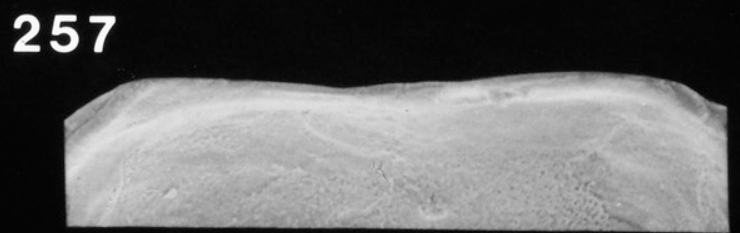

671

711

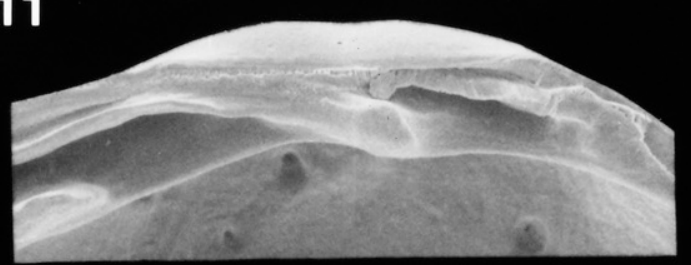

1066

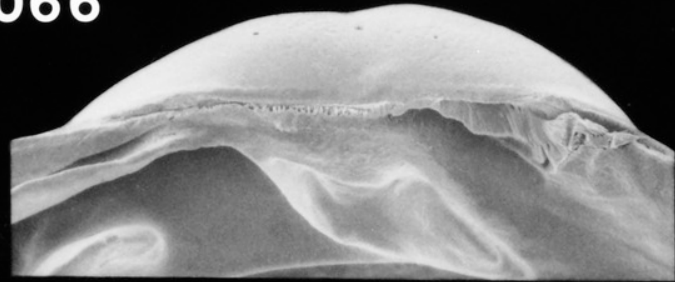

2548

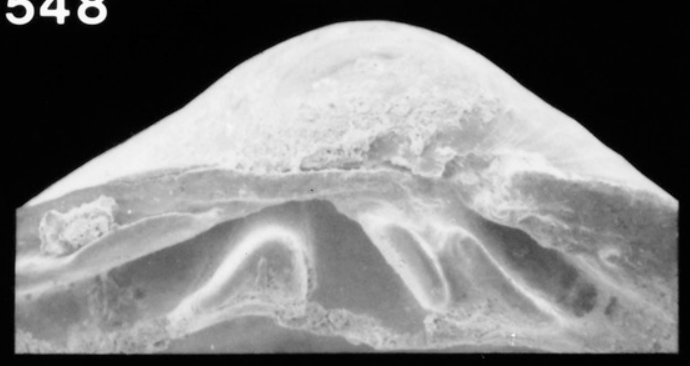

Figure 195. Scanning electron micrographs of the hinge of disarticulated shell valves of Corbicula fluminea postlarvae seen in Figure 194. Numbers indicate the maximum linear shell dimension in micrometers. Modified from Kennedy et al. (1991). 